\title{
SMITHSONIAN INSTITUTION.
} UNITED STATES NATIONAL MUSEUM.

\section{Chas. W. Hangitt SYRACUSE UANERSITY, rancuse,}

SPEOIAL BULLETIN.

A MERICAN HYDROIDS.

PAITII.

\section{THE SERTULARIDE,}

WITH FORTY-ONE PLATES.

\author{
BS \\ CHARLES CLEVELLLV NUTTING, \\ PROFESSOR OF ZOOLOGY, UNIVERSITY OF IOWA.
}

WASHINGTON:

GOVERNMENT PRINTING OFFIOR.

1904 . 




\section{SMITHSONIAN INSTITUTION.}

UNITED STATES NATIONAL MUSEUM.

SPECIAL BULLETIN.

\section{AMERICAN HYDROIDS.}

PA R T I I.

\section{THE SERTULARID E,}

WITH FORTY-ONE PLATES.

BY

CHARLES CLEVELAND NUTTING,

PROFESSOR OF ZOOLOGY, UNIVERSITY OF IOWA.

WASHINGTON:

GOVERNMENT PRINTING OFFICE.

1904. 


\section{ADVERTISEMENT.}

This work (Special Bulletin No. t) is one of a series intended to illustrate the collections belonging to, or placed in charge of, the Smithsonian Institution and deposited in the United States National Museum.

The publications of the National Museum consist of two series, the Bulletin and the Proceedings.

The Bulletin comprises complete technical works of considerable size, zoological monographs, handbooks of the Museum collections, records of scientific expeditions, etc. Most of the volumes hitherto published have been octavos, but a quarto form has been adopted for works like the present one, which, on account of the character of the illustrations, require a large page.

The Proceedings are intended primarily as a medium of publication for shorter technical papers, many of them of a preliminary character, containing newly acquired facts relating to biology, anthropology, and geology, new schemes of classification, descriptions of new forms of animals and plants, discussions of nomenclature, and the diaries of minor expeditions.

The Proceedings are issued annually to libraries in volumes of about 1,000 pages. A small edition of each paper is distributed in pamphlet form to specialists in advance of the bound volume.

Papers of more general popular interest are published in the appendix to the Annual Report.

Papers intended for publication in the Proceedings and Bulletin are referred to an advisory committee composed as follows: Frederick W. True (chairman), William H. Holmes, George P. Merrill, James E. Benedict, Otis T. Mason, Leonhard Stejneger, Lester F. Ward, and Marcus Benjamin (editor).

Washington, D. C., Aprit 15, 1904.

S. P. Langley, Secretary of the Smithsonian Institution. 


\section{INTRODUCTORY NOTE.}

Almost all that was said in the introductory note to the first part of this work could truthfully be said here. At that time it was thought that the Plumularidre was a much larger family than the Sertularidæ, and the author has been greatly surprised at the large number of species of the latter family that he has been called upon to discuss in the following pages, and the extent to which the literature on the subject is fragmentary and seattered will be apparent when it is said that not more than 20 speeies of Sertularida from American waters have been mentioned in any one publication up to the present time, while the present writer has found no less than 130 species that should be included in the American fauna.

This large number of species has been brought to light more through a careful scrutiny of foreign publications than through the discovery of new species in the large collections that have passed through the author's hands, although the number of the latter is by no means small, amounting to more than 30 new forms. The writer has thus been much impressed with the necessity of bibliographic work, and, as a result, has presented as full a bibliography and as complete synon. ymies of species as he has heen able to secure. While this is true, it must be confessed that there is much still to be desired in this direction, and that there are many papers that have not been available for reference, as will be seen by consulting the list on page 143 of this work.

This bibliographic work has been greatly facilitated by courtesies from the authorities in charge of the Library of Congress in Washington, and by the courtesy of my colleagues at home and abroad, who have been generous in sending me their publications.

Almost all of the friends mentioned on page 2 of the first part of this work have continued to render aid in the preparation of the second part, and in addition I take pleasure in expressing my gratitude to the following:

To the Directors of the British Museum (Natural History) for portions of a number of Allman's types of the Challenger Sertularidæ; to Prof. G. M. R. Levinsen, of Copenhagen, for specimens, literature, and advice; to Prof. D'Arey W. Thompson, of Dundee, for specimens and correspondence; to Dr. Clemens Hartlaub for his valuable publications; to Prof. Maurice Bedot, of Geneva; Dr. Kristine Bonnevie, of Christiania; Dr. Edward T. Browne, London, for literature; and Sir William Dawson and Prof. J. F. Whiteaves, of the Canadian Geological Survey, for specimens.

Among my own countrymen I have the pleasure to acknowledge aid from the following, in addition to those mentioned in the acknowledgments on page 2 of the first part of this work: Hon. George M. Bowers, for facilities granted for investigation at the laboratory of the U.S. Bureau of Fisheries, in Woods Hole, Massachusetts; to Prof. H. C. Bumpus for special favors at the same place; to Prof. William E. Ritter, of the University of California, for specimens; to Prof. Trevor Kincaid, of the University of Washington, for specimens; to Mrs. G. Gibbs for specimens, and to Dr. Harry Beal Torrey, of the University of California, for literature.

The author also desires to acknowledge with gratitude the great service rendered by his wife, and Prof. H. F. Wickham of the State University of Iowa, in verifying references and other bibliographic work connected with the preparation of this section of the monograph. 



\section{AMERICAN HYDROIDS.}

\section{SFCTION 2.-TIE SERTUIARIDAE.}

\section{ERRATA.}

Page 46, 7th line from top, cylindritheca should be cylindrica.

Page $46,2 \mathrm{~d}$ line from bottom, tamariska should be tamarisca.

Page 46,39 th line from bottom, $77^{\circ}$ should be 770 .

Page 50, 7th line from bottom, sertularioides should be rathlumi.

Page 77, 30th line from top, alba should be albida.

Page 77,4 th line from bottom, quadridens should be quadrifida.

Page 102 , last footnote, p. 1876 should be p. 221 .

Third. Such investigations as have just been referred to led to a general understanding of the morphology of the Hydroida as a whole, and, as the Sertularidæ offered little that appeared to be novel, that family was naturally passed by in favor of groups offering more interesting, because more novel, structures for investigation.

The writers who have contributed most to our knowledge of the morphology of this family, purely systematic work being excluded, are the following: Louis Agassiz, who gives an excellent and superbly illustrated account of Sertularia pumila; ${ }^{3}$ Allman, ${ }^{4}$ who discusses the gonosome of

${ }^{1}$ American Hydroids. Part I, The Plumularidæ, 1900, p. 3.

${ }^{2}$ While this is true when the Sertularide and Plumularide are compared, it by no means follows that the Sertularide are of low rank when compared with the hydroids in general. Indeed, quite the opposite is true if we admit the view now very generally adopted that the sessile gonophores represent degraded meduse. This matter, however, will be discussed later.

${ }^{3}$ Contributions to the Natural History of the United States, IV, 1862, p. 326.

*Monograph of the Gymnoblastic Hydroids, 1871, p. 50. 


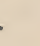




\title{
AMERICAN HYDROIDS.
}

\author{
SECTION 2.-THE SEIRTUIAARTDA:
}

\section{MORPHOLOGT OF THE SERTULARTDA.}

As indicated in the first part of this work ${ }^{1}$ it is the intention to defer the general discussion of the morphology of the order to the last part. In accordance with this plan nothing will be discussed here except those structures which are peculiar to the Sertularide, or those which, while shared by other forms, still furnish peculiarities upon which diagnostic features can be based. In the former eategory will be included the operculum, although this structure is found in the Campanulinide, and under the latter head will be discussed other features, particularly" the stem, the hydrinths, the hydrothece, and the gonangia.

A little study will make it evident that the Sertularida contain few characteristic struetures. at least as compared with the P'lumularida, and that the family is therefore lower in the zoological scale. ${ }^{2}$ It has therefore not received the attention from the morphologists that has been paid other groups. Indeed, it appears to have received less careful study than any of the

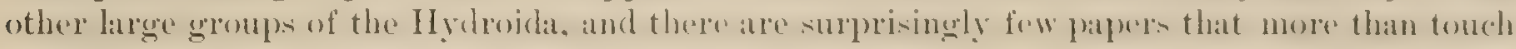
on the morphology of this family. At first sight this seems rather strange, especially when we remember that this is the longest known and most familiar family of the order. 'This lack of interest is probably due mainly to the following reasons:

First. The earlier naturalists were nearly all of them systematists rather than morphologists, and studied the more superticial characters.

Second. When eflective morphologieal investigation became practicable by the introduction of mieroscopical and histological technic, investigators became interested in the larger forms with larger and more conspicuous hydranths, as in the grmmoblastic forms, or the beautiful and wonderful meduse attracted their attention, and their investigations were thus led to the colonies which produced the free meduse; or the nematophores and conspicuous features of the gonosome of the Plumularide lured the student to the serutiny of these intensely interesting structures.

Third. Such investigations as have just been referred to led to a general understanding of the morphology of the Hydroida as a whole, and, as the Sertularidie offered little that appeared to be novel, that family was naturally passed by in favor of groups offering more interesting, because more novel, structures for investigation.

The writers who have contributed most to our knowledge of the morphology of this family. purely systematic work being excluded, are the following: Louis Agassiz, who gives an excellent and superbly illustrated account of Sertulerie pumile; ${ }^{3}$ Allman,' who discusses the gonosome of

${ }^{1}$ American IIydroids. I'art I, The I'lumularidae, 1900, p. 3.

${ }^{2}$ While this is true when the Sertularilie and I'lumularide are compared, it by no means follows that the Sertularide are of low mak when comprared with the hydroids in general. Indeet, quite the opposite is true if we admit the view now very generally adopted that the sessile gonophores represent decpraded medusie. This matter, however, will be discussed later.

${ }^{3}$ Contributions to the Natural Mistory of the United States, IV, 1562, 1\%. 326.

Monograph of the Gymnoblastic Iy 
Sertularia pumita and of Diphasia rosacea; Thallwitz ${ }^{1}$ describes the origin of the sex cells in Sertularelln polyzonias; de Varenne ${ }^{2}$ published a careful account of the reproduction of Sertularia pumila; Allman, in the introduction to his Report on the Cleallenger Hydroids, discussed the gonosome of Synthecium (p. xxv), and the origin of the sex cells in Sertularia pumila (p. xxxmi); Levinsen carried on important investigations regarding the operculum, and published the results in 1892 and $1893 ;^{3}$ Hartlaub, in his masterly work, ${ }^{4}$ discusses some morphological problems, such as the opereulum, hydrothecal teeth, and gonosome of Sertularella, although these discussions are merely incidental to the main purpose of the work, which is almost purely systematic.

One of my students, Mr. J. H. Paarmann, has done some excellent work, which has not been published, on the operculum. To these works I shall have frequent occasion to refer.

\section{TROPHOSOME.}

The general form of the colony in Sertularide is pinnate, the branches usually being on opposite sides of the main stem, the branches themselves being opposite or alternate. Simple, noncolonial forms are entirely lacking in this group, there being no such a thing as a mature hydranth with its hydrotheca entirely independent of others, ${ }^{5}$ as is found frequently in the campanularians among the Calypteroblastea, and a number of tubularians among the Gymnoblastea. As a result we find the usual outcome of the communistic idea, the subserviency of the individual to the colony as a whole, and a tendency toward a bilateral rather than a radial arrangement of branches. This may account for the fact that nowhere among the Sertularidre do we find a true verticillate arrangement of the branches, such as is found among the Campanularide in Campanularia verticillata, and among the Plumularida in Antennularice antennina. There are, however, a number of cases where the branches spring from all sides of the stem, as in several species of Thuiaria. In these cases we have the pinnate arrangement of branches modified by torsion into a spiral which may be rendered more or less obscure by the irregularity of the branching, but which is quite evident in Thuiaria thrija, for instance. A more open spiral is found in a number of species, illustrated by the very graceful colony of Sertularia argented and IIydrallmania fulcata. Unbranched colonies are uncommon in this family, although several are found in Sertularia, especially in the Desmoscyphus group, as, for instance, S. stookeyi (Plate V, fig. 6), and in the genus Sertularella several of the rugosa group, as, for instance, S. rugosa, are often unbranched.

Among the Sertularide are found the only species of hydroids that have regularly anastomosing branches, which sometimes form a rude mesh or network, as in Dictyocladium flabellum; and here also occur the only examples of hydrothecal branch origins that $I$ have seen in the order. This is illustrated in the genus Thecocladium, not represented in American waters, and also by sporadic cases which are not infrequent in the genus Sertularella, as, for example, S. dentifera Torrey (Plate XXV, fig. 1) and Abietinaria gracilis Nutting (Plate XXXV, fig. 1). In all probability, however, this occurs occasionally in other groups, such as the Campanularidx, although the present writer has not seen it there.

In size no sertularian yet reported reaches the maximum found among the Plumularidx. (See Part I, p. t.) The largest colonies that I have seen were those of Thuiaria cumessinu, that attain a height of about 18 inches under favorable conditions. Kirchenpauer, however, reports specimens from the mouth of the Elbe that are 2 feet in height. ${ }^{6}$ This is perhaps the maximum size reported for any sertularian. As a rule they are very much smaller, from 1 to $t$ inches being the ordinary proportions. Many, of course, are much smaller than the

${ }^{1} J$ enaische 'Zeitschrift, XVIII, 1885, p. 426.

${ }^{2}$ Recherches sur la reproduction des Polypes Hydraires, 1882, p. 27.

${ }^{3}$ Videnskabelige Meddelelser fra den Naturhistoriske Forening i Kjobenhavn, 1892, p. 22, and 1893, p. 41 et seq.

${ }^{4}$ Revision der Sertularella-Arten, 1900, pp. 10-12.

${ }^{5}$ An apparent exception to this statement is found in the case of Serlularella solitaria, a new species described beyond, which bears single hydranths on pedicels. It is possible, however, that the single known specimen may be immature and that the adult colony may resemble that of $S$. fusiformis.

${ }^{6}$ See Hincks, British IIydroid Zoophytes, 1868, p. 27\%. 
minimum just given. Mature specimens of P'tsythere quedridentutu, for instance, are sometimes less than one-fourth of an inch in height. It must be remembered, however, that height is not necessarily a true criterion of the actual size of the colonies. Dr. Dall found a specimen of Abietinuria gigented which consisted of 350 shoots, averaging 13 inches in length, estimated to contain $1,000,000$ individual hydranths. ${ }^{1}$

The Stem.-In by far the greater number of Sertularida the stem is a perfectly simple structure, being monosiphonic (consisting of a single tube), composed of the normal histological layers as found in the hydroids, divided into more or less recrular internodes. 'The regularity of the latter, however, is greater anong the Plumuluride than in the family under discussion. There are but two departures from this simple type of stem that are of sutficient importance to demand attention here. 'These are-

(a) The fascieled stem, as illustrated in Scrtulurelle gmyi. (Fig. 1). 'This consists of an aggregation of tubes that are closely adherent so as to form a compound stem made up of numerons tubes. There is a diflerence, which we will find to be more apparent than real, between the fascieled stem as found in the Sertularide and that found in many l'lumularida and discussed in the first part of this work $(p p .4-8)$, where there is a central or axial tube from which arise all of the branches and a number of peripheral tubes that do not grive origin to branches or hydrochadia, and therefore it (the axial tube) has receired the name "hydrochatiate tube." In Sertulurella guyi this state of attairs does not "plecer to exist. On the contrary, the branches seem to arise from almost any of these tubes which compose the fascicled stem. In figr. 1 we have a portion of the stem which has been boiled in potash to loosen the connection between the tubes in situ. 'The upper part has been disseeted with needles, so that the component tubes are separated. It is readily seen that the branches bearing hydrotheca arise from several of the tubes insteal of one. Sometimes these tubes seem to originate from one of the branches, as at $\ell$ in the figure, and pass downward, giving off another branch, as at $b$. A gain, one of the tuhes can be traced for a long distance without griving any indication of brunches. An cximmination of the point of attachment of this same specimen shows that the hydrorhiza appears to be made up of a continuation of these same tubes, which simply separate to form individual rootlets. I have

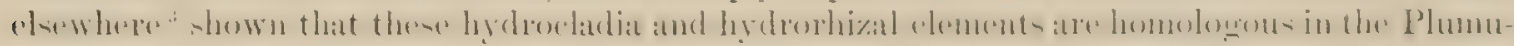
laride, and the same thing appears to be true here, and in some instances it is perfectly clear that the hydrorhizal elements sure modified hydrocladia.

A further dissection of this specimen, represented in fig. 2, clearly reveals that this is constantly true in $5 \%$ areyi. By carefully dissecting out the tube a $t$ wo find that it continues downward through the stem and is hydrothecate throughont, although the bydrotheca are completely covered by the other tubes when in normal relation, heing axial in the polysiphonic stem. We will therefore call it the axial tube. From the bases of the hydrotheca on this axial tube are eriven off branches which pass dommard in the form of tubes and in their normal relations form the accessory or peripheral tubes of the fitscieled stem. (Fig. 2, $(t, u)$. We thus tind that the accessory tubes are merely modified hydrochadia aring, as do the normal hydrocladia, from the bases of the hydrothece. Some of these accessory tubes thus formed give origin to other branches bearing hydrothece a long distance below the nctual origin of the tube. (Fig. 2, c.) It thus appears that all of the branches arise either directly (lig. "D, b) or indirectly from the axial tube, the dillerence being that in the latter case they arise from accessory tubes that are themselves really modified lrydrochadia.

This discovery is of great morphological and systematic importance, because it gives us a clue to the real origin of the accessory or peripheral tubes, a matter not hitherto explained in as stisfactory mamer, so far as I know, although I have found the same condition of alliars in the plumularian Cladocopus paratisece and in a species of Thecocarpus, but did not at that time see the full significance of the fact.

'Clark, Alaskan Hyiroids, 1876, 13. 2:30.

"The term "hyctrocladia" as applied to the I'lumularide signifies the ultimate branches which lear the hydmthece. It is not ordinarily used in connection with other groups.

s see l'art I, p. 7.

- See Part I, p. 6. 
By tracing downward some of these accessory tubes it is found that they end in hydrorhizal elements.

With these facts before us the entire manner of growth of such a fascicled stem becomes clear. The planula attaches itself, forms the primary hydranth, and grows upward in the form

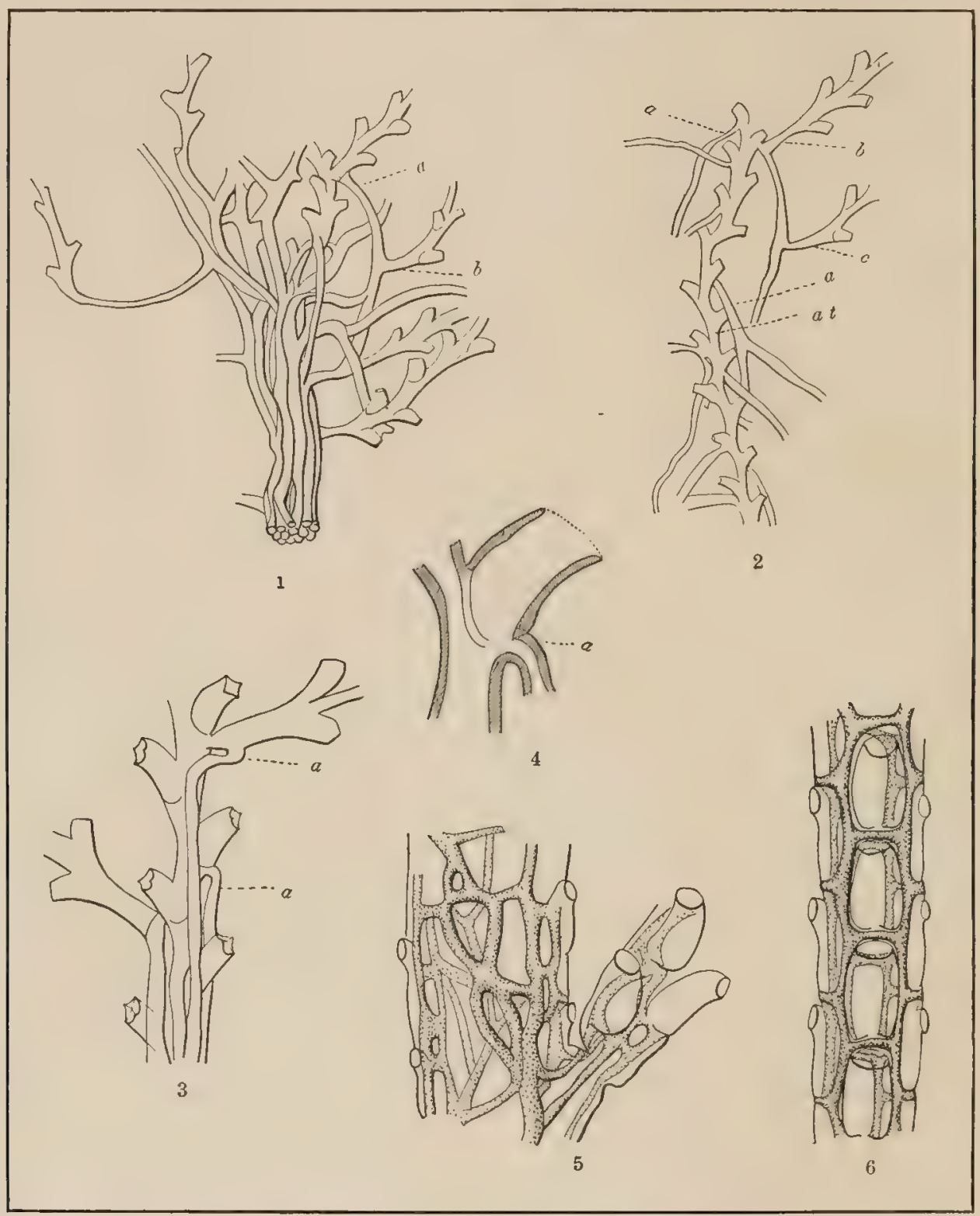

THE FASCICLED AND CANALICULATED STEM UF TIUE SERTULAKIDX.

Fig. 1.-Fascicled stem of Scrtularella gayi, partly dissected to show the origin of the peripheral tube (a), and the origin of a branch from the peripheral tube $(b)$.

Fig. 2.-The same specimen with the axial tube $(a t)$ dissected out. $a, a$, peripheral tubes dissectel out springing from the buses of hydrothece; $a t$, the axial tube; $b$, origin of branch; $c$, origin of branch from peripheral tube.

Fig. 3.- l'art of distal portion of colony, more highly magnified, showing origins of neripheral tubes at $a, a$.

Fig. 4.-A single hydrotheca, greatly magnified, showing origin of peripheral tube at a.

Fig. 5.-Purt of stem of Selaginopsis ornata, showing the extensive canaliculation of the conosare; the dotted jortions represent the conosareal canals.

Fig. 6.-A branch of the same specimen, showing regular arrangement of the conosarcal canals.

of an ordinary monosiphonic stem. It gives forth branches from the bases of the hydrothecre which at first form ordinary branches. As the colony becomes larger some of the branches turn immediately downward. become agglutinated to the original monosiphonic stem (now becoming the axial tuhe), and finally form a bundle of tubes which entirely conceals the axial tube and its 
hydrotheex, so that the presence of the latter would not be suspected without dissection. 'These branches (now become accessory tules) themselves grive off brunches and patss on downward to the base of the stem, where they spread for a short distance orer the base of attachment and function as hydrorhizal elements. We are thus able to homologize the ordinary stem of a

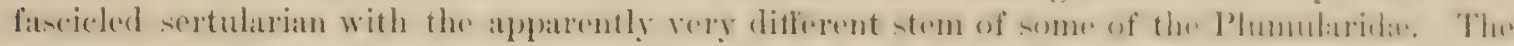

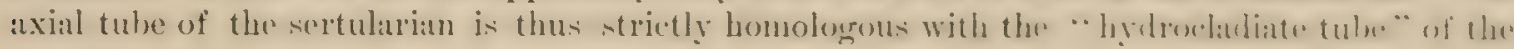
plumularian.

But we can extend this homolore mueh further. and find that it will apply to the peri-iphonic stem upon which Allman bases his family Perisiphonida. That writer says: ${ }^{1}$

There is among the Calyptoblastic Hydroids no more natural and distinctly definel family than that of the l'erisiphonide. The remarkable structure of the trophosome with its axial hydrotheca-bearing tube enveloperl by the peripheral facicle is, except in (Grammarin, quite unknown in any other (uroup); for this condition unst mot le confounded with the fasciculation of the stem which occurs in many Plumularinte and is common in IInlerium, Sermluria, Thuictin, and ofher genera, in which the component tubes are not divisible into an axial tuhe which carries the hydrothecie and peripheral tubes which are destitute of hydrothecae.

Our investigation of the stem of Sertularella gayi, however, has demonstrated that this species has just as clearly defined an axial stom as any of the Perisiphonide of Allman, the main difference being that the hydrotheca on the axial tube are completely hidden in S. guyi, while they project between the peripheral tubes and open on the exterior in the Perisiphonida. I3ut even this distinction disappears when we examine the stem of $S$. gayi near the point where the

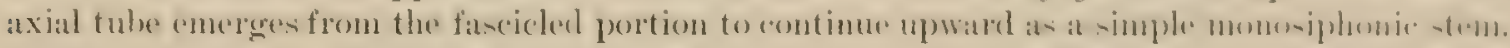
(See ligs. 3 and 4.) That portion of the stem which bears the hydrothece answers precisely to

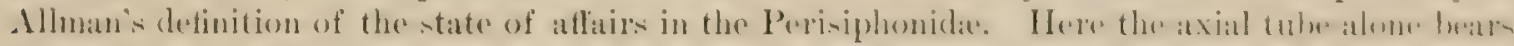
hydrothece, and the latter bear exactly the same relation to the peripheral tubes as they do in Perisiphonia, for instance. In this figure the origin of the peripheral tubes is plainly seen at ", ", and the relation of the component parts is not in any way disturbed by dissection, as is the case in the other figures.

Only one other sertularian with a fascieled stem is available to me for dissection, and that is Sertularella megastoma Nutting, which shows the same features of axial and peripheral tubes and the same origin for the latter as have been deseribed at length for Sevtulurella greyi. Sentularelle cutena, S. lata, S. pinnigera, and S. tropien also have fascicled stems; lut my specimens of the first two are too small to admit of dissection for this purpose, and I have not seen specimens of the others.

In none of these cases does there seem to be any cross connection between the various tubes such as is found in certain of the Plumularidie nor does there seem to be any sarcodal connection exeept at the point of origin of each tube. The tubes seem to adhere together by virtue of the gelatinous consistency of the chitin of which their walls are formed.

(b) Stems with conosareal canals are found in a few Sertularidie. Morpholorrically these do not appear to differ appreciably from those found in the plumularian crenus Antemulurin. ${ }^{3}$ This feature is not always apparent, even when present, and in specimens that have been poorly preserved all trace of it sometimes disappears. The best illustration that I have seen among the Sertularide is found in the genus Selaginopsis. In a new species described heyond, s. ormetn. the conosarcal canals are very regular and symmetrical, there being four canals in each branch, one canal to each of the four rows of hydrotheca, and frequent and regularly spaced crossconnections between the canals themselves form a ladder-like structure. with a round of the laddor beneath each hydrotheca. (See fig. 6.) In the main stem of this same species there is an excedingly complex system of anastomosing camals that does not exhibit the recrularity of arramernent found in the branches. (See fig. 5.)

The mode of origin of the cmaliculated conosare is not well understood. Allman's investigations of these canals "in Antemuluria would lead one to suppose that the young colony hats at

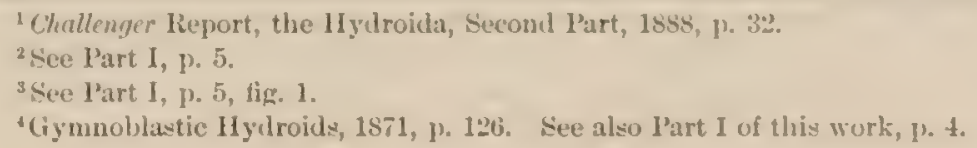


first an ordinary monosiphonic stem, and that the cunaliculations are formed by portions of this common conosare becoming surrounded by tubes of chitin, learing the center of the stem entirely vacant, the canals being peripheral. I am not satisfied, howerer, that each of these canals is surrounded by perisare.

The Branches.--There is but little that is characteristic to be found in the branches of the Sertularida. Their disposition has already been discussed. They never' become highly specialized to form protective structures for the passive or active defense of the gonophores, as they so often do in the Plumularida, where they form the curious phylactoearps. They do, however, become modified to form accessory tubes in the fascicled stem, as we have seen, and they often

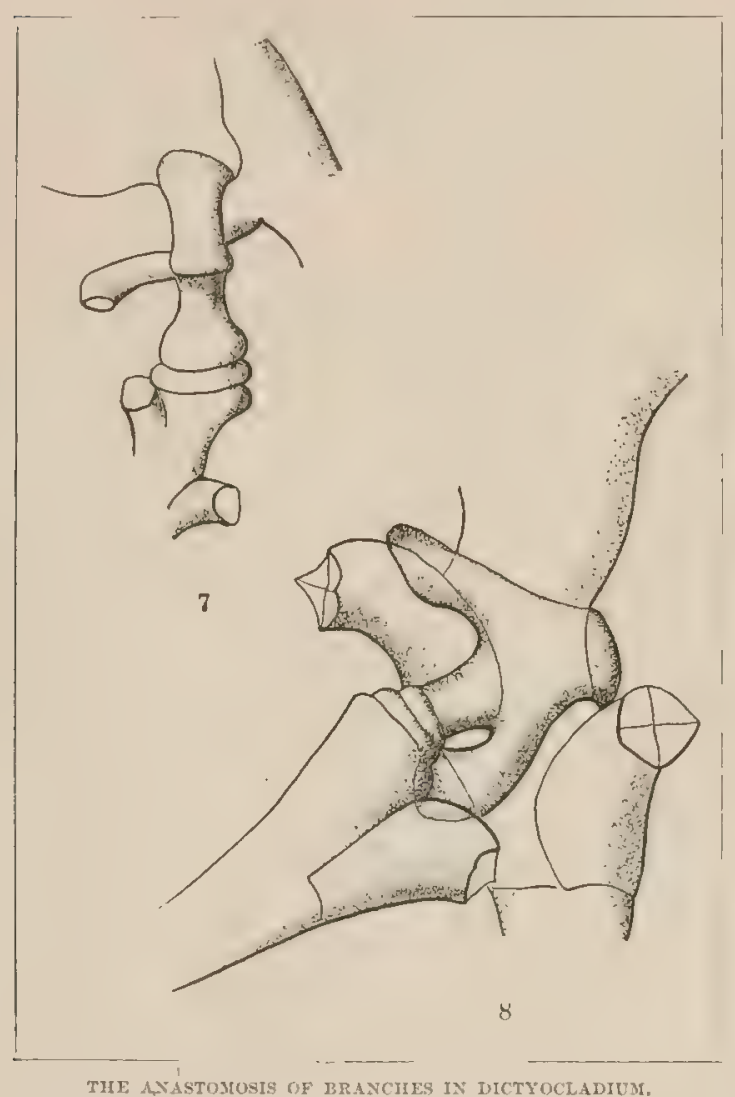

Fig. 7.-Tip of branch of Dictyoclalium flatellum clasping another branch.

Fig. 8.-Another branch termination which forms lobe-like processes to secure firmer attachment to another branch. become tendril-like at their distal ends and clasp other branches so as to form anastomoses and sometimes a flabellate structure, as in the genus Dictyocladium.

There appear to be two methods by which the attachment of these new tendril-like branches is formed. In D. Tichotoma, "when a branch is destined to form a union of this kind its distal extremity becomes elongated into a tendril-like continuation destitute of hydrothece. When this meets a neighboring branch, the end of the tendril unites with a branch, not howerer with any part of the surface of the branch indifferently, but, directing itself toward the orifice of a hydrotheca, it here attaches itself, its axis becoming dixectly continuous with that of a hydrotheca." 1 In the only other species of the genus thus far discovered, $D$. Habellum Nutting, the connection is formed much more simply. The tip of the tendril-like process grows around the branch that it meets and clasps it very much as does the tendril of a vine. (Fig. 7.) The adhesion is quite strong and permanent, and the clasping portion of the tendril may become eventually embedded in the branch so as to be hard to see, being indicated merely by a swollen area over the original point of contact. Sometimes the growing tip upon meeting a branch spreads out in lobular projections, thus increasing the extent of the surface of adhesion, as in fig. 8 . This same method of joining different branches is found quite commonly in sereral species of Sertularella, especially those of a straggling habit of growth, such as S. dichotome and $S$. elegans.

A merely temporary joining of the tips of hydrocladia has been reported in the case of a species of Aglaopheniu. ${ }^{2}$ This, however, seems to be for an altogether different purpose from the one subserved in the examples described above, and served to join two colonies, apparently for the purpose of conjugation.

I have seen no sertularians, aside from the genera Sertulurellu and Dictyocladium, in which anastomoses of branches occur, except perhaps as a rare abnormality.

The IIyctrenth. - I bave been unable to find any evidence of the hydranth being studied with care in any sertularian, at least since modern histological technic became available. Without this aid, however, Lonis Agassiz was able to make ont most of the essential points, even of histo- 
logical structure, especially in the matter of the relation of the cell layers. Indeed, the more one studies his masterly work the more profound becomes the conviction that a careful and thorough use of good powers of observation and interpretation applied to living or at least fresh material is capalole of yielding results that will bear comparison with those attaned with the use of the most advanced technic.

'The writer does not believe that any' worker has done more to clucidate the entire subject of hydroid morphology, at least in the groups investigated hy the ofder A gassiz, than has that writer himself. His is the only good description that I have been able to lind of the sertularian hydranth.' 'The subject of one of his careful studies is the common Sertularic pumilu, and he reports the following points regarding the hydranth: ${ }^{2}$ 'The conosarc of the stem consists of two cell layers. In the stem this is of uniform thickness to a point just below the hydrothece, where it expands on two opposite sides, giving otl eylindrical extensions which are uniform in diameter and pass through the diaphragm at the base of the hydrotheca, traverse the length of the latter, and terminate in a simple, short, conical proboscis, around which a single row of slender, tapering tentacles, nsually sixteen in number, is disposed in a uniform series. The extended hydranth hats no thicker ectodern than in the main stem, but the endoderm is twice as thick, although the ectoderm and endoderm are ahout equal in the stem. The cetoderm of the body wall is connected in places with the hydrothecal wall by filmlike projections or pseudopodial prolongations.

So far as the present writer has been able to ascertain, the hydranths of all of the Sertularide are very similar to those of S. pumilu, having a conical or dome-shaped prohoscis and a single whorl of filiform tentacles. (Fig. \%) It is seldom that the hydranth can be studied to adrantage in preserved specimens, us they are usually either in astate of contraction or have been macerated or in some way disintegrated

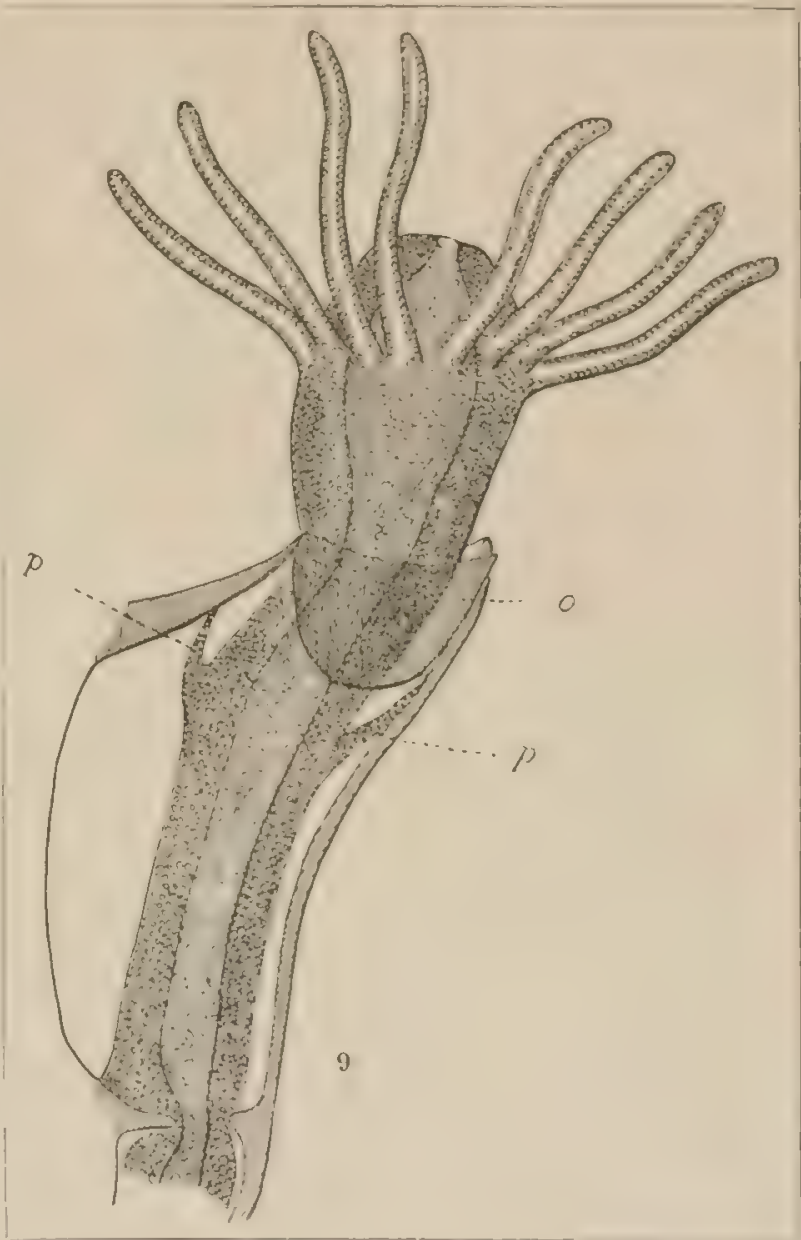

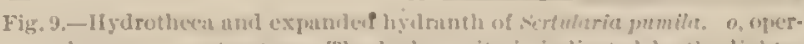
culum; $\mu, \mu$, protructors. The lexly cuvity is indiented loy the lighter axial portion of the hydranth.

in the preserving fluid. If care is taken, however, it is possible to preserve cxpanded hydranths of shatlowswater forms by the methods of killing recently devised. It seems useless to expect that we shall ever be able to study the living and expanded hydranths of deep-water species.

As indieated in Part I of this work, ${ }^{3}$ there is but little difference between the hydranths of the Plumularide and Sertularide, the main distinction being in a constriction some distance below the tentacles of the former which divides the hydranth hody cavity into two portions, which, however, communicate broally.

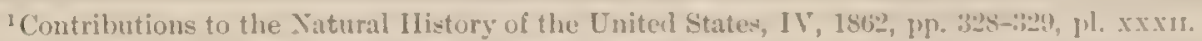

${ }^{2}$ The terminology need lw I'rofessor Igassiz is so different from that now in vogte that I lave thought it best to give the following points in more modern phraseology for the sake of lucidity.

${ }^{3}$ l'age 9. 
There are certain special features of the hydranth in this group, however, that are worthy of presentation, one of which is what may be called the protractor of the bydranth. This is a band of tisuse, probably ectodermal, that originates from a point on the hydranth hody ahout halfway between the tentacles and hase on the abeauline side and passes ohliquely upward and outward till it meets the inner surface of the abcauline wall of the hydrotheca, where it is firmly attached. (See figs. $10,11,12 p$ ). It is obvious that a contraction of this band would aid in the protraction of the hydranth, and also in the initial stages of its retraction. 'The best examples of this structure that I have seen are in certain species of Sertularella, as S. magellanica (fig. 10), S. levinseni (fig. 11), and S. megastoma (fig. 12). Hartlaub, in discussing this structure, ${ }^{1}$ says that it is formed before the diflerentiation of the tentacles and is evident upon the first withdrawal of the hydranth, and that in many species this hand of attachment ("Inftzipfel ") makes a mark ats if it were a septum instead of a band, which divides the dorsal (abcauline) part of the hydrotheca into two chambers. That portion of the hydranth body wall to which the band is attached seems to

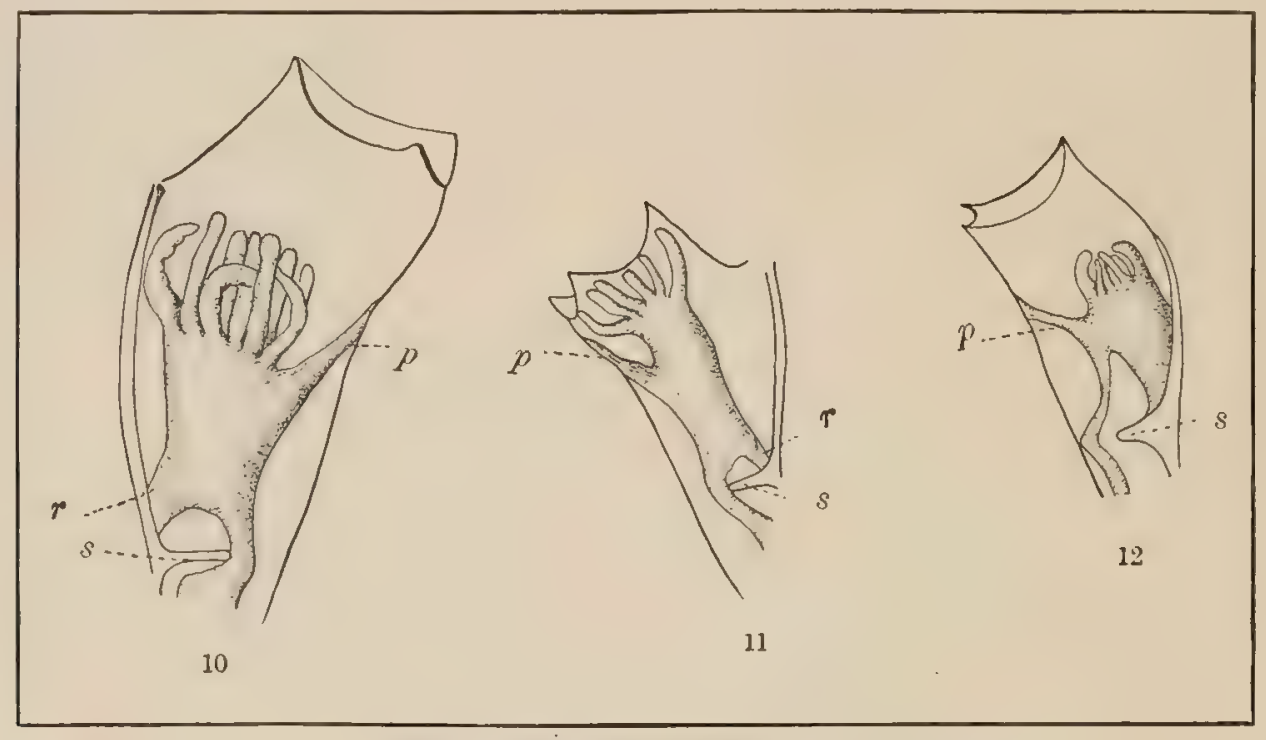

RETRACTED HYDRANTHS, SHOWING PROTRACTORS.

Fig. 10.-Scrtularclla magcilanica. p, protractor; $r$, retractor; $\varepsilon$, septum.

Fig. 11.- Siertulavella levinecni (lettering the same).

Fig. 12.-Siertularclla meyastoma (lettering the same).

be stretched outward into a hernia-like protuberance which contains a sack-like divarication of the hydranth body cavity. 'To this latter Hartlaub has given the name "Blindsack." (Fig. 13, bs.)

In the material at my disposal it is difficult to ascertain the relationships of the various parts in the proximal end of the liydranth and bottom portion of the hydrotheca. In many species of Sertularella the septum at the bottom of the hydrotheca extends more than halfway across from the adcauline to the abcauline side, leaving an aperture that is unsymmetrically placed, being on the abcauline portion of the bottom of the hydrotheca. The connection between the hydranth and the sarcode of the stem passes through this aperture. (Fig. 14 $s c_{\text {. }}$ )

It appears that a large portion of the bottom of the hydranth is permanently attached to the septum, and this part of the bydranth corresponds to the foot of the hydra. At times this portion of the foot seems to be muscle-like in function and to work in opposition to the protractor mentioned above. It thus serves functionally as a retractor muscle, and secures its point of resistance on the upper side or face of the septum. This condition of affairs seems to be common in those species that have a well-developed protractor on the abcauline side, and this fact would seen to support the view that it works functionally in opposition to the latter.

\footnotetext{
${ }^{1}$ Revision der Sertularella-Arten, 1900, pp. 10, 11.
} 
The blind sack is very well shown in Abictinerin ubietinu (figs. 13-16i), where it is perfectly

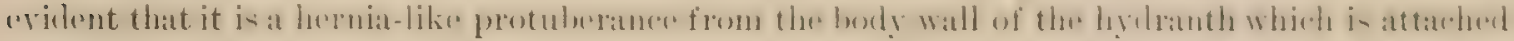
to the hydrothecal wall by a band of ectodermal tissue. That the structures just deseribed are very widely distributed among tlie Sertularida is proved by the fact that I have found them in one or more typieal species of the following anenera: Thuiario, Sertularia, Synthecium, ISydrall-

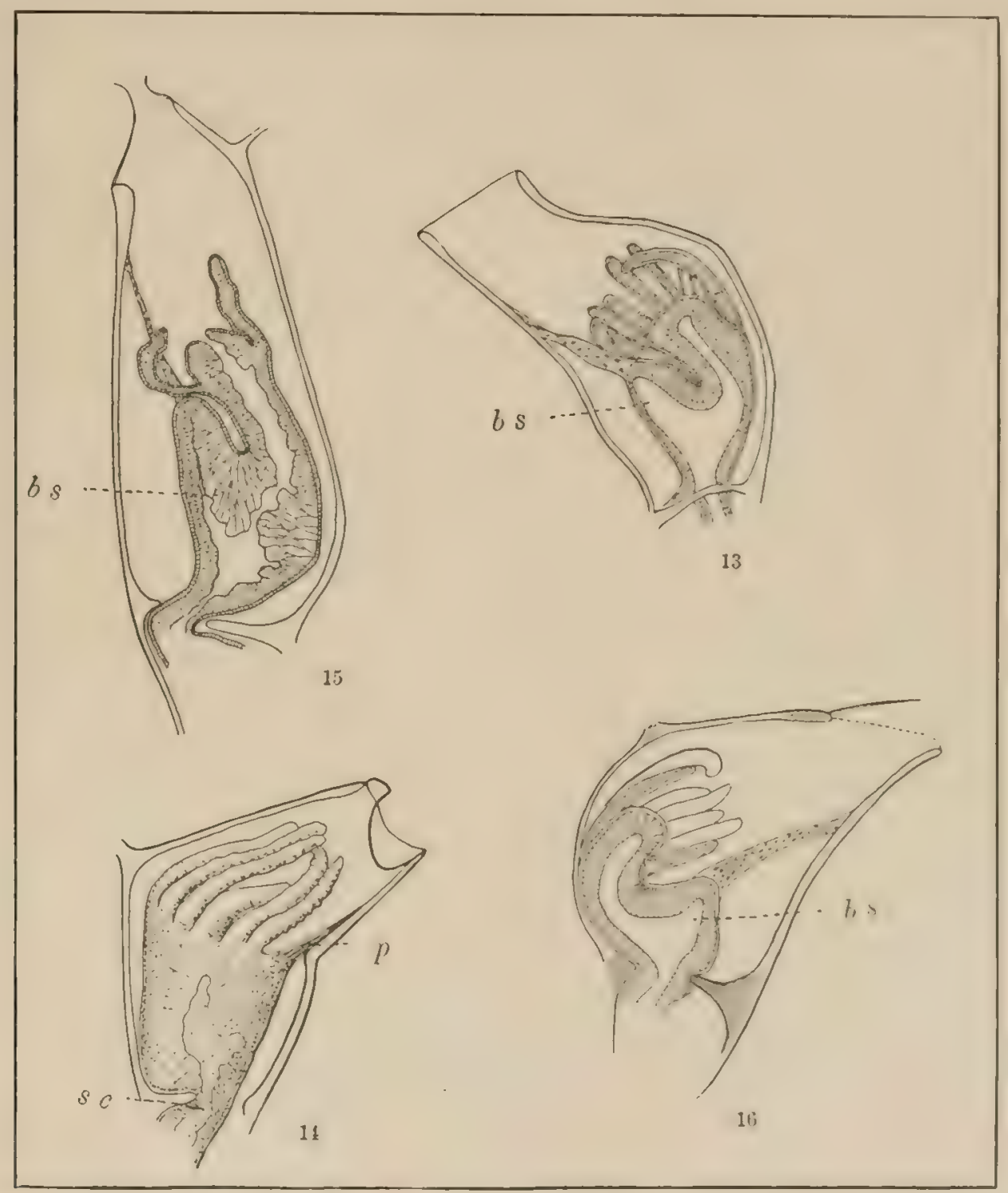

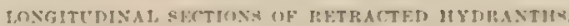

Fig. 13, $\rightarrow$ Abirtinnria nbitina. $b$, blind sack.

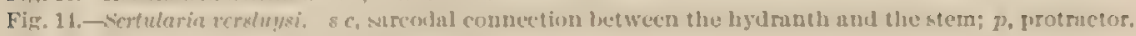

Fig. 15.-Thuinrin robuste. $b$ \& blind suek.

Fig. 16.-Lictinariu trakki. bs, blind mek.

mania, Sctarginopsis, Diphessin, Abietinaria, Dictyocladium, and Sertulurelle. In Semtulavin pumila there are apparently two protractors on opposite sides of the hydrunth. (See fig. 9, p. 9.) These may be the structures referred to by Lonis Agassiz as "film-like projections or" pseudopodial prolongations" by which the ectoderm of the body wall is connected with the wall of the hydrotheca. A still more striking case in which two protractors are present is found in Diphasia digitalis. (See tig. 17.) 
Hartlamb ${ }^{2}$ says that he has seen the blind sack filled with food particles, and suggests that it may function as the stomach of the hydranth. It is not improbable that it may share this function with the rest of the body eavity of which it is merely a divarication, but $I$ see no proof that it assumes the full burden of the digestive function. This writer also calls attention to the fact that the adcauline wall of the sack has an endodermal lining of columnar epithelium like that of the body cavity in general, while the abcauline wall is lined with ordinary endodermal cells. (Fig. 15.) He suggests that the blind sack may have something to do with the renewal of the hydranth, but does not support this suggestion with any definite proof. He doubtless infers that the undifferentiated endoderm of the sack must be eapable of some function other than that performed by the columnar epithelium, and this may have given rise to the suggestion regarding the connection between the blind sack and regeneration. He says that this structure is absent from the Campanularido in general, and believes that it constitutes a good systematic character by which that (group may be separated from the Sertularida. It is doubtless true that this important structure has been altogrether too much neglected by systematists. The present writer, however, desires to make a critical study of it in connection with the other groups before adopting it as a criterion for the division of family groups.

In several species of Sertularella, as S. dichotoma, and in the Desmoscyphus group of Sertularia, there is an internal ridge on the abcauline wall of the hydrotheca that corresponds to the intrathecal ridge in the Plumularide and appears to be for the firmer anchorage of the protractor. (Fig. 20, r.)

But one other feature pertaining to the hydranth need be discussed here, and that is the structures that are supposed to be muscles for the closing of the operculum. I have been unable to find them as a constant feature in any one species. Hartlaub figures them as present in Sertularella goyi $i^{1}$, but they are certainly not at all constant in that species.

While I have found a number of cases which I at first was inclined to consider as opercular muscles, they were found on closer examination to end on the margin of the hydrotheca, and not to reach the operculum at all. In such cases it is reasonable to interpret the structures rather as protractors than as opercular muscles. (See figs. 17-19, o m.) In other cases the muscular bands end freely in the upper part of the hydrothecal carity, as if they had been torn from their attachments. These may be opereular muscles, but until they are found connected directly and definitely with the operculum the writer belieres that it is wisest to refrain from ascribing to them a definite function in connection with the opercula. It must be remembered that the bydranths at times send forth all sorts of projections from the ectoderm toward the hydrothecal walls, and doubtless these are occasionally attached to the operculum. But we have as yet no evidence that such attachments are permanent or constant, as are the protractors described above. Hartlaub, who copied the figure mentioned abore from Allman, is not at all convinced that there are such things as retractors of the opercula, and suggests that Allman was mistaken in his interpretation, as it often happens that one or more tentacles of a retracted hydranth remain with their tips attached to the opercula. The present writer has not seen instances of this. In one case (fig. 18) there is a structure that looks a good deal like a retractor of the opereulum. The figure was taken from a section, and it appears that the long sareodal process from the hydranth is directly attached to the operculum, but it may not be ar retractor at all, but simply one of the many processes thrown out by the hydranth under certain conditions, particularly when the latter is about to begin the process of disintegration. The mechanical necessity for retractors to the operculum does not seem at all evident. The valves are so arranged that they would naturally fall back into place upon the retraction of the hydranth, and this action is probably aided and hastened by the elasticity of the chitinous material of which they are composed.

In size the Sertularian hydranth does not differ appreciably from that of the Plumularida, although they average somewhat larger. Although they are almost always retracted in preserved specimens they are still available for study, while those of the plumularians are usually entirely absent in specimens preserved in alcohol or formalin. Hartlaub says that the proboseis is

${ }^{1}$ Revision der Sertularella-Arten, 1900, p. 11. 
trumpet-shaped in well-preserved specimens, but I have not been able to verify this observation; and those specimens that $\perp$ have seen alive, as S. pumila and $S_{0}$ comicina, have invariably had true conical proboscides like those of the Plumularide. I have also seen the expanded living hydranths of Sertularella polyzonias and Thuiaria argenter, and here, too, the proboscis was conical.

The Ilydrothecre. - All of the Sertularide being colonial forms the individuals, as already indicated, are subordinate to the colony as a whole. None of the hydrotheese in this (rroup are furnished with pedicels of any considerable length, ${ }^{3}$ and the sessile condition has resulted in a true bilateral symmetry that seems to be universal in this family and the Plumularida. 'The

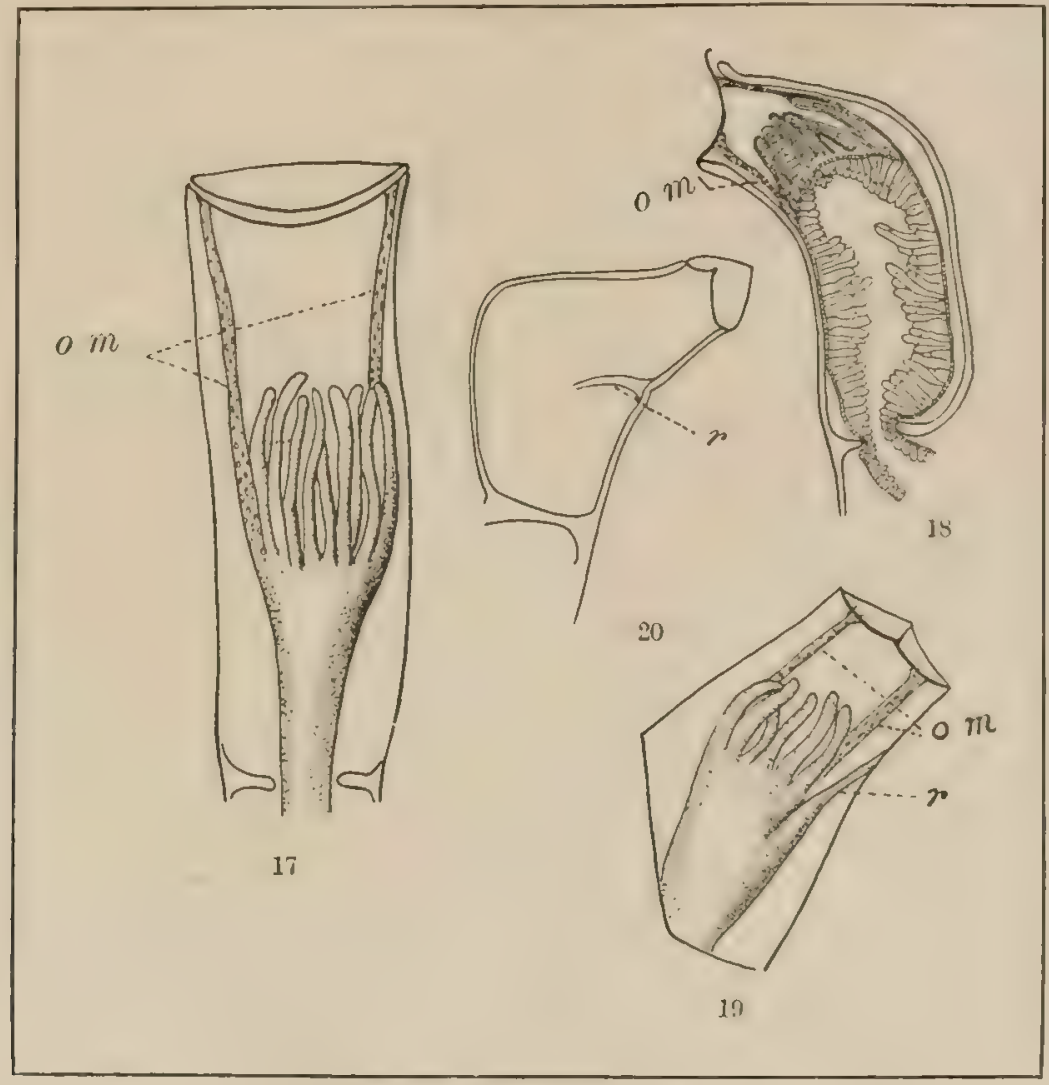

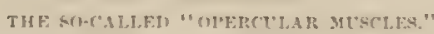

Fig. 17.-lliphasia digitedis. o zh, opercular muscle.

Fig. 1s,-Thuiaria sy). o $m$, upercular musele.

lig. 19.- vertularelle mrgnstomu. a m, opereular musele; $r$, rutractor muscle.

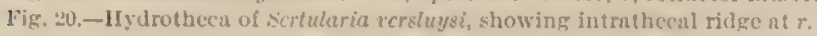

reason for this seems to be that the stems and branches upon which the hydrotheca are sessile are in general more or less erect, or at least not horizontal in position. The normal posture of the hydranth is erect or nearly so, the mouth being directed upward.

Hence the axis of the hydrotheca forms an acute angle with that of the stem or branch upon which it grows, and as a result the adeauline side tends to be shorter than the abeauline. In other words the posture of the hydranth determines the inclination of the hydrotheca in the Sertularide, while the flexihility of the pedicel in the Campanularidie permits the hydranth to be directed upward without disturbing the radial symmetry of the hydrotheca. It thus comes ahout that the sertularian bydrotheca tends to assume a symmetry that is bilateral rather than

${ }^{1}$ If the sertularella solituric describu in this work (see Plate $\mathrm{IX}$, fies. 10, 11) is alult, as seems altogether likely, it would be an exception to this statement, as the hydrothece in this species hare pedicels of considerable length. 
radial. Of course this symmetry is often interfered with, particularly where the hydrotheca has a curve that is not in the vertical plane, as is the case with many species in which the hydrothece curve forward as well as outward and upward, as Sertularella pinnata (Plate XXI, fig. 10), and S. allmani (Plate XVIII, fig. 3). Again the implantation of the bydrotheca may be upon the front rather than upon the sides of the stem, and thus we have a difference between the front and back, as well as between the adcauline and abcauline sides of the hydrotheca as in the case of IIydrallmania fulcata (Plate XXXVIII, fig. 1), and in the Desinoscyphus group of Sertularia (Plate I, fig. 7). That the bilateral symmetry is the result of the mechanical causes referred to is rendered all the more probable from the fact that the primary hydranth of many species of sertularians is seen to be radially symmetrical if observed at a very early stage in its developement. If we examine very young specimens of Sertularella rugosa, for instance, we find that the primary hydranth is at first mounted on a distinct pedicel like that of a campanularian, and is radially symmetrical (see fig. 21).

It very shortly, however, becomes bilaterally symmetrical by the production of a protuberance on one side of its base, and this protuberance shortly gives rise to a second hydrotheea. 'This seems to indicate that radial symmetry is the original condition and bilateral symmetry a later acquisition in the group, brought about by mechanical causes relating to the necessity of adjusting the sessile hydrothece to the hydrociulus. The condition of affairs described above

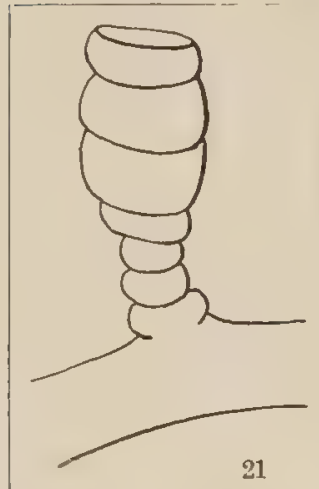

Fig. 21,-Very young hydrotheer of scriblarella rugosa, showiug radial symmctry. is true only of those species having alternate hydrothecæ. When they are strictly opposite, the two terminal hydrothece are produced together, and hence such species produce primitive pairs of hydrothecre that are necessarily bilateral.

In almost all species of sertularians the several hydrothecre of the mature colonies are substantially alike, the only notable exception being in the genus Pasythea, where the hydrotheca are in groups of pairs and no two pairs in a given group are alike either in form or size (see Plate XIII, fig. 4).

With the exception of the genus Selaginopsis all of the American sertularians conform to the bilateral plan not only in regard to the shape of the individual hydrotheca, but also in the arrangement of the hydrothecre on the stem and branches (see fig. 32). This is due to the fact that the hydrothece are arranged in two usually opposite rows. If a branch of such a species should be split vertically from front to back it would be divided into two equal and symmetrical parts. When the hydrothece are alternate, these two parts would be similar but not symmetrical. The same is true in Ilydrallmania, where the hydrotheca are all in a single row but have their distal ends bent alternately to the right and left. In Selaginopsis the hydrothecre are arranged in more than two rows, in one case, S. decemserialis, there being ten longitudinal rows. In this genus there is not only the regular vertical arrangement of hydrothece, but a spiral arrangement as well.

The hydrothece vary greatly in different species both in size and shape. In general they are much deeper in proportion to their diameter than those of the Plumularidie. Perhaps the most common form is more or less tubular, with the distal end bent to one side, as in Sertularia pumila. Most species of the genera Sertularia, Synthecinm, and Thuiaria have hydrothece of this type, which reaches its most perfect form in such species as Synthecium rectum (Plate XLI, fig. 2).

Sometimes the tube is not bent, and the hydrotheca becomes an almost perfect cylinder, as in Sertularella formosa (fig. 22) or Synthecium cylindricum (Plate XLI, fig. 7). Again it may be so short, truncated, and expanded at the base as to resemble the frustum of a cone, as in Sertularella hartlaubi (Plate XXVII, fig. 5). The cylindrical bydrothece, like all others among the Sertularide, vary greatly in the extent to which they are immersed in the hydrocaulus, sometimes being attached to the latter by their extreme base only, as in S. quadrata (fig. 23); or it may be immersed to the margin all around, as in Sertularella distans (Plate XIX, fig. 6) or Sertularella lata (Plate XVIII, fig. 10). Every possible intergradation between these two extremes can be found. Sometimes great variation occurs in a single colony, as in the case of Sertularella magellanica 
(Plate XXIV, figs. 6,7), where the hydrothece atre almost cntirely exwerted on the proximal part and more than hall of their adcauline wall is achate in the distal parts of the colony. This condition, however, is quite exceptional, the extent of immersion being much more constant us a

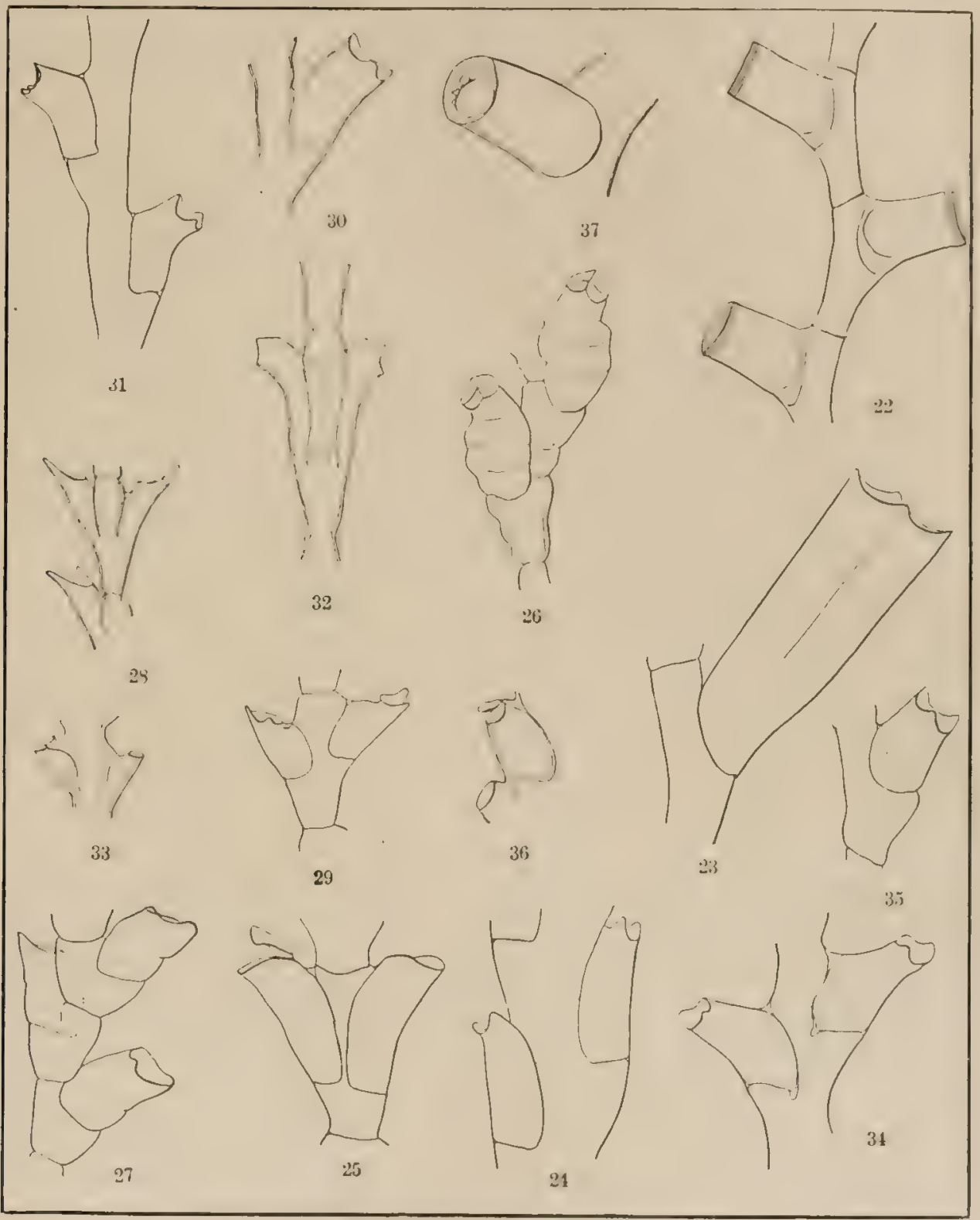

F'ig. 2.!- - verlularella formona

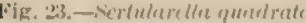
Fig. "1.-Thninrin robuste.

Fig. 25.-Diphersine fullar.

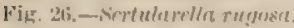

Fig. 27 , - vertularclla pinnetu.

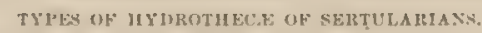

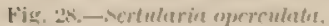

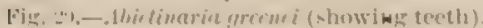

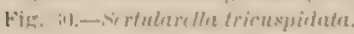

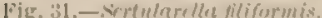

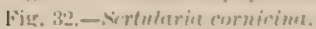

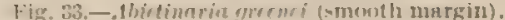

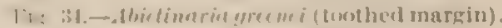

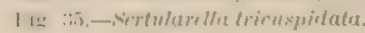

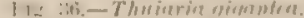

lis. 37.-ivetulurelle jurmoste.

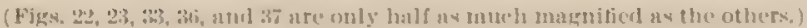

rule. The departures from the eylindrical form of the hydrothece are almost innumerable, but can most of them be reduced to the following types:

(a) Flaxk-shuped, in which the basal part is swollen, and the distal part constricted and often bent. Illustrated by many species of Thuiurie, such as $T$. robustu (tig. 2t), $T$. polycerpu (Plate $5125-\mathrm{PT}^{2} 2-0.4-2$ 
VIII, fig. 8), and T. immersa; in several species of Sertulariu, as S. desmoides (Plate III, fig. 2); and in Sclayinopsis, as S. cylindrica (Plate XXXIX, figs. 7 and 8).

(b) When the neck of the flask becomes elongated and curved to one side, we have what may be called the "bottle-shaped" hydrotheca, which is characteristic of the genus Lbietinaria as used in this work and well shown in such species as A. whetinc (Plate XXXII, fig. 1), A. varitbilis (Plate XXXI, fig. 5), 1. fracilis (Plate XXXV, fig. 2). The bottle-shaped hydrotheca intergrade with the llask-shaped hydrothece on the one hand and the triangular forms on the other.

(c) Pitcher-shuped hydrothece are found in certain species of Diphasiu, as D. fullux (fig. 25), D. rosace (Plate XXVIII, fig. 4), D. parmanni (Plate XXXI, fig. 5), and occasionally in Sertulerella, as in S. episcopus (Plate XXVI, fig. 7). Such forms are produced by having the margin of the hydrothece expanded and sinuous on the abcauline side so as to resemble the lip of a pitcher.

(d) Burrel-shaped hydrothece are round, with both distal and proximal ends slightly diminished in diameter, and both upper and lower profiles convex. They are more nearly radial in symmetry than most of the others, and are found almost exclusively in the genus Sertulurellu, as S. migosa (fig. 26), S. areyi (Plate XVII, fig. 6), S. goniculuta (Plate XVI, fig. 2), S. putugonica (Plate XVI, fig. 3). This form is usually provided with a square collar, which interferes with the symmetry of the "barrel." In S. tumneri (Plate XVI, fig. 1), a very large and beautiful hydrotheca is seen which, in some instances at least, attains almost a perfect barrel shape.

(e) When this latter type is greatly elongated a slender terete outline is produced, which gives the typical fusiform hydrotheca, which is very rare, illustrated by Sertularellu fusiformis (Plate XX, fig. 3), and less perfectly by S. giganter (Plate XIX, fig. 7).

$(f)$ In a few cases the axis of the hydrotheca is straight and the base expanded, while the diameter gradually decreases toward the distal end. Thus a conoid form is produced, which is guite rare. Illustrated by Abietineria alexanderi (Plate XXXV, fig. 5). If the distal two-thirds of such a hydrotheca were cut off, we would have such a form as Scrtularella hartlaubi (Plate XXVII, fig. 5).

(g) Triangular bydrothece. In a few cases hydrotheex are triangular in outline as viewed from the front, being bounded by three approximately straight sides. This occurs in the Desmoscyplus group of Sertularie as S. verstuysi (Plate I, fig. 9), in which the two imner sides of a pair of hydrothecx are contiguous and pressed together so as to form a straight line, and the aperture at the supero-lateral angle is very small. The triangular outline is also approached in Abietinaria traski (Plate XXXIII, fig. 10).

(h) Perhaps the rarest form of hydrotheca is one that approaches a parallelopipedon in shape, having a quadrate cross section and four parallel sides. This form is well shown in Sertularella quadrate (fig. 23), and in S. cylindrithece (Plate XIX, fig. 1). A combination of this form and the barrel-shaped hydrotheca is found in Sertularella rugosa, where the upper part of the hydrotheca is modified in shape so as to be square in section, while the remainder is barrel-shaped. The extent of immersion varies greatly in most of these types, but is probably most complete in some species of Thuiuria, as T. immerse (Plate IX, fig. $t$ ), in which the entire bydrothecal margin is sunk to the general level of the hydrocaulus so as to be flush with it all around.

There is in general a pretty close allserence to type in the hydrothece of a given species, the most notable exception being the case of Pusythen quedridentata (Plate XII, fig. $t$ ), in which the hydrothece are arranged in groups of pairs, no two pairs in a group being alike, the upper pair being smaller than the lower and more or less quadrate in outline. A slight approach to the same condition is found in the case of Thuiuria tubuliformis. On Plate XI, fig. 2, for instance, the lowest pair of hydrothece is much broader from margin to margin than the next pair. Another and more evident example is found in Sertulurie mayeri (Plate V, figs. 1, 2), where the hydrothece on the basal part of the stem are much longer than those on the distal part, and are bent abruptly outward, forming nearly a right angle at their middle portion. 
The ornamentation of the hydrothecal surfue in the sertularide is eflected mainly by annulations, stria, and reduplications of the maregins, and each of these is confined mainly to the grenus Sertulurdlle. The rugosities are sometimes contined to the free part of the adcauline side, as in Sertulurella greyi (Plate XIV, fig. 1), N. emicu (Plate XV, fig. 1), and S. cutcree (Plate XV, fig. 3). Often they are continued entirely around the hydrothecal wall ats in the mupose group. Ordinarily this latter condition is assochated with the quadrate neck, but a notable exception is found in a new species with very large barel-shaped hydrothece, S. tanneri (I'late XVI, fig. 1). Anmulations difler from ruerosities in being finer and more sharply cut, although the terms are often apparently used as if they were interchangeable. $\Lambda$ notable instance of this style of ornamentation is found in Dipheaxir eropice (Plate XXX, fig. 1), in which the entire hydrotheal wall is marked with very the but greatly laised annulations, the outer surface of which is so fine as to be linear. If the bottoms of a pile of very thin dinner plates were removed, and the remainder of the plates fitted to a cylinder, they would represent fairly well the structure of these annular ridges. 'There is but one species that I know of with longitudimal markings like ribs or coste, and that is Sertulurelle ereyi (1'ate XVII, fig. 6). Strie are simply very tine anmulations ruming in a parallel direction. These are well shown in sotulemella pradratu (Plate $\mathrm{XV}$, fig. 5). Under favorable conditions of illumination the entire surface of the bydrothecal walls is seen to be marked by these fine, closely set lines.

The hydrothecal aperture is largely determined by the shape of the margin and the marginal teeth. Most commonly it is round or oval in shape (fig. 3is); of ten it is quadrate, as in the moga group of semelevelle, or in S. quedrete; rarely it is lunate, as in Thuierie diftere (Plate X, fig. 2). The margin is often more or less everted, as if rolled outward, as in the case of Synthcoium tubithecum (Plate XLI, fig. 1); or it maty be expanded, as in sortulurella pinnute (fig. 27) and S. elergens (Plate XXIV, fig. 1); or sometimes it is contracted, as in Sertularic versluysi (Plate I, fig. T) or Abretimurie traski (Plate XXXII, fig. 10).

'The ornamentation of the hydrothecal margin is sometimes in the form of a distinet narrow band or rim, as in Sertulurelle formese (fig. 22), Synthecinn rectum (Plate XLI, fig. 2), or Sep. tuldedlu distans (Plate XIX, tig. 6); or it may be effected by means of closely approximated circular striations, as in ibietinaria aleeenderi (I'late XXXV, fig. 5) or Synthecium marginatum (Plate XLI, fig. 3).

'The reduplication of the margin often seen in the Sertularida, but displayed best in Iralecium, seems to be produced by periodic and successive stages in the growth of the hydrunth, or, as Levinsen seems to have shown, by the suceessive renewal or regeneration of the bydrunth. In this latter case each reduplication represents a complete regeneration of the hydranth occupying the hydrotheca. 'These reduplications produce the appearance of a number of false margins below but parallel with the functional one. There are many illustrations of this among American forms, such as Synthecium tubithecum, Sertulardla juedratu, S. dentifere (Plate XXV, fig. 2), and $S$. gigantece.

'The marginal teeth of the hydrothece, whatever their origin or function, form a character of the very greatest importance from the standpoint of the systematist, and are therefore worthy of eareful consideration. They consist of more or less evident prominences projecting from the margin and following in general the direction of the hydrothecal walls from which they spring. They vary ereatly in size, form, and position. Nany hydrothece are entirely destitute of marginal teeth, in which atse the margin is defined as even, plain, or sinuous.

The even margin is common in Thuiura (fig. 36), Selarginopsis, and Abietinurie, and is present in all species of Synthecium thus far described. It is only exceptionally present in Sertularia, as S. desmoides (Plate III, tig. 1), and in Sertularelle, an in S. fimmosa (fig. 22) and S. hartlaubi. The sinuous margin is found in several species of Diphessin, as in I). rosacen, in which the margin exhibits broad and low undulations, which are not sufliciently pronounced to be called teeth. 'This form of margin often produces the eflect of the mouth of at pitcher, and is usually found in connection with the "pitcher-shaped" hydrothece. It is often very diflicult to decide whether" a given margin is sinuous or toothed becuuse the two completely intergrade. 
Again, it often happens that an oval aperture seems to be pinched, as it were, on opposite sides at the ends of its long diameter. This produces what is known as the angulated margin, such as is found in several species of Seleginopsis, as S. pimate (Plate XXXIX, fig. 6), and is very diflieult to distinguish from certain margins with two teeth, when looking directly into the aperture, as in Thuiaria tenera (Plate XI, fig. 11). A lateral view of the same hydrotheca, however, discloses the fact that the margin is bidentate (Plate XI, fig. 10).

Among American species of Sertularide the number of teeth never exceeds four in normal hydrothecie. There are several Australian forms, however, in which the dental armature is much more complicated, there being sometimes as many as sixteen, as in Sertularia acanthostoma Bale. ${ }^{1}$ In designating the position of the teeth it is customary to speak of those on the side of the margin nearest the hydrocaulus as "adcauline," those on the opposite side as "abcauline," and any situated about midway between these points as "lateral."

Hydrothece with a single marginal tooth are rare, the examples being practically confined to the grenus Thuiariu, as T. elegans (Plate VII, fig. 4). In this case, however, there is a very large abcauline tooth and the adcauline margin is so closely appressed to the hydrocaulus that it is difficult to tell whether there is an adcauline tooth or not. In T. kurilæ (Plate IX, fig. 1) there is a single very conspicuous adcauline tooth.

The bidentate margin is very common in the Sertularida, and is in general characteristic of the genus Sertuldrid. The teeth are usually lateral and opposite, and appear often as if a tubular hydrotheea had been beveled on the adcauline and abcauline sides of the distal end. These opposite lateral teeth are often quite unequal in size, as in the case of Thuiaria argenten (Plate XU, fig. 4) and T. diffese (Plate X, fig. 2). But in many other cases they are proximally of equal size, as Thuiuriu plumulifere (Plate IX, fig. 9). Sometimes the two teeth are both abealine and

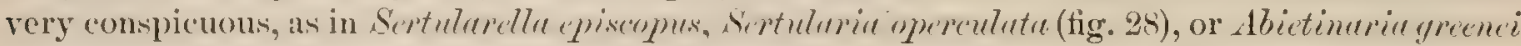
(figs. 29,34). In this latter case we have perfectly even margins on the hydrothecie on one part of the colony, and two strong marginal teeth on those of another part of the same colony.

Three marginal tecth are found in many species of Sertularella, and a few in Sertularia and Thuiaria. In Sertularella they are usually equal in size and equidistant from each other, and vary from almost imperceptihle prominences on the margin to pronounced pointed teeth that

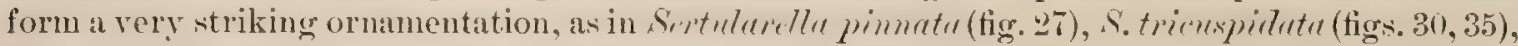
and S. filiformis (fig. 31). Rarely there is a small adcauline tooth and two large and conspicuous abcauline teeth, as Sertularella turgida (Plate XXII, fig. 3). In the genera Sertularia and Thuiaria the three teeth, when present, differ greatly in size, there being two large opposite lateral teeth, and one very sinall adcauline tooth, is in sevtuluren mothmi (Plate III, fig. 9), and Thuiaria tubuliformis (Plate XI, fig. 5).

Four marginal teeth are found in the genus Sertularella alone, and their variations are about the same as those just mentioned in connection with three-toothed forms. They are often so low and inconspicuous as to be difficult to make out, as in S. lata (Plate XVIII, fig. 10), and S. pinnigere (Plate XIX, fig. 3). These very low teeth are apt to be associated with practically complete immersion of hydrothece, as shown in the figures just cited. In only a few cases are they very pronounced and conspicuous, and then they are apt to be unequal in size, the abcauline pair being the larger, as in S. contorta (Plate XVIII, fig. 7).

It has been suggested by Hartlaub that the hydrotheea is lined by an epithelial membrane. ${ }^{2}$ In a certain species of Sertularella this writer found a membrane with a large central opening stretched across the aperture of the hydrotheca, as a velum is stretched across the bell opening of a medusa. From a study of this specimen, and also from the fact that empty hydrotheca often present certain shrunken structures fastened around the inside of the margin, and from the presence in many species of a ring-like line just below the margin and running around the hydrotheca, this writer suggests that the hydrothece have a thin epithelial lining which sometimes diseloses itself in empty hydrotheere in the form of a shallow funnel-like sack attached to the hydrotheca along the ring-like line referred to.

\footnotetext{
Australian Hydroid Zoophytes, 1884, p. 85, pl. IF, figs. 7 and 8. $\quad{ }^{3}$ Revision der Sertularella-Arten, 1900 , p. 11.
} 
In the examination of serial seetions of hydrotheca I have been unahle to find any epithelial structure of this sort. It is probable, however, that there is at times a chitinous lining to the hydrothecal chamber that may he sepatrated from the hydrotheral wall through shrinkatere. If we remember the origin of the hydrotheca and its redation to the young hydranth a very probable explanation sugerests itself. The hydrotheca is formed as an exeretion from the epidermal oells of the budding hydrath which fills the cavity of the hydrothecat until the latter has attaned its full size and tinal form. An examination of the hydrotheral walls under high magnification and in sections shows that they are laminate, as if formed by the deposition of sucession thin layers of chitin. When the hydranth nears maturity it withdraws from contact with the hydrothecal walls, the separation procereding from helow upward, the top of the hydranth being the last to become separated from the hydrotheca. 'The last area of union, therefore, is annular and near the top of the hydrothera just beneath the margin. Thus it will be seen that the last delicate layer of ehitin wouk line the hydrothera up to a ring-like hand which may he somewhat thicker than the rest because here the serereting surface has been longest in contact with the hydrothera. Under certain conditions it is entirely conceivable that this thin membrane should become separated from the hydrothecal wall, of which it is really a part, by shrinkage, especially in preserved specimens. In this case it would be apt to remain attached to the annular area longer than to other portions on the hydrothecal walls, and we would then have exactly the appearance which attracted the attention of Hartlaub. 'The lining is not epithelial, however, in a striet sense, and does not belong properly to any one of the cell layers, because it is not composed of cells or of moditied cells. On the contrary, it is histologiently and morphologically merely the innermost of a number of layers exereted by the ectoderm of the hydranth and forming the hydrothecal walls.

The Operculum.-This is a structure of great systematic importance that has been made especially prominent through the careful work of Prof. G. M. R. Levinsen, and his admirable presentation of the results of his investigations. ${ }^{1}$

One of the earliest specitie accounts of the operculum among the Sertularidae is found in Louis Agassiz's Contributions to the Natural History of the United States. ${ }^{2}$ 'This author, in describing the growth of the hydranth, says: "And the body retrats altogether from the "alyele. after having completed the formation of a bivalve-like operculum." "When the hydra protrudes from its "alycle for the tirst time it pushes aside the opereulum, yet the latter may remain adherent for some time, but evidently for no particular purpose."

A still earlier mention of the operculum, in the genus Sertularella, is found in a work written in 1857 by Joshua Alder ${ }^{3}$ who notes the presence of the four-parted operculum in $S$. rugasa and S. tenella, but seems not to have observed it in S. polyzonius nor in S. tricuspiduta, both of which species were known to him. In lsge Hincks, in his British Hyidroid zoophytes, mentions the opereula in the genera Sertulurella, Diphusiu, and Thuiaria, but does not seem to have found it in Sertularia. Allman, in his Challenger Report, the Hydroida. Second Part, 1888, gives as a part of his definition of Sertularia "orifice with or without an opereulum" (p. 50), and has this to say regarding the operculum: "The valves in all these cases are so thin and perishable that it is only in recent or exeptionally well-preserved specinens we "an hepe to meet with them, a fact which in itself deprives the distinctions derived from them of that pratetical value which ought, if presible, to be found in all woll-selected systematie chamaters" (p. .51). This author also adopts " "lid-like operculum formed by" a single valve" as a character of the genus Diphasia, and notes that two species of his grenus Desmoscyphus, D. pectinatus and D. acanthocarpus, possess opercula.

'Om Fornyelsen af Emeringsindividerne hos Hydroiderne; Videnskabelige Meddelelser fra den naturhistoriske. Forening i Kjobenhavn., 1892; Copenhagen, 1892.

Meduser Ctenophorer og Iydroider fra Grönlands Vestkyst tilligemed Bemerkninger om Hydroidernes Systematik; idem., Copenhagen, 1893.

${ }^{2}$ Vol. IV, 1862, 1.331.

${ }^{3}$ A Catalogue of Zoophytes of Northumberland and Durham, Newcastle-on-Tyne, 1857, p. 23. 
In 1890 Marktanner-Turneretscher ${ }^{1}$ used the operculum in giving the diagnostic features of the genera Sertularella, Calyptothriarir, Nonopoma, Diphasia, and Dymamena. In the present work Calyptotheiaria is included in the genus Sertularelle and Monopoma in Abietinaria.

As before indicated, it remained for Levinsen to make a systematic and comprehensive study of the operculum in various groups, and this he has done with the painstaking care that is characteristic of our Seandinavian fellow-zoologists.

The following points are quoted direct from his systematic discussion of the Sertularidie ${ }^{2}$ and translated by Mr. J. H. P'armann, who studied the opereulum in connection with a thesis for the master's degree in the State University of lowa:

Our attention has before been called to the fact that an operculum is found in all Sertularidie, and that it, together with the form of the margin of the hydrotheca, is the only character by means of which we can draw a natural boundary line between the Campanularidte and Sertularida. * * * There is at least a certain relation between the form of the margin and the structure and position of the operculum. Thus a sertularclu that has lost its operculum may be easily recognized by the three or four equally developed curves in the margin on which the operculum has been attached; and in the genera in which the operculum is a single flap the attachment of the lost operculum on the inner or outer margin will be indicated by a more or less deepened curve. * * * We may define the genus Sertularia thus: Aperture of the hydrotheca provided on the outer (alscauline) side with a deep emargination in which the Hap-formed operculum is attached; on the opposite (adcauline) side is found a thin portion ("kraven" = collar) of similar form to the emargination mentioned above. It thus appears that on each side of the margin is a dentate or triangular projection, and that hetveen these on the inner side is stretched a thin membrane. This membranous part is, in general, overlooked by authors who describe or delineate the margin as bilabiate or twotoothed. In a number of species this thinned portion of the wall (of the hydrotheca), which we will call the "collar," has been seen by Allman and Marktanner-Turneretscher, who, however, have both misinterpreted it, regarding it as a Hap of the operculum, which, in combination with the real operculum, serves to close the aperture in the same manner as the flap of an operculum in Sertulerelle. *** Not only the species which Marktanner-Turneretscher assigns to the genus Dynamene, but also the remaining species of the genus Sertularia, as we have defined it, have such a collar, which, by this author, is incorrectly interpreted as a Hap of an operculum.

The above rather voluminous quotation from Levinsen has been given, because, in justice to that writer, it is necessary that his position should be made as plain as possible in view of the fact that the present writer is compelled to differ from Professor Levinsen and agree with Allman and Marktanner-Turneretscher in his interpretation of the opereulum of the type found in Sertularia, that is, the so-called "two-valved" operculum (see figs. 38-53).

The origin of this type in its derelopmental history should be understood in order to appreciate the points in discussion that will be presented later. If we examine a very young hydrotheca of Sertulariu pumilu, for instance, we will find that its distal end is entirely covered with a very thin homogeneous membrane, continuous over the entire surface. This is deposited, like the hydrothecal walls with which it is continuous, by the ectoderm of the inclosed young hydranth. There is nothing at this stage to show any distinction whatever between the hydrothecal walls and the operculum, the margin not yet having been differentiated. In preserved specimens, however, the homogeneous membrane covering the hydrotheca is apt to be wrinkled, and these wrinkles may sometimes have the optical effect of structural characters. A little later, but before the tentacles have become plainly differentiated, the hydrothecal margin appears by a strengthening of the chitin, and can be traced as a fine, dark, sinuous line which marks the outline of the two opposite teeth, which rapidly become more and more prominent. We have now a distinct differentiation between the hydrothecal walls and that which is destined to become the operculum, although there is yet no hreak whatever in the continuity between these two structures, nor any opening at the distal end of the hydrotheea. The future operculum is shaped like the side walls of an "A" tent, the front and rear of the tent being closed by the two opposite hydrothecal teeth. The two thips of the tent are of unequal size, however, the abcauline being considerably the larger. These two are nevertheless strictly homological structures, each having originated in the chitinous pellicle that covers the distal end of the budding hydranth, and each being adherent to the sides of the teeth and the portion of the hydrothecal margin between them, the two uniting along the line that would be represented by the ridge pole of the tent.

${ }^{1}$ II ydroiden des k. k. naturhistorischen Hofmuseums, 1890, pp. 249-251.

${ }^{2}$ Meduser, Ctenophorer og Hydroider fra Grönlands Vestkyst, 1s95, pp. 183-200. 


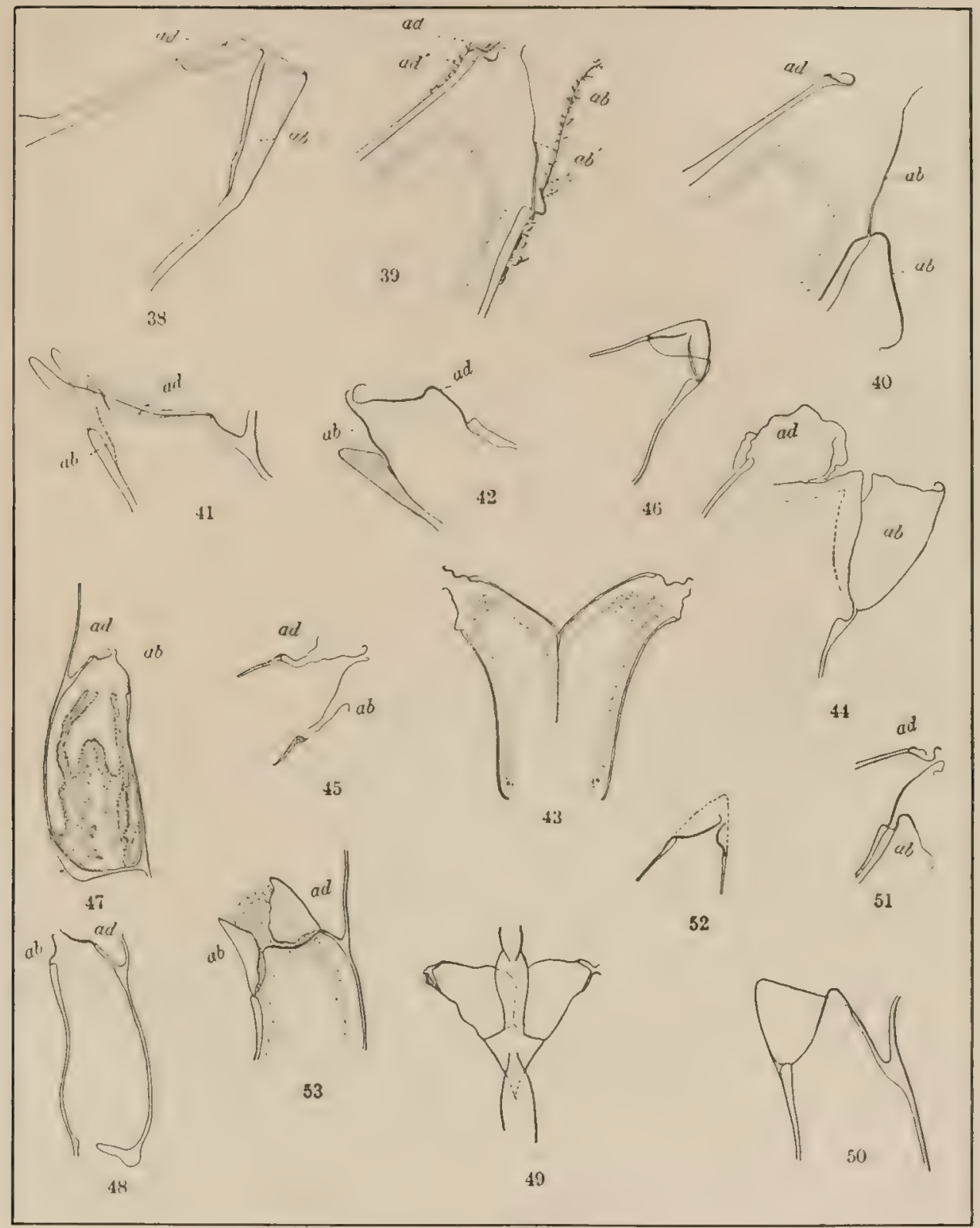

ENIS OF" HYHOTHEC', GRATLY MACNIFIED, TO SHOW BIVALYF OPERCILA.

(ad, andeauline llap; ab, abcanline tlap.)

Fig. 3., - Gertularia memila, showing relation of hydrothecol teeth and onereuln.

Fig. 39_-Longitudinal section of same, showing renewal of opercula. ab and at, original cpercular flaps: ab' and aul", opereular thaps just renewed.

Fig. 40,-Iongitudinal section of same, showing renewal of abcanline finp.

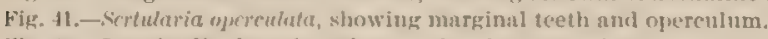

Fig. 42.-Longitudinal section of same, slowing onerenlum.

Fig. 43. - vertuluria corndina, longitudinal section through a juir of hylrothere, showing opercula.

Fig. 4l.-Sirne species, more highly magnitied.

Fig, th, - sume species, sluwing reduplication of opereulum.

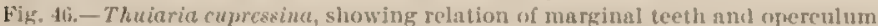

Fig. 47.- Gitme species, showing byjrothecin and retracted hydranth.

Fig. 48. - sume species, showing empty hydrotheril

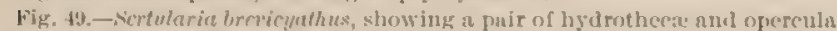

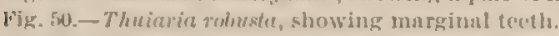

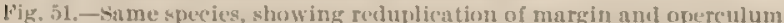

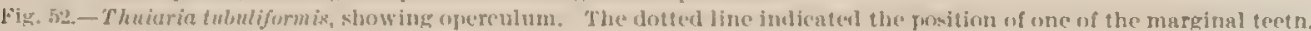
Fig. 53. - Simme species, showing entire operculum. 
There is no important change in the operculum or margin between the stage just described and the completion of the hydranth. When the latter emerges into the outer world for the first time it seems probable that it ruptures by purely mechanical pressure the line between the points of the hydrothecal teeth, or, to use our former simile, the line along the ridge pole of the tent, the pushing tentacles being directed to that line by the sloping inner surfaces of the opercular flaps, and hence the cleavage along the line joining the summits of the teeth. After this rupture has been effected further cleavage takes place along, the line of junction between the slopes of the hydrothecal teeth and the opereulum, beginning at the top of the teeth (fig. 54). 'This may include either or both sides of the "tent," and will continue until there is room for the egress of the hydranth, loaving the bottom of both flaps still attached to the hydrothecal margin.

It is probable that Professor Levinsen would confirm the above account, with the exception of the last sentence. He holds that only the abcauline flap is opened, the adcauline remaining as the "collar" described above. This difference, however, is of great importance, as it is his justification for regarding snch an operculum as composed of a single flap, while the present writer maintains that it consists of two tlaps.

it will be conceded, I think, that the two flaps are identical in their origin and that they are therefore rictly homologens and similar struetures. Levinsen clams that they ditfer in function,

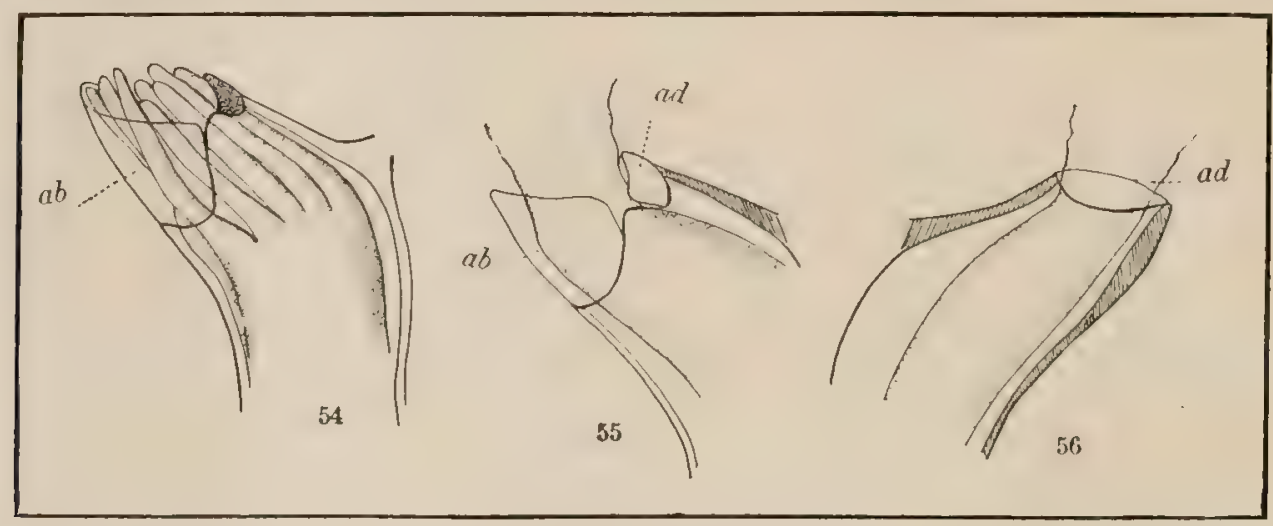

RELATION OF THE OFERCULUM TO THF FXPANDING AND FXPANDED HYIRANTH OF SERTULARIA PUMILA.

Fig. 54.-Tentacles pushing aside the opercular flaps, ab, abeauline fap.

Fig. 55. - Base of expanded hydranth holding aside the opereular fap. ab, abrauline Hap; ad, adcauline flap. Fig. 56.-View of the opposite side, showing adcainine thap. cu, adcauline thap.

the abcauline flap being a movable lid and the adcauline a fixed "collar." Mr. Paarmann's inrestigation seems to prove that this is a mistake, and that "sometimes the adcanline piece is attached while the other is free, and sometimes the reverse is true. Often the sides of a flap are attached for a greater or iess distance proximally while they become free distally, the degree of attachment varying greatly in the same species. In most cases both flaps are functional."

In fig. 9, taken from a specimen preserved with the hydranth fully expanded, it can be plainly seen that the abcauline flap is not functional, and most careful scrutiny of the original under the microscope does not reveal that it has opened at all. The hydranth is well expanded, however, and so in this case the adcanline thap must be the functional one, unless, indeed, it is so very tlexible and elastic that it allows of the passage of the hydranth without the lid being elevated at all. In fig. 55 we have a case in which both flaps are plainly functional, and both are separated from the hydrothecal margin well down toward the bottom of the tooth. It thus appears that Mr. Paarmann was correct in his statement that both the abcauline and adcauline flaps are functional, although neither is constantly so, and therefore the operculum of $S$. pumila and many of its allies are properly called "two-ilapped." " The two flaps are the same in origin, are entirely"

1. H. Paarmann, manuscript.

¿The present writer has carefully verified the accuracy of Mr. Parmann's drawings by direct couparison with the material from which they were taken. 
homologous, and are usually similar in function. I wall themefore speak of the operenta of such species as S. pumila as two-flapped, and will include practically all of the species in which the "collar" deseribed by Levinsen appears." I have not been able to find specimens in which the collar presents just the appearance delineated by Levinsen. ${ }^{2}$ This may be explained by the fact that my specimens were in a very good state of preservation and stained, while the hydrotheca figured by him do not appear to contain hydranths, and may have been boiled in caustic potash or otherwise treated to bring out the unimpeded riew of the chitinous parts, thus destrosing the hydranthe and posibly altering the appearaner of the operenlum. In unstaned spereinens it is very diflicult, if not impossible, to see the fine line marking the outline of the upper border of the adcauline flap seen in tig. 56 ad. When this is not seen the structure looks very much as it does in Levinsen's ligures.

In species with very long teeth it appears that the teeth continue growing after the operculum has been formed. If we examine a specimen of Sertulariu operculutu, for instance, we will find that the teeth project far beyond the distal ends of the opercular tlaps (see fig. 41). If the operculum originated in this species in the same manner as it does in $S$. pumila, the greater part of the growth of the teeth must take place after the operculum has been formed. Otherwise the latter would reach clear to the points of the teeth. It would he interesting to study the operculum in sertularians with numerous teeth, such as are found in Australian species of Sertuluria, and to investigate the relations between the two structures. I do not know that any one has investigated these species with this point in view.

The one-flapped opereulum (figs. 66-69) is common in Thuiaria, and is universally found in Abietinuria. Diphasia, and Sclaginopsis. As maintained by Levinsen, the number of teeth seems to determine the number of valves. This ma he understood on purely mechanical principles. In the one-flapped forms the cleavage sepms most easily effected where the operculum joins the thimner parts of the hydrothecal margin. It so happens that large groups of species serem to be farly constant in this matter, some having the hychotheral matrgin thickened on the adeauline side, as Diplusia and Lbietimeria, and henee the opercular flap remains attached to that side. In other cases, as Thuiuria (in part), and Selaginopsis, the thickening is on the abeauline side and the operculum is abcauline in position. There is one very curious exception to the undoubted systematic value of this character, and that is in the case of Thuiaria thuiarioides, in which the species is a typical thuiarian in both trophosome and gonosome save in the one matter of the operculum, which is unmistakably adcauline in position.

The strongest and most easily seen opercula of this type are found in the genius Diphasia, notably in D. digitulis (1'late XXX, fig. 5), where this strueture takes the form of at vaulted, almost dome-shaped hood, which seems to be of texture as strong and dense as that of the hydrothecal walls, and fits like a cap over the hydrothecal aperture.

'The three and four flapped opercula are characteristic of the genus Sertulurellu and Dictyoclarlinem, a closely related genus. Iartlaub, as before stated, claims that this kind of an oper culum differs essentially from the two-flapped form. I fail to find any very material difference, the main distinction being that in Sertularella the margin of the hydrotheca is usully thicker and better outlined, and the opercular structure stronger and more evident. 'The cause of the initial rupture of the operculum may be somewhat different in this case, although purely mechanical. The margin is stronger and more thickened at the points occupied by the teeth. These latter, moreover, are often, if not generally, slightly inclined outward or away from the center of the aperture. 'The former consideration would render the hydrothecal margin stiffer at the points occupied by the teeth, and the latter would result in greater tension across the operculum along lines connecting opposite teeth. When the hydranth pushes outward for the first time the elastic

${ }^{1}$ In orler to be very sure that my interpretation of this structure is correct I have examined a number of stained and mounted specimens with great care, using high powers of magnilication and examining specimens in which the hydranth was in various stages of contraction and expansion. In figs. 55-56 a specimen is illustrated which was turned over so that both the front and back views of the margin were obtained. The sketehes were made by" myself with the use of the camera lucida. I also examined a number of other species in which the "collar" is found.

${ }^{2}$ Meduser, Ctenophorer og Hydroider fra Grönlands Vestkyst, 1895, pl. VII, figs. 8-10. 
operculum would be apt to yield first at the center, as the tentacles would there exert the most force, and then it would tend to split along lines radiating from the center toward the teeth. Thus there would be formed an operculum of triangular thaps, corresponding in number to the teeth of the hydrotheca (figs. 5i-65).

This explanation seems to be reenforced by the condition of affairs found in the few forms of Sertularellu that have a perfectly plain margin without teeth. In S. formosa, for instance, where the operculum is stretched like a drumbead across the aperture, and the margin is perfectly even, the operculum may be ruptured in almost any way, sometimes around the edge and sometimes

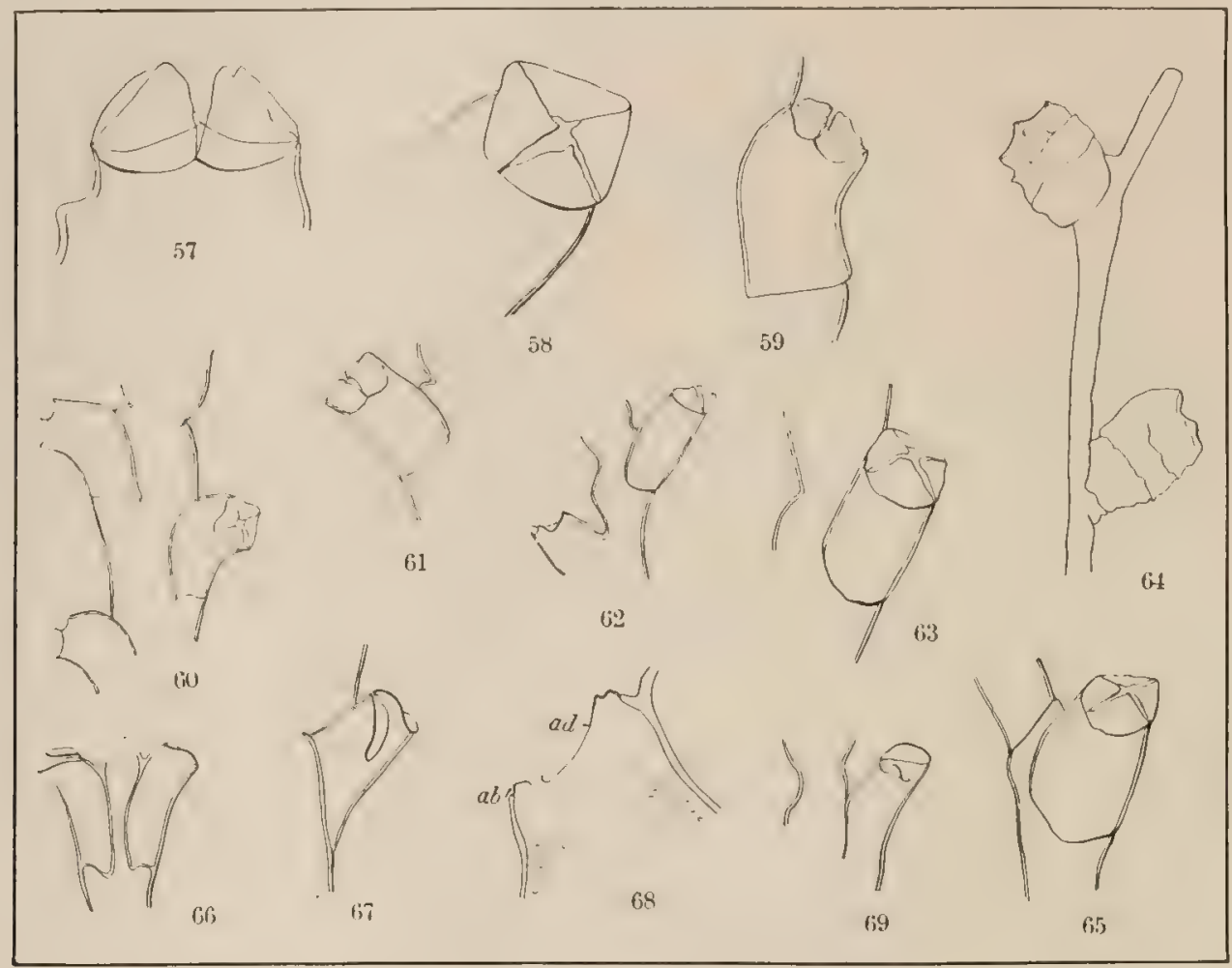

OPERTITA (IF FUER, THREE, ASI) UNE FLAP.

Fig. 57.-Sertularclla rugosa, showing four-vulved opereulum.

Fig. 58,-Sertulcrelli yrui, showing four-ralved otierculum.

Fig. 59.-Siertulardla albita, showing four-yalved oneroulum.

Fig. 60.-Dictyocladim thebllum, showing four-valved opereulum.

Fig. 61.- - iertularella trieuspictata showing opereulum of three valves.

Fig. 62.- Cietularella turgida, showing operculum of three valves.

Fig. 63. - Sertularella complexa, showing opereulum of four valves.

Fig. 64.-Sictularelle areni, showing opereulum of four flaps.

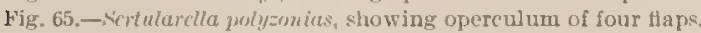

Hig. 66.-Diphasia fallar, showing operculum of one ralve.

Fig. 67.-IIylrallmamia fulcata, shoving operculum of one valve.

Fig. 6s.-IImdralmania fulata, end of hydrotheca highly magnified to show a rudimentary abeauline tiap. ab, abcauline flap; all, adcauline tlap.

Fig. 69,-Diphasin ruscuch, showing one-valved operculum.

in jagged and irregular tears across its surface. In this case there are no points around the margin to cause greater tension along definite lines, and hence there is no regularity whatever in the formation of the opercular flaps (fig. 37).

In all the cases that I have seen where there is a distinct reduplication of the margin, the opereulum has also been reduplicated, the reduplications of the latter being equal to those of the margin. When we consider the genesis of the operculum and its relation to the margin, it is hard to conceive of any explanation other than that there is a direct relation between the process of regeneration of the hydranth and the reduplication of the margin and operculum. 
A careful study of the matter of reduplication here referred to and the renewal of the hydranth bas been made by Professor Levinsen, and the results embodied in a short but important paper, Om Fornyelsen af Emeringsindividerne hos Hydroiderne. 'The paper is written in Norwegian, but a condensed summary of the conclusions arrived at is found in latin at the end of the paper. The following presents Professor Levinsen's conclusions so fall as the Sertuluridu are concerned:

In Sertularidis et in multis Chmpanuluriedis et Campanularinis gemma nova extra hydrothecam antecedentem procrescit et secretio chitinea extra marginem hujus hydrotheede extensa novam marginem vel aperturam (ot in speciebus operculiferis etiam operculum novum) format.

Opercula of almost every type found among the sertularians seem to be reduplieated, as is illustrated in figs. 70-73.

Certain species of Sertulurin, Thuiariu, and Symthecium are characterized by the fact that the distal portion of the hydrotheca is produced into a very thin collapsible tuhe, which is usually of very indelinite shape in preserved specimens. It is seldom that they are of sufticient consistency to preserve their shape after the hydranth has retracted, and they are for this reason very unsatisfactory structures to study. In Serfuleria meneri, for instance, there is such a tube

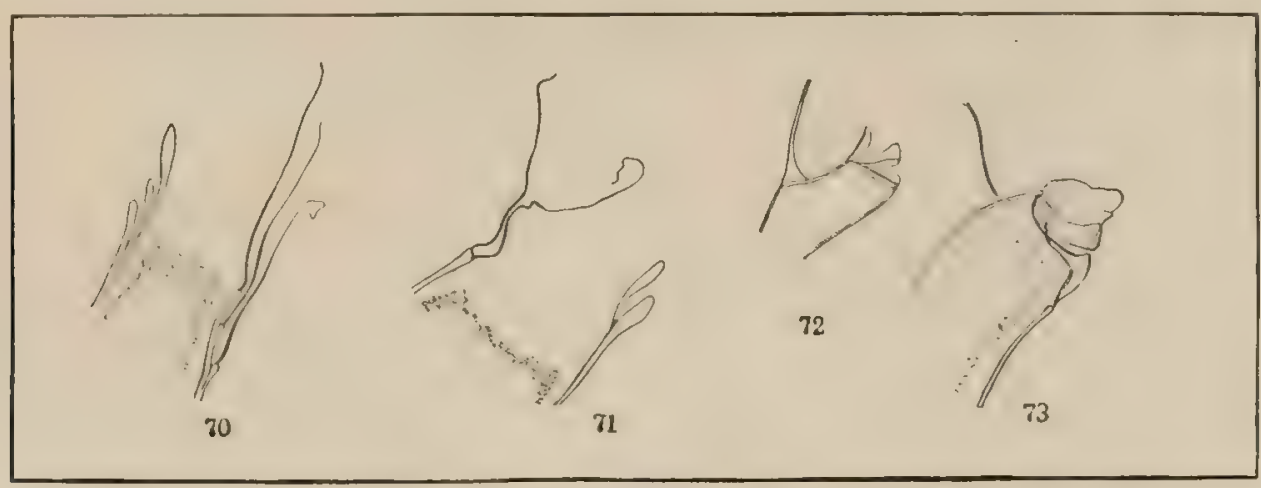

REDLPLICATION OF MARGIN ANI OPERCULUM.

Fig. 70.-Diphasia rosacen; longitudinal scetion of end of hydrotheen, highly magnified, showing the twire reduplicuted margin and operenlum.

Fig. 71.- Sane, showing single rechuplication.

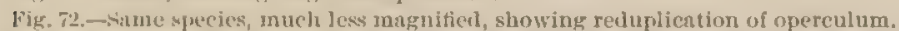

Fig. 73,-Thuiarie tubuliformis, highly magnified, showing reduplicution of opercuhm.

in many cases, and it seems to extend beyond the operculum (Plate V, fig. 4). Although the origin of this tube is not definitely known, it seems reasonable to suppose that it is formed, as are all the chitinous parts of the hydrothece, by the excretion from the ectodermal cells of the body wall of the hydranth, and difiering from the true hydrothecal walls in being very delicate and collapsible. I have not been able to assure myself of the presence of an operculum at its distal end. It may be merely an exaggerated form of reduplicated margin, having the same genesis, but not being completed to the extent of the formation of a new operculum.

The Dinpluarm.--This has been already mentioned incidentally. It occurs in all of the Sertularide that I have examined, and does not vary greatly in form, being merely a horizontal circular shelf running around the hottom of the hydrotheca, near the point where its base joins the hydrocaulus, and dividing the hydrotheeal eavity from that of the stem. There is thus left a circular opening, through which the sareodal contents of the hydrotheca and stem form a connection. 'This aperture is usually eccentric in position, being nearer the abouline than the adcauline side of the hydrothecal base (tigs. $74-75$ ). The diaphragm is regarded by Allman as one of the systematic character's by which the Sertularide are differentiated from other groups. It is also found, however, in other families of the Calypteroblastea, as the Campanularida and Campanulinide, although in the Sertularide alone it is uniformly ecentric or rather unsym- 
metrical, as indicated ahove. It has occurred to the writer that this eccentricity of the aperture of the diaphragm in the Sertularide may be accounted for in much the same way as the lack of radial symmetry. A nearly vertical position of the hydranth seems to be the most favorable, and where the hydrotheea is sessile the hase of the hydranth is fored away from the hydrocaulus by the eccentricity of the aperture of the diaphragm, and it is thus made possible for the hydranth to assume a vertical position without the tentacles being impeded in their action by coming in too close contact with the hydrocaulus.

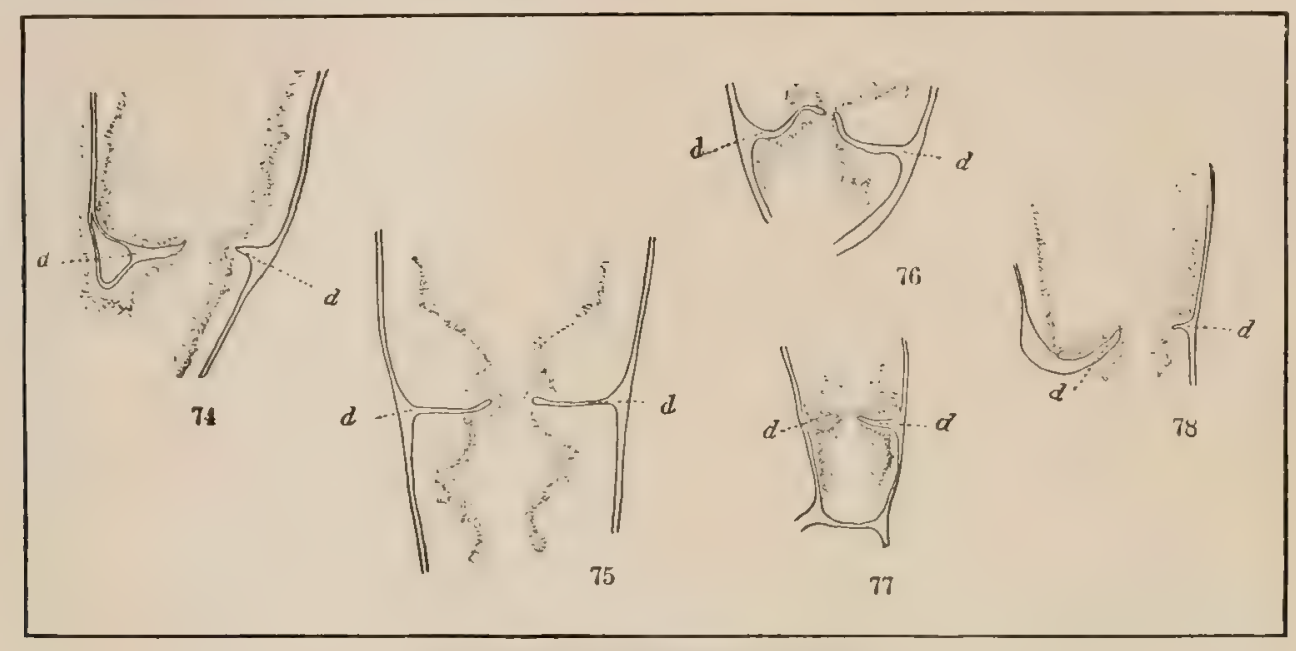

THE NIAPHRAGM OF THE SERTUI,AMID.

Longitudinal sections of lower parts of hydothecse (highly magnified).

Fig. 74.-Sertularia pumila; section taken in the median plane of a pair of hydrothecr: $d$, $d$, the diaphragm in section. Fig. 75.-Same species; section taken in a plane at right angles to the last. Lettering as before. Fig. 76,-Hydralmania falcata. Lettering as before.

Fig. 77.-Thuiaria robusta. Lettering as before.

Fig. 75,-Diphasia rosacea; section similar to that represented in fig. 74. Lettering as before.

\section{GONOSOME.}

The structures which have to do with the reproduction of the species of the Sertularidie include nothing aside from the gonangia and their contents, the being nothing to represent the corbula and phylactocarps so conspicuous in the Plumularide." The absence of these has been offset in the Sertularidie by a much greater variety of gonangia and gonophores, especially the former, which often exhibit ormamentations of surprising beauty.

Gonophores. - These structures are fundamentally the same as have been described under the Plumularida, but are often more conspicuous and highly specialized. Perhaps the most common form is that exhibited by Sertularia pumila (figs. 81-83). The blastostyle originates in the usual manner as a sort of hernia-like diverticulum from the stem or branch, containing the ectoderm and endoderm in their normal relations, and bearing a number of ova in the endoderm (see figs. 79, 84, ov). Weismann says that there are three cell layers external to the ora, and homologizes these layers with those of a medusa, claiming that the gonophore is merely a degraded medusa (see also Part I, p. 30). The distal end of the blastostyle is expanded into a round, more or less oheonical plug ("Derkenplatte" of authors), composed of large, loomely aggregated cells principally from the ectoderm, although the endoderm is also involved in its formation. At a later stage the blastostyle is crowded to one side by a rapidly growing gonophore, which is formed as an outgrowth from the proximal end of the blastostyle, and grows to such a size that it sometimes almost fills the cavity of the gonangium from top to bottom. When fully developed (see fig. 79, ov), the ova are seen to have taken up their position in the ectoderm, having pierced

\footnotetext{
${ }^{1}$ See Part I, pp. 31-35.
} 
the struetureless stutylamelle and enreatly colarged during the growth of the now practically mature gonophore.

The distal end of the latter at this stage is covered by a distinct layer of perisare, which has a definite function presently to be described. It will be noted that only a few of the numerous ova in the blastostyle are included in the gonophore at this stage. A still further development results in the formation of the acrocyst, at strueture found in several groups of calypteroblastic hychroids which comsists in a more or less globular londy composed of ehitin which surmount the cronangium and contains the oval in their later stages of development. The acroerst is formed an follow: The chitinous dintal and of the gonophore described ahove is pressed against the

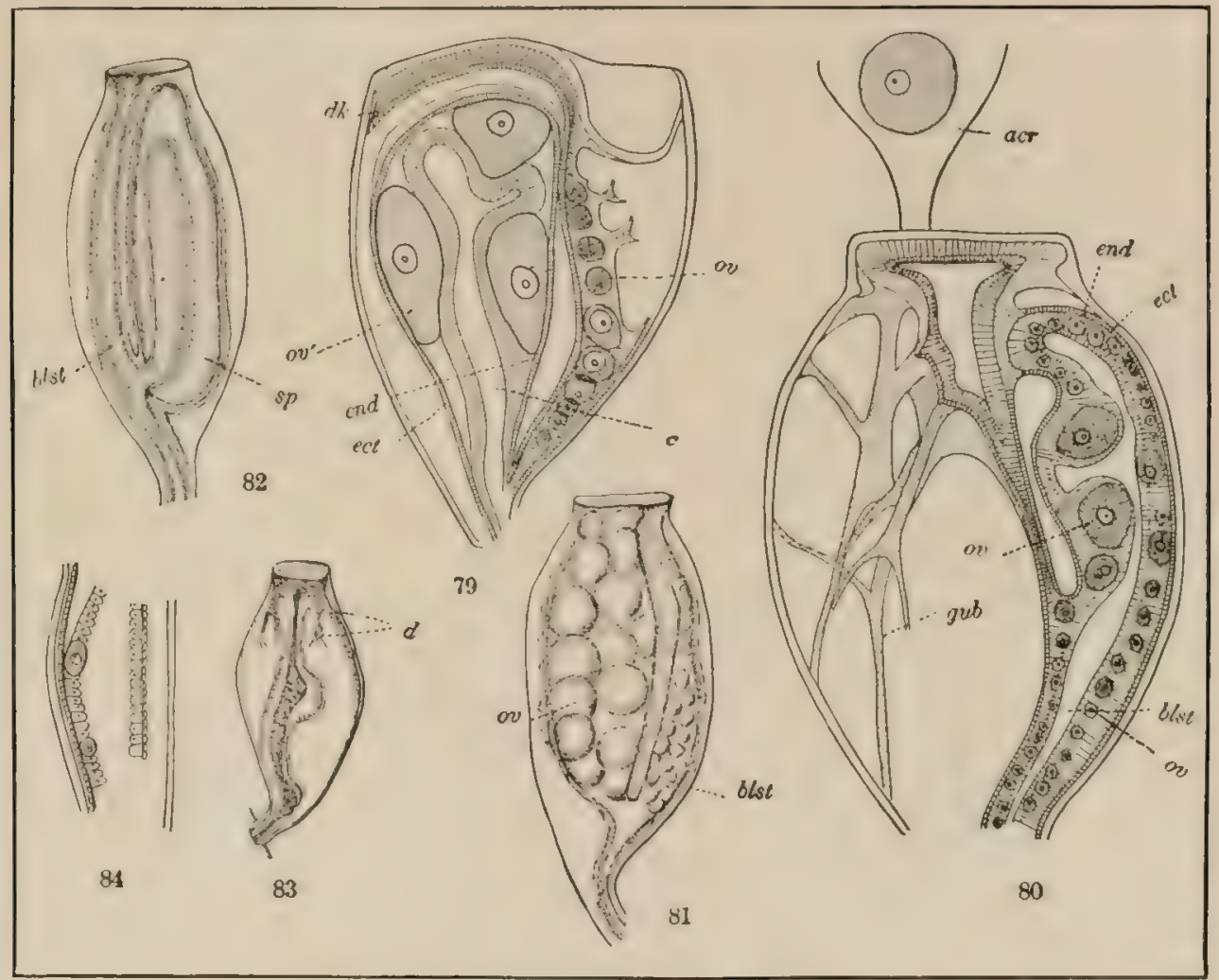

THE CONGSUMF: OF SEITULARIA FMILA.

(Figs, 79 anul so, after Weismann; Jigs, 81,82, and 83, after L. Agrsaiz.)

Fig. 79.-Inngitudinal section of gonungium. dk, "deckenplatte"; $c$, cavity of gonophore; cot, ectorierm; end, endoderm; nv, orum in enderlerm of hlastostyle; or', ovum in ectoderm of gonophore.

Fig, s0.-Longitudinal section of nn older gonangium. acr, acrocyst; blst, cavity of blastostyle; gub, gubernaculum; other lettering as on fig. 79. Fig. 81. - General view of female gonangium. or, ovum; Jlot, blastostyle.

Fig. 8:-General vicw of male gonungium. Wat, blasfostyle; gp, spermary.

Fig. 83.-Gonangium, showing diverticula from deckenplatte. d, diverticula.

Fig. 84.-Longitudinal section of purt of the stem, showing developing ova in the endoderm.

deckenplatte by the further npward growth of the gonophore. Weismatm 'says that this distal end is thrust through a hole or opening in the ond of the gronamgium. I have heen unable to find

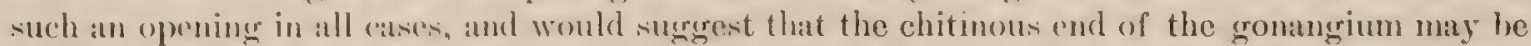
sometimes piereed by the chitinous end of the gomophore, much as, aceording to Weismann's own account, the incipient gonophore pierees the thick perisare of the stem in Plumularie whimulate hy what appear's to be a dissolving secretion of some kind. However this may be, the end of the gonophore in some way penetrates the top of the gronangium and then expands into a globular chitinous sac into which the ova pass, and thus the acrocyst is formed (see fig. $80, a c r$ ). Those parts of the gronophore that are not needed in the acrocyst indred all parts except the developing 
ova, so fur as I can discover-are then withdrawn into the gonangium, not, says Weismam, by contraction of the tissues, but by a resorption process. After the formation of the first acrocyst a number of long processes are given forth from the deckenplatte which Weismann says contain nutritive material, and may serve in the nourishment of the gonophores. The present writer has not seen these in young blastostyles, but is unable to tell whether a fully developed gonophore is the first one, or one of its many successors in a given gonangium, ats the arocyst seems to be but a transient structure, and mat be replaced several times during the functional lifetime of the gonangium.

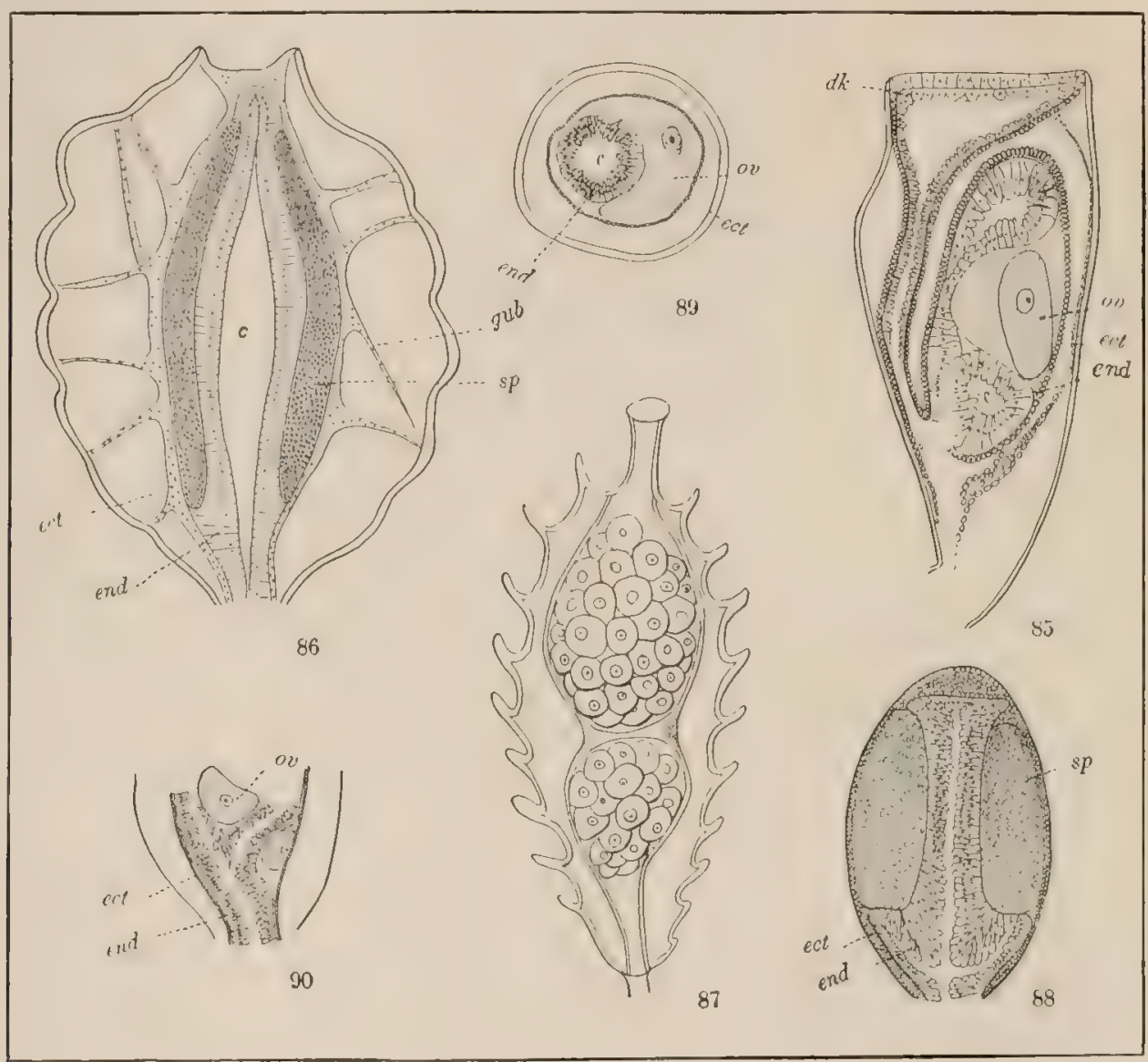

TYPICAL GONANGIA AND GONOPHORE.

(Lettering as in precesing figures.)

Fig, k5.-Diphnsia kinertici; longitudinal section of female gonangium, showing a single large ovum in the single gonophore.

Fig. $46,-4$ rtulardla complexa; longitudinal section of male gonangium, showing the spermaries in the blastostyle, there being no proper gonophore.

Fig. 87.-Gonangium of scrlularelln filiformis, showing large musses of ova.

Fig. s.,-Hylrallmanin falcala; longitudinal scetion of male gonangium, showing spermaries, sp.

Fig. 83. - Same species; section aeross young female gonophore, showing relation of parts.

Fig. 90. Same species; longitudinal section, including lower part of gonangium, and showing two ova.

During the formation of the first gonophore there are a large number of ova in the blastostyle above the point of origin of the gonophore (fig. $79,(o v)$. When the remains of the latter have been largely resorbed after the formation of the acrocyst another gonangium is formed in the same way as the first and another lot of ora are transferred from the endoderm of the blastostyle to the ectoderm of the new gonophore, and are finally pushed through the top of the gonanium into the acrocsst.

After the retraction of the remains of the first gonophore from the acrocyst a number of irregular bands and threads tre seen passing outward and downward to the gonangial walls. These are called "gubernacula" by Weismann (fig. 80, gub), and are supposed by him to serve 
to pull aside the tissues to make room for a second gronophore. They atre composed of both cetodermal and endodermal cells, and may be largely the disorganized remains of the first gonophore.

'Those who are familiar with Weismann's great work will see that the above account is practically a summary of the results of his investigations. The present writer, however, has gone orer the ground with some are and with grood material and finds that the facts are as described by Weismann. 'The deductions are given on the authority of that writer, unless the context shows then to be my own.

Probably the simplest form of gronophore found in this group is illustrated by Diplusin Rincaidi, a new species deseribed beyond. In this ase the gronophore consists of a structure similar to that of Sertuluric pmmila given off from the lower part of the blastostyle. It contains, however, but a single ovum, and in optical section shows very beatifully the relationship between the ova and the virious histological layers, the former being outside of the stutzlamelle and embedded in the ectodem (fig. S5). The deckenplatte is also well shown and is seen to consist of both ectoderm and endoderm. The acroegst does not appear to be present in this species and it is probable that the ova are discharged directly through the tops of the gronangia into the water. Practically the same type of gonophore is found in Sertulnvia stooticyi, S. comicime, Dictyocladium, flabellum and Theiarie rubustr, and doubtless in many other species.

Weismann examined the gronophores of Sertularella polyzonies and found that they differed from those of Sertuluria mumila in the fuct that no true gonophores are found, but that the sexual products are developed in the walls of the spadix of the blistostyle. I fouml that the sane state of affairs was evident in optical section of Sertularelle complere. This is shown in fig. Sti, where the axial blastostyle does not bear gronophores, but in which the spermaries are found embedded in the endoderm of the blastostyle itself. Numerous thread-like processes extend from the ectoderm of the blastostyle to the gronangial walls, resembling greatly the gubernacula described by Weismann. As there is here no likelihood of an acrocyst being formed, the specimen being a male gonangium, and as there is no gonophore to be accommodated, the function of these threads can not be explained as in the case of Sertularin pumile. They seen to be a very common feature of the various genera of Sertularide, and doubtless have a definite signiticance. In some cases there is a thin layer of ectoderm lining the gonangial walls, and these thread-like structures seem to connect this ectoderm with that of the blastostyle or gonophores in the center of the gonangial cavity. They may, of course, have a nutritive function, as suggested by Weismann in the case of the gubernacula of Septuluria pumila. In many species of Sertulurelle there seem to be no true gonophores, the ova being in masses around the axial blastostyle. Often they are aggregated in two or more distinct globular masses, ats in S. filiformis (fig. 87), and some at least of these forms are provided with an acrocyst, as in $S$. murns (Plate XVII, fig. 2), where this structure is rery conspicuous. The exact succession of events has not been worked out in such cases, but it is likely that these masses of ova are discharged into the acrocyst just as those in the gonophores of Sertulurid pumila, the successive masses acting as do the successive gonophores.

In some species of Sertularella, as S. albida, the male gonangium contains an immense mass of sperm cells that is ovate in form. A longitudinal section of this mass shows that it is permeated by a system of diverticula from the axial blastostyle. 'These diverticula are apparenty composed cntirely of endoderm ${ }^{2}$ covered with the stutzlamelle, and I find no ectodem save that which forms a coating over the entire sperm mass. This scems to be a form of psendo-gonophore derived from the condition found in p polyzonies by Weismam and in S. complere by myself. The diverticula spoken of are probably necessary as a means of conveying nourishment to the mass of sperm cells that is too large to be supplied by a simple unconvoluted endodermal layer, such as is found in $S$. polyzomints. If correctly interpreted, we have here a state of affairs almosi

${ }^{1}$ This structure is probably that which is called a "Stroma-Setzes." Weismann does not state the origin of this structure, and I am by no means sure that it is correctly interpreted by me as endodermal. It appears, however, to be derived directly from the endoderm of the spadix, and seems to be composed of loosely agerregated tissue, such as we often find in the deckenplatte, where both ectoderm and endoderm are often of this histological structure. 
exactly intermediate between that of $S$. complexe and the ordinary gonophore, such as is found in Sertularia pumila, for instance.

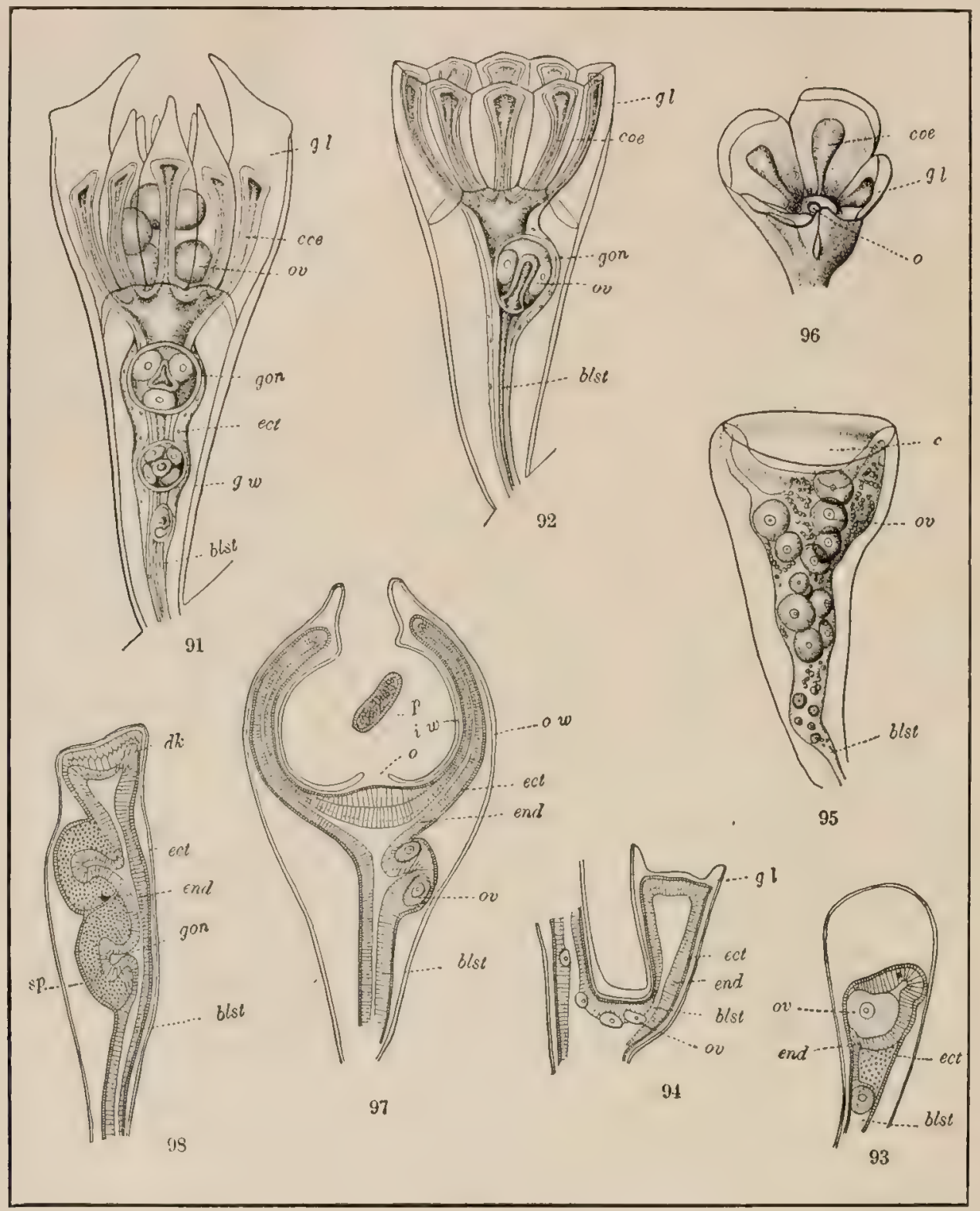

THE GONOMOMF ON DIPHASIA.

(Figg. 91 and 92 after Allman.)

Fig. 91-Gonangium of Dijhasia rosacce. coc, lobe of cenosarc extending upward into the gonangial leaf, $g l$; gon, gonophore; $g u$, gonangial wall; $o v$, ova in the "marsupial chamber." Other letters as in preceding figures.

Fig. 92.- Same species; a younger gonophore, showing earlier stage in the formation of the gonangial leaves.

Fig. 93.-Diphasin fallax; \& very young gonangium, showing the blastostyle entering with a comparatively large ovum at its summit.

Fig. 94. - Same species; a somewhat older gonophore, showing optical longitudinal section (schematic) with ova in endoderm of stem.

Fig. 95.-Same species; a young gonangium before the development of the goningial leaves. $c$, convex summit of gonangium.

Fig. 96.-Sume species; young gonangium in which the gonangial lcaves are forming, viewed from above. 0 , small, round opening in summit of the original top of the gonangium.

Fig. 97. Same species; a semidiagramatic longitudinal section, showing the formation of the "marsupium;" $i w$, inner wall of gonangial leaf; of $w$, outer wall of gonangial leaf; $o$, opening in the original top of the gonangium; $p$, planula.

Fig. 9..-Same species; longitudinal scction of a male gonangium, showing two gonophores with spermaries

A very simple male gonangium is found in Ilydrullmania falcata (figs. 88, 90, 111), where the axis of the blastostyle, composed of endodermal cells, constitutes a simple spadix around which the sperm cells grow in a mass, the outside of the mass being covered with ectoderm. 
The most complicated gonosome found in the Sertularide is that illustrated by Diphersia rosace and several other species of the same genus which appear to possess an acrocyst which is itself inclosed in a marsupial chamber (tigs. 91, 92). This very remarkable structure was first described with care by Professor Allman, ${ }^{1}$ and this description still remains the hest that I have seen, although it contains some inaccuracies that will shortly be pointed out. I have made a careful study of Diphusic fullax, both entire and in serial sections, with the following results:

A very young female gonangium (see fig. 93) is a club-shaped chitinous pellicle within which the young hlastostyle grows as a direct derivative of the conosare of the stem. At its very summit is a large orum enveloped apparently in lobular diverticula from the blastostyle, another and smaller orum being seen a short distance below. At a later stage the gronunginm is

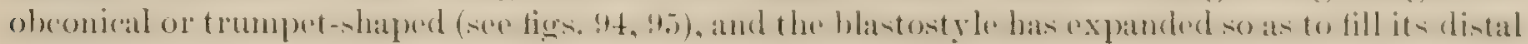
portion with a sort of plug. At this stage the summit of the gonangium is convex, or howlshaped, with the aperture in the center of the bowl, just above the axis of the blastostyle. The rim of this bowl now grows rapidly, forming four broad scallops, and ultimately four broad leaves, which are really flattened tubes of chitin. If rom the peripheral portion of the distal end of the cnenosircal plug (deckenplatte) four lobes composed of ectoderm and endoderm project into the flattened tubes of chitin just mentioned and doubtless furnish material for the growth of the latter (see tig. 96). These lobes grow rapidly, especially in length, and finally their tips arch over until they meet. The edges of the leaves coalesce, and thus is formed a globular chamber above the original top of the gonangium, the walls of the chamber being composed of the broad leaves which originated from the edgre of the bowl-like summit of the young gonangium. In the meantime the ova in the blastostyle have arranged themselves in definite groups, the largest group being the distal one, each group being now borne in a separate gonophore, the gonophores being arranged serially along one side of the blastostyle. A tendeney toward such a grouping is seen in even quite a young gonophore (see lig. 95). The present writer believes, from his study of Diphasia fullex, that Professor Allman was mistaken in two particulars in his description of the gonosome of Diphasia. First, in describing the development of the gonangium (of $D$. rescecu) that writer salys: ${ }^{3}$

A blastostyle occupies its axis, having upon its sides, one over the other, the young buding gonophores, and expanding at its summit into a broad, thick disk, which closes, as with a plug, the free end of the gonangium. Upon the onter side of this disk a thin chitinous investment is excreted, becoming continuous at the edge of the disk with the chitinous walls of the gonangium.

'This latter sentence conveys the idea that the end of the gonangium is formed subsequent to the formation of the walls. As a matter of fact, it is entirely homologous with the summit of other gonangia, and is continuous with the walls in the youngest gonangium that I have been able to find (see fig. 93 , which is a highly magnified view of a very young gonangium). In its early stages the gonangium of Diphrisie fullur is precisely similar to all other gonangia, so far as this character is concerned. Fig. 95 presents an appearance that might at first lead one to adopt Allman's view, as in this case the concave summit of the gonangium rests immediately on the deckenplatte. But when one studies a series of youngrgonangia it becomes evident that we have here merely the elevation of the peripheral portion of the gronangium top preparatory to the growth of the leares destined to form the marsupium. Secondly, Professor Allman, after describing the acrocysts of several species, adds:

In the cases above described the acrocyst is destitute of any further covering, and has its walls with their gelati-

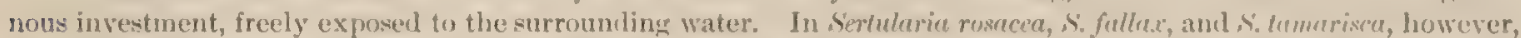
an additional covering is provided for the acrocyst, and there is thus formen a curious and conplicatent receptacle, in which the ova, as in a sort of marsupium, pass through certain early stages of their development, previously to being discharged into the surrounding water (1.50).

${ }^{1}$ A monograph of the (iymuoblastic or Tulularian IIydroids, London, 1871, pp. $50-54$.

"These lobes Allman very plausibly interprets as being the homologues of the lobular or sack-like processes Which extend downward from the deckenplatte in Sertularia jumile. The derivation of the two structures is evidently identical, and the only difference between then seems to be in the direction of their growth, which is upward in Ihiphesief follex and downward in Sertulurie punilu.

${ }^{3}$ Gymnoblastic IIyctroids, nn. 50-51.

$5125-1 \%:-04-;$ 
A study of serial longitudinal sections of Diplasia fullax shows that no true acrocyst is found in this species. It is true that an examination of entire adult gonangia with transmitted light seems to reveal an inner globular chamber besides the outer one formed by the gonangial leares. That this is an optical illusion is seen when a median longitudinal section is studied (see fig. 97).

The inner and outer walls of a gonangial leaf are seen to be widely separated and not strictly parallel, the distal end being much thicker than the rest. The result is that the inner profile of the leaf forms nearly a half circle and, in conjunetion with its fellow on the opposite side, forms nearly a complete circle which looks almost exactly like the outline of a sphere when seen from the side. Thus it happens that we have the appearance of a sphere in the center of the marsupial chamber, occupying, indeed, the exact position of an acrocyst. As there are eight of these leaves in $D$. rosacea their inner edges would thus simulate the outline of a sphere when viewed from any side.

It might be argued that the acrocyst, according to my own statement, is but a temporary structure, and might therefore have been absent in the specimens studied by me, but present in those studied by Professor Allman. In some of my specimens there were ova or planula in the marsupial chamber (fig. $97, p)$. Under these conditions, if ever, the acrocyst wculd be present.

The male colonies of Diphasia produce gonangia without the marsupium, and hence of very different appearance, and it was this fact, doubtless, that led the elder Agassiz to give the name "Diphasia" to this genus. Fig. 98 represents a longitudinal median section of a male gonangium of Diphasia parmanni containing a blastostyle which bears gonophores in a series, each consisting of a simple spadix surrounded by a mass of sperm cells. The gonangia are unusually long and slender, and often contain a row of five or six gonophores.

We have now considered all of the distinct types of gonophores found in the Sertularidx, so far as known to the writer.

\section{THE GONANGIUM.}

This structure is much more diversified in the Sertularide than in the Plumularidx, due probably to the fact already suggested that the gonamgia in the latter family are often protected by various forms of phylactocarps, and hence are not so much influenced by the immediate environment of the species.

Perhaps the most typical form of gonangium is the simple oblong oval, truneated at the top, well illustrated by Sirtularia pumila (fig. 99), S. operculute (fig. 100), S. stookeyi (fig. 101), Thuiaria thija (fig. 102), Diphusia Kincaidi (fig. 112a), and Abietinaria sigantea (fig. 103). 'The main modification of this form consists of the narrowing of the distal end of the gonangium so as to form a short tubular neck, as in A. costata (fig. 10t), Thuiaria turgida (fig. 105), and Thuiaria tubuliformis (fig. 106). This narrowing may be such as to form a short cone instead of a tube, as in Dictyocladium. Acabllum (fig. 107); or it may form a frustum of a cone, as in Abietinaria greenci (fig. 108). Where the aperture is large an operculum is usually present, as in Sertularia stookeyi (Plate V, tig. 6), and Sertularella formose (fig. 109).

The most common form of ornamentation found in the gonangia of this group is brought about by annular rugosities which are often exceedingly graceful and beautiful. One of the most attractive structures in the whole family is the gonangium of Sertularelle tricuspidata (Plate XXV, figs. 4 and.5). Similar gonangia are found in S. filiformis (fig. 113), and the most excessive ornamentation along this line is seen in Sertularella elegans (fig. 114), where the annulations take the form of greatly compressed ridges which are elaborately frilled so as to resemble lace work (Plate XXIV, fig. 1). Sometimes these annulations are confined to the distal or upper part of the gonangium, and are much broader and less incised, as in $S$, allmani (fig. 115), S. catene (fig. 112), S. meridionatis (fig. 116), and S. albida (fig. 122).

These sections, as well as the others used in the study of the gonosome of the Sertularidre, were made for me by Mr. William B. Bell, one of my students. 
In most eases the annulations are approximately parallel, but sometimes, ats in sertularell pimuta, they are exceedingly irregular, giving an appearance of great distortion (fig. $11 \%$, and Plate XXI, fig. 10). Every intergradation in the depth of these rugositics is found, langing

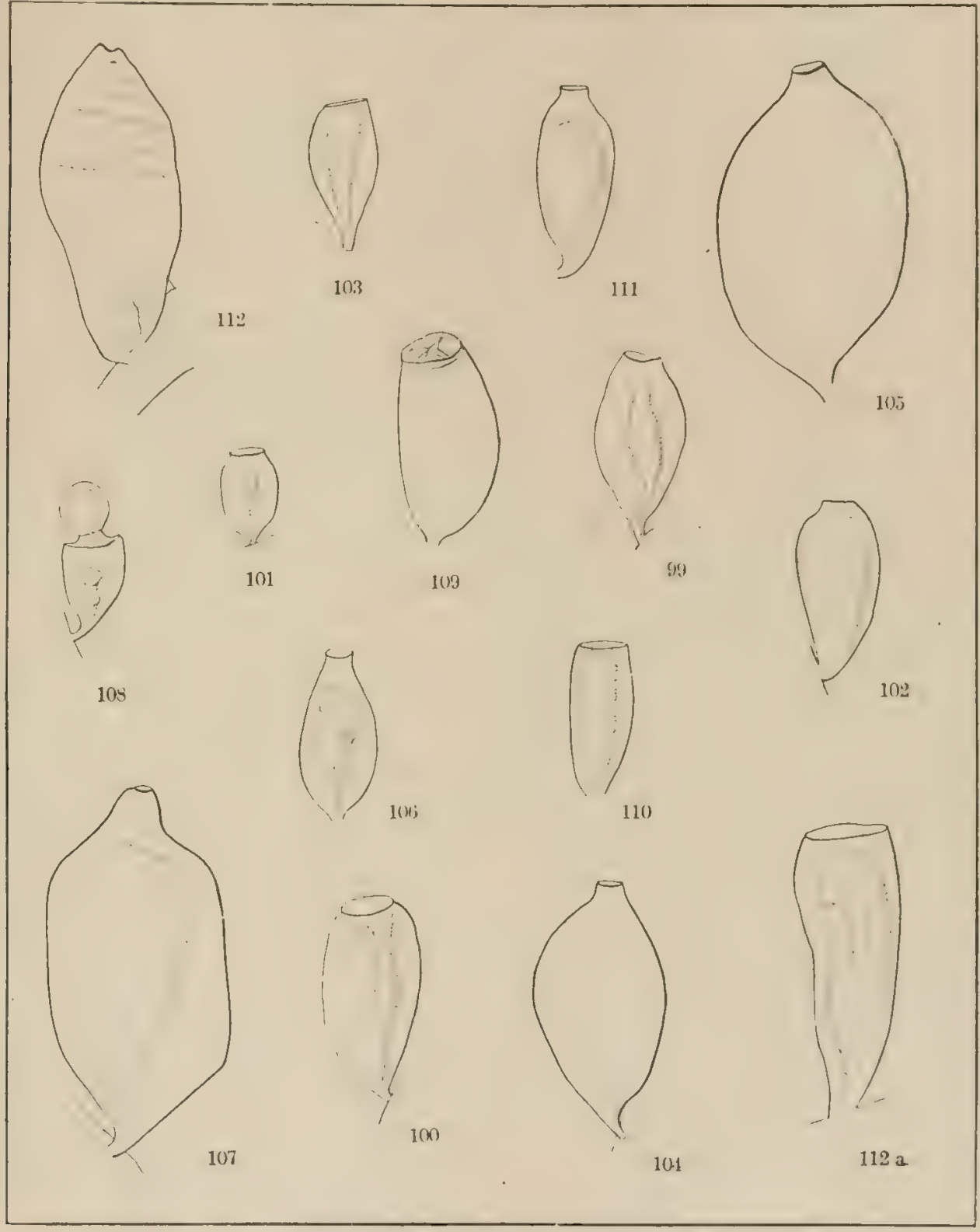

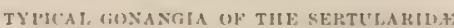
(All tigures druwa to the sume: seale.)

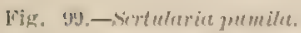
Fig. 100. - Sirnturit opsereutute Fis. 101 -vertularise stowhervi. Fin. 102-v-Thuintie the je. Fig. 103,-Abiclinaris spigemente

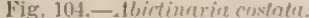
Fig. 10.5.-1birtinerin turguta. Fig. 10i,-Thniarin tubuliforn is.

$$
\begin{aligned}
& \text { Fig, 107.-Dictyockelium flatellum. } \\
& \text { Fig. 10s,-1hirlinurie grenci, with nerexese. } \\
& \text { Fig. 10y, - Sortulerelle formose, slyowing ofnerculum. } \\
& \text { Fig. 110-Diphaxiu Jullus (young). } \\
& \text { Fig. 111.-Myelrallmanio fuimbla. }
\end{aligned}
$$

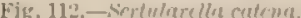

$$
\begin{aligned}
& \text { Fig, 112!.-Diphasin kincrinli. }
\end{aligned}
$$

between the excessively deep ridges of Sertuluvellu degens and the hatrly visible ones of s: lerinsemi (fig. 118). While these ammulations are especially charateristic of the genus Sertulurellu they are also found in Sertuluriu, as in S. comicinu (fig. 119), in sbivtinurie coci (tig. 120), and in a few other species ontside of the genus Sertulurella. 
A phenomenon so constant and so widespread as this kind of gonangial ornamentation is generally supposed to have some utility to the animals possersing it, and it is not difficult to find a use for these corrugations on purely mechanical grounds. Gonangia are structures that are

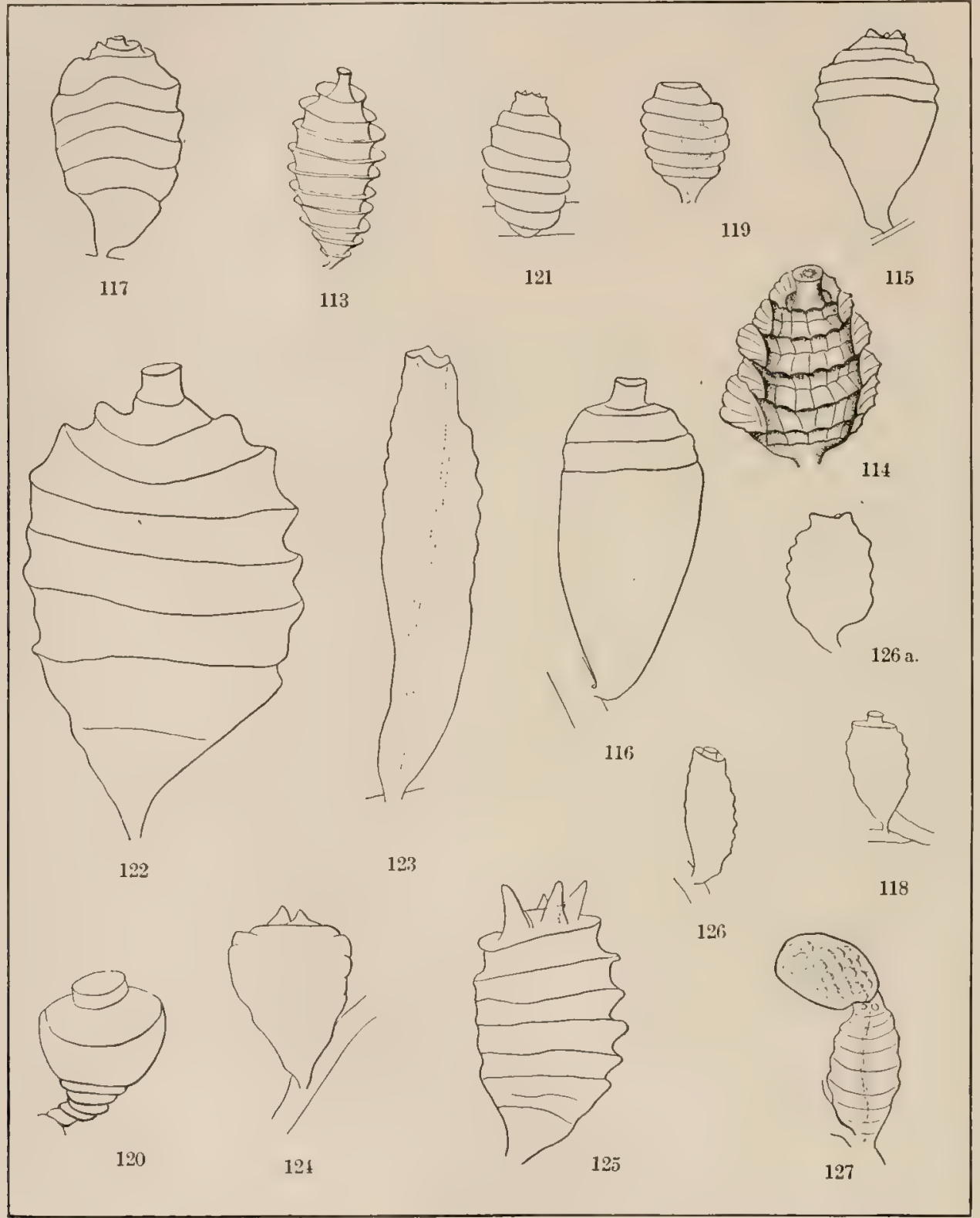

ANNULATED GONANGIA OF THE SERTULARIDE

(All figures drawn to the same seale.)

Fig. 113.-Sertularella filiformis.

Fig. 114.-Sertularclla elegans.

Fig. 115.-Sertularella allmani.

Fig. 116.-Sertularella metidionalis.

Fig. 117.- Sertularella pinnata.

Fig. 118-Sertularilla levinsenzi.

Fig. 119.-Sertularia cornicina.

Fig. 120.-Abietinaria coei.
Fig. 121.-Sertularclla complexa.

Fig. 122. - Sertularella albida.

Fig. 123. - Sertularclla gayi var. robusta (an exceptionally slender specimen).

Fig. 124.-Sertularella contoria.

Fig. 125.- Sertularella polyzonias.

Fig. 126.-Sertularella subdichotoma.

Fig. 126a.-Sertularella subdichotoma (without tubular neck).

Fig. 127.-Sertularella rugosa.

primarily for the protection of the sexual persons of the hydroid colonies, and the stronger their walls the more efticient is the protection afforded. Man has long ago found that by corrugating sheets of iron or tin their strength to resist lateral pressure is greatly increased. Doubtless the same thing is true of gonangial walls made of chitin, and this may indicate a possible utility for 
this feature, one that 18 ordinarily spoken of as being merely ornamental in strueture. But what shall we say when contemplating such apparently riotous and frivolous excesses as are indulged in by Sertularella elegans, for instance? It seems as if here Nature had grone to altogether unnecessary lengths, even if she did start by forming the rugosities on purely

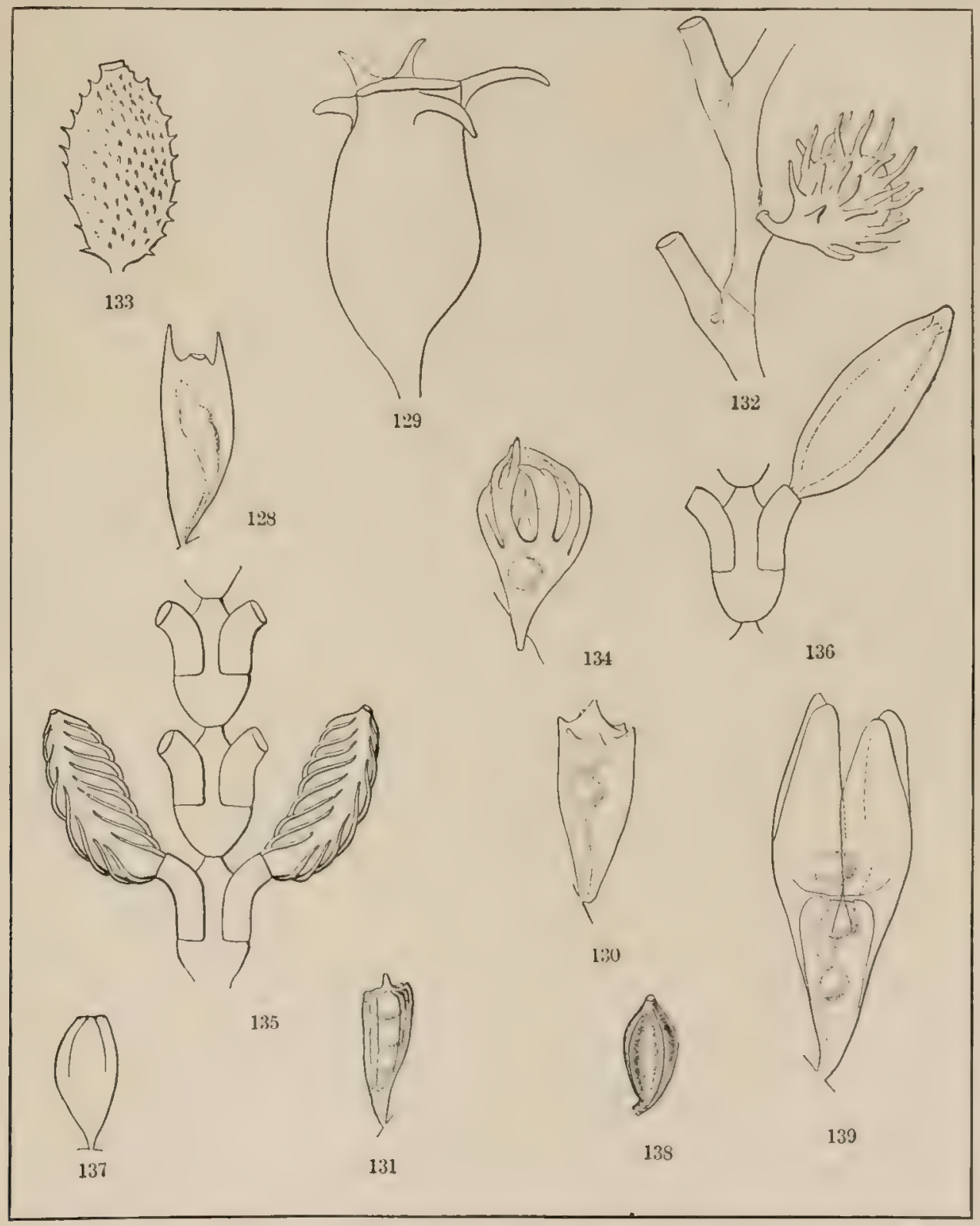

S(PINEI) ANI) RIBBEI) (OONANGIA OF THE SFRTUIAATI,K,

(All figures, exeept 13:, 135,136 , and 135 , drawn to the sume seale.)

Fig. 128.-Thuiaria rolusta.

Fig. 129.- Serlulurdla qualrata.

Fig. 130,-Diphasia pnarmanni.

Fig. 131.-Diphasia ronacea (female).

Fig. 132.-Sertularia celunneurpa. (Aiter Allman.)

Fig. 133,-Diphasia digitalis.
Fig. 131. - ilayinopsis omata.

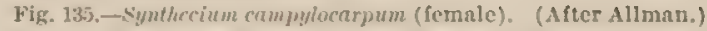

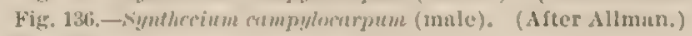

Fig. 137.- Ibietinaria alementeri.

Fig. 13s, - Listinaria costats.

Fig. 139.-Iiphasia paarmanni (male).

utilitarian lines. There are many such cases known to naturalists, in which it appears that development along certain lines had received in some way such an impetus or momentum that the resulting structure goes far beyond the utilitarian demands of the case and enters the realm of merely capricious excess. 
As an outcome of this we have many structures that are exquisitely beautiful or graceful, or at times merely grotesque.

In a few cases the rugosities are longitudinal, rather than transverse or annular, and we have the ribbed gonangia, such as are seen in Sertularelle episcopues (Plate XXVI, fig. 7), Abietinaria gracilis (Plate XXXV, fig. 1), and Lbietinaria costata (fig. 10t). In a number of species the superficial ornamentation takes the form of horn-like processes or long spines, which may be two in number and borne on the shoulders of the gonangium, as in Thuiaria argentea (Plate XII, fig. 9) or $T$. robuste (Plate VII, fig. 7), or there may be four or more radiating from the gonangial aperture, as in Sertularella quadrata (fig. 129). In the male gonangia of several species of Diphasia there are a number of conical spines arranged in a circle around the distal end, as in D. paamanni (fig. 130), or the whole of the distal end of the gonangium may be bristling with spines, as in Sertularella turgida (Plate XXII, fig. 2). The extreme of spinulation is reached in Sertularia echinocarpa Allman (fig. 132) and Diphasia digitalis (fig. 133), where the entire surface of the gronangium is beset with spines. A very curious ornamentation is found in Selaginopsis ornata (fig. 134), where there arise from the distal surface eight long slender bifurcating processes which may be for the purpose of forming a sort of pseudo-marsupium as a protection for the ora in the later stages of their derelopment.

Still another kind of gonangial ornamentation has already been discussed, that is the broad leaves, four or eight in number, that form the marsupial chamber in the female gonangium of several species of Dipleteic (figs. 91-97).

A very graceful surface marking is seen in Synthecium campylocarpum, where the gonangia are furnished with two series of opposite and gracefully curving rugosities forming a bilateral ornamentation that is very rare among the Hydroida (fig. 135).

The gonangial aperture is usually either round or squarish in outline, and is always terminal in this group, never taking on the lunate form and lateral position seen in some of the Plumularidie. ${ }^{1}$ As would be expected, the aperture of the female gonangium is, in general, considerably larger than that of the male. Probably the largest aperture in proportion to the size of the gonangium that I have seen is that of Sertularelle megastoma (Plate XX, fig. 9). In many cases the aperture is elevated on a sort of collar which may be a simple narrow band, as in Sertularia gracilis (Plate III, fig. 10), or a broad band, as in Lbietinaria coci (fig. 120), where it is quite conspicuous on the upper surface of a top-shaped gonangium. Often this collar is produced into a tube with a flaring or trumpet-shaped distal end, as in Sertulurella filiformis (fig. 113), and $S$. meridionalis (Plate XXIII, fig. 8). In some cases there appears to be a tube within a collar, as in Sertularella tricuspidata (Plate XXV, fig. 5). Rarely this collar is quadrate in form, as in Sertulurelle fusiformis (Plate XX, fig. t). In many cases, however, the mouth is not elevated above the general surface of the top of the gonangium, where it may be surrounded by a series of from two to five blunt spine-like prominences that are often used as specific characters, as, for eximple, in Sertularella polyzonius (fig. 125), S. contortu (fig. 124), and S. complexa (l'late XXI, figs. 7 and 9). This kind of ornamentation appears to be confined to Sertularella.

Superficial color markings are exceedingly rare on the gonangia. The only cases that I know of among American Sertularide are found in Alietinaria costata (Plate XXXVI, fig. 12), where the summits of the longitudinal ridges are marked by distinct black lines that are very conspicuous in comparatively fresh specimens, and the same thing is much less conspicuously seen in A. amphoru (Plate XXXIV, fig. 4).

The gonangia of several species of Thuiaria, as T. theiarisides (Plate VIII, fig. 6), and Abietinaria, as in 4 . veriabitis (Plate XXXII, fig. 7), are peculiar in having a number of sharp chitinous teeth arranged in a circle on the inside, just below the aperture. I am unable to understand the function of these teeth, unless they serve as a sort of anchorage for the deckenplatte, very much as similar teeth at the bottom of the hydrothece of certain campanularians are supposed to serve for points of attachment for the hydranth.

The text figures 99 to 139 are all drawn to the same scale, and show the variation in size that is found among the gonangia of the Sertularida. 


\section{DEVELOP'MENT OF' 'THE' SERTULARID L:}

Origin of the sex cells.-As in so many respects the two families Plumularido and Sertularide here show their close relationship. So far as I can determine there is no diflerence between them in this respect. In all species of Sertularida in which the matter has been investigated both the male and female sex cells origginate in the endoderm of the stem and branches, or at least are found in this position at a very early stage. Weismann reports this to be true of Sertularia prumila and Sertularella polyzonias, and I have found the same thing in Sertularia pumila, Iyydrallmania fulcata, Sertularella complexa, Diphasia fullux, Diphasia kincaili, and Abietinaria turgida. These comprise all of the species that I have examined for the purpose. 'The sex cells originating in the endoderm of the stem are "arried into the developinge conangium along with the young blastostyle, or clse migrate as do those of the Plumularida, the presumption being in favor of the latter, although I do not know that the process has been completely demonstrated.

The development of the gronangium has been partially described in the ase of Diphereve fallax. It seems that the process is, in general, the same as in the Plumuluride, ${ }^{1}$ and the same thing seems to be true in the development of the ovum and that of the colony as a whole.

As already stated, there are no known sertularians that produce free medusa, nor do the gronophores present any easily recognizable medusoid features.

Weismann has found, however, the characteristic cell layer's that are seen in the medusoid forms, and this leads him to pronoune the sertularian gonophore a very mode degraded medusi, an opinion that can not he gainsaid in the present state of our knowledge.

\section{STSTEMLATIC DISCUSSION.}

\section{Family SERTULARIDA Fleming (moditied).}

Trophosome.-Hydranth with a conical or dome-shaped proboscis and a single verticil of filiform tentacles. Hydrothece sessile, adnate or more or less embedded in the hydrocaulus, arranged definitely and in more than asingle row." An operculum composed of from one to four parts is almost always present. Nematophores wanting.

Gonosme.-Gonophores inclosed in gonangia, and always producing ova or spermatozoa without the intervention of a medusoid form.

The family Sertularidae, ${ }^{3}$ containing as it does the longest known genera of calypteroblastic forms, has been defined by a number of writers, the greneral tendency being, as would be expected, toward a more and more strict delimitation of the group. The above definition is in substantial agreement with the views of most of the present authorities. Taken as a whole, the family is a fairly well circumscribed group, although it has points of contact with campanularian forms through the genus Thyroxcypleus Allman," which agrees with the Campanularide in having the hydrothecar supported on perdieels, and with the sertularida in the characters of its hydranths,

1 See Part I, pp. 36-39.

${ }^{2}$ An apparent exception is found in IIydrallmania, where the bases of the hydrothece are aligned in a single row on the upper side of the branches. Here, however, the distal portions of the hydrothecie are bent alternately to the right and left, and nematophores are never found. These characters are wuflicient to separate the genus from the family Plumularida with which it was formerly associated. Its place in the sertularidie has not been questioned by any recent writer.

"The original spelling of this word scems to have been Sertulariade. The first time that it occurs is in $\mathrm{A}$ History of British Animals, by Fleming, Edinburgh, 1828, p. 538. Johnston, in the second edition of British Iydroid Zoophytes, London, 1847, uses the same spelling, as does Alexander Agassiz, in his Catalugue of North American Acalephac, Cambridge, 1865. IInchs, in his classic work, British Hydroid \%oophytes, London, 1868, p. 233, adonts the spelling Sertularidie, in which he has been followel by a few British and American writers.

Mccready, one of the pioneer Imerican workers in this field, introduces the spelling "Sertularidke," in 1S58, in which he is followed by Louis Agassiz, in his Contrilution to the Fatural History of the United States, IV, 1862, p. 355, and Allman in several of his later works, and most of the present workers, botl dmerican and kuropean.

"Hydroids of the Gulf Stream, Memoirs of the Museum of Comparative Loology, V, No. 2, 1877, p. 10. 
and in haring a well-marked opereulum consisting of four segments. On the other hand, we find in some species of Selaginopsis a superficial resemblance to certain of the Perisiphonida and Laffoeidar, hoth of which families have the hydrotheese without pedicels and arranged on all sides of the hydrocaulus, but which differ from the Sertularidx in having the stem and usually the branches composed of a number of parallel tubes.

The genus Hydrallmanio, as indicated above, bears some resemblance to the Plumularidre in baring its hydrothecar arranged in a linear series on the upper sides of the branches, but differs from all known plumularians in having the distal ends of the hydrotheca bent alternately to the right and left, as well as in the absence of nematophores.

Although the family itself seems to be sufficiently well characterized, almost insuperable difficulties are encountered when we attempt to break it up into genera. Various writers have offered solutions which seem well conceived when the material at hand is limited, but which break down more or less completely when all material available from more recent explorations is taken into consideration. Perhaps the difficulties encountered in trying to solve this exceedingly perplexing problem can best be demonstrated by a brief summary of the attempts made by the more important authorities, beginning with Hincks's epoch-making work, British Hydroid Zoophytes, published in 1568 . This writer divides the Sertulariidie into the following genera: ${ }^{1}$

Seriularella.-Hydrothecx biserial, decidedly alternate, operculum composed of several pieces.

Diphresia.--Hydrothece opposite, occasionally subalternate, a pair to each internode, with an internal valve-like operculum. Female gonangium with an internal marsupial chamber.

Sertularia.-Hydrothecre biserial, opposite or alternate, without external operculum. Gonangia without internal marsupium.

Thuirria.-Hydrothece biserial, embedded in the substance of the stem and branches.

All of these genera, modified to accommodate themselves to the results of later inrestigations, are still retained by recent writers and in the present work.

In December, 18 7 , Professor Allman read a paper before the Linnean Society, ${ }^{2}$ in which he defined the following new genera:

Desmocyphus,--Hydrocaulus bearing hydrothece which are adnate to each other in pairs, and each pair adnate to the front of the hydrocaulus.

Symthecium. - Each internode of the hydrocaulus bearing a pair of opposite sessile hydrothecie. Gonangia on peduncles springing from within the cavity of hydrothece.

Sclaginopsis. - Hydrothece disposed in sereral longitudinal rows about the nonfascicled hydrocaulus.

Pericladium.-Hydrothece more or less immersed and closely set around bifurcating ramuli which spring from the sides of a common stem.

In this work Professor Allman separates the genus Thuiaria from the Sertularida and places it in a new fimily, the Thuiariidx.

In his report on the Hydroida collected by the Challenger ${ }^{3}$ the same author modifies the genus Sertularia so as to include the genus Sertularella, modities the genus Thuiaria and restores it to the Sertularidie, and forms three new genera. His classification is as follows:

Seriularia.-Hydrothece sessile, in two series, opposite or alternate, margins entire or dentate, sides more or less adnate to the hydrocaulus, an internode to each two hydrothece. Operculum present or absent.

Thuiaria.-Internodes of hydrocaulus each hearing many hydrothece which are alternate or opposite, more or less adnate to hydrocaulus, margin entire or ilentate.

Diphasia. - Substantially as defined by Agassiz and Hincks.

Desmoscyphus, Synthecium, and Thecocladium.-As defined above.

Iypopy.ris-Like Desmoscyphus, but with two minute cup-shaped appendages (nematophores?) at the base of each hydrotheca.

Stcurotheca.-Hydrocaulus with opposite bydrothece arranged in decussating pairs.

Dictyocladium.-Hydrocaulus forming a flabelliform network of anastomosing stems and branches. Hydrothece on all sides of branches.

${ }^{I}$ British Hydroid Zoophytes, London, 1868, p. $23 \pm$ et seq. The above table is not a guotation direct, but a condensed statement of the most important points in his definitions of genera.

${ }^{2}$ Linnean Society Journal, Zoology, XII, 18i6, p. 252 et seq.

${ }^{3}$ Report on the Hydroida, Part 2, 1888, pp. 49, 50. 
The tendency to multiply genera reached its maximum in a work published in 1590 by Marktanner-'Turneretscher ${ }^{1}$ in which he adopts all of Allman's genera, restores Sertularella, and proposes two new genera. As this writer's schene of elassification is more comprehensive than any other, it is given here in somewhat condensed form and translated into English:

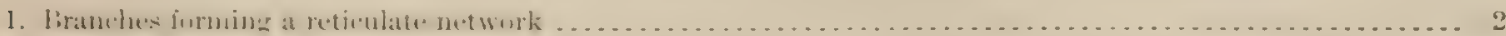

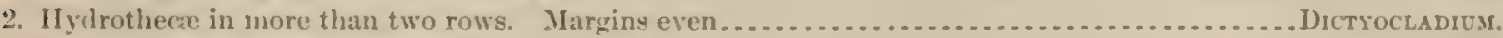

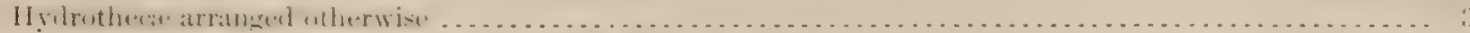

3. Hydrothece paired, adjacent pairs at right angles to each other ............................. STAtrotruca.

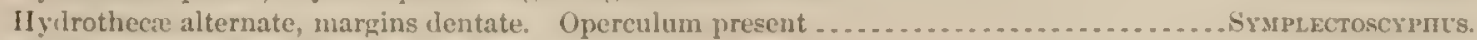

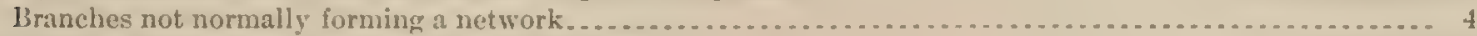

4. Branches arising from cavities of the hydrothece . . . . . . . . . . . . . . . . . . . . . . . . . TrFcocLidus.

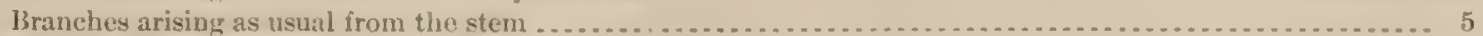

5. Stem polysiphonic, the central tube bearing hydrothecie . . . . . . . . . . . . . . . . . . . . . . GrasmanA.

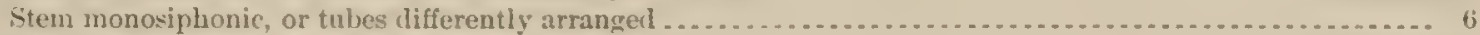

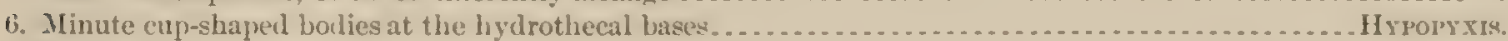

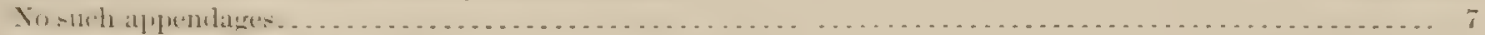

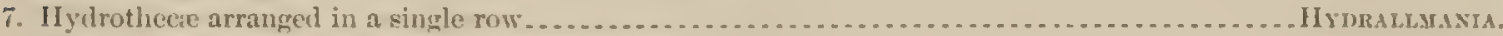

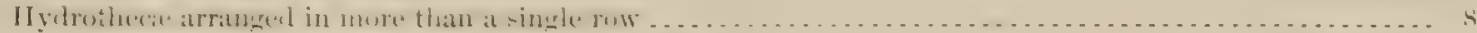

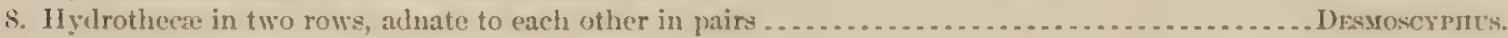

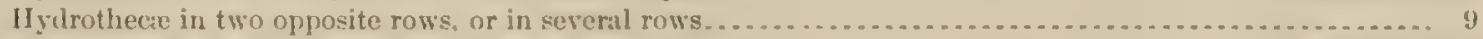

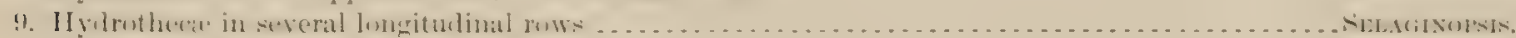

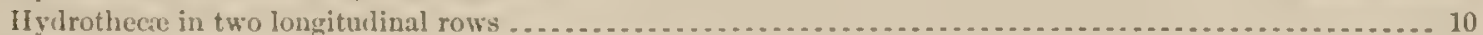

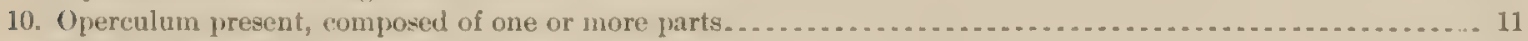

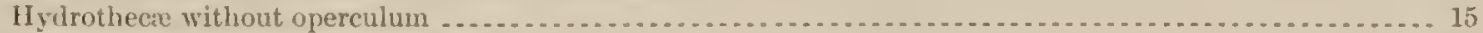

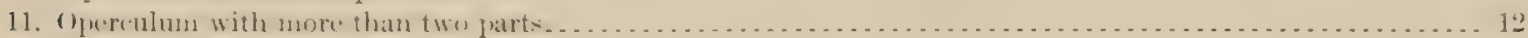

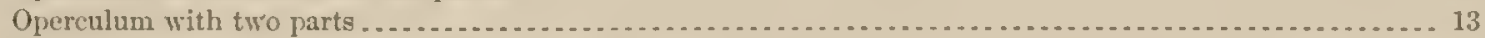

12. Hydrothecae usually alternate, and one to an internode .................................... SERTULARELLA.

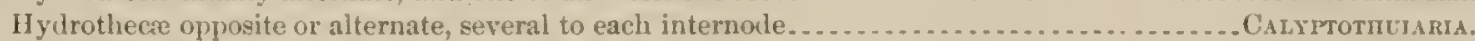

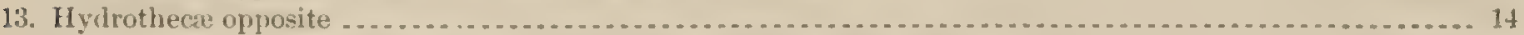
Hydrothece alternate, often several to an internode, an operculum present .................. Moxoros..

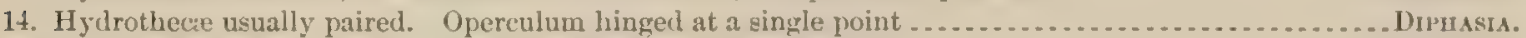

15. Hydrotheae opposite, several pairs in the middle of each internode ......................... PASYTIEA. One, two, or more hydrothece to each internode, the latter not much produced beyond the hydrotheca-

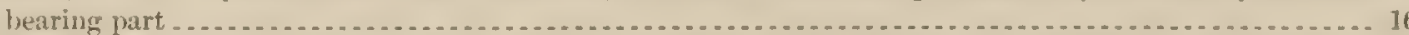

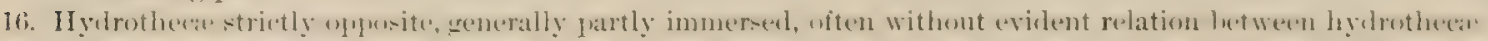

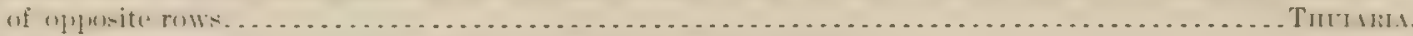

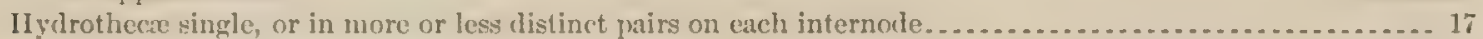

17. Hydrothece paired, sometimes not strictly opposite. Distal jart of branches usually with a pair to each

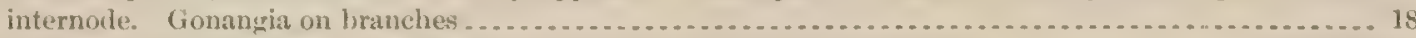
Hydrothece single or paired. Gonangia springing from lnmen of hydrothece ................. SYstuecius

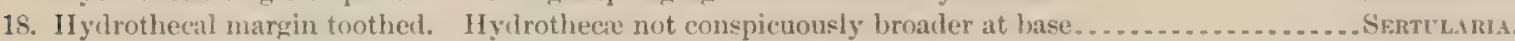

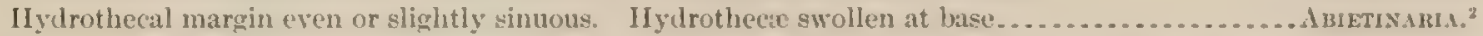

It will be noted that this scheme denies the presence of the opereulum in the genera I'usyther. Sertularia, Thuiuriu, and Abietinaria, in all of which it is actually present.

In 1893 there appeared a scholarly work by Prof. G. M. R. Levinsen, ${ }^{3}$ in which a serious attempt is made to arrange the genera of the sortularide on the basis of the characters of the opereulum in connection with the comblition of the hydrothecal mangin." This writer asserts that the operculum is found in all Sertularida, without exception, and carries his belief to the extent of casting out all genera that do not possess that structure. He states that the genera Grammerie, Synthecium, and ITypopyxis should all find their places outside of the Sertularida, an opinion in which I concur, exeept in the case of the genus Synthecium. He maintains that such features as the relation of the hydrothere to the hydrocandus and to one another atre of little sys-

Die Hydroiden des $k$. k. naturhistorischen Hofuuseums, V, Vienna, 1890.

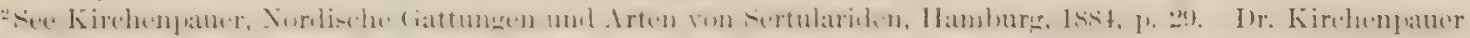
recognizes the following genera: Seluginopsis, Thuiaria, -1bietinaria, and Sertulurella.

${ }^{3}$ Meduser, Ctenophorer oy IIydrolder fra Ginulands Vestkyst tilligemed Bemerkninger om Hydroidernes Systematik. Sartryk af Videnskabelige Meddelelser fra den naturhistoriske Forening i kjobenhavn, $1892,1893$.

'The writer is under great obligation to Mr. J. H. Paarmann for translating the systematic portion of Levinsen's work. 
tematic value unless reenforced by the characters of the operculum and hydrothecal margin, upon which he chiefly relies in his system of classification. He maintains that there is a constant relation between these last two structures, and that the operculum is always attached to more or less deepened curves or sinuosities of the margin.

In accordance with this position, based, as the author expressly states, on his studies of the Greenland species only, Professor Levinsen in another work published during the same year $(1993),{ }^{1}$ classifies the Sertularida as follows:

(a) Operculum of 3 or 4 flaps which are attached to a like number of emarginations of the walls of the hydrothecx.

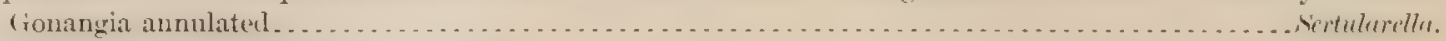
(a') Operculum of a single flap.

(b) Margin of hydrotheca with two lateral teeth.

(c) Hydrothece in a single zigzag row, Opereulum adcauline ........................ Hydrallmania.

(c') Hydrothece in two rows. Operculum attached to adcauline side of margin ............... Sertularin.

(b') Margin of hydrothecxe without teeth.

(c) Operculum attached to adcauline side of margin.

Diphasia.

(c') Operculum attacherl to abcaline side of marin.

Thuinrin.

In applying this key to the large number of species discussed in the present work it becomes evident that it is inadequate to meet the requirements of the case, however well it applies to the Greenland forms discussed by Levinsen.

The scheme is so attractive at first sight that the writer must confess to a sense of personal disappointment at the failure of a method of classification for which he sincerely desired success. The following considerations, and several other's could be added, are sufficient to show the inadequacy of the key.

In the genus Sertularella the form S. formose Fewkes (Plate XXVII, fig. 2), has an absolutely even margin, and an operculum that, when present, is stretched like a drumhead over the very wide operculum. The same is true of $S$. hartlaubi Nutting. I can not see how either of these can be rightfully separated from the genus Sertularella.

The hydrothecal margins in IIydrallmania can seldom be said to have two teeth, and indeed are often perfectly oval, or with slight angulations at the sides that cannot properly be called teeth in the sense in which the term is used in reference to the margins of hydrotheca.

Ir. Parmann, who has very carefully studied many species of sertularians that would come under the genus Sertularia, according to the key given above (including S. mumila and other long-known forms), by means of serial sections concludes that Professor Levinsen is incorrect in saying that the operculum of this genus consists of a single flap. As this is a matter of unusual importance I quote from his unpublished manuscript:

In the species having bilabiate (bidentate) margins each of the einarginations is surmounted by a membranous piece of the operculum. Levinsen (p. 187) says that the adcauline piece is permanently attached to the margins of the teeth, thus forming a "collar," while the abcauline piece is a free functional flap which opens when the hydranth expands and closes after the hydranth has retracted. Upon this type he bases his genus Sertularia. The investigation of a large number of specimens by means of longitudinal and cross sections shows that this condition is by no means uniform. Sometimes the adcauline piece is attached while the other is free, and sometimes the reverse is true. Often the sides of a flap are attached for a greater or less distance proximally while they become free - distally, the degree of attachment varying greatly even in the same species. In most cases both flaps are functional.

I have examined Mr. Paarmann's sections and am convinced that the statements above quoted are correct. It seems evident that Allman ${ }^{2}$ and Marktanner-Turneretseher ${ }^{3}$ are correct in interpreting the hydrotheca of such species as Sertularia pumita as having a two-valved operculum. ${ }^{*}$ This conclusion would make it necessary to fundamentally molify the table of classification proposed by Levinsen. But there is still another and even greater objection to relying exclusively

${ }^{1}$ Annulata, Hydroidne, Anthozoa, Porifera in: Det videnskabelige Udbytte af Kanonbaasen "Hauchs" Togter, Copenhagen, 1893, pp. $321-425$.

Memoirs of the Museum of Comparative Zoology, V, 1877, p. 25.

Iydroiden des k. k. naturhistorischen Iofmuseums, Vienna, 1890, p. 238.

'It seems to me that even by Levinsen's account the operculum is here morphologically, although not functionally, two-valved, and that his so-called "collar" is, like the operculum, simply a thin membranous extension of the hydrothecal wall. See Meduser, Ctenophorer og Hydroider fra Grönlands Vestkyst, 189:3, p. 186 et seq. 


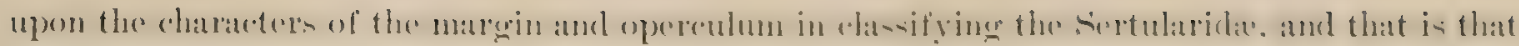
these characters are inconstant, not only in some of the grenera, but also in some individual species. I have already pointed out the fact that certain species of Sertularelle lack the supposed three or four flapped operculum. In Seluginopsis mirabilis (Verrill) there are two flaps to the opereulum, while the one-flapped operculum is characteristic of the genus as a whole. I do not believe that any one would separate S. mirubilis and S. cylindrica (Clark) generically, and yet they differ in this feature upon which Levinsen bases his genera. In Sertularid desmoides Torrey, a form found on the Californian coast (Plate III, fig. 1), the hydrothecal margins are sometimes without teeth and at others show two small teeth. The operculum is usually of a single adcauline llap, but sometimes, in other parts of the same colony, is composed of two parts. In this case neither the margin nor the operculum furnishes a constant feature, even in a single colony. In Abietinariu greenei (Murray) the hydrothece on one part of a colony will be of the typical abietinarian form, while those on another part of the same colony will have two very conspicuons teeth, both of which are adeauline and not strictly lateral (Plate XXXVI, ligs. 3 and 4). The operculum is of a single adeauline flap. Probably enough illustrations have been given to show that the characters used by Professor Levinsen are insufticient in themselves to furnish a basis for the classification of the Sertularida.

It by no means follows, however, that the operculum and hydrothecal margin are character: to be neglected. On the contrary, I think them most important aids in defining certain genera, such as Abietimurie and Dipluesir, and feel that we owe much to l'rofessor Levinsen for his painstaking work ealling general attention to these features. Careful and eonscientious work such as his is always valuable, whether the results are in all respects confirmed or not.

The only remaining author whose seheme of classification we need diseuss at present is Dr. Karl Camillo Schneider, who published a work of interest in this comnection. ${ }^{1}$ Dr. Schneider (p. 521) was at first much impressed with Levinsen's method of classification, but decided that a review of the whole group revealed the inadequacy of the plan, and also many intergrading forms. On the whole, this writer prefers the older classification of the Sertularidie, and adopt the following genera, but calls them "groups" on account of their incomplete separation: Sertularella, Dynamena, Thuiuria, I'esythea, Sdaginopsis, and ITydrallmania."

Lest itmay appear that the writer has intentionally or carelessly neglected to include the works: of American writers in the summary just given, attention is called to the fact that there bas been no general work, nor any general discussion of the fimily Sertularide produced by an $\mathrm{American}$ writer since the appearunce of the classic work by the elder $A$ gassi\%, in $186,2,{ }^{3}$ before the appearance of Hineks's British Hydroid '/oophytes, 1868, which I have taken as my point of departure in the preceding discussion. I gassiz proposed three new genera of Sertularida (pp. 355-356): Lmphisbetia, Cotulinu, and Amphitrochu, which were not adequately defined, and which have not been adopted by later writers, except that two of them are used by his son, Dr. Alexander Agassiz.

In attempting to break up the fumily Sertularida into genera, there are several principles that should be clearly grasped at the outset:

First. No one character, nor combination of two characters can he successfully used throughout, as is illustrated by Levinsen's attempt based on the characters of the hydrothecal margin and operculum.

Second. It sometimes happens that a single character will sharply differentiate a siugle genus. For example, the unilateral arrangement of the hydrothece in Ifydrallmania.

Thime. The hydroids are an extremely plastic group, and certain characters may occur sporadically in many unrelated species that oceur normally and regularly in certain closely related forms. 'This fact has been the cause of great confusion in the systematic treatment of

'Hydroidpolypen von Kovigno, nebst Uebensicht über das System der Hydroidpolypen in Mllgemeinen. Zowlnqische Jahrbücher, Systematik, X, pp. 472-55\%, Jena, 1898.

"Nlthough Doctor Schncider calls these "groups" he treats them as genera, for convenience in handling.

${ }^{3}$ Contributions to the Natural History of the United States of America, IV, Boston, 156.2.

"North American Acalephx, 1865, 1). 146-147. 
the subject, and has brought about the rejection of several genera which it would be convenient and reasonable to retain.

For instance, it occurs not infrequently in several widely different forms among the Sertularide that a gonangium will occasionally have its origin within the lumen of the hydrotheca, although these species normally produce gonangia in the ordinary position. But there are several species, otherwise closely related in the form of the hydrothece and in the apparent absence of the operculum, in which the gonangium normally and regularly springs from the inside of hydrothecx.

Such species should, it seems to me, be placed in the genus Synthecium of Allman. ${ }^{3}$ The sporadic appearance of the gonangium of the Synthechum type occurring as an abnormality in other nonrelated species which commonly produce gonangia in the ordinary way does not, in my opinion, invalidate the genus in the slightest degree.

Again, we find that in many species of the Sertularidx, not otherwise closely allied, one or more branches spring from the lumen of hydrotheca, although these species normally and regularly branch in the ordinary way. But Allman has found several specimens of a certain species in which the hranches "invariably spring from the hydrotheca," " and for this species he instituted the genus Thecocladium. He afterwards found other colonies of the same species ${ }^{3}$ that showed the same constant character, the branches arising normally and regularly from the lumen of the hydrotbeca. These specimens, being more complete than the ones originally described, furnished additional characters that still further confirmed his judgment in establishing the genus. Here again, it seems to me, we are by no means justified in following those who would discard the genus Thecocludium, hecause species of widely different genera will sporadically exhibit the same peculiarity that is uniformly possessed by the specimens studied by Allman.

Foncth. The number of rows of hydrothecre on the branches is a character by which groups of species otherwise closely related ean be segregated to form genera that appear both convenient and naturai. Thus we find a number of species closely related to each other and having manifest aftinities to certain species of Thuidrie that are characterized by having the stem beset with more than two regularly disposed longitudinal rows of hydrothece. For such forms Allman has instituted the genus Selaginopsis."

Again, there are two species closely allied to the genus Sertularella that agree more closely with each other than with other species from the fact that the hydrotheca are placed on all sides of the branch in an ascending spiral. Associated with this character in the two species thus far discovered is a remarkable tendency toward anastomosis of the branches which are all in the same plaue, forming a flabellate colony. For the first of these species Allman formed the genus Dictyocladium. Another species is described in the presentwork. One species has been found, otherwise related to the genus sirtularie, that differs from all others in the fact that the suecessire pairs of hydrothecre are rotated on the stem so that each pair is set at right angles to the plane of the pairs immediately above and below. The result is that there are four longitudinal rows of hydrothece on the hydrocaulus, the individuals of a given row being very widely separated, and each individual forms one of a pair of opposite hydrothece. For this species Allman has established the genus Stanrothece, ${ }^{6}$ a genus not found in American waters.

$F: f t h$. The operculum can be used as an important factor in separating out some of the generic groups from the great mass of Sertularidx in which the hydrothece are arranged in two longitudinal rows, but this character is not in itself sufficient, and we find it necessary to use different combinations of two or more characters for this purpose, among which the combination of the form of the operculum and the arrangement of the hydrothece on the hydrocaulus is of great value. There is a certain long lnown form that has an operculum of two valves and in which

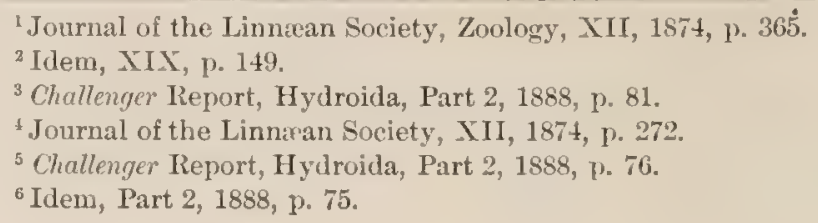


the hydrothece are arranged in compact groups of pairs, a group to each internode, the upper pair of a group being noticeably smaller and diferent in shape from the lower. This very characteristic form is the basis of the grenus P'usythea of Lamouroux."

A large number of species agree in having the opereulum of three or four flaps and the hydrotheca strictly alternate. These form the well marked and well known genus Sertulerella. ${ }^{2}$

Again we tind that a combination of the ehataeters of the opereulum together with the cerneral form of the hydrothece can be used to advantage. A large number of species agree in having an opereulum composed of a single flap which is hinged to the adeauline side of the margin. Therese have all been included by Levinsen in the genus Diphasia. A study of these forms leads to the discovery that the genus thus constituted is madro up of two woll-mathed groups which anger in the charaeter of the operculum just given, but differ widely in the form of the hydrothecer: one group consisting of species with tubular hydrotheca that are not distinctly swollen below, and that have very larege apertures without any distinct neck or constrietion of the distal part of the hydrothecal wall. These forms can very well be retained in the genus / hipherie, substantially as originally described by Agasiz. The other group having an opereulum of one adealine valye

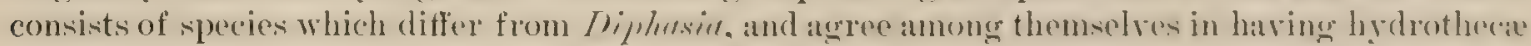
that are more or less bottle-shaped-that is, their lower portion is bulged out or" swollen like the body of a flask, and their distal parts are constricted so that the diameter of the aperture is much smaller than the diameter of the lower portion. 'There is often also a distinct constriction caused by the thickening of the hydrothecal walls below the matren. The forms just described constitute what seems to me to be a very well circumseribed genus Alictinaria. ${ }^{3}$

Sixth. As a last resort we find that a combination of the position of the hydrothecre, whether opposite or alternate, and the character of the internodes will serve to aid in solving the last and most perplexing problem of all, the separation into generic groups of the forms still remaining, which agree in having the hydrothece in two rows, margins smooth or dentate, the operculum of one adcauline flap, or of two (rery rarely three) flaps." We find upon examination of the very large number of species agreeing in these particulars a number that agree in having strictly opposite hydrothece that are not greatly embedded in the hydrocaulus, an operculum comprised almostalways of two valres, and the internodes normally and commonly bearing two hydrothece; or the hydrothece may be slightly subopposite, but the internodes are regular and normally and commonly bear two hydrothece, showing that the latter are essentially paired, as pointed out by Bale. Such forms can be referred to the original grenus of the family, Sertularite.

The remaining forms agree in having the hydrothece normally and regularly subopposite to alternate, usually more or less embedded in the hydroculus; operendum of one flap (ahcauline) or of two flaps; more than two (often many) hydrothece to each internode, the latter being of very irregular length even in the same colony. 'These forms we can refer to the old genus Theiaria.

It will be noticed that seven of the nineteen genera adnitted by Marktanner-T'urneretseher (see p. 39) are not included in the scheme as outlined above. These seem to me to be untenable, and the species included in them ean be disposed of as follows:

Grammariu and IYypopyx is do not belong to the Sertularida.

Calyptothuireria and Symplectosenplus should bo united with Sertulurelle, from which they are not separated by what appear to me to be adequate characters.

Monopoma is quite a typical Thuiarit, according to the scheme here adopted.

Desmoscyphus ean with propriety be referred back to the old genus Sertularia.

${ }^{1}$ Nouveau bulletin philonatique, decembre, 1812, p. 183.

${ }^{2}$ Gray, Radiata, List of specimens of Jritish animals, etc., London, 1847, 1.68.

${ }^{3}$ Kirchenpauer, Nordische Gattungen und Arten von Sertulariden, Iamburg, 1884, p. 29.

'The author does not claim to have successfully solved this problem, which appears with our present knowl. edge to be insoluble, but hopes that the arrangement sugrested will be practical in fact, although unsatisfactory in theory. At any rate, it is the best that he has been able to devise after rery careful pondering of the subject.

${ }^{5}$ Australian Hydroid Zoophytes, 188t, pp. 115, 116. 
Dymemence should be dismembered, part of the species going to Sertuluria and part to Theriarid, as above defined.

For convenience in referring specimens of American Sertularidre to their proper genera, accorling to the plan adopted in this work, the following key is presented, with the confession that, like all such keys, it is purely artificial and does not indicate the interrelationships of these genera:

KEY TO TIE GENEIRA GF AMERICAN GEITULARIDE.

Hydrothecie all on one side of the branches, their distal ends being turned alternately to the right and

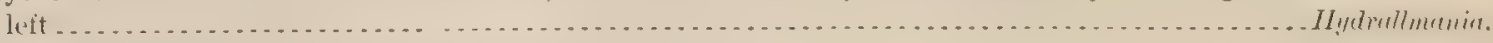

IIydrothece arranged on all sides of branches.

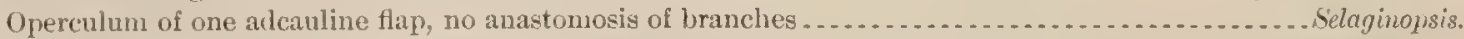

Operculum of several flaps, branches freely anastomosing . . . . . . . . . . . . . . . . . . . . . . Dictyocladium.

Hydrothece arranged in pairs, each pair being revolved so as to be at right angles to the pair immedi-

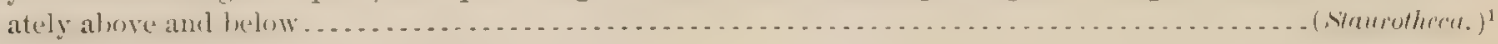

Hydrothece always in two longitudinal rows.

Hydrothece in groups of pairs, the uppermost being decidedly smaller than the lower. ............ I'tsyther.

Operculum adcauline, and of one flap.

Hydrothecal aperture large, body not flask-shaperl . . . . . . Diphasia.

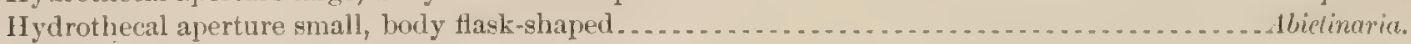

Operculum abcauline, of one flap, or of two or more flaps.

Operculum of three or four pieces." Hydrothegie strictly alternate, margin usually toothed...... Sertulurella.

Operculum of one (abcauline) flap, or of two, rarely three, ${ }^{3}$ Haps.

Hydrothece strictly opposite, each internode normally bearing a single pair . . . . . . . . . . . Sertularia.

Hydrothece subopposite to alternate, each internode normally bearing more than two....... . Thuiaria.

Operculum wanting, margin round.

Branches normally arising from the lumen of a hydrotheca ......................... (Thecochdium.)

Gonangia normally arising from the lumen of a hydrotheca....... . . . . . . . . . . . . . . Synthecium.

In concluding this general discussion of the genera of the Sertularide the author wishes to explain his position in view of some of the more important objections which he apprehends will be urged against the classification here adopted.

First. It will be said, and truthfully, that the system is based on a heterogeneous set of characters, and that different characters are used in defining certain genera from those used in defining others. Of course, the ideal system would be to find one or two characters that would suffice. As a matter of fact, no writer could use more care and ability to effect this end than has Levinsen, as we have seen; and his work has been chietly valuable in demonstrating the impossibility of such a method, at least so far as the Sertularidae are concerned. 'There is also a distinct danger in confining diagnostic features within too constricted limits, and this is that it is almost certain to result in a most unnatural assemblage of species into genera which do violence to actual affinities, as was done, for instance, when Uydrallmanin was regarded as a plunularian on account of using the one character of unilateral arrangement of hydrothece.

With increase in experience the naturalist sees more and more clearly that all characters must receive due consideration, and that the fewer the characters used the less satisfactory will be his groups, if he desires them to indicate real affinities.

Again, it has come to be recognized among systematists that a given character will often be of the greatest value in one section of a family, or other group, while the same character is comparatively worthless in another section of the same fumily or gromp. Thus the operculum is almost an ideal character to use in separating out the genus Diphasia, as used by Lerinsen, but fails in Theirmia and Sertularia.

Second. A still more serious objection will doubtless be raised by those who will discover intergrading forms between the genera that are here recognized.

${ }^{1}$ The brackets indicate that the genus is not found in American waters.

${ }^{2}$ Very exceptionally the hylrothece in this genus are withont teeth, and the operculum is stretched like a drumhead across the very wide, round aperture.

When three teeth are present, as in some of the Desmoscyphus group of Sertularia, the upper one is much smaller than the others, and the operculum is very delicate, while the three-toothed forms of sertulurclla have equal and equidistant or conspicuous teeth, and the operculum is evident. 
In answer to this it must be urged that a condition, not a theory, confronts us, and it appears to be jmpossible to break up the family Sertularida into groups that do not intergrade to some degree. Reducing the number of grenera will not help us, a statement that will bo

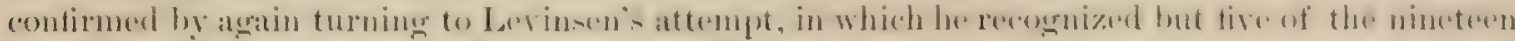
genera used hy Marktanner-'Turneretscher. Investigation shows that these five genera intergrade just as vexatiously as do the twelve included in my scheme, and the five genera are individually much more unwieldy and diflicult to manage than are the twelve. 'Thus there is nothing lost in the delimitation of genera, and much gained in convenience when the larger number is utilized.

Here again the plasticity of the Hydroida as a group is the cause of much of our difticulty. It seems that these lowly animats have not ret crystallized into definite and unvarying forme to the extent that is found andong the higher metazos. and the result is that both - pereifie and generic boundary lines are erossed in various directions, much to the perplexity of the systematist, as I have elsewhere attempted to illustrate. ${ }^{2}$ In this case it seems to me that we must abandon the idea that a genus is untenable so long as there is any intergradation with other genera, and take the position that a genus is simply a group of closely related species that are related more nearly to each other than to members of other similar groups, and that the genus can be good, both in practice and in theory, eren if certain species do intergrade in sume individual characters with species of other genera. We must remember, moreover, that all genera would intergrade with

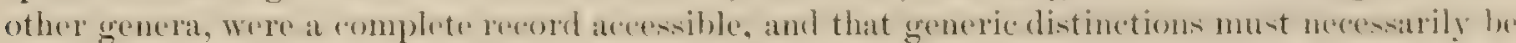
an expression of the gaps in our knowledge rather than of natural boundary lines.

I have taken the position indicated above in this work, and frankly confess that some of the genera used intergrade with others. These intergradations will be pointed out with care when the several genera are discussed later.

\section{Distribution of American Sertuluridz.}

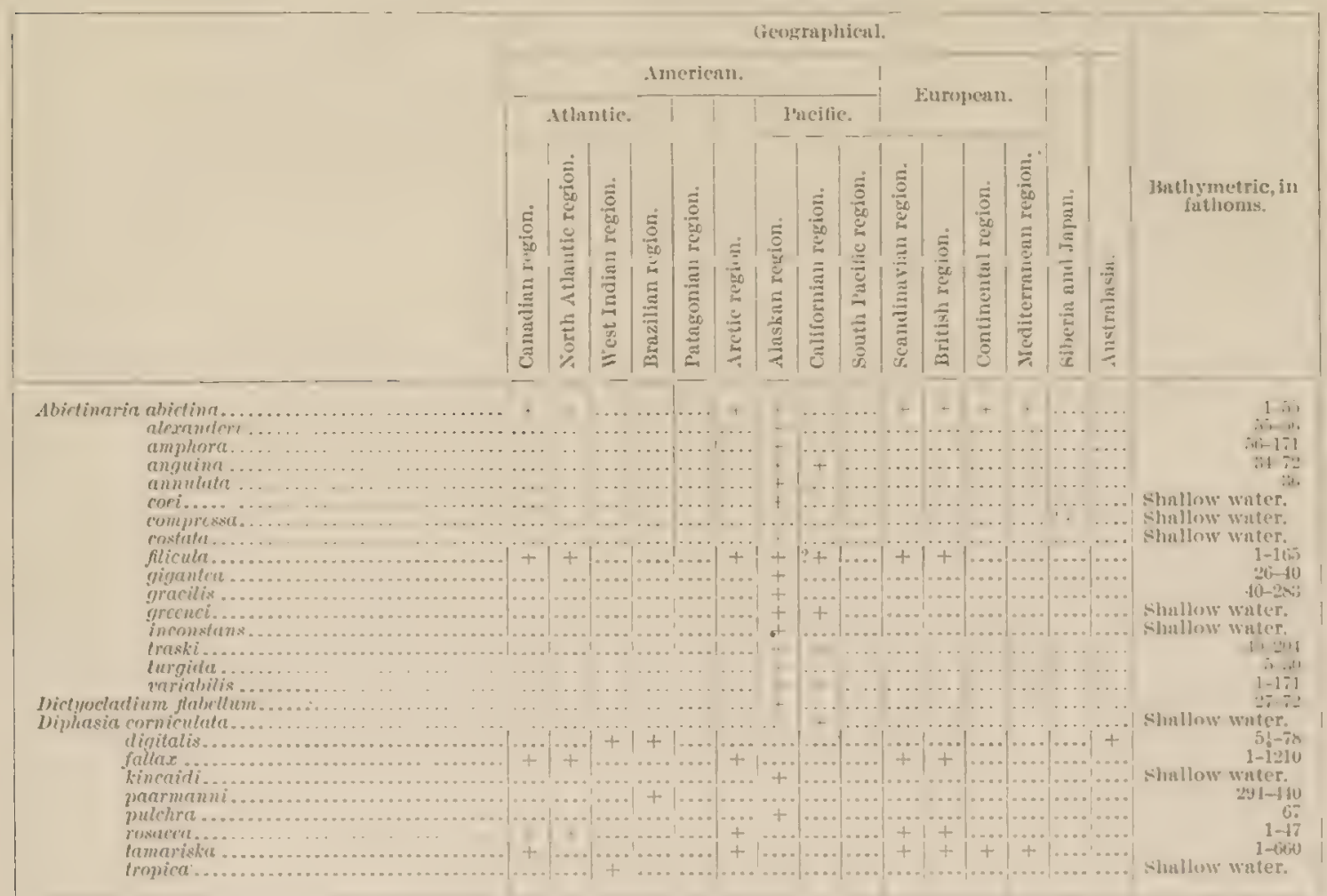

${ }^{\prime}$ C. C. Nutting. Address of the chairman of the section of \%oology and vice-president of the American Association for the Advancement of Science. Science, January 9, l(M):3, p. 9. 
Georraphicul distribution of American Scrtuluridie-Continued.

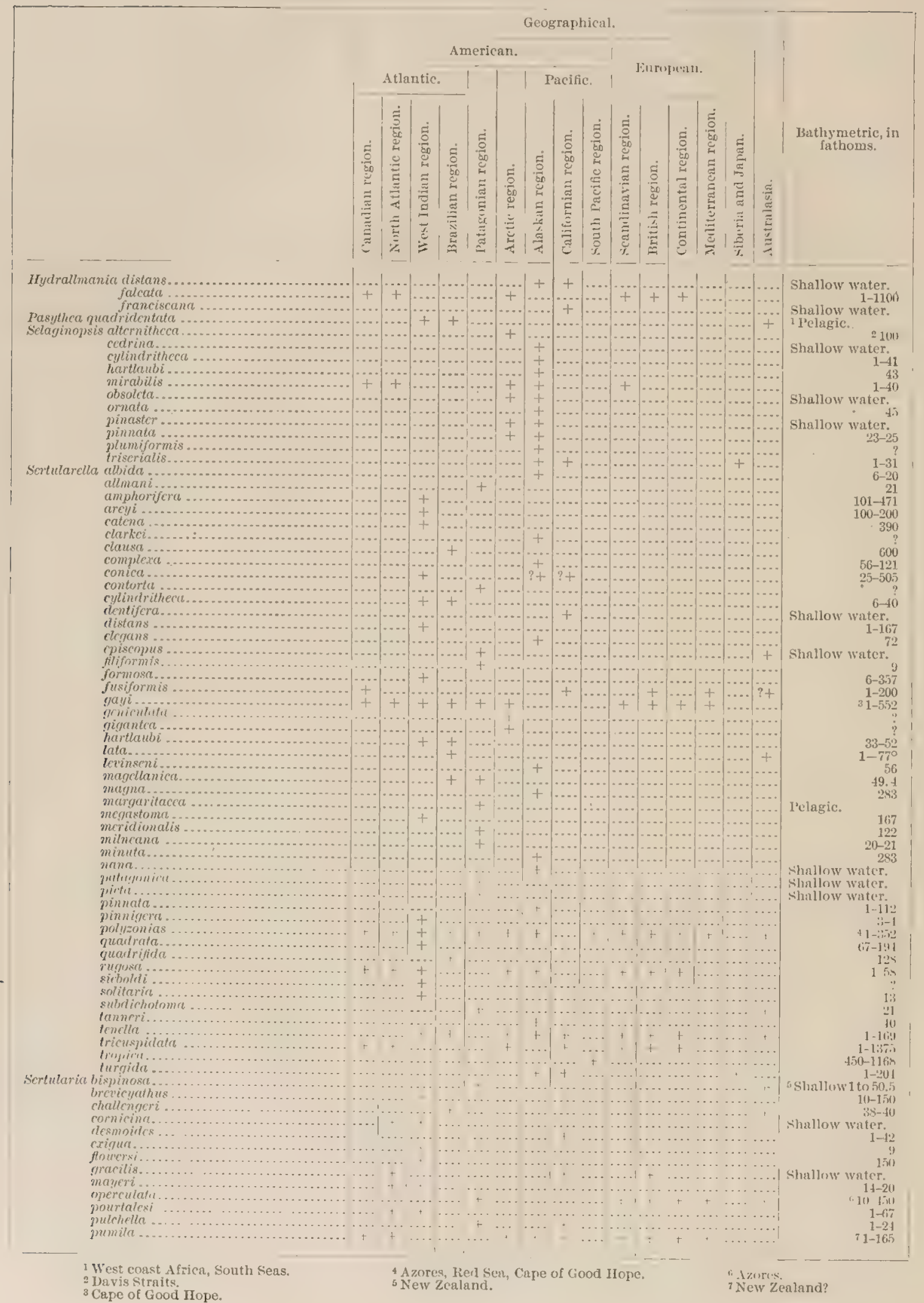




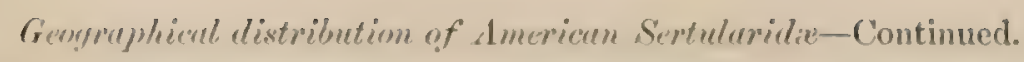

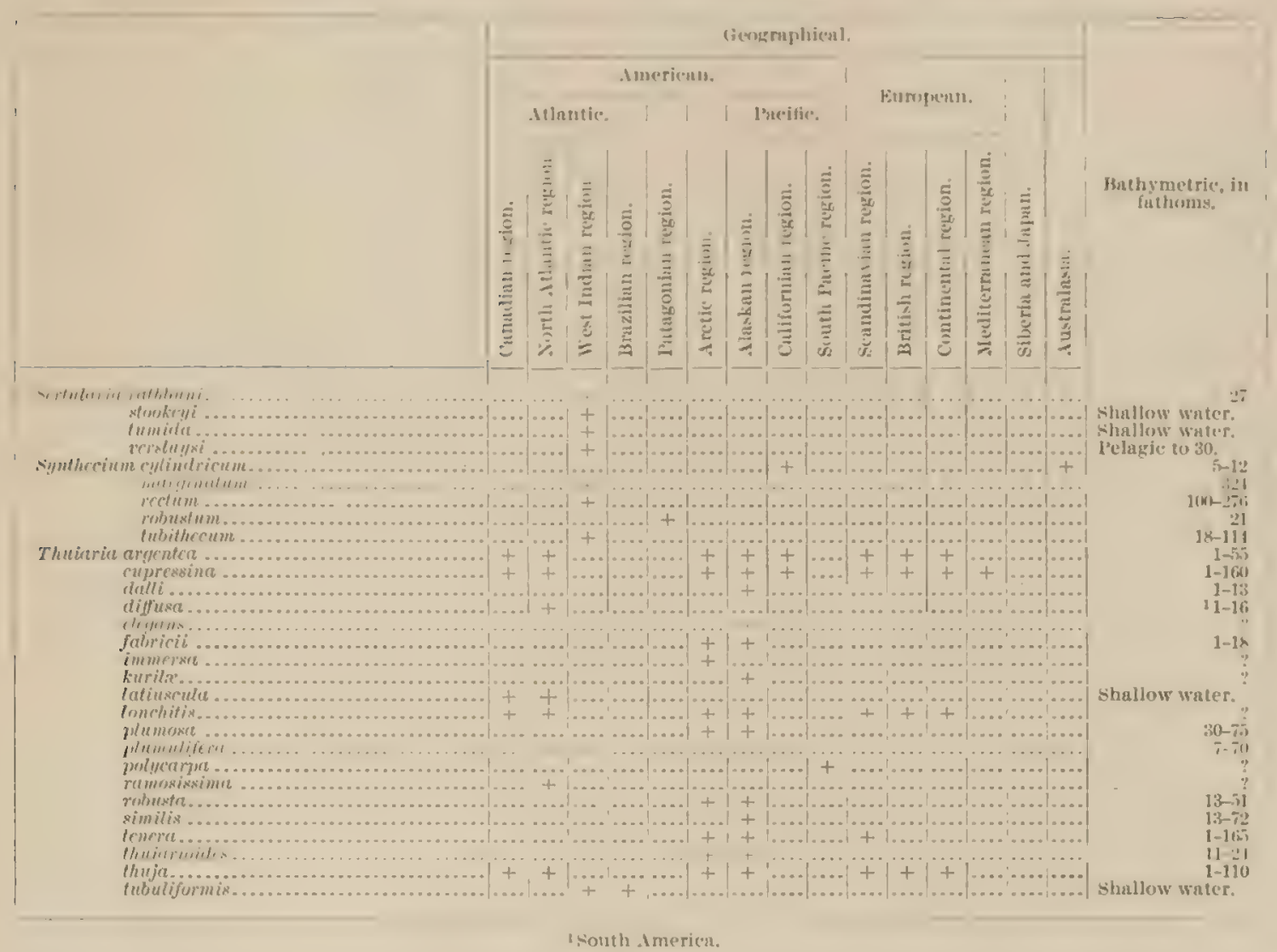

On accomt of the very marked diflerence between the distribution of the Sertularida and that of the Plumularida, it seems best to adopt a different classification of greographical regions: from that presented in the first part of this work. 'The two groups have entirely different renters of distribution, and the Plumularide are atmost wanting in regions where the Sertularida are most alundant. I bave therefore adopted for the latter family the following regions:

Canabiax. - To include the Jorth American coast region from Lastport, Maine, to the Aretic Cirele, or the south end of (ireculand.

Nonтi Atuxte.-From Listport, Mane, to Charleston, Sonth Carolina.

WEst IxDiax,-Including region sonth of Charleston, the Gulf of Mexico, Caribhean Sea, North coast of South Americat to Brazil.

Braznax. From Northern Brazil to Southem Argentina.

Patagondax,-Southern Argentina, Patagonia, Terra del Fuego, Falkland Islands, and Southern Chile.

Arctic - All north of Aretic Circle in general, but including the White sea of Russia.

Alaskax.-From Bering straits south to and including Puget Sound。"

Calforsiax. - From l'uget Sound to and including Mexico.

Soutu PAcrere. - South of Mexien to the Patagonian region as here defined.

Scavinaviax,-Ineluding Denmark, sweden and Norvay to the Aretic Cirele.

Butrsu. -Ineludinge the British Islands and Ielgoland.

Contivistal. - Including the coasts of Belgium, France, and Atlantic coast of Spain.

${ }^{1}$ American If

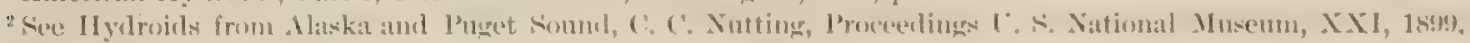
1). 742; also lapers from the Harriman Maska lixpedition, The Hydroids, l'roceedings Washington Academy of Sciences, III, $1401,11 \mathrm{p} .158$ to 162.

$$
5125-1^{2} \mathrm{~T}:(1)-1
$$


Mediterraxeax.--Including the Mediterranean proper and the Adriatic.

The other regions named are self-explanatory. The few cases where American species are found in regions not mentioned above are indicated in footnotes.

It will be seen that most of these regions are quite arbitrary, and their faune intergrade in almost all cases. Until a more serious and comprehensive study is made of the distribution of all groups of marine organisms no final or eren approximately sat isfactory set of zoogeographical regions can be made. In the meantime, however, each worker can exercise his own judgnent in devising a scheme that will satisfy his special requirements and aid him in indicating the facts of distribution so far as bis field of work is concerned. It remains for some master mind to correlate these various attempts into a well-digested zoothalassography.

The table given above will serve to indicate some points of interest, the most notable being the richness of the sertularian fauna in the Alaskan region, in which 58 of the 131 species of American forms are found. This may be due to the excellent work done in that region, heginning with the extensive collertions made by Dr. Dall and his party, ${ }^{1}$ and terminating with the notable collections made by the Harriman Alaska Expedition. ${ }^{2}$ In the meanwhile the U. S. Fish Commission steamer Albatross made rery extensive collections during her several cruises in Alaskan waters, the material of which is included in the present work.

Next to this region come the West Indian and the Aretic, with 35 and 29 species. An examination of the table clearly reveals another fact, and that is that the sertularian fauna secms to have its present center of distribution in the far north, probably in the Aretic regions, as is indicated by the holaretic distribution of many species-a matter that the present writer han already discussed. ${ }^{3}$

In working with material from the far north, particularly from Alaska, one is greatly impressed with the luxuriance and thrifty appearance of the hydroids - an indication that the region is peculiarly adapted to their needs. The finest specimens, both of campanularian and of sertularian colonies, that the writer has ever seen came from the cold waters of Alaska. The rarious Scandinavian writers have found a rich field for work in the hydroids, and Kristine Bonnevie has produced a sumptuous monograph on the Hydroids of the Norwegian North Atlantic Expedition. It seems, then, that the group has spread from the Arctic region southward on both shores of the Atlantic and on the Pacific coast of North America, and there are so many species common to these four regions that we can hardly escape the conclusion that the group, at least in its present forms, had a polar origin. The number of species found in the West Indian region would seem to militate against this view, but many of these belong to special groups, such as the Desmoscyphus group of Sertularia, indicating that they have long been separated from the ordinary types of the family. The Sertuliride appear to have spread, from whatever center, over the ocean floor throughout the world; at least they have been found in every region where any considerable amount of dredging has been done. They must be quite abundant in the Patagonian region, for the small amount of collecting done there has given us no less than seventeen species. Australia also has a rich sertularian fauna of about sixty species, according to Bale, ${ }^{4}$ which seems to be rather closely allied to the Patagonian forms, indicating the possibility of an Antarctic center of distribution, for certain groups at least. The west coast of South America seems to be the poorest in Sertularidie of all the American regions included in the table. This may be due to the comparatively few hanls made in these waters, but probably indicates a real dearth in that region.

It is interesting to note the great difference shown in this table and the one on pages 49 to 51 of Part I of this work hetween the distribution of the Sertularida and the Plumularide, the former having its greatest wealth of material in the Alaskan region and the latter in the West Indies.

See Clark. Regort nn the IIyidroids collected un the Coast of Mlaska and the Aleutian Islands by W. H. Dall, Proceedings, Acalemy of Natural Sciences of Philadelphia, 1876.

See Papers from the Harriman Alaska Hxpedition, XXI, The Iydroids, C. C. Nutting, Proceedings Washington Acarlemy of Sciences, III, 1901, p. 157.

${ }^{s}$ Hydroids of the Harriman Expedition, 1901, p. 16:.

"Catalogue of the Australian Hydroid Zoophytes, W. M. Bale, Sydney, 1884. 
Bathymetric distribution. - Ireve again it has seemed best not to follow the scheme adopted

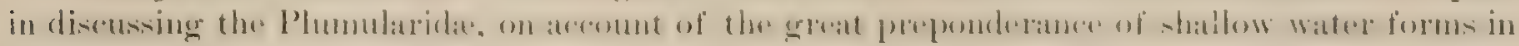
the Sertularidie, and also for the reason that the table given for the lumularidie involved more labor than is necessary in the case of other species. By gring the maximum and minimum

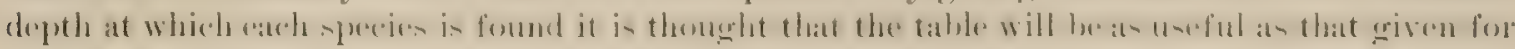
the Plumularda, in which the record is maintained for all the intermediate zones, it being, indeed, more probable that the actual conditions of bathymetrie distribution are thus presented, as it is altogether more likely that the nonoccurrence of a species in the table given for the Plumularida is due to incomplete exploration than that the bathymetric distribution of these species is actually discontinuous, as would be indicated by that tahle. In other words, we have a right to consider that a species that has been reported from 100 and 300 fathoms actually exists somewhere at a depth of 200 fithoms, or that it has recently existed at that depth.

In comparing the two tables it becomes at once apparent that the Sertularida are much more generally found in shallow. water than the Plumularida. 'The proportion of shallowwater forms-that is, those found in less than 50 fathoms-being a little over 75 per cent in the Sertuluride and 50 per cent in the Plumularide. There are 41 per cent of the Sertularida contined to the shallow-water zone. while there are only sis pere cent of the Plumularida confined to the same zone.

The following table shews very plainly the diflerenes in the bathymetrie dintribution betweren the two families:

Comparutive distribution at increasing depths.

\begin{tabular}{|c|c|c|c|c|c|c|c|}
\hline Finily. & $\begin{array}{l}\text { Less than } \\
50 \text { fathoms. }\end{array}$ & $\begin{array}{l}\text { Over } 50 \\
\text { fathoms. }\end{array}$ & $\begin{array}{l}\text { Over } 100 \\
\text { finthoms. }\end{array}$ & $\begin{array}{l}\text { Over } 150 \\
\text { fathoms. }\end{array}$ & $\begin{array}{l}\text { Over } 200 \\
\text { fathoms. }\end{array}$ & $\begin{array}{l}\text { Over } 500 \\
\text { fathoms. }\end{array}$ & $\begin{array}{l}\text { Over } 1,000 \\
\text { fithoms. }\end{array}$ \\
\hline $\begin{array}{l}\text { Plumuluridale } \\
\text { Sertulnride.. }\end{array}$ & $\begin{array}{r}\text { Per cent. } \\
0.50 \\
.75\end{array}$ & $\begin{array}{r}\text { Per cent. } \\
0.63 \\
.40\end{array}$ & $\begin{array}{r}\text { I'cr cent. } \\
0.49 \\
.30\end{array}$ & $\begin{array}{r}\operatorname{Pcr} c c u t . \\
0.40 \\
.26\end{array}$ & $\begin{array}{r}\text { Ifr cent. } \\
0.28 \\
.16\end{array}$ & $\begin{array}{r}\text { Irer ccut } \\
0.05 \\
.06\end{array}$ & $\begin{array}{r}\text { Int cent } \\
0.03 \\
.03\end{array}$ \\
\hline
\end{tabular}

The following species of Sertularide have been dredged at depths greater than 500 fathoms: Diplereia fallax, 1,210 fathoms (Bonnevie); Diphasia tamariska, 660 fathoms (Bonnevie); Sertulurella clause, 600 fathoms (Allman); Sertularella tricuspidata, 1,375 fathoms (Bonnevie); Sertularelle tropica, 1, 168 fathoms (Clarke).

The well-known Sertulurella tricuspidatu seems to have the greatest vertical distribution of any sertularian, ranging from the littoral region to the depth of 1,375 fathoms. The only American hydroid that has been found at a greater depth than this is Aglaophenopsis rerrilli Nutting, which was found at 1, 742 fathoms. In this case, however, the known bathymetric range is from 1,497 to 1,742 fathoms."

\section{SERTULARIA Linngus (modified).}

Trophosome.-Hydrotheca in strictly opposite or rarely subopposite pairs. Stem and branches normally divided into regular internodes, each of which bears a pair of hydrotheca. but sometimes there are more than one pain to the internode, in which case the hydrotheca are strictly opposite. Operculum normally of two llaps.

Gomosme.-Gonangia oval or orate, with a short collax and broad aperture and no internal marsupium. An acrocyst is oecasionally present.

This being the original I simman genus for the hydroids, it has necessarily suffered many vicissitudes, most of which have been in the direction of closer and eloser delimitation, Lamouroux

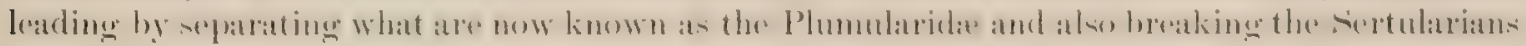
proper into two eroups, Dymemene to include those with strictly opposite hychothece, and Sertularin those with more or less alternate hydrotheca." Were both these genera used in the present work, the species that I include in Sertularia would go into the genus Dynuman. Lamouroux alvo set ande the species now included in the IIalecidie in the genus Thou, afterwands 
supplanted by IIalecium of Oken, ${ }^{1}$ the species now included in the Lafoeida in his genus Lafver; many of the Campanularide in Lumeded and Clytic. At nearly the same time (1816) Lamarck issued the first edition of his classic work, Histoire naturelle des animuux sans vertèbres, -II, in which be separated most of the present Campanularide under the name Campanuluria, and the Plumularidie under the names Antemuluric and Plamularia, and retained the name Sertularin for the species then known that would now be included in the family Sertularida. In the same year, (1816), ${ }^{2}$ Lamouroux published his Histoire des Polypiers coralligènes Flexibles, etc., in which he divided the sertularians into the genera Pasyther, which included the Pasythea of sub. sequent authors plus certain nonrelated forms, Dymamena, including the forms that would bo placed in Sertularia and Diphasic in the present work, and Sertularie, including forms with alternate hydrothece, such as are now placed in Scrtularelle, Thuiuriu, Abietinuria, etc.

The next work of importance is that of Fleming, ${ }^{3}$ who instituted the grenus Thuiarin to include what now would be called the typical species of that group. He followed Lamouroux in the use of the generic name Dynumenu.

Johnston in his British Hydroid Zoophytes, 1828, returns to the use of the genus Sertularia in nearly its original meaning, drops the genus Dynament, and adopts the genus Thuiarit of Fleming.

In 1862 Louis Agassiz ${ }^{4}$ differentiated the genus Diphasia from the Sertularia or Dynamena of other writers, and uses the word Sertularic in a very restricted sense, including only Sertultria argented, Thuiarie cupressina, Abietinaria abietina, and A. filicula. He also proposed the genera Aimphitroctea and Cotulina for certain species that are now included in Sertularella, and Amphistretia for Sertularin operculata.

With the great work of Hincks, British Hydroid Zoophytes, 1868, what may be called the modern era began. He reinstated and moditied the genus Sertularella, ${ }^{5}$ which is by far the largest in the family, if not in the entire order Hydroida, and also proposed the genus IIydrallmania for the Sertularia falcata Linnæus, which many writer's had erroneously placed in the Plumularidie.

The further vicissitudes of the genus Sertularia are sketched in preceding pages of the present work, in connection with the general systematic discussion of the family.

\section{POINTS OF INTERGRAIATION BETWEEN SERTULARIA AND OTHER GENERA.}

As above defined, the genus Sertularin is a well circumscribed group, but in certain individual characters it has points of contact with other genera, among which the following may be found in species treated in this work:

First. With Thuiaria. In several cases, such as S. bispinosa, challengeri, and desmoides, the internorles are of irregular length and bear more than a single pair of hydrothece. In all such cases, however, the hydrotheca are normally strictly opposite, and never subopposite nor subalternate, as in Thuiaria.

Secumed. With Sertularella, in having a three-flapped opereulum and three-toothed margin, as in S. sertularioides and $S$. brevicyuthes. Here, also, the hydrotheca are strictly opposite and not strictly alternate, as in Sertularella.

Third. With Thuiaria, in having a round aperture, without teeth, and an abcauline operculum composed of a single flap as in $S$. desmoides. Here, also, the hydrotheca are strictly opposite. In this case there is the further complication of extreme variability in the hydrothecal margin and operculum, there being an oceasional hydrotheca in which the margin is obscurely two-toothed, and the operculum apparently of two valves. In each of these cases it

${ }^{1}$ Lehrbuch der Naturgeschichte, 1815, p. 91.

${ }^{2}$ The nearly simultaneous appearance of the works of Lamouroux and Lamarck have caused almost inextricable confusion in the systematic treatment of this and of other groups of hydroids. See Part I, p. 54.

${ }^{3}$ A History of British Animals, ete., Edinburgh, 1828, p. 545 .

* Contributions to the Natural History of the United States, IV, 1862, p. 355.

${ }^{5}$ Originally proposed hy Gray. List of the specinens of British animals in the collections of the British Museum, I'art 1, Radiated Animals. London, 18t7, p. 68. 
will be observed that the species is, on the whole, more closely allied to sertuluria as here defined than it is to the particular genus to which it approximates in the special character discussed.

Colony branched, at least in typical specimens.

Branches regularly disposed.

Branchesenpusite.

pumilin.

Branches alternate.

Hydrothece largely contingent in front ............................................ .rersluysi.

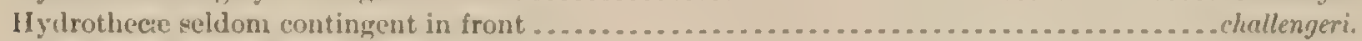

Branches loosely or irregularly disposed.

Hydrothecal teeth two, long, recurverl, conspicuous.

One tooth much longer than the other.

operculala.

Teeth approximately equal.

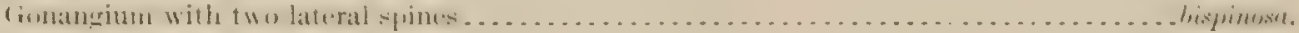

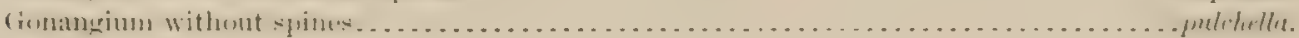

Hydrothecal tecth not conspicuous.

Margin generally without teeth.................................................... desmoides.

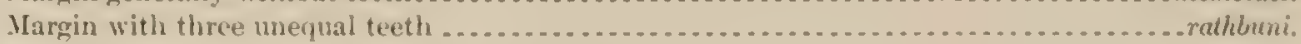

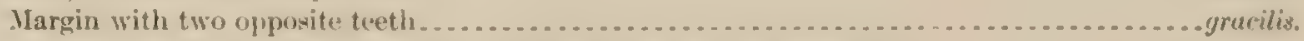

Colony normally unbranched (one or two unsymmetrical branches may be present).

Hydrotheca placed on front of stem, and largely contingent.

Hydrothece on proximal portion differing greatly from those on clistal portion...................mayeri.

II yilrothecae alike on all parts of stem.

Chitinous processes projecting downwarl from hotfon of hydrothece .................... cornicina.

No noticeable chitinous processes.

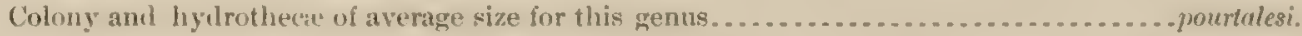

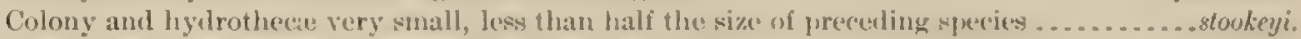

Hylrothere not placed on front of stem, whether contingent or not.

Hydrothece contingent of average size, margin with three tecth . . . . . . . . . . . . . . .....lirericyathue.

IIydrothece contingent, very suall, naryin with three teeth ............................ floutersi.

IIydrothece not contingent, margin two-toothed.

Distal part of hydrothece bent at right angles to proximal part .........................tumida.

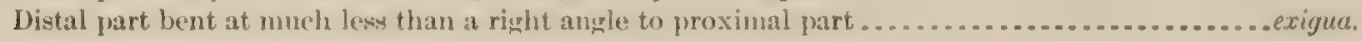

\section{SERTULARIA PUMILA Linnæus.'}

(1'late I, tigs, 1-i,.)

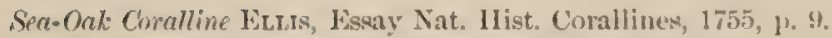

Sertuluric gumilu Lixx.sus, Systema Saturie, 1758, p. 807.

Sertuluria pumilu L.xx.zus, Fauna Suecica, 1761, 1. 540.

Sermluria pumilu Ioumoxx, Natumrlyke historie, XVII, 1761-1773, 1. 527.

Sertularia pumile l'A dacas, Elenchus zophytorum, 176ti, [2. 130.

Sertuluria pumila Loxw.ts, Gystema Naturit, 12th ed., 1767, p. 1306.

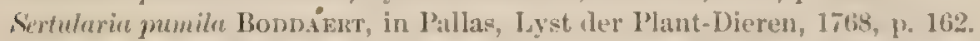

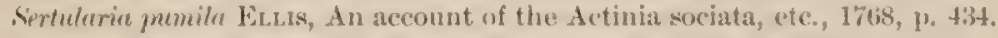

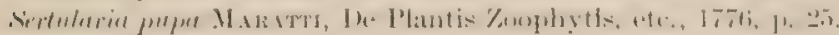

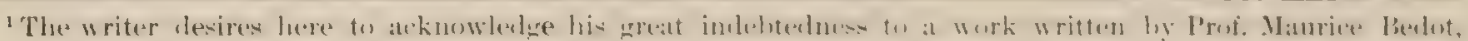
entitled Matériaux pour servir à l'histoire dew Hydroides, publisheul in Rever Suiste de \%onlogie, Annales de la Société Zoblogigue Suisse et du Musée d'histoiro naturelle de Genève. Geneve, 1901.

This work is invaluable to the systematist in the hydroids, as it gives a very complete bibliography of the group up to the year 1820 . Desiring to make the bibliography and synonymy of the serfularidie as complete ar possible, the present writer has included a number of references that he has not personally verifiecl, taken from the work of Bedot. In a great majority of cases the references have been verified, and it has thins been demonstrated that Professor lBedot's work has been very carefully done and is entirely reliable.

This has male it possible to include other references found in Bellot's work that I have been unable to verify. I feel confident that the number of errors thus admitted will be found fo be certainly nog greater than would have been found if I had personally verified every reference.

On page 143 will be found a list of works that are cited in the following pages, but which I have been unable to consult. It will be understood that all of the references to these works are on the authority of Berlot, unless otherwise stated. 
Sertularia pumila Groxorıus, Zoophylacium gronovianum, I't. 3, 1781, p. 357.

Sertularia pumilu Cavolini, Fil. Memoire per servire alla storia dei Polipi marini, 1785, p. 216.

Serfularia pumila ELus and SoLANDER, Nat. Hist. Zoophytes, 1786, p. 40.

Sertularia pumila WiLkins and HerBst, in Pallas, Characteristik der Thierptlanzen, 1787, p. 169.

Sertularia pumila GMeln, in Linnæus, Systema Naturie, 13th ed., 1788-1793, p. 169.

Dymamena pumila EsPER, Die PHanzenthiere in Abbildungen, III, 1788-1830, p. 196.

- Sertularia pumila Berk ennout, Synop. Nat. Hist. Great Britain, I, 1789, p. 215.

Sertularia pumila OLrI, Zoologia Adriatica, 1792, P. 288.

Sertuluriı prumilı Esper, Fortsetzungen der P'lanzenthiere, II, 1794-1806, P. 10.

Sertularia qumila Bosc, Hist. naturelle des Vers, 1802, p. 195.

Sertuleria premila TurTon, British Fauna, 1807, p. 212.

Sertulurin tamurisca Bertolosi, Rariorum Italire plantarum decas tertia, 1810, p. 106.

Sertularia pumila JAMESON, Catalogue of animals of the class Vermes, 1811, p. 564 .

Dynamena (Sertularia) pumila Lamouroux, Nouv. Bullet. des Sc. par la Soc. philomatique, III, 1812, p. 184.

Nigelustrum (Sertularia) pumila OKEN, Lehrbuch der Naturgeschichte, Pt. 3, 1815, p. 93.

Sertularia pumila Lamarck, Hist. Nat. des Anim. sans Vert., II, 1816, p. 119.

Dynamena pumila Lamouroux, Hist. des Polypiers, 1816, p. 179.

Sertuluria pumila STEwakt, Elements of the Natural History of the Animal Kingdom, 2d ed., II, 1817, p. 441.

Sertularia pumila Bertoloni, Specimen zoophytorum Portus Lunæ, 1819, p. 268.

Sertulariu pumila LaMarck, Hist. Nat. des Anim. sans Vertébres, 2d ed., 1836, p. 145.

Sertularia pumila Hassall, Ann. and Mag., VI, 1811, 1. 168.

Sertulario pumila HAssalL, Ann. and Mag., VII, 1841, p. 284.

Seriularia pumila Macgillivray, Ann. and Mag., IX, 1842, p. 463.

Sertularia pumila Gray, List British Animals, 1847, p. 70.

Sertularia pumila Jonnston, Hist. Brit. Zoophytes, $2 \mathrm{~d}$ ed., 1847, p. 66.

Sertularia pumila ALDER, Catalogue Zoophytes Northumb., 1857, p. 24.

Dynamena punila Agassiz, L., Contrib. Nat. Hist. U. S., IV, 1862, p. 326.

Dynamena pumila Packand, Canadian Naturalist, Dec., 1863, p. 4.

Dynamena pumila KirchenPader, Neue Sertulariden, 1864, p. 8.

Dynamena pumila AgAssiz, A., North American Acalephæ, 1865, p. 141.

Dymamena pumila Van Beneden, Faunæ litorale de Belgique, 1866, p. 186.

Sertularia pumila Hrncks, British Hydroid Zoophytes, 1868, p. 260.

Sertularia pumila Verriu, Invert. Vineyard Sound, 1871-2, p. 732.

Sertularia pumila SArs, Bidrag til Kundskaben, 1873, p. 49.

Sertularia pumila Verrill, Proc. Amer. Assoc. Adv. Sci., 1873, pp. 370, 374.

Sertularia pumila McIntosH, Ann. and Mag., 4th ser., XIII, 1874, p. 212.

Sertularia pumila VERrLL, Amer. Journ. Sci. and Arts, VII, 1874, 1) 133.

Sertularia pumila Schulze, Nordsee Exped., 1874, p. 132.

Sertularia pumila Covgntrey, Ann. and Mag., 4th ser., XVII, 1876, p. 29.

Sertularia pumila Clark, Hydroids of the Pacific Coast, 1876, p. 251.

Sertularia pumila MEReschkowsky, Ann. and Mag., 5th ser., I, 1878, ․ 323.

Sertularia pumila Wintmer, Om Internodiets, etc., 1879-80, p. 304.

Sertularia pumila WIntiner, Fortignelse di i Danmark Hydr., 1880, p. 245.

Sertularia pumila DE VArenne, Sur la Reproduction des Polypes Hyd., 1882, p. 27.

Sertularia pumila WeIsmann, Entstehung der Sexualzellen, 1883, p. 169.

Dynamena pumila Marktanner-Turneretscher, Hydroiden des k. k. naturhist. Hofmus., 1890, p. 239.

Sertularia pumila Bourne, Hydroids of Plymouth, 1890, p. 396.

Sertularia pumila Driescr, Tektonische Studien, 1890, p. 213.

Sertularia pumila Fewres, Guide to Collector, 1891, p. 39.

Seriularia (Dynamena) pumila Levinsen, Meduse, Ctenophorer, etc., 1892, p. 50.

Sertularia pumila Levinsen, Det Vidensk, Udbytte af Kanonbaaden "Hauchs" Togter, 1893, p. 370.

Sertularia pumila Crawford, Ann. and Mag., 6th ser., XVI, 1895, p. 261.

Sertularia pumile Hartuavb, Hydromedusen Helgoland, 1897, p. 451.

Sertularia pumila BonNevie, Norwegian North Atl. Exped., 1899, p. 79.

Sertularia pumila Nuttixg, Hydroids of the IVoods Hole Region, 1901, p. 359.

Sertularia pumila HARgITT, American Naturalist, 1901, p. 389.

Seriularia pumila Whitesves, Catalogue Marine Invert. Eastern Canada, 1901, 1). 25.

Sertularia pumila S.emundsson, Islandske Hydroider, 1902, p. 63.

Trophosome-Colonies growing in tufts from a creeping root stalk, attaining a height of about 2 inches, stem not fascicled, straight, divided into regular internodes, each of which bears a pair of hydrothece, or a pair of hydrothecre and a pair of branches; every third internode usually bearing branches, each pair of hydrothece and their internode forming a triangle. 


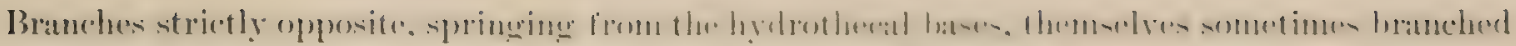
unsymmetrically, divided into regrular internodes each bearing at parir of hydrotheces. Hydrotheca strictly opposite, moderately distunt, tubular, regularly "urved, not adnate to each other

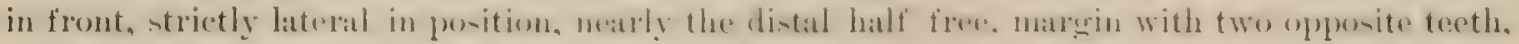
and a two-liapped operculum; aperture oval.

Gonoseme.-Gonangia borne on the front of the stem and branches, ovoid, with a very

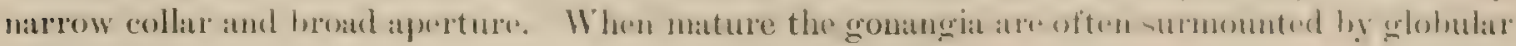
acrocysts.

Distribution.-Almost throughout the Northern Hemisphere: Vineyard Sound (Verrill);

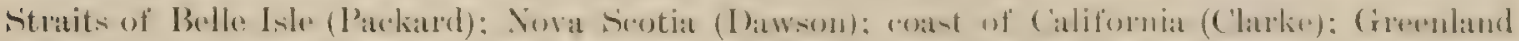

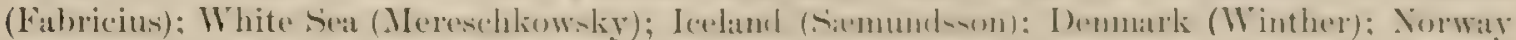

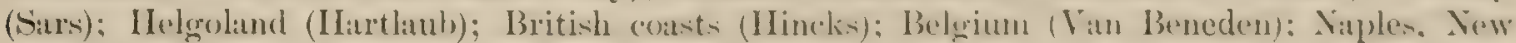
Zealand (Coughtrey).

This is one of the longest known and most widely distributed of the Sertularide, and has been the subject of much investigation. P'erhaps the most notable study of the species is that given by the older Agassiz in his Contributions to the Natural History of the United

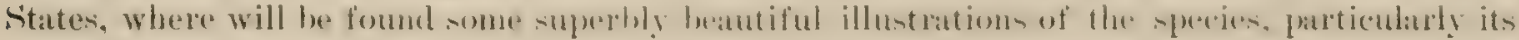
reproductive parts. (Plate XXXII.)

\section{SERTULARIA VERSLUYSI, new name.}

(Plate I, figs. 4-9.)

Desmoscyphus gracilis AluMan, Challenger Report, Hydroids, I't. 2, 1838, j. 71.

Desmoscyphus inflatus VErsuUxs, Hydraires de la Mer des Antilles, 1899, p. 42.

Trophosome.-Colony growing from a ereeping stolon and attaining a height of about 2 inches, but many specimens are not more than one-half inch high. Stem not fascieled, sinuous, divided into regular internodes, each of which bears a branch and two hydrotheca on one side and a single hydrotheea on the other; nodes oblique. Branches strictly alternate and regular, undivided, projecting at nearly a right angle from the stem. and livided by straight noder into regular internodes. Hydrothece widely separated laterally on the stem, where they are alternate; strictly opposite on the branches, where the pair's are distant, being separated by about twice the height of the hydrothece and borne on the front of the branch. 'l'he individual hydrothece are short and stout, each contiguous with it- follow for nearly its entire height, the free distal ends having a horizontal upper outline and narrowing rapidly to a small bilobed dorso-ventrally compressed margin. In some specimens the hydrotheca are much more robust, each pair, with its internode, making a triangular figure, as in fig. 9. Versluys belieres that he found an opereulum with a single flap attathed to the alsatulime side of the marerin. My own specimens appear to show two flaps, but the opereula are badly ruptured and can not be interpreted with safety.

Gromosome.-Not known.

Distribution.-Off Bermuda, depth 30 fathoms (Challenger); (ape Verde Islands, 25 meters, (Versluys); found on floating gulf weed (Albatrows).

An examination of Allman's type of Desmoscyphus gracilis shows that it agrees very exactly with the excellent description given by Versluys of his D. influtus, the hydrotheca on the stem being strictly alternate as in P'late I, fig. 4 , of the present work, and not opposite as figured by Allman, Plate XXXIV, fig. 2.

M. Versluys was unavoidably misled by an incorrect drawing. 'The species is hero placed in the genus Sertularie and, as the name Sertularia gracilis is preoceupied, I take pleasure in giving to this form the name of the first author who described and figured it correctly.

Type in the South Keusington Museum, London. A fragment in possession of the author. 
SERTULARIA CHALLENGERI, new name.

(I'late II, figs. 1-2.)

Desmoscyphus pectinatus Altwax, Challenger Report, The Hyciroids, I't. 2, 1888, p. 71.

Trophosome-Colony attaining a height of about 2 inches. Stem thick, not fascicled, slightly sinuous, divided into regular internodes, each of which bears, in the portion of the type examined by me, two alternate branches and six hydrothece. Branches alternate, springing from short processes of the stem, from which they are divided by two internodes, including a short nonhydrothecate internode; thick, divided into irregular internodes with a tendency to a regular arrangement of two hydrothece to each. Hydrothece strictly opposite, borne on the front of the branches, but seldom contingent', tubular, not noticeably swollen below, the distal portion bending gently outward and ending in a bilabiate margin, and a two-valved opereulum.

Gonesome.-Unknown.

Distributim.-Off Bahia (Allman): off Mone'(x) Island, Bass Struit, 3s-4) fathoms (Allman).

The above description is based on a portion of Allman's type kindly sent me by the South Kensington Museum. The character that seems most marked is the nonhydrothecate internode at the base of each branch. The portion of the specimen examined also had the peculiarity of baving two alternate branches to each internode. The species is a typical Sertuluric in the sense used in this work. 'The name Sertularia pectinata being preoceupied, ${ }^{1}$ I herewith substitute that of the famous vessel by which the type was collected.

Type.-In the South Kensington Museum, London. Fragment in possession of the author.

SERTULARIA OPERCULATA Linnaeus.

(Plate II, figs. 3-5.)

Sen hair Eutis, Essay Nat. Hist. Corallines, 1755, p. 8.

Serhelurin operculato Lins.ais, Systema Naturie, 1758, p. S0S.

Simlatire operculatu Houtury, Natunrlyke Historie, XVII, 1761-17T:3, p. 531.

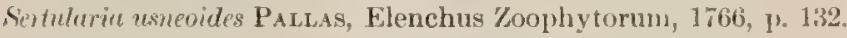

Sirtulurie operculata LINNacs, Systema Nature, 1767, p. 1307.

Sertularia usneoides BoDDAERT, in Pallas, Lyst der Plant-Dieren, 1768, p. 164.

Serfularie coperculatu MARATT1, De Plantis Zoophytis, ete, 1776, p. 26.

Serfulumil usneoides Grosovits, Zoophylacium Gronovianum, 1II, 1781, p. 357.

Semulerin operculata ElLIs and Sola NDER, Nat. Hist. Zoophytes, 1786, 1. 39.

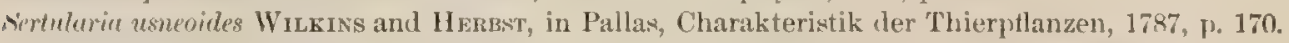

Serfulurin operculutu Gmelis, in Linnens, Systema Nature, 13th ed., 1788-1793, 1. 384t.

IImamenu operculata EsPer, Die l'flanzenthiere in Abbildung., III, 1788-1830, p. 191.

Simuluric operculata Berkexnout, Synopsis Nat. Hist. Great Britain, I, 1789, p. 216.

Serhulerin operculatu Siraw, Vivarium Naturae, etc., 1789-1813, pl. Mv.

Sertulariu operculata EsPER, Fortsetzungen der Pthanzenthieren, II, 1794-1806, pl. IV.

Sertuluria operculatu Bosc, Hist. Nat. des Vers, III, 1802, p. 92.

Sertulurin operculatı Túnton, British Fauna, 1807, p. 212.

Serfularia operculata JAmeson, Catalogue of Animals of the Class Vermes, 1811, P. 564 .

D!numenu (Sertularia) opermelata Lamonroux, Nonv. Bullet. des Sc. par la Sou. philomatique, 1812, p. 184.

Nigellustrum usneoides Okex, Lehrbuch der Naturgeschichte, Pt. 3, 1815, 1. 93.

Sertularin operculate LAMARCK, Hist. Nat. des Anim. sans Vert., II, 1816, p. 118.

Dimemena operculuta Lasovroux, Hist. des P'olypiers, 1816, p. 176.

Sertuleriu operculatu STEWART, Elements Nat. Hist. Animal King., II, 1817, p. 44.

Simtulurin operculata Schwergaer, Handbuch der Naturgeschichte, ete., 1820, p. 427.

Iyzument operculata LAvorrotx, Exposition Méthodique, 1821, p. 12.

Diruemence operculute Fumsa, British Animals, 1828, p. 544.

Serhularia operculatu LAaARck, Ilist. Nat. des Anim, sans Vert., 1836, 1. 144.

Serfularia operculata Macgildivay, Ann. and Mag., IX, 1842, p. 464.

Dynumenu operculitu Jonxstox, Hist. Brit. Zooph., 1842, p. 77.

Serlularic operculuta ALDER, Cat. Zooph. Northumb., 1857, p. 26.

Amphisbetia operculate Acassiz, 1., Cont. Nat. Hist. U. S., IV, 186», p. 355.

I)yncmenu operculata KIRCHEXPAUE, Neue Sertulariden, 1863, p. 8.

Dynamena juscimulata Kirchenpaver, Neue Sertularilen, 1863, p. 12. 
Sertularia operculata Hiscks, Brit. Hydroil /onph., 1868, p. 2633.

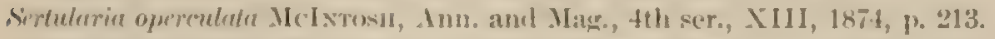

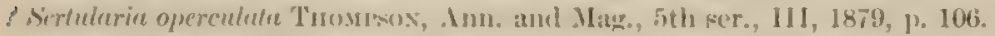

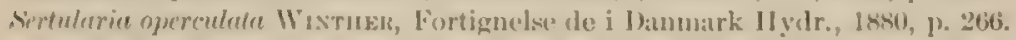

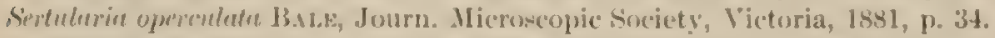

Sertularia operculatu B.4.E, Cat. A ustralian 11 yelroid Zooph., 1884, 1.67.

Serfularia operculata vos Lessesfolb, Australian 11 yilromeduse, 1884, p. 622.

Sernlaria operculate Almax, Challenger Report, Hyilroida, Pt. 2, 1888, p. 61.

Sermlerin operculata Crawfonn, Inn, and Mag., fith ser., XVI, 1895, p. 261.

Serfularia operculut Bosxevie, Jorwegian Jorth Itl. lixped., 1899, p. 79.

Thophosome-Colonies growing in tufts of very slender, delicate stems, sometimes attaining a beight of 8 to 10 inches. Stem simple, straight, translucent, divided into more or less regular internodes, each of which normally bears a pair of hydrotheca. Branches distant, alternate, themselves profusely branched in a dichotomous manner and tending toward an erect. posture; internodes like those of the stem. Hydrotheca rather distunt, strictly opposite, leaning forward, tubular, the abcaline side nearly straight, the adcauline side immersed except its distal third; aperture large, beveled so as to face upward and slightly inward. Margin with two large abcauline teeth, one of which is much longer than the other and continued to a slightly ('urved sharp point. Operculum very delicate, of two parts, one of which is much larger than the other.

Gonosome.-Gonangia borne on stem and branches, long, ovate, with large distal aperture and operculum, and no neck. Walls perfectly smooth externally.

Jistribution.-Almost world-wide, except on the coasts of the United States. Aretic Atlantic (Bonnerie); Denmark (Winther); British coasts (Hincks); Belgrum (Van Beneden); near A\%ores, 450) fathoms (Allman); Africa (Busk); Australia (Bale); New Kealand (Thomp-

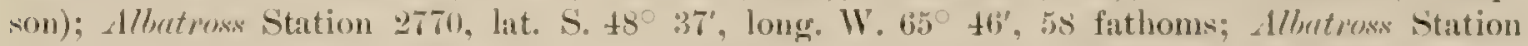

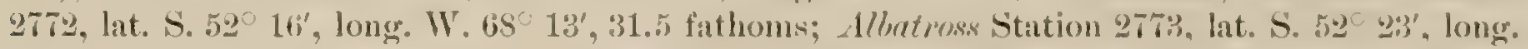
W. (is 11', 10 futhoms; Allutrows Station 275 , Strats of Magellan, 29.5 fathoms; Allutross Station 2777 , Strats of Magellin, 19.75 fathoms.

The distribution of this beatiful sertularian is quite unusual, reaching from the Aretic Ocean to the Straits of Magrellan. As yet it has not been reported from the coasts of the United States.

\section{SERTULARIA PULCHELLA (d'Orbigny).}

(I'late II, lign. 6-7.)

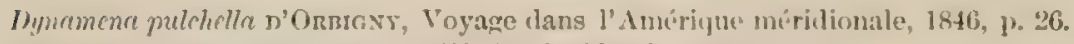

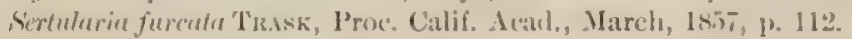

Serfulurie furcale Acissiz, North American Acalephie, 1865, 1. 145.

Sertulurin furentu CLakк, Hydroids of the Pacitic Const, 1876, 1) 2058.

Sertuleria furcate 'Forier, Hydroinda of the Pacific Coast, 1902, 1. 6it).

Trophosome. Stem short, unbranched, rooted by a creeping stolon, simple, spreading in every direction forming dense verticillated clusters around the pieces of fucus on which it is usually found, attached to the stolon by a short, slender, twisted process about the length of an internode, divided by transverse joints into short regular internodes each bonring a single pair of hydrothees; color concous. Hydrothece opposite, deeply immersed in the stem, with the two large, short teeth on the outer margin and a large aperture grenerally reaching to the stem. (Clark.)

Gonosme.-Gonotheca large, sessile, generally borne near the base of the stem, though ocasionally found scattered over the entire length, of an elongated oval form, sometimes slightly compressed, with a large, circular, terminal aperture. (Clark.)

Distribution.-Bay of San Francisco and Farallone Islands (T'rask); Santa Cruz, Bay of Monterey, San Diego, Santa Barbara (Clark); San Pedro, Coronados Islands (Torrey), shore to 24 fathoms. Patagonia (d'Orbigny).

I have not seen this species, and the above deseription is copied entire from that of Clark, who Was the first one to give al complete description, including gonosome. 'The hautiful figures

1 Torrey claims to be the first to describe the gonosome of the $s$. furcult, when, curiously enongh, the paper of Clark's which he cites gives both a clear description and a gool tigure of both trophosome and gumusome. 
given by d'Orbigny make it practically ertain that his speries was identical with the one deseribed long afterwards as Sertuluria furcute by Trask and universally accepted by later writers under the latter name. This species differs from $S$. operculate in having the two conspicuous hydrothecal teeth of the same size. On the other hand, S. pulchella is closely allied to S. bispinosin Gray, from which it differs in having no spines to the gonangium.

\section{SERTULARIA BISPINOSA (Gray).}

(Plate II, 1igs. 8-11.)

Dynamena bispinosa Grar, Dieffenbach, Travels in New 'Lealand, 1842.

Dynamenu bispinosa Iutros, Trans. New Zealand Inst., Y, 1872.

Sertularia bispinosa Covgntrex, Trans. New Zealand Inst., VII, 1875, p. 284.

Sertularia bispinosa CougnTrey, Ann. and Mag., 4th ser., XVII, 1876, p. 27.

Sertularia bispinosa von Lendenfeld, Australian Hydromedusæ, Pt. 3, 1883, p. 407.

Sertularia bispinosa BaLE, Catalogue Australian Hydroid Zoophytes, 1884, p. 68.

Diphrsia symmetrica VoN LeNDENFELD, Australian Hydromedusie, Pt. 3, 1884, p. 414.

Sertularia bispinosu Von Lendenfeld, Australian Hydromedusa, Pt. 5, 1884, p. 622.

Diphasia symmetrica Yos Lendenfeld, Australian Hydromedusie, Pt. 5, 1884, p. 623.

Trophosome.-Colony attrined a height of 6 to 8 incles (Bale). Stem not fascicled, bearing hydrothece throughout, internodes irregular, nodes distant, branches irregularly alternate, themselves branching dichotomously, internodes as in stem, a hydrotheea in the axil of each branch. IIydrotheca strietly opposite, not leaning forward, well separated in front, tubular, but somewhat flask-shaped, adnate to the stem or branch by one-half the adcauline side, distal end narrowing to a moderately large aperture, margin with two abcauline teeth. Operculum not evident in specimens examined. Entire periderm thick and heary, giving a rigid aspect to the colony.

Gonosome.-Gonangia large, obovate, with two flattened spines, one projecting from each shoulder; aperture large, with narrow collar or neck.

Distribution.-East Coast of South America, Albatross Station 2771, lat. S. $51^{\circ} 34^{\prime}$, long. W. 68 , 5n.5 fathoms. New Zealand (Huttou); Australia (Bale); "Trod. Hav." (specimen from Levinsen.)

The above description is taken from a specimen from Professor" Levinsen and labeled " $S$. bisprumse Gray, Trod. Hav.," which agrees quite exactly with the description given by Bale, and the specimen dredged by the U. S. Fish Commission steamer Albatross off the east coast of South America. This species seems much more rigid in habit than $S$. operculata, and the difference in the hydrothecal armature, is reinforced by the conspicuous flattened spines on the gonangia.

\section{SERTULARIA DESMOIDES Torrey.}

(Plate III, figs. 1-3.)

Sertularia desmoides Torrey, Hydroida of Pacific Coast, 1902, p. 65.

Trophosone.-Colony very straggling and irregular in growth, arising from a creeping rootstalk and attaining a height of ahout 2 inches. Stem very long and slender, divided into irregular internodes, each of which hears one or more pairs of hydrotheca, branches exceedingly irregular in their disposition, sometimes being very distant and forming a right angle with the stem and at others forming an irregular tuft at the distal end, internodes variable, sometimes absent from the greater part of a branch, and at others being divided by fairly constant joints placed a short distance below the hydrothece. Hydrothece strictly opposite, pairs usually quite distant but sometimes only moderately so, contingent in front for less than half their length, the distal portion curving outward and ending in an apparently round or oval aperture, facing outward and a little downward; no marginal teeth as a rule, but at times the margin has two obscure teeth. Operculum usually of one flap attached to the abcauline side, others with two ill-defined flaps, and again there will be two flaps, one above another, both attached to the abcauline side. 
Gonosome. "Gonothecre borne on stem; sessile, ovate with a wary outline and broad round aperture; half as broad as long. Single gronophore centrally placed, with conosarcal processes connecting it on all sides with gonothecal walls." (Torrey.)

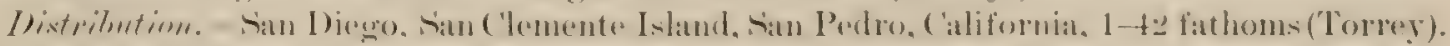
Allatross Station 2939 , lat. N. $33^{\circ} 36^{\prime}$, long. W. $115^{\circ} 09^{\prime} 30^{\prime \prime}, 2 \pi$ fathoms.

Type--In the collection of the University of California.

SERTULARIA RATHBUNI, new name.

('late III, figs, +9.)

Thuiaria sertularioides Alturax, ${ }^{1}$ Memoirs Mus. Comp. Zool., 11, 1877, p. 28.

Desmoscyphus dalmasi Versluys, Hydrairey Calyptohlastes recueillis dans la Mer des Antilles, 1899, p. 38.

Trophosome.-Colony consisting of main stem and irregularly disposed rigid branches, attaining a height of three inches. (Allman.) Stem without nodes on distal portion, with irregrularly disposed nodes on proximal portion where the internodes are long and tend to bear each a singhe pair of hydrotherate. Hydrotherat strietly opposite, roughly tuhular. narrowing amewhat at both ands, antingent in front for about half their height, separated behind, onding in at margin with two latrege lateral and one small superior tooth, the latter inconspicuous and abily. overlooked. Operculum with three llaps or valves.

Gonosome.-Not known.

Distribution.-Gulf of Mexico (Allman); Dry 'Tortugas, $45 \mathrm{~m}$. (Versluys). Albatross Station 2389 , lat. N. $29^{\circ} 28^{\prime}$, long. W. $87^{\circ} 56^{\prime}$; depth, 27 fathoms.

It seems to me to be altogether likely that Allman has figured the posterior aspect of this species, which will account for the separation of the pairs of hydrotheca as shown in his tigures. The figure given by Versluys and that drawn by me agree with Allman's figures. The three teeth of the hydrotheca might easily be mistaken for two, unless special care were taken. They are unmistakably present, however, in my specimens.

Type in the Museum of Comparative Zoology, Cambridge, Massachusetts.

\section{SERTULARIA GRACILIS Hincks.}

(Ilate III, fiu. 10.)

Sertularia mumila var. B. Jomxstox, British Zoophytes, 1848, p. 169.

Serlularia gracilis HAss.ALL, MSS. (according to Hincks).

Sertularia gracilis HIxcks, British Hydroid \%oophytes, 1868, p. 262.

Sertularia gracilis VerktLL, Am. Journ. Sei. and Arts, X, 1875, p. 43.

Sertularia gracilis Manktanner-Turseretscuer, Hydr. des k. k. Hofmuseums, 1890, p. 240.

Sertularia gracilis PicteT and Benot, Rés. Camp. Sc. Hirondelle, XVIII, 1900, p. 23.

Trophosome.-Colony small, rarely attaining a height of $\frac{1}{3}$ inch. Stem not fiscicled, slender, often unbranched, divided into long and irregular internodes. Branches irregular, often wanting, and like the stem in all particulars. Hydrotheca strictly opposite, pairs distant, the members of a pair contiguous in front and with their distal half free and regularly curved outward; margin with two opposite teeth and a two-llapped operculum.

Gonosome. -Gonangia borne on front of stem, large, obovate, with a wide neck and narrow but distinct collax, and evident operculum.

Distribution.-Naushon, Coast of Massachusetts (specimen in U. S. National Museum): Shetland (Norman); St. Malo (v. Marenzeller).

This species was formerly confounded with $S$. pumila, but is much more slender and delicate, with more distant hydrothece.

${ }^{1}$ In changing the genus of this species to siertuluriu the name would hecome Sertulurin sertularisiles, a name preoccupied by Bale, Catalogue of the Australian I ydroid \%oophytes, $18 s t$.

${ }^{2}$ Hydraires Calyptoblastes recueillis dans la Mer des Antilles, 1899, 1). 39, thg. 8. 


\section{SERTULARIA CORNICINA (McCready)}

(Ilate IV, tigs. 1-5.)

Dynamena cornicina MCCreanY, Gymnophthalmata of Charleston Ilarbor, 1858, p. 204.

Dynamena comicina A. Agissiz, North American Acalephe, 1865, p. 142.

Sertularia cornicina V'ERrill, Invert. Vineyard Sound, 1871-72, p. 733.

Sertularia cornicim Verrich, Amer. Journ. Sci. and Arts, III, 1872, p. 437.

Sertularia complexe Clarke, Bull. Mus. Comp. Zool., X, 1879, p. 245.

Sertularia compler BALE, Proc. Linn. Soc. New South Wrales, III, 2d Ser, 1888, p. 769.

Sertularia cornicina Nutrixt, Hydroids of the Woods Hole Region, 1901, p. 359.

Sertularia complexa Nutring, Hydroids of the Woods Hole Region, 1901, p. 360.

Sertularia comicina HaRgITT, Amer. Nat., 1901, p. 390.

Trophosome.-Colonies growing in the form of erect unbranched stems, often bearing closely associated colonies of a parasitic campanularian, IJeblla calcarata, and growing from a creeping root stalk, and attaining a beight of about one-half inch. Stem delicate, straight, with a pinched place near its base, divided into regular internodes, each of which bears a pair of hydrothecæ. Hydrothece tubular, strictly opposite, rather distant, adnate in front for about twothirds their length, the free distal portions being bent rather abruptly outward; margin with two broad opposite teeth; operculum of two Haps. The height of the hydrothecre is usually about equal to that portion of an internode that lies between the hydrothecal base and the node below. There are usually four chitinous points extending downward into the carity of the stem from the bottom of each hydrotheca. Hydranths of the usual sertularian type, capable of protruding far beyond the hydrothecal margin, ats in fig. 1.

Gomosome.--Gonangia borne singly or in pairs at the base of the stem, subglobular in form, with a narrow round collar and large aperture, sides beautifully and regularly annulated.

Distribution.-Charleston Harbor (McCready); Woods Hole, Massachusetts (Nutting); Pourtales Plateau (Nutting); Yucatan coast, attuched to an alga (Clarke); Australia (Bale).

This beautiful species has a curions distribution, being reported only from the widely separated regions noted above. There seems to be little doubt that Bale rightly identified his Australian specimens, and be also was the first to describe the profusely annulated gonangia, a type rarely seen in this genus.

The Woods Hole specimens were found first by Mr. Walmsley, and, like those originally deseribed by Clarke, were always found growing on alge. I am unable after eareful study to separate the S. complexe, Clarke, from the present species, although I did so in a former work. ${ }^{3}$ The characters there given are found to intergrade upon the examination of more material. The fact that the form called $S$. comicme in that work always bore the parasitic Irebella calcarata, while the gonangia were always found associated with the S. complexa of that work, even at the same time of year, would render the identity of the two species doubtful. In the absence of any good morphological character, however, it seems best to combine them, although I do so with considerable hesitation.

Type.-Destroyed by fire in Charleston during the Civil War.

SERTULARIA MAYERI, new species.

(Plate V, figs. 1-1.)

Trophosome.-Colony unbranched, springing from a creeping root stalk, and attaining a height of about one-half inch. Stem constricted basally and divided into regular long internodes, each of which hears a pair of opposite hydrothece on its anterior side and tapers slightly at each end. Hydrotheex with their bases a little below the middle of the internodes and contiguous for about half their adcauline sides. The distal hydrothece and those in a young colony are larger in their basal half and gradually narrow to a tubular distal portion which points outward and upward, ending in a three-toothed margin and appressed aperture. Operculum very delicate, apparently of two flaps. 'The proximal hydrothece are tubular, but little larger basally and bent abruptly 
outward at ahout their middle, so that their distal half is at right angles with their basal half and ends in a delicate collapsible tube, the margin and operculum of which is so thin that no constant form can be discerned. Entire colony excessively thin and delicate.

Comosomm.-Xot kinown.

Distribution.- Shallow water between Elenthera and little Cat Islands. Bahamas: on float ing seaweed, Great Bahama Banki (Bahama Expedition from the State University of lowa).

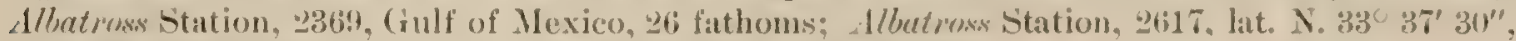

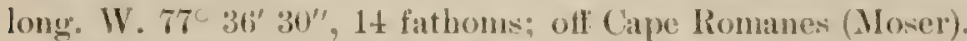

Type slides. - Cat. Nos. 18661, 186633, Nus. State Univ. Lowa; Cat. Nos. U.S.N.M. 18719, 187:0); also in the collection of the anthor.

\section{SERTULARIA POURTALESI, new name.}

(l'late $\mathrm{V}$, tig. 5.)

Sertulurie distuns' ILLMaN, Mem. Mus. Comp. Zool., V, No. 2, 1877, 11.25.

Dynamener distans Casike, Bull. Mus. Comp. Zool., V, No. 10, 1879, 1). 24ti.

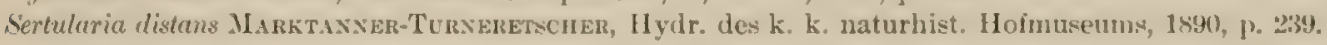

Trophosome.-Colony unbranched or with a few irregularly disposed branches, attaining a height of $1 \frac{1}{3}$ inches. Stem divided into long, irregular internodes, each of which bears one or more pair's of opposite hydrothece, the pair being on the distal half of the internode when but one pair is on that internode. Branches, when present, projecting from the stem in an exceed. ingly stiff and ungraceful mamer. Hydrotheca longer than in most of the closely allied species, distant, tubular, contingent in front for a varying portion of their length, the distal portion being curved gently outward and ending in a margin which is very thin and ill-defined in texture, but bears two teeth and an opereulum of two Hlaps.

Gomosme.-Not known.

Distribution.-Albatross Station 2369, lat. N. $299^{\circ} 16^{\prime} 30^{\prime \prime}$, long. W. $85^{\circ} 32^{\prime}$, $26^{\circ}$ fathoms: Station 2315 , lat. N. $24^{\circ} 26^{\prime}$, long. W. $81^{\circ} 48^{\prime} 15^{\prime \prime}, 37$ fathous; Station 2404, lat, N. $27^{\circ} 04^{\prime}$, long.

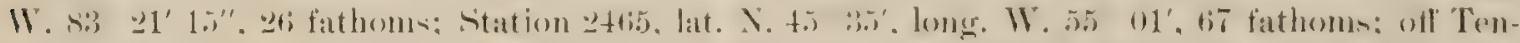

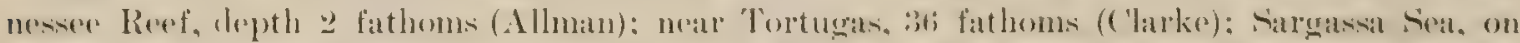
Furrus (Marktanner-Furneretscher'); Pourtales Plateau (Bahama kxperdition from the sitate University of Iowa).

The specimens from the Pourtales Plateau on which this description was based were compared directly with the type in the Museum of Comparative Zoology and found to agree. It belongs to the Desmoscyphes group, Allman's drawing having evidently been made from the posterior aspect of the colony. The hydrothece rary considembly in shape.

Type.-In Museum of Comparative Zoology, Cambridge, Massatchusetts.

SERTULARIA STOOKEYI, new species.

(Ilate $V_{\text {, tigs. } 6-7 .)}$

Tropheseme.-Colony consisting of unbranched stems springing from a crecping root-stalk and attaining a height of about one-third inch. Stems constricted basally and divided into regular internodes, except proximal portion where the nodes become indistinct or obsolete; internodes long and slender, the hydrothece being placed in front of the distal half, the nodes being just above the hydrothece. Hydrotheca strictly opposite, adnate to each other by about the basal one-third of their adcauline wall, the line of juncture being straight; basal portion not distinctly swollen, distal one-half free, a slender cone in shape projecting at an angle of about 45 degrees with the stem, and ending in a bidentate margin and two-flapped operculum.

Gommente.-Gonangia borne at bases of colonies, large, oval, with a straight narrow collar, wide narrow aperture, and operculum; pedicel very short.

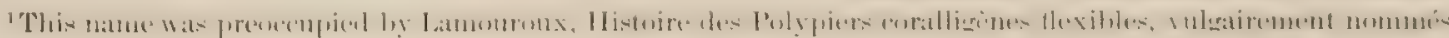
Zophytes, 1816, p. 191, for a (ampanularian, and was used later by Lamarck, Historie naturelle des Animaux sans yertibres, 2d.edition, 1836, p. 151. 
Distribution.-Found on floating seaweed on the Great Bahama Banks (Bahama Expedition from the State University of Iowa).

This species is more delicate, and the hydrotbece are more slender than in other species of this group. I take pleasure in naming it after Professor Stookey, member of the Bahama Expedition.

Type slides.-Cat. Nos. 18665, 18666, Mus. State Univ. Iowa; Cat. Nos. 19710, 19711, U.S.N.M.; also in collection of the author.

\section{SERTULARIA BREVICYATHUS Versluys.}

(Plate VI, figs. 1-2. )

Desmoscyphus irevicyathus Vussuxis, Hydraires Calyptoblastes recueillis dans la Mer des Antilles, 1899, p. 40.

Trophosome.-Colony consisting of an unbranched stem springing from a creeping root-stalk. Stem divided into regular long internodes, each bearing a pair of hydrothece on its distal half, and being enlarged at the middle to form a base of support for the hydrothece, the proximal and distal portion of each internode being narrowed. Hydrotheca strictly opposite, turgid below, the inner outline being nearly a semicircle, the two of a pair being contiguous in the front of the stem on account of the extent to which they embrace the latter, but they are not placed in front as in typical species of the Desmoscyphlus group; distal portion directed outward and narrowing rapidly to the three-toothed margin; opereulum two-flapped.

Gomosome.-Not known.

Distributiom.--Between Eleuthera and Little Cat islands, and near Spanish Wells, Bahamas (Bahama Expedition from the State University of Iowa); Cape Verde Islands, 25 meters (Versluys).

The specimen above described was collected by the Bahama Expedition from the University of Iowa. The hydrothece are somewhat more slender distally than indicated by Versluys's figures, but some individuals agree with them exactly.

Type.-In the collection of Comte R. de Dalmas.

SERTULARIA FLOWERSI, new species.

(Plate VI, tigs. 3-4.)

Trophosome.-Colony minute, consisting of a very slender unbranched stem, attaining a height of about one-fourth of an inch. Stem divided into long, slender internodes by nodes placed immediately above the hydrotheca. Hydrotheca very small, in strictly opposite pairs, which are situated on the distal ends of the internodes, distant, placed on the sides of the stem which they embrace, so as to be contiguous in front for about half their height; margin tridentate with a two-valved operculum. Inconspicuous chitinous processes extend downward from the bottoms of the hydrothecæ, as in S. comicina.

Gomosome.-Not known.

Distribution.-Dredged near Habana, Cuba, from a depth of about 150 fathoms. Collected by the Bahana Expedition from the State University of Iowa.

This is the most slender and delicate species of Sertularia that the writer has seen. Named in honor of Capt. Charles B. Flowers, of the Bahama Expedition.

Type.-In the Museum of Natural History, State University of Iowa.

SERTULARIA TUMIDA Allman.

(P'late VI, fig. 5.)

Sertularin tumida, Altman, Mem. Mus. Comp. Zool., V, No. 2, 1877, p. 23.

"Trophosome.-Hydrocaulus attaining a height of three-fourths of an inch, simple, internodes of moderate length, thinning arwa for some distance below each pair of hydrothece. Hydrothece opposite, short, tumid below, adnate to the stem for about half their length, and with the distal half free and diverging at nearly a right angle."

tromesmur:-Not known.

Distribution.-Tortugas, shallow water (Allmau). 
I have not seen this spereies and yuote the orierinal deseription entire. It in quite possible that

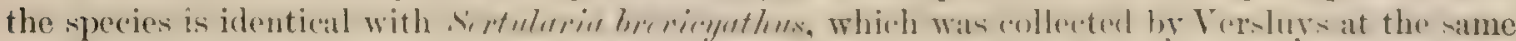
place, but this point cannot be determined except by a comparison of the two types.

Type.-In the Museum of Comparative Zoology, Cambridge, Massachusetts.

\section{SERTULARIA EXIGUA Allman.}

(1'late V'I, fig. 6.)

Serhulerin exigue Aluasas, Mem. Mlus. Comp. \%ool., V, No. 2, 1877, p. 24.

"Trophosome.-Hydrocaulus minute, simple, attaining a height of about one-fourth of an inch; internodes very short, not prolonged by an attemated continuation below the pairs of hydrothece. Hydrotheca opposite, not tumid below; free and divergent on their distal half, and with the opposed sides of each pair parallel to one another."

Gomosome.-Not known.

Distributiom.-Off Cape Fear, 9 fathoms (Allman).

I have not seen this species and have copied the original description entire.

Type. - In the Museum of Comparative Zoology, Cambridge, Massachusetts.

\section{THUIARIA Fleming (modified).}

Trophosome.-Hydrothecae normally subopposite to alternate, and more than two to each internode. Internodes vary greatly in length. Hydrothece with smooth margin, or with one or two teeth, usually more or less immersed in the hydrocaulus. Operculum of one abcauline flap, or of two tlaps.

Gonosome.-Gonangia oval, with large terminal aperture, unornamented or with one or two spines on the shoulders.

As before intimated, this genus as established by Fleming (1825) was very much restricted, containing but two speeses, and based solely on the immerserd eondition of the hydrotheeare. There was no change made by either Johnston (1848) or Hincks (1865).

In his diagnoses of new genera and species of hydroids Allman adopted a new criterion for the genus, holding that the best character was based on the division of the hydrocaulus into internodes, there being an internode to each pair of hydrotheca in Sertulariu, Sertularelle and Diphersie, "while in Thuiurie the joints oceur at distant and, for the most part, irregular intervals, thus leaving numerous hydrotheca to he carried on each internode." He was thus led to admit such species as Sertularia urgentere and $S$. cupressina into the genus, as is done in the present work. In his report on the hydroida of the Challenger Expedition (1sisis Alhuan maintains this same position.

In his (atalogue of Australian Hydrod hoophytes (1sit) Bate gives a further eriterion. His definition of Theiari, is "\%oophyte plant-like-Hydrothece biserial, not in pairs, usually more or less immersed." He points out the distinction between the hydrotheca being in two series and being in pairs. 'This, however, often seems to depend on the thickness of the hydrocaulus. If it is very thick there are two series, while it often happens that on the more slender distal branches the hydrothece are regularly subopposite or alternate, or in pairs, as Bale uses the term.

Levinsen in his Meduser, Ctenophorer og Hydroider fra Grönlands Vestkyst, p. 193, defines the genus as follows: "Apertum hydrothece rotundata (ovalis vel semicircularis). 'Collare' et 'dentibus' nullis instructa. In margine exteriore (abeaulinii) valvula opereularis allixa est." Like the other genera founded on the characters of the margin and opercuhm, this one inchudes forms that the present writer and others regard as generically distinct, as Selaginopsis altemitheca Lerinsen, and excludes others that are rery closely related, as Thuirvic dalli or $T$. robusta Clark or $T$. thuiarioides Clark, the latter being a typical thuiarian, but with an' adeauline operculum. Horeover in some cases certain parts of a colony would belong to Thuiarin, and others not, were the definition of Levinsen adhered to, as $I^{2}$. romestr, in which part of the 
hydrotheca have two teeth and a two-Happed opereulum and part no tooth and a single-tlapped operculum.

The genus, as I have defined it, is confessedly the least natural and satisfactory of those admitted in this work.

\section{POINTS OF INTERGRADATION BETWEEN THUIARIA ANI) OTILER (IENERA.}

First. With Sertularia, in having the hydrothecal margin with two teeth and a two-flapped operculum, as in $T$. argented, $T$. similis, T. temere, $T$. fabricii, and T. cupressime. In all of these cases there are many hydrothecæ to an internode, and they are not strictly opposite.

second. With Abietinaria in having an adcauline operculum, as in T. theiurioides Clark. In every other respect, both in trophosome and in gonosome, this species is a typhical Thuiuria.

KEY TO AMEIIICAN SPECIES OF THLTARIA.

Ilydrothecal margins smooth, except on distal ends of branches, where they are bidentate. Operculum of one abcauline Hap. ${ }^{2}$

Branches springing from all sides of stem.

Colony in the form of a stiff "bottle brush". thuja.

Colony not so stiff and rigid.

Hydrothece alternate.

Margin produced on outer side into prominent recurved hooks.........................elegans.

Margin smooth, except on distal parts of branches, where there are two strong teeth ........ rolusftr.

Hydrothece sub-opposite, margin smooth, operculum adcauline ....................thuiarioides.

Branches alternate.

Hydrothec:e opposite.

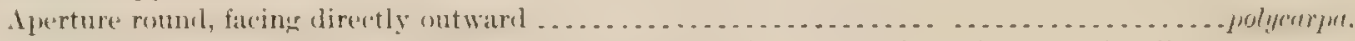

Aperture facing outward and upward, margin produced into a prominent lolse on adcatine

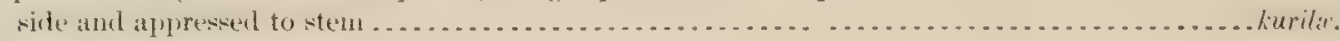

Hydrothece alternate.

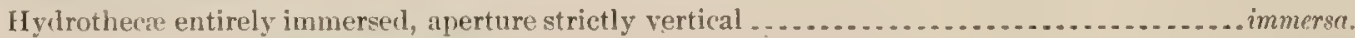

Distal end of hydrothece free, aperture facing outward and upward . . . . . . . . . . . . . . . . . lonchitis.

Hydrothecal margin toothed, opereulum with two Haps.

Hyilrothece strictly alternate.

Branches opposite plumuliferi

Branches not opposite.

Margin with two large pointed teeth.

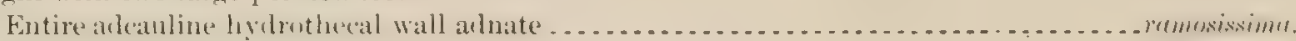

Distal half of adcauline wall free ... . .

Hydrothece sub-opposite, marginal teeth two, opposite.

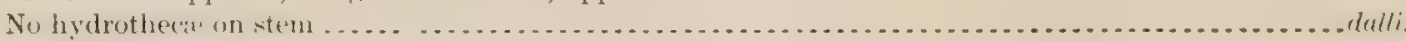

Hydrotheca on stem.

Hydrothecue tlask-shaperl, their long axes not parallel with stem.

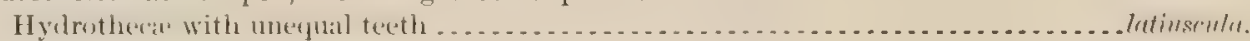

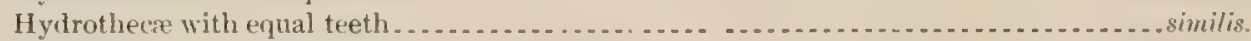

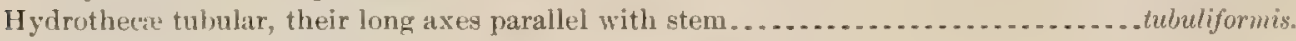

Hydrothece sub-opposite, one or two marginal teeth.

Branches alternate, and usually undivided, hydrothecre not immersed.............................

Branches in a spiral, usually divided dichotomously.

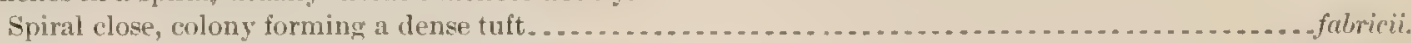

Spiral loose, hydrothece not greatly immersed . . . . . . . . . . . . . . . . . . . . . . . . . . . . . . . . . .

Spiral loose, hydrothece extensively immersed, their axes not parallel with stem ...............cumessinu.

Spiral loose, hydrothece extensively immersed, their axes parallel with stem................... plumosa.

THUIARIA THUJA (Linnæus).

(Plate VII, tigs. 1-3.)

Butle-bmesh Corullime Eulus, Essay Nat. Hist. Corallines, 1755, p. 10.

Sertularin thuin LiNN.ex-s, Systema Naturxe, 1758, p. 809.

Serfularin thuj Hostrrys, Natuurlyke Historie, 1761-1773, p. 543.

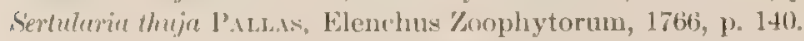

Sertularia thuja LIxw.'s, Systema Nature, 12th ed., 1767, p. 1308.

${ }^{1}$ Except in the case of $T$. thuiarioides Clark. 
Sertularia thija BonnAERT, in Pallas, I.jst der I'lant-Dieren, 176s, p. 175.

Serlularia thija MaratT, De I'lantis Zoophytis et Lithophytis, 1776. p. 29.

Sertularic thuja Fabricics, Fauna Gruenlandica, 17s0, p. 444.

Sertularia thije Grosovits, \%oophylacium gronovianum, III, 1781, p. 358.

Sertularia thuja Fudas and SoLaxner, Nat. Hist. \%oophytes, 1786, p. 41.

Sertularia thuja WrLkiss and HerBst, in Pallas, Charakteristik der Thierpflanzen, 1787, p. 179.

Sertularia thijo GMELrx, Systema Nature, Linneus, 13th ed., 1788-1793, p. 3848.

Sertulariu thrja ExPEn, Die I'llanzenthiere in Abbildungen, IIf, 1788-1830, p. 184.

Sertularia thuja Benkenirotт, Synop. Nat. Hist., Great Britain, I, 17S9, p. 217.

Sertularia thuyg Esiper, Fortsetzungen der P'lanzenthiere, II, 179t-1806, pl. xxir.

Sertularia thuja Curmen, Tableau Elémentaire de l'Hist. Nat. des Anim., 1798, p. 666.

Sertularia thuja Bosc, Hist. Nat. des Vere, III, 1S02, p. 94.

Sertularia thuja Tertos, British Fauna, 1807, p. 213.

Sertularia thuy J.amesos, Catalogue Animals of Class Vermes, 1811, p. 564 .

Nigellastrum (Sertularia) thuja Okex, Lehrbuch der Naturgeschichte, 1815, p. 93.

Cellaria thuja Lamarcz, II ist. Nat. des Anim. sans Vert., 1E16, p. 139.

Sertuleria thuju LAsouroux, Hist. des Polyp. Coral. Flex., 1816, p. 195.

Serhlaria thuja Sтеwarт, Elements nat. hist. animal King., 2d ed., II, 1817, p. 442.

Thuiaria thuic Ftemixg, British Animals, 18:8, 1). 545.

Thuiarie thuia Micothaves, Ann. and Mag., IX, 1842, p. 464.

Thuiaria thuia Jonsstox, Hist. Brit. Zoophytes, 1847, p. 83.

Theiaris thuje Grst, Liat of British Inimale, 1847, p. 76 .

Theiaric thuia Alnen, Cat. Zooph. Northumb., 1857, p. 27.

Thuiarin thujn A. Acissiz, North Amer. Acalephe, 1865, p. 148.

Thuiarin thujn Hrscks, British Hydroid Zoophytes, 1868, p. 275.

Thuiaril thuju Scruthe, Nordsee Expedition, 1872, ]). 133.

Thuiaria thuia S.Ise, G. O., Bidrag til Kundskaben om Norges Hydroider, 1873, p. 18.

Theiaria thuje ICIxtosn, Inn. and Mag., th ser., XIII, 187t, p. 214.

Thuiuric thuje Menescikowsky, Ann. and Mag., 5th ser., I, 1878, p. 324.

Thuiaria thuia Wrxtren, Fortignelse de i Dammark, etc., 1880, p. 251.

Thuiaria thuia Kircheve.teEn, Nordische Gattungen und Arten, 18st, p. 18.

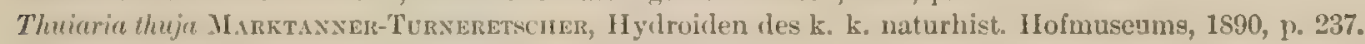

Thuirria thuja Druscir, Tektonische Studien, 1890, 1. 207.

Thuiaria thija Levissex, Meduser, Ctenophorer og Hydroider, 1892, p. 52.

Thujarin thuja I.Evasex, Vid. Uab. "IIauchs" "Togter, 1893, 1. 371.

Thuiarie thuie Crawford, Inn. and Mag., 6th Ser., XVI, 1895, p. 261.

Thuiuriu thuje Bowneve, Forwegian North Atlantic Expedition, 1899, p. 83.

Thuiaria theje HARGrT, Ameriean Naturalist, 1901, p. 392.

Thuiuria theja Nutruxa, Hydroids of the Woods Hole Region, 1901, n. 364.

Thuiaria thuja Wnote.15es, Catalogue Iarine Invert. eastern Canala, 1901, p. 26.

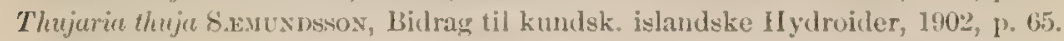

Trophosome.-Colony sometimes attaining a height of a foot or more. Main stem geniculate, rigid, slender, divided proximally into obsenre internodes, each of which bears the stump of a branch. Branches arranged in a spiral around the stem, from which they project at nearly a right angle, dichotomously branching several times so that each forms al flabellate structure with the upper side concave. Conjointly the branches and branchlets form a typical "bottle-brush" structure. Hydrotheca subalternate, closely approximated, almost entirely immersed in the hydrocaulus; aperture a flattened oval without conspicuous tecth and opening vertically. Opereulum a single abcauline flap.

Gonosome.-Gonangit borne on the upper sides of the branches, oblongr ovate with a round aperture, short but distinct collar, and no lateral spines.

Distribution. - One of the common species in comparatively shallow water on both sides of

the North Atlantic. New England coast (Nutting); Mingun Islands ( . Agassi\%); Bering Strait. (Stimpson); Gulf of St. Lawrence (Whiteaves); Greenland (Levinsen); Iceland (Siemundson); Norway (Sars); British coasts (Hincks); Mediterranean (Pallas); Albutress Station 2256, lat. N. $40^{\circ} 38^{\prime} 30^{\prime \prime}$, long. $\mathrm{W}^{\circ} 69^{\circ} 29^{\prime}, 30$ fathoms; Albatress Station 2843 , lat. N. $53^{\circ} 56^{\prime}$, long. W. $165^{\circ}$ $56^{\prime} 45^{\prime \prime}, 45$ fathoms; Albatros. Station 3558, lat. N. $56^{\circ} 58^{\prime}$, long. WT. $170^{\circ} 09^{\prime}$, 25 futhoms.

This is one of the oldest and best known of the Sertularide, and one of the rery few that have not been bandied about between genera for the list half century. It has a peculiarly rigid habit that is characteristic of no other hydroid. 


\title{
THUIARIA ELEGANS Kirchenpauer.
}

(Plate VII, fig. 4.)

Thuiaria elegans Kincmenpaver, Nordische Gattungen und Arten, 1884, p. 21.

Trophosome.-Colony attaining the height of about $4 \frac{1}{2}$ inches. Stem slender, slightly flexuose with irregularly disposed deep annular nodes, beset on all sides with the stumps of broken branches. Branches inserted on all sides of stem, flexuose, divided by deep nodes into long internodes. Hydrothecr alternate, oval, entirely immersed; aperture obliquely cut so as to form two angles to the otherwise horizontal margin, the outer angle or projection being much larger than the inner (adcauline), so much so that it (the outer tooth) forms a backward directed horn.

Gonsome.-Unknown.

Distribution.-Plover Bay, Bering Sea (Krause).

I have not seen this species, and have taken the above description from the original by Kirchenpaner, the translation being modified to accord with the plan of description followed in this work.

Type.-In the Lcipsic Museum?

\section{THUIARIA ROBUSTA Clark.}

\author{
(Plate VIII, figs. 5-7.)
}

Thuiaria robusta ClAnk, Proc. Acad. Nat. Sci., Philadelphia, 1876, p. 227.

Thuiaria robusta Kircnexpauer, Nordische Gattungen und Arten, 1884, p. 81.

Trophosome.-Colony consisting of a simple stem attaining a height of about 12 inches in the largest specimen exanined. Stem strong, tlexuose, bearing stumps of spirally arranged branches throughout about three-fourths of its length, the upper portion hearing large branches which bear branchlets arranged in a spiral so that the distal part of a colony assumes the shape of a dense brush or tuft. The main stem and branches give off a branch to each internode, while the hydrocladial internodes are of varying length, each usually bearing a number of subalternate, thickly approximated hydrotheca. Hydrotheca long. tubular, slightly swollen below, immersed to the aperture on larger branches, but with distal one-third exserted on distal part of branchlets: aperture bilabiate, operculum with two flaps on distal portions of branches, often with round margin and single abeauline flap on proximal portions. At the base of each hydrotheca is a thickening of the perisare described by Clark as a double-pointed py ramid (see fig. 5).

Gonosome.-Gonangia borne in rows on the terminal branchlets, slender, with a terminal collar and aperture, and two long curved spines rising from the antero-lateral corners of the shoulder's.

Distribution.-Sea Horse Islands and Cape Prince of Wales, Arctic Ocean; Hagmeister Island, and 12 miles east of Kings Island, Bering Sea (Clark). Aretic eruise of Corwin, 1885. Albatross Station 2875, lat. N. $48^{\circ} 30^{\prime}$, long. W. $124^{\circ} 57^{\prime}, 40$ fathoms; Station 3153 , lat. N. $37^{\circ} 57^{\prime} 10^{\prime \prime}$, long. W. $122^{\circ} 56^{\prime} 20^{\prime \prime}$, 32 fathoms; Station 3504 , lat. N. $56^{\circ} 57^{\prime}$, long. W. $169^{\circ} 27^{\prime}$, 34 fathoms; Station 3505, lat. N. $57^{\circ} 09^{\prime}$, long. W. $168^{\circ} 17^{\prime}, 44$ fathoms; Station 3511, lat. N. $57^{\circ} 32^{\prime}$, long. W. $169^{\circ} 38^{\prime}$, 39 fathoms; Station 3515 , lat. N. $59^{\circ} 59^{\prime}$, long. WV $167^{\circ} 53^{\prime}, 13$ fathoms; Station $35 \pm 0$, lat. N. $56^{\circ} 27^{\prime}$, long. W. $166^{\circ} 08^{\prime}, 51$ fathoms.

This species is not nearly so rigid as $T$. thuja, and the gonosome is entirely different.

Type.-In the collection of the U. S. National Nuseum.

\section{THUIARIA THUIARIOIDES (Clark).}

(Plate VIII, figs. 1-6.)

Sertularia thuirarioides CLARK, Alaskan Hydroids, 1876, p. 223.

Thuiaria thuiaroides CALkIss, Some Hydroids from Puget Sound, 1899, p. 361.

Thuiaria thujarioides HartuavB, Hydroiden aus dem Stillen Ocean, 1901, p. 354.

Thuiaria thuiarioides NutTixg, Hydroids of the Harriman Expedition, 1901, p. 186.

Trophosome.-Colony attaining a height of about $7 \frac{1}{2}$ inches. Main stem irregularly branched, the branches being inserted in a spiral owing to the twisting of the stem; internodes 
long and irregular, sometimes bearing two hydrothece and a branch on one side and a single hydrotheca on the other. Main branches like the stem, bearing alternate branchlets that often divide dichotomously, divided into long and irregular internodes each bearing two lateral rows of hydrothece.

Hydrothece subopposite, tubular, expanded below, narrowing above into a very short neck ending in a circular aperture which faces upward and slightly toward the branch. Operculum of one adeauline valve.

Gonosome.-Gonangia horne on upper sides of branchlets, ovate, flattened, expanded laterally and dista!ly into two that spines set on the shoulder. Aperture terminal, round, borne on as short neck resembling the frustum of a cone.

Distribution.-Bering Sea, west of Nunivak Island, 24 fathoms; Chignik Bay, Alaska (Clark); Puget Sound (Calkins); Yakutat, Mlaska (Nutting). Lat. N. $62{ }^{\circ} 15^{\prime}$, long. W. $165^{\circ} 4 S^{\prime}$, Lieut. George N. Stoney, U. S. Navy.

This is a rery well-marked species of a typical thuiarian character, except in its operculum. The opercula are well shown in some of the specimens collected by Dr. WV. H. Dall.

Type.-In the collection of the U. S. National Museum.

THUIARIA POLYCARPA Kirchenpauer.

(Plate YIII, fige. $7-9$. .)

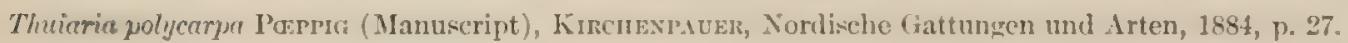

Trophosome.-Colony (fragmentary) about 1 inch in height. Stem straight with very uneren internodes and two opposite rows of hydrotheca, branches irregularly alternate, rigid, divided into long and uneven internodes, each bearing several pairs of hydrotheca. Hydrotheca in strictly opposite pairs, long, tubular, with distal ends bent outward, aperture round, facing directly outward, the top of one hychrotheca not reaching the base of the next one above, the pairs being slightly but definitely separated.

Gomenome.-Unknown.

Loculity.-Valparaiso, Chile (Poppig).

The above description is from a specimen kindly sent me by Professor Levinsen. 'This species differs from most of the grenus Thuiuric in having exactly opposite hydrothece. The other character's are so strictly thuiariu, however, that there seems little doubt regarding the propricty of including it in the genus.

Typre-In the Leipsic Museum.

THUIARIA KURILAE (Pœppig).

(Plate IX, figs. 1-2.)

Sertularia hurile Pa:penc (AIanuscript)?

Trophosome.-Specimen about 3 inches high. Stem unbranched, divided into very long and irregular internodes and bearing a row of hydrothece on each side, there being three hydrothecie, one axillary and two others, between adjacent branches. Branches strictly alternate and divided into long and irregular internodes by distant nodes. Hydrotheca subopposite, Haskshaped, the distal end but little constrieted. Aperture large, opening outward and a little upward, margin with a rery large tooth or lobe rising upward on the adcauline side and elosely appressed to the hydrocaulus. This tooth is apparently broken off in many cases.

Gonosome.-Not present in the specimen described.

Locality.-Unalaska.

The specimen above deseribed was received from Prof. G. M. R. Levinsen. I have not seen the original description and am unable to cite it. Coming from so high an authority 1 have felt justified in including it here. The very large lobe or tooth on the adcauline side of the hydrotheca is a character that divides this species from all other American members of the genus. 
THUIARIA IMMERSA, new species.

(Plate IX, figs. 3-4.)

Thuiaria lonchitis Marktanner-Turneretscren, Hydroiden des k. k. naturhist. Hofmuseums, 1890, p. 236.

Thuiaria lonchitis MarkTanser-Turneretscier, Hydroiden Ost Spitzbergen, 1895, p. 422.

Trophosome.-Colony (incomplete) less than 1 inch high. Stem irregularly but deeply amnulated throughout the thick proximal portion which bears no branches and which appears to have been broken off and renewed, the new portion bearing all the branches. Distal part of stem feebly geniculate, without evident nodes, bearing alternate lateral branches, one to each geniculation, and two rows of hydrothece. Hydrothece alternate, slender, Hask-shaped, much smaller distally, the apertures opening vertically and not projecting at all from the general surface of the hydrocaulus. Just under the lower edge of the margin is a thickening of the hydrothecal wall that is plainly erident in a side view. 'The aperture is perfectly smooth and round, without teeth. There is a well-marked space between the top of one hydrotheca and the bottom of the next. Texture of colony corneous, much stiffer and stronger than in T. Tonchitis.

Gonosome.-Not known.

Distribution.-Coast of Greenland, U. S. S. Alert, 1884; Austro-Hungarian Polar Expedition, lat. N. $76^{\circ} 14^{\prime}$, long. E. $85^{\circ} 5 t^{\prime}$. (Marktanner-Turneretseher.)

This species seems to me to be certainly distinct from T. Jonchitis of authors, which is a much larger and more graceful species, with hydrothece projecting perceptibly from the stem and branches, and opening obliquely upward and outward. The specimen collected by the U. S. S. Alert agrees exactly with the figure and description given by Marktanner-Turneretscher under the name Thuiaria Tonchitis.

He calls attention to the main differences between this specimen and the typical lonchitis, but apparently did not regard these differences of sufficient import to warrant a separation, an opinion with which I am unable to agree.

It is possible that other writers have had this species in hand and described it either as T. articulate or T. Ionchitis.

Type.-In the U. S. National Museum. Fragment in collection of the author.

THUIARIA LONCHITIS (EIlis and Solander).

(Plate IX, figs. 5-8.)

Sea-Spleenuort or Polypody Elis, Essay Nat. Hist. Corallines, 1755, p. 42.

Sertularia lonchitis Euts and Solander, Nat. Hist. Zoophytes, 1786, p. 42.

Sertularia lonchitis Bosc, Hist. Nat. des Vers, 1802, p. 101.

Sertularia lichenastrum Turtox, British Fanna, 1807, p. 216.

? Nigellastmem (Sertularia) articulata $0 \mathrm{kEN}$, Lehrbuch der Naturgeschichte, 1815, p. 93.

Cellaria lonchitis LAMArck, Hist. Nat. Anim. sans Vert., 1816, p. 139.

Thuiaria articulate FLEMING, British Animals, 1828, p. 545.

Theiarin artichlata HAssaLL, Mnn. and Mag., VI, 1841, p. 284.

Thuiaria articulala HrNDMa, Ann. and Mag., X, 18+2, p. 20.

Thuiaria articulata Gray, Brit. Animals, 1847, p. 76.

Thuiaria articulate Jonnstos", Hist. Brit. "Looph., 1847, P. 84.

? Thuiaria articulata Alder, Cat. Zooph. Northumb., 1857, p. 27.

?'Thuiaria articulatu HINcks, British Hydroid Zoophytes, 1868, p. 277.

Thuiaria articulate WHne.1VEs, Ann. and Mag., 4th ser.; X, 1873, p. 345.

Thuiaria articulata Scrulze, Nordsee Exped., 1874, p. 133.

? Thuiaria articulata Merescenorsk'r, Ann. and Mag., 5th ser., 1, 1878, p. 324.

Thuiaria articulata Verril, Prelim. Check-list, 1879, p. 18.

? Thuiaria articulata D'URBAx, Zool. Barent's Sea, 1850, p. 269.

Thuiraria lonchitis KrrcheNpAUER, Nordische Gattungen und Arten, 1884, p. 22.

? Thuiaria articulata BERG I, Goplepoly per fra Kara Havet, 1887, p. 337.

Thuiaria articulata Bourse, Iydroids of Plymoutb, 1889-90, p. 397.

Thijaria lonchitis Levinsex, Vid. Udb. "Hauchs" Togter, 1893, p. 371.

Thuiaria articulata Cr.ATford, Ann. and Mag., 6th ser., XVI, 1895, p. 261.

?huiaria articulatr Boxxevie, North Atlantic Expedition, 1899, p. 83.

Thiaria articulata PICTET and BEDOT, Hydraires de I'Hirondelle, 1900, p. 25.

Thiaria articulate. WIITEAves, Cat. Marine Invert. Eastern Canada, 1901, p. 27.

Thujuria lonchitis S.EMundssox, Bidrag til Kundskaben islandske Hydroider, 1902, p. 65. 
Trophosome-Colony attaining a height of 10 to 12 inches, usually much less, main stem with very distinct but irregular nodes below, slightly llexuose, bearing usually a pair of subalternate hydrotheca on each of the upper intemodes. Branches irregularly alternate, simple, or dichotomously branched, forming a rather dense tuft on distal part of colony. Branches and branchlets divided into long and irregular internodes each of which bears several pairs of subopposite to subalternate hydrothece. Hydrotheca of the ustal thuiarian type, deeply immersed in proximal parts of branches and less so in distal parts, closely approximated. Aperture circular to subtriangular, facing forward or outward, margin often with a single broad tooth on its posterior side. Operculum of a single abcauline flap.

Gomosome.-Gonangia borne on upper side of branches, long, slender, with a round aperture, narrow collar, and operculum.

Distribution.-Common on British and Continental shores of North Atlantic; New Fngland Coast (Verrill); "Atlantic coast" (specimen from the United States National Museum); Iceland (Samundsson); Gulf of St. Lawrence (Whiteaves); ? Barents Sea (D'Urban); Polar Sea (Bonnevie).

In the absence of the gonosome this species is notalways easy to distinguish from $T$. cupressine. The babit of growth, however, is entirely different from the graceful spiral arrangement which characterizes the latter. Branches stifler and harsher. 'The gonosome is entirely different. The species appears to be rare on our Atlantic coast.

The synonymy of this species is exceedingly uncertain on account of a mistake of Pallas who gave the name Sertuluric articulute to an Atlantic species under the mistaken impression that it was identical with the "Sea-Spleenwort" of Ellis. Afterwards Fleming (1812) instituted the genus Thuimin, and, apparently misled by Pallas, called the Spleenwort of Ellis Thuiaria articulata. In the meantime Ellis and Solander (1755) gave the name Sertuluria lonchitis to Ellis's species of Sea-Spleenwort, thus securing the priority for the name lonchitis, which is essentially a northern form. Since that time most writers have confused the two species under the common name Thuiuria articulata. Hincks in his great work (186s) seems to have done this. In 1sit Kirchenpature clearly explained the situation and reestahlished the name T. Ionchitis for Ellis's species, in which he was followed by Levinsen (1893). In most eases it is impossible to tell which species is meant when the name $T$. articulate is used, and we can only judge from the distribution.

THUIARIA PLUMULIFERA Allman.

(Ilate IX, tign, 9-13.)

Thuiaria plumulifera Alusan, Mem. Mus. Comp. Kool., V, No. 22, 1877, p. 27.

Thuiurir plumulifera Kirnexpuer, Nordische Gattunenen und Arten, 1884, p. 25.

Trophosome-Colony attaining a lheight of 10 inches in the largest specimen examined. Main stem exceedingly long and slender, divided into internodes of unequal length, bearing rather distant and opposite branches ench of which bears an axillary hydrotheen; an additional hydrotheca being between each two branches on each side. Branches rather distant, alternate, divided into long and very unequal internodes, and contracted at their origins. Hydrotheca alternate, well separated, tubular, not extensively immersed for this genus; aperture with two broad, rounded teeth and a tubular collapsible extension of the hydrothecal walls. This tube is not constant, and in some hydrotheca where it is wanting a two-valved operculum is seen.

Gonosome.-Not known.

Distribution.-Otl Cape Fear, $\tau$ fathoms (Allman); Allotross Station 2015, lat. N. 3T 31 ', long. W. $74^{\circ} 53^{\prime} 30^{\prime \prime}, 19$ fathoms; Station 2960 . lat. N. $40^{\circ} 13^{\prime} 15^{\prime \prime}$, long. W. $69^{\circ} 29^{\prime} 15^{\prime \prime}$, 46 fathoms; Station 2265 , lat. N. $37^{\circ}\left(6^{\prime} 40^{\prime \prime}\right.$, long. W. Tt $35^{\prime \prime} 40^{\prime \prime}$, To fathoms; Station 2279 , lat. N. $35^{\circ} 20^{\prime} 55^{\prime \prime}$, long. W. $75^{\circ} 20^{\prime} 55^{\prime \prime}$, 16 fathoms; Station 2307 , lat. N. $35^{\circ} 42^{\prime}$, long. W. $74^{\circ} 54^{\prime}$ $30^{\prime \prime}, 57.3$ fathoms; Station 2308 , lat. N. $35^{\circ} 43^{\prime}$, long. W. $74^{\circ} 53^{\prime} 30^{\prime \prime}, 45$ fathoms; Station 2421 , lat. N. $37^{\circ} 07^{\prime}$, long. W. $7 t^{\circ} 3 t^{\prime} 30^{\prime \prime}$, $6 t^{\text {fathoms. }}$

Type - In the Museum of Comparative Zoology, Cambridge, Massachusetts. 
'This species is squarely intermediate between the genera Thuiaria and Sertularella, having the characters of numerous hydrotheca to the internode, and the two-toothed margin and twovalved operculum of the former, and the exactly alternate hydrothece of the latter. I place it provisionally in the latter genus, as it seems here to find, on the whole, its closest affinities, although it agrees quite well with Sertuluedlu menu Hartlaub, so far as the nonspecific characters are concerned.

\section{? THUIARIA RAMOSISSIMA Allman.}

Thuiaria ramosissima AlLMax, Gatty Coll., 1885, p. 146.

"Trophosome.-Hydrocaulus monosyphonic, main stem sending off in every direction branches which are themselves profusely branched; ramifications subdichotomous, each bifurcation preceded by a transverse joint. Hydrothecre alternate, adnate to the hydrocaulus by the whole of their epicauline walls, deep, tubular; the apocauline margin of aperture deeply cleft.

"Gonosome.-Gonangia springing each from a point placed laterally just below the base of a hydrotheca. None mature in the specimen.

"Locality.-Northeast const of America."

I have not seen this species and have copied the above description entire. It resembles greatly the common Thuiaria argentea, but it does not seen likely that P'rofessor Allman would have made a mistake regarding such a well-known form.

\section{THUIARIA DIFFUSA (Allman).}

(Plate X, figs. 1-3.)

Sertularella diffusa AzLanan, Gatty Coll., 1885, p. 136.

Sertularid diffuse A llmax var. Mark tanner-Turveretscner, Hydroiden des k. k. naturhist. Hofmuseums, 1890 , p. 229.

Trophosome.-Colony attaining a height of 9 inches (Allman), much branched, stiff, and corneous in aspect. Stem nearly straight, divided into long and irregular internodes, lower part without hydrothece. Branches straight, alternate, themselves dividing alternately and the branchlets ultimately dividing dichotomously, divided into usually long internodes of unequal length, the distal being generally the shorter. Hydrotheca tubular, gracefully curved, ordinarily strictly alternate, about the distal half free and pointing forward and outward, margin with two large pointed lateral teeth, aperture crescent-shaped. Operculum not evident, the distal superior part of the hydrothecal wall being very thin and collapsible so that it seems to serve as an operculum.

Gonosome.-Gonangia borne on distal part of the branches, ovoid, with two lateral anterior spines and a narrow collar surrounding a broad, round aperture.

Distribution.-Rockaway (Atlantic coast, U. S. ?) (Allman). South America (MarktannerTurneretscher); "South America," specimen from Levinsen; Albatross Station 2279, lat. N. $35^{\circ} 20^{\prime} 55^{\prime \prime}$, long. W. $75^{\circ} 20^{\prime} 55^{\prime \prime}, 16$ fathoms.

This species also is very near Thuaria argentea, and the specimen deseribed by Allman may belong to this species. Those described by Marktanner-Turneretscher, the one from Station 2279, and the specimen sent me by Professor Levinsen from South America seem to be specifically distinct. The whole texture is stitf and rigid and deeply corneous in color, differing greatly from $T$. argentea. The forming of a pseudo-operculum by the thin collapsible distal part of the inner (upper in position) hydrothecal wall is an interesting feature.

THUIARIA DALLI, new name.

(1'late $\mathbf{X}$, figs. 4-6.)

Sertularia cupressoides CLARK, Alaskan Hydroids, 1876, p. 2:20.

Thuintia cumessoides ${ }^{1}$ NutTING, Hydroids of the Harriman Expedition, 1901, p. 185.

Trophosome.-Colony small, in specimens examined, and plumose in form. Main stem straight, divided into usually short internodes by oblique nodes, many internodes bearing two species.

${ }^{1}$ Name preoccupied by Kirchenpauer, Nordische Gattungen und Arten, 1884, p. 18, for an entirely different 
branches, others more, but an equal number on both sides, no hydrothece on main stem.

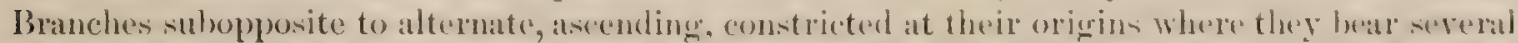

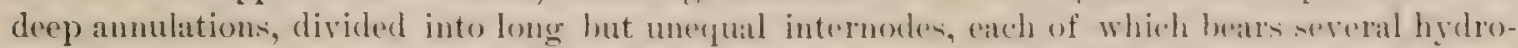
thecat. Ilydrothece subopposite, closely approximated, derply immered, their distal onds only being free, tubular, very slightly curved distally; aperture with two rather broad teeth; operculum composed of two llaps.

Gonosome.-Not known.

Distribution. Shumagin Islandsand Port Moller, . Maska (( lark); Yakutat, Alaska (Nutting). Type slides.-Cat. No. 19721, U.S.N.M.; Cat. Nos. 18666, 1867\%, State Univ. of Iowa; also in the collection of the author.

?THUIARIA LATIUSCULA (Stimpson).

Sertularia latiuscula Sturpson, Marine Invert. Grand Manan, 1853, p. 8.

Sertularia latiuscula V'errill, Proc. Am. Assn. Adv. Sci., 1873, p. 356.

Sertula ria latiuscula Verril, גm. Journ. Sci. and Arts, VII, 187t, p. 39.

Sertularia latiuscula A. AGAssiz, North American Acalephe, 1865, D. 145.

"P'inne broad, compressed, attached by a slender base to the main stem; cells crowded, nearly opposite, shaped as in Sertularie argentea; vescicles elongated, ovate, with a single strong spine on one side at the extremity. Color, brownish. Breadth of pinna, 0.03 inch. Dredged in the laminarian zone."

Distribution.-Grand Manan (Stimpson); fi miles cast of seguin Island, an: fathoms (Verrill); between Cape Cod and Gulf of St. Lawrence (Verrill).

I have been unable to obtain an authentic specimen of this species. The abore description is taken entire from that of the original deseriber. No further description nor any figure has thus far been found. There is no doubt that it is a Thuiaria, and it is quite probable tbat it is T. argentea. The single spine to the gonangium occurs oceasionally in that species.

Type.-Apparently lost; at least, I camnot find where it is.

THUIARIA SIMILIS (Clark).

(Hlate $\mathbf{X}$, figs. $7-9$.

Sertularia similis Ciark, Alaskan Hydroids, 1876, p. 219.

? Sertularia similis HARTLAUB, Hydroiden aus dem Stillen Ocean, 1891, p. 354.

Sertularia similis NutTing, Hydroids of the Harriman Lxpedition, 1901, p. 185.

Trophosome.-Colony usually consisting of a central stem, sometimes attaining a height of orer 3 inches. Stem geniculate, divided into regular internodes, each of which bear's a branch and two hydrotheca on one side and a single hydrotheca on the other. Branches divided into usually short internodes, each of which bears from one to sereral pairs of opposite or subopposite hydrotheea. Hydrothece in clowely approximated pairs, the individuals of a pair being distinctly separated in front, and of the serfularie jumile type, with free outwarly inclined distal portions; aperture with two well-marked and nearly opposite teeth and a two-ralied operculum.

Gonosme.-Not known.

Distribution.-Hagmeister Island (Clark); Bare Island (Hartlaub); Berg Inlet, Glacier Bay (Harriman Expedition); Puget Sound (Nutting); Albutross Station 2St2, lat. N. 5t 15', long. W. $166^{\circ} 03^{\prime}, 72$ fathoms; Station 2865 , lat. N. $48^{\circ} 12^{\prime}$, long. W. $122^{\circ}+9^{\prime}$, 40 fathoms; Station 3465 , lat: N. $48^{\circ} 21^{\prime}$, long. W. $123^{\circ} 14^{\prime}, 48$ fathoms; Station 3515, lat. N. $59^{\circ} 59^{\prime}$, long. W. $167^{\circ} 53^{\prime}$, 13 fathoms; Station 3557 , lat. N. $57^{\circ} 0 t^{\prime}$, long. W. $170^{\circ} 2 t^{\prime}, 26$ fiathoms.

The specimen from Station 3515, from which the above description was taken, agrees very well with Clark's original description and figure. Other specimens vary considerably, but not sufticiently to demand separation. Indeed, none of them vary as much from the type as the specimen figured by IIartlaub, which seems to me to he quite distinct.

Type.-In collection of the U. S. National Museum. 
THUIARIA TUBULIFORMIS (Marktanner-Turneretscher)

(Plate XI, figs. 1-8.)

Dynamena tubuliformis MIAкKanNer-Tunveretscil R, Hydroiden des k. k. naturhist. Hofmuseums, 1890, p. 238.

Trophosome-Colony growing in tufts of straight stems, reaching a height of about 3 inches. Stem straight and even throughout, divided into regular internodes, each of which bears a branch and two hydrothece on one side and a single hydrotheca on the other. Branches strictly alternate, divided into irregular internodes and much constricted at their origins. Hydrothece subopposite, long, tubular, with the greater part of their lateral outline parallel to the branch, the upper portion being abruptly bent outward and ending in two large opposite teeth and a two-valved operculum.

Gonosome.-Gonangia growing on front of stem, large, ovate, with a constricted curved neck and round terminal aperture.

Distribution.-Dschidda (Dr. Billitzer); Bay of Bahia, Brazil (Rathbun); Florida, between Salt Pond and Stock Island (Dr. E. Palmer); Bahama Banks, 3 to 6 fathoms (Nutting).

The gonosome of this species is figured here for the first time. There is a slight tendency for the hydrothece to arrange themselves in groups, reminding one of those found in the genus Pasyther, the upper ones in each group being somewhat smaller than the lower pair.

Type.-In the k. k. Hofmuseums, Vienna.

\section{THUIARIA TENERA (Sars).}

(Plate XI, figs. 9-12.)

Sertularia tenera Sans, Bidrag til Kundskaben om Norges Hydroider, 1873, p. 20.

Sertularia tenera Hincks, Ann. and Mag., 4th ser., XIII, pp. 129 and 151.

Sertularia tenera Wixtiter, Naturhist. Tidsskrift (3), XIII, 1879-80, p. 246.

Sertuluria tenera Levinsex, Vid. Udb. "Hauchs" Togter, 1893, p. 38.

Sertularia tenera Manktaxier-Turneretscher, Hydroiden des k. k. naturhist. Hofmuseums, 1890, p. 230.

Sertularia tenera Levissen, Vid. Meddel. naturhist. Foren., 1892, p. 48

Sertularic tenera MARKTANNER-TurNeretscner, Hydroiden von Öt Spitzbergen, 1893, p. 418 ,

Sertularia tenera Nutrixg, Hydroids from Alaska and Puget Sound, 1899, 1). 743.

Thuiaria tenera Boxwevie, North Atlantic Expedition, 1899, p. 83.

Thuiaria tenera S.emundsson, Bidrag til Kundsk. islandske Hydroider, 1902, p. 62.

Trophlosome. Colouy attaining a height of about 3 inches in largest specimens cxamined. Main stem straight proximally and slightly flexuose distally, divided into long and irregular internodes bearing strictly alternate branches and three hydrothece (one axillary and two not) between adjacent branches on ench side. Branches usually undivided and with rather short internodes, which often bear a single pair of hydrothece. Hydrothece subalternate, tlaskshaped, rather slender, widely separated, much exserted, with a tubular listal portion; margin varying greatly, sometimes being round and without teeth, and often being curved, with two teeth of regular sertularian type. In many cases the margin is produced into a thin collapsible tube. Operculum usually composed of one thap attached to abcauline side of margin, but sometimes composed of two flaps.

Gonosome.-Gonangia ovate, with a round terminal aperture and a short collar.

Distribution-Kodiak Island and Bering Straits (Dall); Albatross Station 2865, lat. N. $48^{\circ} 12^{\prime}$, long. W'. $122049^{\prime}$, 40 fathoms; St. Pauls Island (Nutting); Norway, 159 fathoms (Sars); Iceland (Hincks); Denmark (Winther); Christiania (Marktanner-Turneretscher); Spitzbergen (Marktanner-Turneretscher); North Atlantic (Bonnevie).

This species appears to break down the generic distinctions proposed by Levinsen in that it has both a one-flapped and a two-tlapped operculum in the same specimen. 


\section{THUIARIA FABRICII (Levinsen.)}

(I'late XII, tiegr. 1-2.) )

Serlularia fastigiata FAbnçеs (not Linnæeus), Fauna Grönlandiea, 1780, p. 458.

Sertulario cupressinu Fabricses, Manuseript, III, p. 388.

Sertuleria argentea WINTnEn, Naturhist. Tidsskrift (3), XII, 1879-80, p. 278.

Sertularia fabricii Levrssex, Vid. Middel. Naturh. Foren., 1892, p. 48.

Sertulurit fabricii CaLKrss, Hydroids from P'uget Sound, 1899, p. 361.

Serlularic fabricii Hartutu, Hydroiden aus dem Stillen Ocean, 1901, p. 354.

Thuiuria fabricii Numsag, Hydroids of the Harriman Expedition, 1901, p. 185.

Trophosome-Colony attaining a height of about 2 inches in the specimens examined. Main stem straight, proximal part marked by very deep irregularly spaced annular nodes; distal part divided into irregular internodes ach bearing one or more buanches which are inserted on all sides of the stem in a spiral manner so as to give the colony the shape of a bushy tuft. Branches very closely approximated, dichotomously divided once, twice, rarely three times; internodes rather long and irregular, each bearing several pairs of hydrotheca, exceptionally a single pair. Hydrotheca subopposite on proximal parts of hranches and subalternate at tips of hranches. Iydrothecae flask whaped, of the sertularian type, distal portions free, slightly out-curved, aperture narrow and furnished with two strong marginal teeth and a two-flapped operculum.

Gonosome.-Gonangia borne on upper sides of branches and branchlets, oblong oval in shape, very delicate in texture, with a terminal round aperture on a neck resembling the frustum of a cone, and two lateral spines which, however, are only exceptionally present in the specimens examined. An acrocyst is often present.

Distribution.- West coast of Greenland (Levinsen); Puget Sound (Calkins). ${ }^{1} \quad$ Dutch IIarbor, Alaska, and Orca, Alaska (Nutting).

THUIARIA ARGENTEA (Linnæus).

(Plate XII, figs. 3-9.)

Squirrel's-tcil, Eilus, Nat. Hist. Corallines, 1755, p. 6.

Sertularia argentea Lixw.eis, Systema Natura, 1758, p. 809.

Sertularia cupressime (part) Palias, lilenchus Zoophytorum, 1766, 1) 141.

Sertulcria cupressina, var. ß. urgentea, Lisw.eus, Systema Nature, 1767, p. 1308.

Sertuleric urgented Jar.stri, De Plantis Zoophytis, 1776, ". 27.

Sertuleria ergenter, Eulus and Socander, Nat. Ifist. of '/ooph., 1786, p. 38.

Sertularia argenten (Bsels, in Linnxus, Systema Nature, 1788-1793, p. 3847.

Sertulerin strgentca LisPer, De Pflanzenthiere in Abbildungen, III, 1788-1830, p. 179.

Scriulariu argenteu Веккемлогт, Synop. nat. hist. Great Britain and Ireland, 1, 17S4, 1. 216.

Sertularia argentea Bosc, Nat. II ist. des Vers, III, 1802, p. 93.

Sertularia argentea Ttriox, British Fauna, 1807, p. 213.

Seriuluria argenter JAsresos, Catalogue of Animals of the Class Vermes, 1811, p. 564.

Sertularia argente Lasmovroux, Bullet. philomatique, 181:, p. 184.

Sertulariu argente L.ı.ırck, Hist. Nat. des anim. sang Vert., II, 1816, 1. 117.

Sertularia argentra L.smothovx, Hist. des Polypiers Coralligènes, 1816, 1. 192.

Sertularia argentea Strw AnT, Elements Nat. Hist. Animal Kingdom, II, 1817, 1. 442.

Sertularia argenten Bosc, Ilist. Nat. des Vers, 18:30, p. 108.

Sertularia argented DE BLANvilLe, Manuel d'Actinologie, 1834, J. 480.

Seriularia argented Lasarck, Nat. Hist. Anim. sans Vert., 1836, p. 143.

Seriuluria crgentec H.ıss.t.L, Ann. and Mag., VI, 1811, p. 168.

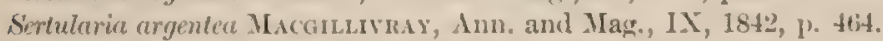

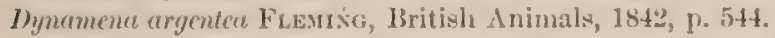

Serlularia argenter Jonsstos, Ilist. I3rit. 'Zooph., 1847, p. 74.

Sertularia ctrgente DAsxer., liare and lemarkable Animals of Seotland, I, 1847, p. 189.

Sertularia argentea (in.1\%, List Brit. Animals, 1847, 1).73.

Sertularia argentea (iosse, Devonshire Coast, 1853, 1\%. 434.

Sertularia argentea Stmıмо, Marine Invert. Grand Manan, 185̃ , p. 8.

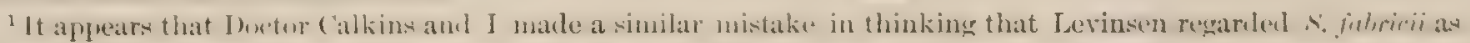
the same as $S$. argenlen of author, instead of $S$. argentea of Winther. See references given above. 
Sertularia argentea ALDER, Cat. Zooph. Northumb., 1857, p. 26.

Sertularic argentea A. Ag Assiz, North American Acalephæ, 1865, p. 144.

Sertularia argentea van Bexedex, Fauna Littorale de Belgique, 1866, p. 184.

Sertularia argentea Hrxcks, British Hydroid Zoophytes, 1868, p. 268.

Sertularia argentea Verrilt, Invert. Vineyard Sound, 1871-72, p. 732.

Sertularia argentea Schulze, Nordsee Exped., 1872, p. 132.

Sertularia argentea Verril., Proc. Am. Assn. Adv. Sci., 1873, pp. 256, 359, 364, 374.

Sertularia argentea McInTosir, Ann. and Mag., th ser., XIII, 1874, p 213.

Sertularia argentea Verrill, Amer. Journ. Sci., VII, 187t, P. 39.

Sertularia argentea Verrill, Amer. Journ. Sci, VII, 1874, p. 133.

Sertularia argentea CLARk, Hydroids of Pacific Coast, 1876, p. 257.

Sertularia argentea, var. dicaricata $\mathrm{CLARK}_{\mathrm{K}}$, Hydroids of New Eng. Coast, 1876, p. 64.

Sertularia argentea Merescinowsk Y, Ann. and Mag., 5th ser., I, 1878, p. 324.

Sertularia argentea W IxтmER, Naturhist. Tidsskriit, 1850, p. 249.

? Sertuluriu argentea BERGI, Goplepolyper fra Kara Havet, 1887, p. 335.

Sertularic argentea Bourne, Hydroids of Plymouth, 1889, p. 396.

Sertularia argentea Driescr, Tektonische Studien, 1890, p. 206.

Serlularia argenter Marktanner-Turneretscher, Hydroiden des k. k. Naturhist. Hofmuseums, 1890, p. 232.

Sertularia argentea Levixsen, Vid. Udb., "Hauchs" Togter, 1893, 1). 370.

Sertularie argented CRAwFord, Ann. and Mag., 6th ser., XVI, 1895, p. 261.

Thuiaria argentea Boxneyre, Norwegian North Atlantic Exped., 1899, p. 83.

Thuiaria argentea Nutrixs, Hydroids from Alaska and Puget Sound, 1899, p. $7 \pm 1$.

Thuiaria argenten Nutrine, Hydroids of Woods Hole, 1901, p. 363.

Sertularia argentea HARGITT, Amer. Naturalist, 1901, p. 390.

Thuiaria argentea Nutrixa, Hydroids of the Harriman Exped., 1901, p. 184.

Thuiaria argented WhIteAvEs, Cat. Marine Invert. Eastern Canada, 1901, p. 27.

Sertularia argentea S.jwundson, Bidrag til Kundskaben islandske Hydroider, 1902, p. 62.

Sertularia argentea Torkey, Hydroids of Pacific Coast, 1902, p. 67.

Trophosome.-Colony attaining a height of a foot or more, usually considerably less. Stems growing often in clusters, long, slender, divided by distant nodes into irregular internodes, with distant hydrothece. Branches rather distant, spirally arranged, each branch dividing dichotomously into an exceedingly delicate and graceful tracery of branchlets, the whole colony being among the most beautiful of the hydroids. The axil of each branch and branchlet is occupied by a hydrotheca. Internodes distant and irregular. Hydrotheca subopposite to alternate, not greatly immersed, the terminal one-third often being free, bending gracefully outward, with a strongly bilabiate aperture, one tooth being usually much longer and more acute than the other. Operculum two-valved.

Gonosome.-Gonangia borne on upper sides of branches at bases of hydrothece, subtriangular in outline, being widened distally by two blunt lateral spines. Aperture terminal, collar very low, acrocysts borne on mature gonangia.

Distribution.- One of the commonest species in shallow water on both shores of the North Atlantic, Alaska, and the North Polar regions.

This is one of the best known of the Sertularida. It most nearly resembles $T$. cupressina, from which it differs in having a much more bushy habit, more exserted hydrotheca with more conspicuous teeth. The gonangia are broader in proportion to their height, and the lateral spines are usually less conspicuous. The finest specimens I have seen came from derome Creek, Maryland.

\section{THUIARIA CUPRESSINA (Linnæus).}

(Plate XIII, figs. 1-3.)

Sea-cypress Ellis, Essay Nat. Hist Corallines, 1755, p. 7.

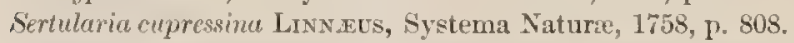

Sertularia cupressinc Houtrux, Natuurlyke Historie, XVII, 1761-73, p. 537.

Sertularia cupressina (part) PALLAs, Elenchus Zoophytorum, 1766, p. 141.

Sertularia cupressina (part) Liswats, Systema Nature, 1767, p. 1308.

Sertularia cupressina (part) Bonda ERT, Lyst der Plant-Dieren, 1768, 1. 176.

Sertuleria cupressina MARATt, De Plantis Zoophytis, 1776, p. 27.

Sertularia cupressine (part) Groxovius, Zoophylacium gronovianum, 1781, p. 358. 


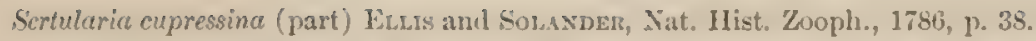

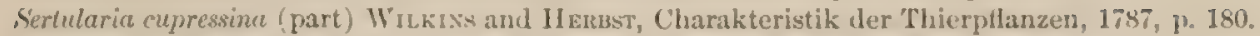

Sertuleria cupressinn (part) Giselxs, (Linneus) Systema Nature, 178s-93, 1). 3847.

Sertuluria cupressina (part) Expen, Die I'flanzenthiere in Abbiliungen, III, 1788-1830, 1). 177.

Sertularin cupressinu Benkexnocr, Synop. nat. hist. Great 13ritain and Irelanel, 1, 1789, 1. 216.

Sertuluria cupressina (part) IBose, Hist. Nat. des Vers, III, 1802, 1. 9.3.

Sertularia cupressina T'umos; British Fauna, 1807, y. 213.

Sertuluriu cupressina Jasesos, Catalogue Animals Class Vermes, 1811, p. 564.

Sertuluria cupressina Lasoenotx, Bullet. philomatique, 1512, p. 184.

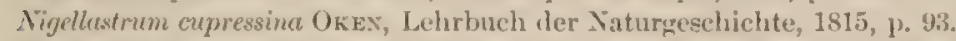

Sertulurie cupressinc Isamsek, Hist. Xat. des anim. sans Vert., II, 1816, 1. 118.

Siruleria cupressine LAsovirodx, Hist. des Polypiers, 1816, p. 192.

Serluleria cupressine STEWA1T, Elements Tat. Hist. Animal Kingdom, II, 1817, p. 442.

Sertularic cupressina Bosc, Hist. Nat. des Ven, 1830, p 108.

Sertuluriu cupressine de Brasvilue, IIanuel d'Actinologie, 1834, 1). 480.

Seriularia cupressina OкЕ:, Allgeneine naturgeschichte, 1835, p. 79.

Seruluria cupressina Lamanck, Hist. nat. anim. sans vert., 1836, p. 14.

Sertularin cupressince IIAssald, Ann. and Mag., VI, 1841, \%. 168.

Sertularia cupressinu MIccillerral, Ann. and Mag., IX, 184:, p. the.

Linamena cupressinu Fuevixa, Jritish Animals, 1542, p. 544.

Sirnlaria cupressina Jonxstox, Jist. British Zoophytes, 2d ed., 1847, p. 80.

Sertularin cupressina Gkar, List of British Animals, 1847, 1) it.

Sertularia cujressina Al,1)ER, Cat. Kooph. Northumb., 1857, p. 26.

Sertularia cupressince A. Acisssz, Forth American Acalephas, 1865, p. 143.

Serilariu cupressina VAv Besenex, Faune littorabe de Belgique, 1866, p. 178.

Sertularia cupressina Hiscks, British Hydroid Zoophytes, 1868, p. 270.

Serfulariu chpressinu Verand, Invert. Vineyard Sound, 1871-2, pp. 408, 732.

Sertularia cupressina Verrilu, Proc. Am. Assn. Adr. Sci., 1873, pI. 353, 364.

Sertularia cupressina VenkiLl, Amer. Journ. Sei. and Art, 3d ser., VII, 187t, p1).44, 413, 504.

Sertularia cupressinn MICITosir, Inn. and Mag, tth ser., XIII, 1sit, p. 213.

Sertularia cupressina WINTIFI, On Internodiets, etc., 1579-80, p. 308.

Sertularia cupressina Wistien, Vaturhist. Tidsskrift, 1879-80, p. 248.

Sertularia cupressina 1'UnB.sx, Zoology of Barents Sea, 1850, 1). 269.

Thuariu cupressina ALLa.s, Challenger leport, Hydroida, I't. 2, 188s, p. 67.

Sertularia cupressina Bocrse, Hydroids of I'lymouth, 1859-90, I. 394.

Serhularia cupressina Levinsex, Vul Udb. "IIauchs" Togter, 1893, p. 370.

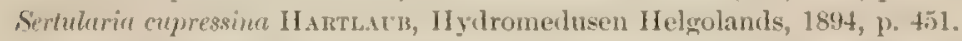

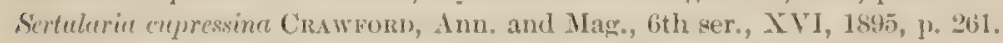

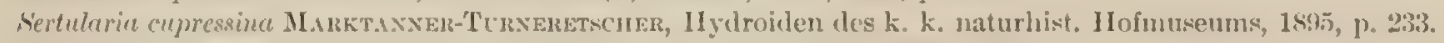

Thuiuria cupressinu P'ICTET and I3Enot, Réw. Camp. Sc. Hirondelie, 1900, ]2. 24.

Thuintia cupressina Nutrixa, Iydroids of the Woods Hole liegion, 1901, 1. 364.

Sertuluriu cupressinu HAngrTT, American Naturalist, 1901, jo. 390.

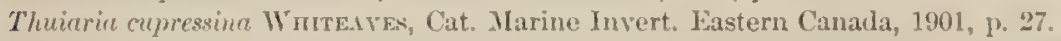

Thuiaria cupressina S.emc:xpsos;, Bidrag til Kundskaben islandske Hydroider, 1902, p. 62.

Troptersome-Colony sometimes attaining a beight of a foot or more, usually much less. Main stem long, very slender, internodes not evident, a hydrotheca in the axil of each branch. Branches regularly alternate, dichotomously branching, with a tendency toward a spiral arrangement; internodes distant and irregularly spaced. Hydrotheca subopposite to subalternate, deeply immersed, of the regular thuiarian pattern, with a rather large bilabiate aperture and a two-lobed opereulum. The distal hydrotheee are more exserted and alternate than the proximal, and in some cases are almost identical with those. of $T$. lonelitis, on the one hand, and T. ergenter on the other.

Gronesme.-Gonangia horne in rows on the upper sides of the branchlets, rather stout, flattened, with a terminal round aperture, distinct collar and operculum, and two very strong, sharply pointed, lateral spines projecting upward, one from each shoulder. An acrocyst is present when the gonophores are mature.

Distributim.-Common on European and New England shores of the North Atlantic, extending downward to a deptls of about 150 fathoms; Denmark (Winther); Barents Sea, 160 
fathoms (D'L'rban); Iceland (Simundsson); Labrador (Packard); Meditcrranean, Gulf of Gascony (Pictet and Bedot); Gulf of St. Lawrence (specimens from Sir William Dawson).

This is one of the oldest and best known of the Sertularide. 'The finest specimens that I have seen came from St. Georges Bank, Newfoundland.

\section{THUIARIA PLUMOSA Clark.}

Thuiaria plumosa CLARK, Alaskan Hydroids, 1876, p. 220.

Thuiaria plumosn Kincrevpauer, Fordische Gattungen und Arten, 1884, p. 21.

"Trophosome.-Hydrocaulus simple, erect, very slender at the base, increasing in size to the distal end, somewhat twisted, jointed transversely, internodes of the proximal portion of very unequal length, some being three times the length of others, those of the upper portion are quite uniform, regularly branched; branches short, arranged alternateiy, one to each internode, but owing to the twist in the stem take on a spiral form, the uppermost erect, lying close to the stem, the lower ones curve outward, attached to the stem by a very prominent process, bearing a few branchlets, regularly jointed; branchlets do not extend beyond the ends of branches, and lie close to the latter. Hydrothece largest at the base, tapering slightly outward, entirely immersed; aperture toward the stem, the outer side produced, rim ornamented with two large teeth placed on the outer side, two tooth-like processes of the perisare also occur in the base of each hydrotheca, arranged sub-alternately upon the branches and branchlets. Upon the stem there are three to each internode, two placed opposite to each other and one in the axil of the branch.

"Gomosme.-Gonangia sessile, very long and narrow, tapering gradually to the base, ornamented with two short horns placed on opposite sides of the orifice near the distal end; orifice terminal, large; borne in single rows on the upper side of the branches and branchlets. Height of largest specimen, $40 \mathrm{~mm}$.

"Matitat.-Bering Sea, 5 miles southwest of the west cape of Nunivak Island; 30 fathoms, sand. Icy Cape, Aretic Ocean; 15 fathoms, sand."

I have not seen this species, and have copied entire the excellent description given by the original deseriber, Clark.

Type. - Should be in the collection of the U. S. National Museum, but I have been unable to find it there.

PASYTHEA Lamouroux (in part).

Trophosome.-Hydrothece biserial, strictly opposite, arranged in groups of pairs, a group to an internode, the upper pair being smaller and differing in shape from the lower; margin bilabiate, with a two-flapped operculum.

Gomosome.-Gonangia oval, smooth or with sides marked by broad annular rugosities, with a large aperture and narrow collar.

This genus was introduced by Lamouroux in $1812^{1}$ to accommodate two unrelated species, one being the well-known $P^{\prime}$. quadriclentata and the other the so-called $P$. tulipier, a bryozoan. It remained for Bale to give an adequate definition ${ }^{2}$ which was adopted in 1890 by MarktannerTurneretscher. ${ }^{3}$ The group appears to be well defined, with evident relationship to Sertularia in several respects, such as the opposite position of the hydrothece and the characters of the hydrothecal margin and operculum. There are but three species known, I believe, one, $P$. quadridentate from both the Atlantic and Pacific, one, $P$. hexodon, from the Australian region, and a third, I'. plilippina, from the Philippines.

The American form is typical of the genus as defined above.

${ }^{1}$ Nouveau Bulletin des Sciences par la Saciété philomatique, III, Paris, 1812, p. 183.

${ }^{2}$ Australian Ifytroid \%oophytes, 1884, 1) 112.

${ }^{3}$ Hydroiden des k. k. naturhistorischen Hofmuseums, 1590, 1. 2234. 
PASYTHEA QUADRIDENTATA (Ellis and Solander).

(Ilate XIII, figs, +7.)

Serluleria puadrilentate Elurs and Solasw)er, Nat. Hist. 'Looph., 1786, 1) 57.

Sertularia guadrilentata Guels, Systema Natura (Linneus), 1785, 1) 3953.

I'tsylhea quadridentata Es'sen, Die I'flanzenthiere in Abbildungen, III, 1788, p. 2337.

Sertularia quadridentate Espers, Fortsetzungen der l'tlanzenthieren, II, 1794, 1) 32.

Sertularia quadridentate Bosc, Hist. nat. des Vers, III, 1802, p. 97.

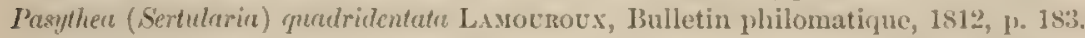

I'isyther quadridentata Lasouroux, Hist. des I'olypiers coralligines, 1816, p. $156^{\circ}$.

Sertulariø quadridentate LAsarck, Hist. nat. anim. sans vert., II, 1816, p. 121.

I'asythea quadridentala ScmwgGer, Handbuch der Naturgeschichte, 18:0, p. 426.

l'asythea quadrielentater LAsourocx, Exposition méthodique, 1821, p. 9.

Tuliparia quadridentate de BLAINYLLE, Manuel d'Actinologie, 183\$-1837.

P'asythea quadridentata B.1LE, Australiax Hydroid Zooph., 185t, p. 112.

I'asythen quadridentate von LExDExFELD, Australian Iydromeduse, 18S4, pp. $\$ 19,621$.

I'usythea quatridentate B.ALe, Proc. Linn. Soc. New South Wales, 2d ser., II I, 1888, p. 770.

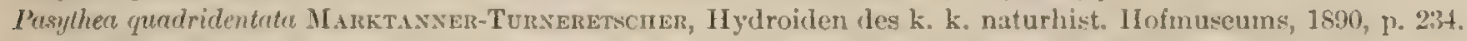

I'tsytheu quadridentatre Tromerr, Hydroid Zoophytes collected by Doctor Willey, 1899, p. 456.

Trophoseme.-Colony attaining a height of about one-third of an inch, consisting of a single unbrunched stem growing from a creeping root-stalk, divided by obiique nodes into regular internodes, each of which bears a pair of hydrotbeca, or two or three pairs in a closely compressed group. Hydrothece on the first internode a single opposite pair, contingent for about half their height in front, somewhat swollen below, the distal part curving to a narrow, bidentate, or obscurely tridentate margin, and an opereulum of two flaps. Sometimes the first internode bears two pair's of opposite hydrothece, the lower of which is like the pair just described, the other pair being wedged in between the diverging free portions of the lower hydrotheca, the bases of the former being indented by the latter. Sometimes two or more internodes have this same arrangement of hydrotheca. One or more of the distal internodes often have a group of three pairs of hydrothece, the lower two being as just deseribed, the upper being wedged in between the second pair, so that they are widely separated, the upper pair loing more erect, more extensively adnate to each other than the others; lowest pair largest, next smaller, and the upper pair smallest.

Cromosome. - I single gonangium is borne at the base of the stem, ovate in shape, with ammular corrugations, a very broad, round aperture, no collar, and an operculum stretehed across like a drumbead.

Distribution.-Coast of Ifriea, near the island of Ascension (Eillis and Solander); Fitzroy Island and Point Stevens, Australia (Haswell); Coogee, Bondi, Australia (Bale); Atlantic Ocean (Marktanner-Turneretseher); South Seas (Thornely); between Eleuthera and Little Cat Islands, British West Indies (Bahama Expedition, State University of Iowa).

This species seems to be always found growing on floating seaweed.

\section{SERTULARELLA Gray (modified).}

Trophosome-Hyclrotheca biserial, strictly alternate, usually with three or four marginal teeth and a well-marked opereulum with three or four flaps. Rarely the tecth are obliterated, in which case the operculum is stretched across the hydrothecal aperture like a drumbead. Branches never regularly anastomosing to form a reticuate, flabellate structure.

Gomosmme. Gonangia usually ornamented with annular corrugations or ridges. A perture at the end of a trumpet-shaped tube, or else encircled by a narrow, broad collar, and several biunt, spine-like projections.

This is perhaps the most satisfactory generic group of the Sertularida, because it is capable of more exact delimitation than the other genera, and is based on characters that are casily seen. As originally defined by Gray, ${ }^{1}$ the genus contained but two species, S. polyzomies and S. migosa.

\footnotetext{
${ }^{1}$ List of Specimens of British Inimais, Radiata, London, 18t7, p. (6S.
} 
Hincks (1stis) described six, and Iartlaub (1) yet included in any one genus of the Hydroida. Allman adopted the genus in his earlier works, ${ }^{1}$ but abandoned it in his Report on the Hydroida of the Challenger Expedition, 1858. Hincks, in his British Iydroid Zoophytes, 1s6s, and Bale, in his Catalogue of Australian Ilydroid Zoophytes, 1884 , called attention to the character of the operculum, now considered the best means of delimiting the genus, and in this they have been followed by nearly all subsequent writers of importance. ${ }^{2}$

In 1900 there appeared a work by Doctor Hartlaub which contains by far the most complete and masterly discussion that has ever been offered concerning any single genus of the order Hydroida. ${ }^{3}$ The ground has thus been so completely covered by one fully equipped for the best work, with unusual advantages for examining a large number of types in the most important museums of Europe, that the present writer has found his labors greatly lightened so far as the genus Sertularella is concerned, and has availed himself freely and with confidence of the results of Doctor Hartaubs lahors, especially in the matter of bibliography and distribution of species of this great genus. In the few cases where Doctor Hartlaub has given references unavailable to myself I have taken them on his authority, having verified so great a majority that I am convinced of their entire reliability. This writer's definition of the genus is substantially the same as the one adopted in the present work. He does not claim to give a final definition, but simply employs it as a means of assembling all the forms that he regards as closely related to Sertulurella as ordinarily understood. He finds that the characters of the internodes relied upon by Schneider ${ }^{4}$ is very inconstant, and that Levinsen has relied too implicitly on the characters of the marginal teeth and operculum. ${ }^{5}$ He does not regard the operculum of Sertularellu as homologous with that of Sertularia, the former being a definite structure added above the real hydrothecal margin, while the latter is the thin end of the hydrothecal wall itself.

POINTS OF INTERGRADATION BETVELEN SEITULARELLA AND OTHEI GENERA.

Although there are certain species that do not come strictly within the definition above given for Sertularelle, there is only one that comes within the limits of any other genus as defined in this work, and that is S. clarkii, which bears considerable resemblance to certain species of Thuiaric in the aperture and marginal teeth. 'The strietly alternate hydrothece, however, and the regularity of the internodes are sufticient, in my opinion, to overbalance these thuiarian features and justify the inclusion of the species in Sertularella.

There are several species in which the gonosome differs from the typical Sertulurelle in not being annulated. S. epriscopus has gronangia that are strongly ribbed longitudinally, reminding one of certain species of Abietinaria, such as $A$. costata Nutting; S. turgiela (Trask) has gonangia that have the distal portion beset with strong spines, reminding one of these structures in some members of the genus Diphesia, such as D. acanthocarpes (Busk), and S. formose Ferves has a perfectly smooth gonangium resembling some of those found in the genus Sertuterite. All of these species, however, come well within the genus and conld not consistently be placed in any other.

The following key, like the others in this work, is purely artificial and makes no claim to indieate the relationship of the speeies involved.

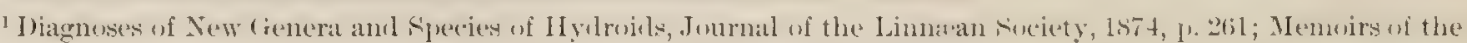
Museum of Comparative Zoology, V. No. 2, 1877, p. 21; Description of Australian, Cape, and other Hydroids, mostly from the collection of Miss H. Gatty, Journal of the Linnrean Society, XIX, 1885, P. 133.

${ }^{2}$ See the General Systematic Discussion, 1, 19.

${ }^{3}$ Revision der Sertularella-Arten, von Doctor Clemens Hartlaub, Hamburg, 1900.

${ }^{4}$ Hydroidpolypen von Rovigno, Kiel, 1897, 1. 523.

${ }^{5}$ Meduser, Ctenophorer og Hydroider fra Grönlands Vestkyst, 1893, p. 57. 
Hydrothece with four teeth.

Iydrothecal walls marked by annular rugosities.

Rugosities on upper sicle of hydrothece only.

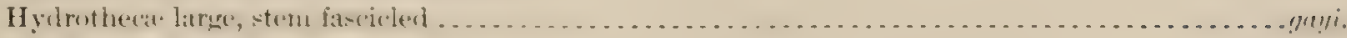

Stem not fascicled.

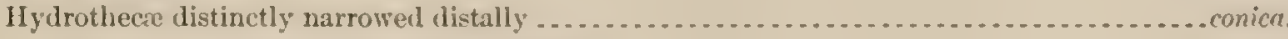

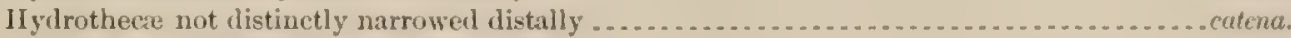

IRugosities on all sides of hydrothecal walls.

No distinct neck to the hydrothece.

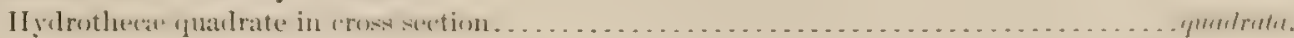

Hydrothece round in cross section.

Hydrothece very large . . . . . . . . . . . . . . . . . . . . . . . . . . . . . . . . . . . frnneri.

Hydrothecre not very large.

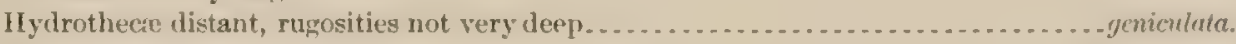

Hydrothecie approximated, rugosities very deep. . . . . . . . . . . . . . . . . . . . pratagonicu.

A ristinct scuare neck to the hydrotheca.

Hydrotheca largely immersed, closely approximated. . . . . . . . . . . . . . . . . . . . . rugosa.

Hydrotheca exserted, not closely approximated.

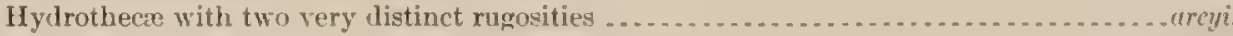

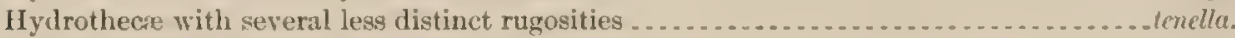

Hydrothecal walls smooth, without regular rugosities.

Marginal teeth distinctly of mequal size.

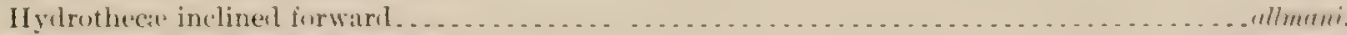

Hydrothece not inclined forwarl in noticeable degree . . . . . . . . . . . . . . . . . . . . . . . . . contorta.

Marginal teeth of approximately equal size.

Entire adcauline wall adnate to hydrocuulus.

II drothece closely approximated.

Colony of very thin hyaline structure . . . . . . . . . .

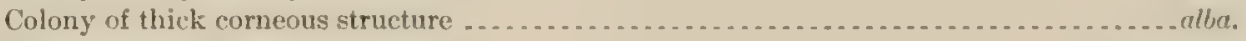

Hydrothece distant, stem fascicled below . . . . . . . . . . . . . . . . . . . . . . . . . . . pinnigere.

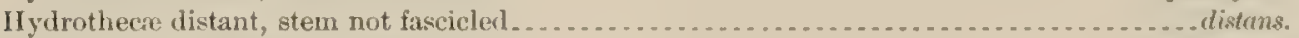

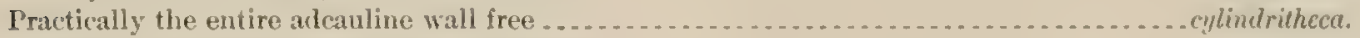

Less than one-third of adcanline wall arlnate.

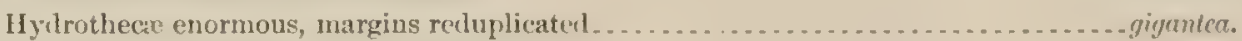

Hydrothece not extraordinarily large.

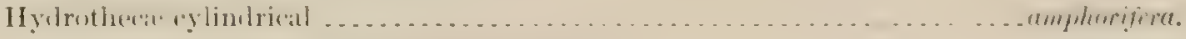

Hydrothece smooth and its internode fusiform... . . . . . . . . . . . . . . . . . fusiformis.

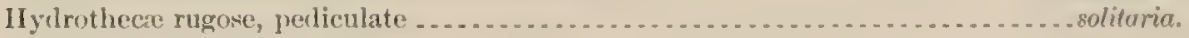

Hydrotheca swollen below.

Hydrothecie distant, gonangia relatively large . . . . . . . . . . . . . . . . . . . . . picta.

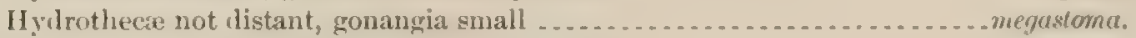

Between one-thirl and three-fourths of adcauline wall andnate.

Ahout one-half of arcauline wall alnate.

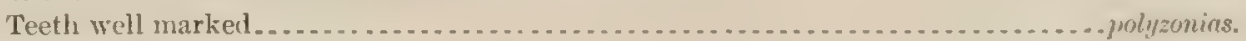

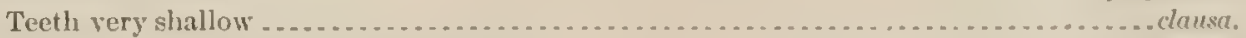

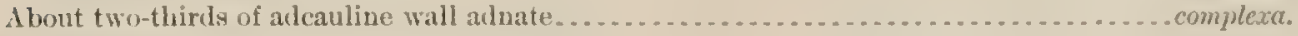

Hydrotheces with three teeth.

Teeth of unequal size.

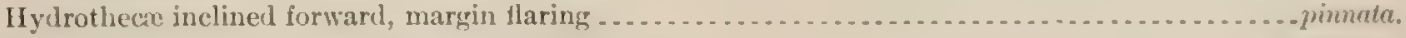

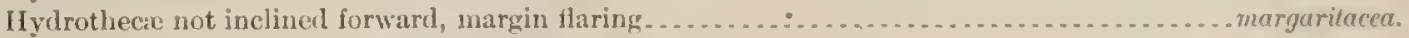

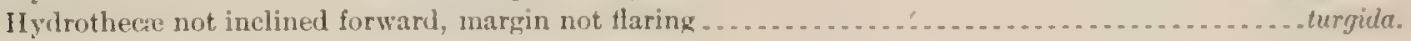

Teeth of equal size.

Distal part of hydrotheca narrowing to orifice.

Arrangement of hydrothece very irregular .... . . . . . . .

Iy yrothece fairly regular.

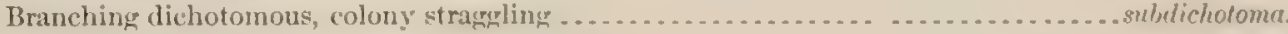

Branching alternate.

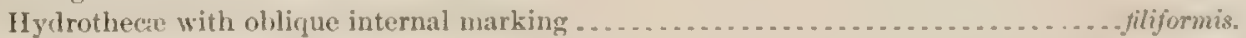

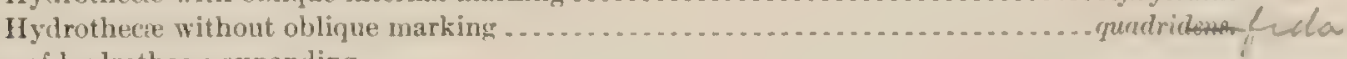

Distal portion of hydrothecie expanding.

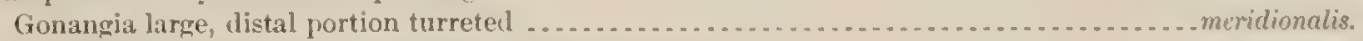

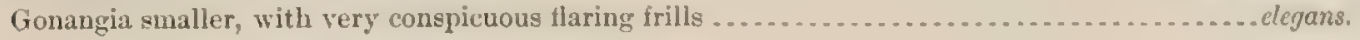


Distal part of hydrothece neither expanded nor contracter.

Mrore than two-thirds of adeanline wall arlnate . . . . . . . . . . . . . . . . . . . . . . . . milneana.

Less than one-half arlcauline wall adnate.

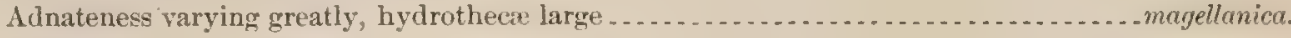
Adnateness fairly constant.

Hydrothecre very small.

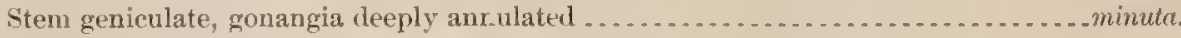

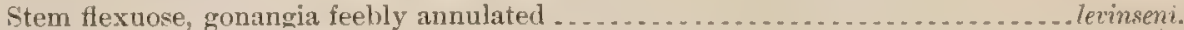

Hydrothecie medium or large.

Margins extensively reluplicated......................................

Margins not extensively reduplicated.

Gonangia deeply annulated throughout ....................... tricuspidata.

Hydrothece with two teeth.

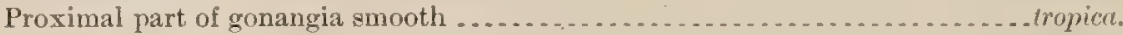

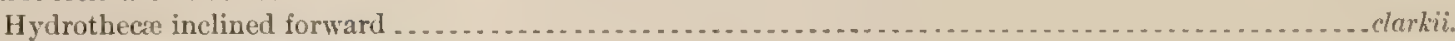

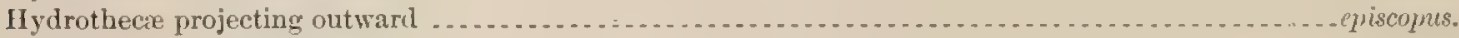

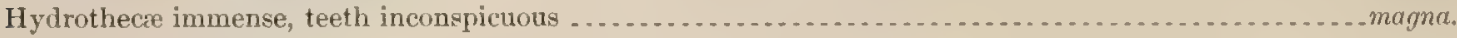

Hydrothecal margin smooth.

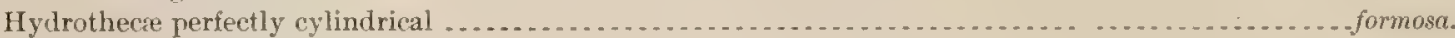

Hydrothece the shape of the frustum of a cone . . . . . . . . . . . . . . hartlaubi.

Hydrothecke with beveled margins . . . . . . . . . . . . .

SERTULARELLA GAYI (Lamouroux).

(Plate XIV, figs. 1-7.)

Sertularia gayi L.wounoux, Exposition Méthodique, 1821, P. 12.

Le Sertularia de Gay DE Blaixille, Manual d'Actinologie, 1834, p. 481.

Sertularia gayi LAMARCк, Hist. nat. anim. sans Vert., 1836, p. 152.

Sertularie pelyzonias var. $\beta$, Jonnstos, Brit. Hyd. 'Zooph., 1847, p. 62.

Sertulerie gayi IIncks, Ann. and Mag., 3d ser., VIII, 1861, p. 252.

Sertularia gayi ALDER, Trans. Tyneside Field Club, V, 1862, p. 237.

Serfularella gayi Hixcks, British Hydroid Zoophytes, 1868, p. 237.

Sertularella gayi S.jns, Jidrag til Kundskaben on Norges Hydroider, 1873, 1. 21

Sertularella gayi var. robusta ALLMAN, Porcupine Fxpedition, 1874, p. 471 .

Sertulerella gayi Norwax, Ann. and Mag., th ser., XV, 1875, p. 173.

Sertularella gayi, var. robusta Alumax, Mem. Mus. Comp. Zool., V, No. 2, 1877, P. 22

Sertularella gayi? YerRiLL, Check List, 1879, p. 18.

Sertuletella gayi Wixtren, Fortignelse di i Danmark Hydroider, 1880, 1. 276.

Sertularella gayi Fewkes, Bull. MLus. Comp. Zool., VIII, No. 7, 1881, p. 128.

Sertularella gayi Kincrumpiver, Norlische Gattungen, 1884, p. 41.

Serfulurella gayi Segerstent, Bihang till K. Svenska Vet.-\$karl., 1889, p. 16

Sertularella gayi Bourne, Hyilroils of P'lymouth, 1890, p. 396.

Sertulerella gayi Gristang, Journ. Marine Biol. Assoc., III, 1595, p. 224.

Sertulerella gayi Cramford, Ann. and Mag., 6th ser., XVI, 1895, p. 261.

Sertulerella gayi Nutrisa, Bahama Expedition, 1895, p. 88.

Sertularella gayi Duerden, Proc. Roy. Dublin Soc., N. S., VIII, 1897, P. 416.

Sertuluella gayi A liev, Journ. Marine Biol. Assoc., 1899, p. 452.

Sertularelle gayi Bonsevie, Norwegian North Atl. Exped., 1899, p. 76.

Sertularella gayi II ARTLAUB, Revision Sertularella-Arten, 1900, p. 61.

Sertularella grini Nurrwa, IIydroids of Woods Itole Region, 1901, p. 363.

Sertularella gayi HargitT, American Naturalist, 1901, p. 391.

Trophosome.-Colony straggling in haljit, attaining a height of about 6 inches in some cases. Stem fascicled, made up of a number of intertwining and intimately connected tubes, which in the aggregate form a very thick woody stem that bear's no trace of internodes or regularity of branching. Branches given off irregularly from the stem, but with a tendency toward a pinnate arrangement. Sometimes a large branch is given off from the main stem which resembles the latter in all particulars, otherwise the branches are nonfascicled, sinuous, divided by oblique nodes into regular internodes, each of which bears a hydrotheca. Hydrothecre ovate, with the distal ends narrowed and bent slightly outward, adcauline side more or less marked by transverse rugosities, distal two-thirds free, ending in a margin ornamented with four shallow equidistant teeth and an operculum consisting of four valves. 
Gonosome.-Gonangia borne on the upper sides of the brancher, inserted near the bases of hydrothece, long, slender, terete, narrowing to a short, broad pedicle at the proximal end and to a two-toothed margin at the other; the upper one-third to one-half is marked hy even shallow annulations.

Distribution.-New England coast (Verrill); Gulf of St. Lawrence (Dawson); common in West Indian region, var. rolnesta (Allman); Bering Sea (Albatross); British coasts (Hincks); Shetland (IIncks); between Shetland and Faroe (Allman), where it reaches a depth of 605 fathoms; Swedish west coast (Segerstedt); Norway (Sars); Greenland (Segerstedt); Mediterranean (Graeffe); Ifrica, Cape of Good Hope (Johnston); Albetross Station 2353, lat. N. 20 59', long. W. $86^{\circ} 23^{\prime}, 167$ fathoms; Station 2416 , lat. N. $31^{\circ} 26^{\prime}$, long. W. $79^{\circ} 07^{\prime}, 2 \pi 6$ fathoms; Station 2663 , lat. N. $29^{\circ} 39^{\prime}$, long. W. $79^{\circ} 49^{\prime}$, t21 fathoms; Station 2668 , lat. N. $89^{\circ} 55^{\prime} 30^{\prime \prime}$, long. W. $79^{\circ} 38^{\prime} 30^{\prime \prime}$, $29 \pm$ fathoms; Station 2886 , lat. N. $43^{\circ} 59^{\prime}$, long. W. $124^{\circ} 56^{\prime} 30^{\prime \prime}$, 50 fathoms. The following localities are given by Fewkes without the station number: Lat. $\mathrm{N}$. 31 5 $5 \sigma^{\prime}$, long. W. 78 18 $35^{\prime \prime}, 383$ f'athoms; lat. N. $32^{\circ} 43^{\prime} 25^{\prime \prime}$, long. W. $77^{\prime} 20^{\prime} 30^{\prime \prime}, 233$ fathoms; lat. X. $32^{\circ} 25^{\prime}$, long. W. $77^{\circ}+2^{\prime} 30^{\prime \prime}$, 262 fathoms; lat. N. $32^{\circ} 06^{\prime}$, long. W. $75^{\circ} 37^{\prime} 30^{\prime \prime}, 229$ fathoms.

The description given above is taken from a specimen from Station 2668 , and helongs to the variety robuste Allman, which hardly differs in any essential character from the original British form. The species, as indicated above. has a very wide distribution, but has not as yet been found in the Pacific.

\section{SERTULARELLA CONICA Allman.}

(Ilate XV, ligs. 1-2.)

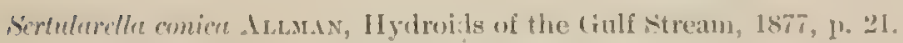

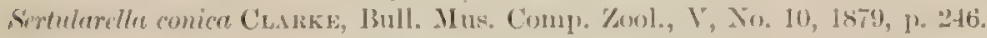

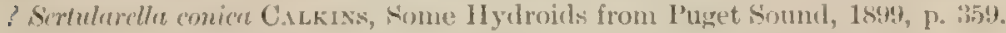

Sertularella conice HARTLAUb, Revision Sertularella-Arten, 19k0, 13.66.

Sertularella conica HarThatb, Hydroiden ans dem Stillen ()cean, 1901, 1. 354.

Trophesome-Colony attaining a height of $1 \frac{3}{3}$ inches. Stem not fascicled, flexuose, divided into regular slender internodes, each of which bears a hyclrotheca. Branches irregular and sparse, themselves sometimes branching dichotomously, divided into long, slender internodes, cach bearing a hydrotheca. Hydrothecae distant, rather slender, free for nearly their distal two-thirds, proximal ends swollen, narrowing regularly to their distal end, which is much more slender and narrow than in allied species, the upper side being marked by shallow corrugations; margin with four equal and equidistant tecth and a conical operculum composed of four flaps.

Gonokmme.-Not known.

Distribution.-Couthwest of 'Tortugas, 60 fathoms (Allman); lat. N. 24 it', longr. W. 83 c

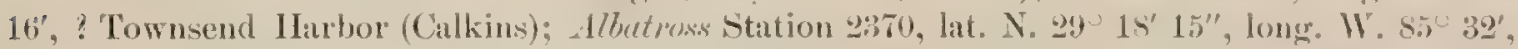
25 fathoms; Station 2385 , lat. N. $29024^{\prime} 39^{\prime \prime}$, long. W. $85^{0} 01^{\prime}$, 35 fathoms; Station 2761 , lat. S. $51^{\circ} 3 t^{\prime}$, long. W. $68^{\circ}, 50.5$ fiathoms.

It is impossible to tell from Calkins's figure and description whether the species that he identified as $S$. comicu is correctly determined or not. There is nothing to indicate the number of hydrothecal teeth. The hydrothece seem to be very stout and closely approximated for that species. Dr. Torrey ${ }^{1}$ identities a species ats $S$. comicr that cannot be placed in that species on account of having three instead of four hydrothecal teeth. It seems doubtful that the species has as yet been correctly reported from the Pacific coast.

Type- - In the Museum of Comparative Zoologr., Cambridge, Massachusetts. 
SERTULARELLA CATENA (Allman):

(1)ate XY, fig. 3.)

Serlularia catena Aluman, Challenger Report, Hylroida, 1’t. 2, 1888, p. 58.

Sertularella catena HARtLAUb, Revision der Sertularella-Arten, 1900, p. 84.

Trophosome.-Colony attaining a height of about 2 inches. Stem fascicled basally and simple distally, geniculate, the distal simple part being divided into regular internodes, each of which 1 s broadened at its distal end to furnish a support for a hydrotheca. Branches roughly alternate, resembling the distal part of the stem as above described. Hydrotheca subcylindrical, almost wholly exserted, narrowed slightly at each end, the upper (adcauline) sides being marked by shallow rugosities; margin with four shallow teeth that are sometimes reduced to mere sinuosities; operculum imperfect in the type, but probably composed of four parts.

Gonosome.-Gonangia borne on stem opposite the bases of hydrotheci, large, terete in form: orifice terminal, small, armed with two shallow processes or teeth. There is apparently a series of very shallow rugosities or annulations on the distal portion of the gonangia.

Distribution.-Off Culebra Island, West Indies, 390 fathoms (Allman).

An examination of Allman's type of this species shows that it is not identical with S. cylindritheca, as suggested by Hartlaub. ${ }^{1}$ The fascicled stem, and not truly cylindrical or quadrate hydrothece, and especially the very different shape of the gonangia, show that this species is very distinct from S. cylindritheca.

The figure here given is from the type collected by the Challenger, and differ's somewhat from those of Professor Allman.

Type.--In the South Kensington Museum. Fragment in the possession of the author:

SERTULARELLA QUADRATA Nutting.

(Plate $\mathrm{XV}$, figs. 4-6.)

Sertularella quadrata Nutring, Bahama Expedition, 1895, p. 88.

Trophosome.-Colony attaining a height of about 6 inches. Main stem sinuous, strong, monosiphonic, divided into regular internodes each bearing a hydrotheca. Branches alternate, each internode bearing a hydrotheca immediately at the base of which is the oblique node. Hydrothees very long, three to four times as long as wide, quadrate in section, maxgin with four equal and equidistant teeth and a four-tlapped opereulum. Hydrothece often with margins several times reduplicated, and a number of fine horizontal striations on the outside of the hydrothecal walls.

Gonosome-Gonangia borne near the hydrothecal bases, broader and stouter than the hydrothece, tubular, with rounded bases and distal part quadrate in section. Aperture in the center of the depressed top. Margin surrounded by usually five or six long recurved horizontal spines arranged so as to present a steilate appearunce when viewed from above.

Distribution.-Near Habana, Cuba (Nutting); Albatrosis Station 2143, lat. N. $9^{\circ} 30^{\prime} 45^{\prime \prime}$, long. W. $76^{\circ} 25^{\prime} 30^{\prime \prime}$, 155 fathoms; Station 2323 , lat. N. $23^{\circ} 10^{\prime} 51^{\prime \prime}$, long. W. $82^{\circ} 19^{\prime} 03^{\prime \prime}, 163$ fathoms; Station 2326 , lat. N. $23^{\circ} 11^{\prime} 45^{\prime \prime}$, long. W. $82 \circ 18^{\prime} 5 t^{\prime \prime}$, 194 fathoms; Station 2330 , lat. N. $23^{\circ} 10^{\prime} 48^{\prime \prime}$, long. W. $82^{\circ} 19^{\prime} 15^{\prime \prime}$, 121 fathoms; Station 2334 , lat. N. $23^{\circ} 10^{\prime} 42^{\prime \prime}$, long. W. $82^{\circ}$ $18^{\prime} 24^{\prime \prime}, 67$ fathoms.

This very striking form has perhaps the longest hydrothece known in the genus Sertulerella. Its nearest ally is $S$. cylindritheca, from which it difters in the length of the hydrotheex and also in the form of the gonangia. The reduplication of the margin seems to be here carried to the extreme known in the Sertularide.

Type Slides.-Cat. No.18714, Museum State Univ. of Iowa; Cat. No. 19773, 1977s, U.S.N.M.; also in coilection of the author.

${ }^{1}$ Revision der Sertularella-Arten, 1900, p. 84. 
SERTULARELLA TANNERI, new species.

(I'late XVI, tig. 1.)

Trophosome.-But a fragment of a single branch of this species is known. Branch slightly flexuose, divided into regular internodes, each bearing a hydrotheca, nodes oblique, decp, accompanied by two or three annular rugosities of the perisare. Hydrothecae very large, subtubular, the terminal portion heing gently eurved outward, only a small part of the proximal adcauline wall being adnate to the hydrocaulus; entire hydrothecal wall both above and below regularly and closely annulated; margin squarish, with four low equidistant teeth and a four-flapped operculum.

Gonosmme.-Not known.

Distribution.-Albatross Station 2873 , lat. N. $48^{\circ} 30^{\prime}$, long. IV. $124^{\circ} 57^{\prime}$, 40 fathoms.

This very striking species shows almost complete intergradation between the rugosa and polyzonias groups, having the deep annulations of the former with a hydrotheca somewhat resenbling the latter in size and shape.

Type.-In the collection of the U. S. National Museum.

SERTULARELLA GENICULATA Hincks.

(Plate XVI, fig. :2.)

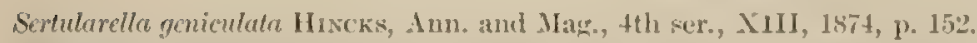

Sertularelle yenieulata Kincukxpauk, Nordische Gattungen, 1884, 1. 44 .

Serhularella geniculata Levines, Meduser, Ctenophorex og IIydroider fra Cirünlands Vestkyst, 1893, p. 201.

Trophosome.-"Stem slender, decidedly geniculate, simple or slightly brunched, jointed and twisted above each calicle; the internodes long, attenuated below and bent in opposite directions. Hydrotheca very distant, ribbed transversely, chiefly on the upper half, rather broad below, and narrowing gradually toward the margin, which bears four very prominent teeth, is sinuated deeply between them, and is surrounded by a conical quadripartite operculum."

Gonosome.-Unknown.

Distribution.-Off Frederickshaub, Davis Strait (Hincks); Jan Mayen (Lorenz).

I have not scen this species, and the above description is copied entire from the original by Hinclis. Hartlaub stoutly contends that this species is identical with S. tenella, and he may be right. Not having material for comparison, and in view of the great difference between the description and illustrations of the species as given by Hinckis and the typical $S$. tenella, the present writer deems it safer to regard the two species as distinct.

SERTULARELLA PATAGONICA (d'Orbigny).

(Plate XVI, tig. 3.)

Serhularia patagonien n'Onisixy, Yoyage dans l'Amérique Méridionale, 1839, p. 25.

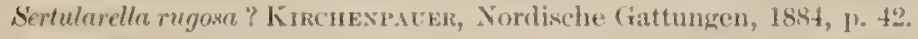

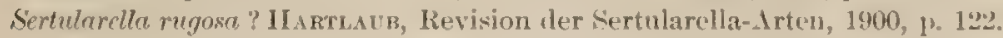

"S. rumulis simplicibus, cellulis alternantibus, ovalibus, transversim rugroso-plieatis; vesiculis magius, transversim 10 costato-gradatis." (Original description.)

Trophosomer. - Colony unbranched, attaining a height of about 1 inch. Stem not fascicled, internodes short, divided by oblique double nodes; hydrothecie oval, alternate, distal end truncated, provided with six wrinkles in the form of strongly projecting tiers.

Gonosome.-Gonangia very large, resembling the hydrotheca, ovil, ornamented transversely by ten ribs in tiers.

Distribution._- Bai de Ros," southern Patagonia.

1 have not seen this species. Judging from the excellent figures given by d'Orbigny, it does

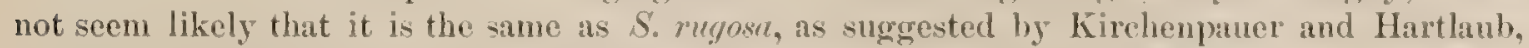
the distal extremities of both hydrotheca and gonangia being entirely different.

\footnotetext{
${ }^{1}$ Description liberally translated from the original more extended description by' d'Orbigny.
} 


\section{SERTULARELLA RUGOSA (Linnæus).}

(Plate XVII, figs. 1-5.)

Simil-trefoil Coralline Eurs, Essay Nat. Hist. Coral., 1755, p. 26.

Sertularia mgose Lixx.ec's, Systema Nature, 1758, p. 809.

Serhularia megosa Hoctrty: Natuurlyke Historie, 1761, 1. 539.

Serhularia rugosa PaLlas, Elenchus Zoophytorum, 1766, p. 126.

Sertularia rugosa Lixx.eus, Systema Nature, 12th ed., 1767, 1. 1308.

Serluluria rugose BondaERT, Lyst der P'lant-Dieren (Pallas), 1768, p. 157.

Sertuleria rugose MLAnatTi, De Plantis Zoophytis, 1776, p. 28.

Serfuluria rugosa Fabricic's, Fauna Groenlandica, 1780, p. 443.

Sertularia mugosu Eucrs and Sou.1xDen, Nat. Hist. Zooph., 1786, p. 52.

Serlularia migosa Winkss and Hersst, Charakteristik der Thierptlanzen, 1787, 1). 164.

Sirtularin rugosa (Helix, Systema Nature (Linnæeus), 1788, p. 3847.

Serfularic mugost. Esper, Die PAlanzenthiere in Abbildungen, III, 1788-1830, p. 182.

Serheleric rugose Berkennotт, Synop. Nat. Hist. Great Britain, I, 1789, p. 216.

Sertulurio rugosn Esser, Fortsetzungen der Pflanzenthiere, II, 179t-1806, I1. xI.

Sertulerir rugose Bosc, Hist. Nat. des Vers, III, 1802, ए. 93.

Sertularia rugosa Tcrtox, British Fauna, 1807, p. 213.

Sirtuluria mugosa J nuesox, Cat. Anim. Class Vermes, 1811, 1.56t.

Sertuluria rugosa Laxouroux, Bull. philomatigne, 1812, p. 184.

Sertuluria nugas OkEx, Lehrbuch der Naturgeschichte, 1815, p. 9\%.

verfulerin rugosn Lamarck, Hist. Nat. Anim. sans Vert., II, 1816, p. 121.

Clyter megosa Latourotx, Hist. Pol. Coral., 1816, p. 203.

Sertularia rugos Stew, Elements nat. hist. animal King., 1817, p. 442.

Scruluria rugose FLEMING, British Animals, 18:8, 1) 542.

Sermularia mugosa Bosc, Hist. Nat. des Vers, 1830, p. 108.

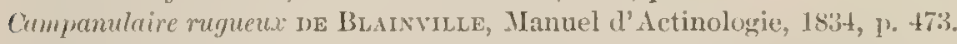

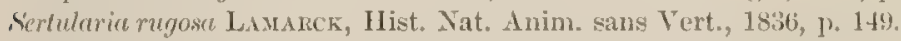

Clyfere rugnse Tempetos, London Magazine Nat. Hist., 1836, p. 466.

Scrtuleria rugosa Jonsstos, Nat. Hist. Soc. Northumb., II, 1837, 11. 257.

Sicrlularice rugase Jornston, Hist. Brit. '/ooph., 1838, 1. 12'3.

Sirluleria rugose Hassalu, Ann. and Mag., VI, 1841, p. 167.

Sertulerie rugose MAcalliviri, Ann. and Mag., IX, 1842, 1). 463.

Serlularie rugose Tnompsox, Report Brit. Assoc. for 1843,1844 , 1. 28*3.

Sérhluria rugosa Jonsstox, Hist. Brit. Zooph., 2d ed., 1847, p. 63.

Serhularia megosa Grax, Brit. Museum Radiata, 1848, p. 69.

Imphitroche megose Stispsos, Invert. Grand Janan, 1853, p. 9.

Seruluria rugosa AlDER, Cat. Zooph. Northumb., 1857, p. 23.3.

Sertularia megos Huxcks, $\mathbf{A n n}$, and $\mathbf{M a g} ., 3 \mathrm{~d}$ ser., VIII, 1861, p. 253.

Imphotrocha cincta L. AGAssiz, Cont. Nat. Hist. U. S., IV, 1862, Г. 356.

Sirtularia mugose Alner, Trans. Tyneside Field Club, $V$, 1862, I. 289.

Imphitrocha rugosa A. AGsssiz, North American Acalepha, 1865, p. 14t;.

Sirtularia rugosa van Benedex, Fauna Littorale Belgicque, 1866, p. 183.

Sertularella migosa Hincks, Brit. Hydroid Zooph., 1868, p. 241.

Sertularella rugose SARs, Bidrag til Kundskaben, 1873, p. 44.

sertulurella tenella ScnuLze, Jahresb. Kanon., Kiel, II, 1874, !. 131.

Sertularella rugose MIČTosI, Ann. and IIag., th ser., XIII, 1874, p. 212.

Sertularella migosa Verkill, Amer. Journ. Sci. and Arts, VII, 1874, 1. 133.

Sertularelle rugyosi Verrill, Amer. Journ. Sci. and Arts, IX, 1875, 1). 43.

Sertularella rugosa CLARK, Alaskan Hydroids, 1876, p. 224.

Sirfularelle rugose Merescikowst, Ann. and Mag., 5th ser., I, 1878, 1. 190.

Sertularelle rugase. Fonmax, Amm. and Mag., 5th ser., I, 1878, p. 323.

Sertulurella migosi Wintmer, Naturhist. Tidsskrift, 1880, p. 244.

Sertularella migona Kirchenpater, Nordische Gattungen, 1884, p. 42.

Sirtularella rugose Segenstedt, Bihang $K$. svensk. Vet. Akad. Handl., XIV, no. 4, 18s9, p. 17.

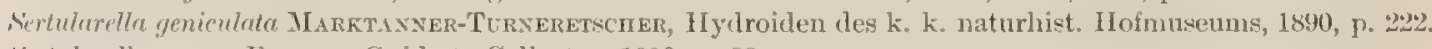

Sertularella mugsi Fewk Es, Guide to Collector, 1890, p. 88.

scrtularelle megose HoYLe, l'roc. Linn. Soc. Zool., XX, 1890, p. 460.

Sertulurella megora Levissex, Yid. Udb., "Hauchs" Togter, 1843, p. 388.

Serhularella rugose Duernex, I'ror. Roy. Irish Acad., (3) III, 1893, p. 388.

itertularella migora H.ıRTLicb, 1 y dromedusen Helgolands, 1897, 1. 451. 
Sertularella migosn Crswronn, Anm. and Jas., 6th ser., XVI, 1845, p. 261.

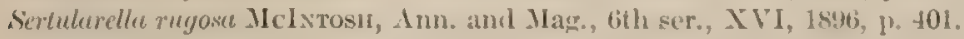

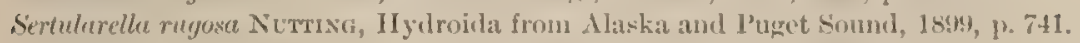
Serhlarelle rugosa BoxxwiE, Norwegian North. Atl. Exped., 1834, 1. 77.

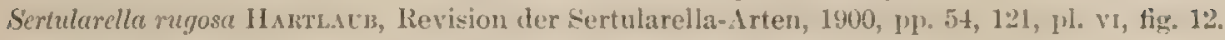

Sertularella migose Nutrixa, Hydroids of the Woods Hole Region, 1901, p. 362.

Serlulurella rugosa HARGITT, American Naturalist, 1901, p. 391.

Sertularelle snceatu Nutrisg, Hydroids Harriman Expedition, 1901, p. 183.

Sertularelle rugose Wimsenve, Cat. Marine Invert. eastern Canala, 1901, p. 25.

Sirhularella rugosi S.enunnssox, Bidrag til Kundskaben islandske Hydroider, 1902, p. 67.

Trophosome.-Colony attaining a height of about three-fourths of an inch. Stem usually unbranched, with several deep annulations on the proximal end, and regular short internodes, each bearing a hydrotheca and usually several annulations; nodes very deeply cut and oblique. Hydrothece not contiguons, barrel-shaped, ornamented with four to six annular rugosities, ending in a short ill-defined square collar; margins square, with four ill-defined teeth and a four-tlapped operculum.

Gonosome.-Gonangia large, ovate to almost globular, with a number of annular rugosities and a small aperture armed with four ill-defined teeth.

Distribution. New England coast (Vorrill); (irand Manan (Stimpron); West Indies (Nutting); Alaska (Clark): Puget Sound (Nutting): British coasts (Hincks): Norway (Nars); North (itpe-

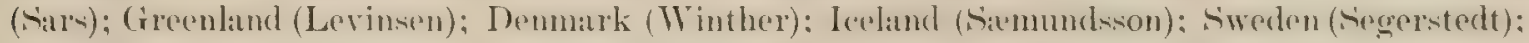
White Sea (Mereschkowsky); Helgoland (Hartlaub); coast of Belgium (van Beneden).

This wide ranging species is quite variable, as would be expected, and the writer has found specimens from our Atlantic coast that agree quite well with his $S$. saccate from Alaska.

SERTULARELLA AREYI, new species.

(Plate IVII, fig. 6.)

Trophosome.-A fragmentary specimen was all that was secured. It was about one-fourth of an inch high. Stem unbranched, very slender, internodes longer in proportion to their thickness than any others of the genus that I have seen, cach bearing a hydrotheea near its distal end. Hydrothece barrel-shaped, very distant, margin square with four obseure tecth and a fourflapped operculum; hydrothecal body marked by two very distinct annular rugosities which divide the body into three nearly equal zones. The surface is further ornamented with distinct longitudinal lines or fine ridges.

Gromosome.-Unknown.

Distribution.-Dredged near Habana, 100 to 200 fathoms, Bahama Expedition from the State University of Iowa.

'This very distinct and beantiful species I take pleasure in naming after my friend l'rofessor' Arey, of Cedar Falls, Iowa, one of the members of the expedition that secured the type specimen.

Type slirle-Cat. No. 18693.

Museum of Natural History, State University of Iowa.

\title{
SERTULARELLA TENELLA (Alder).
}

(Plate XVIII, ligs. I-2.)

\author{
Sertularia rugosa (var.) Jornstos, Jritish Zoophytes, 2al ed., 184, I, j. (it, and fig. c, p. (i2. \\ Sertularia tenella A.DER, Cat. Zooph. Northumb., 1857, p. 2:3. \\ Sertularia tenella Hixcks, Ann. and Mag., 3d ser., VIII, 1861, 1. 20n̈3. \\ Sermlaria tenelle Non:ax, Report British Assoc, 1867, ]1. 200. \\ Sirtularelle tenella Hracks, Brit. Hyel. Zooph., 186s, p. 242. \\ Sevulerelle tenella Hrxcks, Ann. and Mag., thts ser., XIII, 157t, p. 153.

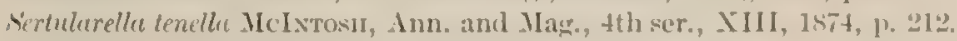 \\ Sertulurella terella Scricize, Nordsee Exped, 187t, p. 131. \\ Serfulurelle tenellu Wintuen, Naturhist. Tidsskrift (B), XI1, 1880, p. 245. \\ Sertulurella tenelle Kinchexpalen, Nordische Gattungen, 1sit, f3. 44. \\ Sertularella tenella SEgerstent, Jidrag til Kïmedomen llydmil faunen, 1889), p. 17. \\ Sertularella tenella Levinsex, Vid. Medtlel. Naturhist. Foren., 1892, p. 59.
}


PSertularella angulosa Bale, Proc. Poyal Soc. New South Wales, 1893, p. 102. Sertularella tenella Crawronn, Ann. and Mag., 6th ser., XVI, 1895, p. 261. Sertularella tenella Boxxevie, Norwegian North Atl. Exped., 1899, p. 77. Sertularelli tonella Hirtlavb, Revision der Sertularella-Arten, 1900, 1.63. Sertularella tenella Hartudu, Hydroiden aus dem Stillem Ocean, 1901, p. 354. Sertularella tenella Torney, Hydroida of the Pacific Coast, 1902, P. 64.

Trophosome.-Colony small, not reaching a hejght of more than one-half inch in specimens examined. Main stem slender, strongly geniculate, divided into regular long internodes, each of which bears a hydrotheca. Branches, if present, few, like the main stem, divided into regular internodes, each bearing a hydrotheca. Hydrotheca distant, fusiform, strongly rugose, almost their whole length exserted, aperture square, mounted on a short quadrate collar which has four equal and equidistant teeth; operculum with four flaps.

Gonosome.-"Gonangia orate, slender, ringed transrersely, produced above into a short tubular orifice." 1

Distribution.-Albatross Station 2333 , lat. N. $23^{\circ} 10^{\prime} 36^{\prime \prime}$, long. W. $82^{\circ} 19^{\prime} 12^{\prime \prime}$, 169 fathoms: Albatross Station '2865, lat. N. $48^{\circ} 12^{\prime}$, long. W. $122^{\circ} 49^{\prime}, 40$ fathoms; Puget Sound (Hartlaub); California (Torrey); Rio de Janeiro (Rathbun); British Coasts (Hincks); Norwegian Coast (Bonnevie); Greenland (Levinsen). If $S$. angulosa Bale is a synonym of $S$. tenella, the range of the species will have to be extended to Australia.

I cannot agree with Hartlaub that S. geniculata Hincks ${ }^{2}$ and $S$. microgena ron Lendenfeld ${ }^{3}$ are synonyms of this species. Specimens dredged by the U. S. Fish Commission steamer Albatross and off the Alaskan coast are quite typical, as are the fragments collected by Doctor Richard Rathbun off Rio de . Ianeiro.

Type--In Museum of the Natural History Society, Neweastle-upon-I'yne, England.

\section{SERTULARELLA ALLMANI Hartlaub.}

(Plate XVIII, figs. 3-6.)

Serlularella unilateralis ALLMAx, Ann. and Mag., th ser., XYII, 1876, p. 114.

Sertularella unilateralis AlL3av, Phil. Trans. Royal Society, London, V, 1879, p. 282.

Sertularia secundu Aldasax, Challenger Report, The Hydroids, Pt. 2, 18s8, pl. xxv, fig. 2. (Explanation of plate.)

Sertularia milateralis A lumax, Challenger Report, The Hydroids, Pt. 2, 1888, p. 53.

Semularella allmani Hartuaub Revision der Sertularella-Arten, 1900, p. 81.

SSertularella antaretica H.ARLAUB, Revision der Sertularella-Arten, 1900, p. 82.

Trophosome.-Colony attaining a height of about one-half inch, growing in a dense tuft. Stem slender, much annulated below, divided into fairly regular internodes by deep nodes. Branches alternate, dividing several times into branchlets, the ultiuate division being dichotomous, lying in two planes, projecting forward, outward, and upward from the stem, divided into regular internodes, each of which usually bears a hydrotheca, or a hydrotheca with a branchlet borne at the side of its base. Hydrothecr lying in two planes projecting forward, outward, and upward, so that they appear in side view to be all inserted on one side of the branch. Hence the name "unilateralis." Hydrotheca Hask-shaped, rather small, about the distal one-half of adcauline wall free, aperture quadrate, margin with four conspicuous slender sharply-pointed teeth, the anterior pair being the longer, and a narrow, even border. Operculum of four flaps.

Gomasome.-Gonangia rather large, ovoid to obconical, annulated on upper half and sometimes throughout, aperture rather large, and margin with tive or six blunt teeth. Acrocysts present when sexual products are mature.

Distribution-Off Accessible Bay, and Swains Bay, Kerguelen Island (Allman); Tierra del

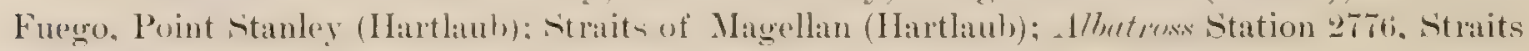
of Magellan.

This is a very variable species, and the quite considerable amount of material collected by the United States Fish Commission Steamer Albatmos in the Straits of Magellan shows the identity of the species named in the synonymy above. The gonangia are particularly variable,

${ }^{1}$ Hincks, British Hydroid Zoophytes, 1868, p. 242.

${ }^{2}$ Annals and Magazine of Natural History, th ser., XIII, 187t, p. 152.

${ }^{3}$ Proceerlings of the Linnæan Society of New South Wales, IX, 188t, p. 416. 
especially in the matter of the marginal towth and the size of the aperture. specimens acreenger with all of the tigures given by $\Lambda$ llman and Hartlaub being found in a single colony. The thickness of the perisarc described by IIartlaub is characteristic of his specimens of $S_{\text {. antureticu }}$ (=S. unilateralis Allman) is not mentioned by Ailman and is not apparent in the specimens collected by the Albutross. It is possible that $S$. anturetica is not the same as $S$. unilaterulis Allman, but a distinct species. Hartlaub claims that the name Sertularella unilateralis Allman (1879) must be abandoned. The facts appear to be that Hartlaub (Revision p. 42) changes the name Sertularia unilateralis Lamouroux (15:4) to Sertularella unilateralis (Lamouroux), thus securing the priority of the name for Lamouroux's species, by a strict application of the A. O. U. Code. It therefore became necessary to give new names to Sertularella unilatemlis Allman and Sertulariu unilateralis Allman, species which seem to the present writer identical.

Type. - In South Kensington Museum, London.

\section{SERTULARELLA CONTORTA Kirchenpauer.}

(Plate XYIII, figs, $7-9$. )

Sertularella contorta lincriexpater, Nordische Gattungen, 188t, 13. 29.

Sirtularlle protect H.nzTLAтs, lievision der Sertularella-Arten, 1900, p. 79.

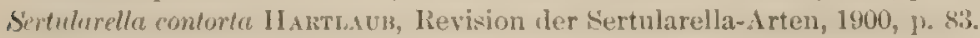

Trophosome-Colony attaning a beight of about 3 inches in type specimen. Stem not fascicled, thick, divided into fairly regular internodes each of which hears a branch and hydrotheca, or a hydrotheca alone; internodes much broadened at their distal ends by a shoulder for the support of the hydrotheca; nodes deep and distinct, there being corrugations or constrictions in addition to the regular nodes giving a twisted appearance to the stem and branches. Branches irregularly alternate, flexuose, their bases with several annular constrictions, divided into regular internodes resembling those of the stem. Hydrothece heary, thick in texture, distal half free and curving outward, margin with a distinct thickened rim and four teeth, the two abcaline ones usually being more pronounced than the adcauline ones. Operculum not seen in specimen described, although Hartlaub fignes a four-flapped operculum.

Gonosome.-Gonangia large, axillary, ohorate or obconical in outline, or terete as in the type, with a short neck shaped like the frustum of a cone, and two prominent teeth in the specimen figured, withont teeth in the one figured by the original describer; strongly amnulated throughout in the sperinen figured, but smooth in the middle portion as tigured by Kirchenpatur.

Distribution.-Falkland Island and the Straits LaMarre (Kirchenpauer).

'The deseription given above is made mainly from a specimen kindly sent me by l'rofessor Levinsen, labeled "Lamarre Straits," the locality from which the type specimen was secured. In the trophosome it agrees well with the original description and figure given hy Kirchenpauer, but the gronangia are quite different, although there is one gonangium that is much nearer the type than the one figured in this work. The specimen agrees very well with S. protecte Hartlaul, which I therefore regard as a synonym.

Type-In the Museum of Leipsic!

SERTULARELLA LATA (Bale).

(I'late XVIII, tig. 10.)

Thuirerie late B.ıLe, Journ. Microsc. Foc., Victoria, 18s:, p. 14.

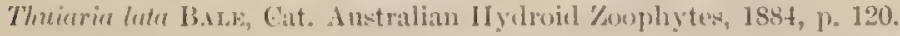

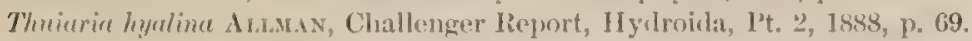

Trophlosomine-Colony attaining a height of 6 or 8 inches (Bale). Stem fascicled below, not fascicled above, where it is thick, divided into regular internodes each of which bears a branch and two hydrothece on one side and a single hydrotheca on the other. Whole hydrocaulus remarkably translueent and hyaline in strueture. Branches alternate, distant, only slightly constricted at their origin, divided into regular, usually long internodes. Iydrothen alternate, widely separated by the thickness of the stem, closely approximated, tubular, completely adnate to aperture on adcauline side, not apparently swollen or gibbous below, margin with a delicate 
but evident rim and four inconspicuous equidistant teeth which are sometimes ahorted leaving an even margin. 'The remains of an operculum can be seen in some cases, and this is probably composed of four tlaps.

Gomosome.-Not known.

Distribution.-Griftiths Point, Port Sterens, Queen's Cliff, Victoria (Bale); Station 126, south of Pernambuco, 770 fathoms (Allman).

An examination of Allman's type of Thuiurie hyulina Allman shows that the species comes well within the genus Scrtularella as used in the present work. The entire structure is very delicate, and the operculum is in no ease perfect. In some cases, howerer, it is partially intact, and is probably composed of four Haps where the four low teeth are present, and of a single thin membrane where the teeth are wanting, leaving a circular margin. Bale's figures and descriptions of Thuiaria lata Bale apply so completely to the Challenger type of T. hyalina Allman before me that I have no hesitation in regarding the two as identical. As Bale's species has the priority, Allman's $T$. hyalina must be regarded as a synonym.

Type.-In Australian IIuseum, Sydney.

SERTULARELLA ALBIDA Kirchenpauer.

(1'late XIX, figs. 1-2.)

Sertularellu robusta, CLARk, Mlaskan Hydroids, 1876, p. 2225.

Sertulurella allida, Kincinenpatier, Fordische Gattungen, 1884, p. 42.

Sertulerella albida, Hartuadb, Revision der Sertulärella-Arten, 1900, p. 26.

Trophosome.-Colony attaining a height of about 2 inches, flabellate in form. Stem not fascicled, thick, with several very deep anmulations at its proximal end, internodes irregular, tending to be shorter in proximal and longer in distal portion, nodes very deeply cut. Branches flexuose, irregularly alternate, themselves hranching, divided into irregular internodes like those of the stem, very broad, resembling those of Thuiaria. Hydrotheca large, closely approximated, alternate, but on account of the thickness of the hydrocaulus appearing to be in two series as in many species of Thuiaria; broadly tubular, immersed to the aperture on abcauline side, distal part bending slightly outward, margin with four teeth. Opereulum of four flaps. An intrathecal ridge originates at the bend in the abcauline side and passes downward and inward to about the middle of the hydrotheca.

Gonosome.-Gonangia axillary, very large, perhaps the largest found in the genus, ovate, regularly and closely annulated with short tubular neck, and round terminal aperture.

Distribution.-I ukon Harbor, Big Koniushi, Shumagin Islands, 6 to 20 fathoms. Collected by W. H. Dall (Clark).

This very striking species has the aspect of a Thuiariu and would doubtless be placed in that genus were it not for the four-toothed hydrothecal margin and the typical Sertularella form of the gontngia. These latter are very large indeed, attaining sometimes a length of nearly a quarter of an inch. The description and figures are from a specimen collected by Dall at Big Koniushi, Shumagin Islands.

Type.-In Museum of the Academy of Sciences, St. Petersburg.

?SERTULARELLA PINNIGERA Hartlaub.

(1'late XIX, fig. :3.)

Thuiaria pimata Atman, Mem. Mus. Comp. Zool., V, No. 2, 1877, p. 28.

Sertularellu primatu Harruavis, Revision der Sertularella-Arten, 1900, p. 113.

Sertulerella pinnigera HaRTLAvr, Levision der Sertularella-Arten, 1900, p. 113.

"Trophosome.-Stem attaining a height of nearly 3 inches, sparingly branched, fascicled below, alteruately pinnate, pinne given off at nearly right angles to the stem, jointed at distant and uncertain intervals. Hydrotheca borne both by sten and pinne, deep eylindrical with obscurely four-toothed margin, adnate to the axis in their whole length.

"Gomoseme.-Not known."

Distribution.-Double-headed Shot Key, 3 to 4 fathoms (Allman). 
There is considerable doubt as to the systematic position of this species. The large and nonretractile hydranth, as represented in Allman's figure, resembles those of Ifulecium, as does also the thick and strongly fascicled stem. The above description is copied entire from Allman. Type--In Museum of Comparative Zoology, Cambridge, Massachusetts.

SERTULARELLA CYLINDRITHECA. (Allman).

(Plate XIX, fig. 4.)

Serlularie mlindrithece Alcsax, Challenger Report, Hydroida, I't. 2, 1858, p. 59.

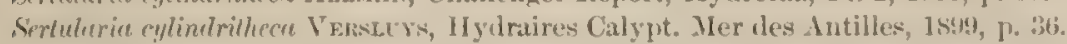

Sertulurellu cylindrithecu II.ARTLAus, Revision der Sertularella-Arten, 1900, p. it (part).

Trophosome.-Colony attaining a height of about $t$ inches. Stem not fascicled, geniculate, divided into regular internodes, each of which bears a hydrotheca. Branches irregularly alternate, themselves sometimes dividing dichotomously and resembling the main stem. Hydrotheca large, cylindrical proximally and quadrate in cross section distally, almost entirely free, the adcauline side only being slightly adnate, about twice as long as broad; aperture quadrate. margin axmed with four equal and equidistant tecth. Opereulum of four tlaps.

Gomsome. -Gonangia borne near the bases of the hydrotheca, pedicel short, hody shaped much like the hydrothece, being cylindrical below and quadrate ahove. Distal end with broadly expanded margin, which is quadrate and armed with four large flaring teeth. There are numerous fine annular rugosities rumning around the whole gonangium, except on the proximal portion.

Distribution.-Off Bahia, Brazil (Allman); West Indies (Versluys); 'Trinidad, specimen in United States National Museum.

Versluys calls attention to the unfortumate name given this species by its original describer, Allman. 'The hydrotheca are distinctly quadrangular in cross section, except at the base, and hence the name "cylindrithece" is misleading. I am indebted to the authorities of the South Kensington Museum for a part of the type collected by the Challenger, from which the accompanying drawing was made. athor.

Type.-In the collection of the South Kensington Museum. Fragment in possession of the SERTULARELLA GIGANTEA Mereschkowsky.

(1'late III, fig. T.)

Sertularella gigantea Merescri kowskx, Ann. and Mag., 5th Ser., I, 1878, p. 330.

Trophosome. "The tolerably flexible stems spring from the branched hydrorhiza often withont ramifying; sometimes they divide at their base into two or three branches, each of which may again ramify once more; the terminal branches are in all cases very long and straight. The hydrotheca are evidently alternately arranged upon the angularly bent stem; frequently we observe three or four undulations (ribs) crossing the hydrothece; its form is much elongated. only a little widened at its base; in size it is two or three times the length of the hydrotheca of S. polyzonies. In adult individuals the margins are always furnished with several ledges and an equal number of small opercula placed one above the other. Below each hydrotheca the stem is slightly ringred."

Gomosme.-Unknown.

Distribution.-White Sea. (Mereschkowsky.)

The above description is quoted entire from that of the original describer. Mereschkowsky believes that this species is the same as $S$. pulyamius var. gigenten Himcks, a position positively denied by Hincks, whoseems to me to have the hetter of the arement. Hartlaub2 considers S. quadricomute Hincks as a synonym of s. polyzomian, which does not appear from a comparison of the original descriptions of the two. He also considers the $S$. pmlysomires, found in Alaskit and

\footnotetext{
${ }^{1}$ Description taken from Versluys, referene in synonymy, who was the first to descrilne it.

${ }^{2}$ Revision cler fertularella-1rten, 1400, 1). 20.
} 
described by Clark, ${ }^{x}$ as equal to S. gigunter Mereschkowsky. I have this specimen from Dall's collection from Alaska, and it is a typical S. polyzonias. 'The size of this species in connection with the very pronounced reduplication of the hydrothecal margins, if constant, as the describer claims, seem sufticient characters to mark it as a distinct speeies, not identical with S.polyzonias, var. gigantea Hincks or var. robustu Clark.

\section{SERTULARELLA DISTANS (Allman).}

(Plate XIX, figs. 5-6.)

Thuiaria distans Alluan, Mem. Mus. Comp. Zool., V, No. 2, 1877, p. 27.

Sertulurella distans Hartaun, lievision Sertularella-Arten, 1900, p. 100.

Trophlesome.-Colony plumose, attaining a height of about 4 inches. Stem not fascieled, not crtnaliculated (in specimens examined by me), flexuose, divided into regular internodes each of which bears two hydrotheca and a branch on one side and a single hydrotheca on the other. Branches alternate, distant, nodes very distant or absent, divided from the stem by a deep constriction. Hydrothece distant, alternate, immersed to the margin on adcauline side, broadest at margin, gradually uarrowing downward, margin with a narrow but distinet border and four very low and inconspicuous teeth; operculum very delicate and hard to interpret, apparently of four Haps.

fomosnme.-Not known.

Distribution.--Tortugas, shallow water (Allman); Shallow water between Elenthera and Little Cat Islands (Babama Expedition from the State University of Iowa); Albatrose Station 2324, lat. N. $23^{\circ} 10^{\prime} 25^{\prime \prime}$, long. W. $82^{\circ} 20^{\prime} 24^{\prime \prime}$, 33 fathoms; Station 2353 , lat. N. $20^{\circ} 59^{\prime}$, long. W.

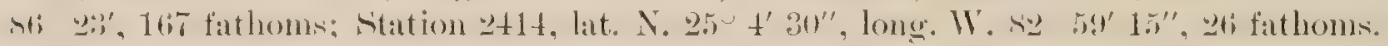

Specimens collected by the Expedition from the State University of Iowa were compared directly with Allman's type in the Museum of Comparative Zoology at Harvard, and were found to agree. There is no doubt that this species is very nea. S. lata (Bale), but the hydrotheca are more distant in S. distans, and the entire structure is more corneous and much less delicate and lyyaline.

Tippe-In the Museum of Comparative Zoology, Cambridge, Massuchusetts.

\section{SERTULARELLA AMPHORIFERA Allman.}

(Plate $\mathbf{X X}$, figs. 1-2.)

Sertularella amplorifera Alwarax, Mem. Mus. Comp. Zool., V, 187\%, p. 222.

Sertulurella amphoriferu CLARKF, Bull. Mus. Comp. Zool., V, 1879, 1. 246.

Sertulurella amphomifere H.aRTLav's, Revision der Sertularella-Arten, 1900, p. 23.

Trophosome-Colony (fragmentary) about one-third inch high, stem not fascicled, flexuose, slender. diehotomonsly branched, divided into very long internodes each of which bears a hydrotheca near its distal end. Branches like the stem. Hydrothece tubular, long, gracefully curved, adnate for about their proximal third, margin four-toothed?, reduplicated, or at least the distal parts of the hydrothece are marked by parallel horizontal lines that seem to indicate reduplication.

Gonosome.- "Gonangia springing each from a point near the base of a hydrotheca; obovate, atrongly annulated, rapidly narrowing to its point of attuchment and terminating distally in a ronical neck, which "arrieson its summit a small cireular orifiee with ererted margin." (.1liman.)

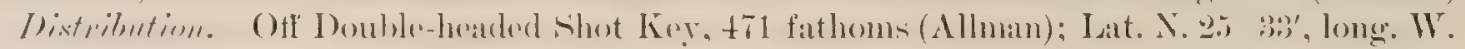
5: 16', 101 fathoms, abundant (Clarke); Albatross Station 235t, lat. N. $20^{\circ} 59^{\prime} 30^{\prime \prime}$, long. W. $86^{\circ}$ $25^{\prime} 33^{\prime \prime}, 101$ fathoms.

The fragment from which the above description of the trophosome was taken differs from Allman's deseription in having apparently four tecth to the hydrotheea. 'This may be due, howerer, to mutilation of the specimen, the hydrothecal margin being apparenty worn and perhaps broken.

Type--In the Museum of Comparative Zoology, Cambridge, Massachusetts. 


\title{
SERTULARELLA FUSIFORMIS (Hincks).
}

\author{
(I'late XX, tigs, 3-4.)
}

Sertularia fusiformis InNcks, Ann. and Mag., 3d ser., VIH, 1861, 1. 2553.

Sertuluria fusiformis Nors.4, Report British Assoc, ;36th meeting, 1867, p. 200.

Sertularella fusiformis Hixcks, Brit. Hydroid Zooph., 1868, p. 243.

Sertulurella fusiformis GrıEFFE, Arb. Zool. Inst., Wien und Triest, V, 1884, p. 356.

Sertulurellu fusiformis PIEPER, Kool. Anz., VII, 1884, 1. 185.)

Sertularellu fusifornis CAnus, Prodromus Faune Medit., I, 1885, p. 12..

Sertularella fusiformis Horte, Joum. Linn. Soc., Zool., XX, 1890, 1). 460.

Sertularellu fusiformis Tnorselr, Trans. Biol. Soc, Liverjool, VIII, 1S9, p. 7.

Sertulurellu fusiformis Baßic, Ral. Jugosl. Ak., CXXXIV, 1898, 1). 37.

Sertularella fusifomnis H.ntraub, levision der Sertularella-Arten, 1900, p. 85.

Sertulaviu fusiformis Winteaves, Cat. Marine Invert. Lastern Canada, 1901, p. 26.

Sertularella fusiformis Tonkex, Hydroida of Pacilic Coast, 1902, గ̧. 61.

Trophosome.-Colony minute, stem slender, slightly zigragr, generally unbranched, annulated at the base and below each hydrotheca; hydrotheca alternate, bent in opposite directions, elongate, somewhat flask--haped, smooth, aperture qualridentate, with an operculum compond of four pieces; each hydrotheca and its internode of a fusiform tigure.

Gonosome.-Gonangia elongate, slender, tapering above and below, ribbed across, produced at the upper extremity into a short neck and toothed, springing here and there just below a hydrotheca. Height about a quarter of an inch.

Distribution.-Devonshire, England (Hinclis); Hebrides (Norman); Gulf of St. Lawrence 200 fathoms (Whiteaves); San Fruncisco, California (Torrey); Mediterranean (Carus); (?) New Zealand, S. simplex Hutton.

I have never seen this species and the above description is taken almost entire from the original deseription by Hincks, the only changes being in the substitution of the words "hydrotheca" "and "gronangia" for "cells" and "gonothees" and in the addition of the words "trophosome" and "gronosome" to conform to the plan of description of this work.

SERTULARELLA SOLITARIA, new species.

(Plate XX, tigs. 10-11.)

Trophosorne.-Hydrocaulus a monosiphonic stolon from which spring peduncles which bear hydrothece and have one or two anmulations near their middle. Hydrotheca radially symmetrical, long, fusiform, tapering basally where they merge insensibly into the peduncles, and distally to a square neck and quadrate margin which is slightly ererted and is produced into four strong equidistant teeth. The entire body of the hydrotheca is strongly and evenly annulated. Operculum of four llaps. The hydranth was seen in one specimen, and what appeared to be opercular muscles were evident.

Gomosome.-Not known.

Distribution.-Shallow water, between Eleuthera and Little Cat Islands, Bahamas. Dredged by the Bahama Lxpedition from the State University of Iowa. Found growing as a parasite on Nematophomes grandis.

This curious form is placed provisionally in this genus. At first thought one would consider it a young specimen of a species belonging to the mignsu group, which as get hat developed but a single hydrotheea. I have, however, not seen any young specimen of any regular sertularian in which the hydranth and opereulum had been fully formed and in which there was no indication of another hydrotheca or internode springing from the side of the first hydrotheca. If the hydrothece were sessile the species would he very near Allman's genus Calumplem. which he regards as a campanularian, but which Iartlaub ${ }^{1}$ and the present writer regard as belonging to the genus Sertulurelle on account of the form of the hydrotheca and particulaty the margin and operculum. So soliturice appears to be almost exacty intermediate between the 
campanularian and sertularian types, agreeing with the former in the fact that the hydrothece are radially symmetrical and pediculate and with the latter in the structure of the hydrotheca and operculum. Were it not for the presence of the hydranths this form could readily be mistaken for the gonangia of $S$. fusiformis, although the hydrothecx are more slender than any representation of the gonangia of $S$. fusiformis that $I$ hare seen. It is, of course, possible that older specimens will demonstrate that the adult colony resembles that of $S$. fusiformis in the manner of branching, but the bydrothece are readily distinguished.

Type slide.-Cat. No. 18717, Museum of State University of Iowa.

SERTULARELLA PICTA (Meyen).

(Plate XX, figs. 5-7.)

Sertularia picta MExen, Ủber Leuchten des Meeres, 1834, p. 201.

Sertularella picta Hartuaub, Revision der Sertularella-Arten, 1900, p. 77.

Trophosome-Colony growing in dense masses and attaining a height of 6 to 8 inches. Branches alternate, divided into regular internodes each bearing a hydrotheca and divided by one or two annular constrictions. Hydrothece alternate and axillary. Margin with four small teeth and a small opening, owing to an internal thickening of the perisare near the margin.

Gonosme--Gonangia alternating with the hydrothece, evenly annulated throughont and with four marginal teeth.

Distribution.- On the East Coast of Terra del Fuego and near the Falkland Islands (Meyen); Puerto Toro and Lennox' Island (Hartlaub).

Hartlaub, who has examined the type, says that Meyen is in error in saying that the gonangia alternate with the hydrothece, and that the presence of the hydrothecal teeth is uncertain. Hartlaub and Kirchenpauer both suggest the identity of this species and $S$. gandichaudii Lamouroux, ${ }^{1}$

Type-In the Berlin Museum.

SERTULARELLA MEGASTOMA, new species.

(I'late $\mathbf{X}$, tigs. 8-9.)

Trophosome.-Colony rigid, compact, pinnate, the single fragmentary specimen known attaining a height of about 2 inches. Stem fascieled, straight, without evident internodes, color dark brown. Branches regularly alternate, rigid, without evident constrictions at base and without evident internodes. Hydrothece cylindrical or subconoid, outer profile nearly straight, withont evident swelling at base, distal two-thinds of adcauline wall free. No noticeable constriction near distal end, margin square with four low but evident teeth. Operculum of four valves.

Gonosome.-Gonangia horne on branches, small, oblong-ovoid, regularly and deeply annulated, with a very large quadrate aperture, and without an evident neck.

Distribution.-Albatross Station 2353 , lat. N. $20^{\circ} 59^{\prime}$, long. W. $86^{\circ} 23^{\prime}, 167$ fathoms.

This very distinct species has a particularly rigid habit of growth, without the sinuous bends to its stem and branches almost universally found in the genus. The small gonangia are unique in the genus, so far as I know, in the very large size of the quadrate aperture.

Type slides.-Cat. Nos. 19765, 19766, U.S.N.M. Cat. No. 15708, Museum State University of Iowa: also in collection of the author.

SERTULARELLA POLYZONIAS (Linmæus).

(Plate XXI, figs. 1-2.)

Grat Tooth Coralline EuLIs, Essay Nat. IHist. Corallines, 1755, p. 5.

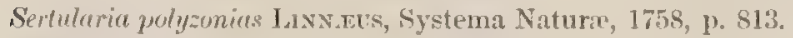

Serlularie flexuosa Linv.eus, Systema Nature, 1758, p. 814.

Sertularia polyzonias Linneus, Fama Suecica, 1761, p. 541.

Serhulariu texuosa Lrsx.sis, Fauna Suecica, 1761, p. 542.

"See Iartlaub, Revision der Sertularella-Arten, 1900, 1, 77, and Kirchenpaner, Nortische Gattungen und Arten, 1884, p. 38 
Sertulerin polyzonias IIovtrux, Naturlyke Ilistorie, XVII, 1761-7.3, p. 57\%.

Scrtularia ericoides 1'AlLas, Eilenchus Zoophytorum, 1766, p. 127.

Sertularir golyzonias lisw.ex's, Systema Naturae, 1767, p. 1312.

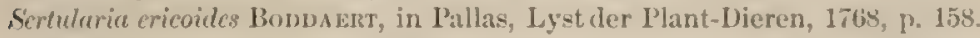

Serfulurie polyzonirs ForskiL, Descriptiones Animalium, 175, p. 27 (note).

Sertulurie ciliate F.sBricis, Fauna Groenlandica, $1780,1 \%$

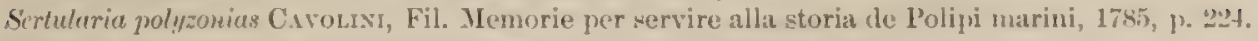

Sertuleria polyzonicts libus and Solaxder, Nat. Hist. Zooph., 1786, p. 37.

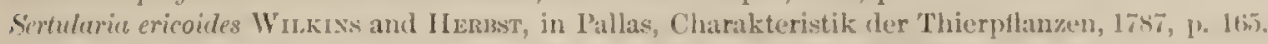

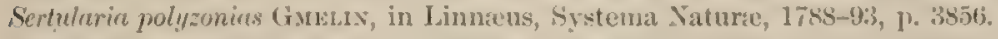

Sertuhric polyzonins LSPER, Die I’tlanzenthiere in Abbildungen, III, 17S8, 1\% 173.

Scrtuluriu polyzonius BER ExInouT, Synop. nat. hist. Great Britain and Ireland, I, 17S9, 1. 219.

Serblurir polyzonias OLvi, Zoologica Ariatica, 1792, p. 290.

Scrlularin polyzonits Fsper, Fortsetzungen der I'flanzenthiere, II, 1794-150t, pl. v.

Sertulurir polyzonius IBosc, Hist. nat. des Vers, III, 1802, p. 100.

Sertularie polyzonirs Turtos, British Fauna, 1807, p. 216.

Sirlularie polyzonius IBertolovi, Rariorum Italie plantarum, 1810, p. 10s.

Sertuluriu polyzonius Jasesox, Cat, animals class Vermes, 1811, P. 564.

Scrlularie polyzonius Lamouroux, Bullet. Soc. philonatique, 181:2, I. 184.

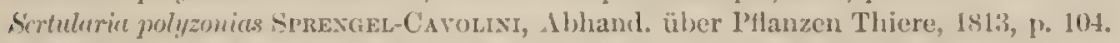

Serluluria ericoides OkEx, Lehrh, der Naturgeschichte, 1’t. 3, 1815, p. 92.

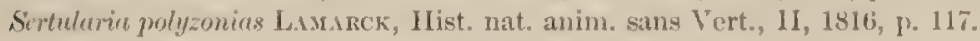

Sertuluria polyzonius Lisourovx, Hist. coral tlex., 1816, 1) 190.

Scrtularic polyzonius Srew.117, Elements nat. hist, anim. King., II, 1817, 1\% 417.

Serlularin milyzonins Bertolos, De plantis in itinere ad urben lavenne, 1819, p. 218.

Serlularia prilyzonias Bentoloxi, Specimen zoophytorum P'ortus Lunx, 1819, p. 271.

Serfulurie polyzonias Golswess, Handbuch der 'Koologie, 15:20, p. 88.

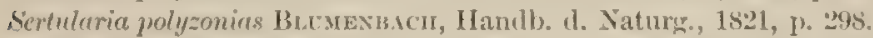

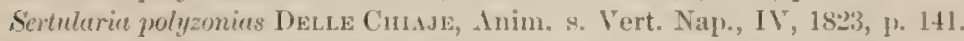

Sertularia polyzonias Deloxciscumus, Lucyclop. méth., 18\%4, 1).681.

Sermbluria polyzonias Risso, L’ Europe mérid., V, 1826, p. 310.

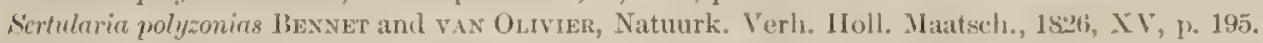

Serlulurir polyzonices Delde ChIA.Je, Mem, de Anim, senzal Vert., IV, 1528, p. 128.

Sertuleria polyzonias Fleming, British Animals, 1828, p. 542.

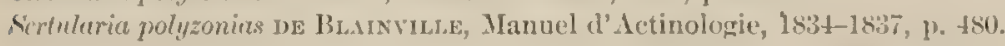

Serhuluria polyzanias Templetos, Loulons Mag. Nat. Hist, IX, 18:3, p. 468.

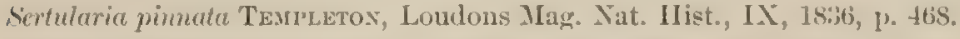

Serfulerie polyzonires Lumarck, Hist. Nat. anim. sans Vert., 18:36, 1. 142.

Sevtularia polyzonias Jomsstox, Trans. Vewcastle Soc., II, 15:37, 1). 256.

Sertularia polyzoniats Cotcri, Cornish Fauna, III, 1838, p. 17.

Sentularia cllisii Jomxstux, British Zooph., 1838, p. 124.

Sirmlaria cllisii Covcu, Cornish Fauna, III, 1838, p. 17.

Serlularic polyzonices 'Tnompsos, Ann. aud Mag., V, 1540, p. 250.

Sertuluric pinnata Trostsos, Ann. ant Mag. Nat. Hist., V, 1840, 13. 250.

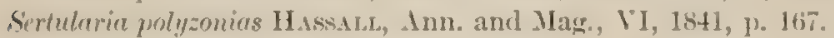

Serfuluria pinnate (ioct I), Report Invert. Inim. of Mass., 18+1, 1) 330.

Sertularia ellisii Couci, Zooph. Cornwall, 1841, p. 6.

Serfularia polyzonias Cotcr, Zooph. Cornwall, 1841, p. 6.

Serhularie polyzonias Trosmsox, Report Brit. Assoc. for 1843, 1844, 1. 2383.

Serlularia polywonias Jorsstox, Brit. \%ooph., פd ed., 1847, 1). 61.

Sertularia polyzonias D.LYLiL, lemark. Inimals of Scotland, I, 1St7, 1. 1:H.

Serlulurella polyzonias GRAY, British Radiata, 1847, p. 68.

Sertularia polyzonias Fonuss, Report 20th Meeting Brit. Assoc., 1850, 13. 245.

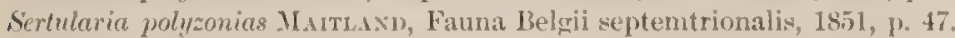

Sertularia polyzonias Strmpox, Marine Invert. Grand Manan, 1853, 1. 9.

Sertularie polyzonias Mijncr, Beskr. af (irönlands, 1857, p. 9.

Sertularin polyzonias SiRs, Bidrag til Kundskaben, 1857, p. 54.

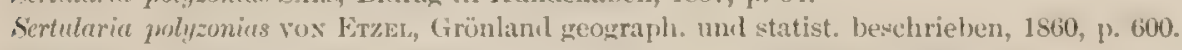

Serfulurie polyzonias (iresx, Manual Anim. King., II, Colenterata, 1861, 13. 95.

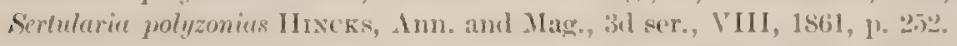

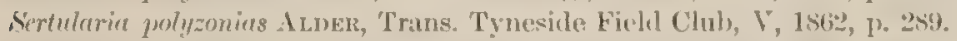

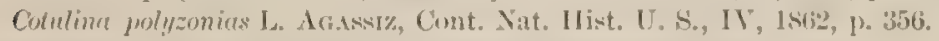

Sertularia pulyzonias L'sck.sm, Canalian Naturalist, 1863, 1). 40 !.

Sertularia polyzonias Grube, Die Insel Lussen, 1864, p. 119. 
Colulina golyzonias A. Acisssiz, North American Acalephe', 1865, 1. 146.

Sertulurir polyzonias Norsus, Report IBrit. Assoc., 36th meeting, 1867, p. 200.

Stmulurim cllisii Nomax, Report Brit. Assoc., 36th meeting, 1867, p. 200.

Sertularia sllisii H ELLER, 'Kooph. und Echin. Arlriatic, 1868, p. 33.

Semulerella polyzonias HiNcks, Brit. Hyd. Zooph., 1S68, p. 235.

Sivlularclle polyzonias Normax, Report Brit. Assoc., 38th meeting, 1869, p. 321.

siertularllu polyzonias HERzLotz, Natuur. Hist. van Nederland, 1870, p. 404.

Sevtularille polyzonias Sars, Norges Hyctroider, 1873, p. 44.

Sectularelle polyzonias Alla.is, Trans. Zool. Soc., Lomdon, VIII, 1873, pp. $469,471$.

Serinlerelle polyzonias Vemsil, P'roc. Am. Assn. Adv. Sci., 1873, pp. 353, 356, 359, 364.

Sertularelle polyzonius McIxrosi, Ann, and Mag., fth ser., XII, 1874, p. 212.

Sertularella polyzonias Scrubze, Nordsee lixped., 1874, 1. 131.

Sertulurella polyzonias Verrith, Am. Journ. Sci., VII, 187t, pp. 39, 504.

Sertularella polyzonius Vertilu, An. Journ. Sci., X, 1875, P. 43.

Scrtularella qmlyzonias Norsan, Inn. and Mag., th ser., XV, 1875, p. 173.

Sertulerelle polyzonias Surn and H.ARGEl, Trans. Conn. Acad., III, 1S76, p. 21.

Serhularellu polyzmins Clark, Alaskan Hydroids, 1876, p. 224.

Sirtulerelle simplex Covgrisei, Ann. and Mag., th ser. XVII, 1876, p. 27.

Sertularella polyzonias Allasan, Mem. Mus. Comp. Zool., V, No. 2, 1877, 1. 21.

Sertularella prolyzonias Menescnkowskx, Ann. and Mag:, 5th ser., I, 1878, p. 331.

Sertularella polyzonias Norman, Ann. and May., 5th ser., I, 1878, 1. 190.

Sertulurelle simplex S'Tuder, Areh. fur Naturg., Jahrg. 45., I, 1879, p. 120.

Sertulurella polyzoniess Wintren, Naturh. Tidsskr., 3d ser., XII, 1880, pp. 243, 276.

Siertularella polyzonias Rrnex, Proc. Zool. Soc. London, 1881, p. 101.

Simtularella polyzomiuts Stork, Norske Selsk. Skr., 1881, J. 20.

Sertularelle polyzonias BALE, Journ. Microse. Soc. Victoria, II, 1882, p. 34.

Sertularella polyzonies Ratibun, I'roc. U. S. Nat. Mus., VI, 1853, p. 216.

Serhlarell polyzonies Wersurdns, Entstehung der Sexualzellen, 1883, p. 165.

Scrlularelle polyzonices BaLE, Cat. Austral. Hydroid Zooph., 1884, p. 104.

sertulurella polyzónirs Kircnenraver, Norlische Gattungen, 1884, p. 37.

Serhulirille polyzonias Tnallwitz, Ueber die entwickl. Keimzellen, 1884, p. 426.

serlularclla polyzonics I'IEPER, Zool. Anz., VII, 1884, p. 185.

, Sertularella polyzonias Graeffe, Arb. Inst. Wien, V, 1884, p. 24.

Sertularclla polyzonins Laxbexfedd, Proc. Linn. Soc. New South Wales, IX, 1885, p. 417.

Sertulurella polyzonius LExDExfeLd, Proc. Linn. Soc. New South Wales, X, 1886, p. 478.

Serfularella polyzonies Meldy, Report Fauna Liverpool Bay, 1886, p. 108.

Sertularella polyzonias Lexdexfeld, Descript. Cat. Austral. Hydromeduse, 11, 1887, 1. 19.

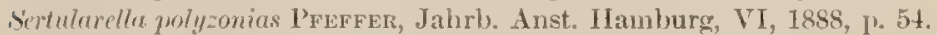

Sertuluria prolyzonies Altm.1x, Challenger Report, Hydroida, Pt. 2, 1888, p. 55.

Sertularelle implexa Altsax, Challenger Report, Hydroida, I’t. 2, 1858, p. 54.

Sirtulerella polyzonias Betexcourt, Bullet. Sci. France et Belgique, 18s8, p. 107.

Sertulurella polyzonigs SEgERstedt, Bih. Svenska vet. Akad. Zool., XIII, 1899, p. 16.

Sertulerelle polyzonias Botraxe, Journ. Marine Biol. Assoc., 1890, p. 396.

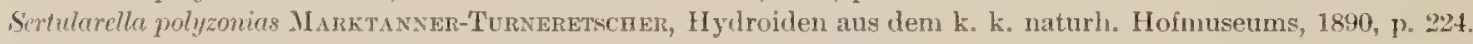

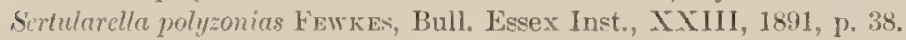

Sertulerclla polyzonias Hout, I'roc. Royal Dublin Soc., VII, 1892, p. 251.

Siertukria pmlyzonias P'rEFFer, Deutschen Polar Exped., 1892, p. 519 and p. 567.

Sertularella polyzonias Levinsex, Meluser, Ctenophorer og Hydroider fra Grönlands Vestkyst, 1892, p. 58.

Sertulurelle polyzonius Levinsex, Virl. Udb. "Hawchs" Togter, 1893, p. 388.

Sertulurella polyzonias Möıres, Sitz. Ber. Ak. Berlin, 1893, p. St3.

Simularia folyzonius Dtwidex, I'roc. Royal Irish Acal, 3kl ser., III, 1893, p. 145.

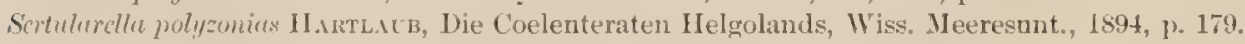

Sertulerelle polyzonirs Tronsely, Trans. Liverpool Biol. Soe., VIII, 1894.

Sorularella polyzonias CRtwrom, Inn. and Mag., 6th ser., XIV, 1895, p. 261.

Serulurelle polyzonius Fanquink, Trans. New Zealand Inst., XXVIII, 1896, p. 463.

Sertularella polyzonias RovLe, liesultats sc. Campagne du Caudan, II, 1896, Pp. 301, 733.

Sertularella polyzonias H.IRL.ıR, Hydromedusen Helgolands, Wis. Aleeresuntersuchungen, new ser., I, 1897, p. 451.

Sertularella polyznnius Browve, Irish Naturalist, VI, 1897, p. 246.

Sertularella polyzonias De eirbex, Proc. Dublin Soc, new ser., VIII, 1s97, p. 416.

Sertularella polyzonias ScriNEIDER, Zool. Jahrb., X, System., 1898, I. 483.

Seriulerella polyzonius Huriexdors, Trans. New Zealand Inst. XXX, 1898, p. 210.

Sertularella polyzonias Boxwevie, Norwegian North Atl. Exped., 1899, p. 78. 
Sertularella polyzonias ALLEN, Journ. Marine Biol. Assoc., V, 1s9!?, 1. 453.

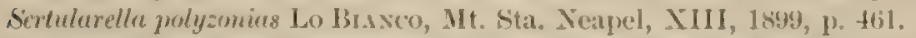

Serlulerella polyzonias Beтвxcouk, Travaux Stat, Zool. Wimerenx, V1I, 1899, P. 10.

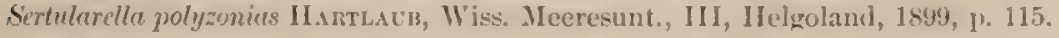

Sirtularelle polyzonirs IRsD), samml. Kauk. Mus. Tillis, 1899, p. 517.

Sertulerella polyzonias P'PCTEт and BEDot, Iyciraires de l'Hirondelle, 1900, p. 20.

Serhlarella polyzonias HanTuack, Revision Sertularella-Arten, 1900, p. 88.

Sertulerella polyzonies NuTrsat, IHydroids of Woods Hole Region, 1901, p. 362.

Sertularella polyzonias Nixtrisa, Hydroids Harriman Expeel., 1901, p. 183.

Serfularella polyzonias WnTtaves, Cat. Marine Invert. Wastern Canada, 1901, 1. 25.

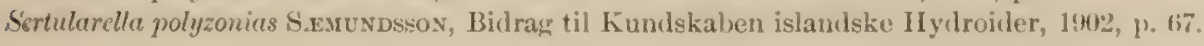

Trophosome.-Colony of exceedingly irregular growth, attaining a height of 4 or 5 inches. Stem not fascicled, slender, flexuose, irregularly branched; nodes very distant and irregular. Branches irregularly alternate, flexuose, themselves often branching profusely, divided into irregular internodes, the tendency being to have an internode to each hydrotheca. Hydrothecae rather distant, stout; proximal portion somewhat swollen, about the distal half free and with approximately parallel sides; aperture squatre, marein with four low eruidistant teeth; operenlum of four flaps.

Gonosome.-Gonangia ovate, with four conspicuous horn-like projections around the marrin and very deeply rugose throughout, those of the female being much larger than those of the male colonies. When the sexual elements are mature the gonangia are surmounted by globular acrocysts, within which the ova develop into planula.

Distribution.-One of the most abundant and widely distributed of the hydroids. New England coasts (Verrill), Bay of Fundy (Stimpson), Gulf of St. Lawrence (Dawson), Lliskit

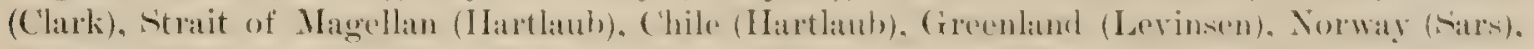

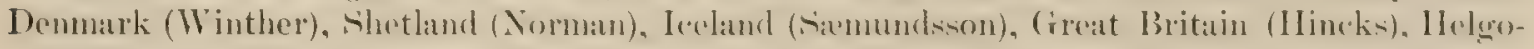

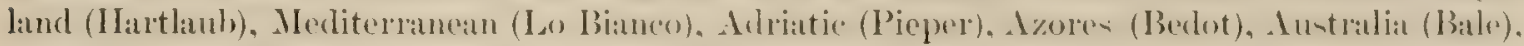

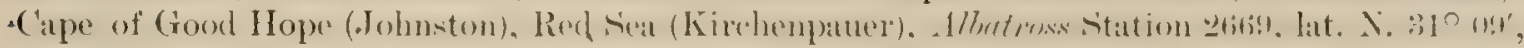
ong. W. $79^{\circ} 33^{\prime} 30^{\prime \prime}$, 353 fathoms; Station 2699, lat. N. $45^{\circ} 04^{\prime}$, long. W. $55023^{\prime}$, 72 futhoms; Station 3294 , lat. N. $57^{\circ} 16^{\prime}+5^{\prime \prime}$, long. WV. $159^{\circ} 03^{\prime} 30^{\prime \prime}$, 30 fathoms; Station 3505 , lat. N. $57^{\circ} 09^{\prime}$, long. W. $168^{\circ} 17^{\prime}, 4 t$ fathoms; Station 3511 , lat. N. $57^{\circ} 32^{\prime}$, long. W. $16938^{\prime}, 39$ fathons.

This species has frecquently been mistaken for $\mathrm{s}$. grey. It can be distinguished from that species, however, by the fact that it has a nonfiscicled stem, al smooth hydrotheca, and stouter gonangia which have four teeth instead of two.

SERTULARELLA CLAUSA (Allman).

(Plate XXI, tige. $3,4$. )

Sertularie chetese Ir.LMAs, Challenger report, Hydroida, 1't. 23, 1885, p. 54.

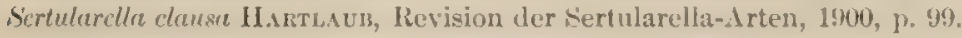

Trophesome-Colony attaining a height of about 1 inch. Stem not fascicled. delicate. sinuous, divided into regulur internodes, each of which bears a hydrotheca. Branches irregular, with a tendency to an alternate arrangement, themselves sometimes dichotomously branched. internodes slender :und rather long.

Hydrothece rather distant, swollen below, exserted, throughout their distal half, narrowing gradually to the margin; marein with four very shallow teeth and with a strong four-liapped operculum, which forms a low pyramid above the hydrothecal aperture.

Gomosome.-Not known.

Distribution.-Otf Montevideo, lat. S. $37^{\circ} 17^{\prime}$. long. W. $533^{\circ} 32^{\prime}$, 600 fathoms.

The above description and the figures of this species were taken from a part of Allman's type specimen, kindly sent me by the authorities of the South Kensington Museum. 'The depth at which this species was found is exceptional for the genus. The very strong opereulum is a feature that one wonld not expect to find associated with such inconspicuous hydrothecal teeth.

Type.-In South Kensington Museum, London. A frament in the collection of the author. 
SERTULARELLA COMPLEXA, new species.

(Plate XXI, figs. 5-9.)

Trophosome.-Colony attaining a height of about 3 inches, exceedingly straggling in habit, the stem and branches being very long and slender, the latter often anastomosing, forming a rude mesh, in which the stem and branches are hardly distinguishable from each other. Stem slightly Hexuose in places, divided into regular short internodes, each with a single hydrotheca, or in other places with nodes not perceptible. Branches growing at right angles with the stem, themselves branched irregularly, often the terminal branches being dichotomous, the distal ends of branches often anastomosing firmly with other branches.

Hydrothece fairly distant, quite short, about the distal third free, and much constricted by the leveling off of the adcauline side; margin with four rather low equidistant teeth; opereulum four-1liapped.

Gonosome-Gonangia borne in rows along the stem and branches, small, regularly oval, with broad, even annulations orer the entire surface; aperture round, not elerated on a neek, and surrounded at some distance by a series of from three to seven blunt tooth-like points.

Distribution.-Albutross Station 28t3, lat. N. $53^{\circ} 56^{\prime}$, long. W. 165 56', 45 fathoms; Station 2553 , lat. N. $56^{\circ}$, long. W. $154^{\circ} 20^{\prime}$, 159 fathoms; Station 2858, lat. N. $58^{\circ} 17^{\prime}$, long. W. $145^{\circ} 36^{\prime}, 230$ fathoms; Station 3500, lat. N. $56^{\circ} 02^{\prime}$, long. IV. $169^{\circ} 30^{\prime}$, 121 fathoms.

This species occurred quite abundantly in the U. S. Fish Commission steamer Albatross dredgings ofl the Alaskan coast. It first sight it greatly resembles in mode of branching, shape of hydrotheca, etc., S. dichotoma, but the four hydrothecal teeth, and particularly the unusual structure surrounding the mouth of the gonangia, render it, in my opinion, a distinet species.

Type slides.-Cat. No. 19745, U.S.N.M. Cat. No. 18696, Museum State University of Iowa; also in collection of the author.

\section{SERTULARELLA PINNATA Clark.}

(Ilate XXI, figs. 10-12.)

Sertularello pimenta CLARK, Alaskan Hydroids, 1876, p. 2206.

Serfularlla pimutu M EREschKowskr, Ann. and Mag., 5th ser., II, 1878, p. 450.

Sertulurlla fruticulosa Kincnenpaver, Nordische Gattungen, 1884, 1. 50.

? Sertularella pimetn Lorexz, Internat. Polarforsch. Jan Mayen, 18s6, III, p. 2.

? Sertuluclla pimatu Marktanser-Turneizetsciner, Hydroiden aus den k. k. naturh. Hofmuseums, 1890, p. 2223.

Sértularelle pimata Hartlaub, Revision der Sertularella-Arten, 1900, p. 40.

Tropherome.-Colonies growing in dense clumps, sometimes attaining a height of about 1 inch. Stem not fascicled, divided into regular short internodes each of which bears a branch and an axillary hydrotheea. Branches alternate, divided into regular internodes which are very short, each bearing a hydrotheca on a very broad shoulder on the internodes, the nodes being opposite the middle of the hydrothece, often branching dichotomously; branches themselves often branching dichotomously, nodes very deeply cut, giving sharp constrictions of the thick perisare. Hydrotheea inclined forward and outward, appearing in front view to be borne on the front of the branches, very closely approximated, short, stout, the distal half free; margin greatly and abruptly expanded and rimmed, with three very large pointed teeth, the two outermost being the larger; an intrathecal ridge extends horizontally from a constriction in the outer wall around the inside of the hydrotheca to about the middle of the side wall. The floor of the hydrotheca is of very thick chitin with a pointed process extending downward from the posterior lateral corners.

Gomosome.-Gonangia borne in double rows on the front of the main stem and branches, large, hroadly ovate, exceedingly rugose, the rugosities not being even and parallel, as in other species, but sinuous, giring a peculiar appearance of distortion; aperture broad, round, not monnted on a collar.

Distribution.-Unalaska, Coal Harbor, Shumagin Islands, Lituya Bay, 112 fathoms (Clark).

'This species excels all others that I have seen in a general appearance of rugosity, the chitinous periderm being very thick and much wrinkled. 
The present writer agrees with Hartlaub in regarding S. fruticulose Kirchenpauer as a synonym of $S$. pinnata Clark.

Type.-In the collection of the U. S. National Mfuseum.

\section{SERTULARELLA MARGARITACEA Allman.}

(Plate X.III, fig. 1.)

Sertularella margaritacea Altuax, Linn. Soc. Journ., Zool., XIX, 1885, p. 133.

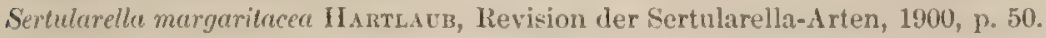

"Trophosome.-Stem monosiphonic, much branched. Hydrothece distant, adnate by about half their height to the stem, from which they then become strongly divergent, epicauline side ventricose toward the base; orifice with a thickencd rim and with a deep sinus at its apocauline side.

"Gronosme. - Gonangia springing from the angles of the ramitication, oroid, marked by wide transverse rugae toward the summit and base.

"Locality. - Straits of Magellan. On an air rescicle of Macrocystis pyrifera."

I have not seen this species, and have copied the above description entire from that of the original describer. The figure would seem to indicate that there were three hydrotbecal tecth, although their number is not given in the deseription. The form bears considerable resemblance to that of S. dichotoma, which came from the same region and is apparently a very rariable species, so far as the trophosome is concerned. 'The gonangia, however, are quite different.

Type.-In the collection of Miss H. Gatty.

SERTULARELLA TURGIDA (Trask).

(Plate XXII, figs. 2-5.)

Sertularie turgida Trask, Proc. Cal. Acad. Nat. Sci., 185i, p. 113.

Serfularic turgila A. AgAssiz, North American Acalephe, 1865, p. 145.

Sertularella turgida CLark, Hydroids of the I'acific Coast, 1876, p. 259.

Sertularella turgida Kirnciexpaden, Nordische Gattungen, 1884, p. 51.

Sertularella conica Gilkiss, Hydroids from P'uget Sound, 1899, p. 359.

Serlularella nodulosa CaLEsxs, Hyidroids from P’uget Sound, 1899, p. 360.

Seriularella turgida Hartadis, Revision der Sertularella-Arten, 1900, p. 67.

Sertulerella turgida H.1RTLAUb, Hydroiden sus dem Stillen Ocean, 1901, p. 360.

Sertularelle turgida TonRE;, Hydroida of the P'acitic Coast, 1902, p. 64.

Trophosome.-Colony small, sometimes consisting of an unbranched stem, attaining a height of about 1 inch in specimens examined. Stem geniculate, divided into regular short internodes, each of which bears a hydrotheca. Branches, when present, not regularly arranged, few in number, and resembling the main stem in all respects. Hydrothece elosely approximated, rather large, stout, subeylindrical, the ends being slightly constricted; aperture large, margin with three unequally dereloped teeth, the two outer ones being rery strong and equal, the other smaller. As a rule less than the distal half of the hydrotheea is free.

Gonosome.-Gonangia borne in the axils of the hydrotheca, large, obovate, terminating in a small inconspicuons aperture at the summit of a short collar, and with the distal portions armed with a number of blunt spines, these being much more numerous in some specimens than in others. There is also a sort of dimorphism in size which probably corresponds to sex, the larger gonangia being female.

Distribution.-Bay of Sin Francisco, Monterey, Tomales Point, California (Trusk); Sam Diego, California (D. C. Cleveland); Vancouver Island, J. M. Dawson (Clark); 'Townsend Harbor (Calkins); Oregon (Nutting); Albatross Station 2861, lat. N. $54^{\circ} 14^{\prime}$, long. W. $129^{\circ} 50^{\prime}$, $20 t$ fathoms. Albatross Station (Hydrographic) 3775, off Japan, 57 fathoms.

I agree with Hartlaub in the opinion that the $S$. nodulose of Calkins is really identical with the present species. The specimen from Japan is more branched and the hydrothece more distant and more exserted than in otber specimens that I bare examined. 


\section{SERTULARELLA SIEBOLDI Kirchenpauer.}

(Plate XXII, figs. 6-7.)

Sertularella sieboldi Kincrientauer, Nordische Gatiungen, 1884, p. 49.

Sertularella sieboldi Hartuadb, Revision der Sertularella-Arten, 1900, p. 69.

Trophosome.-Colony small, branches profuse and irregular. Stem not thicker than the branches, slender, gnarled, twisted, and amnulated, those internodes bearing branches being generally separated by internodes without branches. Branches partly quite regular and partly irregular, springing from the sides of hydrothece. Hydrotheca arise from the flexures of the stem, sometimes closely approximated, sometimes distant, very irregular, pitcher-shaped, swollen, with slender necks and three-toothed apertures.

Gonosome.-Gonangia oral, deeply annulated above and below. Aperture with three teeth; neck slender.

Distribution.-Cuba.

In the absence of specimens the above description was compiled by combining points given by Kirchenpauer and by Hartlaub, who studied the type specimen.

Kirchenpauer's drawings are evidently from dried specimens, or else the anuulations, etc., are greatly exaggerated, as claimed by Hartlaub. At any rate, no one would suppose that the drawings given by these two authors were from the same species, much less the same type specimen.

Type.-In museum at Leipsic.

\section{SERTULARELLA SUBDICHOTOMA Kirchenpauer.}

(Plate XXII, figs. 8-12.)

Serlularella subdichotoma Krncmexpauer, Nordische Gattungen, 1884, p. 46.

Sertularella subdichotoma BALE, Trans. Royal Soc. Victoria, 1887, p. 107.

Sertularella subdichotoma Hartuavb, Revision der Sertularella-Arten, 1900, p. 33.

Trophosome.-Colony exceedingly straggling and irregular in growth, sometimes attaining a height of about 2 inches. Stem not fascicled, hranching dichotomonsly, but in a very loose and straggling manner. Stem and branches not divided into regular internodes in the proximal portions, but distally divided into long slender internodes, each of which bears a bydrotheca. Hydrothece small, varying greatly in shape, usually rather distunt, short, attached for more than two-thirds their adeauline side, the free portion being abruptly narrowed; margin usually with three broad equal and equidistant teeth; operculum of three flaps. There is often an oblique or horizontal intrathecal ridge.

Gomesmm.-Gonangia slender, oroid, annulated rather feebly, with a distal flange-like outer collar and a slender neck ending in a round aperture. In some cases there is no outer collar nor inner neck, but a broad, round terminal aperture as figured by Kirchenpauer. ${ }^{1}$

Distribution.-Bass Straits. Australia (Kirchenpauer); Straits of Magellan (Kirchenpauer); Patagonia (Hartlaub); Albatross Station 2776, lat. S. $52^{\circ} 41^{\prime}$, long. W. $69^{\circ} 55^{\prime} 30^{\prime \prime}, 21$ fathoms.

This appears to be an exceedingly variable species in almost every detail of its structure. Specimens from Station 2760 agree well with one sent me hy Profesior Levinsen from the Straits of Magellan. The gonosome, as well as other parts, is very variable, and some of the gonangia resenble Kirchenpauer's figure, and others the original tigure of d'Orbigny for S. milneana. ${ }^{2}$

Type.-In the Berlin Museum.

${ }^{1}$ Nordische Gattungen und Arten, 1884, pl. xri, fig. 1, b.

${ }^{2}$ Voyage dans l'Amérique Méridionale, 1839, p. 26, pl. xı, fig. 8. 


\section{SERTULARELLA FILIFORMIS (Allman).}

(Plate XXIII, figs. 1-3.)

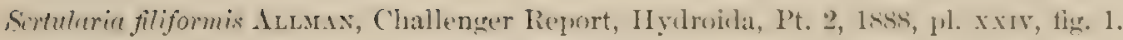

Sertularia gracilis ArLsaN, Challenger heport, Iydroida, I't. 2, 1858, p. 51.

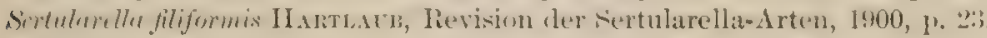

Trophosome.-Colony of graceful and delicate texture, attaining a height of 5 inches. Stem not fascicled, slender, llexuose, divided into irregrular internodes. Hinuches not flexuose, alternate, themselves often branching like the main stem in an alternate manner, and sometimes these branches again divide; internodes irregular, each bearing a hydrotheca or a hydrotheca and branchlet on distal portions of colony, while the nodes are generally lacking on proximal parts. Hydrotheese tubular, gracefully and regularly curved outward, with about their distal third free, and an oblique intrathecal ridge; margin with three well-defined teeth, and an operculum composed of three parts.

Gonosome--Gonangia borne on the stem and branches in all their ramifications, clongateoval, with rather long curved pedicels, and a series of rery deep compressed amnular ridges extending much beyond the general surface, like a series of superimposed dinner plates, the uppermost being bowl-shaped, and giving origin at its center to a long, slender, tubular neck, which is slightly expanded at both ends. Aperture small.

Distribution.-Port Famine, Patagonia, lat. S. $53^{\circ} 37^{\prime}$, long. W. $70^{\circ} 56^{\prime}, 9$ fathoms. (Allman.)

The above description is from a portion of Allman's type, which differs from the original description in having three well-marked hydrothecal teeth, instead of two. The species is evidently allied closely to $S^{*}$ tricuspidata, but differs in the shape of the hydrothecre and gonangia.

Type.-In South Kensington Museum, London; also in collection of author.

SERTULARELLA QUADRIFIDA Hartlaub.

(Plate Xxill, figs. 17. .)

Thuiaria quadridens Aluman, Challenger Report, Hydroida, I't. 2, 1888, p. 66.

Pertulcelle alfinis HARTLIUB, Revision der Sertularella-Arten, 1900, D. 43.

Scrularella quadrifida, new name, Hartuavi, Revision der Sertularella-Arten, 1900, p. 120.

Trophosome.-Colony attaining a height of about 2 inches. Stem not fascicled, flexuose, divided into regular internodes, each of which bears a branch and two hychothecar on one side. and a single hydrotheca on the other. Branches regularly alternate, themselves often branehing dichotomously, internodes very long, the nodes often being entirely wanting. Hydrotheca rather distant, small, ardnate to the branch by more than half their adkauline side, the fres portion forming an acute angle with the branch; margin with three tecth, instead of four, although an appearance of four teeth is sometimes produced by a reduplieation of the mategin on the adcauline side, which reduplicates the single adcauline tooth; operculum of three flaps.

Gomosome.-Not known.

Distribution.-Between Cape Virgin and Falkland Islands, lat. S. $51^{\circ} 35^{\prime}$, long. W'. $65^{\circ} 39^{\prime}$, 70 fathoms.

The above description is taken from Allman's type collected by the Challenger. Of course the presence of three instead of four teeth renders the name quallifidu misleading, but it seems preferable to preserve the name even at the expense of incongruity.

Hartlaub finds that the name originally given to this species by Allmun was preoceupied by Bale in $1884 .{ }^{2}$

Type.-In South Kensington Museum. Fragment in possession of the anthor. 


\section{SERTULARELLA MERIDIONALIS, new species.}

(Plate XXIII, figs. 8-9.)

Trophosome.-Colony compactly pinnate in shape, attaining a height of about 2 inches. Stem not fascicled, flexuose, proximal portion not differing from the rest, not noticeably annulated, divided into fairly regular internodes by oblique nodes, each internode often bearing a branch and two hydrothecre on one side and a single hydrotheca on the other. Branches regularly alternate, rather closely approximated, constricted sharply at their origins, divided into long and irregular internodes. Iydrotheca large, closely approximated, tubular, with both proximal and distal ends expanded, both lower and upper profiles concave; ahout one-half of the adcauline wall free; margin expanding, with three strongly developed teeth, and a three-flapped operculum.

Gonosome.-Gonangia quite large, oblong-conical, the distal portion being ornamented with thrce to five, usually three, pronounced annular turets; neck small, tubular, suddenly expanding distally into a trumpet-shaped termination with a round orifice.

Distribution.-Albatross Station 2783, lat. S. $51^{\circ} 02^{\prime} 30^{\prime \prime}$, long. W. $74^{\circ} 08^{\prime} 30^{\prime \prime}$, 122 fathoms.

This very striking species bears considerable resemblance to $S$. milneana, but has fewer annulations and a more suddenly enlarged termination to the neck of the gonangia. 'The trophosome is very much more compact and robust than that of $S$. milneana, and the hydrotheca are quite different in shape.

Type slides.-Cat. No. 19767, U.S.N.MI.; Cat. No. 18709, Museum of State University of Iowa; also in collection of the author.

SERTULARELLA ELEGANS, new species.

(Plate XXIV, fig. 1.)

Trophosome-Colony growing from a root stalk parasitic on Abietinaria, and attaining a height of about 3 inches. Stem not fascicled, with several strong annulations on proximal portion, divided into regular internodes, each bearing a hydrotheca, which is directed forward, outward, and upward; nodes very strong and deeply cut. Branches straggling and irregular, tending to an alternate arrangement, and sometimes anastomosing as in $S$. johnstoni, divided by deeply incised nodes into rather short, regular internodes, each of which bears a hydrotheca. Hydrothecie directed forward, outward, and upward, rather closely approximated, tubular, gently curved, adherent by about their proximal adcauline third; margin expanding, with three strong and equidistant tecth, and with a narrow border or rim; operculum of three flaps. Hydrotheca often with an oblique intrathecal ridge rumning downward from the anterior margin.

Gonosome.-Gonangia in rows on stem and main branches, exceedingly elaborate in ornamentation, oval to round, neck tubular with trumpet-shaped aperture, the usual annulations produced into raised fluted frills that look like a series of lace collars, giving an exceedingly ornate effect.

Distribution.- Llbatross Station 2842, lat. N. 54 15', long. W. $166^{\circ} 03^{\prime}, 72$ fathoms.

At first view this species bears a general resemblance to S. tricuspidata, but the hydrothecæ lie in two planes, are more crowded and heavier, and the gonangia carry oruamentation to its greatest length as found in the genus.

Type slides.-Cat. No. 19752, 19753, U.S.N.M.; Cat. No. 18701, Museum State University of Iowa; also in the collection of the author.

\section{SERTULARELLA MILNEANA (d'Orbigny).}

(Plate XXIV, figs. 2-5.)

Sertularia milneana D'ORBIGNY, Voyage l'Amérique Méridionale, V, 1839, p. 26.

Serhlurella milneana Kincrievpauer, Nordische Gattungen, 1884, p. 52.

Sertularella milneana H.artuaub, Revision der Sertularella-Arten, 1900, p. 39.

Trophosome.-Colony very striking in habit, attaining a height of about 4 inches. Stem proximally without hydrothecie, slender and with numerous anulations, remainder very slightly 
flexose with distant nodes. Bramedes irregularly alternate, themselves hranching dichotomously.

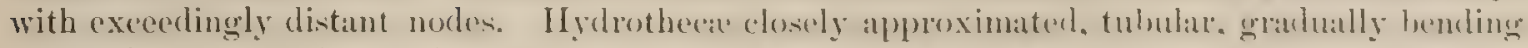
outward, extent of immersion varying greatly. almost the entire adraline wall being sometimes adnate to the hydroeatus, and at other times the distal half is frees, orery intergradation between these extremes sometimes being found in one colony, margin with three well-marked and equidistant teeth and a three-flapped operculum.

Gonosome.-Gonangia large, borne on all parts of the colony, sometimes agrgregated on distal portions, oblong-ovate, distal third ornamented with six to eight even annular rugosities, remainder perfectly smooth; aperture small, at the summit of a small tubular neck with a slight distal expansion.

Distribution.-Southern coast of Patagonia, Ross Bay, south of Rio Negro (d'Orbigny). Albatross Station 2766 , lat. S. $52^{\circ} 41^{\prime}$, Jong. W. $69^{\circ} 55^{\prime} 30^{\prime \prime}, 21$ fathoms; Station 2777 , lat. S. $52^{\circ} 38^{\prime}$, long. W. $70^{\circ} 10^{\prime} 30^{\prime \prime}$, 19.75 fathoms.

'The very characteristic gonangia with smooth walls, save for a few distal annulations, seems to me to serve at once for the identification of this species. Specimens collected by the U. S.

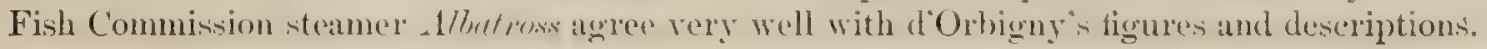

\section{SERTULARELLA MAGELLANICA (Marktanner-Turneretscher).}

(Plate XXIV, figs. 6-8.)

Calyptothuiaria magellanica MArkTANner-Tunveretscher, Hydroiden aus den k. k. naturhist. Hofmuseums, 1900, p. $2+4$.

Sertularella magellanica IIARtuatu, Revision der Sertularella-Arten, 1900, p. 22.

Trophosome-Colony attaining a height of about 2 inches in largest specimen examined. Stem not fascicled, with several deep annulations on its proximal nonhydrothecate part, basal portion tuhular, broadening and flattening distally. Branches somewhat irregular, but tending to an alternate arrangement, narrow at their origin, ahmost straght, internodes long and irregular. Hydrotheca alternate, large, tubular, gentle curving throughout their length: differing creatly in the extent of their immersion, some on the distal parts of the colony having not more than their distal third free, while some near the hase of the man stem are fres throughout their entire length; margin with three laige equal and equidistant teeth. Operculum with three flaps.

Gonosome.-Unknown.

Dintribution. - Straits of Magellan (Marktanner-Turneretscher); Alluetrusis station 2761 , lat. S. $51^{\circ} 34^{\prime}$, long. W. $65^{\circ}$, depth 50.5 fathoms.

This species is remarkable in reversing the ordinary condition of affairs among sertularians in two particulars: first, the stem widens distally; second, the proximal hydrothece tend to be more exserted than the distal.

Type.-In k. k. maturhistorischen Hofmuseums, Vienna.

SERTULARELLA MINUTA, new species.

(1'late XXIV, figs. 9-10.)

Trophosome.-Colony exceedingly fragile and delicate, attaining a height of about one-half inch. Stem not fuscicled, strongly geniculate, divided into regular long internodes. Branches very irregular, often forming a right angle with the stem, branching dichotomotsly, slonder, very strongly geniculate, divided into regular long internodes each of which hears a hychrotheea near its distal end. Iy yrotherae distant, actually small but large in proportion to the diametere of the stem and branches, slender, almost tubular, bending grently outward, almost completely exserted but a small portion of the adcauline wall being adnate to the branch, margin with thee teeth; operculum with three tlaps.

Gonosome-Gonangia borne on stem and main branches, small, oroid, strongly and erenly annulated throughout, with a short tubular neck and slightly expanded aperture.

Distribution.-Albatross Station 3480, lat. N. 520 06', long. WV. $171^{\circ} 45^{\prime}$, 283 fathoms.

This exceedingly delicate and beautiful species seems to be quite distinct. In some respects it resembles a miniature of $S$. tricuspidata, and in others a miniature of $S$. tropica. It differ. 
from both, however, in its very long internodes, from the former in the degree of exsertion of its hydrothecx, and from the latter in the form and ornamentation of the gonangia.

Type slides.-Cat. Nos. 19,771, 19,772, U. S. N. M.; Cat. No. 18,711, Museum State University of Iowa; also in the collection of the author.

\section{SERTULARELLA LEVINSENI, new species.}

(Plate XXV1, figs. 1-2.)

Trophosome.-Colony very loose and straggling in habit, sometimes attaining a height of 3 inches. Stem not fascicled, slenter, flexuose, divided into regular internodes each of which bears a hydrotheca or a hydrotheca and branch. Branches irregularly alternate, slender, flexuose, often dividing dichotomously, rarely anastomosing, divided into regular internodes throughout. Hydrothece rather small and distunt, stout, swollen below, their adcauline wall adnate for from one-half to three fourths it length; margin with three well-marked equal and equidistant teeth; operculum with three flaps.

Gonosome.-Gonangia borne in rows on stem and all the branches, although they are more apt to be aggregated proximally, small, ovoid, somewhat elongate, with shallow broad annulations particularly on distal portions; neck short but distinet.

Distribution.-Albatross Station 2842, lat. N. $54^{\circ} 15^{\prime}$, long. W. $166^{\circ} 03^{\prime}, 72$ fathoms.

This species is allied to S. dichotoma in the general appearance of its trophosome, but differs in having more distant and much larger hydrotheea, a complete division of stem into regular internodes, and a different gonosome. It is allied to $S$. tropica Hartlaub in the shape of its gonangia, but differs in having smaller hydrotheca which are much more exserted, and gonangia not nearly so slender.

I take pleasure in naming this species in honor of Professor G. M. R. Levinsen, whose valuable papers on the hydroids of northern waters have greatly extended our knowledge.

Type stides.-Cat. No. 19,761, U. S. N. M.; Cat. No. 18,706, Museum State University of Iowa; also in collection of the author.

\section{SERTULARELLA DENTIFERA Torrey.}

(Plate XXV, figs. 1-2.)

Sertularella dentifera TorReY, Hydroida of the Pacific Coast, 1902, p. 61.

"Trophosome.-Stem slender, Hexuose, branched. Branches arising within or in place of hydrotheca; similar to stem. Hydrothecæ free for three-quarters of their length, tubular, slightly enlarged at base; margin reduplieated, furnished with three moderate teeth forming a triangle with apex nearest stem."

Gonosome.-Not known.

Distribution.-San Pedro, California.

1 have not seen this species, and have copied the original description entire, although there is considerable likelihood that it is identical with $\mathrm{S}$. tropicu Hartlaub. ${ }^{1}$ The character given by Torrey, as, "branches arising within or in place of hydrothecx" occurs as a sort of abnormality in numerous species of hydroids that normally branch in the ordinary manner, and it is of doubtful value as a means of distinguishing species.

Type.-In the collection of the University of California.

SERTULARELLA TRICUSPIDATA (Alder).

(Plate XXV, figs. 3-7.)

Sertularia tricuspidata Alder, Ann. and Mag., 2i ser., XVIII, 1856, p. 356.

Sertularia tricuspidate ALDER, Cat. Zooph. Northumb, 1857, p. 21.

Sertularia ericoides Mörcr, Rink. Grönland geograph. og statisk beskr., 1857, p. 97.

Sirtularit trimtspidata Greene, Ann, and Mag., 3 ser., V, 1860, p. 431.

The Clarke's description and figures of S. mrimbilis (=, tropicu Hartlaub), Bulletin of the Museum of Comparative Zoology, XXV, 1894, p. 75, pl. IV, fig. 20, and pl. v, figs. 21 and 22. 
Sertularia tricuspidata ALDEn, Trans. Tyneside Field Club, V, 1862, 1. 289.

Sertularia tricuspidata PACKARD, Canadian Naturalist, 1863, p. 4.

Cotulina tricuspidata A. AGAssiz, North. Amer. Acalephlıe, 1865, p. 146.

Sertularella tricuspidata Hiscks, Brit. Hydroid Zooph., 1868, p. 239.

Sertularella tricuspidate Vernill, Proc. Am. Assn. Adv. Sci., 1873, pp. 353, 359, 364.

Sertularella tricuspidate Kincriexpaven, Zweite deutsche Fordpolarfahrt, 1869-70, II, 1874, p. 416.

Seriularella tricuspidata Hixcks, Ann. and Mag., 4th ser., XIII, 1Sit, 1. 151.

Sertularella trimspidata VernuL, Am. Jour. Sei. and Arts, VII, 1874, p. 44.

Sertularella tricuspidata lötcen, Arctic Manual, 1875, p. 190.

Sertularella tricuspidata CLARK, Alaskan Hydroids, 1576, p. 224.

Sertularelle tricuspidata Switir and HARGER, Trans. Conn. Acad., III, 1876, p. 7.

Seriularella tricuspidata Hrxcks, Ann. and Mag., th ser., XX, 1877, p. 67.

Sertularella tricuspidata NorMAx, Ann. and Mag., 5th ser., I, 1878, p. 190.

Sertularella tricuspidata Mereschkowsky, Ann. and Mag., 5th ser., I, 1878, p. 323.

Sertularella tricuspidata D'U IrBaN, Ann. and Mag., 5th ser., VI, 1850, p. 268.

Sertularella tricuspidata W'sner, Naturh. Tidsskr., (3), XII, 18S0, p. 276.

Sertularella tricuspidata Ridley, Ann. and Mag., 5th ser., VII, 1881, p. 455.

Sertularella tricuspidata R.ATnвun, Proc. U. S. Nat. Mus., 1883, p. 216.

Sertularella tricuspidata Trompsos, Bijdragen to de Dierkunde, Af1. X, 1884, p. 6.

Sertularella tricuspidata Kirncirexpauer, Nordische Gattungen, 1884, p. 45.

Sertularella pallida Kincinespaten, Nordische Gattungen, 1854, p. 48.

Sertularella tricuspidata Murdocr, Polar Exped. Point Barrow, 1855, p. 16f.

Sertularella tricuspidata Lorexz, Die intern. Polarforschung, Jan Mayen, III, 1886, p. 2.

Sertularella tricuspidata Trompsox, Vega Experlition, Vet. Jacktag., IV, 1857, p. 394.

Sertularella tricuspidata Bengn; Goplepolyper fra Kara Havet, 1887, p. 335.

Sertularella tricuspidata MARkTaxaer-Turseretsciner, Hydroiden aus den k. k. naturhist. Ifofmuseums, 1890, p. 222.

Sertularella tricuspidata FETKEs, Bull. Essex Inst., XXIII, 1891, p. 88.

Sertularella tricuspidata Lefinsen, Vid. Meddel, naturh. Foren., 1892, p. 59.

Sertularella tricuspidata MarkTaNer-Turseretscmer, Hydroiden von ost Spitzb., 1895, p. 425.

Scrtularella tricuspidata JADERITozs, Bihang svensk. Akad., XXI, 1896, p. 12.

Sertularella tricuspidata Rovle, Köhler, Risultats sc. Campagne du Caudan, Pt. 2, 1896, p. 301.

Sertularella tricuspidata P'Edascrieszo, Trav. Soc. Nat. St. Petersbourg, XXVIII, 1897, p. 226.

Sertularella tricuspielata Sixizix, Arb. Zool. Inst. Warschau, 1898, p. 228.

Sertularella tricuspidala Brruld, Ann. MLus. I'etersbourg, 1898, p. 203.

Sertularella tricuspidata V. ADELung, Zool. Centralblatt, 1899, p. 518.

Sertularella tricuspidata Nurtskg, Hydroids from Alaska and Puget Sound, 1899, p. 741.

Sertularella tricuspidata Bonnevie, Norwegian North Atl. Exped., 1899, p. 78.

Sertularella tricuspidata CaLKIss, Hydroids from Puget Sound, 1899, p. 360.

Seriularella tricuspidate Pictex and Bedot, Hydraires de l'Ilirondelle, 1900, p. 222.

Sertularella tricuspidata H.Artaum, Revision der Sertularella-Arten, 1900, p. 23.

Sertularella tricaspidate HazTLAUB, IIydroiden aus dem Stillen Ocean, 1901, p. 354.

Sertularella tricuspiduta Nutrixg, Hydroids of the Woods Hole Region, 1901, p. 362.

Sertularella tricuspidata NuTtrsg, IIarriman Expedition, the IIydroids, 1901, p. 183.

Sertularella tricuspidata H.IRGITT, Amer. Naturalist, 1901, p. 391.

Sertularella tricuspidata Wmiteaves, Cat. Marine Invert. Eastern Canada, 1901, p. 26.

Sertularella tricuspidate S.muxnssos, Bidrag til Kundskaben islandske Hydroider, 1902, p. 68.

Sertularella hesperia ToRrex, IIydroida of the Pacific coast, 1902, p.63.

Trophosome.-Colony a matted mass of shoots and twigs sometimes attaining a height of 5 or 6 inches. Stem not fascicled, slender, divided into internodes ach of which hears a hydrotheca or a branch with its axillary hydrotheca. Branches irregularly alternate, often branching profusely either alternately or dichotomously, divided into regrular internodes eateh of which bears a hydrotheca, some of the nodes being double and oblique, which gives a twisted appearance to the branch. Hydrotheral distant, small, cylindrieal, without eorrugations, the distal half

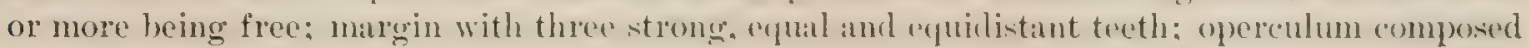
of four tiaps.

Gonosome.-Gonangia borne profusely on the main stem and branches, large, oblong-orate, marked throughout with very prominent compressed annular ridges, the uppermost of which forms a bowl-shaped structure from the center of which arises the tubular neck which ends in a slightly ererted margin and roand aperture.

Distribution.-Abundant thronghout the north polar and north temperate regions of the world. New England coast (Verrill); Gulf of St. Lawrence (Dawson): Latbrador (Patelard); 
Alaska (Clark); Aleutian Islands (Clark); St. Pauls Island (Clark); Puget Sound (Nutting); Port Townsend (Calkins); San Diego Harbor (Torrey); Greenland (Winther); Polar Sea (Bergh): Iceland (Hincks); Spitzhergen and Torth (ape (Bomnerie); British Islands (Hincks); Gulf of Gascony (Bedot); Albatross Station 2557, lat. N. $39^{\circ} 53^{\prime} 10^{\prime \prime}$, long. W. $71^{\circ} 31^{\prime}$, 154 fathoms; Station 2850 , lat. N. $54^{\circ} 52^{\prime}$, long. Wr. $159^{\circ} 46^{\prime}, 21$ fathoms; Station 2857 , lat. N. $58^{\circ} 05^{\prime}$, long. W. $150^{\circ} 46^{\prime}, 51$ fathoms; Station 2858 , lat. N. $58^{\circ} 17$, long. W. $148^{\circ} 36^{\prime}, 230$ fathoms; Strtion 2865 , lat. N. $48^{\circ} 12^{\prime}$, long. W. $122^{\circ} 49^{\prime}$, 40 fathoms; Station $2866^{\circ}$, lat. N. $48^{\circ} 09^{\prime}$, long. W. $125^{\circ} 03^{\prime}, 171$ fathoms; Station 3225 , lat. N. $54^{\circ} 48^{\prime} 30^{\prime \prime}$, long. W. $165^{\circ} 49^{\prime}, 85$ fathoms. fathoms.

The bathymetric distribution of this species is phenomenal, being from shallow water to 1,375

S. tricuspidata, like all other wide ranging species, varies greatly, especially in the size of the hydrothece. Clarke found specimens in the material collected by Dr. Dall in Alaska that were very much larger than the typical form. (See Plate XXV, fig. 6.)

S. hesperia Torrey appears to be a synonym for this well-known species. His figures are exactly matched by specimens of $S$. tricuspidatc in my possession. The size also agrees, and I am unable to find anything in his deseription by which I can differentiate his species.

Type.-In Museum of Nat: Hist. Society, Neweastle-upon-Tyne, England.

\section{SERTULARELLA TROPICA Hartlaub.}

(Plate XXVI, figs. 3-4.)

Sertularia variabilis Clarke, Bull. Mus. Comp. Zool., XXV, 1894, p. 75.

Sertularella tropica HartlaUB, Revision der Sertularella-Arten, 1900, p. 41.

Trophosome.-Stem sometimes simple, sometimes compound, slightly flexuous, main branches few and irregularly disposed; a pinnate arrangement of the small branches is in some cases well marked. Color, light horn. The hydrothecæ are alternately arranged, usually one to an internode; they are largest near the base, have a tricuspid margin, which is generally thickened and provided with a three-lobed valve; they are strongly divergent and very much exserted. The degree to which they are embedded in the stem varies greatly; in some cases they are scarcely more than attached to the side of the stem, and in others are embedded more than a third of their length.

Gonosome.-The gonangia spring from just below the hydrothece, are much elongated, length two and a half to three times their width, the upper portion marked with five or six rings, the opening terminal and tubular, the pedicel extremely short.

Distribution. - Albatross Station 3357, lat. N. $6^{\circ} 35^{\prime}$, long. WV. $81^{\circ} 44^{\prime}, 782$ fathoms; Station 3384, lat. N. $7^{\circ} 31^{\prime} 30^{\prime \prime}$, long. W. $79^{\circ} 14^{\prime}, 450$ fathoms; Station 335s, lat. N. $7^{\circ} 06^{\prime}$, long. W. $79^{\circ} 48^{\prime}, 1,168$ fathoms.

I have not seen this species, and have copied the above description entire from the original by Dr. Clarke. The name given by Dr. Clarke was preoccupied by Bale in $1885^{1}$ and by Clarke himself in $1876^{2}$ and Hartlaub gave the species the name $S$. tropica.

The depth from which this species was dredged is quite exceptional for the genus, and indeed for the family Sertularidie.

Type.-In Museum of Comparative Zoology, Cambridge, Massachusetts.

SERTULARELLA CLARKII Mereschkowsky.

(Plate XXVI, tig. 5.)

Seriularella clarkii Merescikowsky, Ann. and Mag., 5th ser., II, 1878, p. 447.

Sertularella clarkii HARTLAUB, Revision der Sertularella-Arten, 1900, p. 25.

"Trophosome.-Hydrorhiza forming a compact layer of hydrophytons. Hydrocaulus straight, long, cylindrical, not angularly bent, with regular internodes, destitute of branches to the apex, where the width of the axial tube suddenly diminishes considerably, and it at the same time gives

${ }^{1}$ Proceedings of the Linnean Society of New South Wales (2), III, p. 764.

${ }^{2}$ Proceedings of the Academy of Natural Sciences of Philadelphia, 1876, p. 1876. 
origin to the branches. Branches divided into internodes, rather short, istuing from all siden of the principal stem, one from each of the internodes, ramified in their turn so that each branch internode gives off a secondary branch, which is divided once or twice; and all these secondary branches are turned toward the axis of the colony (inward). Hydrothece tubular, a little contracted at the extremity; aperture broad, oval, furnished with two large teeth arranged unsymmetrically; arrangement of the hydrothecar, although biserial, not in the same plane, having at the first glance the appearance of being uniserial."

Gonosome.-Unknown.

Distribution.-Unalaska (M. Petelin), $18+7$.

I have not been able to secure a specimen of this species, and have copied the original description entire, as well as the drawing.

Type.-In collection of the Academy of Sciences, St. Petersburg.

SERTULARELLA EPISCOPUS Allman.

(Plate XXVI, fig. 7.)

Serlularia fusiformis IIUtros, Trans. New Zealand Inst., V, 1872, p. 257.

Sertularella episcopus Alluax, Journ. Linn. Soc. Zool., XII, 1874, p. 263.

Sertularia fusiformis Cougntrex, Trans. New Zealand Inst., VII, 1875, p. 285.

Sertularic longicosta Covantrex, Ann. and Mag., th ser., XVII, 1876, 1. 28.

Sertularella episcopus Krrcnexpsuen, Nordische Gattungen, 1881, p. 51.

Sertularella episcopus BaLE, Trans. Royal Soc. Victoria, 1887, p. 103.

Sermlaria fusiformis I'FEFFER, Die niedere Tierwelt des Ant. Ufergeb., 1893, p. 568.

Sertulardla episcopus FARQdiHR, Trans. New 'Zealand Inst., XXVIII, 1896, p. 464.

Sertularella episcopus Hartuaub, Revision der Sertularella-Arten, 1900, p. 49.

"Trophosome.-Hydrocaulus attaining a height of about an inch, simple, giren off at short intervals from a creeping ramified tubular fibre. Hydrothecie tubiform, springing from the distal end of the supporting internode, to which they are attached by their fundus, free in the remainder of their height, and strongly diverging from the stem; orifice deeply cleft athore and below, so as to present a mitre-like form, bordered by a thickened margin, below which, on the side facing the internode, there is a thickened involution of the walls of the hydrotheca.

"Gonosome.-Gonangia elongated, ovoid, with one wide and shallow and two narrow and decp longitudinal depressions, which extend from the summit to the base, supported ly a whort. thickish peduncle springing one from each internode at the side opposite to that which carries the hydrotheca."

Distribution.-New Zealand, Lyall Bay (Hutton); Straits of Magellan (Pfeffer).

I have not seen specimens of this species and have copied the abore deseription from that given by Allman. The form of the gonangia as figured is unique, I believe, among the species of this genus, reminding one of certain ones in the genus fbietinaria.

SERTULARELLA MAGNA, new species.

(Plate XXYII, fig. 1.)

Trophosome.-Colony (fragmentary) about $3 \frac{1}{2}$ inches high, not fascicled, internodes irregular, long. There is but a single dichotomous branching near the top, the usual axillary hydrotheca being present; but sereral of the proximal hranches are produced into much amulated shoots which resemble the so-called stolons found in varions sproups of hydroids. Hydrothecat enormous for this group, being many times as large as those of s. prolyzunies, alternate, tubular, doubly curved, the distal extremity being turned slightly upward, about the distal two-thirds free: margins several times reduplicated, either smooth or with two or threr or sometimes four low inconspicuous teeth. Opereulum thiek, conspictous, a simple membrane of a single flap) wherer the margin is even, with two flaps when there are two erichent teeth, sometimes apparently with more than two flaps, but they are not well defined, probably because the teeth, when three or four, are very low and inconspicuous.

Gonosome.-Not known. 
Distribution.-17batross Station 3480, lat. N. $52^{\circ} 06^{\prime}$, long. W. $171^{\circ} 45^{\prime}, 283$ fathoms. Bering Sea.

This species bears some resemblance to S. giganted Mereschkowsky, but the bydrothecie are quite different in shape. No better example could be found of the futility of basing generic distinction on the number of parts to the operculum. One branch of this species could be placed in three different genera were that criterion to be used.

Type.-In the collection of the U. S. National Museum.

\section{SERTULARELLA FORMOSA Fewkes.}

(Plate XXVII, figs. 2-4.)

Sertularella formosa Ferves, Bull. Mus. Comp. Zool., VIII, No. 7, 1881, p. 130.

Sertularia integritheca Allman, Challenger Report, Hydroida, Pt. 2, 1888, P. 60.

Sertularella formosa Nutring, Bahama Expedition, 1895, p. 88.

Seriularella integritheca VersLuYs, Hydraires de l'Hirondelle, 1899, p. 37.

Sertularella cylindrithece HARTLAUB, Revision der Sertularella-Arten, 1900, 1). 77 (part).

Trophosome.-Colony attaining a height of about 6 inches. Stem not fascicled, sinuous, internodes not evident. Branches regularly alternate, there being three hydrothece between adjacent branches on the same side, divided into regular internodes each of which hears a bydrotheca. Hydrothecæ entirely exserted, cylindrical, set nearly at right angles with the stem or branch, wides nearly parallel; aperture perfectly round and smooth, except for a subuarginal annulation or rim, which is not always present. Operculum apparently wanting. Sometimes, however, it appears in the shape of a thin membrane stretched like a drumbead across the aperture.

Gonosome.-Gonangia oblong-oval, inserted on the bases of the hydrothecr, with smooth walls and a truncated distal end closed with a four-flapped membranous operculum.

Distribution.-Off Granada, 170 fathoms; off Martinique, 357 fathoms (Fewkes); off Habana, Cuba, abundant, 100 to 200 fathoms (Nutting); Testigos Island, 11 meters (Versluys); Albutross

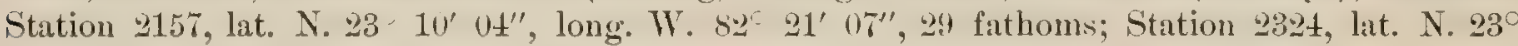
$10^{\prime} 25^{\prime \prime}$, long. W. $82^{\circ} 20^{\prime} 24^{\prime \prime}, 33$ fathoms.

Having secured a portion of Allman's type of S. integritheca, and compared it carefully with S. formosa Fewkes, I do not hesitate to consider the two species as identical. Hartlaub ${ }^{1}$ regards $S$. integritheca and $S$. cylindritheca Allman as identical. Having seen both types, I am unable to agree with him, and the matter is perfectly plain when the types can be consulted.

Type.-In the Museum of Comparative Zoology, Cambridge, Massachusetts.

SERTULARELLA HARTLAUBI, new species.

(Plate XXVII, fig. 5.)

Trophosome.-Colony (fragmentary) about 2 inches high. Stem straight, dark colored, not fascicled, divided into fairly regular nodes by very faintly marked oblique nodes, each internode bearing a hydrotheca or a hydrotheca and a branch. Branches alternate, given off at right angles to the stem from just below the bases of the hydrothece, sharply constricted at their bases. Only the stumps of branches remain in the type specimen, but another specimen from a widely different locality consists apparently of detached hranches, which are long and slender with obseure nodes. Hydrotheca excedingly shallow, shaped liko the base of a low, truncated cone, with its axis forming nearly a right angle with that of the branch; margin perfectly smooth and even; operculum in some cases an adcauline liap, in others apparently an irregularly ruptured membrane stretched straight across the aperture like a drumbead.

Gonosome.-Not known.

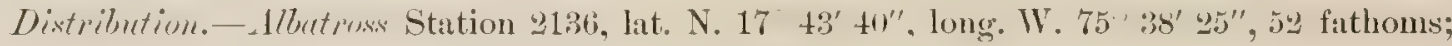
Station 2796 , lat. S. $8^{\circ} 5^{\prime}$, long. W. $78^{\circ} 51^{\prime}, 33$ fathoms. 
This very peculiar species is with doubt referred to the genus sertulum llu. I talie pleasure in naming it in honor of Doctor Hartlaub, who has done more than any other one man to bring order out of chros in this very perplexing genus.

Type slides.-Cat. No. 19760, U.S.N.M.; Cat. No. 18705, Museum State University of Iowa; also in the collection of the author.

\section{? SERTULARELLA NANA Hartlaub.}

(Plate XXVI, fig. 6.)

Sertularella nana HARTLAUB, Hydroiden aus dem Stillen Ocean, 1901, p. 361.

Trophosome.-Colony unbranched (fragmentary), about $5 \mathrm{~mm}$. high. Stem not fascicled, slender, divided into irregular internodes by usually distant nodes, proximal hychrothecate nodes smooth, short, not sharply separated from each other; the following internodes longer, hearing as many as four hydrothece. Hydrothecat lying in one plane, alternate, inserted below the internodes, deep, distal portions strongly narrowing and gracefully curved, with convex adcauline side, base somewhat swollen; margin with two teeth, or perfectly smooth, in which case the aperture is beveled so as to be nearly vertical; operculum present.

Gonosome.--Not known.

Distribution.-Found growing on Lafoëa gracillima at Bare Island, Puget Sound.

I have not seen this species, and have drawn the above description from that of the original describer. It is almost certain that it is not a sectulurellu, and would probably go more properly in Thniuriu, as used in this work. I do not feel justified in disturbing its position, howerer, without more evidence.

Type.-In the collection of Professor Schauinsland?

\section{DICTYOCLADIUM Allman.}

Trophosome.-Colony flabellate in form. Branches anastomosing and forming a rudely reticulate structure or network. Hydrothece on more than two sides of the stem. Aperture without conspicuous teeth. Operculum variable.

Gonosome.-Gonangia borne in the bifurcations of the branches and marked with annular rugosities.

This genus was instituted by Allman to accommodate one of the many new types secured by the Challenger." It was also recognized by Marktanner-Turneretscher, ${ }^{2}$ although at that time but a single species was known. The one herein described shows more evident relation-

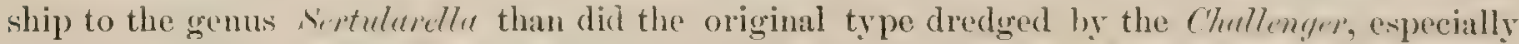
in the opereulum, which is essentially of the sertulerdle pattern. Allman makes no mention of this structure, lut it is plainly evident in II. Alubellum, being composed of four distinct flups, although the teeth are so small as hardly to he cvident, being represented merely by four corner. to the margin which have the structural effect of low teeth.

DICTYOCLADIUM FLABELLUM, new species.

(Plate XXVIII, figs. 1-3.)

Trophesome-Colony flabellate in form, attaining a lieight of about 4 inches and branching in a strictly dichotomous manner; few evident internodes on stem or branches, the only annulations or constrictions ordinarily being those at the origins of branches or branchlets. Branches straight, not flexuose, themselves dechotomously branching in the same plane, the ultimate branches often anastomosing with other branches, forming a rude reticulate pattern.

Hydrothece arranged in four longitudinal series on stem and branches, so as to form an ascending spiral, tubular, about the distal one-third free, curved gently outward, margin

${ }^{1}$ Challenger Reports. The Hydroida I't. 2, 1888, p 76.

${ }^{2}$ Hydroiden des k. k. naturhistorischen Hofmuseums, 1890, p. 219. 
irregular, but usually with a quadrilateral outline, with the corners of the quadrilateral very slightly, if at all produced into four very low obscure teeth; operculum with four flaps.

Gonosome.-Gonangia borne in bifurcations of the branches, very large, ovate, body with shallow broad obscure annulations; neck in the form of a long truncated cone with a round terminal aperture.

Distribution.-Albatross Station 2842 , lat. N. $54^{\circ} 15^{\prime}$, long. W. $166^{\circ} 3^{\prime}, 72$ fathoms; Station $287 t$, lat. N. $48^{\circ} 30^{\prime}$, long. W. $12 t^{\circ} 57^{\prime}, 27$ fathoms.

Type slides.-Cat. No. 19789, U.S.N.M.; Cat. No. 18721, Museum of State University of Iowa; also in the collection of the author.

\section{DIPHASIA Agassiz (modified).}

Trophosome.-Hydrotheca biserial, opposite or alternate, aperture broad, operculum evident, of a single adcauline tlap.

Gonosome.-Gonangia usually differing in the sexes, and marked with spines or lobes; an internal marsupium usually present in the female.

This genus as proposed originally by Louis $\mathbf{A g a s s i z}^{1}$ was very inadequately characterized, the only definition being in a footnote, as follows: "In the genus Diphasia the fertile bydra are deeply dentated." Hincks, in his British Hydroid Zoophytes, 1868, insists that the main feature is the marsupial chamber of the female gonangium, in which he is followed by Bale. ${ }^{2}$ Four years later Allman ${ }^{3}$ called attention to the important character of the lid-like operculum which is more conspicuous and constant in this than in any other genus of the family. Kirchenpauer practically adopted Allman's definition." All of these writers considered the marsupial chamber in the female gonangium as a necessary character of the genus. Levinsen ${ }^{5}$ claims that this character is not constant, and occurs also in other genera, and bases his diagnosis of the genus on the characters of the margin and operculum alone, thus including all of the species of Abietinaria as used in this work. My own opinion is that Abietinaria is a good genus, based on the sbape of the hydrothecax, and an very well be diflerentiated from Difhlisice on that character, there being but one form, at least among American species, that cannot readily be relegated th one or the other of these genera, and that is D. pulchra Nutting, which in general texture is more closely allied to Diphusin, which usually lacks the riggid clear-cut sturdy hydrothecal outline that appears to be characteristic of Abietinaria.

REY TO AMERICAN SPECIES OF DIPIIASIA.

Hydrothece in strictly opposite pairs borne on sides of hydrocaulus.

Margin sinuous, but not toothed, hydrothece not regularly annulated.

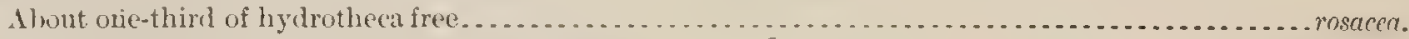

Less than one-third of hydrothece free, aperture very widé $\ldots \ldots \ldots \ldots \ldots \ldots \ldots \ldots \ldots \ldots \ldots \ldots$ fallax.

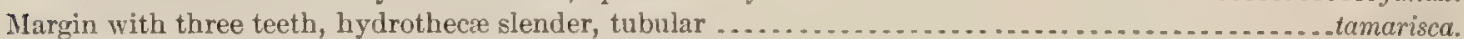

Margin not toothed, hydrothecal walls regularly annulated . . . . . . . . . . . . . . . . . . . . . . . . ...tropica.

Hydrothece in opposite pairs, borne on front of hydrocaulus . . . . . . . . . . . . . . . . . . . . . . . . . . . . .

Hydrothece not strictly opposite, at least on branches.

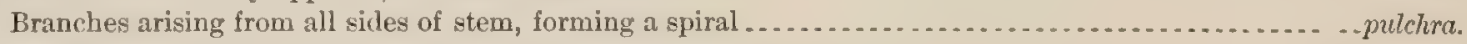

Branching pinnate.

Each internode of stem bearing a pair of opposite hydrothece. . . . . . . . . . . . . . . . . . . . . parmanni. More than two hydrothece to eacn internode.

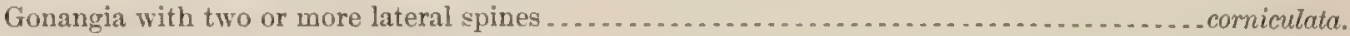

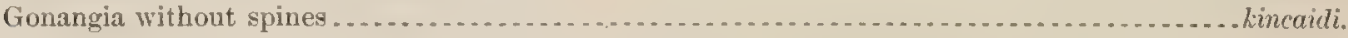

${ }^{1}$ Contributions to the Natural History of the United States, IV, 1862, p. 355.

${ }^{2}$ Australian Hydroid Zoophytes, Sydney, 188t, p. 98.

${ }^{3}$ Challenger Report, Hydroida, Pt. 2, London, 1858, p. 63.

${ }^{4}$ Hydroiden des k. k. naturhistorischen Hofmuseums, 1890, p. 237.

SMeduser, Ctenophorer og Hydroider fra Grönlands Vestkyst, Copenhagen, 1893, p. 196. 


\section{POINTS OF INTERGRATATION BETWEEN DIPHASIA AND OTHEIR GENEIRA.}

With Sertularia, in the general form of the hydrothecx, as in D. tropicu, and in the general shape and appearance of the gonangia, as in D. Fincaidi.

With Thuiaria, in the absence of regular internodes, as in D. Kincaidi, and in the narrow distal end of the bydrothece, as in $D$. pulchra.

With Abietimerin, in the acdeanline oprerculum, and in the narrowed distal extremity of the hydrothece, as in $D$. pulcher.

\section{DIPHASIA R.OSACEA (Linnæus).}

(Plate XXVIII, figs. 4-5.)

Lily or Pomegranute flowering Coralline Eluss, Essay, 1755, 1. 8.

Sertularia rosacca. Lixw.ecs, Systema Nature, 1758 , p. 807.

Sertularie rosace Hourrers, Natuurlyke Historie, XVII, 1761, 1. 525.

Sertularia nigellastrum P'ALLAs, Elenchus Zoophytorum, 1766, p. 129.

Sertularia rosacea Lixw.ets, Systema Naturac, 12th ed., 1767, p. 1306.

Sertularia nigellastrum Bond.AER, Lyst der Plant-Dieren, 1768, p. 161.

Sertularia rosa Maвatт, De I'lantis Zoophytis, 1776, p. 25.

Sertularia rosacea ELLIs and Solds DER, Nat. Hist. Zooph., 17S6, p. 39.

Sertularia nigellastrum WILKINS and HERBST, Charakteristik der Thierptanzen, 1787, p. 168.

Dynamena rosacea Esrer, Die PHanzenthiere in Abbildungen, III, 1785-1830, p. 194.

Sertularia rosacea Berkennout, Synops. Nat. Hist. Great Britain, I, 1789, p. 215.

Sertularia rosacea Potket, Yoyage en Barbarie, II, 1789, p. 69.

Sertularia rosacea Esi'Er, Fortsetzungen der Pflanzenthiere, II, 1794-1806, pl. xx.

Sertularia rosacea Bosc, Hist. Nat. Des Vers, III, 1802, I. 91.

Sertularia rosacea Tuntos, British Fauna, 1807, p. 212.

Sertularia rosacen Jamesox, Catalogue Animals Class Vermes, 1811, p. 564.

Dymamena (Sertularia) rosacea L.wornoux, Bullet. philomatique, 1812, p. 184.

Nigellastmim (Seriularia) nigellastmu OkEx, Lehrbuch der Naturgeschichte, 1815, p. 93.

Nigellastrum (Sertularia) rosacea OkEN, Lehrbuch der Naturgeschichte, 1815, p. 93.

Sertularia rosacea LAMskck, Hist. nat. anim. sans Vert., II, 1816, p. 119.

Dynamena rosacea Lamovroux, Hist. des Polypiers, 1816, p. 178.

Sertularia rosacea StewART, Elements nat. hist. animal Kingdom, II, 1817, p. 40.

Dinamena rosacea FLEMING, British Animals, 1828, \}). 544 .

Sertularia rosacea Bosc, Hist. nat. des Vers, IIX, 1830, p. 105.

Sertularia rosacca Jonxstox, Trans, Nat. Hist. Soc. Northumb, 1832, p. 255.

Dynamena rosacea If BLAsvilue, Iranuel d'Actinologie, 183t, p. 484.

Sertularia rosacea LAMARCK, Hist. nat. anim. sang vert., 2d ed., 1836, p. 145.

Sertulario rosace HAssald, Ann, and Mag., VI, 18ł1, p. 167.

Sertularia rosaced Macgillivelis, Ann, and Mag., IX, 1842, p. 463.

Serfularic rosace Grar, List. British Animals, 1847, p. 69.

Sertularia rosacea Jonsstos, Hist. Brit. 'Zooph., 1847, P. 64.

Sertularic rosacea D.syeld, Rare and Reinark. Animals of Scotland, I, 18+7, p. 159.

Sertularia rosacea Goss, Deronshire Coast, 1857, p. 434.

Sertularie rosace $\triangle$ LDER, Cat. Zooph. Northumb., 1857, p. 24.

Diphasia rosacea L. AGAssiz, Cont. Nat. Hist. U. S., IV, 1862, p. 355.

Sertularia rosacec PAckARD, Canadian Naturalist, Dec. $1863, \mathrm{p} .4$.

Dynamena rosace Kimciexpduen, Neue Sertulariden, 186t, p. 7.

Diphasia rosacea Acassiz, North American Acalephe, 1865, p. 142.

Diphasia rosace Hixcks ${ }^{1}$, Iritish Hydroil Zoophytes, 1868, p. 245. .

Diphasia rosacea Verrili, Proc. Am. Assn. Adv. Sci., 1873, p. 364.

Diphasia rosacca McINTosn, Ann. and Mag., th ser., XIII, 1874, p. 212.

Diphasia rosacea Scnclze, Nordsee Wxped., 1874, p. 132.

Diphasia rosacea VerriL, Amer. Journ. Sci., X, 1875, p. 43.

Diphasia rosacea Wistren, Naturhist. Tidsskrift, 1880, p. 265.

Diphasia rosacea Driescr, Tektonische Studien, 1890, p. 213.

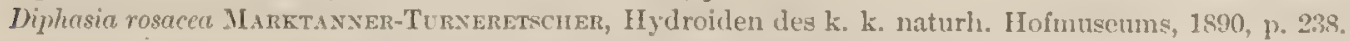

Diphasie rosncen Levises, Vi(l. U(l). "Hauchs" Togter, 1893, p. 371.

${ }^{1}$ Authors before Hincks (1865) did not distinguish 1 ). rosece from D. ulternatu, and hence we can only assume that they refer to the originally described form. 
Diphrasia rosace CRAwford, Ann. and Mag., 6th ser., XVI, 1895, p. 261.

Dynamena rosacea Bonvevie, Norwegian North Atlantic Exped., 1899, p. 79.

Diphasia rosacea NuTTra, Hydroids of the Woods Hole Region, 1901, p. 361.

Diphasia rosacea HargitT, Amer. Naturalist, 1901, p. 392.

Diphasia rosacea Whiteaves, Marine Invert. Eastern Canada, 1901, p. 26.

Diphasia rosacea S.zuundsson, Islandske Hydroider, 1902, p. 66.

Trophosome.-Colony attaining a height of 3 or 4 inches, of very delicate texture, translucent. Stem not fascicled, its proximal portion smooth and without hydrothece, no regular internodes; remainder divided into regular short internodes, each bearing a pair of opposite hydrotheca and sometimes a branch. Branches alternate, distant, often irregularly spaced, proximal internode without hydrotheca, other's bearing a pair of opposite hydrothecar; branches themselves often divided into branchlets. Hydrothece strictly opposite, long, tuhular, the two of a pair not contingent in front but with their proximal adcauline sides parallel. upper one-third to one-half free and bending abruptly outward and forward and ending in an oblique margin. which is sinuous but not toothed. Opereulum of a single adeauline flap, usually situated just at the margin, but when closed sinking considerably below the margin, especially on the adcauline side. Nodes of the branches just between the distal divaricated portions of the hydrothecte.

Gonosome.-Gonangia borne in rows on the upper sides of branches, male gonangia long, slender, narrowing very gradually proximally to a short curved pedicel and rery abruptly distally to a small tubular neck and minute round aperture; sides ornamented with eight compressed longitudinal ridges ending in points on distal end of gonangia. Four to eight spermaries are seen in a row through the transparent gonangial walls. Female go!sangia larger, more rohust, pyriform, with eight conspicuous longitudinal ridges ending in lamellate processes which curve inward toward a common center, and two of which, on opposite sides, are much larger than the other six; apparently an internal marsupial chamber of globular form can be seen in mature gonangia. ${ }^{1}$ When immature the gonangia are obconical in form, with eight regularly spaced projections around the top.

Distribution.-New England coast, common (Verrill); Labrador (Packara); Gulf of St. Lawrence (Whiteaves); British coasts (Hincks); Denmark (Winther); Norway (Levinsen); Iceland (Sremundsson); North Sea (Schulze).

Albatross Station 2250, lat. N. $40^{\circ} 17^{\prime} 15^{\prime \prime}$, long. W. $69^{\circ} 51^{\prime} 45^{\prime \prime}, 47$ fathoms.

This is a well-known shallow water species, occurring from tide level to about 50 fathoms.

DIPHASIA TAMARISCA (Linnæus).

(Plate XXVIII, figs. 6-7.)

Sect iamarisk Ellis, Nat. Hist. Corallines, 1755, p. 4.

Sertulario tamerisce LINNELs, Systema Nature, 1758, p. 808.

Sertularia tamarisca Houtwoy, Natuurlyke Historie, XVII, 1761-1773, p. 533.

Sertularia tamarisca Paldas, Elenchus Zoophytorum, 1766, p. 129.

Sertularia tamarisca Linsweus, Systema Natura, 1767, p. 1307.

Sertularia tamarisca BoDdant, Lyst der Plant-Dieren, 1768, p. 160.

Sertularin tamariscus Marattr, De P'lantis 'Zoophytis, 17j6, 1. 26.

Sertularia Tamarisca Grovovies, Zoophylacium gronovianum, 1781, p. 357.

Sertularia tamarisce Ellis and Solaxder, Nat. Hist. Zooph., 1786, p. 36.

Sertularia tamarisca WILKins and HERBst, Charakteristik der Thierptlanzen, 1787, p. 167.

Sertularia tamarisca Guelis, Systema Nature, Linneus, I, 1788-1793, p. 3845.

Sertularia tamarisca BERKexHout, Synops. Nat. Hist. Great Britain, 1, 1789, p. 216.

Sertularia tamarisea OLIvi, Zoologia Adriatica, 1792, p. 288.

Sertularia tamarisca Lamarck, Systême des anim. sans Vert., 1801, p. 382.

Sertularia tcmarisca Bosc, Hist. nat. des Vers, III, 1802, p. 92.

Sertularia tamarisca Turton, British Fauna, 1807, p. 212.

Sertularia tamarisec Lamovrovx, Bullet. Philomatique, 1812, p. 184.

Nigellastmem (Sertularia) tamarisca Okev, Lehrbuch der Naturgeschichte, 1815. p. 93.

Sertularia tamarisca Lamovnovx, Hist. nat. des Polypiers, 1816, p. 188. 
Scrularia tamarisca StewaTr, Elements Nat. Hist. Animal Kingdom, II, 1817, p. $4 \pm 1$.

Dinamena tamarisca de BrAixville, Manuel d'Actinologie, 183t, P. 483.

Sertularia tamarisca Lamanck, Hist. nat. anim. sans Vert., 1836, p. 153.

Sertularia tamarisca Hassalt, Ann. and Mag., VI, 18t1, p. 168.

Dinamena tamarisca Fleming, British Animals, 1842, p. 543.

Sertularia tamarisca MAcgrlivrar, Ann. and Mag., IX, 1842, p. 164.

Sertularta tamarisce Grar, British Animals, 1843, p. 72.

Sertularia tamarisca Jomsstov, Hist. Brit. Zooph., 1847, p. 74.

i Sertularia producta Stimpsox, Marine Invert. Grand Manan, 185.4, p. 8.

Sertularia tamarisca Alder, Cat. Zooph. Northumb., 1857, p. 25.

Sertularia tamarisca MLLusx, Ann. and Mag., 3d ser., III, 1859, p. 238.

Diphasia tamarisca Agassiz, Cont. Nat. Hist. U. S., IV, 1862, p. 355.

? Sertularia producta A. AGAssiz, Nortl American Acalephre, 1865, P. 145.

Diphasia tamarisca Hixcks, British Hydroid Zoophytes, 186s, p. 254.

Diphasia tamariska SARs, Birlrag til Kundskaben, 1873, p. 19.

Diphasia tamarisca ScruLzE, Nordsee Exped., 1874, §. 132.

Diphasia tamarisca Crawforn, Ann. and Mag., 6th ser., XVI, 1895, p. 261.

Dymamena tamarisca Boxsevie, Norregian North Atlantic Exped., 1899, p. 81.

"Shoots stout and ereet, irregularly branched, the branches commonly alternate, sometimes opposite, long. simple or variously branched. Hydrotheca very laree, eylindrical, the upper half free and divergent, with a wide tridentate aperture; gonotheca (male) compressed, obcordate, attenuated below, broad and truneated above, with a small spine at each side, and a central tubular aperture; (female) elongate, oval below, above three-sided with a prramidal summit, the edges of the pyramid serrated and its basal angles produced into spines."

Distribution.-? Grand Manan (Stimpson); Great Britain (Hincks); Adriatic (Olivi); North Sea (Schulze); Norway (Sars); Bay of Biscay (Beltremieux, teste Hincks).

I have not seen this species, and the above description is taken entire from that of Hincks, which seems to be the best one avalahle. The species may not be American, and is introduced here because it seems that the sy rulurin proturte of stimpson is this form, a view entirely consistent with his deseription, which is as follows: "Cells opposite, elongated, curving ontward, with ovate apertures. Vescicles slender, elongated, subtruncate and covered with spines at their extremities. It differs from S. margareta Hassall, in having more numerous spines at the top of the vescicle and none on its sides." It seems evident that Hincks regarded S. producta as a synonym of $D$. tamarisca, although he does not say so directly. He does, however, assign it to Grand Manan on authority of Stimp-on, in his account of the distribution of the species, and as

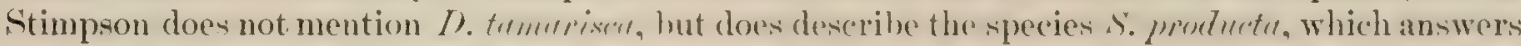
to the description of $D$. tumurised, it seems certain that Hincks regarded the two as identical species.

DIPHASIA FALLAX (Johnston).

(Plate XXLX, figs. 2-6.)

Dynamena pinnata Fuesung, Hist. Irit. Animals, 1828, p. 545.

Sertularia pinnata Jonsstos, British 'Zoophytes, 1838, p. 127.

Sertularia pinnata MacgillivriY, Ann. and Mag., IX, 1842, p. 463.

Sertularia fallax Jomstos, British Zoophyteg, 1847, p. 73.

Sertularia fallax Stmpson, Marine Invert. Grand Manan, 1854, p. 9.

Sertularia fullax ALDer, Cat. Zooph. Northumb., 1857, p. 24.

Diphasia fallax A. Agassiz, North American Acalepha, 1865, p. 142. •

Diphasia fallax Hixcks, British Hydroid Zoophytes, 1868, p. 249.

Diphasia fallax Verrill, Proc. Am. Assn. Adv. Sci., 1873, p. 364.

Diphasia fallax Verrich, Amer. Journ. Sci. and Arta, VII, 187 4 , p. 44.

Diphasia fallax VErriLl, Amer. Journ. Sci. and Arts, V1I, 1874, p. 504.

Diphasia fallax Fewkes, Bullet. Essex Inst., XXIII, 1891, p. 38.

Diphasia fallax Levinses, Vid. Merddel. naturh. Foren., 189:2, p. 55.

Dymamena fallax Bovxevie, Norwegian North Atlantic Exped., 1899, p. 78.

Diphasia fullax Nutrma, Hydroids of the Woods Hole Region, 1901, p. 361.

Diphasia fallax HARgits, American Naturalist, 1901, p. 391.

Diphasia fallax Wniteaves, Marine Insert. Eastern Canada, 1901, 1. 26.

Diphasia fallax S.exundsson, Islandske Hydroider, 1902, p. 66. 
Trophosome.-Colony attaining a height of 3 or 4 inches. Stem not fascicled, proximal part smooth and without regular nodes, remainder divided into regular internodes each of which hears a pair of hydrotheca and sometimes a branch. Branches irregularly alternate, the proximal internode bearing a pair of hydrothecx as do all the others; branches often terminating in a long hooked, tendril-like process and often dividing into branchlets. Hydrothece opposite, tubular, rather short and stout, those of a pair rather widely separated, adnate to branch for about three-fourths their beight, the distal one-fourth being abruptly divergent and ending in a large broadly sinuous margin, the aperture reaching nearly or quite to the branch. Operculum a single large adcauline flap.

Gonosome.-Gonangia borne in rows on front of branches. Female gonangia oblong-ovate in general outline, the summit crowned by four long pointed lobes or flaps of equal size, converging above. The appearance of an internal marsupial chamber is present in mature specimens. Male gonangia much smaller, summit quadrangular, with each angle produced into a tubular process and the center oceupied by a small tubular neek terminating in a minute aperture.

Distribution.-New England coast (Verrill); Grand Manan (Stimpson); mouth of St. Lawrence (Whiteaves); British coasts (Johnston); west coast of Greenland (Levinsen); Tromsoe, Norway (Nars); Ieeland (Semundsion); U. S. Fish Commission Station 760, Narragansett Bay, $8 \frac{1}{4}$ fathoms.

This species seems to be confined to shallow water.

DIPHASIA TROPICA, new species.

(Plate XXX, fig. 1.)

Trophosome.-Colony unbranched, arising from a creeping root-stalk and attaining a height of one-fourth inch. Stem slender, not fascicled, divided into regular internodes, each of which bears a pair of strictly opposite hydrothece. Hydrothecre tubular, five-sided, contingent in front for nearly half their length, searcely touching each other on the posterior side of stem. Three of the sides of each hydrotheca are seen from the front and two from behind. Distal half free and curving regularly outward and a little upward. Margin circular, aperture closed by an opereulum which is adcauline in position. The hydrothece are ornamented throughout by pronounced compressed external ridges ruming entirely around the walls, closely set and parallel to each other, forming a conspicuous and unique ornamentation. Pairs of hydrothece are separated by about their own height.

Gonosome.-Not known.

Distribution.-Shallow water between Eleuthera and Little Cat Island. Collected by the Bahama expedition from the State University of Iowa.

The beatiful and regular annulation and the five sides to the hydrothece are features that render this species peculiarly striking and distinct.

Type slides.-Cat. No. 1980t, U.S.N.M..; Cat. No. 18729, Museum State University of Iowa; also in collection of the author.

DIPHASIA DIGITALIS (Busk).

(Plate XXX, figs. 2-7.)

Sertularia digitalis Busk, Voyage of Irattlesnake, I, 1852, pp. 387, 393.

Desmoscyphus longitheca Aldrax, Mem. Mus. Comp. Zool., V, No. 2, 1877, p. 26.

Diphasia digitalis BALE, Australian Hydroid Zoophytes, 1884, p. 101.

Desmoscyphus acanthocarpus Aldaras, Challenger Report, Hydroida, 1't. 2, 1888, p. 73.

Trophosome. - Stem not fascicled, attaining a height of about $t$ inches, divided into regular but obscure internodes, each of which bears a pair of opposite hydrotheca and occasionally a branch. Branches irregularly alternate, arising from short processes which spring from the postero-lateral surface of the stem, rigid, divided into regular internodes, each of which bears a pair of hydrothece on its anterior face. Hydrothece borne on front of the stem in pairs the individuals of which are contingent on their adcauline sides for almost their entire length, long, 
tubular, squarish in cross section, closely approximated, parallel to each other and to the branch for nearly their contire length, their short fror distal ond bending ontwad and forward; margin simous, but not toothed; aperture large, directed more nearly upward than is usual in this genus; operculum very conspicuous, forming an arched cap over the aperture.

Gonosme. - Gonangia attached to the back of stem, small, pellucid, oblong-oval, with a short, tubular neck and with the walls heset throughout with small, sharp, thorn-like spines.

Distribution. - West Indian region and Florida keys, Bahama expedition from the State University of lowa; off Bahia, Brazil, Chullenger; Key West (Allman); Prince of Wales Channel, 'Torres Strait (Busk); Albetrows Station 2323, lat. N. $23^{\circ} 10^{\prime} 51^{\prime \prime}$, long. W. $82^{\circ} 19^{\prime} 03^{\prime \prime}$,

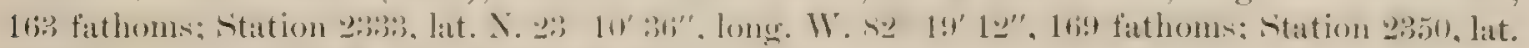
N. $23^{\circ} 10^{\prime} 39^{\prime \prime}$, long. W. $82020^{\prime} 21^{\prime \prime}, 213$ fathoms.

Haviug examined Allman's type of Desmoseyphus acanthocarpus and compared it with his Desmoseyphes Iongithece, I have no hesitation in declaring them identical. Bale ${ }^{1}$ calls attention to the close resemblance between $D$. longithece Allman and $S^{\prime}$. digitalis Busk. The drawings and descriptions of this latter species given by Bale agree exactly with the type of $D$. accuthocarpus Allman. Busk's description has the priority, and the other two must be regarded as synonyms. Type.-In South Kensington Museum, London. Fragment in possession of the author.

? DIPHASIA PULCHRA, new species.

(Plate XXXI, tigs, 1-3.)

Trophosome.-Colony attaining a height of about 5 inches. Stem strongly geniculate, divided into fairly regular internodes, at least in distal part, each internode giving forth a branch, the nodes being just under the processes which support the branches. Branches arranged in a spiral, rising gracefully from the main stem, forming a dense, symmetrical, bushy tuft, giving a very elegant appearance to the colony; branches divided into long internodes, each of which bears several hydrotheca. Hydrotheca rather distant, subalternate, long, piteher-shaped, the distal end narrowed and terminating in a mouth like that of a pitcher; margin with two broad opposite teeth, and a sinuation or excaration on the adcauline side, where the one-flapped operculum is attached.

Gomasome-Not known.

Distribution.-Albatrows Station 2863, lat. N. $48^{\circ} 58^{\prime}$, long. W. $123^{\circ} 10^{\prime}, 67$ fathoms.

This graceful species bears considerable resemblance to certain forms of Thuiurie, but seems to have more attinities for Diphasia, where it is provisionally placed. When the gonosome is diseovered it may be necessary to place it in another genus.

Type slides - Cat. No. 19799, 19800, U.S.N.M.; Cat. No. 18724, Museum of State University of lowa; also in the collection of the author.

DIPHASIA PAARMANNI, new species.

(Plate XXXI, tigs. 16 .)

Trophosome.-Colony erect, ligid, plumiform, attaining a height of about 3 inches. . Stem stiff, straight, the proximal unbranched part smooth and without nodes, the remainder divided into obscure but regular internodes, each of which bears a pair of opposite hydrotheca and at branch. Branches strictly alteruate, stiff, divided from the stem by a sharp basal constriction; internodes regular, each bearing tro alternate hydrothece and divided by oblique nodes. Hydrothece alternate on branches, opposite on main stem, rather distant, about the distal one-third free, tubular, curving gently outward, ending in a sinuous margin shaped like the mouth of at pitcher. Operculum adcauline, consisting of a single flap.

Gonosome.-Gonangia borne in rows along the front of branches. Female gronangia large, oblong-ovate, proximal end narrowing to a short slender pedicel, distal end dome-shaped and consisting of four large lobes with contiguous or coalesed edges arching orer to form the dome; 
an internal marsupium is present in mature specimens. Male gonangia rather slender for this genus, oblong conold, with six to eight longitudinal ridges becoming more prominent distally and ending in a circle of six to eight elevated points, which surround the slender tubular neck which occupies the center of the distal end of the gonangium.

Distribution.-Albatross Station 2415, lat. N. $30^{\circ} 44^{\prime}$, long. W. $79^{\circ} 26^{\prime}, 40$ fathoms: Station 2663, lat. N. $29^{\circ} 39^{\prime}$, long. W. $79^{\circ} 49^{\prime}, 421$ fathoms; Station $2666^{\circ}$, lat. N. $30^{\circ} \pm 7^{\prime} 30^{\prime \prime}$, long. W. $79^{\circ} 49^{\prime}, 270$ fathoms; Station 2668 , lat. N. $30^{\circ} 55^{\prime} 30^{\prime \prime}$, long. W. $79^{\circ} 35^{\prime} 30^{\prime \prime}$, 294 fathoms.

This species seems to be the most southerly in it distribution of all of the typical Diplasia species, and is also found in deeper water thun is usual in this group. It is probably nearest D. pimata, from which it differs in having a sharp constriction at the base of each branch, alternate and more distant hydrotheca, and in the character of the male gonangium. I take pleasure in naming this very beatiful form in honol of Mr. J. H. Parmann, who has done much to elucidate the structure of the operculum in this fimily of hydroids.

Type slides.-Cat. No. 19797, U.S.N.MI. Cat. No. 18726, Museum of State University of Iowa; also in collection of the author.

\section{DIPHASIA CORNICULATA (Murray).}

(Plate XXIX, fig. 1.)

Sertularia corniculata Murkar, Ann. and Mag., 31 ser., V, 1860, p. 251.

Diphasia comiculata A. Agassin, North American Acalephie, 1865, p. 143.

Sertularia corniculate CLark, Hydroids of the Pacific Coast, 1876, p. 251.

"Cells not quite opposite, sometimes nearly alternate, forming an open cup resting on the stem; lip not distinct; exterior margin somewhat projecting at tip; a single one in the axilla of ach pinna. Vescicles pear-shaped, with two long points projecting like horns at the thick end; aperture between then.'

Distribution.-Bay of San Francisco (Murray).

I have not seen this species, and copy the above description, which is entirely inalequate, from the original by Murray. His figure, which I also copy, shows that the gonangia, or at least one of them, resemble that of $D$. tamurixed, but the hydrothece seem much stouter and more nearly opposite.

DIPHASIA KINCAIDI (Nutting).

(Plate XXXI, figs: 7-9.)

Theierie elegues Nutrine, Hydroids of the Harrinan Hxpedition, 1901, 1\% 187.

Thuiurie kinertidi Netrixi, American Satnralist, sept., 1901, p. 789.

Thuiarid elegans Torrex, Hydroida of the l'arific Coast, 1902, p. 14.

Trophosome.-Colony plumose, attaining a height of about 6 inches. Stem not fascicled, with a row of hydrothece on each side, divided by oblique nodes into long and irregular internodes; in distal part each internode bears from two to four branches. Branches irregularly alternate, unbranched for ahout their proximal half, the distal portion dividing into a number of branchlets, the whole giving a very elegant plumose appearance to the colony. Branches divided into irregular internodes by oblique nodes, each internode ordinarily bearing more than two hydrothece. Iiydrothece subalternate, short, stout, pitcher-shaped, the abeauline outline being a double curve and the adcauline a single curve; margin sinnous, like the month of a pitcher. Operculum consisting of a large, slightly vanted adeauline flap. The top of one hydrotheca is separated by a considerable space from the bottom of the one immediately above it.

Gonosome. Gonangia arranged in crowded double rows along the distal parts of the stem and branches, small for this genus, rather slender, oblong-oral, the distal end truncated and entirely oceupied by the large round aperture. There is an internal distal phig which appears as a dark collar in fresh specimens. 'The gonangia have no spines or external projections of any sort.

Distribution.-Berg Inlet and Duteh Harbor, $\Delta$ laska (Nutting). Collected by the IIarriman Alaska Expedition.

Type slidex.-Cat. Nos. 19795, 19796, U.S.N.M. Cat. No. 18\%25, Museum of State University of Iow:a also in the collection of the anthor. 


\section{ABIETINARIA Kirchenpauer (modified).}

Trophosome.-Hydrothece not strictly opposite, more or less bottle-shaped (the proximal portion turgid, distal portion marrowed), operculum of a single adcauline llap, margin usually without teeth.

Gonosome-Gonangia plain, corrugated or ribbed, without lateral spines and without an interual marsupium.

'This genus was proposed by Kirchenpatuer' to include a few species allied to Sertulrevid abietinu of authors, his formal characterization being as follows, freely translated:

Sertularians with branched stem. Stem or branch bearing pinnate branches. Hydrotheca Hask-shaped, decidedly bulging (rentrieose), with a tubulax neck, and aperture directed laterally.

Neither Kirchenpauer nor Marktanner-'Turneretscher, ${ }^{2}$ who adopted this genus, recognized the important character of an adcauline operculum, the latter writer expressly stating that Abietinuriu is composed of nonoperculate forms. Levinsen, on the other hand, placed great stress on the opereulum, as we have seen, and included all species with a single-flapped adeatuline operculum in the genus Diphusiu. ${ }^{3}$ Here, again, it seems to me, that reliance on a single character has been misleading and has resulted in an unnatural association of species.

The genus as above defined appears to be a fairly natural group, and one easily identified in nearly all cases. Of course the operculum is sometimes difficult to make out by the novice, but any good observer should be able to detect it and to decide whether it is adeauline or abeauline, thus differentiating between Abietinnin and Thuirere in cases where other characters fail. In most cuses the general shape of the hydrothece will at once determine the matter.

\section{POINTS OF INTERGRADATION BETWFEN IBIETINARIA AND OTHER GLNERA.}

With Theneria, in general shape of hydrotheca, extent of immersion of hydrothecan, and character of margin and aperture, as in -1. unnulutu, Kirchenpauer, 1. turgidu Clark, and A. riguntea Clark. In all of these cases the operculum is evidently of a single adcauline tlap.

With Diphaxie, in the character of the margin and opercuhum. This prevails throughout the genus, and makes it necessary to consider other characters that are given in the definition of the genus Abietimerin, particularly the shape of the hydrothece. In those cases where the hydrothece are not typically bottle-shaped, as in A. turgide and A. giguented, the orifice is still much more constricted than the hody of the hydrotheca, and in none of these cases does the gronosome resemble that which is characterintic of Jiphesice.

This genus is essentially arctic and north temperate in distribution, a great majority of species oceurring in particularly luxuriant colonies in the cold waters of Alaska. Not a single American species is found in tropical seas, and none extends south of California, on the Pacific coast, or south of New England, on our North Atlantic coast. One species, A. abintince, extends to the Mediterranean. on the cast shores of the Atlantic.

Wore than one-fourth of atcauline wall free

Hydrothece not leaning forward in noticent, le dewree.

Internodes of stem fairly rextlar, each hearing a brameh.

Hydrothece large and fairly robust.

Gonangia not top-shaped nor anmulated.

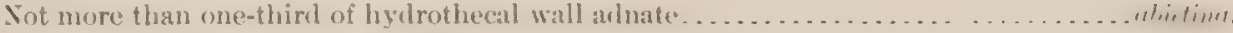

It least half of adcauline wall adnate.

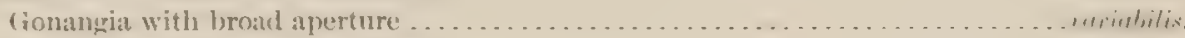

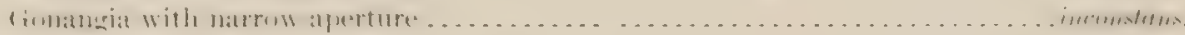

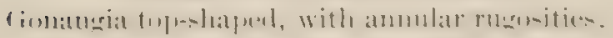

.........ni

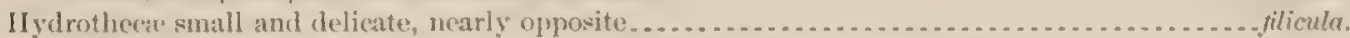

${ }^{1}$ Nordische Gattumgen und Irten, 18st, p1]. 29-31.

${ }^{2}$ Die Ifydroiden des $\mathbf{k}$. $\mathrm{k}$. naturhistorichen Hofmuseum, 1s90, pp. 22:0, 244.

"Vilenskabelige Medlelelser fra den naturhistoriske Forening, Kjøbenhavn, 1s9:, 1. 196. 
Internodes of stem irregular.

Distal ends of hydrothece very greatly narrowed, hydrothece very short ....................trkski.

Distal ends of hydrothece much compressed . . . . . . . . . . . . . . . . . . . . . . . . . . . . . . . . . . . Distal ends of hydrothece not greatly compressed.

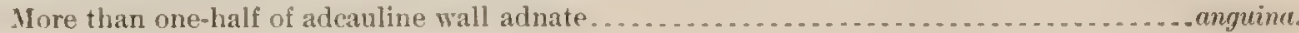

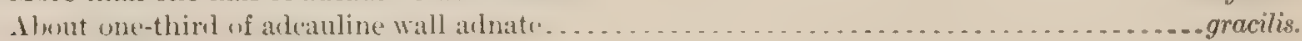

Hydrothec:e leaning forward in noticeable degree.

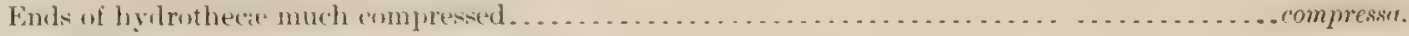

Ends of hydrotheca not noticeably compressed.

Hyilrothecas' not curved......

Hydrothece distinctly curved.

Hydrothecal margin with two adcauline teeth in some cases, and without teeth in

others, in the same colony. Gonangia annulated . . . . . . . . . . . . . . . . . . . . . . .

Margin always without teeth, gonangia with longitudinal ribs. . . . . . . . . . . . . . . .

Leas than one-fourth of adcauline wall free.

Stem very dark, thick, and woody, not translucent . . . . . . . . . . . . . . . . . . . . . . . . . . . . . . . . . . . .

Stem thick, but not woody, horn color, translucent.

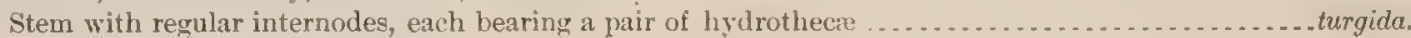

Stem with irregular internodes. ... . . . . . . . . . . . .

\section{ABIETINARIA ABIETINA (Linnæus).}

(Plate XXXII, tius. 1-3.)

Sea fir Eulis, Essay Nat. Hist. Cor., 1755, p. 4.

Sertularia abietina Linn.eus, Systema Naturie, 1758, p. 808.

Sertularia abietina Linn.eus, Fauna Suecica, 1761, p. 540.

Sertularia abietina HouTtuYN, Natuurlyke Historie, XVII, 1761-73, 1. 534.

Sertularia abietina BASTER, Dissertation de Zoophytis, 1762, 1. 113.

Sertularia abietina PALLAs, Elenchus Zoophytorum, 1766, p. 133.

Sertularia abietina Lins.eus, Systema Nature, 1767, p. 1307.

Sertularia abietina BoDD.tent, Lyst der Plant-Dieren, 1768, p. 166.

Sertularia abietina OLAfsen and Povelsen, Rejse igiennem Island. Soröe, 1772, p. 40.

Sertularia abietina MaRatTi, De Plantis Zoophytis, 1776, p. 27.

Sertularia ábietina Mẗ́LLER, Zoologise Danicre, 1776, P. 255.

Sertularia abietina FABRICI's, Fauna Groenlandica, 1780, p. 442.

Sertularia abietina Groxovits, Zoophylacium gronovianum, 1781, 1. 35ं.

Sertularia abietina Ellis and Solander, Nat. Hist. Zooph., 1786, p. 36.

Sertularia abietina WiLkiss and HERBs, Charakteristik der Thierptlanzen, 1787, 11. 172.

Sertularia abietina Grelix, Systema Nature (Linneus), 1788-93, p. 3845.

Serlularia abietina EsPEr, Die Pflanzenthiere in Abbildungen, III, 1788-1830, p. 171.

Sertularia abietinn Berk Ennout, Synops. Nat. Hist. Great Britain and Ireland, I, 1789, p. 216.

Sertularia abietina Porrkt, Voyage en Barbarie, II, 1789, p. 70.

Sertularia abictina EsPer, Fortsetzungen der Pflanzenthiere, II, 1794-1806, pl. I.

Sertularia nbietina Bosc, Hist. Nat. des Vers, II, 1802, 1. 92.

Sertularia abietina Turton, British Fauna, 1807, p. 212.

Sertulariu abietinu Jasiesos, Cat. Animals Class Vermes, 1811, p. 564.

Sertularia abietina L.trounocx, Bull. philomatique, 1812, p. 184.

- Nigcllastrum abietimum OEEv, Lehrbuch der Naturgeschichte, 1815, 1. 43.

Sertularia abietina LАмАлск, Hist. nat. anim. sans vert., II, 1816, p. 116.

Sertularia abietina Lasorrotx, Hist. des Polypiers, 1816, p. 187.

Sertularia abietina StEWART, Elements Nat. Hist. Animal King., II, 1817, 1. 441.

Sertularia abietina ScmwergGer, Handbuch ler Naturgeschichte, 1820, p. 427.

Sertularia abietina L.wocroux, Exposition Méthodique, 18:1, p. 12.

Sertularia abietina ne Blainvilue, Manuel d'Actinologie, 1834, 1) 480.

Sermlarin abietina OKEx, Allgemeine Naturgeschichte, 18:35, p. 80.

Serhlarin abietina L.MnRck, Hist. nat. anim. sans vert., 1836, p. 141.

Sertularia abietina Gray. British Animals, 1841, 1. 7\%.

Sertularia abietina HAsssLl, Ann. and Mag., VI, 1841, p. 168.

'Dynamena abietima Fismisg, British Animals, 1842, p. 543.

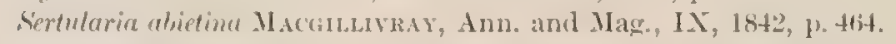

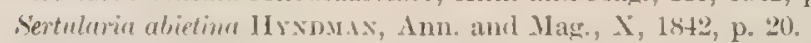

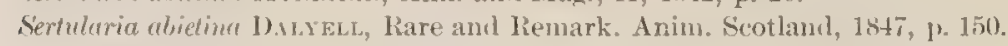

Sertulariu abietina Jomstos, Hist. British Zoophytes, 2d ed., 1847, p. 75.

Sertularia abietina Giosse, Devonshire coast, 1853, p. 434. 
Sertularir abietina ALDER, Cat. Zooph. Northumb., 1857, p. 25.

Sertularia abietina ALExaxDek A6issi, North American Acalephap, 1865, p. 143.

Sertularia abietina Helen, \%ooph. and lichinodermen, 1868, ]. :3.

Serlularia alietina vas Bexenes, Famna Littorale, 1866, p. 185.

Sertularia abielina Hıcks, British Hydroids, 18ti, 1). 236t.

Sertularia abietina Schulze, Lordsee Exped., 1872, p. 132.

Sertularia abietina McIstosn, Ann. and Mag., th ser., XII, 187t, 1, 213.

Sertularia abietinn MEReschkowsky, Ann, and Mag., 5th ser., I, 1878, p. 32t,

Sertularia abietina WiNTHER, Naturhist. Tidsskrift, 1879-80, p. 250.

:1bietinaria abietina Kirchexpaver, Nordische Gattungen, 1884, 1. 31.

Sertularia abietina Beran, Goplepolyper fra Kara Havet, 1857, p. 335.

Sertularia abietina Allsax, Challenger Report, Iydroida, Pt. 2, 1888, p. 62.

Sertularia abietina Driesch, Tektonische Studien, 1890, p. 202.

Abietinaria abietina MARKTAxxer-TurNeretsciner, Hydroiden des k. k. naturhist. Hofmuseums, 1890, p. 245.

Sertularia abietina Bourse, Hydroids of Plymouth, 1890, p. 397.

Diphasia abietina Levisses, Vid. Meddel, naturh. Foren., 1892, j). 56.

Sertularia abietina Crawforn, Ann. and Mag., 6th ser., XVI, 1895, p. 261.

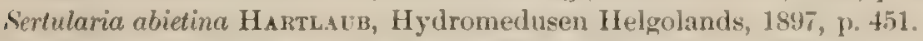

-Thuiaria abietina Boxwevie, Norwegian North Atl. Exped., 1899, p. 10.

- Sertularella abietina Nuxtisc, Hydroids of the Woods Hole Region; 1901, p. 361.

Sertularia abietina Wnitesves, Cat. Marine Invert. Eastern Canada, 1901, p. 25.

Diphrsia abietina S.muxpssos, Bidrag til Kundskaben om islandske Iydroider, 1902, p. 65.

Trophosome-Colony sometimes attaining a height of 12 to 14 inches. Main stem heavy, Hexuose or feebly geniculate, divided into fairly regular internodes by oblique nodes, each internode bearing a branch and two hydrothece on one side and one hydrotheca on the other. Branches regularly alternate, pinnate, themselves sometimes branched, divided into internodes of very irregular length, bearing from two to many hydrothece. Hydrotheca very large, subopposite to alternate, flask-shaped or bottle-shaped, gibbous below. narrowing above into a gracefully curved neck ending in a round smooth margin which incloses an aperture directed upward and slightly outward; distal one-third entirely free from the hydrocaulus; opereulum (seldom seen in preserved specimens) consisting of a single adeauline thap.

Gonosme.-Gonangia borne on the upper sides of the branches, rather small in comparison to the hydrothece, oval, with a very short pedicel, a short collar, wide terminal aperture, and :n operculum. Some specimens are more or less annulated.

Distribution.-One of the common species on European and British coasts. Woods Hole Region (Nutting), Newfoundland (Stimpson), Gulf of St. Lawrence (Whiteaves), Labrador (Packard), Mediterranean (Palliss), Adriativ (Helker), Bolgium (van Beneden), British coasts

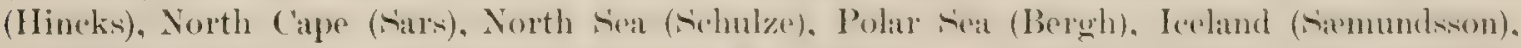
Greenland (Fabricius), Alaska (Lieut. Geo. M. Stoney, U. S. Navy), Bering Sea (Albatross collections), off Washington (Albutross collections); Albutross Station 2S6t, lat. N. $48^{\circ} 22^{\prime}$, long. W. $122^{\circ} 51^{\prime}, 48$ fathoms; Station 3159 , lat. $N^{\prime} 37^{\circ}+\tau^{\prime} 20^{\prime \prime}$, long. W. $123^{\circ} 10^{\prime}$, 27 fathoms; Station 3443 , lat. N. $48^{\circ} 13^{\prime} 30^{\prime \prime}$, long. W. $123^{\circ} 11^{\prime} 20^{\prime \prime}, 97$ fathous; Station 3546, lat. N. $54^{\circ} 12^{\prime}$, long. W. $165^{\circ} 42^{\prime}, 36$ fathoms; Station 3552, lat. N. $56^{\circ} 28^{\prime}$, long. W. $1699^{\circ} 25^{\prime}, 5+$ fathoms.

'This species flourishes best in northern waters, and I have no record of its occurrence south of Massachusetts on our east coast nor south of Washington on the Pacific. 'The Mediterranean record of Pallas seems somewhat doubtful. It appear's to thrive best in depths of 30 to 100$)$ fathoms.

\section{ABIETINARIA VARIABILIS (Clark).}

(1'late XXXII, tigs. $4-7$.

Sertulario variabilis CLARK, Alaskan Hydroids, 1576, p. 22:1.

- Ibietinaria variabilis KIRCHEXPACR, Nordische Gattungen, 1854, 1). 35.

Sertularia variabilis Netrixa, Iydroids of Alaska and P'uget Sound, 1899, p. 711.

Thuiaria variabilis Notrixa, Hydroids of the Harriman Exped., 1901, p. 185.

Trophosome.-Colony attaining a height of about 5 inches in largest specimens. Stem stout, rigid, flexuose, divided into fairly constant internodes each of which bears two hydrotheca and a branch on one side and a single hydrotheea on the other in some specimens, while in others the internodes are long and irregular and the hranches far apart. Branches alternate typically, but 
sometimes very irregularly so, often divided into internodes each of which bears two hydrotheca. but in other cases with no nodes at all, unless the constriction of the base be regarded as such. Hydrotheca excedingly variable, those in typical specimens collected by Dr. Dall are very short and stout, subalternate, swollen below, rapidy constricting throughout their free distal third, and ending in a smooth circular margin and aperture directed upward and outward. There is often a sharp constriction or indentation just below the margin on the adeauline side. The operculum could not be seen in specimens examined, but is doubtless present in fresh specimen. and consists of one adcauline flap. All intergradations occur between the hydrotheca above described and one much more slender with distal one-half free and aperture horizontal.

Gonosome--Gonangia ovate, small, borne on upper sides of branches, with a large distal aperture and a row of chitinous points some distance below the aperture. Another form described by Clark is pyriform instead of ovate.

Distribution.-Abundant on Alaskan coasts, Aleutian Islands, Bering Ser, San Miguel Island, California (Dall); Hlbatrose Station 2857, lat. N. $58^{\circ} 05^{\prime}$, long. W. $150^{\circ} 46^{\prime}, 51$ fathoms; Station 2864 , Iat. N. $48^{\circ} 22^{\prime}$, long. W'. $122^{\circ} 51^{\prime}, 48$ fathoms; Station 2866 , lat. N. $48^{\circ} 09^{\prime}$, long. WV. $125^{\circ} 03^{\prime}$, 171 fathoms; Station 2886 , lat. N. $43^{\circ} 59^{\prime}$, long. W. $124^{\circ} 56^{\prime} 30^{\prime \prime}$, 50 fathoms; Station 3231 , lat. N. $58^{\circ} 35^{\prime}$, long. W. $157^{\circ} 28^{\prime} 50^{\prime \prime}, 12$ fathoms; Station 3465, lat. N. $48^{\circ} 21^{\prime}$, long. W. $122^{\circ} 14^{\prime}, 48$ fathoms; Station 3599, lat. N. $52^{\circ} 05^{\prime}$, long. E. $177^{\circ} 40^{\prime}, 55$ fathoms; Puget Sound (Nutting).

This is one of the most variable species known, and it is fortumate that Dr. Dall secured a large series showing the intergradations between the extreme forms. The species ranges from shallow water to a depth of 171 fathoms.

Type-In the collection of the U. S. National Museum.

\section{ABIETINARIA INCONSTANS (Clark).}

(Plate XXXII, figs. 1-2.)

Sertularic inconstans CL.IRK, Alaskan Hydroids, 1876, p. 22.2.

Alietimurie inemstous Kincuexpauter, Norlische Gattungen, 1884, 1) it.

Trophosome.-Colony attaining a height of about 1 inch in specimens examined. Stem very stifl and coarse, dark colored, divided into numerous sharply separated internodes on proximal unbranched portion; branched portion divided into regular internodes by oblique nodes; internodes each bearing a branch and two hydrothece on one side and a single hydrotheca on the other. Branches erect, almost parallel with main stem, forming a dehse tuft, alternate, basal portion marked by several sharp annulated constrictions, internodes short usually bearing one or two pairs of hydrotheea. Hydrothece very similar to those of 1 . filicula, but much heavier and coarser, although not attaining anything like the size of 1. whitim, swollen below, the distal third free, narrowing to a cireular margin beneath the arleauline side of which is a constriction and thickening of the hydrothecal wall; aperture facing upward. Sometimes there is a chitinous tooth projecting inward from the adcauline margin. Operculum not seen, but doubtless of the regular Abietimuria pattern.

fomseme.- "The gonangia show the greatent amount of variation of any species that I know of; it is impossible to describe their form, for there is not one of them that seems to agree with any other."1 "Sessile, large, orifice terminal, small, discoidal; outline very irregular, tapering usually at the base; borne in two rows on distal portion of min stem." The present writer has not seen the gonangia.

Distribution.-Chalaska beach (Dall). 'This species can readily be distinguished from its nearest ally, A. filiculu, by its thick, dark stems, and very deep annulations and nodes, as well as by the heavier and denser lyydrothece and ascending branches.

Typre.-In the collection of the U. К. National X̣Tuseum. 


\section{ABIETINARIA COEI (Nutting).}

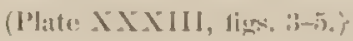

Thuiaria coei NutTwa, Ilyalmids of the Harrinan lixpeclition, 1901, p. 185.

Trophosme.-Colony attaining a height of 3 inclies. Stem with several deep annulations near its base, which is constricted; abore these annulations the stem is straight, divided into regular short internodes, each bearing a par of nearly opposite hydrothecas above the origin of the first branch the stem becomes geniculate, divided into regular internodes, each of which bears a branch and two hydrotheca on one side, and a single hydrotheca on the other. Branches alternating, not branching again, rigid, divided into irregular, rather short internodes, each of which usually bears more than one pair of hydrotheca, although in many terminal branches there is seen the regular sertularian arrangement of an internode to each pair of hydrotheca. Hydrothecre of the filicula type, subopposite, proximal end swollen, outer edge straight or with a simple curve, distal one-half free and gradually narrowing to the round aperture which opens upward. There is a slight constriction and thickening of the hydrothceal wall on the adcauline side, and a regularly curved chitinous thickening on the inner side of the hydrotheca. Operculum consisting of a single flap attached to the adcauline side of margin.

Gonosome. - Gonangia large, borne on front of main stem and upper sides of branches; topshaped, with a broad collar and large terminal aperture; proximal portion with broad annular corrugations and nurrowing rapidly to a curved short pedicel.

Distribution.-Dutch Harbor, Mlaska. Collected by Dr. W. R. Coe of the Harriman Expedition, after whom the species is numed; 'Tledis Village, near Susk, British Columbia, . James G. Swan.

Type slides.-Cat. No. 19904, 19906, U.S.N.M. Cat. No. 18749, Museum of State Unirersity of Iowa; also in the collection of the atuthor.

ABIETINARIA FILICULA (Ellis and Solander).

('late XXIIV, tig. 1.)

Sertularia filicula Eulds and Sorander, Nat. Hist. Zoophytes, 1786, p. 57.

Serlularia fliculn GreLix, Systema Naturae (Linneus), 1788-9:3, p. 3853.

Sertularia filicula Bosc, Hist. Nat. des Vers, III, 1802, 1. 97.

Sertularia filicule TukTos, British Fauna, 1807, p. 215.

Sertularir filieula Jasresox, Catt. Inim. Class Vermes, 1811, p. 56it.

Sertularia filieulu L.dmurck, Hist. Nat. Anim. sans Vert., II, 1816, p. 119.

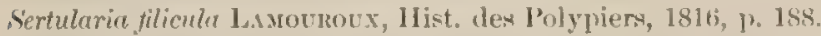

Sertularia filicula Stewart, Elements Nat. Hist. Animal Kingtom, II, 1817, p. +45 .

Serfularia filicula Lasovmoux, lexposition Méthodique, 1821, p. 12.

Serfularia filicula Bone, Ilist. Nat. des. Vers, 1s30, 11. 114.

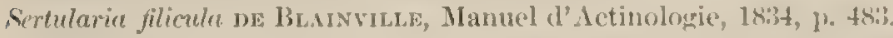

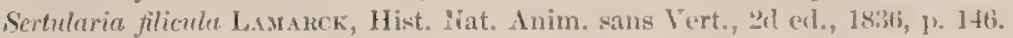

Sertulurie filieule H.ssids, $\mathrm{Ann}$. and Mag., VI, 18t1, p. 16s

Dinemene filicula Fumesa, British Animals, 1842, 1. 54t.

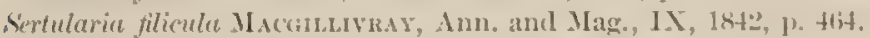

Sertularia filicula Jonsstos, Hist. Brit. '/ooph., 18t7, p. 7ti.

Sertularia filicule Gras, List British AnimaIs, 1sts, 1. 72.

Sertularia flicula Stmpox, Marine Invert. (irand Manm, 18ñt, 1. 8. .

Sertularia fliculn AL.sen, Cat. Zooph. Northumb, 18.57, p. 25.).

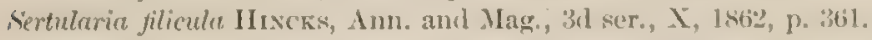

D) ynamena filicula Kincuexp'ster, Neue Sertulariden, 186t, 10.7.

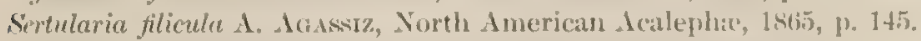

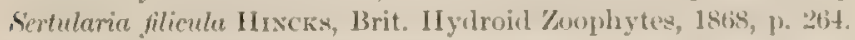

Sertularie filienla MoIntosir, Ann. and Mag., th ser., XIII, 187t, p. 2213.

Sertularia filimulu CLARk, Alaskan Hydroids, 1876, 1). 219.

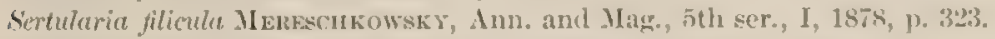

Serfularia filimla. Wixtren, Naturhist. Tilsskrift, 1879-80, 1. 277.

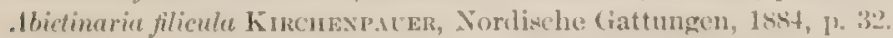

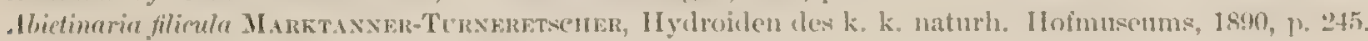


Diphasia filicula Levinser, Vid. Meddel. naturh. Foren., 189:2, p. 57.

Sertularia filicula Crawforn, Ann. and Mag, 6th ser., XVI, 1895, [). 261.

Thuiaria filicula Boxwers, Sorwegian North Atlantic Exped., 1899, p. 8t.

Thuiorir filicula Whitesve, Cat. Iarine Invert. Eastem Canada, 1901, 1).25.

PSertularin filiculu Torner, Hydroida of Pacific Coast, 1902, P. 68.

Trophosome.-Almost an epitome of A. abietime. Colony attaining a height of about 2 inches. Main stem straight on proximal unbranched portion, geniculate throughout the rest of its extent, divided into fairly regular internodes in the branched portion, each internode bearing a branch and two hydrothece on one side and a single hydrotheca on the other. Lower portion with long and irregular internodes. Branches often branching again, divided into irregular internodes which usually bear sereral hydrothece each. Hydrothece more nearly opposite than in A. abietina, and not so closely approximated, slender, delicate, bottle-shaped, the proximal portion being gibbous, and the distal one-half to one-third narrowing into a slender recurved neck ending in a round aperture which points almost directly upward and is furnished with a one-flapped operculum attached to the adcauline side. Immediately below the attachment of the opereulum is a sharp constriction or indentation of the hydrothecal neck.

Gonosome.-Gonangia pyriform, with a short, narrow neck ending in a small, round aperture. They are found both on the stem and branches.

Distribution.-New England coast, Cape Cod to Gulf of St. Lawrence (Verrill); Grand Manan (Stimpson); Labrador (Packard); Alaska (Clark); Albatross Station 2565, lat. N. $48^{\circ} 12^{\prime}$, long. W. $122^{\circ} 49^{\prime}$, 40 fathoms. Great Britain, north of Scotland to Cornwall (Hincks); White Sea (Mereschkowsky); Christiania (Marktanner-'Turneretscher); Greenland (Levinsen); North Atlantic (Bonnevie).

I have not seen this species on our Atlantic coast, although I have examined a great deal of material from that region. If it occur's there it is probably rare. Kirchenpaner ${ }^{1}$ considers that the specimens from Alaska described by Clark are a distinct variety from the British form. I can see no material difference between the two. The resemblance between this species and $A$. abietina is so exact in all except size that they would doubtless be regurded as identical, could intergrading specimens be found. Such specimens, however, are not fortheoming, and hence the two species must be held as good.

\section{ABIETINARIA TRASKI (Torrey).}

(Plate XXXIII, figs. (i-11.)

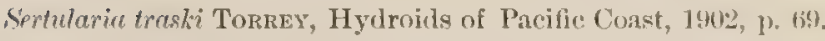

Trophosme.-Colony attaining a height of about 6 inches. Stem straight, thick, not fascicled; lower portion without branches or hydrotheca, smooth, divided into irregular, usually long internodes by deep nodes; upper portion with a donble row of bydrothece and alternate branches, there being three hydrotheca between adjacent branches on the same side. Branches much more slender than the stem, alternate, with a deep constriction near the base, nodes entirely absent or distant. Hydrotheca alternate, rather distant, short and thick, with subtriangular bodies and constricted neck ending in an even margin which is flattened on the adcauline side; aperture directed upward; opereulum consisting of a single adcauline thap.

fomosome--Gonangia small, ovate, sessile, without ornamentation of any kind; aperture large, round; no collar.

Distribution.-San Pedro, California (Torrey); Albatross Station 2861, lat. N. $51^{\circ} 14^{\prime}$, long. IV. 12950 , 204 fathoms; Station 2873, lat. N. $48^{\circ} 30^{\prime}$, long. W. $12 t^{\circ} 57^{\prime}, 40$ fathoms; Stution 2886 , lat. N. $43^{\circ} 59^{\prime}$, long. W. $124^{\circ} 56^{\prime} 30^{\prime \prime}$, 50 fathoms; Station 3192 , lat. N. $35^{\circ} 33^{\prime} 40^{\prime \prime}$, long. W. $1211^{\circ}$. 101 fathoms.

This species seems quite distinct, the difference in size hetween stem and branches and the triangular shape of the hydrothece being the main diagnostic features.

Type.-In the collection of the University of Californiar. 
ABIETINARIA AMPHORA, new species.

(I'late XXXIV, figs :-4.)

Trophosome. Colong about 4 inches high, consisting of al single struight stem pinnately branched. Stem neither sinuox nor flexuose, proximal unbranched portion deeply but irregularly annulated and without hydrothees; distal branched portion with distant and very irregular

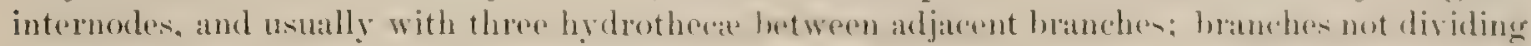
into branchlets, nodes sometimes entirely absent, usually very distant, there often being but one on a branch, besides the basal constriction. Hydrothece subopposite to subalternate, much more

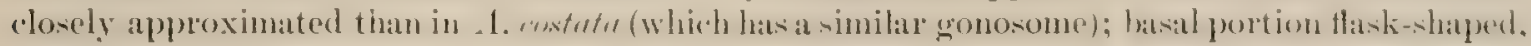
distal one-half free and curved outward and then upward; margin without teeth, often berring collapsible tubular membrane; distal end of hydrothece dorso-rentrally compressed; aperture oval, directed upward and slightly inward; operculum consisting of a single adcauline flap.

Gonosome.-Gonangia borne on front of stem and sometimes on basal parts of branches, very large, slender, with long neck and round terminal aperture. There are four or five strong longitudinal ridges or crests rumning from base of neck to near the pedicel.

Distribution.-Albatrose Station 2841 , lat. N. $54^{\circ} 18^{\prime}$, long. W. $1655^{\circ} 55^{\prime}$, 56 fathoms; Station 2866, lat. N. $48^{\circ} 09^{\prime}$, long. W. $125^{\circ} 03^{\prime}, 171$ fathoms; Whidley Island, Puget Sound (specimen from Professor 'Trevor Kincaid).

This species closely resembles A. aledemderi, but its hydrothece are not straight, but curved. as is common in the genus. The gonosomes of the two species are entirely different.

Type slides. Cat. Nos. 195\%1, 19900, U.A.N.M. Cat. No. 1s7t5, Museum State University of lowa: also in the collection of the author.

\section{ABIETINARIA ANGUINA (Trask).}

('late XXXIV, tigs. 5-7.)

Sertularin anguina Trask, I'roc. Cal. Acal., 1857, p. 112.

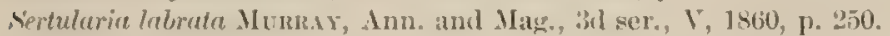

Sertularia anguina A. Acissiz, North Aner. Acalephas", 18tio, p. 14.

Sertularie ampmine var. robustu Clakk, Iyclmids of Pacitie Coast, 1876, p. 255.

Alicharia lebiatu hinchexpacen, Nordische Gattungen, 188t, 1) 34.

Trophersome.-Colony attaining a height of about 5 inches. Stem genienlate except on proximal unbranched portion, where it is straight and divided into unequal internodes, distal branched portion divided into unequal internodes, the tendency being to have a branch and two hydrothecas on one side and a single hydrotheca on the other side of each internode. Branches alternate, divided into unequal internodes, the tendency being to have a pair of hydrotheca to cach internode. As a rule the branches do not subdivide into branchlets. Hydrotheca large, of the abietina type, subopposite to alternate, batsal part swollen, distal one-third to one-half narrowing and rurving to the round, partially everted margin surrounding the aperture which is usually directed upward; in some cases the margin is distincty everted all the way around, while in others there is no eversion whatever; operculum adcauline, of a single flap.

Gonosme-C Gonangia small, ovate, with short collar and small aperture, curved slightly in upper part; collar marked with short, spine-like vertical internal projections. Gonangia borne on front of stem and upper side of branches.

Distribution.-San Diego, California (Hemphill); Monterey Bay (Anderson); Vancouver Island (Dawson); San Francisco (Trask); Bering Sea (Aloutrose collections); Albutrows Station 2842, lat. N. $54^{\circ} 15$ ', long. W. $166^{\circ} 03^{\prime}, 72$ fathoms; Station 3230 , lat. N. $58^{\circ} 31^{\prime} 3 v^{\prime \prime}$, long. W. $157^{\circ} 13^{\prime} 30^{\prime \prime}$, 30 fathoms; Station 3599, lat. N. 52 05', long. W. $177^{\circ} 40^{\prime}$, 55 fathoms.

The specimens that I have seen are from Santa Bathara, California, and Bering Sea, and they all agree well with Doctor Clark's description of sertulario anquime var. rolustu. The A. lubiata Murray of Kirchenpaner (incorrectly spelled lubintu by Kirchenpaner) cannot be identified with certainty by his description, but it may perhaps be identical with $A$. coci Nutting. I am unable to agree with Doctor 'Torrey in considering this species identical with A. filiculu. ${ }^{1}$

'Hydroida of the Parific Coast, p. 6s. It is posvible that the name cumpinu should be retained for the var. robusti of Clark, which is apparently distinct. 


\section{ABIETINARIA GRACILIS, new species.}

(I'late XXXV, Higs. 1-2.)

Trophosome.-The largest colony examined was about 3 inches high. Main stem straggling in habit, nearly straight below the lowest branch, the branch-bearing portion being geniculate, divided into irregular internodes, the tendency being to have a branch and two hydrotheca on one side and one hydrotheca on the other. Branches distant, irregularly alternate, often dividing into branchlets, usually arising from near the base of a hydrotheea, but sometimes springing from the lumen of the hydrotheca as in the specimen figured; divided into irregular internodes. some of which bear but one or two hydrothece. Hydrothece subopposite to alternate, more distant than in other species of the genus and more slender distally; basal portion tlask-shaped, more than the distal half free and gracefully narrowing until near the end, where it expands into an everted rim around the aperture which is abruptly turned upward; operculum consisting of one adcauline flap.

Gonosome.-Gonangia borne on front of main stem, flask-shaped, with short neck and round aperture, ornamented externally with about six conspicuous longitudinal ridges.

Distribution. - Ilbatross Station 2873 , lat. N. $48^{\circ} 30^{\prime}$, long. W. $12 t^{\circ} 57^{\prime}$, 40 fathoms; Station 3480 , lat. N. $52^{\circ} 06^{\prime}$, long. W. $171^{\circ}+5^{\prime}, 283$ fathoms; Station 35999 , lat. N. $52^{\circ} 05^{\prime}$, long. E. $177^{\circ}$ $40^{\prime}, 55$ fathoms.

The hydrothece of this species are among the most elegantly formed that I have seen among the Sertularida. The whole structure of the colony is much less compact than in its allies, bearing more distant branches and hydrothece and having a more straggling habit of growth. The hydrotheca are about the size of A. filiculu, but their shape is entirely different, as can be seen by comparing the figures.

Type slides.-Cat. Nos. 19914, 19915, U.S.N.M. Cat. No. 18754, Museum of State University of Iowa; also in the collection of the author.

\section{ABIETINARIA COMPRESSA (Mereschkowsky).}

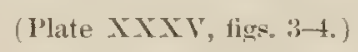

Sertularia compressa MIfrescrikowsky, Ann. and Mag., 5th ser., II, 1878, p. 446.

"Trophosome.-Hydrorhiza in the form of stolons. Hydrocaulus short, erect, not angular, rather rigid, divided into irregular internodes, only giving off very few ramifications. Branches arranged alternately and regularly on two sides of the principal stem, straight, also divided into irregular internodes. Hydrothece arringed alternately, subopposite, one to three pairs on each internode, the base inflated and rounded, the upper lalf strongly compressed in a plane vertical to the plane of ramitication of the colony. Aperture oval, compressed, long hut narrow, with two angles on the two sides, and two very slightly developed teeth."

Gronosome.-Unknown.

Locality.-Port $\Lambda$ jan (M. Wosnessensky).

I have not seen this species, and have copied the original description entire. I am unable to find any mention of Port Ajan in the atlas at my disposal, and the species may not be American, although all specimens described hy Mereschkowsy in the article referred to are from the North Pacitic.

Type.-In the collection of the Academy of Sciences, St. Petersburg.

ABIETINARIA ALEXANDERI, new species.

(Plate XXXY, figs, 5-8.)

Trophosome.-Colony attaining a beight of about 6 inches. Main stem straight, divided into fairly regular internodes, each of which ordinarily hears a branch and two hydrothece on one side and a single hydrotheea on the other. Branches alternate, rarely giving forth branchlets, divided into irregular internodes, ach bearing several hydrothece. Hydrothece subalternate, 
straight, the basal part being flask-shaped, and the distal portion tubular and not curving at in allied species, about the distal half free, and both upper and lower ontlines of free portions con. cave; aperture oval, marerin without definite tecth, although it is often more or less sinuous and sometimes with several reduplications: hydrotheca dirceted forward, upward, and outward; operculum a single adcauline vallve.

Gonosome- Gonangia horne mostly in rows on upper sides of distal branches, small, oroid, without neck; aperture obscurely polygonal, marked by four or five fine durk meridional lines giving the effect of radial canals on sessile meduse.

Distribution.-Albutross Station $28+1$, lat. N. $54^{\circ} 18^{\prime}$, long. $11.165555^{\prime}, 56$ fathoms; Station 3599 , lat. N. $52^{\circ} 5^{\prime}$, long. W. $177^{\circ} 40^{\prime}$. 55 fathoms.

'This fine sertularian differs material!y from others of the genus in having the hydrotheca standing ont rigid and straight, without the gentle curve to the distal free portion that grives such grace to the other species of the grenus Abietimure. 'The margin is apt to be jugrged and have the appeararice of being toothed, but this is not constant. The medusa-like appearance of the gonangia is often quite striking. I take pleasure in naming this species after my friend, Mr. A. 13. Alexander, whose long and finithful service on the U. S. Fish Commission steaner Albatrows has done so much for the cause of deep-sea investigation.

Typres slidew - Cat. No. 19519, 19820 U.S.N.M.; Cat. No. 1st4t, Museum of State University of Iowa; also in the collection of the author.

\section{ABIETINARIA GREENEI (Murray).}

(Plate XXIVI, figs. 1-8.)

Sertularie tricuspidate MurraY, Ann: and Mare, 3d ser., V, 1860, 1). 2200).

Srrtularie greenei MURßı, Ann. and Mag., 3d ser., V, 1860, 1. 504.

Colulina greenei A. A(iAssi\%, North American Acalephax, 1865), p. 147.

Sertularia greenei CLask, Ifydroids of P'acific Coast, 1876, 12. 257.

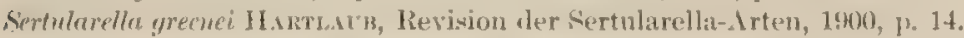

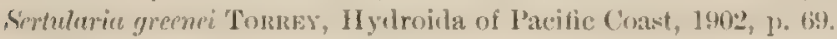

Trophosmme-Colony a dense cluster of erect stems. Sten attaining a height of ahout $t$ inches, not fascicled, slightly sinuous, with a few annulations at its base, with a double row of suhopposite to subalternate hydrotheca throughout its length, divided into very irregular internodes by straight nodes. Branches rather distant, alternate, erect, each with a deep constriction at its base, divided into irregular internodes, but distally with a tendency to a regular division, with a single par of hydrothece to each internode. Branches often subdividing into alternate branchlets, and often ending in a dichotomous branching. Iydrothecar subopposite to subalternate, flask-shaped, the free distal portion narowing and curving upward so that the aperture is horizontal, marein varying from a perfectly round plain rim to the produetion of two strong teeth on the abcauline side. The operenlum consists of a single adealine Hap.

Gomosome.- (xonangia borne on front of branches, conical to oblong-oval in shape, rather feehly but distinctly amulated throughout, ending in at short tubular collar and round aperture which is often surmounted by an acrocyst when the sexual products are mature.

Distribution.- 'omales Point, Monterey, Punta Reves, San firancisco, and Santa Crus (Clark); Vancouver Island (.I. M. I hwson); Point Renfrew, Vancouver lsland (Mrs. (i. Gibbs).

This is a most puzzling species. It can not go into othe genus sotularlli, as here detined, and the extreme variability of the mareminal structures makes it difficult to decide whether it should go into Thererie or Lbietinmill. The teeth, however, are not lateral, but abcauline, and often the margin is perfecty round, in which case we have the typical abictinarian structure. Both margins are found in every colony that 1 have examined, the smooth-rimmed hydrothecat being more abundant in proximal parts of stem and branches, and those with teeth in the distal parts. Very rarely a three-toother marein is sern. I am indebted to Mrs. (r. (rib)s for exeellent specimens from which the above description and the drawings were made. 
ABIETINARIA COSTATA (Nutting).

(Plate XXXVI, figs. 9-12.)

Thuiaria castate Nutrisa, Hydroids of the Harriman Expedition, 1901, p. 187.

Trophosome.-Colony attaining a height of about 3 inches. Main stem straight, the proximal part unbranched and divided into regular internodes, each of which bears a pair of subopposite hydrotbeca, nodes oblique, the upper part of main stem divided into regular internodes, each of which bear's a branch and two hydrotheca on one side and a single hydrotheca on the other. Branches alternate, dichotomously branching several times so as to form a dense tuft; internodes unequal, each bearing several pairs of subalternate to subopposite hydrothecie. Hydrothece resembling those of A. filicula and A. inconstins, as large as the latter, but not so thick and heary, leaning forward so that their distal ends are not in the same plane with the branch; distal one-third free, constricted, narrowing to a round aperture, which points upward and often a little inward toward the stem; perisare thickened on the inner wall just below the margin, furnishing the base of attachment for the one-tlapped operculum. A chitinous thickening projects downward from the inner and lower corner of each hydrotheca.

Gonosome.-Gonangia very numerous, borne on both faces of the stem, and often on basal parts of branches, oblong-ovate, with a small tubular neck and round aperture, sides marked by about five meridional ridges, the crests of which are colored black, making a conspicuous marking.

Distribution.-Yakutat, Alaska (Nutting).

Although this species is doubtless allied to A. inconstans, it differs considembly in detail, being much less woody and heary, and the branches subdividing to a much greater extent. The gonosome is quite distinct. The only specimens known were collected by the Harriman Alaska Expedition.

In its trophosome this species is quite similar to $\mathrm{A}$. coei Nutting, but the gonosomes of the two are widely different, the longitudinally ribbed gonangia of the former being of a rare type in this genus.

Type slides.-Cat. Nos. 19907, 19908, U.S.N.M.; Cat. No. 18750, Museum of State Unirersity of Iowa; also in the collection of the author.

ABIETINARIA ANNULATA (Kirchenpauer).

(Plate XXXVI, figs. 13-15.)

Thuictia cmentela Kircnenpauer, Nordische Gattungen, 1884, p. 26.

Trophosome. - Colony about $t$ inches high. Main stem and branches exceedingly thick and woody, black in color; the main branches spring from near base of stem, and the whole colony greatly resembles that of the plumularian Vudithecr dalli in general appearance and habit of growth. Stem and main branches straight, divided into irregular internodes, each of which bears several closely approximated and upward-directed branches each with an axillary hydrotheca; internodes with wide shallow and equidistant annulations, which in a general way correspond in number to the hydrothece on each side of the internode. Branches divided into irregular and distant internodes, each with several hydrothecre on each side.

Hydrothecre subopposite, very closely approximated, short, stout, tubular, with slightly constricted distal ends; margin even, aperture nearly round, and either borizontal or slightly inclined toward the stem. Operculum of one flap attached to adcauline side of margin.

fromosme.- Not known.

Distribution.- The original description was taken from a specimen without a label indicating locality. The above description is from a specimen in the U. S. National Museum, Albatros. Station $35 \pm 6$, lat. N. $54^{\circ} 12^{\prime}$, long. W. $165^{\circ} 42^{\prime}$, 36 fathoms.

This species has an exceedingly thick and coarse annulated stem that at once distinguishes it from any other Abietinaria that I have seen.

Type.-In Leipsic Museum. 


\section{ABIETINARIA TURGIDA (Clark).}

(I'late XXXV'11, tigs. 1, 2.)

Thuiaria turgidh (HAlkK, Alaskan Hydroids, 187t, p. 2209.

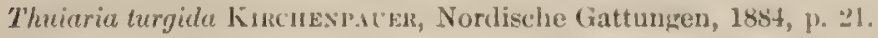

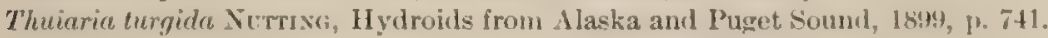

Thuiaria turgidn Nursis, Hydroids of the Harriman Expedition, 1901, 1. 186.

Trophosome-Colony attaining a height of about s inches. Stem mather stout, erlazed, divided into short stout regular internodes by obliyue nodes, each internodo bearing a pair of subopposite hydrotheca. Man banches imenularly altroute and few in number, originating from distal part of stem, constrictod near point of attachment, and resembling the matin stem in their proximal portion, while distally they give origin to altermate branchlets, one being horne on each internode of the branch. Branches dichotomously dividing, with very long internodes divided by oblique nodes. Hydrothece subopposite, tubular, almost wholly immersed, distal end but slightly constricted, terminating in a round margin pointing obliquely outward and upward; the top of one hydrotheca usually reaching just to the base of the next one above. Operculum of a single flap attached to the adcauline side of margin.

Gonosome-Gonangria large, oblong-ovate, attached to the bases of the branchlets so as to form a densely set double row on the front of the branches. There is a short collar, round terminal aperture, and opereulum. Sides of gonangia ornamented with stout longitudinal ridger, three to tive in number.

Distribution.-Abundant throughout the Alaskan coasts and Aleutian Islands and Bering Sea. All of the specimens known were collected eitber by Dr. Dall and party (Clark), or the Harriman Alaska Expedition (Nutting).

'This species is most like A. giguntea (Clark), but the hydrotheca are much smaller and more crowded than in the latter species, and the gonangia are quite different.

Type.-In the collection of the U. S. National Museum.

\section{ABIETINARIA GIGANTEA (Clark).}

(Plate XXXVI, tigs. 3-5.)

Thuiaria giganlea CLArк, Mlaskan Hydroids, 1876, p. \$30.

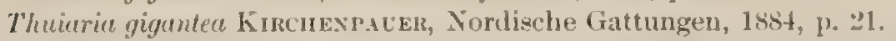

Thuiaria gigunte Nutrixa, Hydroids from Alaska and Puget Sound, 1899, 1. 741.

Theiaria giganten Notrixg, Hÿlroils of the Harriman Expedition, 1901, p. 186.

Trophesome.-Colony attaining a height of abotit 8 inches in the largest specimen examined. Stem undivided, with very distant and irregularly placed nodes and two rows of hydrotheca along its entire lengtb. Branches irregularly alternate, constricted at their origins, occasionally bearing one or more branchlets, with no nodes or one or two very distant ones, and bearing close-set rows of hydrotheca on opposite sides. Hydrotheca very large and stout, immersed almost to theix margins, and with a distinct bare space on the internode between the top of one and the bottom of the next one above; margins elliptical, the horizontal axes being the longer, and sinuous on lateral aspect, giving the appearance of a medium blunt tooth above. Operculum with a single adcauline flap.

Gomosome.-Gonangia comparntively small, borme in dense double rows along the upper sides of the branches, oblong-ovate, with large terminal round aperture and without collar or longitudinal ridges.

Distribution.-Alaskan shores and Aleutian Islands, Bering hea, Hagmeister Island, Akutan Pass, Kyska Harbor (Clark); Orea and Kadiak, Mlaska (Nutting); Belkolfsky (Dall);

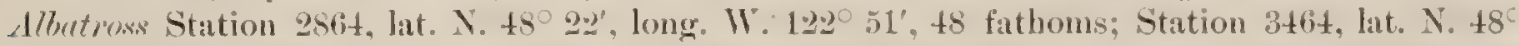

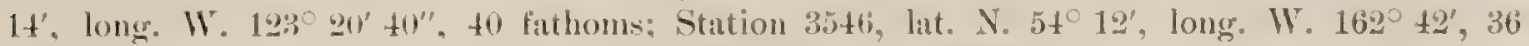
fathoms; Station 3556 . lat. N. $5704^{\prime}$, long. W. 170 $2 t^{\prime}$, 26 fathoms.

Type. - In the collection of the U. S. National II Iseum. 
HYDRALLMANIA Hincks (modified).

Trophosome.-Hydrothece in groups all on one side of the branches, their bases aligned and closely approximated, their distal ends bent alternately to the right and left. Operculum apparently of a single adcauline flap.

Gonosome.-Gonangia oblong-ovoid, without lateral spines or marsupium; aperture large, round.

This is a perfectly well marked genus, consisting of a few species that agree in the peculiar position of the hydrothece and in the special character of the alternate flexing of their distal ends to right and left when viewed from the front. The only species known at the time preceding Hincks's great work had been for a long time placed in the genus I"lumelaria by many authors. The absence of the sareostyle was sufticient to differentiate it from the family Plumularide, and other characters served to settle its aftinities with the Sertularida.

Since the genus was instituted by Hincks in $1868^{1}$ it has heen recognized by practically every writer that has discussed it or had occasion to mention the type species. Mr. Paarmann, who carefully investigated the opercula of this and other Sertularidx, found that the operculum consists of a single functional adcauline flap, and that the margin was produced into a stationary "collar" on the adcauline side.

FEY TU TIF AMERCAN SPECTES OF THE (IENUS IYYUALTAANIA.

Hydrothece distinctly flask shaped, distal ends much constricted, aperture round . . . . . . . . . . . . . franciscant. Hydrothece more nearly tubular, distal ends not distinctly constricterl and not round.

Each hydrotheca in a cromp reaching above the middle of the one next above it . . . . . . . . . . . . . falcatr.

Each hydrotheca in a group not attaining the level of the middle of the next one above................ distans.

HYDRALLMANIA FALCATA (Linnæus).

(I'late XXXVII, figs. 1-1.)

Sickle Corulline Elds, Essaly Nat. Hist. Curallines, 1755, 1. 12.

Sertuluria jalcatu Jixxets, Systena Nature, 1758, 1. 810.

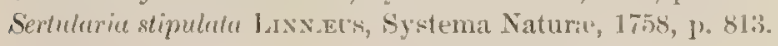

Sertuluriu, falcatu Laxx.es's, Systema Nature, 1761, 1. $5+1$.

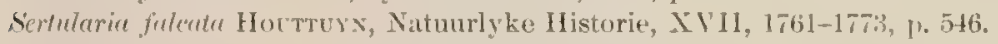

Sertukriu fuketu Pablos, Elenchus Zoophytorum, 1766, 1. 144.

Sertulurie falcalu LIxx.Eus, Systema Nature, 12th cel., 1767, 1. 1309.

Sertularia falcutu. Bodd.nerT (P’allas), Lyst der Plant-Dieren, 1768, 1. 180.

Serluluria fulculu Maratri, De Plantis Zoophytis, 17T6, p. 30.

Sertularin falcala trizoxovis, Zoophylacium gronovianum, 1781, p. 3.9.9.

Sertularie fulente FLLis and SoL.Axisex, Nat. Hist. Zooph., 1786, p. 42.

Sertulariq faleate Wrikiss and HErnst (Pallas), Charakteristik der Thierptanzen, 1787, 1. 183.

Serheluriu fulculu (imecrs, Systema Nature, 13 th ed., 1788, p. 3849.

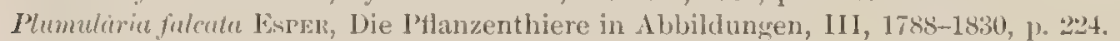

Sertularia folcatu Benkexnoct, Synops. Nat. Hist. Great Britain, I, 1789, p. 217.

Sertularia fulcalu Fispen, Fortwetzungen der P'flanzenthiere, II, 1794-1806, pl. x.

Serlularie fulcalu Bose; Hist. nat. des Verw, III, 1802, 1). 95.

Semelurie fulcele Te1tox, british lama, 1807, p. 213.

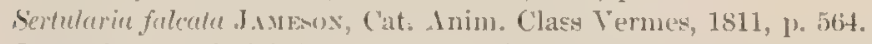

P'ennarir (Sertuluriu) folcatre OkEx, Lehrbuch der Naturgeschichte, 1815, 1. (14.

Plumularic fulcalce L.s.smck, IJ ist. nat. des anim. sans Vert., 1816, p. 125.

Aglophenia falcuth Lssovrocx, Hist. nat. des Polypiers, 1816, w. 174.

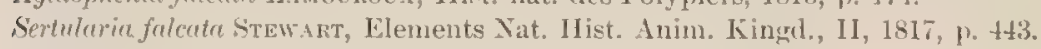

Sertulariu falcutu ScrWEIrigER, Handbuch der Naturgeschichte, 1820, 1) 427.

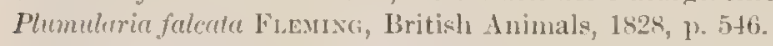

Serlularia falcata Bosc, Hist. nat. des Vers, 1830, 1. 110.

Plumularia filculu Jonsston, Trans. Newastle Society, II, 18;2, 1. 25:9.

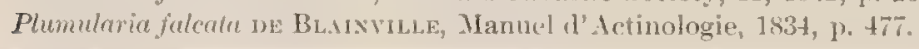


Sertularia falcata OKEx, Nllgemeine Naturgeschichte, 18:35, p. 74.

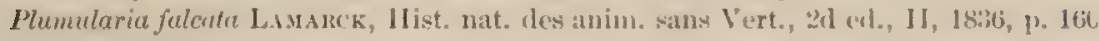

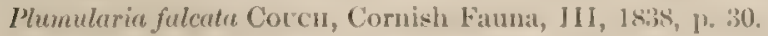

Plumularir falcute HAssiLL, Ann. and Mag., V' 1, 1841, p. 169.

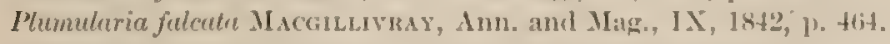

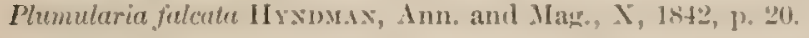

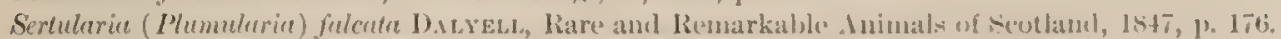

Plumularia falah Jomxtos, British Zoophytes, 21 ed., 1847, p. 90.

Plumuluria falcatu STrmpsos, Marine Invert. Cirand Manan, 1sist, P. \&.

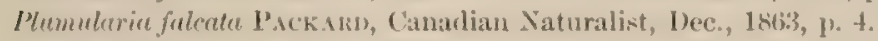

Serluluriet fulcuth A. Arisiz, North American Acalepher, 18tin, p. 144.

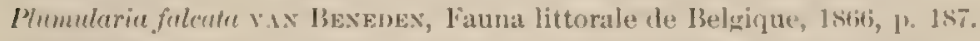

IIydrullmaniu fulcule IIxcks, British IIyiroid Zoophytes, 1sts, 1). 273.

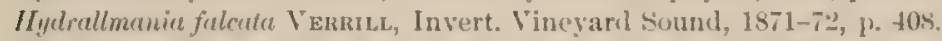

IIydrallmania falcuta G. O. SARs, Bidrag til Kundskahen, 1873, 1). Is.

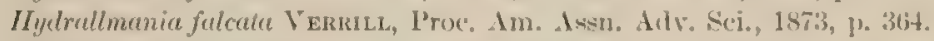

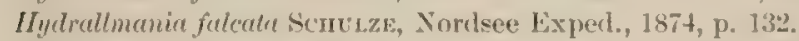

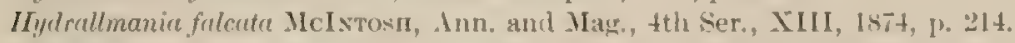

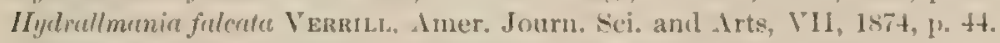

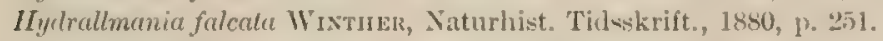

ITylrallmamia fulcata I3Erah, (ioplepolyper fra Kara Havet, 18s7, p. 3is.

IIydrullmania falcult Drerscu, Tektonische Studien, 1890, p. 209.

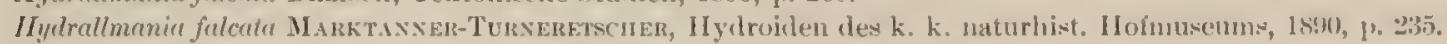

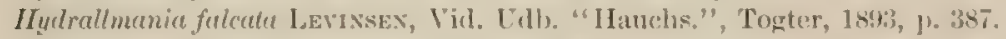

IIydrallmania falcaln Crawfons, Ann. and Mag., 6th ser., X'TI, 1395, 1). 2til.

IIydrallmania fulcala HARTL.AUB, IIydromedusen IIelgolands, 1897, p. t5.

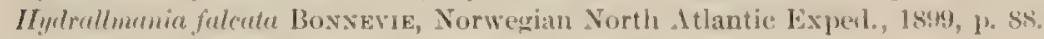

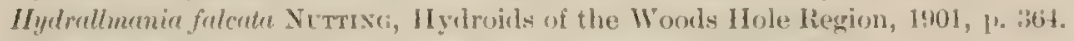

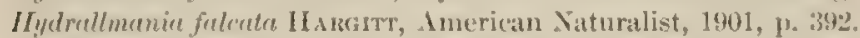

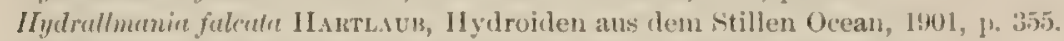

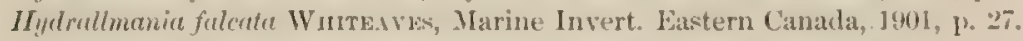

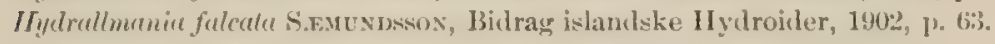

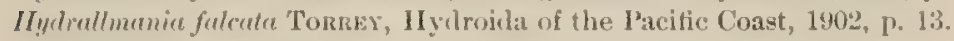

Trophosome.-Colony when typically dereloped assuming an exceedingly erraceful panicled form, and attaining a height of a foot or more. Main stem not fascicled, spirally twisted, destitute of hydrotheca, divided into irregular internodes, the tendeney being to betr a branch to an internode, but there is an occasional intermediate internode. Branches arranged in anore or less regular spiral, and themselves giving forth regularly alternate branchlets which oceupy two planes which meet the branch at nearly a right angle. Branches and branchlets bearing hydrothece and divided into sather irregular internodes, each of which bears a number of hydrothece. Hydrothece tubular, arranged in aroups on front of branches and branchlets, their bases in line, their distal portions bending gracefully to the right and left alternately, as viewed from above, the top of one reaching above the middle of the next one above, directed upward and forward as viered from the side. Aperture oral or lumate, the side of margin nearest stem being flattened; opereulum consisting of a single flap.

Gomosome. - Gonangia borne usually on distal parts of branches and proximal parts of. hranchlets, orate, with several indistinct longitudinal lines or ribs, ending in at short tubular neck and round aperture.

Distribution.-Very abundant in rather shallow water on New England coast; Labrador (Packard); Grand Manan (Stimpson); British coasts (Allman); Belgium (Van Beneden); Nor-

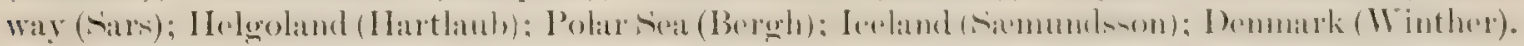

Although usually found in shallow water, this species was found at a depth of 1,100 fathoms by the Norwegrian North Atlantic Lxpedition (Bonnevie). 
HYDRALLMANIA DISTANS Nutting.

(Plate XXXYIII, figs, 5-4.)

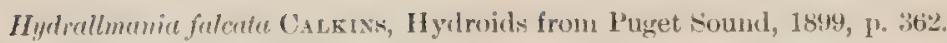

Hinlralmenice distens NitTrsa, Hylroids from Alaska and Puget Sound, 1899, 1. 746.

IIydralmumin distuns Hartuaub, Hydroiden aus dem Stillen Ocean, 1901, p. 355.

Hydralmunia distens Torrey, Hydroida of the Pacific Coast, 1902, p. 70.

Trophosome.-Colony of erect, straggling habit, attaining a height of about 6 inches. Stem not fascicled, spirally twisted, slender, wiry, divided into irregular, usually long internodes, the tendency being to have a branch on each internode. Branches distant, spirally inserted in full-grown specimens, irregularly alternate in young specimens, borne on processes from the stem in the axils of which a hydrotheca is often, not always, found; divided into branchlets which are regularly alternate and divided into regular internodes each of which bears three hydrotheca on its anterior or upper face, and a branchlet; branchlets divided into irregular internodes, each of which bears from two to six (usually four) hydrothece on its upper side. Hydrothece tubular, flattened, not noticeably gibbous below, inserted in a line on the upper sides of branches, their distal portions bending gracefully to the right and left alternately, the top of one not reaching to the middle of the one immediately above it; margin much flattened, the corners angulated; aperture a much flattened oral or crescent. Operculum of a single abcauline flap.

Gonosome.-(Not heretofore described.) Gonangia borne on front of branch, broadly ovate, flattened, with a wide aperture, distinct pedicel, and apparently without the meridional lines seen in 11. falcata.

Distribution.-Puget Sound (Nutting). Dredged by the Young Naturalists' Society.

Since this species was originally described I have obtained additional material through the kindness of Prof. Trevor Kincaid, and have very carefully compared it with specimens of II. falcata from Plymouth, England, with the result of confirming me in the opinion that the differences pointed out before are quite constant, and that $I$. distans is a good species. The shape of the bydrothece of $I I$. fremciscana, as described and figured, is constantly different from that of $I I$. distuns, being flask-shaped and twice as broad in the gibbous lower portion as at the aperture. But a single gonangium has been found, and it is possible that it may have been flattened artificially, making the figure misleading.

Type slides.-Cat. No. 19808, U. S. N. M. Cat. No. 1873ะ, Museum of the State University of Iowa; also in the collection of the author.

\section{HYDRALLMANIA FRANCISCANA (Trask).}

(I'late XXXYII, fig. 10.)

Plumularia franciscunu Trask, Proce. Cal. Acarl. Sci., I, 185̄, P. 113.

Plumularia grecilis Murrar, Ann. and IIag., 3ilser., V, 1860, p. 251.

Sertularia gracilis Agassiz, North American Acalepher, 1865, 1. 14 .

IIydrallmania franciscana CuAnk, Hydroids of Pacific Coast, 1876, p. 260.

IIylrallmania franciscana HARTLAUB, Hydroiden ats dem Stillen Ocean, 1901, 1). 355.

Iydrallmania franciscana ToRREY, Hydroida of the Pacific Coast, 1902, p. 18.

"Polypodom 6 or 8 inches high, color corneous, alternately branched, the branches pinnated, one branch to each internode of the stem. The pinne rise one above the other, are pointed, and support three cells at each joint. On two specimens four cells have been met with, but may be regarded as an exception rather than otherwise. The pinna are dichotomously branched in adult specimens. Cells lagineulate, smooth, free, slightly decumbent; the attachment of the base is marked by a slightly elevated rounded rim; apertures round and smooth."

"Bay of San Francisco, among rejectimenta of the beach."

I have not seen this species, and have here inserted the original description.

Plumulrerin gracilis Murray is doubtless the same species as $I J$. fremrisenu, as Doctor Clarli concludes. If the character given by Murray, three cells at each joint, is at all constant, the author can not regard $I I$. franciscana as a synonym of $I I$. falcate, in which the average is 
uniformly much higher. Both Murray and 'Trask speak of the hydrothece being supported hy a sort of triangular buttress (Murny), or a slightly elevated rounded rim (Trisk).' Mlurray adds that the gonangia are oblong-oval.

\section{SELAGINOPSIS Allman (modified).}

Timphosome. Iydrotheca arranged in more than two longitudinal series, at least on dista] parts of branches, or in two or more series each of which hats the distal ends of the hydrotheca turned alternately to the right and left. Operculum of a single abcauline llap. Internodes long or absent.

Gonosome-Gonangia usually obovate, without internal marsupium or external ornamentation."

This detinition of the grenus is more comprehensive than the original by Allman. ${ }^{3}$ This writer proposed two new genera at the same time, Seluginopsis to include forms with several rows of hydrothece set on simple hranches, and Pericladium to include forms with several rows of hydrotbece set on bifureating ramuli. In 1878 Mereschkowsky, without having seen Alman's paper, proposed the genus I'ulyserius to include sertularians with hydrothecit arminged in several rows on the branches, but which are biserial on the stem. Later, but during the same year, he wrote another paper" in which he acknowledged the priority of Allman's generic mame Selaginopsis, but proposes to include in that genus the forms that Nlman put in P'ericladinm. A little later, 1890, Intktunner-Turneretscher recognized the genus substantially as defined by Mereschkowsy. In 1893 Levinsen ${ }^{6}$ in jursuance of his policy of relying entirely on the characters of the hydrothecal margin and operculum, included the species here considered as belonging to Seldeinepsis in the genus Thuiuria, on account of the single-flapped abcauline opereulum.

The genus Selurinopsis as above detined secms to me to be a perfectly tenable group, indeed one of the best genera in the family sertularidae. Its aflinities are evidently with Lheieria, from which, however, it is sharply differentiated by the arrangement of the hydrothecat.

There are no points of intergradation between this genus and other's that need offer any difficulties in the allotment of species to this genus as here defined. In most species the hydrotheca of the stem are arranged in two opposite series, as in Theraria, and in some cases this is true of the proximal parts of branches. But in these same species the hydrotheca on all but the proximal parts of the brunches are polyserial, furnishing a perfectly evident character for generic identification.

The hydrothece in a given row not turning alternately to right and left.

Distal ends of hydrothece distinctly exserted.

Marmin whit two distim.t molh .

Marcin withust terth.

Distal ends of hydrothece not greatly exserted.

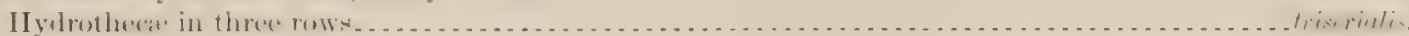

Hydrothece in four rows.

Stem and branches geniculate, branching reqularly compound ....................... plumiformis

Stem and branches not geniculate, branches not rexularly compound:

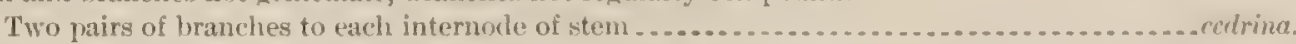

Sten very heavy and wooly. Toules deep, accompanied hy annulations............... pimatr.

Conosarcal canals in branches very regular and four in number. Gonangia with numerous very

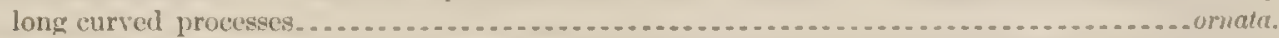

${ }^{1}$ Annals an 1 Magazine, $3 \mathrm{~d}$ ser., $\mathrm{V}$, pl. xir, fig. In, represents each internorle of the branch as bearing three hydrothece, in one case two, which confirms Trask's description and figure.

"The known exceptions among American species are S. ormata and S. cedrine.

3ournal of the Limnan finciety, Zoology, XII, 1s74, p. 27:2.

- New Iydroida from Ochotsk, Kamtschatka, and other party of the North l'acific Ocean, Aumals and Magazine of Natural History, 5 th ser., II, 1s7s, p. 434 .

${ }^{5}$ Hydroiden des $\mathrm{k}$. k. naturhistorischen Hoimuseums, 1890, p. "2t2.".

${ }^{6}$ Meduser, Ctenophorer og Hydroider fra Grünlands Vestkyst, p. 193. 
Hydrothece normally in more than four rows.

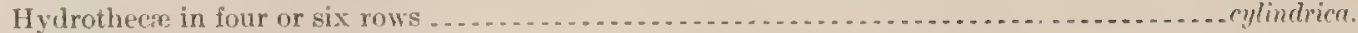

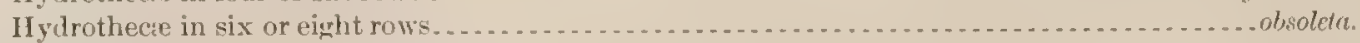

Hydrothece in rows, distal ends turning alternately to the right and left as in $I I y d r a l l m a n i k$.

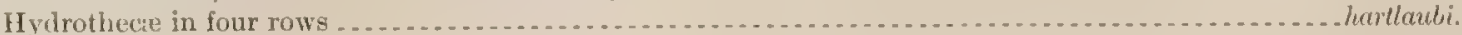

Hydrothece in two rows . . . . . . . . . . . .

\section{SELAGINOPSIS MIRABILIS (Verrill).}

(Plate XXXVIII, digs. 11-12.)

Diphasia mirabilis V'erricl, Amer. Journ. Sci., 34h ser., V, 1872, 1. 9.

Diphasia mirabilis Vernilu, Trans. Conn. Acal. Arts and sei., III, I’t. 1, 1875, 1. i.:.

Diphasia mirabilis CLAR , Alaskan Hydroids, 1876, p. 219.

Polyserias hincksii Menescukowskx, Ann, and Mag., 4th ser., X工, 1877, 1. 2..s's.

Selaginopsis mirubilis NorMtx, Ann, and Mag., 5th ser., I, 18is, 1). 3335.

Selaginopsis mirabilis MIEREscпкowskr, Ann. and MIag., 5th ser., II, 1878, 1'. 45 .

Selaginopsis mirabilis Kincnevparke, Fordische Gattungen, 1854, 1\% 1:2.

Selaginopsis mirabilis BerGi, Goplepolyper fra Kara Havet, 1887, 1\%.337.

Sertularin mirabilis Levrssex, Vid. Meddel. naturh. Foren., 1893, 1. 191.

Selaginopsis mirubilis BoxNeye, Norwegische Hydroiden, 1898, p. 12.

Selaginopsis mirabilis NutTing, Hydroids from Alaska and Pnget Sound, 1sig, p. 741.

Selaginopsis miralilis Boxxeye, Norwegian North Atlantic Experl, 1599, p. 85.

Selaginopsis mirabilis Hartaub, Hydroiden aus dem Stillen Ocean, 1901, 1. 355.

Selaginopsis mirabilis Tonnex, Hydroida of Pacific Coast, 1902, p. 70.

Sertularia mirabilis S.exundsson, Islandske Hydroider, 1902, 1). 63.

Trophosome.-Colony plumose, attaining a height of 4 or 5 inches. Stem thick, not fascicled, sinuous or weakly geniculate, without nodes for the most part, although an occasional one is to be seen. A row of hydrothece on opposite sides of the stem, there being three between adjacent branches. Branches alternate, occasionally dividing into branchlets, with a shallow node dividing them from the stem process on which they are borne and which bears two opposite hydrothecre on the proximal side of the node. Ordinarily there are no other nodes. Hydrothece in six series, immersed for only abont half their length, the distal portion curving outward and ending in an oval margin with two pronounced lateral teeth. Operculum of two valves or flaps. Gonosome.-Gonangia borne on the branches, obconic when young, when mature oval, and having a very broad, round terminal aperture.

Distribution.--La Have Bank, Nora Scotia (Verrill); Hagmeister Island, Bering Sea (Clark); Popoff Straits, Shumagin Islands (Clark); Puget Sound (Nutting). White Sea and Polar Sea, 60 fathoms (Meresehkowsky); Polar Sea (Bergh); Norwegian Coast (Bonnevie); West Coast Greenland (Lerinsen); Iceland (Siemundsson); Albutross Station 2599, lat. N. $3 t^{\circ} 45^{\prime}$ 20)" long. IV. $75^{\circ} 38^{\prime} 10^{\prime \prime}, 25$ fathoms; Station 2865 , lat. N. $48^{\circ} 12^{\prime}$, long. W. $122^{\circ} 49^{\prime}$, 40 fathoms.

This is a very well-marked species, and the only one of the genus that I have seen with hydrotheca on the process that bears the branches.

Type.-In the collection of the U. S. National Museun?

\section{SELAGINOPSIS PINASTER (Lepechin).}

(I'late XxxvII, fig, 13.)

Scrtularia pinaster LePECHIN ${ }^{1}$, Acta Acat. Petropolitane, 1783, p. 2223.

Sertularia pinus Gueln, Systema Nature, Linneus, 1788, p. 3846.

Serhularic pines Bosc, Hist. Nat. des Vers, III, 1802, p. 93.

Serlularia pinaster Lumou Roux, Hist. des Polypiers, 1816, p. 197.

Sertularia pinus Kincnexp.jer, Nordische Gattungen, 1884, p. 11.

"Danach erheben sich aus krieschenden Wurelfasern, meist einfache, suweilen unten creteilte eylindrische Stämmehen bis $6 \%$ ool hoch. Sie sind bis gegen die Nitte ihrer Höhe dunkel-braun,

'The name Serfularin pinaster was nsed for another species, now Diphasia pinater (Ellis and solander), and was in general use at the time that (imelin prepared the thirteenth edition of the Systema Nature (1785). The Sertularia pinaster of Lepechin was not then generally known, and Gmelin retained the name for the Sirtularia pinzster of Ellis and Solander, giving a new name, S. pime, to Lepechin's species. The law of priority, however, makes it necessary to retain the name Sertularia pinaster for Lepechin's species. 
werden aber nach oben zu heller und sind unregelmassig getiedert. Die Fiedern sind fädlich, schlaff und mit mehreven, oft 6 Reihen ron IIydrotheken besetzt. Diese sind eiförmig, sind aber oben mit einem vorragenden Hals versehen, auf welchem sich die Mundöflnung betindet. Die Gonotheken sind schlauchartigg (utriculares), meistens angeschwollen, fast durchichtig, haben cine runde, von einem wulstigen Rand umgabene Öfnung und sitzen oft zu beiden Seiten der Zweige, dicht gedrïngt, fast dachziegelförmig."

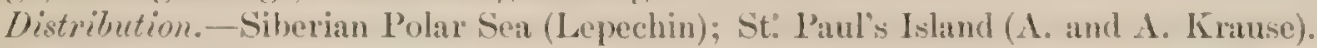

The identity of this species is doubtful. The foregroing description is quoted entire from Kirchenpaner and is the only good description that I can find. Kirchenpauer bases his description on a fragmentary specinen found in the collection made by $\Lambda$. and $\Lambda$. Krause in Bering Sea. His drawing, which I have copied, shows an irregularity in the distribution of hydrotheca, which are represented as not in regular vertical series, not found in other species of the genus.

Otherwise it would seem likely that $S$. pindster and S. cylindrice Clark were identical. It does not secm likely that $S$. pinaxter is the same as I'ericladinm bidentatum, as suggested by Kirchenpauer, the latter species having well-narked lateral hydrothecal teeth, which are not indicated in Kirchenpauer's description or drawing of $S . p$ muns.

\section{SELAGINOPSIS TRISERIALIS Mereschkowsky.}

(Plate XIXIX, tigs, 1-2.)

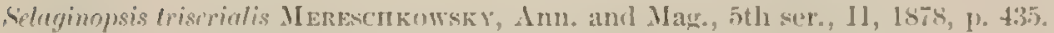

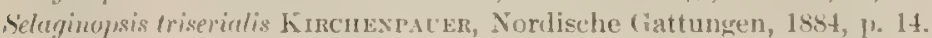

Sertularie incongme Torkex, Hydroilla of the Pacific coast, 1902, p. (it).

Trophessme-Colony attaining a height of about 2 inches. Stem straight, with distant and irregular nodes, and two rows of completely immersed hydrotheca on opposite sides. Branches with a pinnate appearance, but really arranged in an open spiral, borne on short processes from the stem that do not bear hydrothece, with rery distant nodes or none. Hydrothece in two rows on proximal portion and in three rows on distal portion of each branch, where they also follow a spiral arrangement, more distant from each other than is common in the genus, there being often a considerable space between successive hydrotheca and also between the rows, almost entirely immersed, only a very short moiety of the distal end being free; aperture nearly round, without teeth or noticeable angles; opereulum a single adcauline flap.

Gonosome-A single distorted gonangium was present in the specimen deseribed; oblongoral in shape, with a large terminal aperture. I believe it has not been described before.

Distribution. - Kamchatki (M. Kastilsky); San Pedro, California (Torrey); Albatross Station

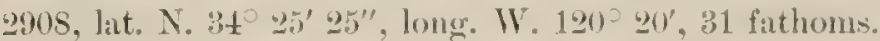

This is the most southern locality for this genus on the Pacific coast. 'Torrey regards this form as showing an intergradation between Thuiura and Selufinopsis. Several species of Selnginopsis, however, have but two rows of hydrothece on the proximal part of ths branches, the other rows being intercalated distally.

Type.-In the collection of the Academy of Sciences, St. Petersburg.

SELAGINOPSIS PLUMIFORMIS, new species

(Ilate XXXIX, lig, 3,

Trophosome-Colony branching in a regular symmetrieal compound manner, and attaining a height of about $t$ inches. Stem regularly geniculate, irregrularly anmulated in proximal portion, divided into very irregular internodes by distant nodes, with a row of immersed hydrotheca on each side. Primary bunches alternate, botne on short processes from the stem, there being three hydrotheca on the stem between adjacent processes; a very short basa internode intervenes between this process and the first hydrotheca of a branch; otherwise there are no regular internodes, the primary branches resembling the main stem in all particulars and bearing a row of immersed hydrothece on each side. secondary branches regularly alternate, 
borne on processes from the primary branches, not divided into internodes. Hydrothece in four equidistant rows, tubulax, larger below, almost completely immersed, margin oval, compressed into angles at the sides, the bottom of one hydrotheca usually being below the level of the top of the one below it. Operculum of a single abcauline flap.

Gonosome.-Not known.

Distribution.-The only specimen linown was found in the United States National Museum collection, labeled lat. N. $60^{\circ} 22^{\prime}$, long. W'. $168^{\circ} 45^{\prime}$, Lieut. George N. Stoney, U. S. Navy.

This species almost exactly agrees with S. pucifice Mereschkowsky in the shape and disposition of the hydrothece, but differs strikingly in the mode of branching, being the only Selaginops s that I have seen with true compound branching in which the stem, primary branches and secondary branches bear the relations to each other that we find in the shaft barb and barbules of a feather.

Type slides.-Cat. No. 19816, U. S. N. M. Cat. No. 187t0, Museum of the State University of Iowa; also in the collection of the suthor.

SELAGINOPSIS CEDRINA (Linnæus).

Serfularia cedrin LinN.eus, Systema Naturie, 1758, p. 814.

Scrularia cedrina Houtroyn, Naturlyke Hist, XVI, 1761-73, 1. $57 \%$.

Sertularir cedrina I'ALLAs, Elenchus Zoophytorum, 1766, p. 139.

Sertularie celrine Linv.eus, Systema Nature, 1767, p. 1313.

Sertularia ecdrina Bonnsert, Lyst der Plant-Dieren, 1768, p. 173.

Sertuluria cedrime WILKINs and IERnst, Charakteristik der Thierpflanzen, 1787, p. 177.

Sertularin cetrina Guistix, Systema Nature, (Linnaeus), 1788-9:3, 1. $355 \%$.

Seriularia cedrina Bosc, Hist. Nat. des Vers, III, 1802, II, p. 100.

Nigellastrum (Scrtularin) cedrinn OKEx, Lehrbuch der Naturgeschichte, 18I5, p. 93.

Sertulariu cedrina L.smouroux, Hist. des Polypiers, 1816, p. 196.

Selaginopsis pacifica Merescrkowskr, Ann. and Mag., 5th ser., II, 1878, I. 438.

Selaginopsis cedrina KrRCHeNI'AUER, Nordische Gattungen, 1884, 1). 8.

"Trophensome-Hydrocaulus slightly curved, divided into regular internodes. Branches arranged alternately on two sides of the principal stem, two pairs on each internode, divided into five internodes, constricted at the point of attachment and at the internodes. Each branch bears one or two, rarely five, secondary branches. Hydrothece cylindrical, almost entirely immersed in the substance of the axial tube; aperture oval, with two angles (not teeth); hydrothecx arranged in four regular series, and at the same time in a spiral, the hydrothece of cach series following one another immediately without leaving any free space or interval.

"Gonosome.-Gonangia arranged in two or three series, of an oval form, narrowing gradually toward the base, and truncate at the apex. The surface is ribbed."

Distribution. - Kamchatka (Linnæus); Metschigman Bay (Mereschkowsky); India Point, Bering Sea (Kirchenpauer).

I have not seen this species, and have copied the most complete description that I could find, that of Mereschkowsky. Kirchenpaner ${ }^{1}$ presents such strong evidence that the S. pracifice of Meresehkowsky is identical with Sertulariu cedrina Linneus that I have here conformed to his view.

SELAGINOPSIS PINNATA Mereschkowsky.

(I'late IXXIX, fig. 6.)

Selaginopsis pinnale Mereschkowser, Ann. and Mag., 5th ser., II, 1S78, 1. 436.

Selaginopsis pinnata KIRCHENPAUEr, Nordische Gattungen, 1854, p. 14.

Trophosome.-Colony plumiform, attaining a height of about 6 inches. Stem not fascicled, but very heavy and woody, divided into internodes which are fairly uniform in length on proximal portion and less so on distal portion; nodes very deeply cut, each accompanied by two or more regular annulations; stem bearing two opposite rows of hydrothece and two opposite rows of branches. Branches borne on very short processes of the stem, and rery deeply constricted at 
the proximal node, those on the two sides of the stem apparently not arranged with any reference to each other, being sometimes opposite and sometimes subopposite, subaltermate or alternate; no nodes. Hydrothee in four series forming regular vertical rows, those in a griven row being separated by about one-fourth their length, the four series heing placed so that not only a vertical but also a spiral arrangement of hydrotheca can be traced; individual hydrotheca rather short and stout, broader below, with a bracket-shaped chitinous thickening at the bottom, and an oval aperture which sometimes shows slight angles at the sides; opereulum a single abcauline flap.

Grmesmme- - Not known.

Distribution.-Port $\Lambda$ jan (M. Wosnessensky); St. Pauls Island, 23 fathoms (Kirchenpauer); Allotrosw Station 355s, lat. N. $56^{\circ} 5 \mathrm{~S}^{\prime}$, long. W. $17009 \%$, 2.5 fathoms.

The specimen from Station 355s answers quite exactly to the original deseription of Mereschkowsky, exeept that the arrangement of the branches seems less regular than his description would indicate. The color of the colony is light hrown, lightening on distal parts to a brownish butf.

Type.-In the collection of the Academy of Sciences, st. Petershurg.

SELAGINOPSIS ORNATA, new species.

(I'late XI, tigs. 1-3.)

Trophosome.-Colony plumose, attaining a height of athout $4 \frac{1}{2}$ inches. Stem, straight, thick, more attenuated in proximal portion, divided into irregular internodes by usually distant nodes; cwnosare canaliculated. Branches on opposite sides of stem and horne on short and inconspicnous processes, irregular in disposition, heingr either opposite or alternate, closely approximated, there being regularly but two hydrotheca between indjacent branches; conosire of branches very regularly canaliculated, there being four canals ruming through each branch, each canal supplying a row of hydrothece; branches not divided into internodes, but themselves often branching to form terminal branchlets. Hydrothece in four regular and equidistant rows, and also in spirals, cylindrical, almost entirely immersed, nothing but the margins being free; aperture oval, nearly round, with shallow lateral teeth and evident sinuations; opereulum an single abeauline flap. The top of one hydrothera does not reach quite to the bottom of the one above.

Gonosmme. Gonangia borne in rows on front of branches, each being inserted just below the base of an hydrotheca, obconical, long, produced into a rather slender pedicel below, and bearing about eight remarkably long, bifureated arms or processes above, which curve inward toward each other at their distal ends so as to form a sort of pseudo-marsupium above the body of the gonangium.

Distribution.-Albatmos Station $28+3$, lat. N. $53^{\circ} 566^{\prime}$, long. W. $165^{\circ} 56^{\prime}, 45$ fathoms.

In its trophosome this species is elosely allied to S. pinnute, from which it differs in the regular arrangement of conosareal canals in the branches and also in having but two hydrotheca between adjacent branches.

Typre slides.-Cat. No. 1981t, U.S.N.MI. Cat. No. 1878s, Musem of the State University of lowa; also in the collection of the author.

SELAGINOPSIS CYLINDRICA (Clark).

(Flate XXXIX, figs, 7-S.)

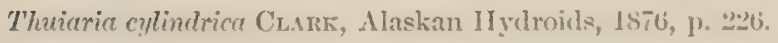

Seluginopsis cylindrice Merescrionsks, Ann. and Mag., 5 th ser., II, 1878, p. 44.

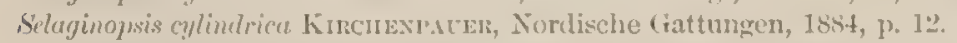

Thuiarice cylindrica MI noocr, Fixpedition to l'oint 13arrow, 1845), 1). 166.

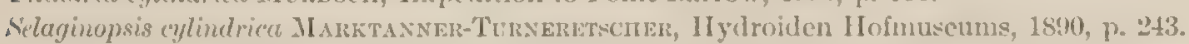

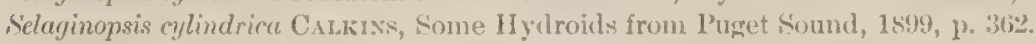

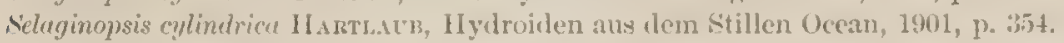

Trophosome.-Colony attaining a height of ahout s inches, plumose. Stem slender basally, enlarging distally, internodes long and irregulin, recgularly geniculate, a row of hydrothece on 
opposite sides. Branches alternate, borne on short, thick processes from the stem, sometimes unbranched, often dividing once and ocensionally bearing regularly alternate branches, as does the stem; nodes very distant or absent. Hydrothece tubular, arrunged in four rows on proximal parts of branches and in six (rarely eight) rows on distal parts, closely approximated, entirely immersed, narrowing toward the distal curved portion and ending in a smooth toothless margin and oral aperture; operculum a single abcauline valve. The number of rows on a branch is suddenly increased from four to six by the intercalation of two new rows between the old ones.

Gonoxome.-Unknown.

Distribution.--Port Moller, Alaska; Hanmeister Island, Bering Sea; Chirikoff Island, Chiachi Islands (Clark), Puget Sound (Calkins), Bristol Bay, Alaska (collected lyy C. L. MeKay), Arctic Ocean (Murdoch). Depth ranging from the shore line to 17 fathoms.

This appears to be a well-marked species, about which there has been little difference of opinion. It is the one most abundant on the North Pacitic coast.

Type-In the collection of the U.S. National Museum.

SELAGINOPSIS OBSOLETA (Lepechin).

(Plate XXXIX, figs, 4, 5; XI, fig. t.)

Sertulariu obsoletu Lepecirn, Acta Acad. P'etropol., II, 1778, Pt. 22, p. 137.

Sertularia obsolela Gimelix, Aystema Nature (Linneus), 1788-1743, 1. 3546.

Serhularia obsoleta Bosc; Hist. Nat. des Vers, 1803, p. 9:3.

Serfularia obsuleta Lasovkovx, Hist. Polyp. Coralligènes, 1816, 1?. 197.

Polyserias ylacialis MERescm Kowskx, Ann. and Mag., the ser., XX, 187i, p. 228.

Polyserins hincksii Mereschkowskr, Ann. and Mag., 5th ser., I, 1878, p. 337.

Selaginopsis hincksi MerescnkowskY, dun. and Mag., 5th ser., II, 1878, p. 44.

Selaginopsis obsolet Kromexpaunr, Nordische Gattungen, 188t, p. 10.

Trophosmne--Colony attaining a height of about 4 inches. Stem thick, slightly geniculate, divided into irregular internoder, the tendency heing toward an arrangement in which there are two branches to an internode, with an oceasional very deeply cut node, particularly on the distal portion, and also very shallow annulations that are much more numerous than the real nodes. Branches alternate, closely approximated, springing from short processes from the stem from which they are separated by very deep nodes; otherwise the nodes are almost entirely absent. Hydrotheca arranged in six regular series so that they form both vertical rows and spirals, tubular, rather short, broader at the base, and narrowing distally to the smooth margin and oval aperture; there are no marginal teeth, and the operculum is composed of a single abcauline flap.

There is usually a distinet spate intervening betwern the tope of one hydrotheras and the bottom of the one immediately above it.

"Gonophores in a young state in the form of a reversed cone, just as in $P$. mirabilis, but generally smaller. In the adult state they retain their conical form, but the cone becomes larger and more elongated; below, it is attached by a short peduncle; above, it is truncute, with the margins much rounded, and furnished with a tube of very inconsiderable length, which is scarcely observable, and much narrower than in the preceding species. The gonothece of this species are never present in such abundance as in $I^{\prime}$. mirabilis."

Distribution.--Polar Sea (Lepechin); Whice Sea (Mereschkowsky); St. Pauls Island, Bering Sea, 23 to 25 fathoms (A. and A. Krause); N7batrose Station 3505, lat. N. 580 33', long. Wr. $16 t^{\circ} 49^{\prime}, 23$ fathoms.

Kirchenpauer, who had access to the type specimens of $S$. obsoleta in the Leipsic Museum, declares that the S. hinclisii of Mereschkowsky is a synonym of this species.

Not having the material upon which to base a decision, the present writer adopts the position

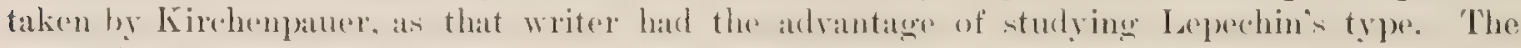
above description of the gonosome is quoted entire from Mereschkowsky. ${ }^{1}$

Type.-In Leipsic Museum. 


\section{SELAGINOPSIS ALTERNITHECA (LevinSER)}

(Plate XI, tign. 5-7.)

Thuiaria allernithea LEvissex, Vid. Meklel. naturh. Foren., 189:, 1. 32.

Trophowome. Colony attaining a height of about 5 inchos. Stem spirally twisted, very thick and coarse, divided into long and irregular internodes. Branches springing from all sides of the stem, dividing dichotomously sometimes three or four times, making a tlabellate structure resembling somewhat the branches of Thuiarie thuju. Nodes usually absent, except that there is a sharp constriction at the base of each branch and branchlet. Hydrotheca very stout, much broader below than above, arranged in two rows on the sides of the flattened branch, each row thus occupying an edge of the branch, the hydrothece of a given row having their distal ends bent alternately to the right and left as in Ifylmallmemia; margin without teeth, aperture round, operculum a single abcauline tap. The top of one hydrotheca rises a little above the base of the one next above.

Gronosme. - Gonangia borne on basal portions of branches. elongate oval, abruptly truncated at distal end, with a very broad aperture and no neck.

Distribution.-Divis Straits, 100 fathoms (Levinsen).

The above description of the main stem and manner of branching is taken from Levinsen's account and figures, the remainder being from a specimen (framentary) from the type locality kindly sent me by P'rofesor Levinsen. The species is a very well marked one and looks like a double Ilydrallmania.

Type slides.-Cat. No. 19809, U.S.X.M.; Cat. No. 18633, Museum of the State University of Iowat also in the collection of the author.

SELAGINOPSIS HARTLAUBI, new species.

(I'late XI, lig. 8.)

Trophosome-Colony in type specimen, which is incomplete, about $4 \frac{1}{2}$ inches high. Stem divided into very long and irregular internodes. Two rows of completely inmersed hydrotheer, which do not have their distal portions inclined alternately to the right and left, are on opposite sides of the stem. Branches irregulary alternate, not ordinarily dividing into branchlets, internodes long, divided from the very short processes of the stem by a deep constriction. Hydrotheca in four rows, each of which resembles in arrangement those found in IIydrallmumia, where the distal ends of the hydrothece are bent alternately to the right and left. Individual hydrothece stout, tubular, completely immersed, with the distal ends much constrieted; margin oval, without teeth or angles. The bases of the hydrotheca in a given row are not in aligmment, as in Mydrallmamia, and in some places the alignment is so disturbed that the effect of eight, instead of four, rows is produced. In places but two rows are visible in looking at a branch from above, and the lyydrotheca look is if implanted in pairs, the two of a pair having their distal ends inclined the same way, as in tig. 8.

cromosome. - Not known.

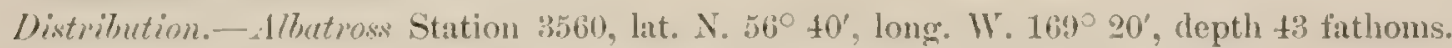

'This remarkable hydroid bears a curious resemblance to what might be called a "four"ply"

Thydrallmanie. 'The type specimen is much damaged and overgrown with bryozoa, and unfortunately lacks the gonosome.

Type slides.-Cat. No. 19812, U.S.N.M.; Cat. No. 18786, Museum of the State University of Iowa; also in the collections of the author.

SYNTHECIUM Allman (modified).

Trophenome.-Branches opposite, nodes regular. Hydrotheca opposite or alternate, margins smooth, round, often rimmed or reduplicated. Operculum apparently wanting.

Gomosme-Cronangia springing from the interior of hydrothece, where they replace hydranths. 
Allman's original description of this genus was as follows:

"Trophosome. - Hydrocaulus divided into internodes, each internode "arrying a pair" of opposite sessile hydrothecie.

"Gonosome.-Gonangia supported on peduncles which spring from the cavity of certain bydrothece, where they take the place of the hydranth."1

In his Chullenger Report, the same writer found reason to modify this detinition, at least so far as the trophosome is concerned, as follows:

"Hydrocanlus divided into definite internodes, each internode carrying a pair of opposite hydrothece, or a single hydrothea which alternates with those of the internodes on each side of it. Hydrothece adnate for a greater or less extent to the internode." ".

This genus was recognized by Bale in $1888^{3}$ and by Marktanner-Turneretscher in 1890, who instituted the family sirnthereidie for the aceommodation of the gemus. Torrey takes just

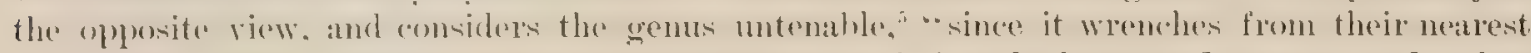
allies such diverse species as Sertulurelle altemans and Sertuluria campylocumpun, and unites them on the basis of a feature which is chiefly interesting to the physiologist.". When such a character, however, is associated with others, snch as the absence of an operculum, the smooth margin, the strictly opposite branches, all in a very definite group of species, we have a perfectly well-defined generic group. The main point of difficulty with the present writer is to determine whether or not this group is of fumily rather than generic value, as held by MarktannerTurneretscher. The basing of genera on single characters is a proceeding that is very likely to lead to error, while the grouping of several characters for generic diflerentiation is a much safer and logical method. As to the gonosome being chiefly interesting to the physiologist, it must be said that in so far as this character is a morphological feature of great usefulness in classification, the systematist would be most unwise to relinquish it.

KEY TO AMERICAN APECILS OF THE GEXLS SYNTHECIUM.

Hydrothecre opposite.

Hydrothecre tubular, curved in the quadrant of a circle, orifice round.

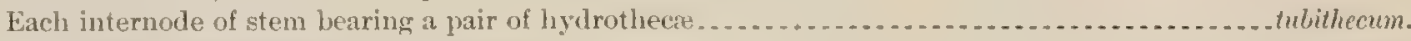

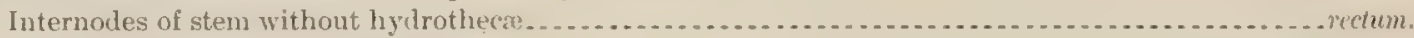

Hydrothece doubly curved, orifice triangular . . . . . $\ldots \ldots \ldots \ldots$.

Ilydrothece short and stout, deeply immersed . .

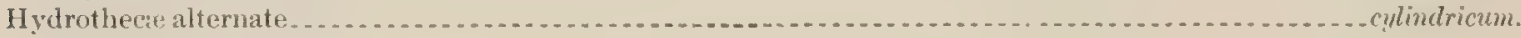

POINTS OF INTERGRADATION BETIVEFN SYNTHECIUM AND OTIIR GENERA.

With Sertuluria, in the strictly opposite hydrothece and regular internodes. The resemblance to such species as S. desmoides Torrey is quite elose. The gonosome, howerer, is entirely different.

With Sertularella, in alternate hydrotheca, as in S. cylindricum. In this case the entire absence of an operculum will serve to identify the genus to which a given species belongs. When the gonosome is present there is no trouble of course.

\section{SYNTHECIUM TUBITHECUM (Allman).}

(I'late XLI, fig. 1.)

Sertularia tubitheca Allanan, Mem. Mus. Comp. Zool., V, No. 2, 187t, p. 24.

Sertularia tubitheer Fewkes, Bull. Mus. Comp. 'Jool., VIII, No. 7, 1881, p. 128.

Sertulerin tubitheca Notrux,, Narrative Bahama Expecl., 1845, p. 88.

Trophosome-Colony consisting of a monosiphonic stem with strictly opposite branches, attaining a height of $1 \frac{1}{2}$ inches. Stem cylindrical, divided into regular, long internodes, each of

\footnotetext{
${ }^{3}$ Journal of the Linnean Society, XII, 1874, 1). 265.

${ }^{2}$ Challenger lieport, The Hydroida, Pt. 2, 188s, p. 77.

${ }^{3}$ Proceedings of the Linnatan Society of New Sonth Wales, 21 series, III, 1888, p. 766.

${ }^{4}$ Hydroiden des k. k, naturhistorivchen Hofmusenms, 1890, p. 24S.

${ }^{5}$ The Ifydroida of the Pacifie Coast of North America, 190:, p. 62.
} 
which bears a pair of branches on its distal end, below which are one or two pairs of hydrothecae. Branches opposite, with a constriction at their origin, divided into regular internodes, each of which bears a pair of hydrotheca near its distal end. Hydrothecae opposite, long, tubular, regularly curved so as to form nearly a yuadrant of a circle; marerin round, flaring, often several times reduplicated, in some cases with quite constantly a single reduplication, as described by Allman. Operculum not eviclent.

Gomosmme-Gonangia springing from the lumen of hydrotheca, oblong-oval, anmulated throughout. When examining the type specimens in the Museum of Comparative \%oology the writer found one specimen in which the gonangium was growing from the hydrotheca, and was of characteristic Symthecium type.

Distribution.-'Tortugas, 18 fathoms (Allman); Albetross Station 2311, lat. N. 32055 , long.

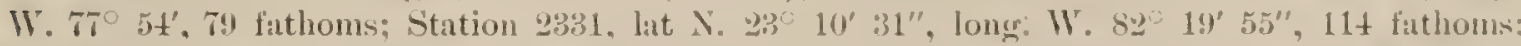

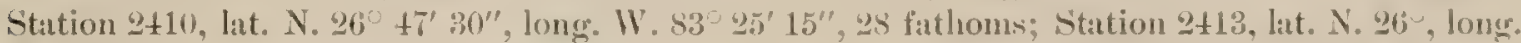
IV. $52.56^{\prime} 30^{\prime \prime}, 2+$ fathoms; Station 2414 , lat. N. $2500 t^{\prime} 30^{\prime \prime}$, long. W. $82^{\circ} 5 y^{\prime} 15^{\prime \prime}$, 26 fathoms. Off Barbados, 76 futhoms (Fewkes).

The presence of pairs of hydrothece on the stem seems to be the best character hy which this species can he separated from S. rectum.

Type.-In the Museum of Comparative /oology, Cambridge. Massachusetts.

SYNTHECIUM RECTUM, new species.

(1'late XLI, lig., 2.)

Trophosome.-Colony consisting of a monosiphonic stem, with strictly opposite branches attaining a height of about three-fourths of an inch. Stem straght, tubular, exceedingly: transparent, with distant and irregular nodes, ol none. IBranches opposite, origrinating from a tubular process of the stem, from which a branch springs like a section of a telescope. This feature, however, is not constant. Branches divided into regular internodes, each of which bears a pair of hydrothece on its distal half and does not become noticeably attenuate near its proximal end, branches in many cases forming a right angle with the stem from which ther spring. Hydrotheca tubular, cylindrical, regularly curved through a quadrant of a circle, the aperture openingr diectly ontward, not contingent in front, free for more than their distal half; margin entire. sometimes slightly ererted, and usually with a distinct narrow rim; no operenlum. There are no hydrothece on the branch-bearing portion of the stem.

Gromosmine.-Not known.

Distribution.-Dredged near Habana, Cuba, by the Bahama Expedition from the State University of Iowa; Albetross Station 2416 , lat. N. 31026 , long. W. 7507 '. 276 fathoms.

This species has been compared with Allman's type of Sertuluriu tubithece in the Museum of Comparative '/oology and found to be quite distinct, being much more transparent in structure and not having pairs of hydrotheca regularly distriluted on the stem.

Type slifles -Cat. No. 19715, U.S.N.M. Cat. No. 1s671, Museum of the State University of Iowa; also in the collection of the anthor.

?SYNTHECIUM MARGINATUM (Allman).

(Plate XI.I, fig. 3.) .

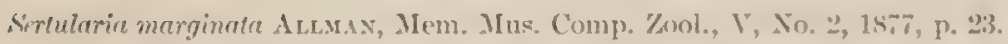

"Trophesome.-Hydrocaulus attrining a height of ahout an inch, simple; internodes clonmited, attenuated below every par of hydrotheca. Hydrotheca opposite, deep, tubular, free and divergent above for about three-fifths of their height, slightly tumid helow, oritice entire. with a broad rin formed by close strie, which run in a circular direction round the distal end of the hydrothecie."

Gromismm.-Not known.

Distribution.-Off Filorida Reef, 32+ fathoms (Allman). 
I have not seen this species and have copied the description of Allman entire. The species evidently belong to the Synthecinm group, and appear's to be an exceptionally well-marked form.

Type. In the Museum of Comparative Zoology, Cambridge, Massachusetts.

\section{SYNTHECIUM ROBUSTUM, new species.}

(Plate XLI, figs. 4-6.)

Trophosome.-Colony attaining a height of $2 \frac{1}{2}$ inches. Stem not fascicled, straight, without hydrotheca below the proximal branches, hydrothecate above, divided into irregular internodes. Branches strictly opposite and divided into branchlets; main branch straight, giving off pairs of strictly opposite branchlets and bearing as a rule three pairs of hydrothece between adjacent branchlets; internodes rariable; the most common arrangement being one for each pair of branchlets, there being two pairs of hydrothece ahove and one below the branchlets; branchlets straight, witl a tendency toward an internode to each pair of hydrothece. Hydrothecae tubular, short, stout, extensively immersed, only a small part of the distal adcauline side being free; margin neither constricted nor flaring, and withont ornamentation, but sometimes broadly sinuated; aperture round, sometimes subtriangular. No operculum.

Gmoxme-Gonangia springing from the interior of hydrothece, terete, heavily annulated, with a very small tubular neck and round aperture. 'The specimens were dried, and the gonangia greatly distorted, making it necessary to attempt a somewhat uncertain reconstruction in the drawings.

Distribution.-Albatrose Station 2766, 'lat. S. 52 41', long. WV. $69^{\circ} 55^{\prime} 30^{\prime \prime}$, 21 fathoms.

This species has shorter and more extensively immersed hydrothece than any of the others of the grenus thus far described.

Ty/pe slides--Cat. No. 1971t, U.S.N.M.; Cat. No. 18670, Museum of the State University of Iora: also in the collection of the anthor.

\section{SYNTHECIUM CYLINDRICUM (Bale).}

(Plate XLI, fig. 7. )

Sertularella cylindrica Bale, Proc. Linn. Soc. New South Wales, 2d. ser., III, 18s8, p. 765.

Serlularella cylindrica HARTLAlB, Revision der Sertularella-Arten, 1900, 1. 65.

Sertukella halecinu Torrey; Hydroida of the Pacitic Coast, 1902, p. 61.

"Hydrocaulus about half an inch in height, simple or slightly branched, divided by" oblique joints into internodes of moderate length, each bearing a hydrotheca on its upper part. Hydrotheere adnate nearly half their height, large, stout, cylindrical, smooth, usually' somewhat rounded at the base, curved outward; aperture looking outwards and upwards, not contracted, margin entire, very slightly everted, peristome often double or triple.

"Gomosome-Gonothece (male) arise from within hydrotheca; long, tubular, somewhat broader than bydrothece, and five or six times as long as broad. A single tubular gonophore."

Distribution.-Port Jackson, Australia (Bale): San Diego Bay, California, 5 to 12 fathoms ('Torrey).

The description and figures of Sertularell halecina Torrey almost exactly agree with those of S. cylindrica Bale, leaving no room for doubt of the identity of the two species. Hartlaub ${ }^{3}$ sugrgests the probable identity of $S$. cylindrica and Sertularia integra $\Delta$ llman. ${ }^{2}$ The original figures of these two species are so different that one is at a loss to imagine why this suggestion was made. ${ }^{2}$

I have not seen this species, and have copied the above deseription of the trophosome from Bale, and that of the gonosome from Torrey.

Type.-In the Australian Museum ?.

lievision der Sertularelli-Arten, 1900, p. 65. "Joumal of the Jinnean Society, XII, 1874, pl. xu1, fig. 4. 


\section{ANNOTATED BTBLIOGRAPHY.}

The author has included in the bibliography for this section:

Iirst. The works contaning original descrptions of the genera of Sertularidar, and also those containing original descriptions of species of this family that have been found in Imerican waters.

second. All works containing important discussions of the embryology and morphology of the characteristic features of the Sertularidic.

Third. All works containing an important systematic discussion of this group.

Fourth. All works which contain original and important data concerning the geographical distribution of the Sertularide. This does not include nere faunal lists, unless they pertain to al gengraphical region not covered by the other works included in this bibliography, or give a new geographical range for American species of Rertularidil.

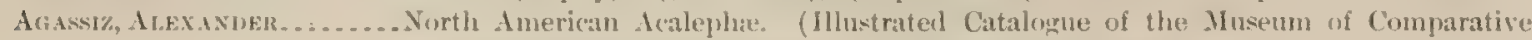
\%oology at Harvard College, No. II, Cambridge, 18t5.)

Contains a mention of all North American Sertularielat known at that time, as well as a bibliography of each speceies.

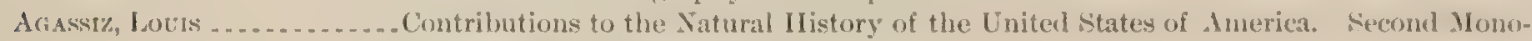
uraph, IV, 13oston, 186:2.

Contains a lesutifully illustrated study of $S$. pumilu and a complete bibliography of the Hydroila.

A.DEk, Josme. ............. Catalogue of the \%oplytes of Northumberland and Durham. (Transactions of the: 'Tyne-Side Naturalists' Field Club, Newcastle-on-Tyne, HI, 1857, 1. 1.)

Contains the original deweriptions of serulurelle tricuspidate and werlulurellet termelle.

The same species, together with the same plates, were lescribed and figured the precelling year in the Innals and Magaine of Satural History, ad series, XVIII, Mp) 356-335, in a praper entitled A Notice of some new genera and species of British Iydroid \%oophytes, by Joshua Alder, esq.

Al,MAx, Georit: J .......... Monograph of the Gymoblastic or Tubularian Hydroids. In two parts. Part I, The IIydroila in General. (Ray Society, London, 1571, Ip. 1-231.)

Contains a good acrount of the development of Diphere rosucect and sertulurie milla.

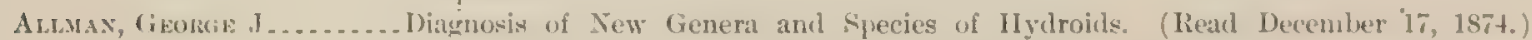
(Joumal of the Limnean Socicty, Zoology, X11, p. 251.)

Original descriptions of the genera simthecium and selaginopsis and of sertularelle epriscopus.

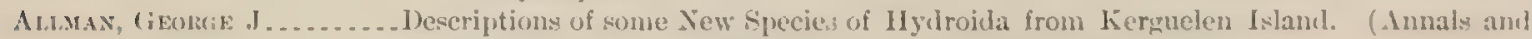
Magrazine of Natural IIistory, th series, XVII, 1576, p. 113).

Contains the original description of sertulurella unilateralis.

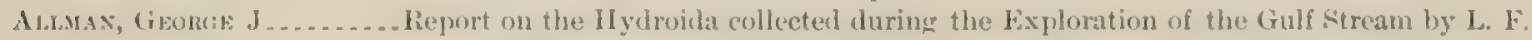
de Pourtales, assistant, United States Coast Survey. (Memoirs of the Musenm of Comparative Zoology at Harvard College, V, No.", Cambridge, 1877.)

Contains original descriptions of Sertularella coniere, st. amphorifert, synthecium marginutum, s: lubitheca, Sertuluria tumider, s. exigun, S. rathbuni (under name of Thuiaria sertuluriodes), S. pourtulesi (under name of sertuluria distans), Theiaria plumulifera, and serfularella distans.

Alimax, Geonge J . . . . . . . Description of Australian, Cape, and other Hydroids, mostly new, from the Collection of Misy 11. Gatty. Rear March 19, 1885.). (Journal of the Linnean society: Zoology, XIX, p. 13:'.)

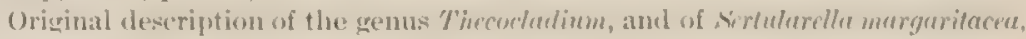
S. rlifuect, and Thuiuria remosissima. 
Allman, George J..........The voyage of H. M. S. Challenger. Zoology. lieport on the Hydroida dredged by II. M. K. Chullomger during the years 1873-187t. Part II. 'The Tubularine, Corymorphine, Campanularina, Sertularinit', and Thalamophora. 1888.

Origrinal descriptions of the genera Stutrothece and Dictyocladium, and of Sertularellu filiformis, S. clausn, S. catena, S. cylindrithece, S. quadrifida (under name of Thuiurio gumdrictens), Sirtularia challengeri (under name of Desmoscyphus pectinu(us), Sertularia vershysi (under name of Desmoscyphns gracilis). ${ }^{1}$

BALE, W. M ............... On the Hydroida of Foutheastern Anstralia, with descriptions of supposed new species, and notes on the genus Aglaophenia. Melbourne, 1881. (Journal of the Microscopical Society of Victoria, II, p. 1)

Valuable as recorling occurrence in Australia of a few American forms.

BALE, W. II ............. . . Catalogne of the Australian Hydroid \%oophytes. Syduey, 1884.

Contains good systematic discuscions, and descriptions of Sertularide.

Bat.e, W. M ............. Some new and rare Hydroida in the Australian Musem Collection. (P'roceedings of the Limnean Society of New South Wales, 2 d series, III, June 27, 188s, p. 745.)

Containg original description of Symthecium cylinelricum.

BEDOT, MAvRIe, and I'ICTEr, lísultats des Campagnes Scientifiques accomplies sur son Yacht par Llbert Ier, l'rince CAMrue. Souverain de Monaco. Fascicule XVIII. Hydraires provenant des campagnes de l'Hirondelle. 1886-188s, Monaco. 1900.

Unrivaled as a perfect sample of illustration and of bookmaking, so far as the literature of the Hydroids is concerned.

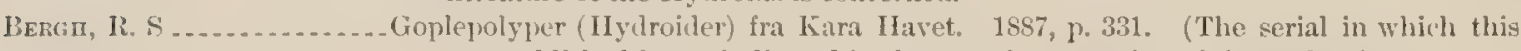
was published is not indicated in the copy in possession of the anthor.)

Extenda the known distribution of several sertnlarians to the Aretic: Soa.

Bonnevie. Kristrne . . . . . . . The Norwectian North Atlantic Expedition, 1876-1878. Zoolngy. IIydroida. Christiania, 1899.

A raluable work, especially in adding to our knowledge of both the geographical and bathymetric distribution of several sertularians.

CALEINs, GAdY N ........... Some IIyclroils from P'uget Sound. (Proceedings of the Boston Society of Natural History, XXViII, No. 13, January, 1899, p. 333.)

Extends known range of several species of sertularidx.

CLARk, S. F . . . . ......... . Report on the Hydroils collected on the coast of Alaska and the Alcutian Islands by W. H. Dall, L.S. Coast Survey, and Party, from 1871 to $187 t$ inclusive. (Proceedings of the Acalemy of Natural Sciences of I'hiladelphia, 1876, p. 209.)

An important paper containing original descriptions of Thuiaria dalli (under name of Serfularia cupressoides), Alietinarie veriabilis, A. incanstans, Thuiariu thuierioides, T. rolneste, T. plumose, Alietinario turgida, 1: gigrentea, sertulareilu gimata. It also extends the known geographical dietribution of a number of well-known species of Sertularidre.

CLARK, S. F ...............The Hydroids of the Pacific Coast of the United States, south of Vanconver Island. With a Iieport upon those in the Iuseum of Yale College. (Transactions of the Connecticut Acadeny, 1II, 1876, 1). 249.)

Gives a list of seven species of sertularians, some of which had not been before reported from the Pacific coast.

CLAREE, S. F ............ Ieport on the Hydroida collecterl during the Exploration of the Fulf Stream and (iulf of Mexico by Alexander Agassiz, 1877-78. (Bulletin of the Museum of Comparative Zoology, V, No. 10, 1879, p. 239.)

Extends known range of Sertulariu cornicina (under name of $S$. complexa) and of several other sertularians.

CLARKE, S. F .............. Reports on the Dredging Operations off the West Coast of Central America to the Galapagos, to the West Coast of Mexico, and in the Gulf of California, in charge of Alexander Agassiz, carried on hy the U. S. Fish Commission steamer Allutross during 1891, Lieut. Commander Z. L. Tanner, U. S. Navy, commanding. XI. The IIydroils. (Bulletin of the Museum of Comparative Zoology, XXi, 1894, p 71.)

Original description of Sertularellu tropsica (under name of serhularia variabilis).

Concinther, Mulex......... Critical Notes on the New Zealand Hydroida, Suborder Thecophora. (Anmals and Magazine of Natural IIistory, 4th series, XVII, 1876, p. 22.)

Finds Sertularic pumilı in New Zealand.

Driescr, HAxt.............. Tektonische Studien an Hydroidpolyper, Jena, 1890, p. 189,

Discusses the mode of lranching and the order of succession of the persons of the hydroid colony.

${ }^{1}$ When both the generic and ppecific names have been changed, the original name is given. Where the generic: name only has heen changed, the original name is not given. 
D'URB.ı, W. S. M ......... The \%onlogy of Barents Sea. (Annals and Magazine of Natural Ihistory, 5th series, ( I , 1880, p. 25\%.)

Adds several species of hyetroids to those known to oecur in the Arctic Oecan.

ELLIs, Jonx ................. In Fssay towarl a Natural History of the Corallines, and other Marine I'rotluctiong of the like Kind, Commonly found On the Coasts of Great Britain and Ireland. London, 1755.

I monumental work, giving original deseriptions of a number of species, but umler linglish names, the binomial system not having at that time been adopted.

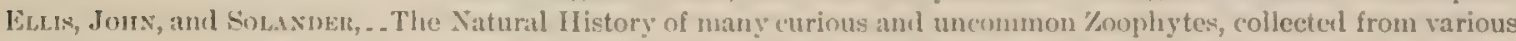
D.MIEL parts of the globe by the late John lillis, caq., L. K. S. London, 1786.

In this work the species described in the preceling, and others, receive their binomial designations. Ijnneus hat, in the mentime, however, applied these binomials, and so receives the eredit of being the original describer accorling to our present system. The work contains strictly original descriptions of Thuiuria

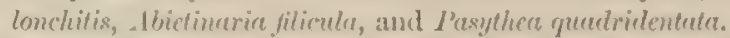

Fıвricis, Otro ............ Fanna (iroenlandica Systematica sistens Animalix, MDCCLXXX.

Contains the carliest report regarding the occurrence of some of the sertularians in (ireenland.

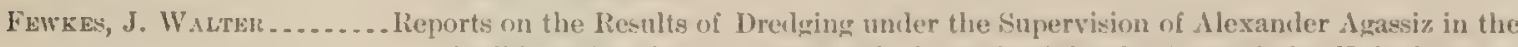
Caribhean Sea, in 1878,1879 , and along the Atlantic Coast of the United States, during the summer of 1850 , by the U.S. Coast Survey Steamer "Blake," Commander J. I. Bartlett, U. S. N., commanding.

Report on the Acalephre. (I3ulletin of the Museum of Comparative Zoology, VIII, No. 7,1881, 1. 127.) Contains the original description of Sirlulurele formoset.

FEwKEs, J. WI.TER.......... In aid to the Collector of the Ceclenterata and Fehinolermata of Xew England. (Bulletin of the lissex Institute, XXIII, Nos. 1, 2, 3, 1891, p. 1.)

Designecl for popular use.

Fonbes, E................ On the Norphology of the Reprouluetive System of the Sertularian Zoophytes, etc. (Amals and Magazine of Natural llistory, . $\mathrm{XV}, 1814$, p. 385.)

Interesting as ascientific curiosity. The writer discusses the analogies between the reproductive systems of plants and hydroids.

Govld, Auguste's A.......... report on the Invertebrata of Massachusetts, comprising the Mollusca, Crustacea, Annelida, and Radiata. Cambridge, 18t1. IReports Sertularin pinnetr Pallas.

Gray. Jonx Euwnd........ List of the Specinens of I3ritish Animals of the Collections of the British Museum. Part I, Radiated Animals. Iondon, 1847.

Contains the original description of the genus sicriularelk.

IAmaxx, Otro .............. Der Organismus der Hyclroidpolypen. (Separat-Ablruck aus der Jenaischen 'Zeitsehrift für Naturwiscenschaft, XV, New Series VIII, Jena, 1S8:, pp. 1-72.)

I ereneral morphological discussion of the IIydroida.

Hargitt, Cuandes W . . . . . Synopees of North American Invertebrates. XIV. The Hydromedusie. I'art II, p.379. (American Naturalist, XXXV, 1901.)

I compilation. Useful in deternining the common species of the New bingland coast, but far from complete.

Hartraub, Clemexs......... Die Iydromedusen Helgolands. 2. Bericht. (Beitrüge zur Meeres-Fana von Ifelgolands. ‥ II issenschaftiche Mceresuntersuchungen herausgegeben von der Kommission zar Untersuchung der deutschen Mcere in Kiel und der biologischen Anstalt auf Helgoland, n. f., II, Heft. 1, Abth. …) 1897.

I valuable work, but containing little of interest concerning the Sertularidic, except a small faunal list.

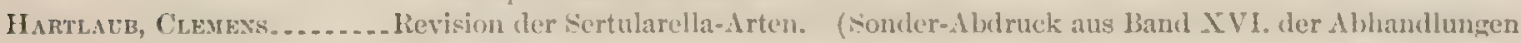
atus den Gobiete der Naturwissenschaften. Herausgegeben von Naturwissenschaftlichen Verein, IIamburz, 1901. . Reprinted from a separate dated 1900.)

I work of the highest rank. So original descriptions, but new nameg are given in three cases, Semblawlln guadritiln (for Thuiaria guatridens Allman), Sertulurellu ullmmi (for Sertulurin unilateratis sllman), and S. tropica (for S. vurialsilis Clarke). The work contains an excellent systematic discussion, extensive talules of synonymy, and complete recorl of the known geographical and bathymetric distribution of the genus.

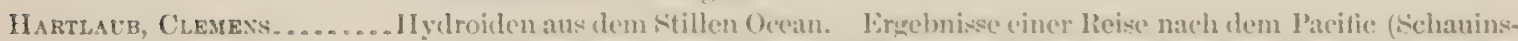

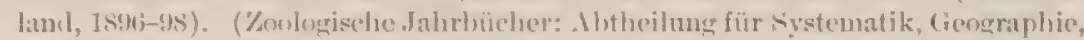

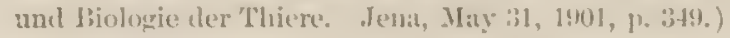

Largely a compilation. Contains the original description of sirtulurcla nana. 
Heller, Cas ............. Die Zoophyten und Echinodemen der ahriatischen Mieeres. k. k. zoologisch-botanischen Gesellschaft. Wien, 1568.)

Interesting, on account of geographical distribution of some well-known sertularians.

Hincks, Thomas H.......... Catalogue of the Znophytes of South Devon and South Cornwall. (Annals and Magazine of Xatural History, 3d series, VIII, 1861, P. 251.)

Contains the original description of serularclle fusiformis.

Hixcks, Tnoms H........... Ilistory of the British Ifydroid Zoophytes, London, 1868.

A very important work. Original description of the genus Hydrallmanict.

Hinckis, Thosas ............ On Deep-water Hydroida from Iceland. (Annals and Magazine of Natural History, the series, XIII, 187t, p. 146.)

Contains the original description of Serhuturelle geniculetu.

Jonnstos, Guontik ........... I History of the British Zoophytes, 2d ed., London, 1847.

One of the British classics.

Kincrexpaver, (i. II . . . . . . Nene Sertulariden aus verschiedenen Hamburgischen Sammlungen, nehst allgeneinen Bemerkungen ülyer Lamouroux's Gattung Dynamena. Dresden, 1864.

I systematic discussion of Sertularice and Dynomena. Excellent figures.

Kirchenpauer, (i. H ........ Nordische Gattungen und Arten von Sertulariclen; (Abhandhungen aus dem fiebiete der Naturwisenschaften herausgegeben von Naturwissenschaftlichen Verein in IJamburg. VIII, I’t. $3,188 t_{0}$ )

Contains descriptions of many sertularians. Proposes the genus Alietinaria. Original description of Thuiuria cleguns, T. annuluta, Sertulurellu contorta, S. albida, S. subdichotoma, S. sieboldi.

LAмаяск, J. B. P. A. de.... . Histoire naturelle des animaux sans vertèbres, 2nd edition, 1836.

I classic work. Restricts the genus Sertularia by setting off the genera Intmmelaria and I'lumelario.

LAsongód, J. V. F......... Extrait d'un mémoire sur la classification des P'olypes coralligènes non entièrement pierreux (Nouveau Bulletin des Sciences par la Société philomatique de Paris, III). Paris, 1812.

In important paper. Defines Dynamena, Sertularia, and P'tsylhen, and sets aside the Campanularians and Plumularians from the Sertularida.

LAmouroux, J. V. F . . . . . . . Histoire des Polypiers coralligènes Hexibles vulgairement nommés Zoophytes. Caen, 1816.

Contains descriptions of all sertularians known at that time. No new species. A good bibliography:

Lamounovx, J. V. F......... Exposition méthodique des Genres de l'orlre des Polypiers, avec leur description et celle des principales espices, figurées clans 84 planches, etc. Paris, 1821.

Original description of Sertularella gryi.

Lendenfeld, R. vox......... The Australian Hydromeduse. (Proceedings of the Linnean Society, New South Wales IX, X. $188+5$, pp. 206-2 $41,401-420)$. Contains an elahorate systematic discussion of the IIydroida, and reports some species of sertularians that are also found in American waters.

Levinsen, G. M. Ii. .......... Meduser, Ctenophorer og Hydroider fra Grünlands Vestkyst telligemed Bemzerkninger om Hydroidernes Systematik. (Saertryk af Videnskabelige Meddelelser fra der naturhistoriske Forening, 1892. Kjohenhavu, 1892, p. 1.)

A very valuable paper, especially in its masterly systematic discussions and investigations concerning the operculum. Contains original description of Thuiaria. fabricii and Selaginopsis altomithecr.

Levinsen, G. M. R.......... Om Fornyelsen af Erneringsindividerne hos Hydroiderne. (Same publication as above, $\left.189^{\circ}, \mathrm{p}, 12.\right)$

Another paper containing a discussion of the operculum, and also of the reduplication of the hydrothecal marcin.

Lrwxt r. . . . . . . . . . Systema Nature per Regna Tria Nature secundum Classes, Ordines, Genera, Species, ('um characteribus Differentiis, Synonymis, Jocis. I0th edition, 1758.

Our present nomenclature being based on the system of Linnens, this work is an indispensable classic. It containg the original binomial descriptions of the following species: Sertularia mumila, S. operculata, Diphasia rosacea, D. tamarisca, Thuiaria cupressina, T. argentea, T. Ihija, IIydrallmania falcata, Abictinaria abietina, Sermularella megose, s: polyzonins, and Selaginopsis cedrima.

McCreadr, John ............ (iymuophthalmata of Charleston Harhor. (I'roceedings of the Elliott Society, I, No. 1, 1858, p. 103.)

An Anerican classic. Original description of Sertuluric connicina. 
MIRKTANER-TUTNERETSCIIER, GOTTLIE.

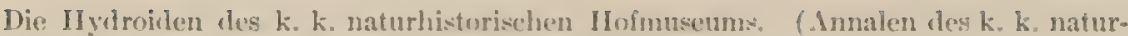

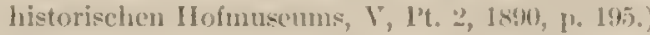

In important work, especially in its systematic discussions. I'roposes the genera Celyptothuerie and Monopome that are not adopted in this work. Contains a good biblingraphy, and original deseriptions of Sertularia lubulformix and sirtulierella magelleniers.

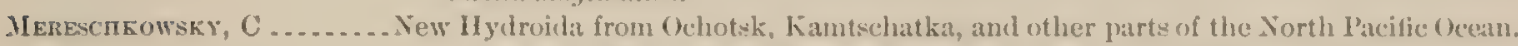
(Annals and Magazine of Xatural History, 5 th series, II, 18i8, p. 4333.)

A comprehensive treatment of selaginopsis. Original asecriptions of S. Iriserialis, S. pinnata, Dhelinaria compresse, and Sertularella clarkii.

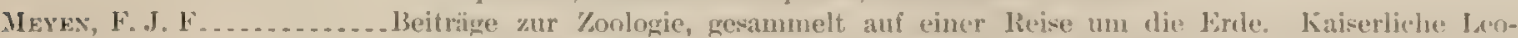
poldino-Carolinische deutsche A kademie der Naturforscher, XV11, 1835, p1. 1-125.

Contains the original description of serlularlla jucta.

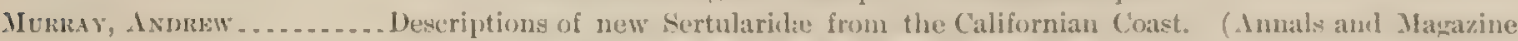
of Natural History, 3il series, $1,1860, \mathrm{p} .250$.

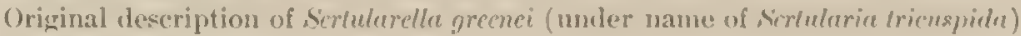
and Diphasiu comiculutu.

Fonsax, A. M ............. Note on Felaginopsis (=l'ulyserins hinclsii, Meresehkowsky) and on the circumpolar distribution of certain Iytrozoa. (Annaly and Mazazine of Natural History, 5th series, I, 1878, p. 189.)

Contents senoted by title.

Nuristi, C. C

Bahama Fixpedition. (Bulletins from the Ialoratories of Natural Ifistory of the State University of Iowa, III, Xos. 1 and 2, 18\%.)

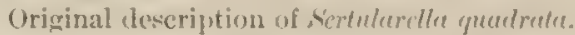

Nutrivi, C. C

Hydroikla from dlaska and l'upet Sound. (l'roceedings of the U. S. Sational Juseum, XXI, No. 1171, 1599, p. 7t1). tion.

Original deseription of IIydrullmeniu distans. Discussey geographiceal distribu-

Nutring, C. C

The Ilylroids of the Wools Hole leerion. (Bulletin of the L. S. Fish Conumission for 1899. 1901, r. 325.)

serves for identification of sertularians of the region.

Nutrixg, C. C ............ Papers from the Harriman Alakka Fiperlition, XXI, The Ifylroids. (Proceedings of the Washington Academy of Sciences, III, 1u. 15i-216, May, 1!01.)

Discusses faumal regions of Forth Pacific Coast, and circumpolar distrilution. Original descriptions of Abietinerin coci, Diphessin kincudi (under name of Thuiarin clegans), and - bictinarin costata.

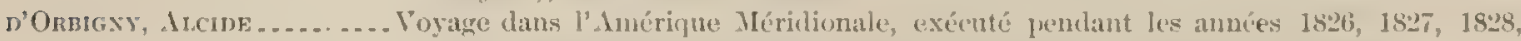
$18: 9,1830,18: 31,18: 32$, et $183: \%, 1$, P't. 4: \%oophytes, l'aris, 18:39 et 1846.

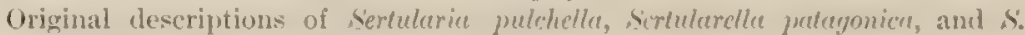
mimerem. Excellent firures.

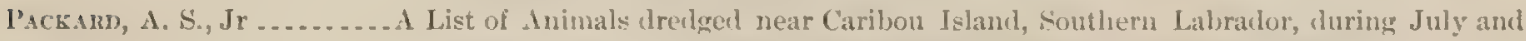
August, 1860. (Cinadian Naturalist and Cieologist, December, 1863.)

Indieates new range for some well-known sprecies.

S.munnssox, B.. . ....... Bidrag til Kundskaben on de Islaniske Iydroider, 1902.

Valuable on aceount of data regarding geographical distribution.

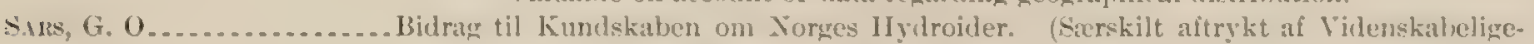
Selskabets Forhandlinger for 1873, p. 1.)

Contains valuable clata on distribution, and the original description of Thumeria temerre.

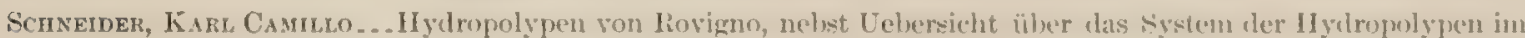
Algeneinen. (Zoologische Jahrbiucher, Ahtheilung für systenatik, $\mathbb{X}$, 1897, p. 47.2.)

Contains a good systematic divenssion of the relationship of the families of Hydroida, and the genera of the Sertularide.

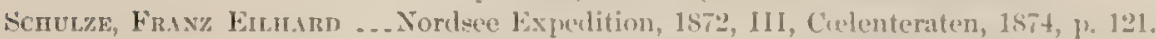

Contains extensive tables showing geographical and lathymetric distribution.

Stmpon, Whum ......... Symopsis of the Marine Invertebatid of Cirmul Mauan, or the region ahout the Mouth of the bay of Fumly, lew lirunswich. (Smithsonian ('ontributions th knowlelge, VI, Article V, 18.5.)

Contains original descriptions (withont ligures) of Thuiurin lefiusculu, and "Serfularin producte" which seems to be as synonym of Diphersin tumariser.

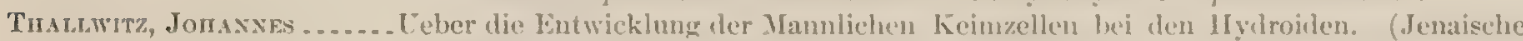
Zeitschrift, XV1II, 185.5, 1.,385.)

Discusses the origin of the spermatozoa in sicrularella prolyzonies. 
Thompsox, D'Ancy W....... On some new and rare Hydroid Zoophytes (Sertularidie and Thuiaricle) from Australia and New Zealand. (Annals and Magazine of Natural History, 5th series, II, 1879, p. 97.)

Describes the only known Selaginopsis from the Southern Hemisphere.

THonver, LuUn Roscok... . The IIydroid Zoophytes collected by Doctor Willey in the Southern Seas. (fieprinted from A. Willey's Zoological Results, l'art IV, 1) 456 . Cambridge University Press, 1899.)

Gives new record for Sertularic zumilt and P'asythed quadridentate.

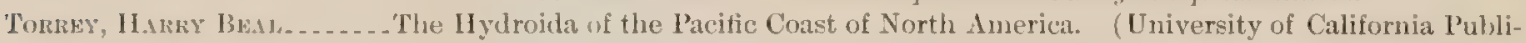
(ations, Zoology 1, pp. 1-104. November, 190\%.)

In important work, containing discussion of geographical distribution on the l'acific coast, and original descriptions of Sertularella dentifere, Sertularia desmoides, and Ihetimerin trosli.

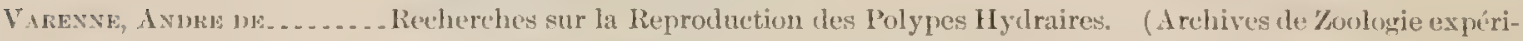
mentale et générale, X, l'aris, 1882, pp. 1-100.)

Includes an account of the embryology of Sermiaria jumila.

VERRILL, 1. Fi, and SMITI,, I.

lieprort upon the Invertebrate Animals of Vineyard Sound and Adjacent Waters, with an Account of the Physical Characters of the Region. (Report of the Commissioner of Fish and Fisheries, $1871-72,150.295-178$.

A valuable work, giving the habitat and local distribution of many sertularians.

Venulu, 1. E............ Preliminary Check-list of the Marine Invertebrata of the Atlantic Coast, from Cape Cod to the Gulf of St. Lawrence. (Prepared for the U. S. Commission of Fish and Fisheries, 1879. Author's edition, New Haven, June, 1579, pp. 1-32.)

Contains a list of 20 species of sertularians, many of which are first reported in America in numerous short papers loy the same author.

Fensurs, J. Junk ........... . Hydraires Calyptoblastes recueillis dans la Mer des Antilles pendant l'une des Choimières accomplis par le Conte $R$. de Dalmas sur son yacht Chrazlie. (Mémoires de la Société zoologique de France, XII, Pt. 1, p. 29, Paris, 1899.)

Contains the original description of Sertularie brcicyathes.

Wamian, Aucust......... bie entstehung der Sexualzellen bei den Hydromedusen. Zugleich ein Beitrag zur Kentniss des Baus und der Lebenserscheinungen dieser Gruppe. Jena, 1888.

Contains a good account of the origin of the sex cells in Sertuluria pumila and Sertularella polyzonias.

WmTeaves, J. F............ Catalogue of the Marine Invertebrates of Eastern Canada (Geological Survey of Canaria), 1902.

Valuable for material on geographical distribution. Gives new locality for Sertularello fusiformis.

Wintuen, Geork............ Om Internodiets Byquing og sammensetning hos Sertularierne. (Naturhistorisk Tidsskxift, 1879-80, p. 304.)

Discusses variation in internodes and position of lydrotheche in five well-known species of Sertularide. 


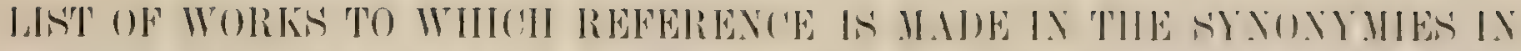

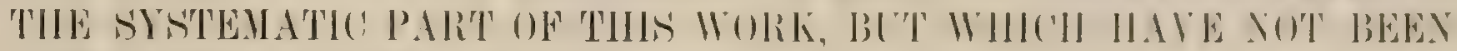 CONSULTED BY THE AUTHOR.}

When the title is preceded by an asterisk $\left(^{*}\right)$ the references to that work are marle on the authority of llartlaub's Revision der Sertularella-irten. Otherwise the references are male on the atuthrity of II. Bedot's Matériaux gour servir à l'Histoire des Iyclrobles.

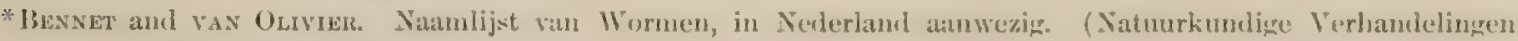

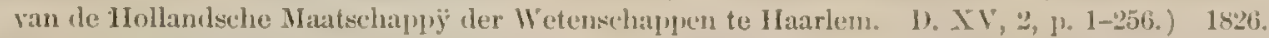

BerkexhouT. Synopsis of the natural history of great-13ritain and Irelam, erntaning an systenatic armangenent and concise description of all the animals, vegetables, and fossils which hate been hitherto discoveret in these Kingeloms. London, 1795.

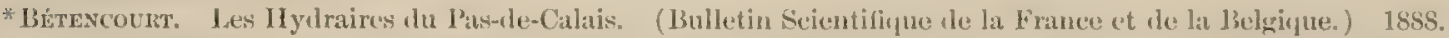

Deuxième liste des Iy yrares du Pass-de-C'alais. ('Trav:ux de l'Institute matritime de l' Institute Zoologique de Lille et Wimereux, VII, p. 1.) 1899.

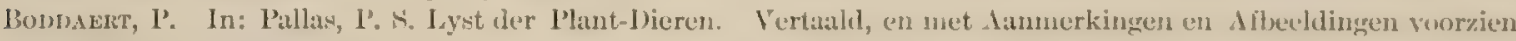
door I', Borldaert. Utrecht, 1768 .

Bnugvime. IIistoire naturelle des Vers, I. (Encyclopédic méthodiçue.) Paris, 1759.

* Cares. P'rodromus Fanne Mediterranex, I. Stutteart, 1885.

C.Mouxr. Memorie per servire alla storia de l’olipi marini. Napoli, 1785.

*Cnidje, Delle. Menorie sulla storia e notomia degli animali senza vertebre del rugno di Najoli. Napoli, 1828.

* Desloxciscriars. Zoophytes (Histoire naturelle des Zoophytes ou animax rayonnés par Lamouroux). (Encylopédie méthodique, Histoire Naturelle, l'aris, 1791.)

Li)Wards, Grorges. Gleanings of Natural Ilistory. 3 vols. London, 1758-1764.

Lispen, F. J. C. Fortsetzungen fler P'lanzenthiere. 1't. 2.. Nïrnberw, 1794-1806.

- Die l’flanzenthiere in Ablildungen nach der Natur mit Farben erleuchtet. 3 vols., Nürnborg, 178s-18s0.

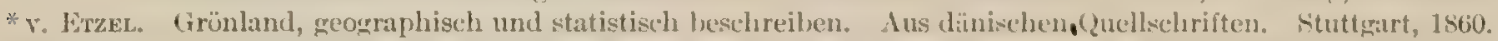

* Farquarre List of New Zealand Hydroida. (Translations of the New Zealund Institute, LXVIII, p. 459, 1895.)

* Graefre. Übersicht der Seetierefauna des Golfes von Triest. (Arbeiten aus dem Zoolologischen Institute, Wien und Triest, Y, p. 3is3.) 1884.

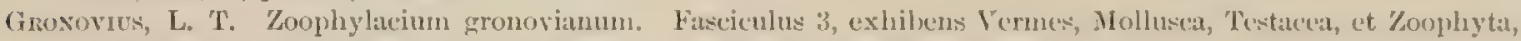
quae in Museo sto adservavit, examini subjecit. Lnerluni l3atavorum, 1781.

* Henksotz. De Weeklieren en lagere Dieren H. (Natumlyke Historie van Vederland.) Ansterlam, 1sto.

* Hingeximar, On the hydroids of the Nejghborhood of Duncolin. (Transactions of the New Yealand Institute, XXX, p. 200.) 1897.

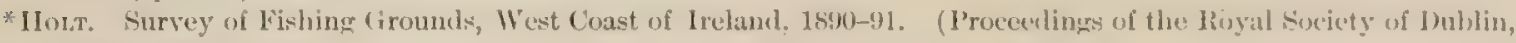
VII, P. 2.25\%) 1892.

Houtroxs, M. Natuurlyke historie of uitvoerige beschryving der bieren, l'anten en Mineralien venlgens het samenstel van den Heer Linneus. Frste Deels, Dieren. Ansterdam, 1761-73.

JAneson, R. Catalogue of animals of the class Vermes found in the frith of Forth and other parts of seotland. (Memoirs of the Wernerian society, I, for the years 1807-1810.) litinburgh, 1811.

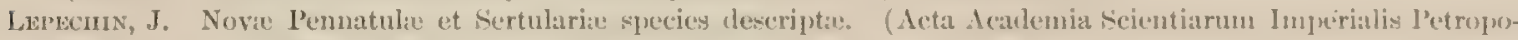
litana pro anno 1778.) 1781 .

Lexpcnix, J. Sertularie species due determinate. (Acta Academia Scientiarum Imperialis f'etropmlitant: pro anno 1780.) 1783.

* Iterker, Cnu. A revised Catalogne of the Anthozoa and Calyeozoa of Greenland. (T. limpert Joness Manual of the Satural Ilistory, efe. of Grenland and the neighbouring regions, prepared for the use of the dretie lixpendition of 1875.) London, 1875 .

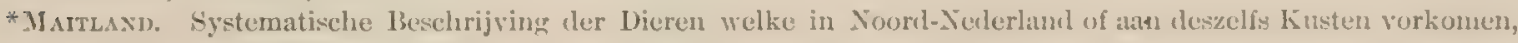
ete. Iseiclen (2zte Uitgave), 1851.

Maratrx, J. Fr. De Plantis Zoophytis et Lithophytis in Mari Meditermen viventibus. Linne, 176ti.

* Mänes. Uber die Thiere der Schleswig-holsteinisehen Austernbanke, ete. (Sitzungsberichte der këniglich I'renssischen Akademie der Wiscenschaften \%u Berlin, Jahruang 1593, p. 67.) 1593.

* Mörcir. Fortegnelse over Grönlands Blüddyr. Mollusca Grünlandica in: link Grünland quograph. og statisk lxeskr. U. 2, 1. 75.1857.

$5125-\mathrm{T} T 2-04-10$ 
Mt̂̀ler, O. F. Zoologiæe Danice prodromus, seu animalium Danie et Norsegi:e indigenarum characteres, nomina et synonyma imprimis popularium. Haunia, 1776.

* Niciols. Ifydrozoa (IIaddon, First lieport on the Marine Faima of the South lVest of Ireland). (Proceedings of the Royal Irish Acarlemy (2), IV, Science, p.615.) 1886.

OLivi. Zooloyia adriatica. Bassano, 1792.

* Pfefrer. Zur Fauna von Sud Georgien. (Jahrbuch Hamburger Wissenschaftliche Anstalt, Jahrgang VI, p. 37.) 1889.

Die niedere Tierwelt des antarctischen Ufergebietes. (Nemmatiner, Ergelmiswe der Deutschen I'olarExpedition, II, p. 455.) 1893.

*Pieper. Ergänzungen zu Heller's Zoophyten etc. des adriatischen Meeres. ('/oologischer Anzeiger, VII, p. 18.j.) 1884.

* Radder Die Sammlungen des Kaukasischen Museums, I. Tillis, 1899.

* Rrdeer, St. O. Celenterata from the Straits of Magellan and of the coast of I'atagonia. (1'roceedings of the Zoological Society of London, 1881, p. 102.) 1881.

SAyigny, J. C. et Audoun, J. V. Explication sommaire des jlanches de I’olypes de l'Egypte et de la syrie, publices par J. C. Savigny. (Deseription de l'Egypte en Recueil des ohservations et des recherches qui ont été faites en Eyypte pendant l'expédition de l'armée française. Histoire naturelle. I, Pt. 4, p. 225.) Paris, 1809.

* Stonir. Bidrag til Kundskab om Throndhjemsfjordens Fauna I. (K. Norkke Videnskabelige Selskabets Skrifter. Jahrgang 1878 , p. 9.) 1879.

*Templeton, J. Catalogue of Irish Annulose and Rayed Animals, selected from the papers of the late J. T. by Robert Templeton. (Loudon's Magazine of Natural History, I. , p. 466.) 1836.

WiLEeNs, C. F. and Herbst, I. F. W. Pallas, P.S. Charakteristik der Thierpflanzen aus dem Lateinischen ubersetzt und mit Ammerkungen versehen. Nürnberg, 1787. 


\section{EXPLANATION OF PLATES.}

Unless otherwise indicated all of the figures in the plates were drawn by Mrs. Lilian Hulwelus Crone after original camera lucicla sketches from nature by I'rof. C. C. Nutting. Where figureg were copled from the works of other authors the souree is indicated, and the copies were malle hy Mrs. Crone.

The text figures illustrating the stem, hydranths, and gonophores, unless otherwise indicated, were drawn by Mr. J. II. Parmann after camera lucida sketches by the anthor. All of the other text figures were drawn by $11 \mathrm{r}$. l'anrmann with the aid of the cancra lucida, excent when copies were made from other publications, in which case the source is indicated in the explanation of the figures.

\section{l'LATE: I.}

Fis. 1. Serlukriu pumilu Linneus. Portion of main stem and branches (enlarged).

2. Sertulariu pumilu. Side view of branch, showing gonangium (enlarged).

3. Sertularin pumila. Iair of hydrotheco and expanded hydranth (greatly conlarged).

4. Serfulariot tersluysi Nutting. P'ortion of main stem and branches (enlarged).

5. Sertularia versluysi. Part of branch (enlarged).

6. Sertularia versluysi. Branch from another colony (enlarged).

7,8,9. Sertularia versluysi. Pairs of hydrotheca (greatly enlarged).

I'LATE: II.

Fig. 1. Sertularia challengeri Nutting. Iortion of stem and branches from Allman's type of Desmoscyphus pectinalus Allman (enlargerl).

2. Sertuluria challengeri. I'art of branch from same specinen (greatly enlarged).

3. Serluluric operculete Linneus. Portion of branch with gonangiun (enlarged).

4. Sertularies operculatu. A pair of hydrothecte (greatly enlarged).

5. Sertularia operculata. Siste view of hylmotheca (ereatly enlarged).

6. Sirtularia pulchelle (d'Orbigny). Portion of branch with gonangium (enlarged). (After d'Orbieny.)

7. Sertularia pulchelle. l'art of branch with gonangium (enlarged). (After Clarke's drawing of Sertularia furcate Trask.)

8. Sertulerice bispinose (Gray). Part of branch (enlarged).

9. Sermlariu bispinosit. Pair of hydrothece (greatly enlarged ).

10. Scrtularia bispinosa. Sile view of branch (enlarged).

11. Sertulariu Lispinosa. Side view of lydrotheca (greatly enlarged).

\section{PI.ITE III.}

Fig. 1. Scruluria desmoides Torrey, I'art of branch (enlargerl).

2. Sermilerin desmoieles. P'air of hydrothecae (greatly enlareed).

3. Sertularin desmoides. Ind of hylrotheca, showing aperture (greatly enlarged).

4. Sertuluria ruthboni Nutting. P'ortion of branch (enlayped).

5. Sertularia rathbuni. I'air of hydrothece (zureatly enlargerl).

6, 7. Serfulurin rathbuni. Iateral views of hydrothece, sluowing tridentate matrgins (greatly (onlatherel).

8, 9. Sertulerice rathbun. Two other views of margins (greatly enlareded).

10. Sertularia gracilis Hincks. Part of branch with gronangium (enlarget).

$$
\text { I'L.ITE: } 11 \text {. }
$$

Fici. 1. Scrtularie cornicina (MeCrealy). Colony with gonangia and expanderl hydranths. I)rawn from life (enlarged).

2. Sertuluria cornicine. I'air of hydrothece (greatly enlarged).

3. Serlularia comicina. Gonangium (enlarged).

4. Serularia comicina. Side view of colony with parasitic campanularian and its gonangum (enlargerl).

5. Sertularia cornicina. Part of same colony (enlarged). 
I'LATE Y.

FIG. 1. Sertulurin mayeri Nutting. Basai portion of colony (enlarged).

2. Sertularie mayeri. Distal part of stem (enlarged).

3. Sertulariu maycri. Side view of stem (enlarged).

4. Sirtularia mayeri. Hydrothece with collapsible tubular extensions (enlarged).

5. Serfularia poutalesi Nutting. I'art of stem (enlarged).

6. Sertularia slookeyi Nutting. Part of stem and gonangium (enlarged).

7. Sertularia stookeyi. Pair of hydrothece (greatly enlarged).

\section{I’LATE VI.}

Fir: 1. Sortularia brcvicyathus Versluys. I'art of stem (enlarged).

2. Serlularia brericyathus. Side view of stem (enlarged).

3. Sertularia Howersi Nutting. Part of stem (enlarged).

4. Sertularia Howersi. Side view of stem (enlarged)

5. Scrularia tumide Allman. P'air of hydrothecie (enlarged). (After Allman.)

6. Sertularia erigua Allman. Pair of hydrothece (enlarged). (After Allman.)

PLATE VII.

FIst 1. Thuiaria thuja (Linneus). l'art of branch (enlarged),

2. Thuiarib thuja. Two hydrothece (greatly enlarged).

3. Thuiuriu lhija. Single hydrotheca (greatly enlarged).

4. Thuirric elegans Kirchenpauer. I'art of branch (enlarged). (Aiter Kirchenpauer.)

5. Thuiuria robusta Clark. Side view of branch (enlarged).

6. Thuicria rolusiat Front view of branch (enlarged).

7. Thuiaria robusta. Part of branch with gonangia (enlarged).

\section{Plate Vili.}

Fig. 1. Thuiaria thuiarioides (Clark). Part of stem, showing branch origin (enlarged).

2. Thuiaria thuiarioides. I'air of hydrothece (greatly enlarged).

3. Thuiaria thuiarioides. Single hydrotheca, showing operculum (greatly enlarged).

4. Thuiaria thuiarioides. Part of branch (enlarged).

5, 6. Thuiaria thuiarioides. Gonangia (enlarged).

7. Thuiaria polycarpa (Kirchenpauer). Part of stem, showing branch origin (enlarged).

8. Thiviaria polycaryo. Part of branch (enlarged).

9. Thuiariapolycarpa. Side view of two hydrothecte (enlarged).

\section{Plate IX.}

FIri. 1. Theiarin kurilx (Poppig), Part of branch (enlarged).

2. Thuiaria kurile. Single hydrotheca, showing margin (greatly enlarged).

3. Thuieric immerse Nutting. Part of branch (enlarged).

4. Thuiaria immersa. Hydrothece (greatly enlarged).

5. Thuiariu lonchitis (Ellis and Solander). Part of branch with gonangia (enlarged).

6, 7, 8. Thuiaria lonchitis. Hydrothece, showing variation on margin (greatly enlarged).

9. Thuiarie plumulifera Allman. Part of branch (enlarged).

10. Thuiaric plumulifera. Part of another colony (enlarged).

11. Thuioric plumulifera. Part of main stem, showing branch origin (enlarged),

12, 13. Thuiaria plumuliferu. Hydrothecx, showing margin (greatly enlarged).

\section{P'LATE X.}

Fig. 1. Thuicric diffusn (Allman), Part of branch (enlarged).

2. Thuiurie diffusa. Two hydrothece (greatly enlarged).

3. Thuioria diflusa. Single hydrotheca (greatly enlarged).

4. Thuiaria dalli Nutting. Part of branch (enlarged).

5. Thaiaria dalli. l'art of stem, showing branch origin (enlarged).

6. Thuiarir dalli. Two hydrothece (greatly enlarged).

7. Thuiaria similis (Clark). Part of colony with gonangium (enlarged).

8. Thuiaria similis. Hydrothece (greatly enlarged).

9. Thuiaria similis. Four hydrothece (greatly enlarged). 
P'..1T: XI.

Fic. 1. Thuiaria lubuliformis (Marktunner-Turneretscher). I'art of colony, showing main stem and branch origin (slightly enlarged).

2. Theiuria lubuliformis. l'art of branch (enlarged).

3. Thuiaria tululiformis. I'art of branch with gonangium (enlarged).

4. Thuiric tubuliformis. Side view of two hyilrothecse (greatly enlarged).

5, 6. Thuiurie tubuliformis. Linds of hyldothece, showing margins (onlarged).

7, 8. Thuturin hubliformis. Gonangia (enlarged.)

9. Thuieria tenere (Sars). P'art of colony' (enlarged).

10. Thuiuria tenerve. I'art of branch (enkarged).

11, 12. Thuiarin tewere. Lnds of hydrothece, showing margins (ureatly cularged).

$$
\text { Pbotte XI1. }
$$

Fis. 1. Thuiuria fabricii (Levinsen). I'art of branch (enlarged).

2. Thuiurin fubricii. l'art of luranch with genangia (onlargerl).

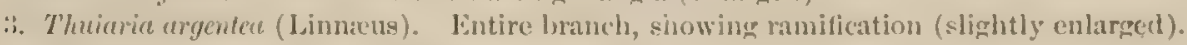

t. Thuidrie argentes. l'art of branch (enlarged).

5. Thuiveric argenter. Distal part of branch (enlarged).

6. Thuireriu argenter. Two hydrothecse: (greatly cnlareced).

7. Theierie angented. Hydranth expanded, etrawn from life (greatly enlarged).

8, 9. Thuiarice argenter. Gonangia (enlarged).

\section{P'I.ITE XIII.}

Fic. 1. Thuiaria cupressinu (Linnens). Part of branch (enlarged).

2. Thuintire cupressine. IIydrothece (greatly enlargerl).

3. Thuiurue cupressinu. Gonangia (enlarged).

4. I'csythea querdridentutu (Ellis and Solander). Trophosome (enlarged).

5. I'usytheu quadridenutu. Hyilrothece and gonangiun (greatly enlarged).

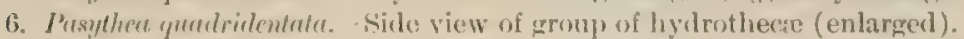

7. Pasylhea quadridentuir. Side view of two hydrothece (greatly enlarged).

\section{PLATE XIV.}

Fig. 1. Sertularella gami (Lamouroux). I'art of branch (enlarged).

2. Sertulerelle groyi. J'art of branch with gonangium (much less enlarged).

3, 4. Sertularella gayi. Hydrothece, showing operculum (enlarged).

5. Sertularellugami. (ionangium (enlarged).

6. Sertularellu ga!li (var. roluklu Allman). Part of branch with gonangium (enlarged).

7. Sertulurelle greyi (var, roluste). I'art of colony overgrown with Filelhem sevpens (enlarged; .

P'L.TTE XV.

Fic. 1. Sertularellu conice Allman. Part of branch (enlarged).

2. Sicrularelle conicu. View of margin and operculum (enlarged).

3. Sirtulerelle catene (Allman). I'art of Allman's type specimen with gonangia (enlarged).

4. Serfulerelle quadruke Nutting. Part of branch (enlarged).

5. Scrtulurelle querelrate. Single gonangium with parasitic campanularian (greatly enlarged).

6. Sertulerelle quadratet. lart of branch with gonangia (enlarged).

\section{P'LATE XII.}

Fist. 1. Semblarelle tameri Nitting. I'art of branch (enlarged).

2. Sertulurella genicululu Hincks (enlarged). (After Ilincks.)

3. Sertulurellu patagonicu (d'Orbigny) (enlarged). (After d'Orbigny.)

PLATE XVII.

Fic. 1. Sertularella muosa (Linnacus). Part of branching colony (enlarged).

2. Scrtularella migosa. Colony with gonosome (enlarget). (After Nutting.)

3. Scrularella rugosa. Three hydrothece (greatly enlarged). (After Nutting.)

4. Sertulurella rugnsa. Single hydrotheca (greatly enlargedi). (After Nutting.)

5. Sertulerelle rugose. Top of gonangium, showing teeth (enlarged). (After Nutting.)

1. Serlulurelle areyi Nutting. I'art of colony (enlarged). 


\section{P'Late XVIII.}

Fic. 1. Sertularella tenella (Alder). Part of colony (enlarged).

2. Sertulurella tenclla. End of hydrotheca, showing operculum (greatly enlarged).

3. Sertularella allmani Hartlaub. Part of colony (enlarged).

4. 5. Sertularellu allmani. If yrothece, showing margin and operculum (greatly enlarged).

6. Siertularclla allmani. (ionangium (enlarged).

7. Sirtularclla contorta Kirchenpauer. Part of branch (enlarged).

8. Sertulerella contorte. Iydrotheca, showing margin (greatly enlarged).

9. Sertularella contortu. Gonangium (enlarged).

10. Sertulurella lutu (Bale). I'art of branch (enlarger).

PJ.ATE XIX.

Fı:. 1. Sertulardla albida Kirchenpauer. Part of branch (enlarged).

2. Sertularella albida. Branch with gonangium (much less enlarged).

3. Sertulurdlu pinnigere Hartlaub. I'art of branch, showing hydranths (enlarged). (After Allman.)

4. Sertularella cylindritheca (Allman). Part of branch (enlarged). (From Allman's type specimen.)

5. Sertularella distans (Allman). Part of branch (enlarged).

6. Sertulurellu distons. Two hydrothece (greatly enlarged).

7. Sirhulurellı gignatu Mereschkowsky (slightly enlarged). (After Mereschkowsky.)

\section{Piate XX.}

Fr:. 1. Sertularella amphoriferce Allman. Part of branch (enlarged).

2. Sertulerella ampliorifera. End of hydrotheca (greatly enlarged).

3. Sertulurella fusiformis Hincks (enlarged). (After Hincks.)

4. Sertularella fusiformis. (ionangium (enlarged). (After IIncks.)

5. Sertularelta picta (Meyen). Part of colony (enlarged). (After Meyen.)

6. Sertularella picta. Single hydrotheea (greatly enlarged). (After Hartlaub.)

7. Sertularella picta. I'art of branch with gonangium (enlarged). (After IIartlaub.)

8. Sertuluwlla megrstomu Nutting. l'art of branch (enlarged).

9. Sertularelle megusfomet. l'art of branch with gonangium (enlarged).

10, 11. Sertularella soliturit. Nutting. Single hydrotheme (enlarged).

\section{PLLATE XXI.}

FIti. 1. Sertularella polyzonicss (Fllis and Solander). Part of branch (enlarged).

2. Sertularellu polyzonias. Gonangium (enlarged).

3. Sertularella clause (Allman). Part of branch from Allman's type (enlarged).

4. Sertulerella clausa. End of hylirotheca, showing operculum, from Allman's type (greatly enlarged).

5. Sertuluella complexe Nutting. I'art of branch (enlarged).

6. Sertulurllu complext. End of hydrotheca, showing operculum (greatly enlarged).

7. Sertularella complex'a. Cionangium (enlarged).

8,9. Sertularellu complext. (ionangia viewed from above, showing teeth (enlarged).

10. Sertulerelle pimutu Clark. Part of colony with gonangia (enlarged).

11. Sertulerella pinnatu. I'art of branch, front view (enlarged).

12. Scrulurclla pinnuta. Single hychotheca (greatly enlarged).

\section{P'LATE XXII.}

Fus. 1. Sertularella margariacert Allman. Part of branch with gonangium (enlarged). (After Allman.)

2. Sertularella turgitu (Trask). l'art of colony with gonangium (enlarged).

3. Sertularelle turgide. Distal part of branch (enlarged).

4,5. Sertularella turgilu. Ends of hydrothece, showing teeth (greatly enlarged).

6. Sertularella sieboldi Kirchenpauer. Part of branch (enlarged). (After Kirchenpauer.)

7. Sertularella sieboldi. Gonangium (enlarged). (After Kirchenpauer.)

8. Sertulurella sulutichotoma li irchenpaner. Part of colony, showing branching (enlarged).

9. Serfulurella subdichotoma. Hydrotheca, showing margin (greatly enlarged).

10. Sertularelle subdichotoma. End of hydrothea, showing operculum (greatly enlarged).

11, 12. Scrulurelle subdichotond. Gonangia (enlarged).

\section{Plate XXIII.}

Fra. 1. Sertultella filformis (Allman). Branch with gonangium, from Allman's type specimen (enlarged). 2, 3. Scrtularella filformis. IIydrothecre, from same specimen (greatly enlarged).

4. Sertularella quatrifitu Hartlaub. Part of Allman's type of Sertuleria quedridens Allman (enlarged).

5. Scrularella quadrifida. Three hydrothecx from same specimen (greatly enlarged).

6, 7. Sevtulurella qualrifulu. Hydrothece from same specimen, showing teeth and opercula (greatly enlarged).

8. Sirmluella merillimulis Nutting. Part of branch with gonangium (enlarged).

9. Sertularelle merilionalis, Single hydrotheca, showing teeth and operculum (enlarged). 


\section{P'TATE XXIV.}

Fir. 1. Serfularella elegans Nutting. I'art of colony with gonangium (enlargerl).

2. Sertulurelle milneaue (d'Orbigny). Part of branch (enlarged).

3,4. Sertularelle milneana. Ginds of hydrothecai', showing teeth and operenlat (greatly enlarger).

5. Sertulardle milneene. Gonangium (enlarged).

6. Sertularella magellanicu (Marktanner-Turneretwcher). Lower part of colony (enlarged).

7. Sertulurelke magellanicu. Distal part of colony (enlarged).

8. Sertulaweln magellanice. End of hydrothera, showing teeth (enlarged).

9. Serfulerelle minuta Sutting. Part of colony with gonangium (enlarged).

10. Serfulurelle mimute. Lind of hydrothesa, showing teeth (greatly enlarged).

\section{I'IAT: XXY.}

Fin. 1. Serfularella dentifera Torrey. I'art of colony (enlarged). (After Torrey.)

2. Sertularella dentifere. Two hydrothecal, showing reduplicated margins (enlarged). (After Torrey.)

3. Serfularella tricuspielatu (Alder). P'art of colony (enlarged).

4, 5. Sertularelle tricuspidate. Gonangia (enlarged).

6. Serfulurelle tricuspidule (large form from Alakia). (1'urt of colony enlarged.)

7. Sertularella tricuspidale. Single dygdrothecar (greatly enlarged).

I'LATE XXVI.

Frr. 1. Serlulurelle levinseni Nutting. I'art of colony with gonangia (enlargerl).

2 Sertulerellu lerinsent. End of hychotheca (greatly enlarged).

3. Sertulurelle tropicu Lartlaub. 1’art of colony (enlarget). (Ifter Clarke.)

4. Scrulurelle tropicu. Gonangium (enlarged). (After Clarke.)

5. Sertulurelle clathii Mereschkowsky. Lart of colony (enlarged). (After Mereschkowsky.)

(i. Sirtularelle mona Hartlauh. l'art of branch (enlarged). (After I Iartlaub.)

7 sertuluelle episcopues sllman. L'art of colony with gonangia (enlargecl). (After Allman.)

\section{PIATF XIVII.}

Fin. 1. Sertularella mama Nutting. Iwo hydrothece (much less enlarged than other figures).

2. Sertulardlu formosı Fewkes. Branch overgrown with parasitic campanularian (enlarged).

3. Sertulurelle formoset. Part of Allman's type of Serfuluric integrilhece Allman (enlarged).

4. Sertularella formosit. l'art of stem with gonangia (enlarged).

5. Sertularelle harllabi Nutting. 1'art of stem showing branch origins (enlarged).

P'LATE XXVIII.

Fre: 1. Dictyocleulium flebellum Yutting. I'art of colony with gonangia (enlarged).

2. Dictyoclediem flabellum. L'art of branch (enlarged).

3. Dictyochdium, flabellum. Lind of hydrothera, showing teeth and operculum (enlarged).

4. Diphasia rosece (Linuzus). Branch with female gonangium (enlargenl).

5. Diphusin rosaces. Side view of branch with gonangium (enlarged).

6. Diphusie temarisen (Limnens). Two pairs of hydrotheene (enlarged). (After Irinchs.)

7. Diphasia tomuriset. l'ortion of colony with gonangia (enlarged). (After Hincks.)

l'LATE XXIX.

F's. I. Diphasia comiculata (Murray). I'art of colony (enlarged). (After Murray.)

2. Diphasie fallax (Johnston). P'art of colony, showing hranching (enlarged).

3. Driphasic fullax. liront view of lranch (enlarged).

4. Diphasiu fuliux. P'art of branch with gonangium (enlarged).

5. Diphlasiu fullux. L'air of hydrothece (greatly enlarged).

6. Diphasiu fallax. End of hydrotheca, showing operculum (greatly cularged).

P'IATE XXX.

Fis. 1. Diphasia tropica Nutting. l'art of colony (enlarged).

2. Diphusice tigintis (B3usk). Front view of hranch (enlarget).

3. Diphessut cligitulis. Side view of branch (enlarged).

4. Diphusic digitulis. P'art of Allman's type of Desmoscyphus acrenthocurpus Allman (enlarged).

5. Diphasiu digitalis. Distal ends of two hydrothece, showing the hood-like operculum (greatly enlarged).

6. Diphasid digitulis. Sinte hytrotheca, showing what appear to be opercular muscles (greatly ('nlarged).

7. Diphesin digitelis. (ronangium (cnlarged). 


\section{Ploate IXXi.}

FIG. 1. Diphasia pulchre Nutting. Two hydrothece (greatly enlarged).

2. Diphesiar pulchra. Part of colony (enlarged).

3. Dipleasia pulchra. Part of branch (enlarged).

4. Diphasia parmami Nutting. Part of branch with male gonangia (enlarged).

5. Diphosic paarmanni. Female gonangium (enlarged).

6. Diphasia patmanni. End of hydrotheca, showing operculum (much enlarged).

7. Diphesia kincridi (Nutting). Distal end of branch, with gonangia (enlarged).

8. Diphasia Kincaidi. Four hydrothece (greatly enlarged).

9. Diphasia kincaidi. Gonangium (greatly enlarged).

\section{P'LATE XXIII.}

Frg. 1: Abietinaria abietina (Linneus). Part of colony (enlarged).

2. Abiclinaria abietinu. Part of a branch (much less magnitied).

3. Abictinaria abictine. Two hydrothees, showing operculum (much enlarged).

4. Alietinaria variabilis (Clark). Part of colony, showing branching (enlarged).

5. Abiclinaria rariabilis. Four hydrothecto (much enlarged).

6. Hhotinariu rariabilis. Group of gonangia (enlarged).

7. Alictinaria rarinbilis. Gonangium (greatly enlarged).

\section{P'L.ITE IXXIII.}

Fig. 1. Abidinaria inconstans (Clark). Part of colony (enlarged).

2. Alietinaria inconstrons. l'art of branch (enlarged).

3. Llielinaria coci (Nutting). Part of branch, with gonangin (enlarged).

4. Alietinaria coei. Single hydrotheca, showing sinuation of margin (enlargerl).

5. Llictinaria coci. Top-shaped gonangium (enlarged).

6. Alictinaria trashi (Torrey). Part of colony, showing branching (enlarged).

7. Lletinaria traski. Two hydrothean (greatly enlarged).

8, 9. Ahictiverin truski. Lnds of hydrothece, showing opercula (greatly enlarged).

10. Abictinarie traski. Branch, with gonangium (enlarged).

11. Alictinaria trasli. Three hydrotheac from another colony (greatly enlarged).

\section{PLate XXXIV.}

FJG. 1. Alictinaria filicula (Ellis and Solander). Part of branch (much enlarged).

2. Alictinaria amphore Nutting. l'art of branch (enlarged).

3. Alictinarie cmphora. Distal part of branch (enlarged).

4. Alictineric amphora. Part of branch, with gonangium (enlarged).

5. Abictinaria anguma (Trask). Part of branch, with very slender liytrotheca (enlarged).

6. Abictinaric anguina. Part of branch with gonangia (enlarged).

7. Abictinaria anguina. Single gonangium (enlarged).

\section{I'L.ITE XXXV.}

Fig. 1. Alictinaric gracilis Nutting. I’art of colony with gonangium (enlarged).

2. Abictinaria gracilis. Four hydrothece (greatly enlarged).

3. Alietinaria compressc (Mereschkowsky). Part of l,ranch (enlarged). (After Mereschkowsky.)

4. Abietinaria compressa. Single hydrothece (nuch enlarged). (After Mereschkowsky.)

5. Abietinaric alexanderi Nutting. P'art of stem and branches (enlarged).

6. Abietinaria alexanderi. Part of branch and gonangium (enlarged).

7. Abictinaria alexanderi. Gonangium, showing meridional lines (enlarged).

8. Abietinaria alexanderi. Gonangium (nuch enlarged).

\section{P'LATE XXXVI.}

Fici. 1. Alietinarin greenei (Murray). Part of branch (enlarged).

2. Alietinaria greenei. Four hydrothece (enlarged).

3. Alietinarir greenei. I'air of hydrothece with toothed margins (much enlarged).

4. Abietinaria greenei. Pair of hydrothece with even margins (much enlarged).

5. Hbietinaria greenei. Side view of hydrotheare (enlarged).

6. Abictinaria greenei. Side view of hydrothece (much enlarged).

7, 8. Lictinaria greenci. Gonangia (enlarged).

9. Alietinaria costata (Nutting). Part of branch (enlarged).

10. Abietinariu costata. lart of main stem, showing branch origins (enlarged). 
Fir. 11. Abietinarin costala. Four hydrothece (much enlargerf).

12. Abitinariu costute. (iroup of gonangia (enlarged).

13. Abietinaria enmulate (Kirchenpauer). Part of main stem and branches (enlarged).

14. Dbictinaria mmelatre. l'art of branch (enlarged).

15. Aliclinarin anmetata. Side view of three hydrothecat (enlarged).

\section{PHATY XXYVII.}

Fici, 1. Abictineric turgille (Clark). Part of stem and branch (enlarede).

‥ Alsetharin turgide. (ionangium (enlarged).

:. Abietinaria giganted (Clark). l'art of branch (enlarged).

4. Alhetharin giganten. Sille view of branch with gonangia (enlarged).

5. Abietinaringigantea. Side view of three hyllothecae (enlarged).

\section{PHATE XXXVIII}

Frci. 1. Irydrallmania falcate (Linneus). Sirle vich of branch (greatly enlarged).

2. IIy lrullmanir fulcrte. Gonangiun (enlarged).

3. IIydrallmanie fulcuti. Front view of end of branch (enlarged).

4. IIydrallmanio falcuta. Sille view of end of branch (enlarged).

5. In!rullumir distans Nutting. Part of branch, side view (enlarged).

6. IIylubllmanic distuns. Front view of branch (enlarged).

7,8. H!ylrallmania distans. Front view of hyilrothece (much enlarged)

9. IIydrallmanire distans. (Yonangimm (enlargerl).

10. IIydrullmanio fronciscuna (Trask). P'art of colony (enlarged). (After Trask.)

11. Selaginopsis mimbilis (Verrill). I'art of branch (enlarged).

12. Seluginopsis mirubilis. Gonangium (enlarged).

13. Selaginopsis pinasler (Lepechin). l'art of branch (enlarged). (After Kirchenpauer.)

\section{P'LATE XXXIX.}

FIc. 1. Selaginopsis triscrialis Mereschkowsky. I'art of branch (enlarged).

2. Seluginopsis triserinlis. Basal part of branch (enlarged).

3. Selagimojsis plumifomis Nutting. Part of main stem, lranch and branchlets, showing manner of branching (enlarged).

4. Selaginopsis ubsoletn (Lepechin). I'art of branch (enlarged).

5. Seluginopsis disolete. Cross section of hranch (enlarged).

6. Seluginopsis pinnutu Mereschkowsky. I'art of branch (enlarged).

7. Selaginopsis cylindrien (Clark). l'art of branch (enlarged),

8. Staginopsis cylindrier. Single hydrotheca (greatly enlarged).

P'L.ITE XI.

IIG. 1. Selaginopsis ornate Nutting. Part of stem, showing canaliculated cenosare (enlarged).

2. Selaginopsis ornata. l'art of branch (enlarged).

3. Selaginopsis ornate. Gionangium (enlarged).

4. Selaginopsis olsoleta (Lepechin). I'art of branch (enlarged). (Aiter Kirchenpauer.)

5. Selaginopsis alternithect (Levinsen). Front view of part of branch (enlarged).

6. Seluginopsis alternithece. Side view of part of branch (enlarged).

7. Selaginopsis alternitheca. Gonangium (enlarged).

8. Selaginopsis harlaubi Nutting. 1'art of branch (enlarged).

\section{P'LTTE XIL.}

Frg. 1. Synthecium tubithectem (Allman). Part of colony, showing opposite branches (enlargerl).

2. Sunthecium rectum Nutting. l'art of colony (enlaryed).

3. S. Simthecium marginutum (Allman). Part of branch (enlarged). (After Allman.)

4. Sigrthecium rolustum Nutting. P'art of colony with gonangia (less enlarged).

5. Simuthecium mbustum. Part of branch, front view (enlargerl).

6. Simthecium rolustum. l'art of hranch, side view (enlarged).

7. Symthecium cylindricum (Bale). Part of branch (enlarged). (After Bale.) 


\section{EXPLANATION TO PIATE I.}

Lil.. 1. Sertuluria pumilu Linneus. Portion of main stem and branches (enlarger1). $\therefore$ Sertulariu pumila. Side view of branch, showing gonangium (enlarged).

3. Serularia pumila. Pair of hydrothece and expanded hydranth (greatly enlarged)

4. Sertularia versluysi Nutting. Portion of main stem and branches (enlarged).

5. Serlularia versluysi. Part of branch (enlargeil).

(i. Sertularia verstuysi. Branch from another colony (enlarged).

i, 8, 9. Sertuluria versluysi. I'airs of hydrothecie (greatly enlarged).

152 

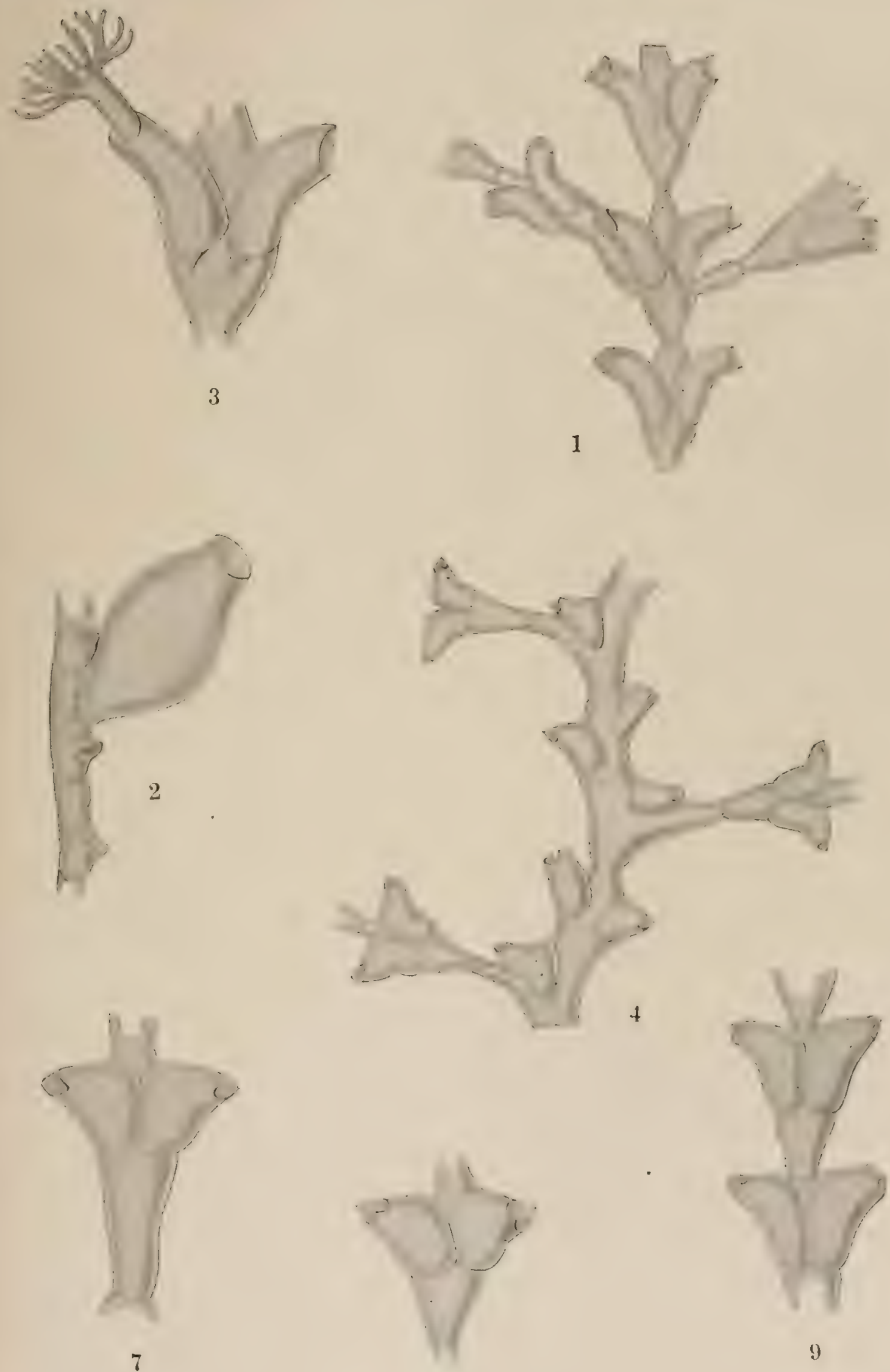

8

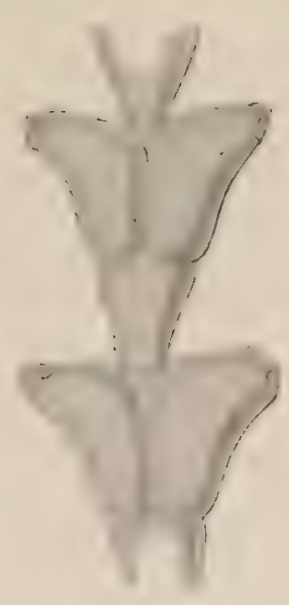

9
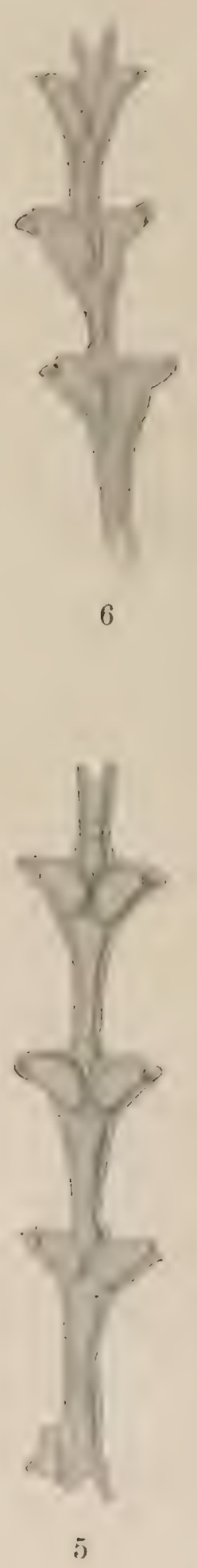

SFRTCLHIDF. 




\section{EXPLANATION TO P'IATE II.}

Fit. 1. Sertularit challengeri Nutting. I'ortion of stem anil branches from Allman's type of Desmoscyphius pectinalus Allman (enlarged).

2. Sertularia challengeri. Part of branch from same specimen (gieatly enlarged).

:. Serlutarin operculata Linneeus. Portion of branch with gonangium (enlarged).

4. Sertularia operculata. A pair of hydrothecæ (greatly enlarged).

5. Serhularia operculala. Side view of hydrotheca (greatly enlarged).

6. Sertularia pulchella (d'Orbigny). P'ortion of branch with gonangium (enlarged). (After d'Orbigny.)

7. Serhularia pulchella. Part of branch with gonangium (enlarged). (After Clarke's drawing of Sertularia furcula Trask.)

8. Sertularia bispinose (Gray). Part of branch (enlarged).

9. Sertularia lispinosa. Pair of hydrothecre (greatly enlarged).

10. Sertularia bispinosa. Sidle view of branch (enlarged).

11. Sertularin bispinosa. Side view of hydrotheca (greatly enlarged).

156 

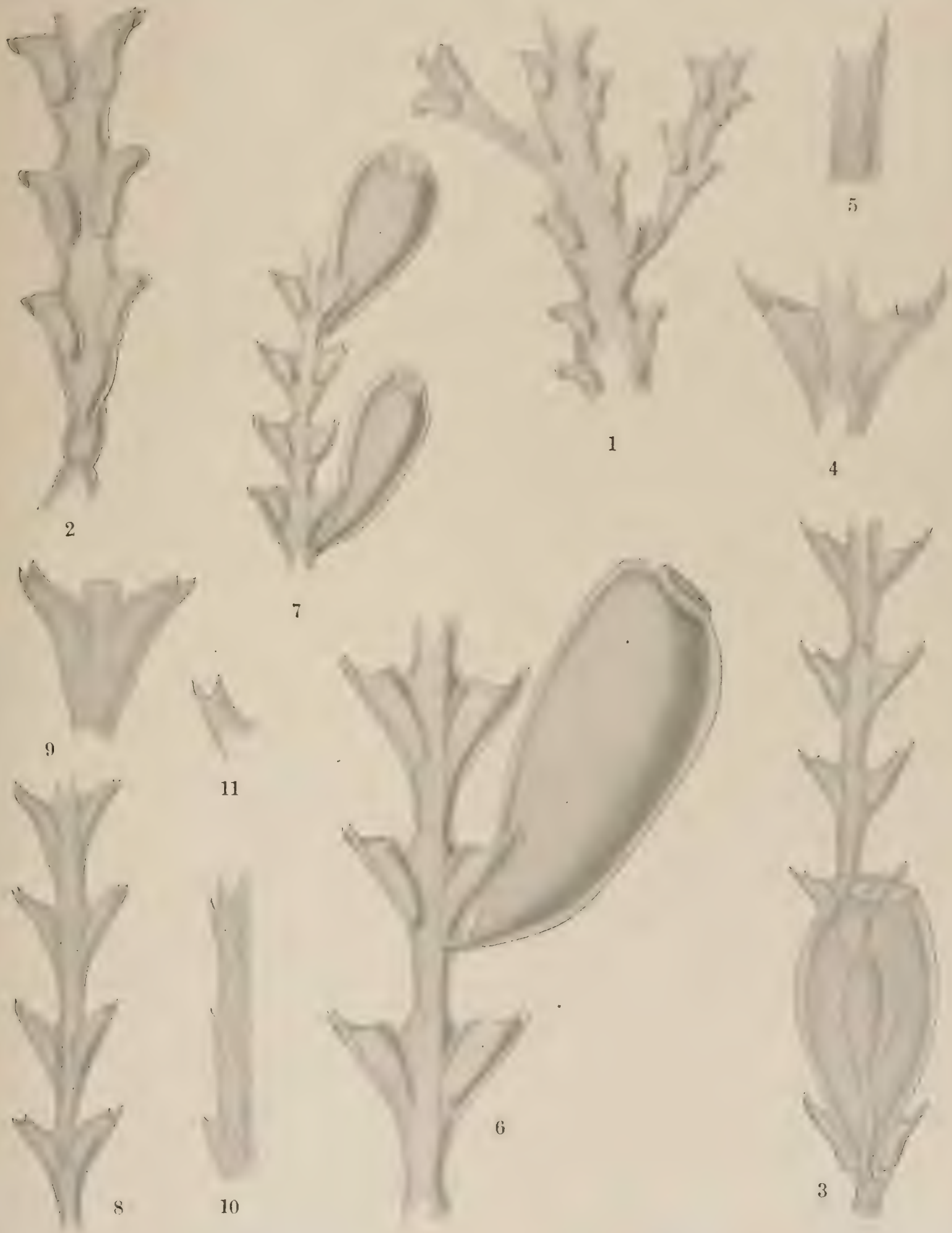




\section{EXPLANATION TO PLATE III.}

Fig. 1. Sertularia desmoides Torrey. Part of branch (enlarged).

2. Sertuluriu desmoides. Pair of hydrothecie (greatly enlargerl).

3. Sertularia desmoudes. End of hydrotheca, showing aperture (areatly enlarged).

4. Scrlularia rathbuni Nutting. Portion of branch (enlarged).

5. Sertularia rathbuni. Pair of hydrothece (greatly enlarged).

6, 7. Sertularia ruthbun. Lateral views of hydrothecre, showing tridentate margins (greatly enlarged).

8, 9. Sertularia ruhbuni. Two other views of margins (greatly enlarged).

10. Serhularia gracilis Hincks. Part of branch with gonangium (eularged). 


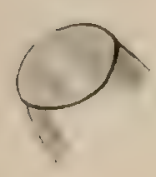

3

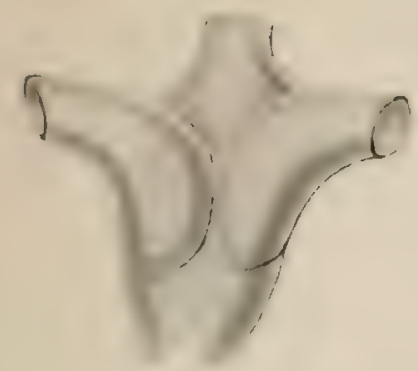

2

6

7
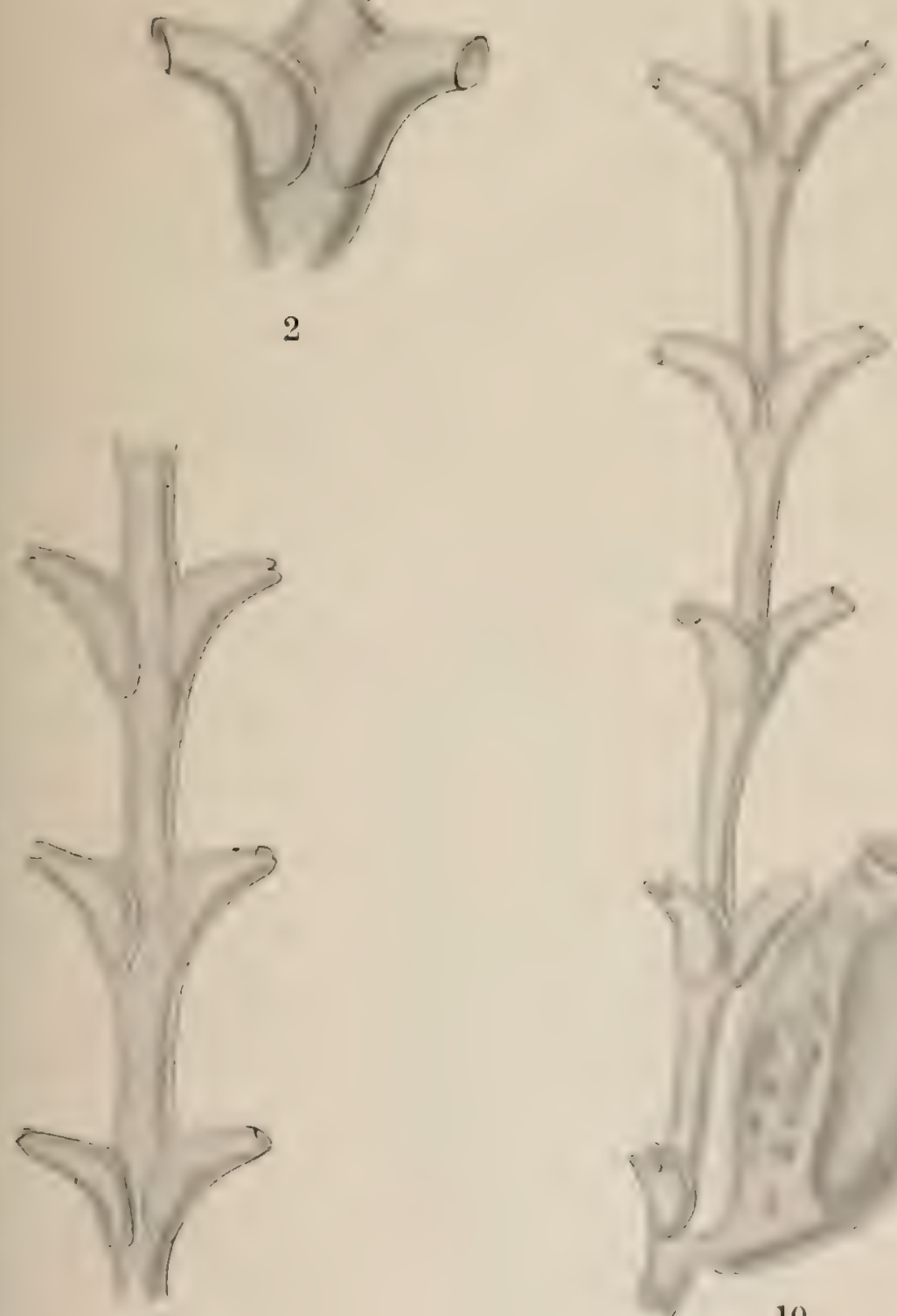

4

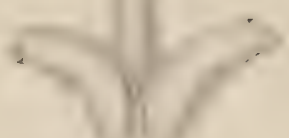

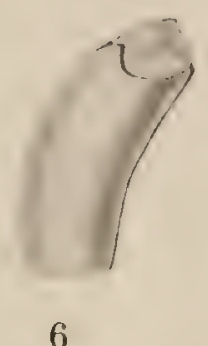

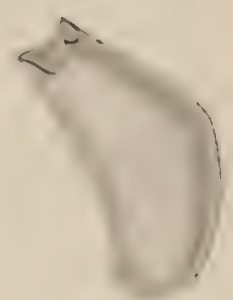

2

8

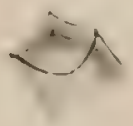

9
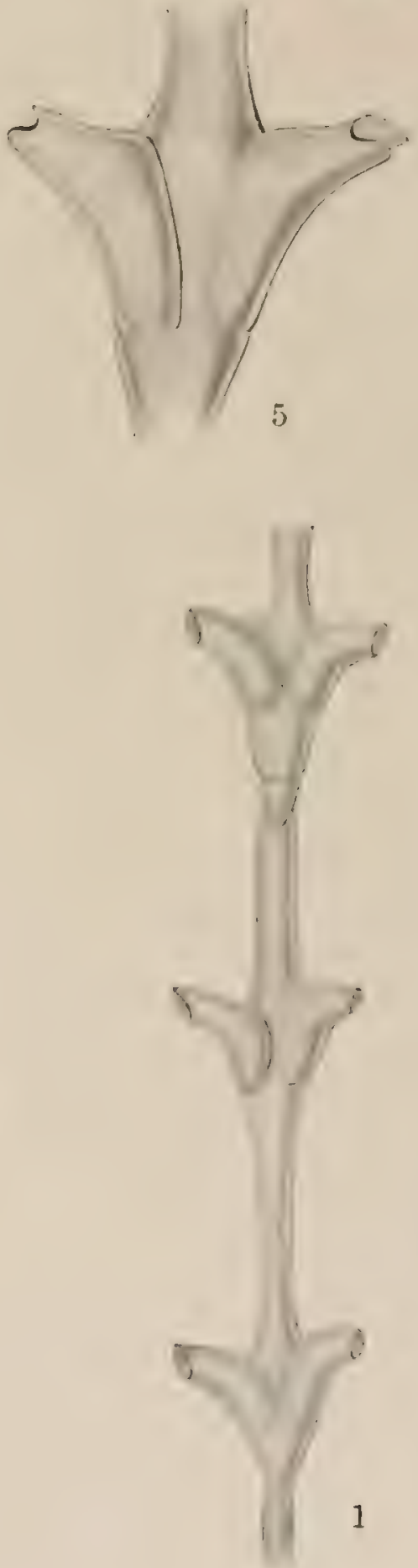


FAPLANATION TO PIATE IY.

Fic. 1. Sertulario comicina (MeCready). Colony with gonangia and expanded hydranths. Drawn from life (enlarged).

2. Serdularia cormicina. Pair of hydrothecte (greatly enlarged).

3. Serfularia comicina. Gonangium (enlarged).

4. Serfularin comicind. Side view of colony with parasitic campanularian and its gonangiun (enlarged).

5. Serfularic cornicinu. Part of same colony (enlarged).

164 


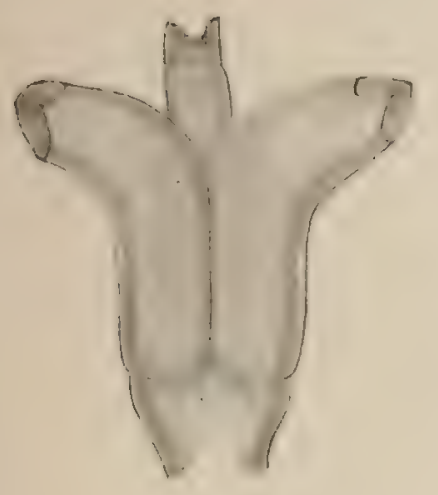

2

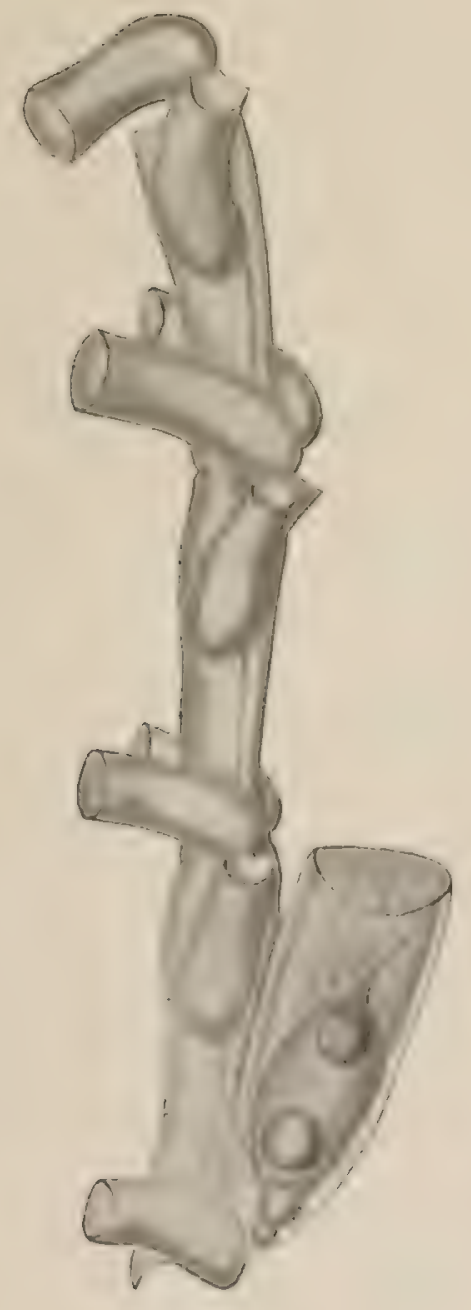

4
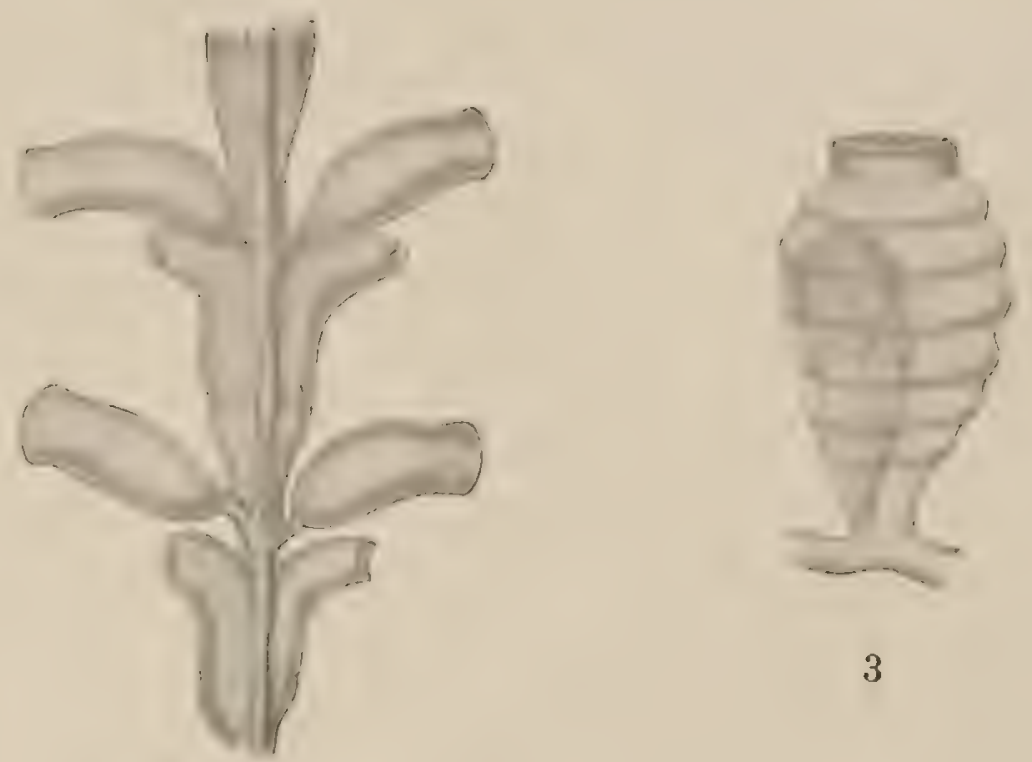

5

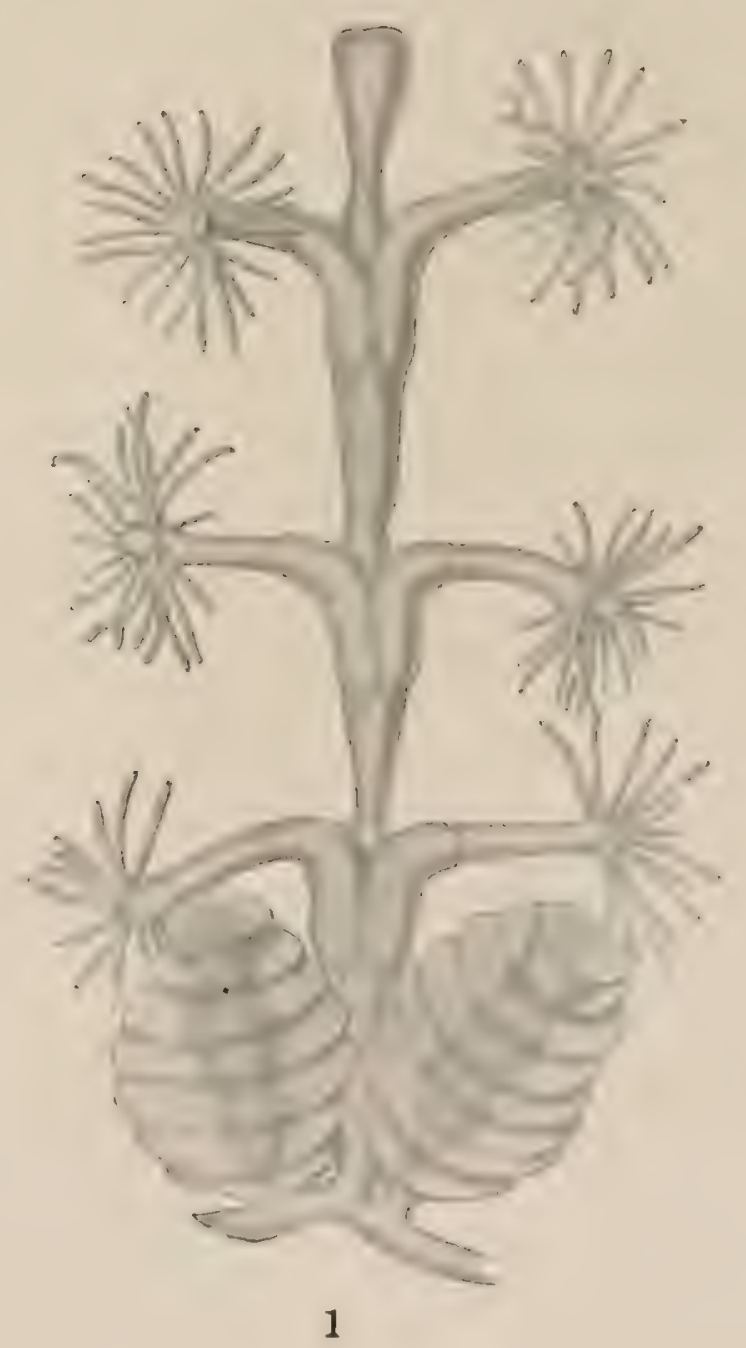

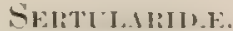






\section{EXPLANATION TO PLATE V.}

Fif. 1. Sertularia mayeri Nutting. Basal portion of colony (enlarged).

2. Serfularia mayeri. Distal part of stem (enlarged).

3. Sertularia mayeri. Side view of stem (enlarged).

4. Sertularia mayeri. Hydrothece with collapsible tubular extensions (enlarged).

5. Sertularia pourtulesi Nutting. Part of stem (enlarged).

6. Sertularia stookey Nutting," Part of stem and gonangiun (enlarged).

7. Sertularia stookeyi. Pair of hydrothece (greatly enlarged).

168 

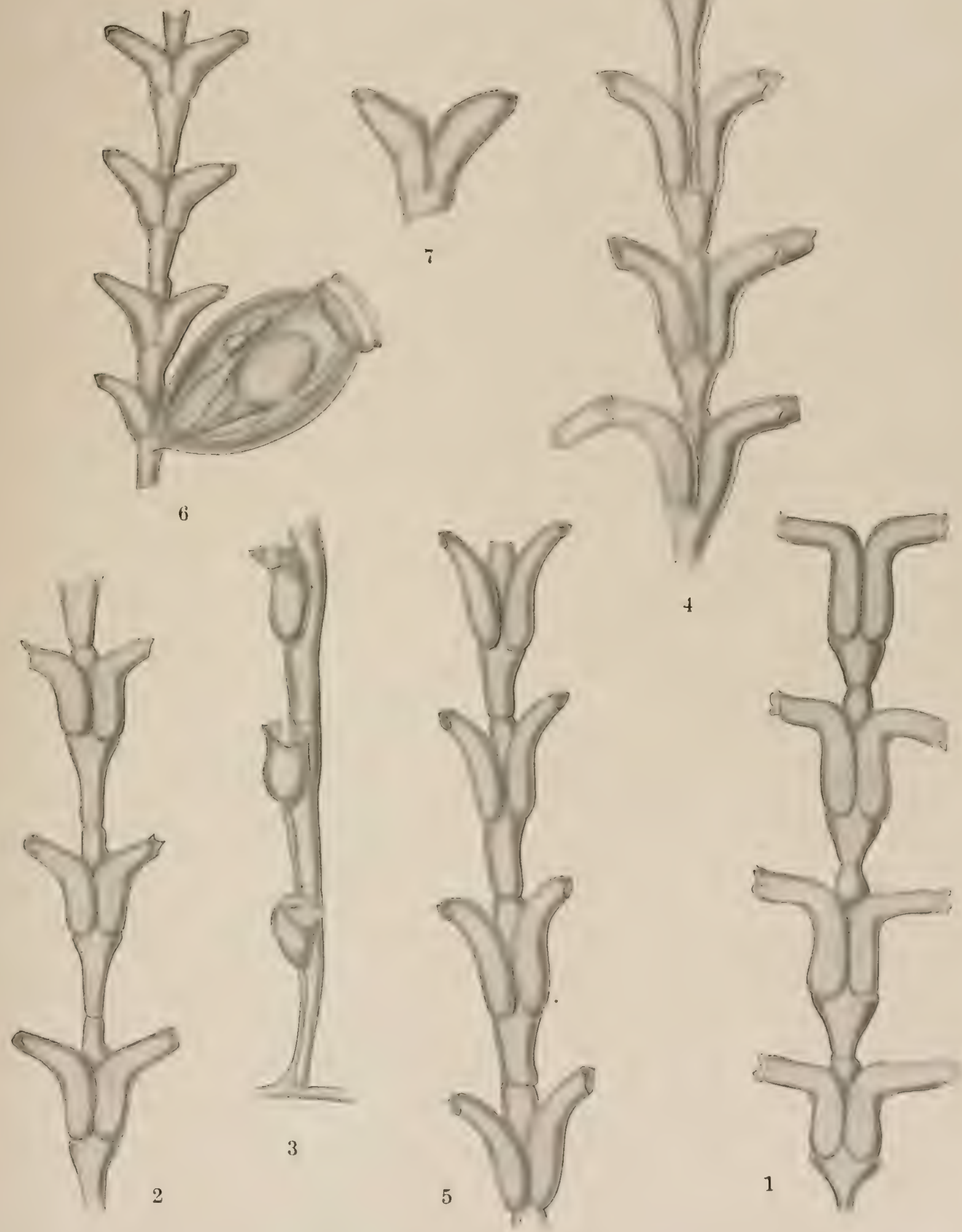


EXPLANATION TO PLATE VI.

Fis. 1. Sertularia brevicyathas Versluys. Part of stem (enlarged).

2. Sertularia brevicyathus. Side view of stem (enlarged).

3. Serlularia flowersi Nutting. I'art of stem (enlarged).

t. Sertularic flowersi. Side view of stem (enlarged).

5. Sertularic tumide Allman. Pair of hydrothece (enlarged). (After Allman.)

6. Somularin exigut Allman. Iair of hydrothece (enlarged). (After Allman.)

172 


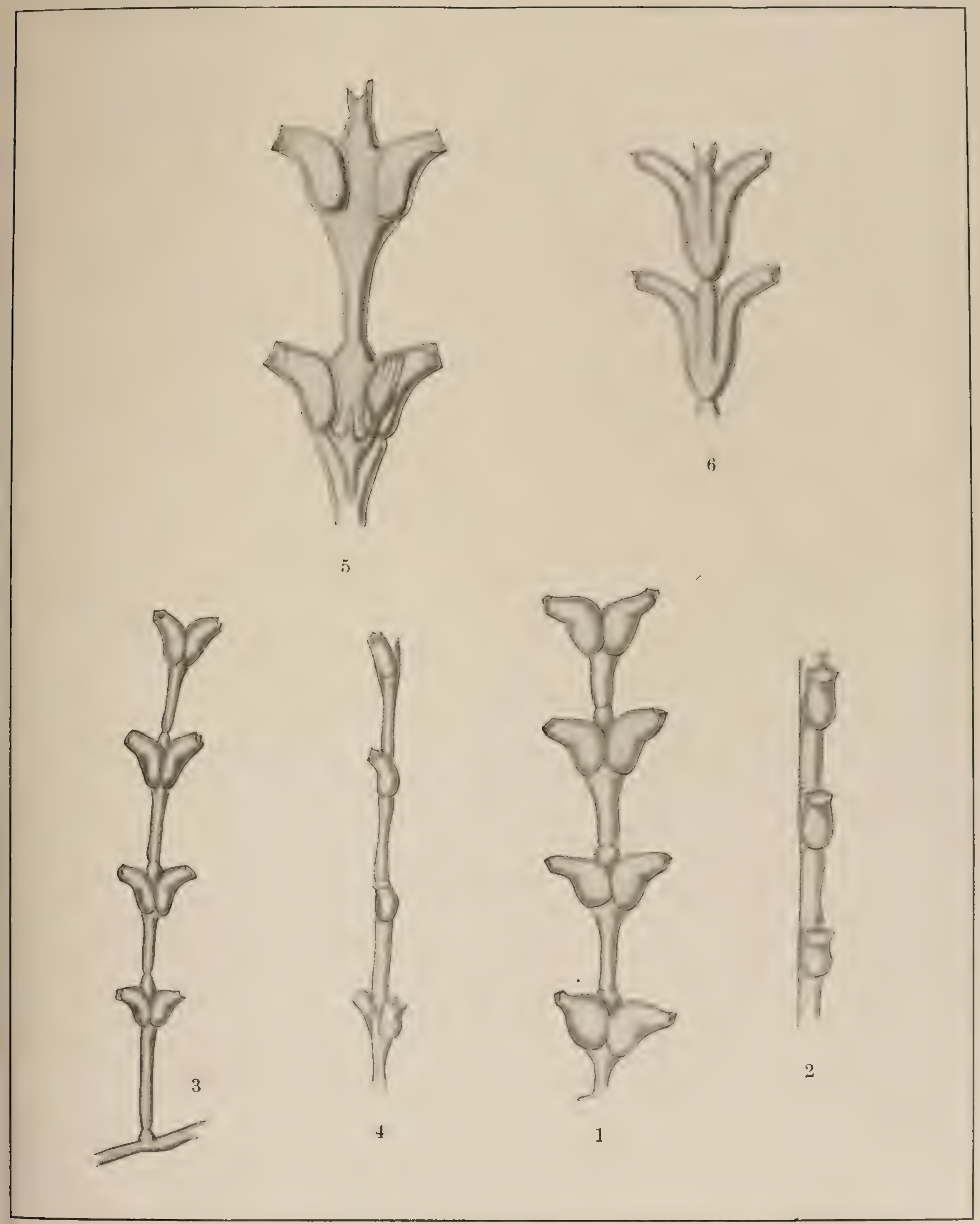




FXPLANATION TO PMATE VII.

Frr. 1. Theinnin therin (Linnens). Part of mameh (enlarged).

¿. Thuiarie theju. Two hydrothese (ureatly cnlarged).

:). Thumiut thije. single hydrotheca (greatly enlarged).

t. Thuiariu degans Kirchenpaner. Part of branch (enlargel). (After Kirchenpauer.)

5. Thuiaria rolustu Clark. Side view of hanch (enlarged).

6. Thuirrice robustu. Front view of branch (enlargerl).

7. Thmintu rolusta. l'art of branch with gonangia (enlarged). 

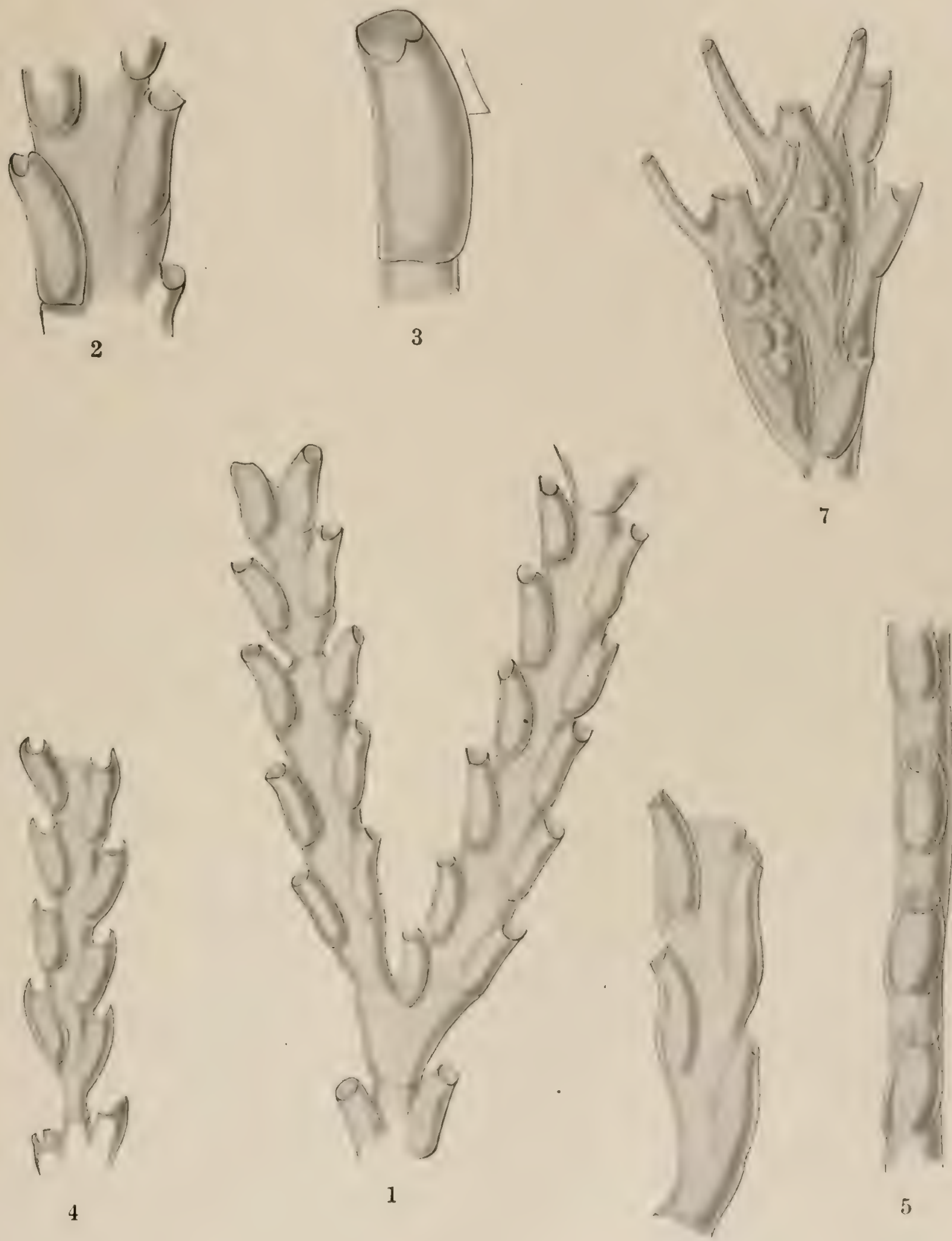

5 


FXPIANATION TO PIATE VIII.

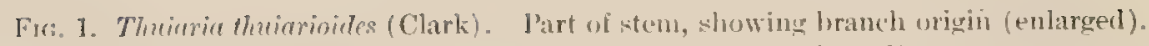

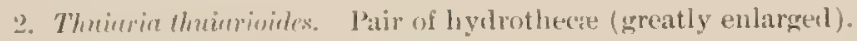

3. Theimin theirrisiles. Single hydrotheca, showing operculum (greatly enlarged).

4. Thuiaria thuiarionites. Part of branch (enlarged).

5,6. Thuiuria thuiarioids. (xomangia (enlarged).

7. Theroria prolycompe (P'xplyg). l'art of stem, showing brand origin (enlarged).

8. Theniariat polycarym. lart of branch (enlarged).

9. Thuinrin polyenqu. Sille view of two hydrothec:e (enlarged).

180 


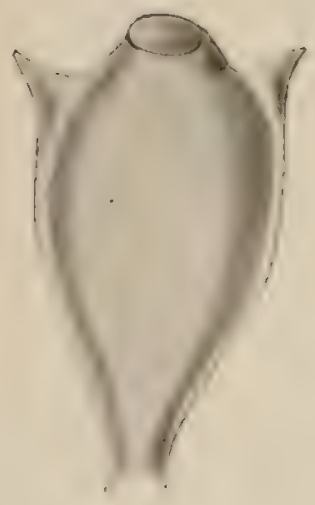

5

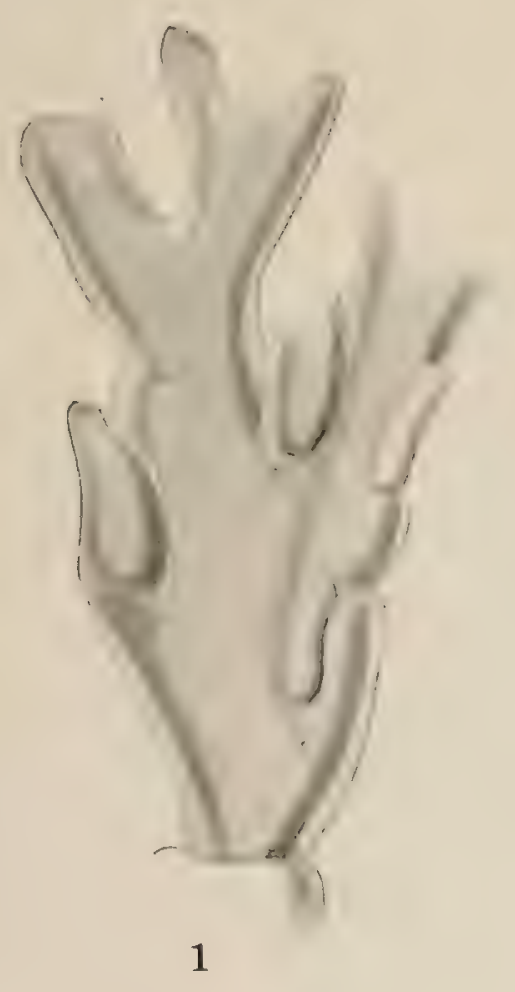

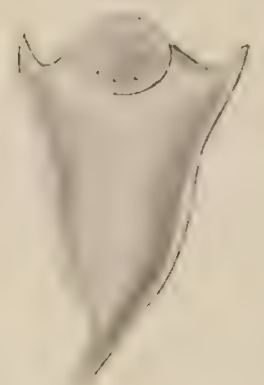
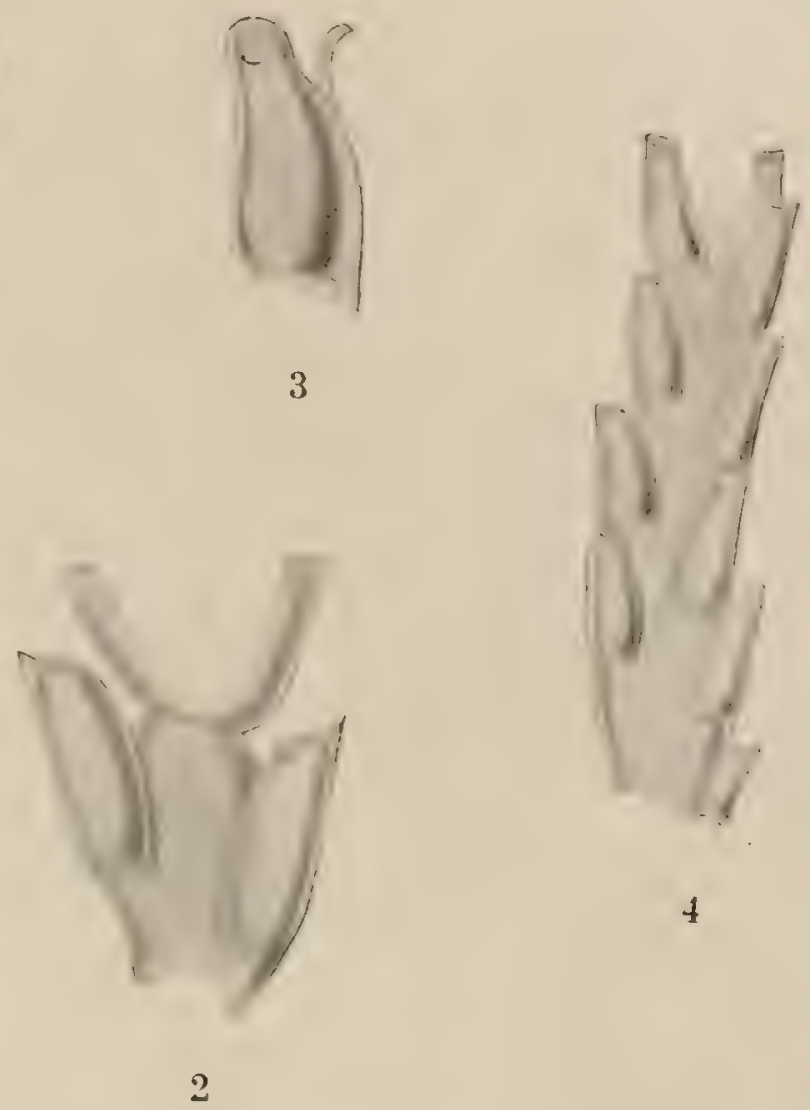

9
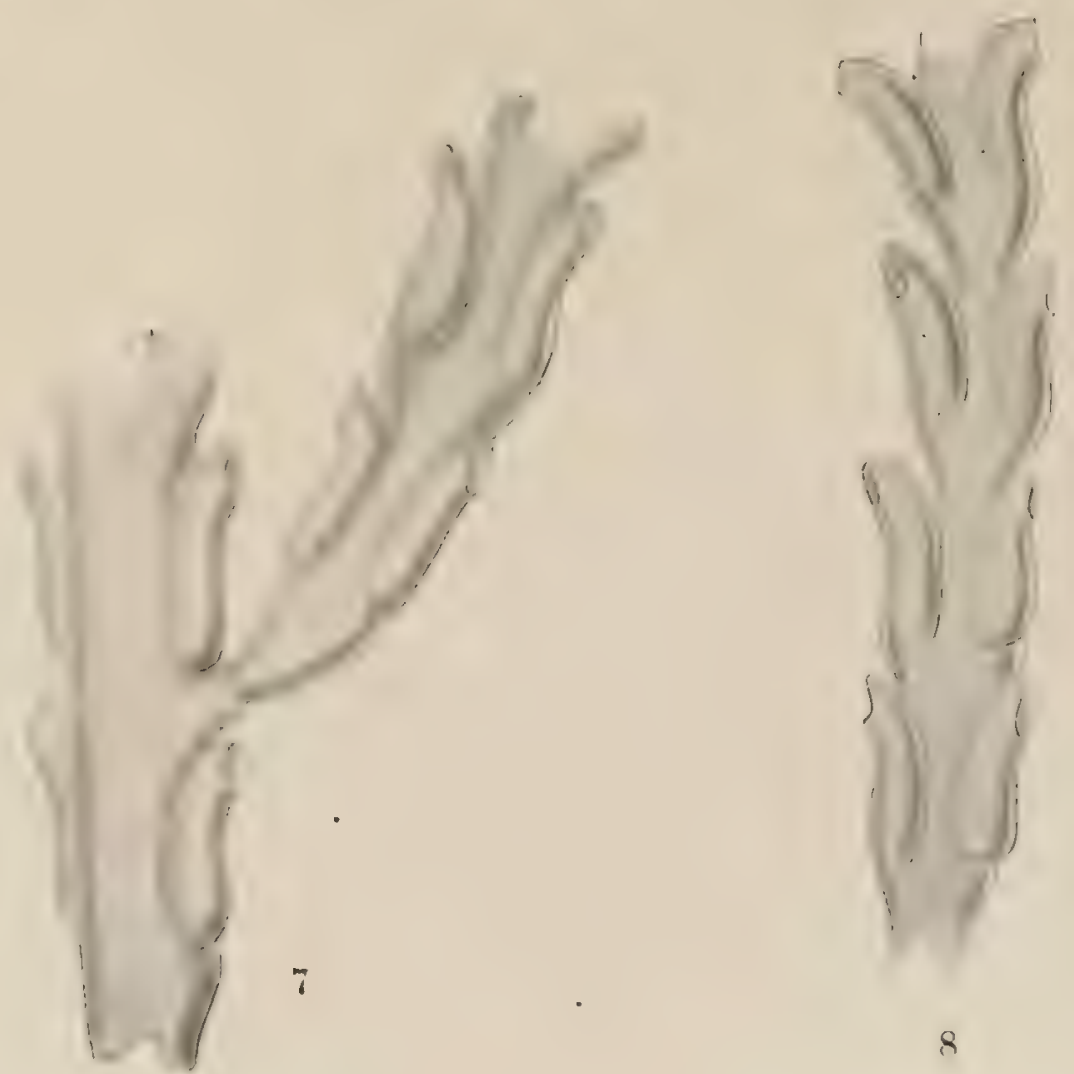




\section{FXPLANATION TO PIATE IX.}

Fig. 1. Thuiaria kurila (Pceppig). Part of branch (enlarged).

2. Thatarin kurilx. Single hydrotheca, showing margin (greatly enlarged).

:3. Thuiaria immersa Nutting. Part of branch (enlarged).

4. Thuiaria immersu. Hydrotheese (greatly enlarged).

5. Thuiaria lonchilis (Ellis and Solander). Part of branch with gonangia (enlarged).

6, 7, 8. Thuiuria lonchitis. Hydrothece, showing variation in margin (greatly enlarged).

9. Thuiaria plumulifera Allman. Part of branch (enlarged).

10. Thuiaria plumulifera. P'art of another colony (enlarged).

11. Thuiaria plumulifera. l'art of main stem, showing branch origin (enlarged).

12, 13. Thuiaria plumulifera. Hydrothece, showing margin (greatly enlarged).

184 


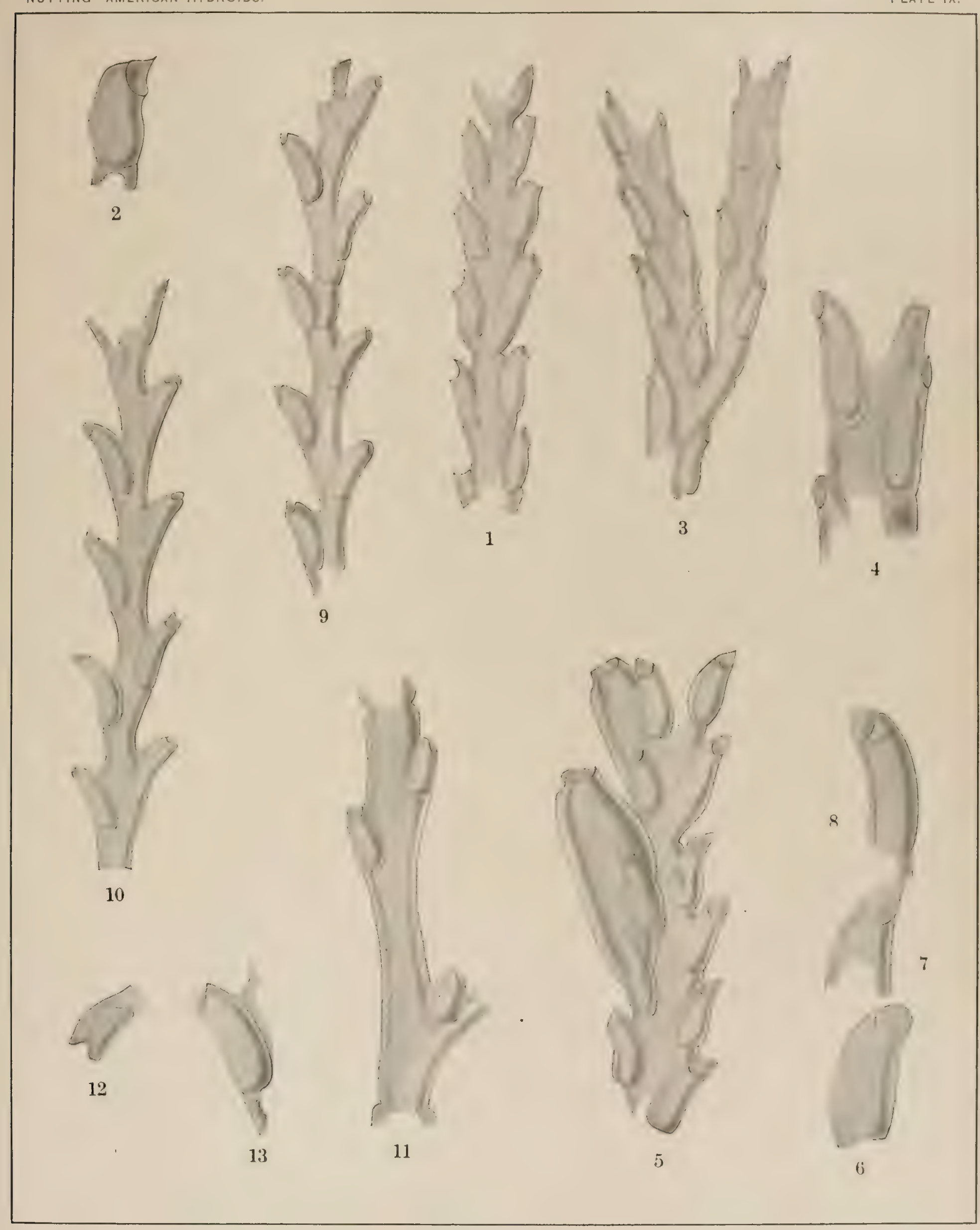




EXPLANATION TO PLATE X.

Fif, 1. Thuiariu diffisue (Allman). Part of branch (enlarged).

2. Thuirrin diffuse. Two hydrothece (greatly enlarged).

3. Thuiaria diffusa. Single hydrotheca (greatly enlarged).

4. Thureria dalli Nutting. I'art of branch (enlarged).

5. Theioric dalli. l'art of stem, showing branch origin (enlarged).

6. Theiarin dulli. Two hydrothece (greatly enlarged).

7. T'miariu similis (Clark). I'art of colony with gonangium (enlarged).

8. Thuirria similis. Hydrothece (greatly enlarged).

9. Thuiarin similis. Four hydrotheca (greatly enlarged).

185 


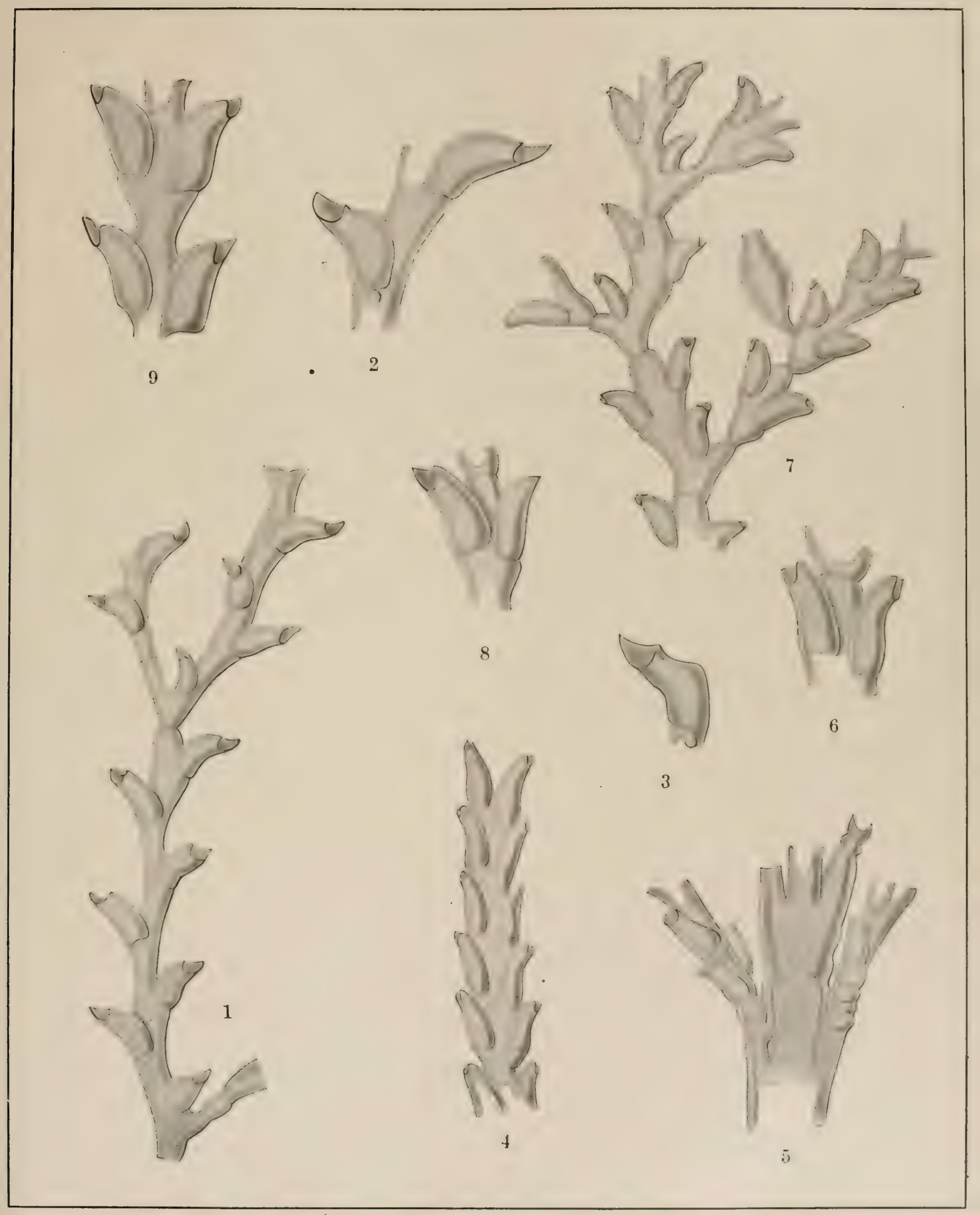






\section{EXPLANATION TO PLATE XI.}

Fus. 1. Thuiurit lnheliformis (Marktanner-Turneretscher). Part of colony, showing main sten and branch origin (slightly enlarged).

2. Thuiariu hulliformis. I'art of branch (enlarged).

8. Thumitu tuhuliformis. I'art of branch with gonangium (enlarged).

4. Thuiefin tuhulformis. Side view of two hydrotheese (greatly enlarged).

5, 6. Thuturn tubulifomis. Ends of hydrothece, showing margins (enlarged).

7, 8. Thuiurin tululiformis. Gonangia (enlarged).

1) Thuierin lenere (Sars). I'art of colony (cnlarged).

10. Thuineriu lineru. Part of branch (enlarger).

11, 12. Thuinria teneru. Ends of hydrothece, showing margins (greatly enlarged).

192 


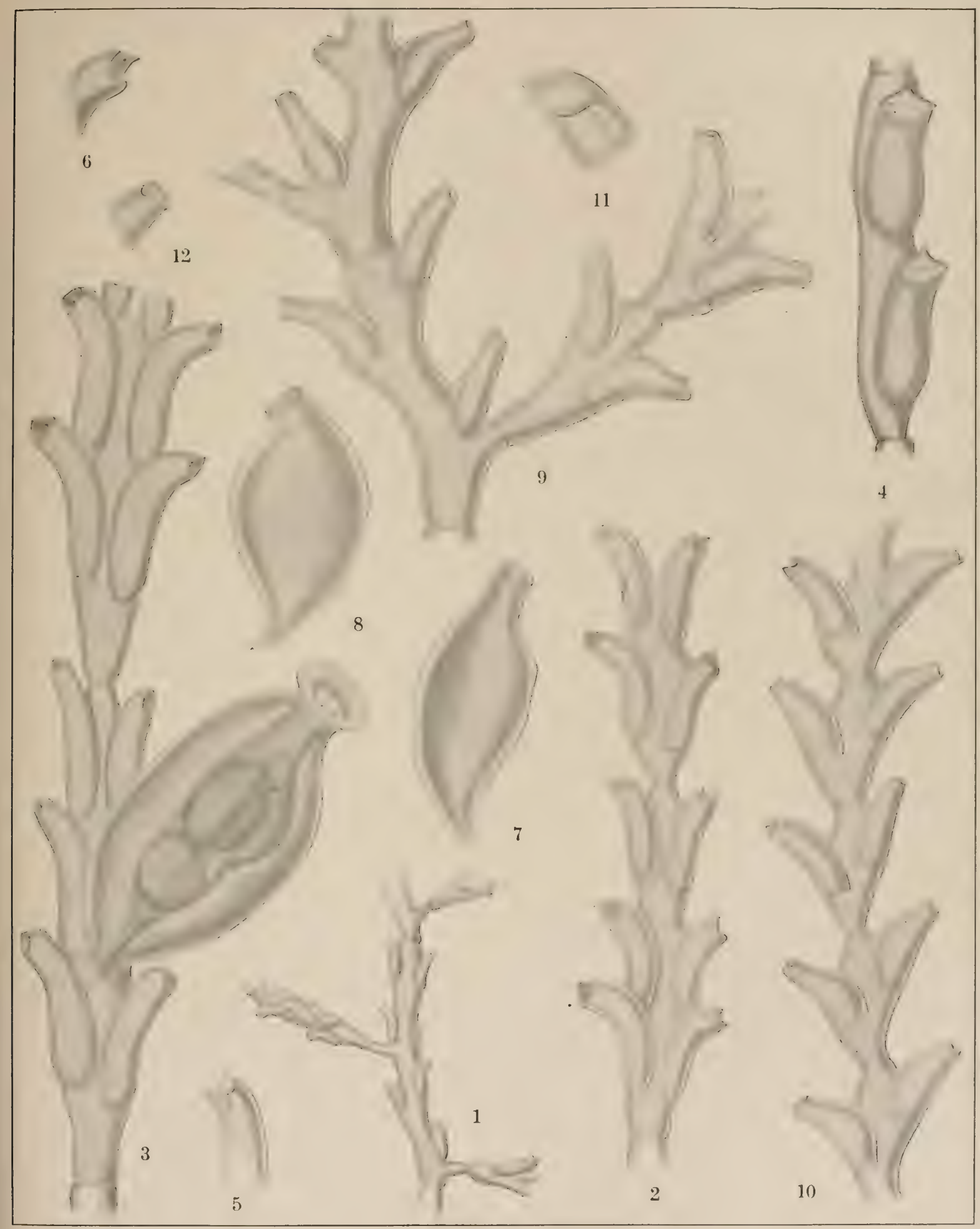

SERTULAIIDE. 


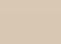



EAPJANATION TO I'LATE XII.

Fu. 1. Thuiuria fubricii (Levinsen). I'art of liranch (enlarged).

2. Thuieria fubricii. Part of branch with gonangia (enlarged).

3. Thumerie argenten (Linneus). Entire branch, showing rauification (olightly enlarged).

4. Thuiarie argentea. Part of branch (enlarged).

5. Thuidria argented. Distal part of branch (enlarged).

6. Thuiaria argenter. Two hydrothece (greatly enlarged).

7. Thumerie urgenteu. Hydrantlı cxpanded, drawn from lifo (greatly enlarged).

s, !. Thuiariu argentert. (ionangia (enlarged).

164 


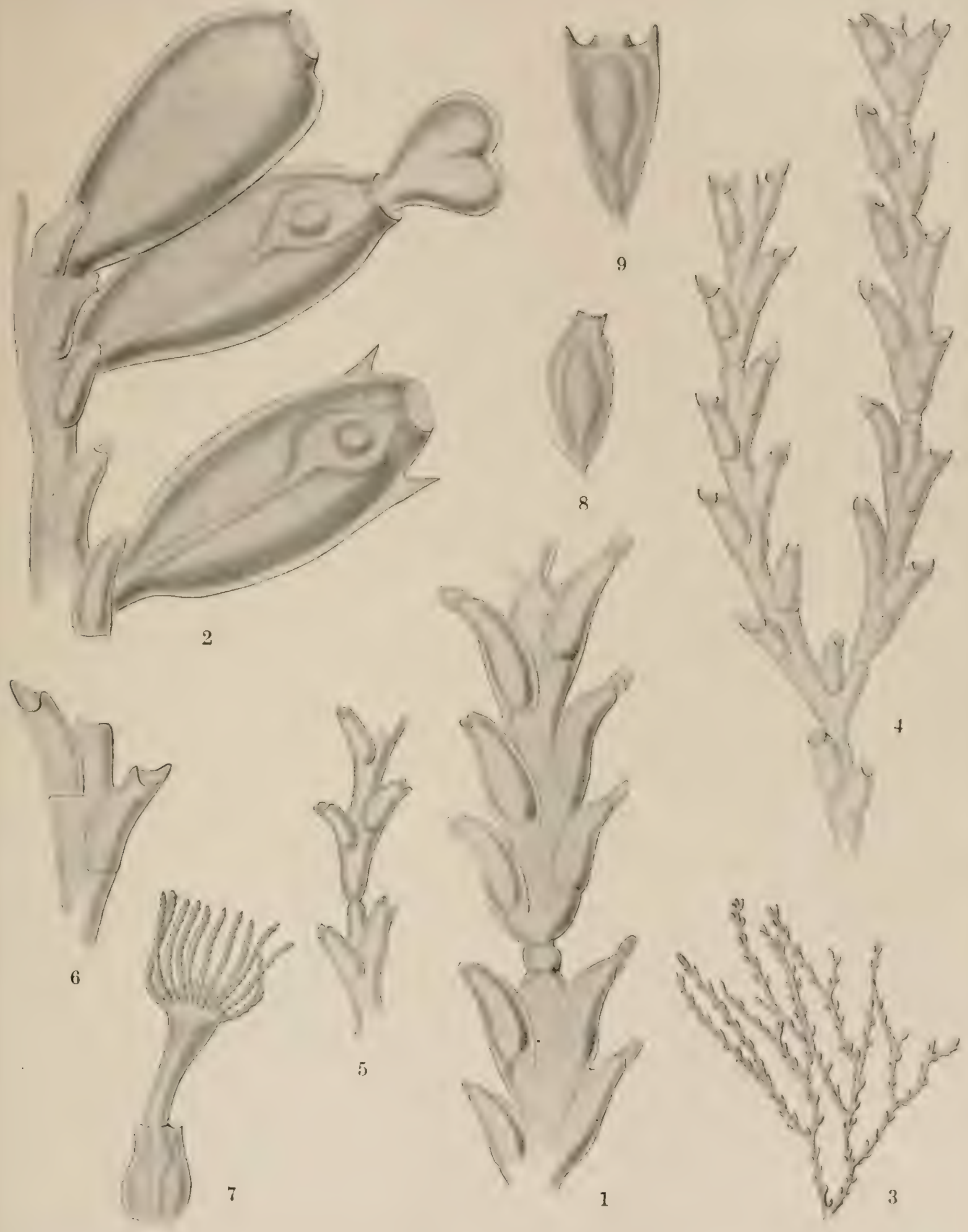





\section{FXNIANATION TO PIATE XIII.}

Itr. 1. Thuiaria cupressina (Linnxus). I'art of branch (enlarged).

2. Thuirrin cupressina. Hydrothece (areatly enlaryed).

:2. Thuicric cupressina. Gonangia (enlarged).

4. P'asylhen quadritentak (Ellis and Solander). Trophosome (enlarged).

i. I'ssylhen quatridentatr. IIydrothece and gonangium (greatly enlarged).

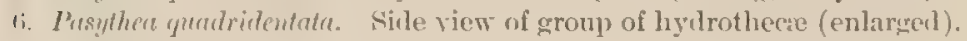

7. Presylhen guudridentatu. Side view of two hydrothece (greatly enlarged). 

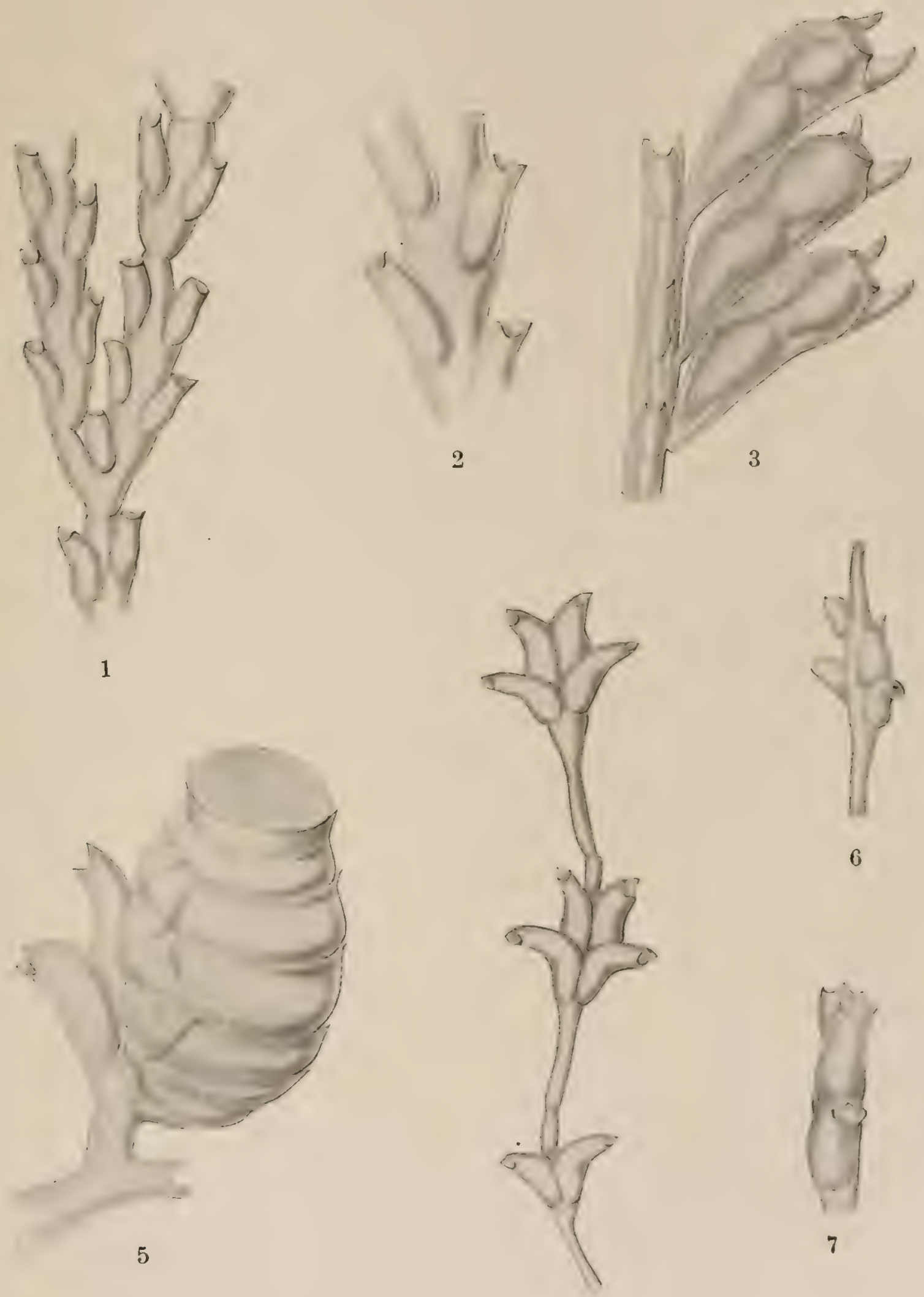

4. 




\section{FAI'IANATION 'TO I'LATE' NIV.}

Fis. 1. Sirmlarella guyi (Lamouroux). Part of branch (enlarged).

2. Sermlerella greyi. l'art of branch with gonangium (much less culareded).

3, 4. Sertulurelle gani. Hydrothece, showing operculum (enlarged).

5. Scrularella ynyi. (ionangium (enlarged).

6. Serlulurcllu grui (var. robustu Allman). Part of branch with gronangrium (enlarged).

7. Sermlarellu guyi (var, rubuster). I'art of colony overorown with Filellum serquens (enlarged). 


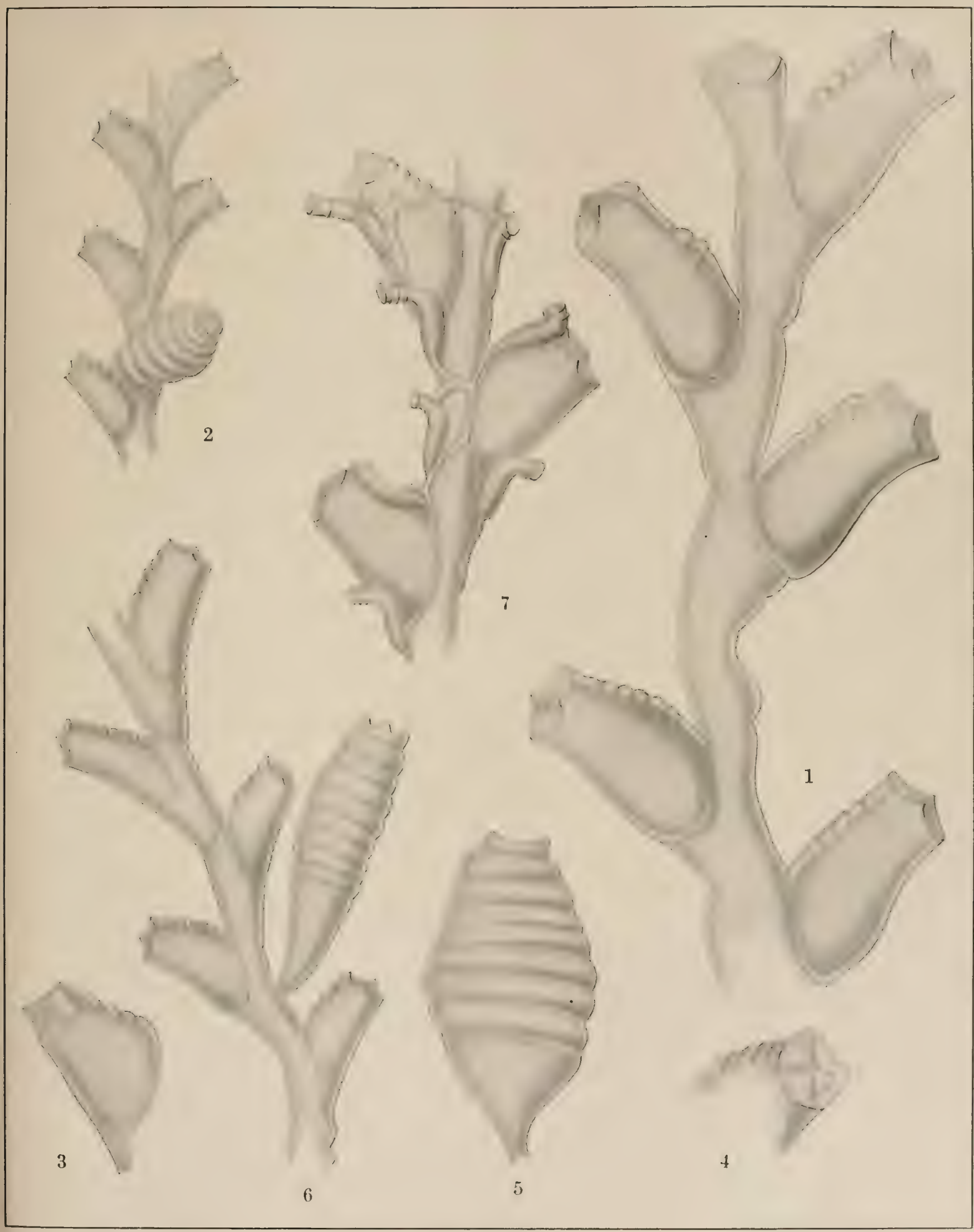

SETrTUARIDE. 

. 


\section{EXPLANATION TO PLATE IV.}

Fis. 1. Sirtulerelln conice Allman. I’art of branch (enlarged).

2. Sirmlarelle conice. View of margin and operculum (enlarged).

3. Sertulerelle cotene (Allman). I'art of Allman's type specimen with gonangia (enlarger).

4. Sirmlarelle quedede Nutting. Part of branch (enlarged).

5. Serbletellu quadrate. Singte gonangium with parasitic campanularian (greatly enlarged).

6. Sertulereila quadrata. Part of branch with gonangia (enlarged). 


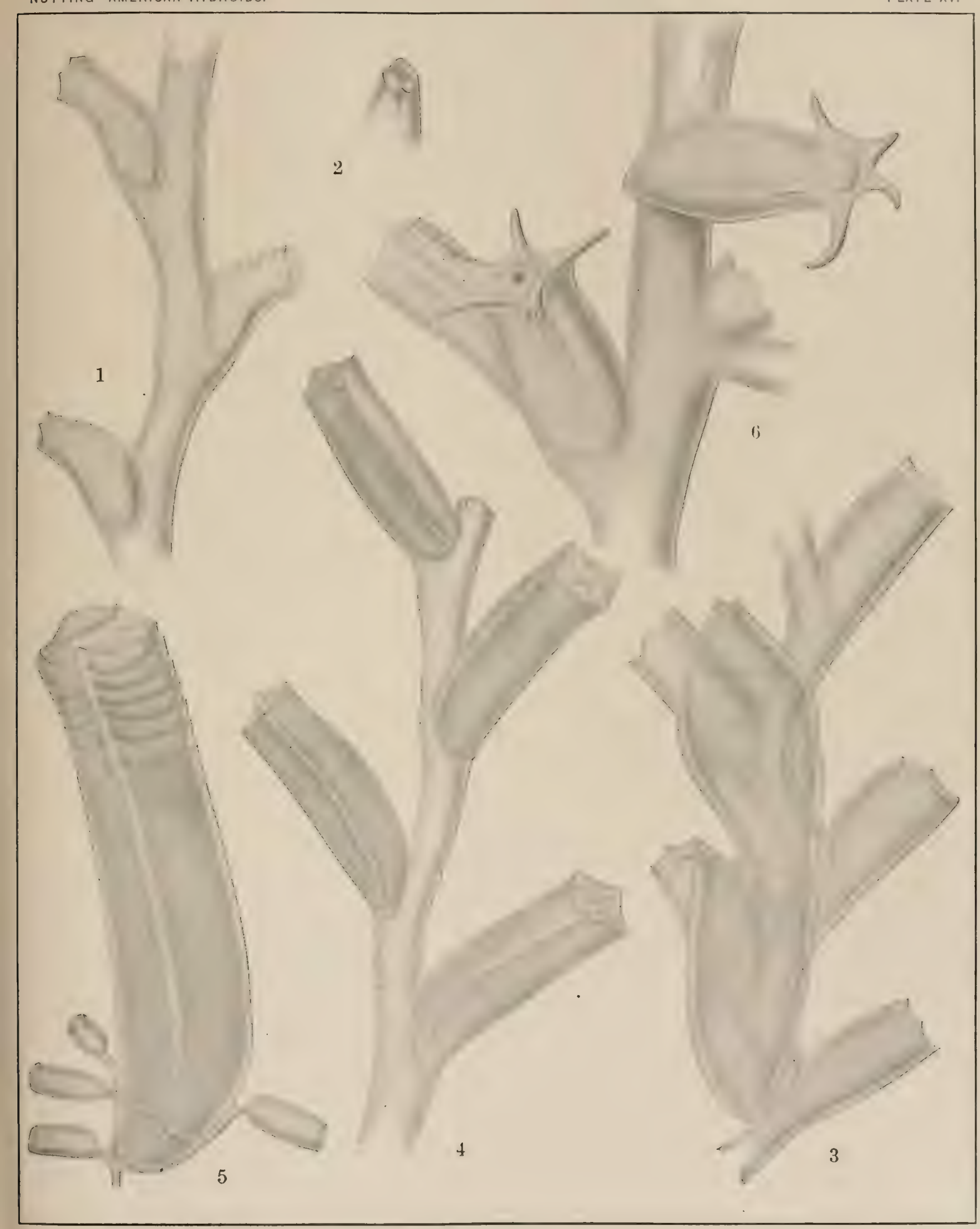

SERtularid 



\section{.}


FXPLANATION TO PIATE XVI.

Frr. 1. Sertularella fanneri Nutting. Part of branch (enlarged).

2. Sertulardle geniculate Hincks (enlarged). (After Hincks.)

3. Sertularella patagonica (d'Orbigny) (enlarged). (After d'Orbigny.)

212 

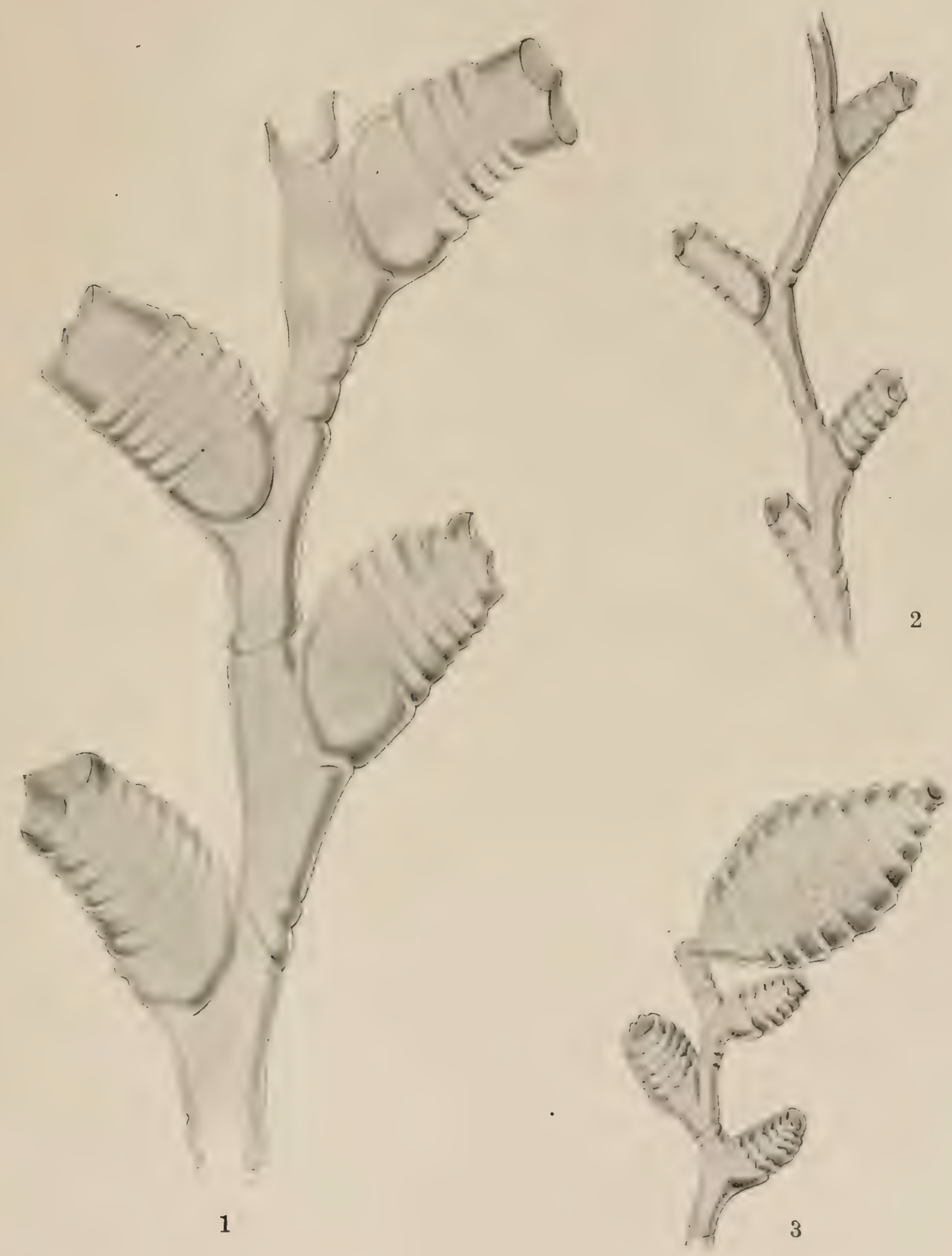



\section{FAPLANATION TO P'LATE XVII.}

Fis: 1. Sertularella mugosa (Jinnxus). I'art of branching colony (enlarged).

2. Sertulurellu migosn. Colony with gonosome (enlarged). (After Nutting.)

3. Sertulerellu rugosa. Three hydrothecte (greatly enlarged). (After Nutting.)

4. Scrtularella rugosi. Single hydrotheca (greatly enlarged). (After Nutting.)

5. Scrtularella migosr. Top of gonangiun, showing teeth (enlarged). (After Nutting.)

6. Sertularella areyi Nutting. Part of colony (enlarged). 


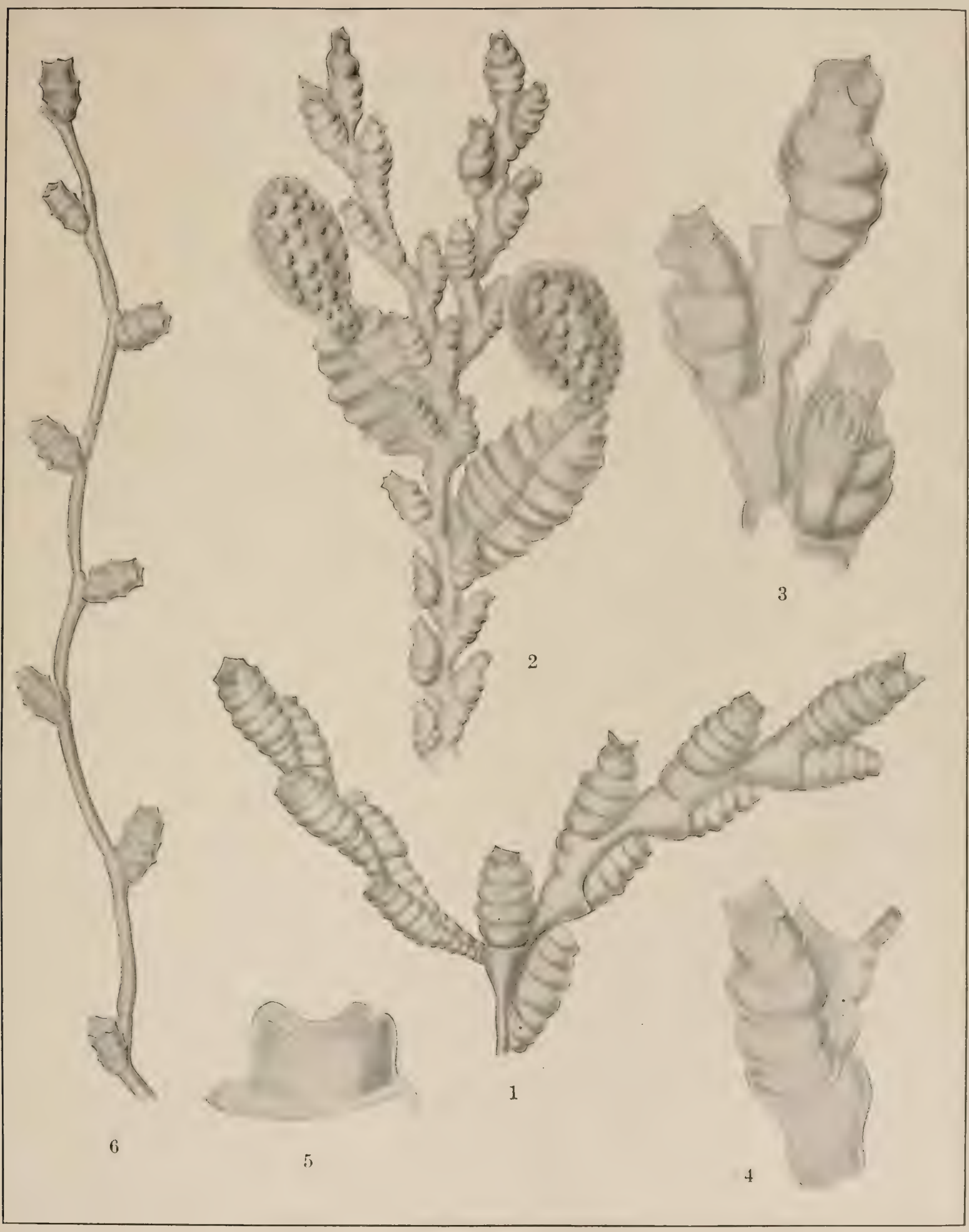






\section{EXI'IANATION TO P'IATE XVIII.}

Fin. 1. Sertulurellu tenella (1lder). P'art of colony (enlarged).

2. Sirtularelle tenelle. End of bychotheca, showing opereulum (greatly enlarged).

3. Sertulurelle allmeni IIartlaub. Part of colony (enlarged).

4,5. Sertulurelle allmeni. Hydrotheete, showing margin and opereulum (greatly enlarged).

6. Scrtularelle allnemi. Gonangium (enlarged).

7. Sertularellu contorta Kirchenpauer. P'art of branch (enlarged).

8. Sertulerelle contorta. Iydrotheca, showing margin (greatly enlarged).

9. Sirtulurellic contorta. Gonangium (enlarged).

10. Sirtulurclla lata (Bale). Lart of branch (enlarged). 


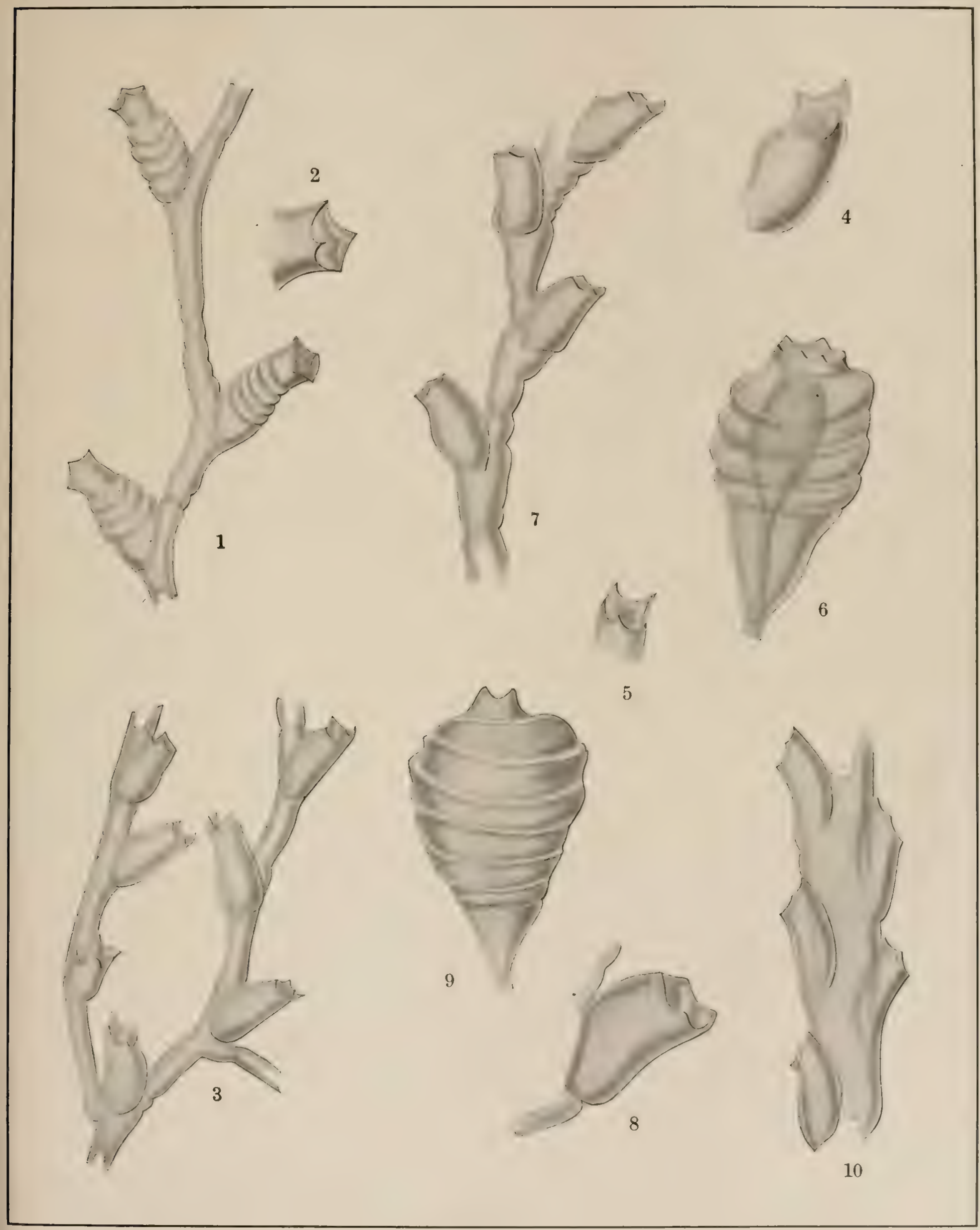






\section{EXPIANATION TO PLATE XIX.}

FIc. 1. Serlularlla albida Kirchenpauer. l'art of branch (enlarged).

?. Sertulurella cellide. Branch with gonangium (much less enlarged).

:3. Sertulurella pimigere Hartlaub. Part of branch showing lydranths (enlarged). (After Allman.)

4. Sertulurrlla cylindrithece (Allman). Part of branch (enlarged). (From Allman's type speeimen.)

i. Sivfularellu distans (Aliman). T'art of branch (enlarged).

1. Sertularelle distans. Two hydrothece (greatly enlarged).

7. Sertulurella gigantea Mereschkowsky (slightly enlarged). (After Mereschkowsky.) 


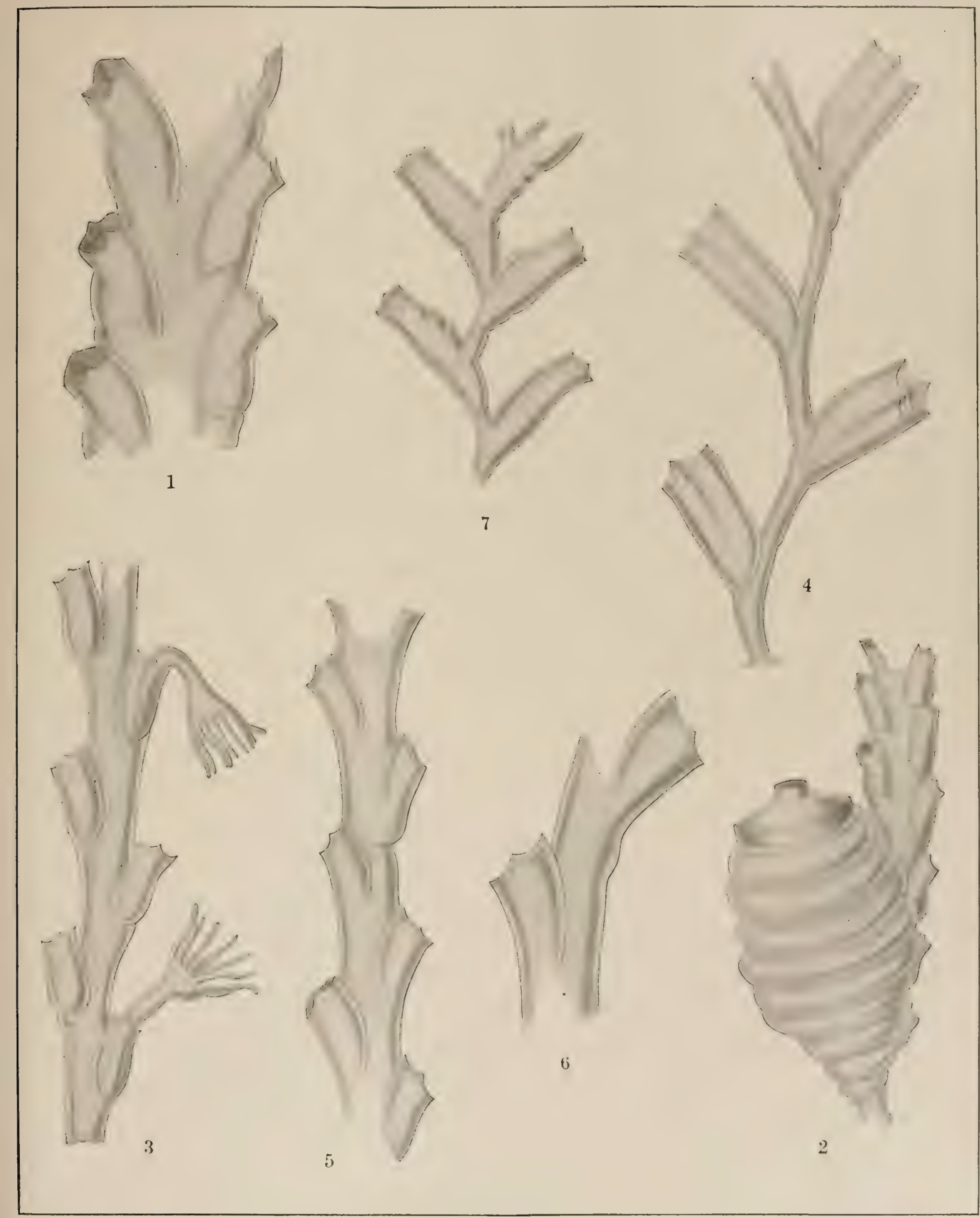

SentutaAtri: 




\section{F.XPIANATION TO IUATE XX.}

Firi. 1. Sertulurella amphorifera Allman. Part of branch (enlarged).

2. Sertularella amphorifere. Iind of hydrotheca (greatly enlarged).

3. Serlulurellu fusiformis Ilincks (enlarged). (After Hincks.)

4. Serlularella fusiformis. Gonangium (enlarged). (After llincks.)

5. Sertultrella picia (Meyen). Part of colony (enlarged). (After Meyen.)

1. Sertularella picta. Single hydrotheca (greatly enlarged). (After Hartlaub.)

7. Sertularelli picta. Part of branch with gonangium (enlarged). (After Ilartlaub.)

$\therefore$ Serlularella megastoma Nutting. Part of branch (enlarged).

9. Sirtularella megastoma. Part of loranch with gonangitum (enlarged).

10, 11. Scrularelle solitaria Nutting. Single hydrothece (enlarged), 


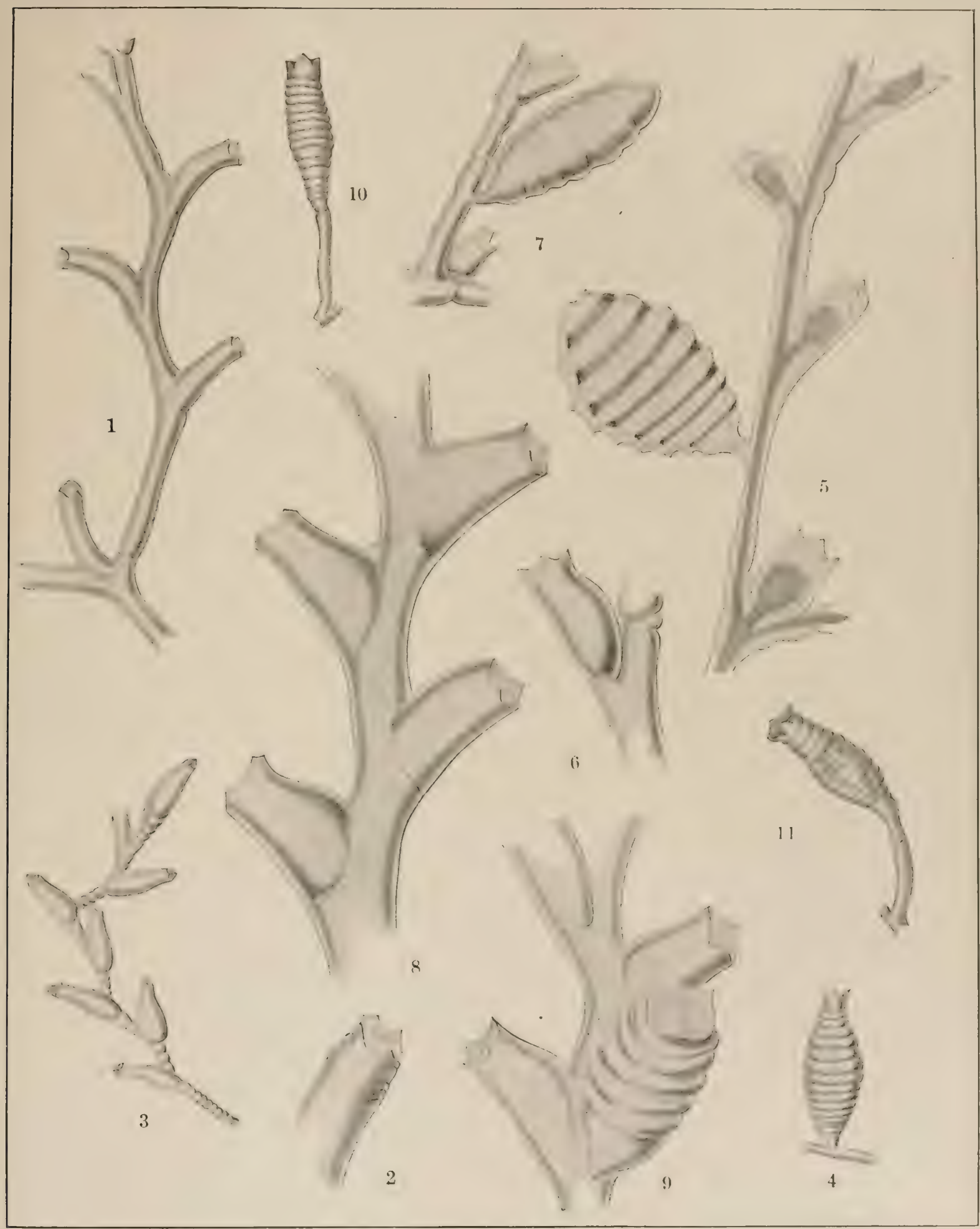

Seritulahindz. 




\section{EXPIANATION TO I'LATF NXI.}

Fig. 1. Sirlulurella polyzonias (Ellis and Solander). Part of branch (enlarged).

2. Sertulurella prolyzomies. Cronangium (enlarged).

3. Sertularella clausa (Allman). P'art of branch from Allman's type (enlarged).

4. Sertulurella clausa. Find of hydrotheea, showing operculum, from Alluan's type (greatly enlarged).

5. Serfularella complexa Nutting. P'art of branch (enlarged).

6. Sertularilla complext. End of hydrotheca, showing operculum (greatly enlarged).

7. Sertulurella complexa. Gonangium (enlarged).

8, 9. Sertularella complexu, Gonangia viewed from above, showing teeth (enlarged).

10. Sertularellu pinnatu Clark. Part of colony with gonangia (enlarged).

11. Sertularella jimmta. Part of branch, front view (enlarged).

12. Simulurella pinnalu. Single hydrotheea (greatly enlarged). 


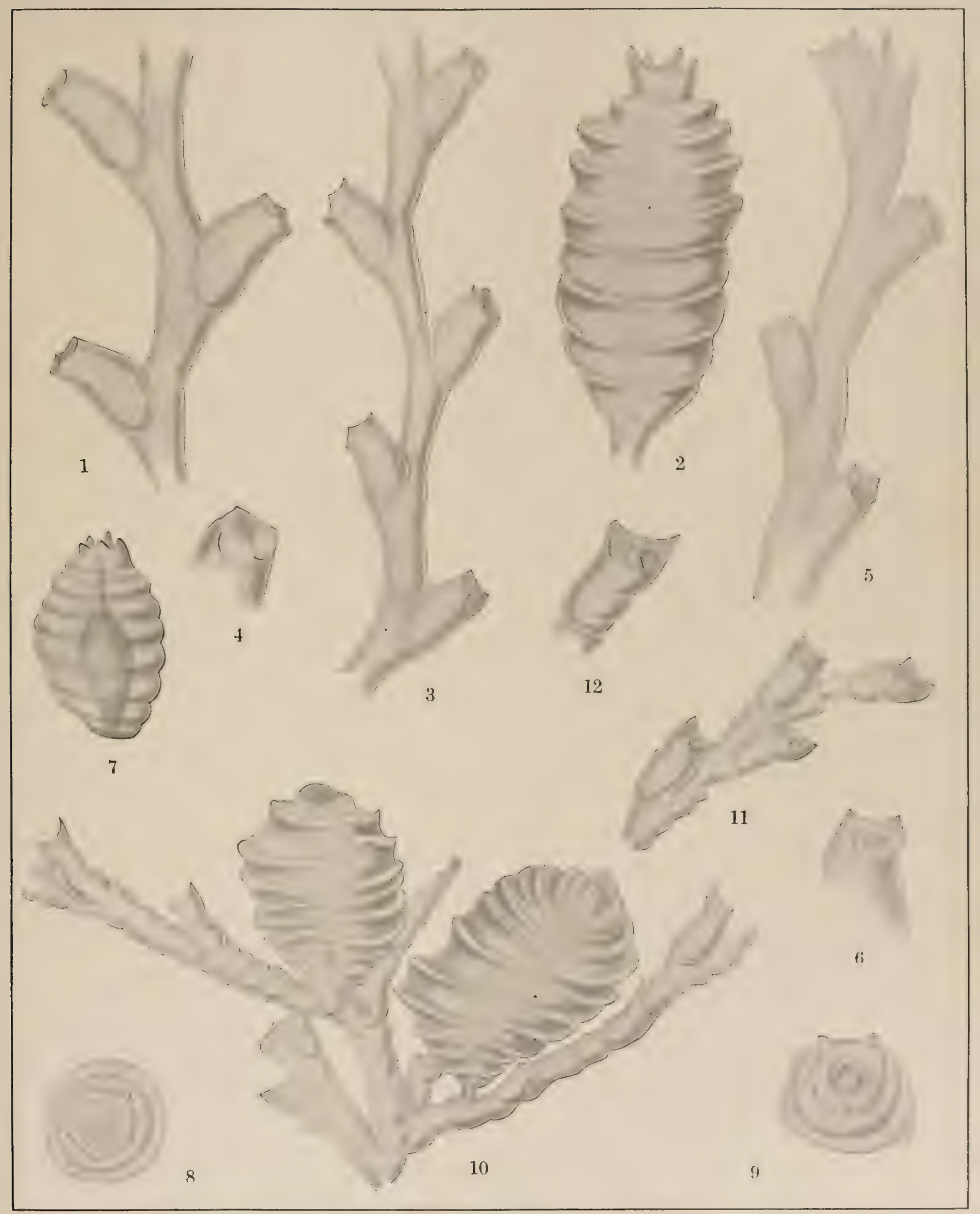

SERTULAIRDA. 




\section{FAPIANATION TO PLATF XXII.}

Fir: 1. Sertularila margaritaced Alnuan. Part of branch with gonangium (enlarger). (After Allman.)

2. Sertulurelle turgicle (Trask). I'art of colony with gonangium (enlarged).

3. Sertularclla turgida. Distal part of branch (enlarged).

4, 5. Sirtulurellu turgida. Ends of hydrothees, showing teeth (greatly enlarged).

6. Serhularella sieboldi Kirchenpauer. l'art of branch (enlarged). (After Kirchenpauer.)

7. Serhularella sicholdi. Gonangitum (enlarged). (After Kirchenpauer.)

8. Serhulurcllu subuchotome Firchenpauer. Part of colony, showing branching (enlarged).

9. Sertulurellu subdichnoma. II ydrotheca, showing margin (greatly enlarged).

10. Serfularllu subdichotoma. End of hydrotheca, showing operculum (greatly enlarged).

11, 12. Sertularella subdichotoma. Gonangia (enlarged). 


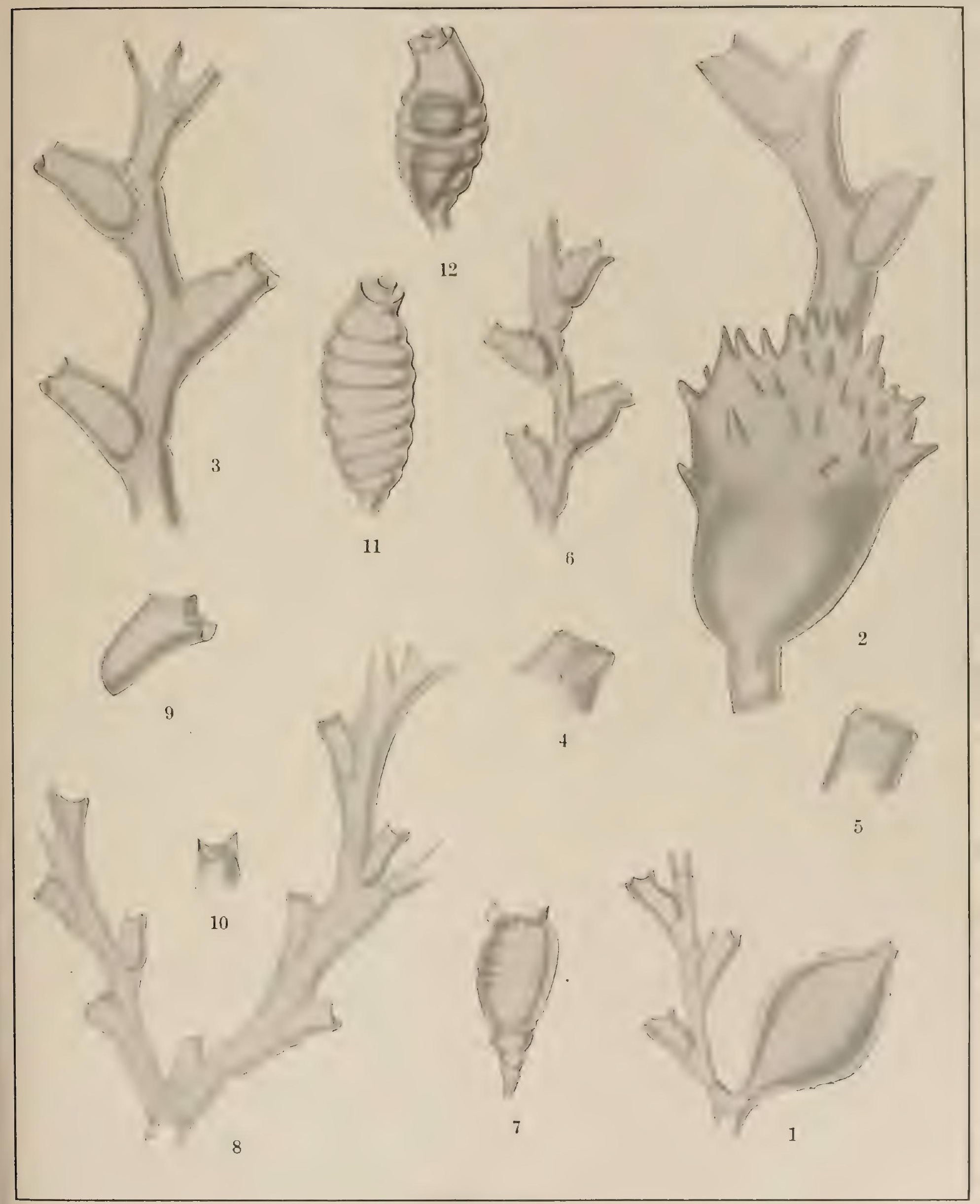

SRrtularide. 




\section{EXPLANITION TO ITLATE XXIII.}

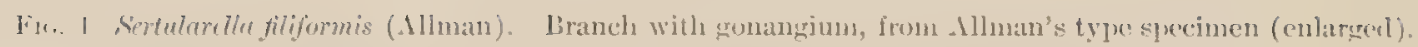

2. 3. Sertulurella filiformis. Hydrothecal, from sane specinen (areatly enlarged).

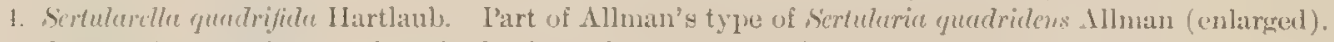

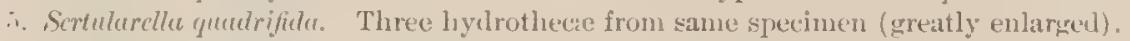

1, 7. Sirtulurelln qualrifide. Hydrothece from same specimen, showing teeth and opercula (greatly enlarged).

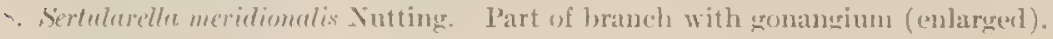

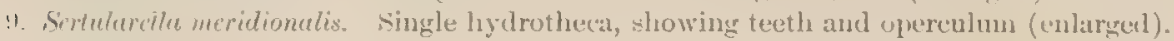




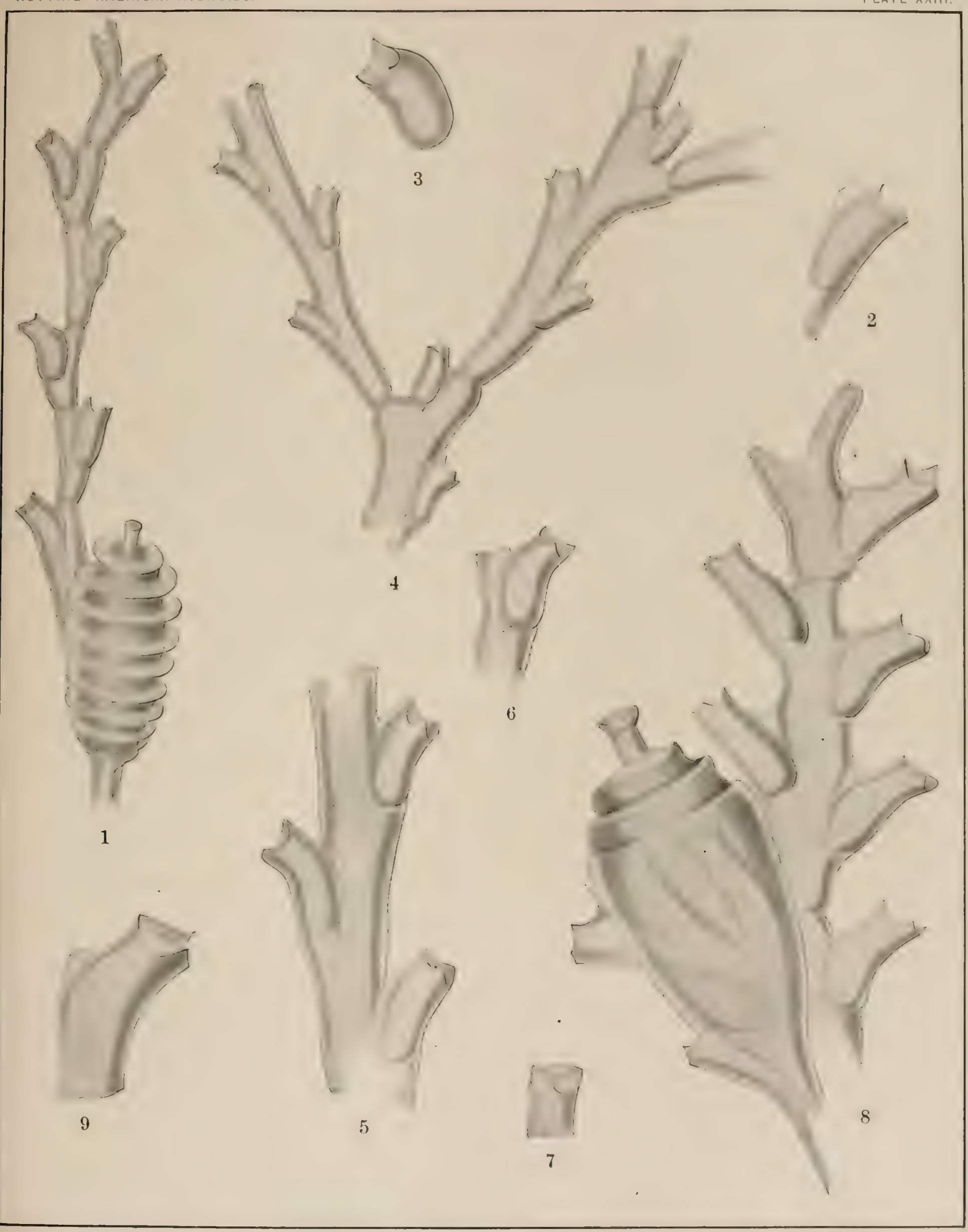

SBRTLLAIIDE. 




\section{FXPIANATION TO JIAATE XYIY}

Furi. 1. Sertularella eleyons Nutting. I'art of colony with gonangium (enlarged).

2. Sertularella milncama (d'Orbigny). P'art of lranch (enlarged).

3,4. Sertulurellu milneame. Ends of hydrothecat, showing teeth and operenla (greatly enlarged),

i. Sertularella milnewee. (Honangim (enlarged).

6. Sertularella mugellunicu (Marktanner-Turseretscher). Lower part of (olony (enlarged).

7. Serfularella magrllunicn. Distal part of ('olony (enlarged).

$\therefore$ Serfulurella magellonicut. Find of hydrotheca, showing teeth (enlarged).

1. Sermblumblle minulu Vutting. Part of colony with gonanginm (enlargeel).

11. Serfulurillu mimulu. End of hythotheca, showing teeth (greatly enlarged). 


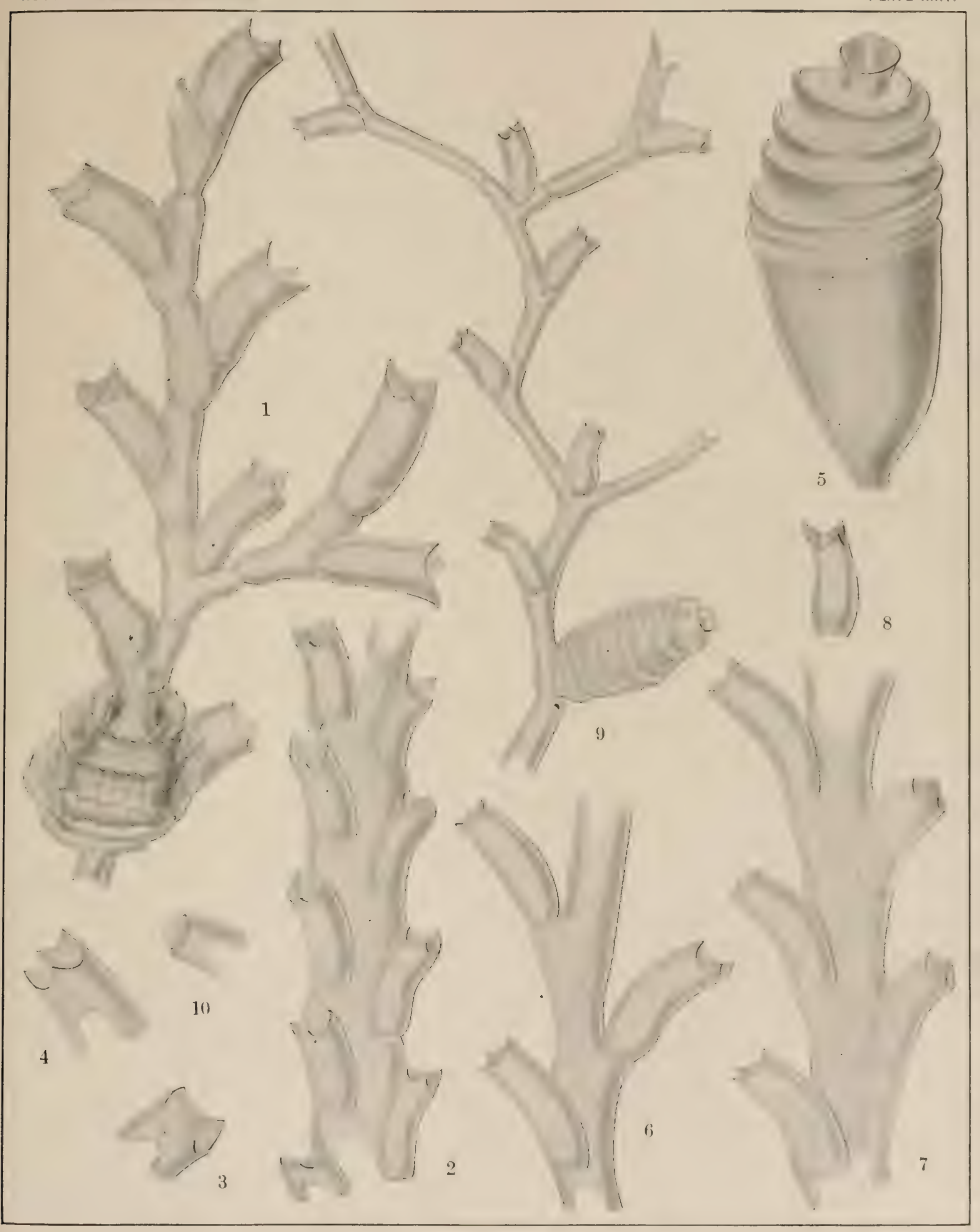






\section{FXPLANATION TO PLATE XXV.}

Fic. 1. Sertularelle dentifera Torrey. Part of colony (enlarged). (After Torrey.)

2. Serularelle dentifera. Two hydrothecx, showing reduplicated marging (enlarged). (After Torrey.)

3. Serlularella tricuspidatı (Alder). Part of colony (enlarged),

4, 5. Sertularella tricuspidatt. Gonangia (enlarged).

6. Sertularella tricuspidatu (large form from Mlaska). I’art of colony (enlarged).

7. Sertularella tricuspidata. Single hydrotheca (greatly enlarged). 


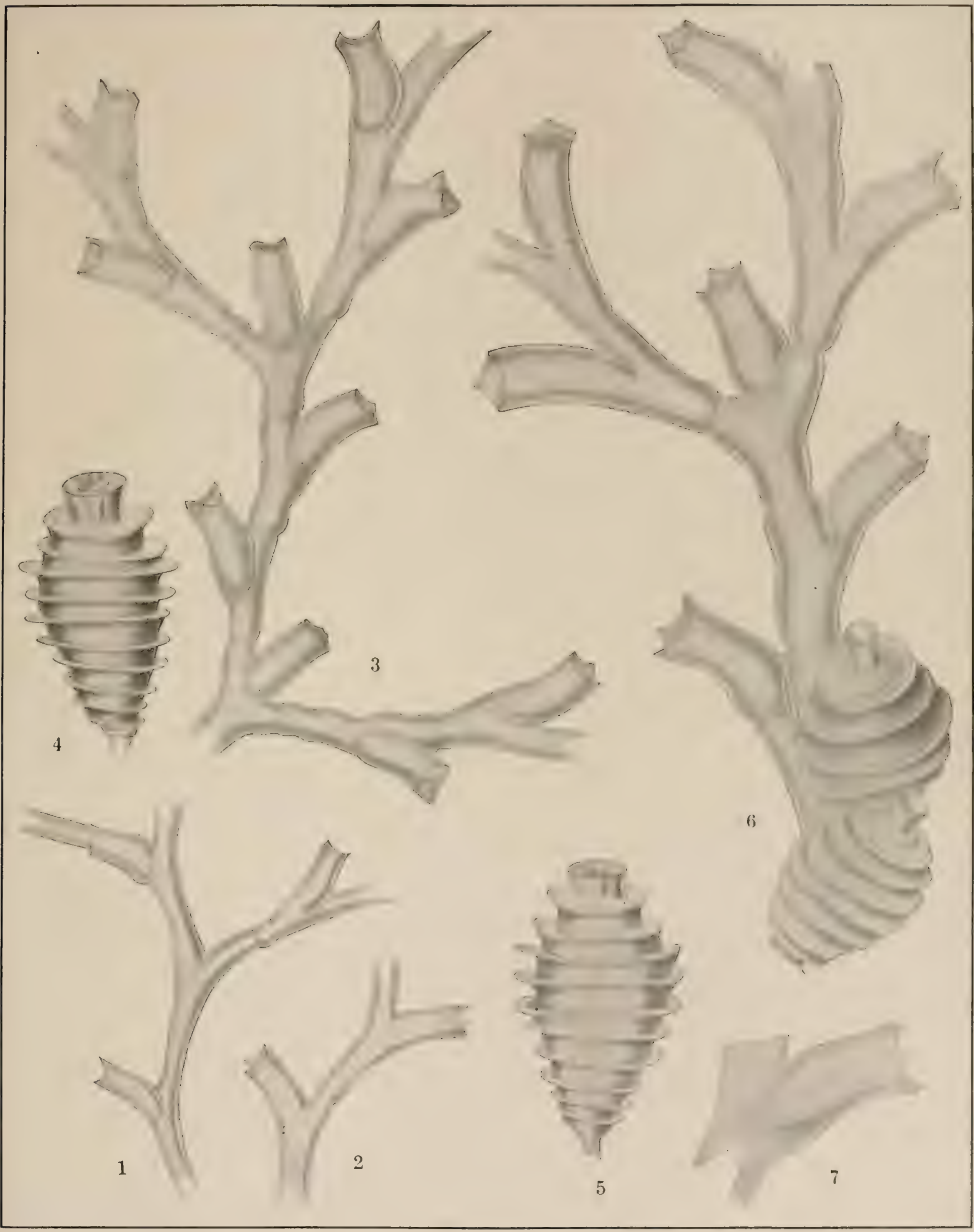






\section{EAPIANATION TO PLATE XXVI.}

Fil. 1. Simfulerdla lorinsmi Nutting. Part of colony with gonangia (enlarged),

2 . Sertulerelln levinseni. End of hydrotheca (greatly enlarged).

$\therefore$ Sirtularella tropica Hartlaub. Part of colony (enlarged). (Aiter Clarke.)

4. Sirfulurellu tropice, Gonangium (enlarged). (After Clarke.)

万. Semblarelln clarkii Mereschkowsky. Part of colony (enlarged). (Aiter Mereschkowsky.)

(i. Sirhlorella nome Hartlauh. Part of branch (enlarged). (After Iartlanb.)

7. Sertularellu episcopus Allman. Part of colony with gonangia (enlarged). (After Allman.) 


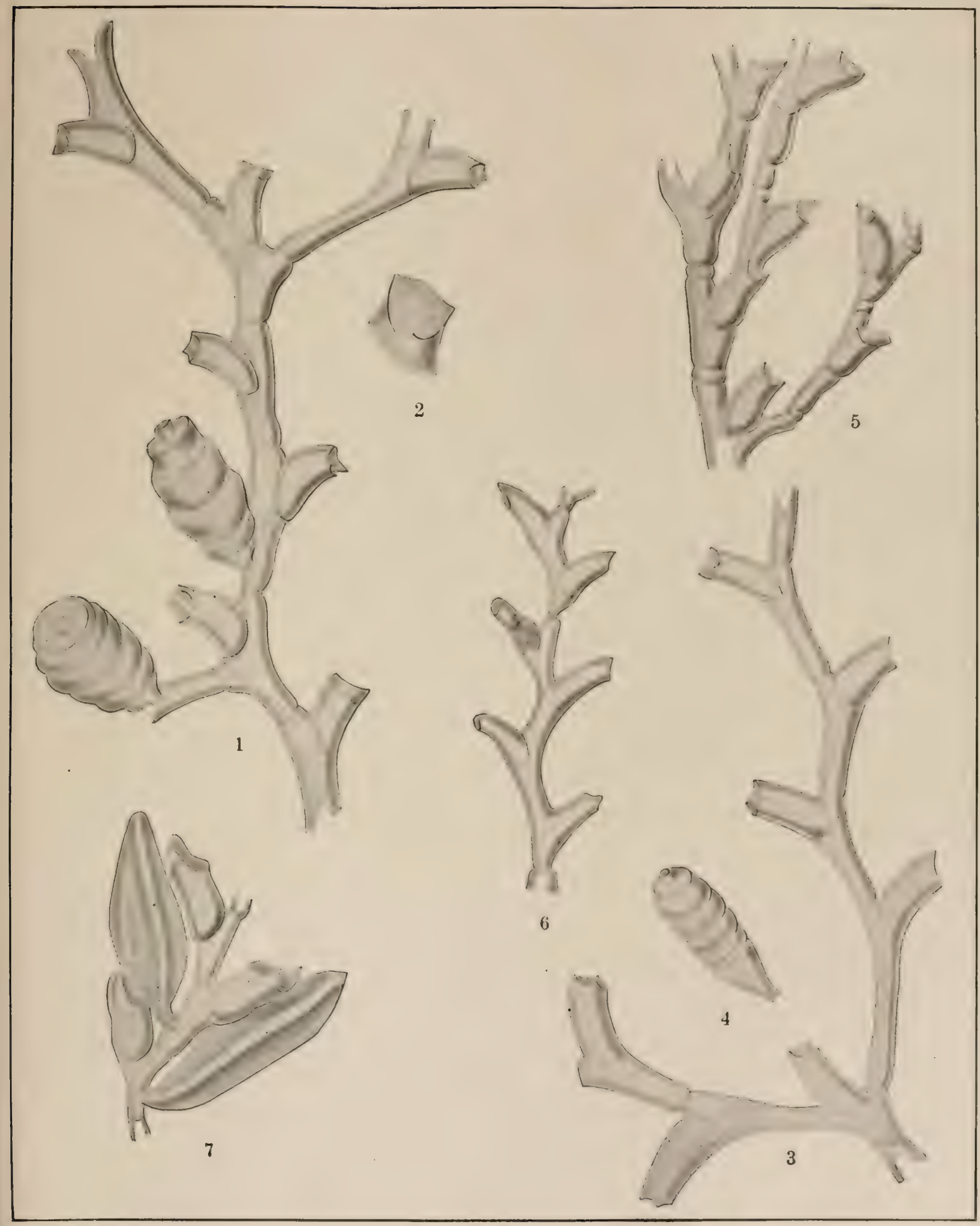

SERTULARIDA. 




\section{FXPLANATION TO IUATE XXVII}

Fic. 1. Smbilarllu mugn Nutting. Two hylrothere (much less enlarged than other figures).

$\therefore$. Semulurellı formose lewkes. Branch overgrown with parasitic campamlarian (enlarred).

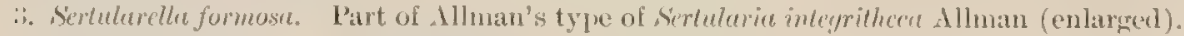

1. Serlularella formosa. Part of stem with gonangia (enlarged).

5. Serlulurelle hurlleubi Nutting. l'art of stem, showing branch origins (enlarged). 


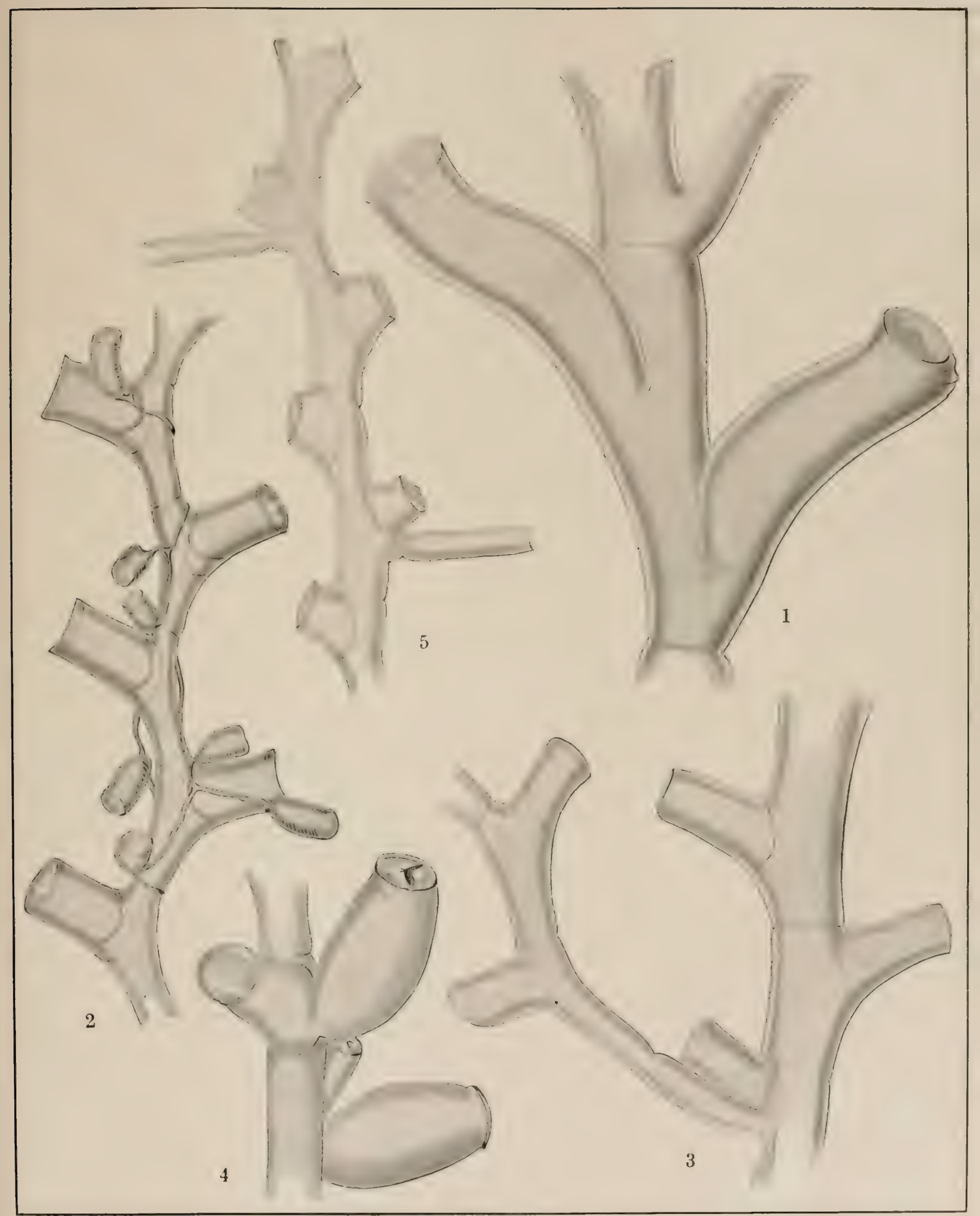






\section{EXT'TANATION TO I'LATE XXVIII.}

In: 1. Distyosladium flabellum Nutting. I'art of colony with gonangia (enlarged).

2. Lictyoctulium, fubellum. l'art of branch (enlarged).

$\therefore$ Diclyocladium flatollum. End of hydrotheca, showing teeth and operculum (enlarged).

t. Diphasia rostcen (Linnxus). Branch with female gonangium (enlarged).

万. Diphasict rusecen. Side view of branch with gonangium (enlarged).

1i. Diphasin hamarise (Linnews). Two pairs of hylrothece (enlarged). (After llineks.)

7. Dipheasa tumarisce. Portion of colony with gonangia (enlarged). (After IIincks.) 


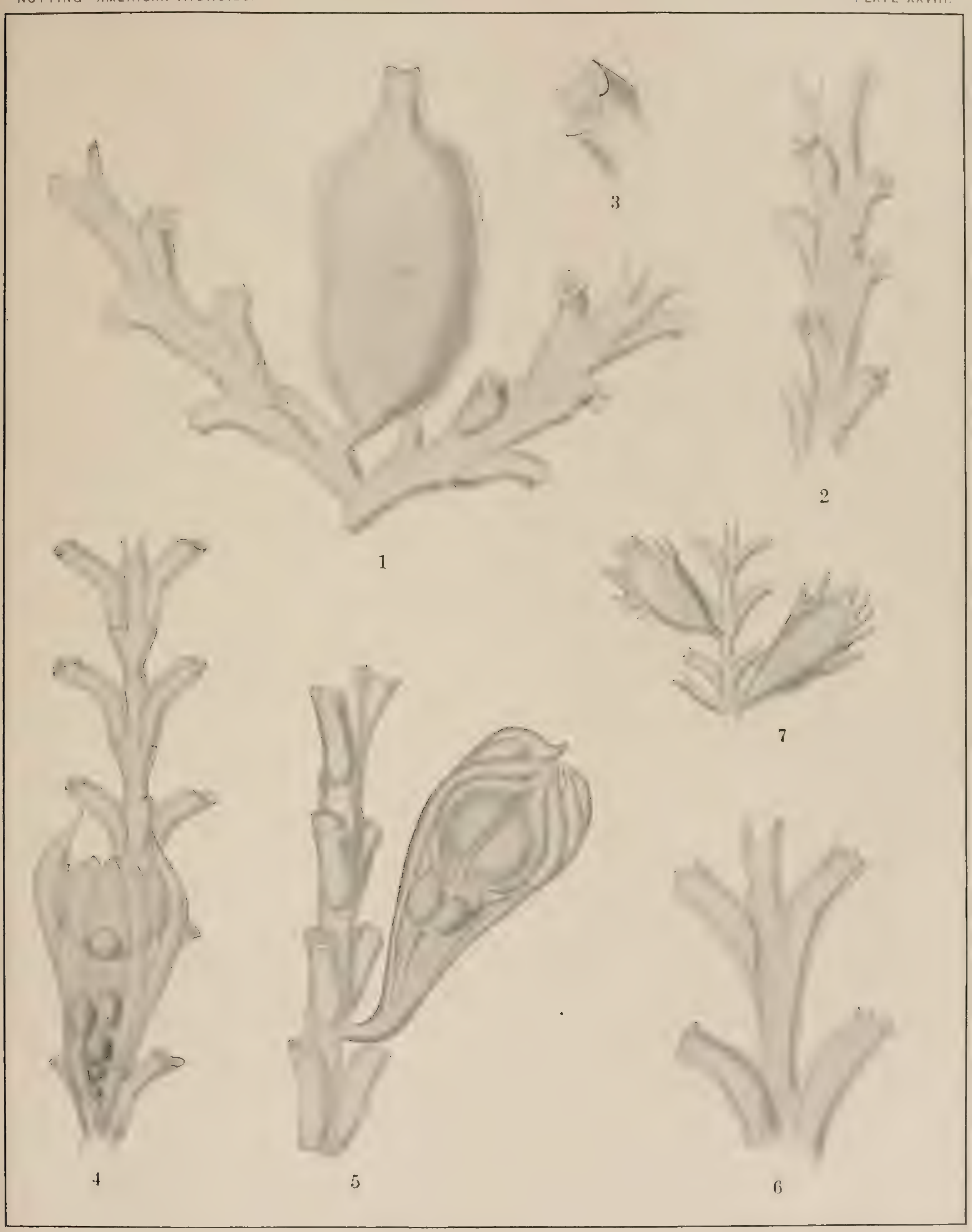

SEmtutamitir. 




\section{EXPLANATION TO PUATE XXIX.}

FIri. 1. Diphlasin corniculata (Murray). Part of colony (enlarged). (After Murray.)

‥ Diplutusit fullux (Jolunston). P'art of colony, showing branching (enlarged).

3. Diphensin fallex. Front view of branch (enlargedi).

4. Diphlusin fullux. Part of branch with gonangium (enlarged).

5. Diphasin fullax. Pair of hydrothece (greatly enlarged).

6. Diphasia fullex. End of hydrotheca, showing operculum (greatly enlarged). 


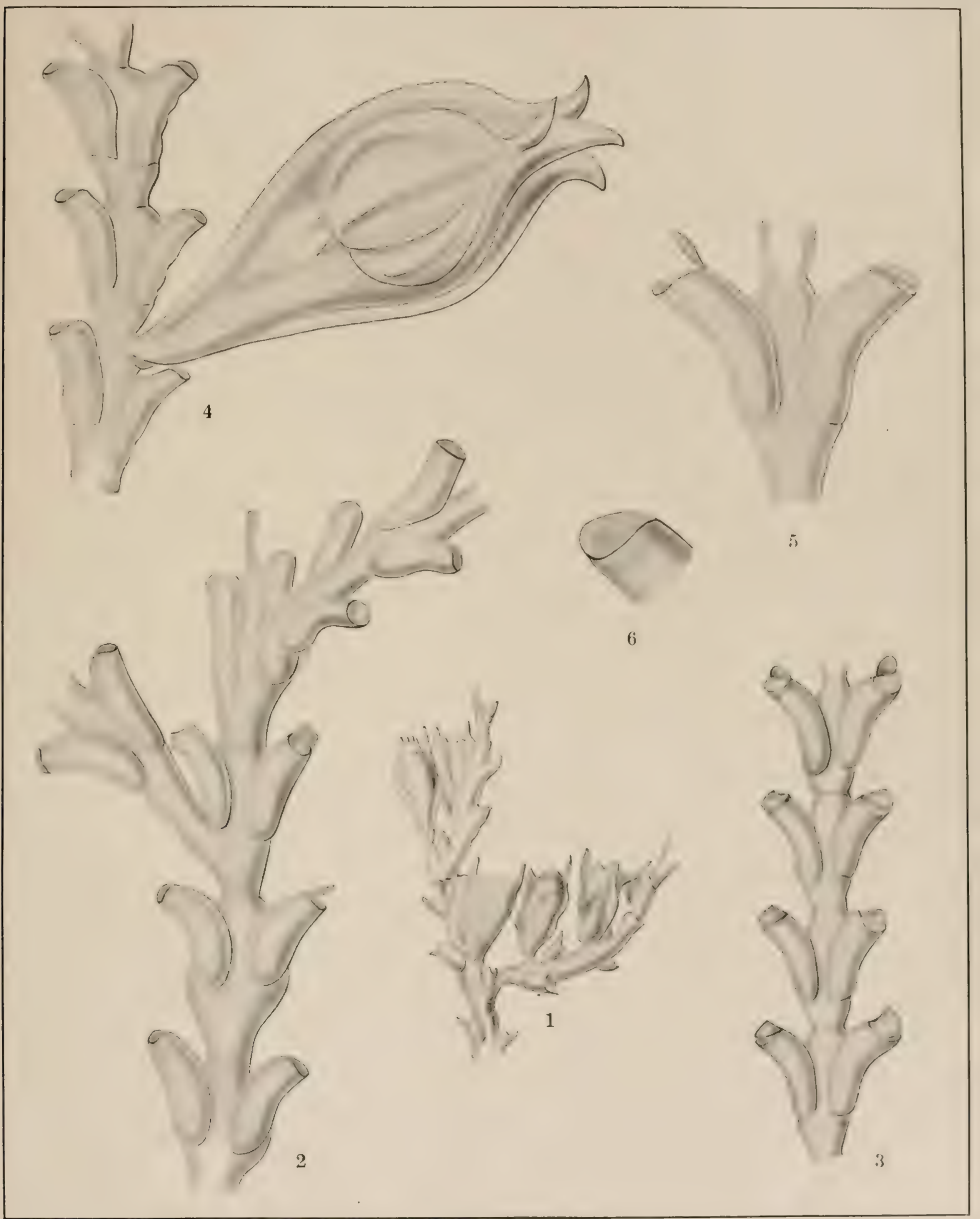

SERTULAIIDE. 


EXPLANATION TO PIJATE XXX.

Fr(a. 1. Diphasin tropica Nutting. Part of colony (enlarged).

$\because$ Diphasia rligitalis (Busk). Front view of branch (enlargerl).

i. Diphasin digitulis. Side view of branch (enlarged).

1. Diphasie rligitulis, Part of Allman's type of Desmoscyphes acanthocrerpus Allman (enlarged).

$\therefore$ Diphusin tigitulis. Distal ends of two hytrothecie, showing the hoof-like operculum (greatly enlarged).

i. Diphasin digitulis. Single hydrotheca, showing what appear to be opercular muscles (areatly enlarged).

7. Diphasie digitalis. Gonangium (enlarged). 


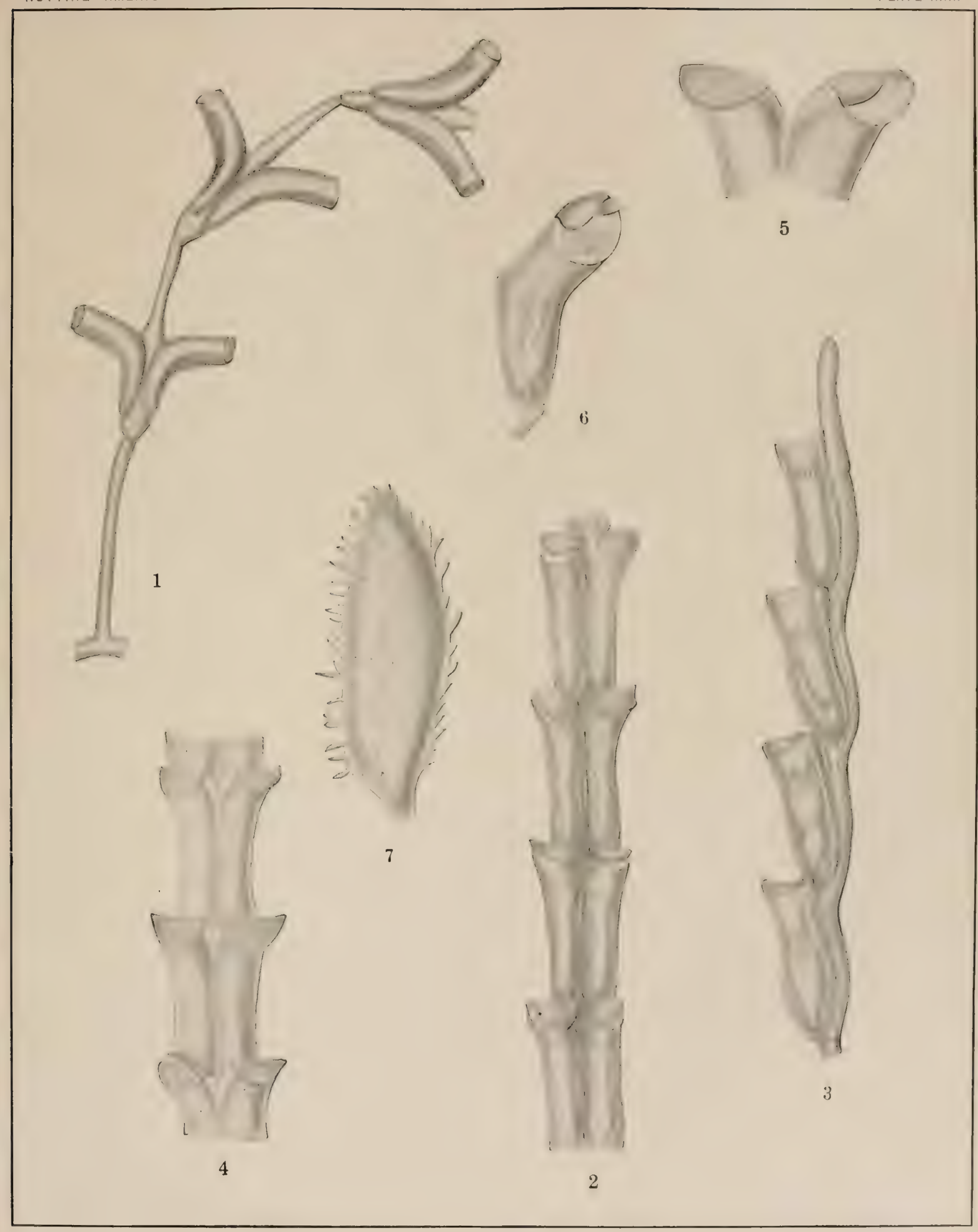






\section{EXPIANATION TO IIATE XXII.}

Fis. 1. Diphesice mulche Nutting. Two hydrothecese (meatly enlarged).

‥ Diphesise pulchre. P'art of colony (enlarged).

:3. Diphesine pulehre. Part of branch (enlarged).

4. Diphesin parmanni Nutting. l'art of branch with nale gonangia (enlargedl).

万. Diphusin purmani. Fenale gonangium (enlarged).

it Diphexic murmenni. End of hydrotheca, showing operenlum (unch enlargerl).

7. Diphersin lincuidi (Nutting). Distal end of branch with gonangia (enlarged).

$\therefore$ Diphesie kincuidi. Four hydrothece (creatly enlarged).

1). Dipherier kincuidi. Gonangium (greatly enlarged).

$\because 72$ 


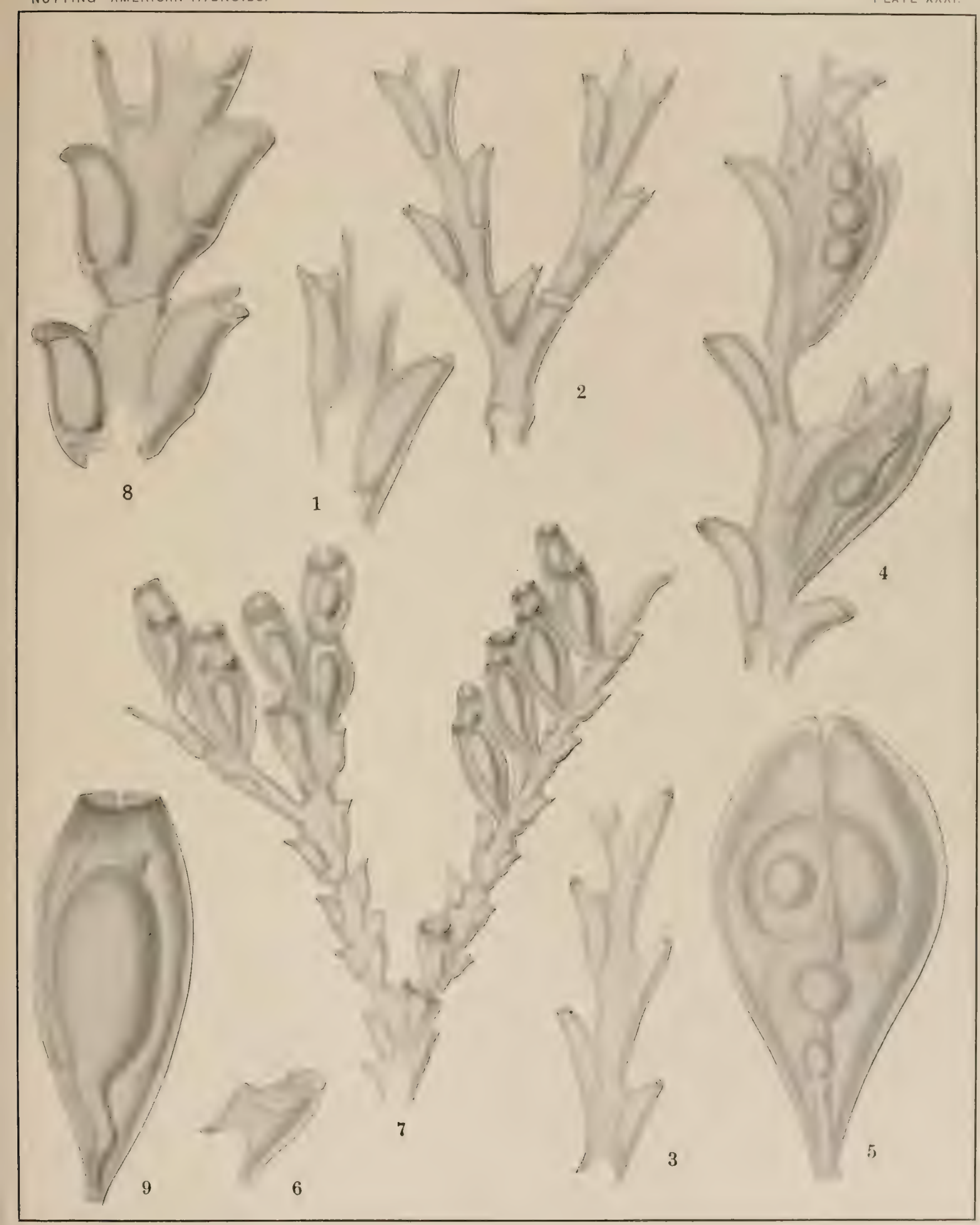

Seirtulaitide. 




\section{EXPLANATION TO PJATE XXXII.}

Fig. 1. Alictinaric abictina (Linneus). Part of colony (enlarged).

2. Ahetinaria abietinu. I'art of a branch (much less magnified).

3. Abietinaria abetina. Two hydrothece, showing ojerculum (much enlarged).

1. Abietinariu verubilis (Clark). Part of colony, showing branching (enlargerl).

5. Abictinaris varialilis. Four hydrothece (nuch enlarged).

6. Abictivuria varubitis. (ironju of gonangia (enlargerl).

7. Alortimuriu roriobilis. ( omangium (greatly enlarged), 


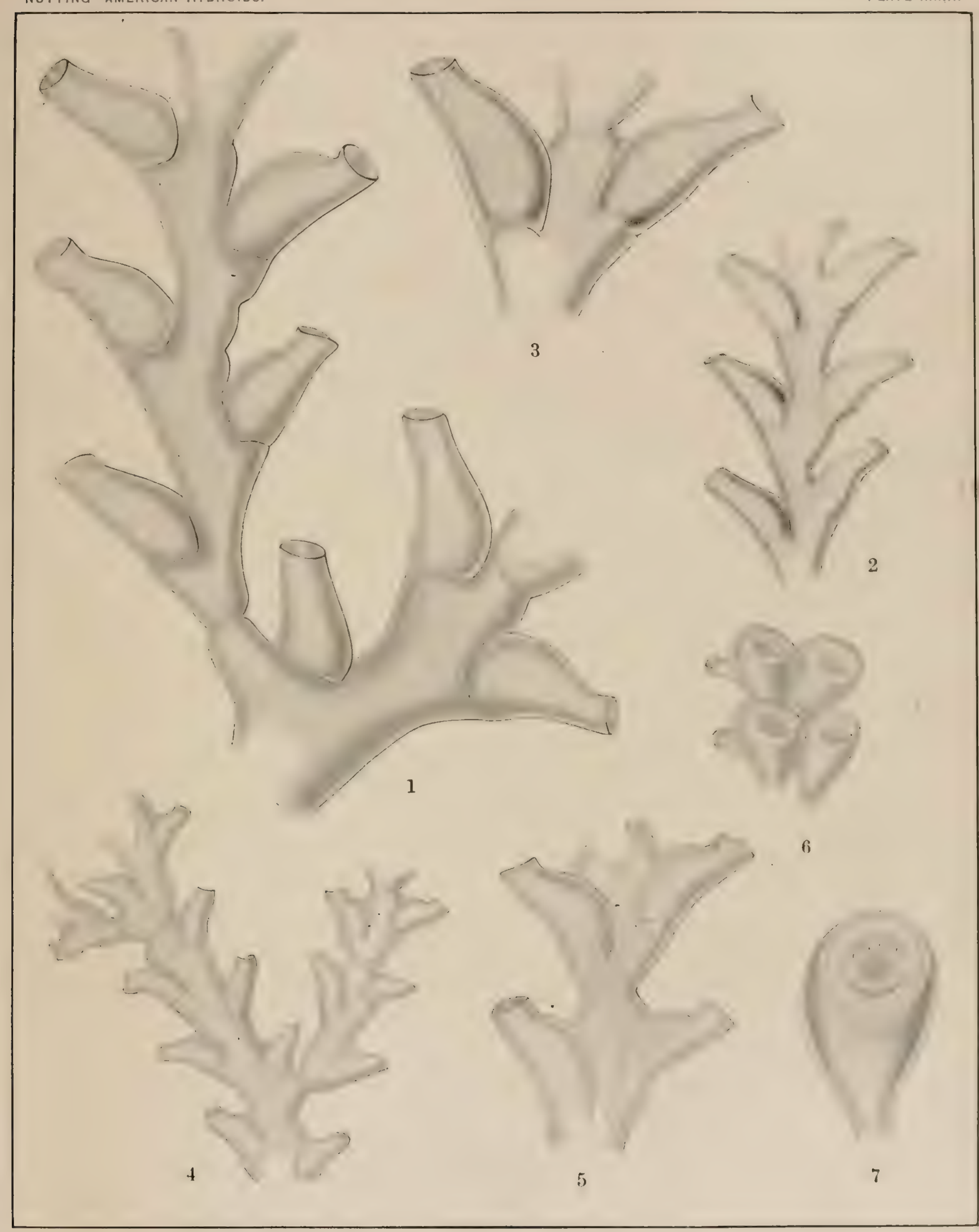

SERTULARME. 




\section{EXPLANATION TO ILATE XXXIII.}

FIG. 1. Alidinaria inconstans (Clark). I'art of colony (enlarged),

2. Abitimarir inconstans. Part of branch (enlarged).

3). Ilictinariu coei (Nutting). Part of branch with gonangia (enlarged).

4. Ahietinuriu coei. Single hydrotheca, showing sinuation of margin (enlarged).

5. Abielinarin coci. Top-shaped gonangium (enlarged).

6. Alietinariu traski (Torrey). Part of colony, showing branching (enlarged).

7. Abirtinarintraski. Two hydrothece (greatly enlarged).

8, 9. Abictimurit traski. Ends of hydrotheca, showing opercula (greatly enlarged).

10. Ibictinaria traski. Branch with gonangium (enlarged).

11. Abietinaria traski. Three hydrothece from another colony (greatly enlarged). 


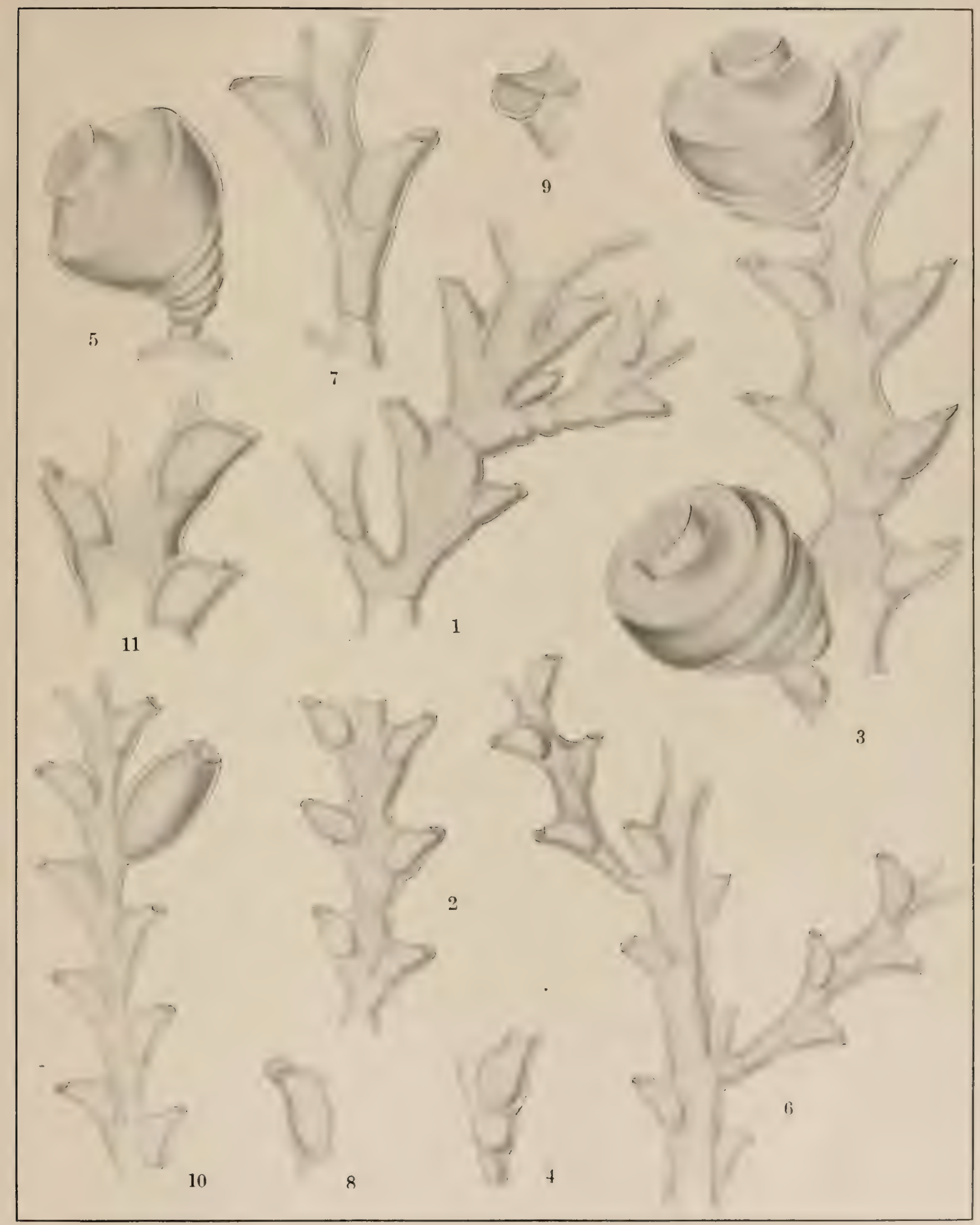

SERTULARTDE. 




\section{FAILANATION TO ILATL XXIIV.}

Fis. 1. Ilielinerin filiculn (Ellis and Solander). Part of branch (much enlirged)

2. Ilietinurin miphore Nutting. Part of branch (enlarged).

:). Llidinaria umphoru. Distal part of branch (enlarged).

1. Uhitinarier amphome. l'art of branch with gonangium (enlarged).

万. Lhefinurin anguinu (Trask). Part of branch with very slender hydrothece (enlarged).

4. Alictimuin muminu. Part of branch with gonangia (enlarged).

7. Alictimerire unguine. Single gonangium (enlarged).

254 


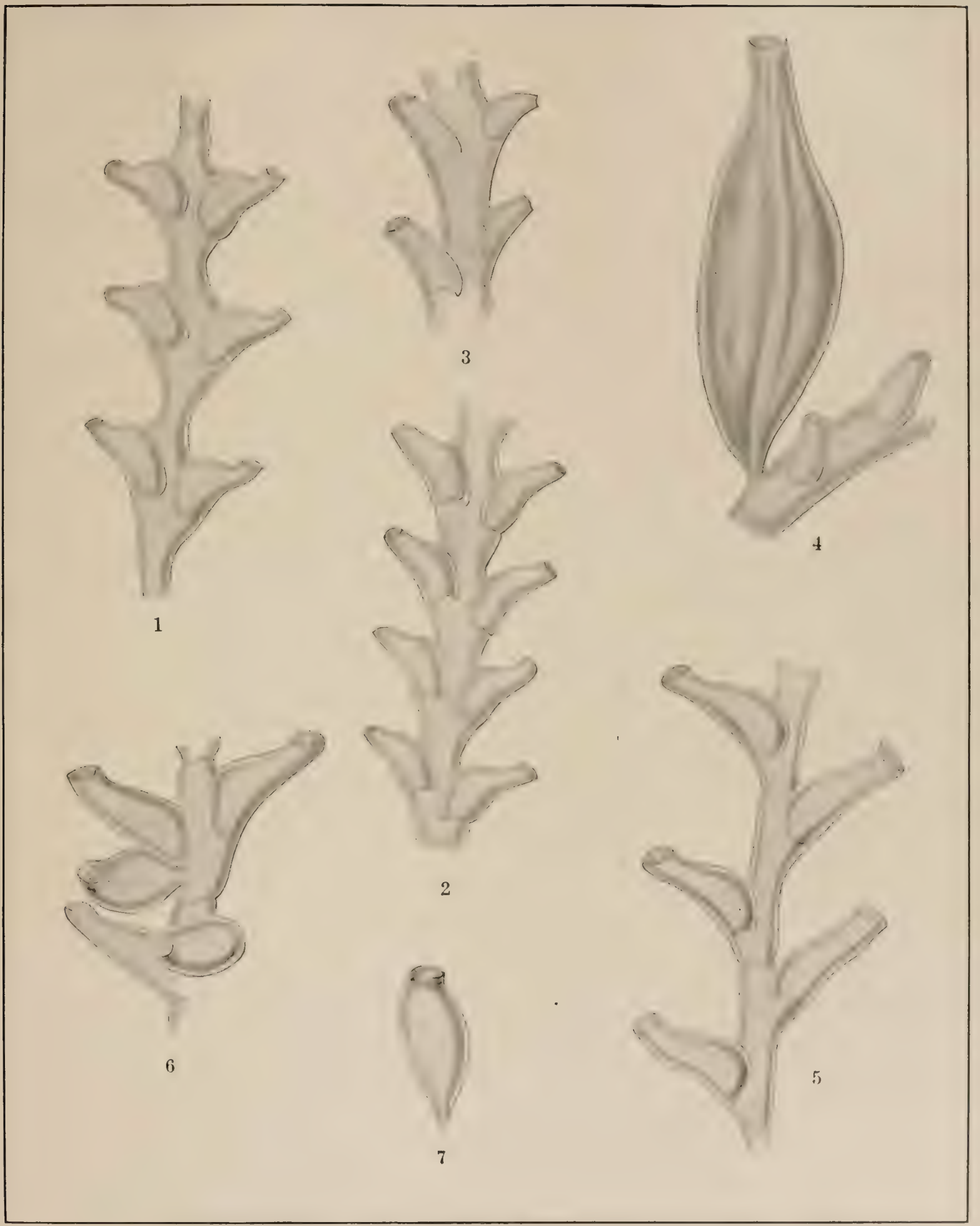

SFETLIAIIDE. 




\section{WXIPUANAION TO PLATE TYYV.}

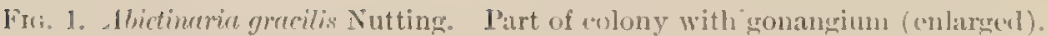

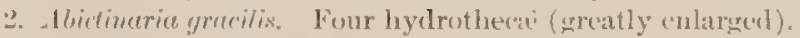

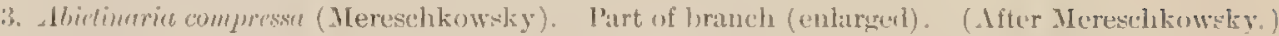

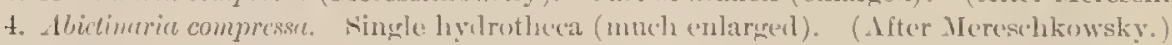

5. Abictinuruc alexomeri Nutting. I'art of stem and branches (enlarged).

6. Llidinctive clexemeri. I'art of branch and gonanginm (enlargerl).

7. - lbitinaria alexameri. (onangiun, showing meridional lines (onlarged).

8. Abictinurie clexunderi. Gonangium (greatly enlarged).

23 


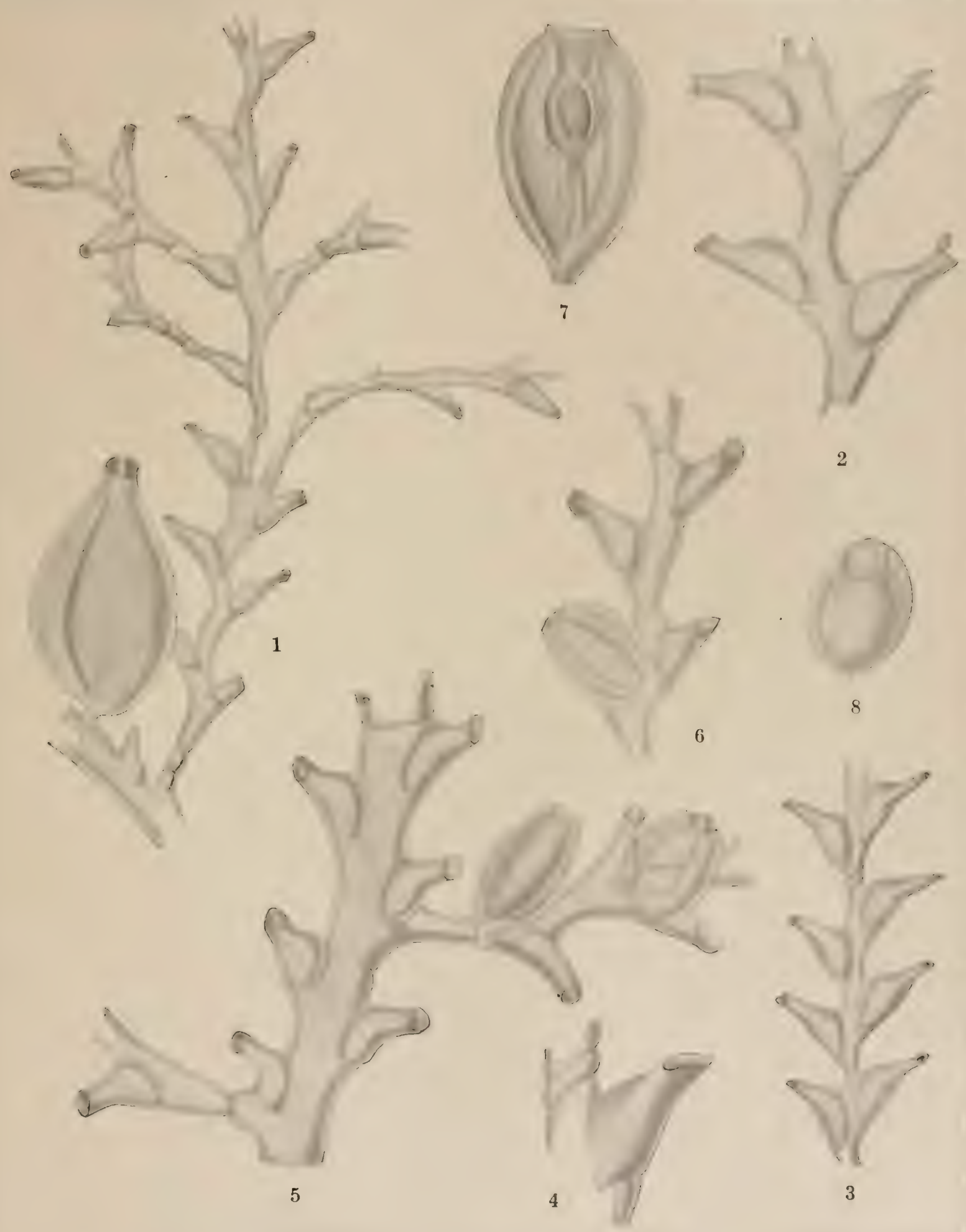

Shrtularide. 




\section{EXPI,ANATION TO PLATE XXXVI.}

Fro. 1. Alietinario greenci (Murray). l'art of branch (enlarged).

2. Ilictinarin yrenei. Fonr hyirothea (enlarged).

3. Abiclinaria gremei. I'air of hydrothece with toothed margins (much enlarged).

4. Lbidimurie grenci. Pair of lyglrothece with even margins (greatly enlarged).

5. Abictinarin grenci. sisle view of hydrothecx (enlarged).

6. - bietinarin gremei. Sicle view of hydrothecæ (much enlarged).

7,8 . 1 lietimerin greenei. (ionangia (enlarged).

9. Ibietimariu costutu (Nutting). Part of branch (enlarged).

10. Lbietinarie costetu. Part of main stem, showing branch origins (enlarged).

11. Hictimarive costute. Four hydrotheces (greatly enlarged).

12. Alietinurio rosteta. (iroup of gonangia (enlarged).

13. - llictinurin chmulutu (Kirchenpaner.) Part of main stem and branches (enlarged).

14. Alsetimumin cmmelete. l'art of branch (enlarged).

15. Lisetimuri c mmulate. Side view of three hydrothecet (enlargenl). 


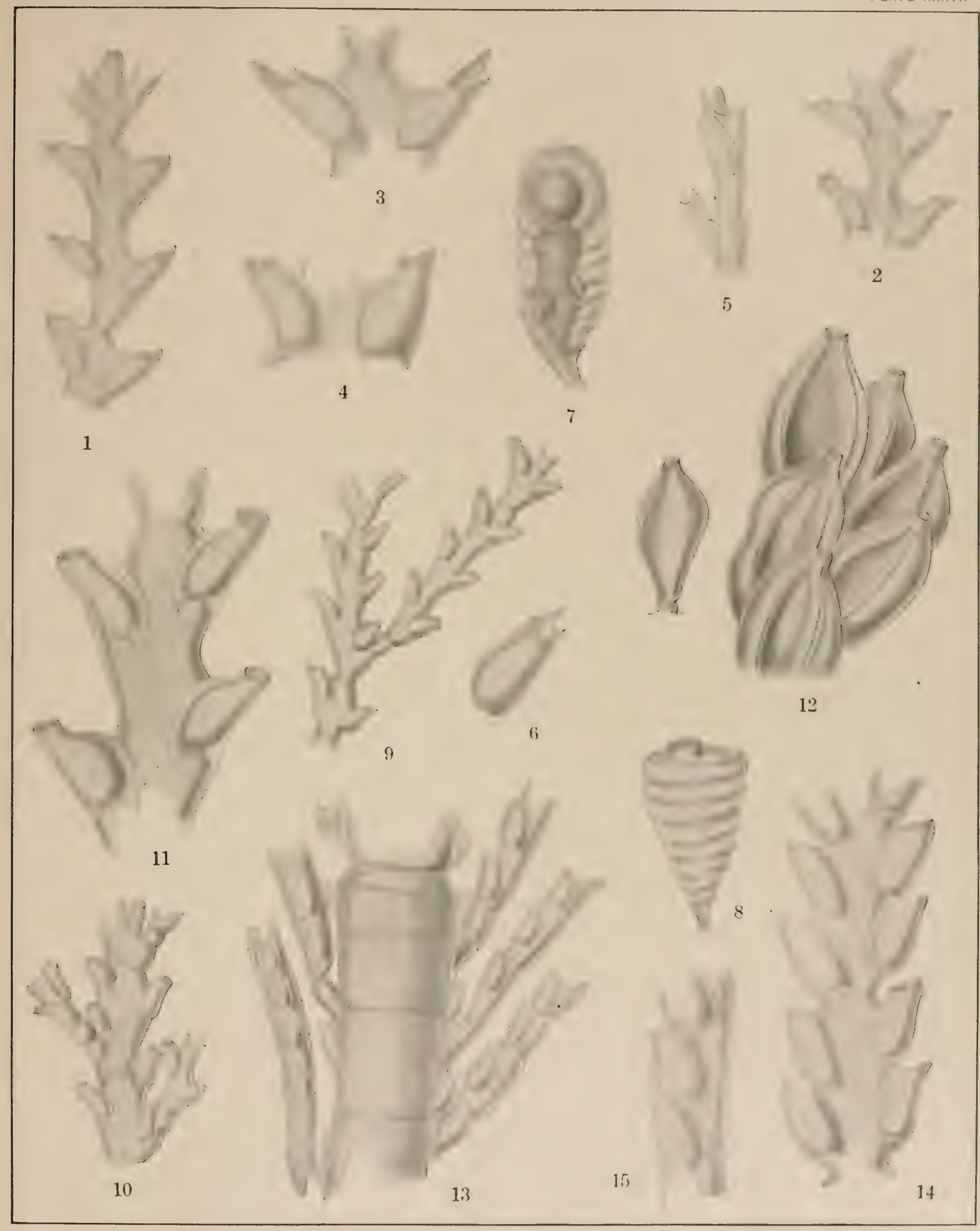






\section{EXPLANATION TO P'LATE XXXYII.}

F11. 1. Abictinaria turgida (Clark). Part of stem and branch (enlargerl).

2. Abietinariu turgidte. Gonanginm (enlarged).

$\therefore$ Abietinarin gigmento (Clark). Part of branch (enlargeel).

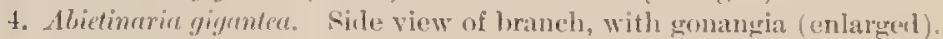

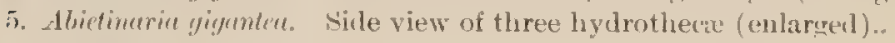




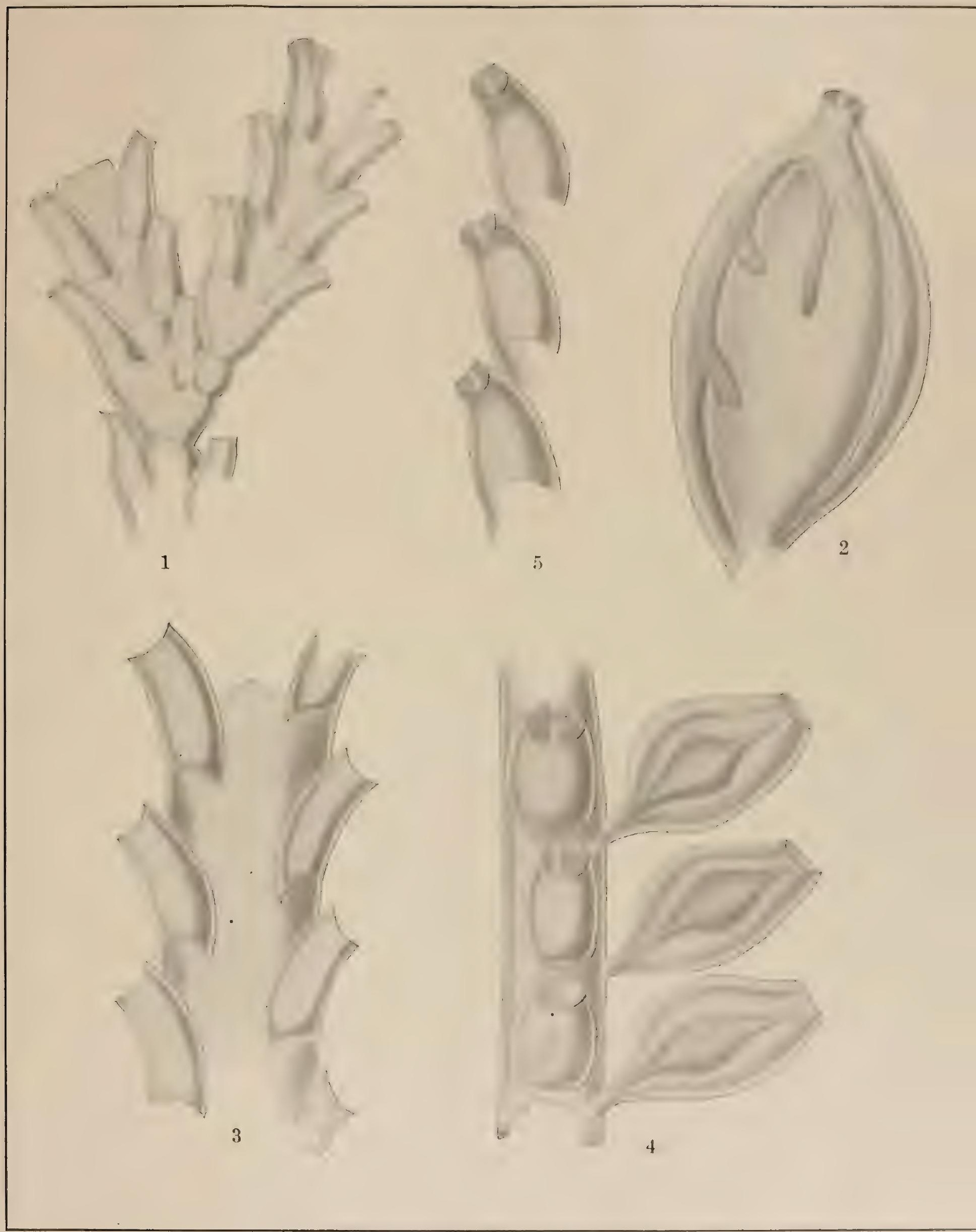






\section{EXPLANATION TO PIATE X゙ẌIVII.}

Fici. 1. Ilydrallmania fulcutu (Linneus). Sideview of branch (greatly enlarged).

2. IIyelrallmanier fulcula. Conanginm (enlarged).

3. Hydralmumia jalcuke. Front view of end of branch (enlarged).

4. Hydrallmanir falcata. Side view of end of branch (enlarged).

5. IIyelrallmenia distens Nutting. D'art of branch, side view (enlarged).

15. IIylrallmemice distens. Front view of hranch (enlarged).

7,8. Mydrallmanie distens. Front view of hydrothecie (much enlarged).

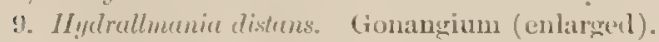

10. II! drallmaniu fonciscenu (Trask). I'art of colony (enlarget). (After Trask.)

11. Scluginogsis mirubilis (Verrill). Part of branch (enlargerl).

12. Siluginopsis mimbilis. (rmangium (enlargerl).

13. Scluginopsis jimaster (Lepechin). I'art of branch (enlarged). (Aitur kirehenunuer.) 

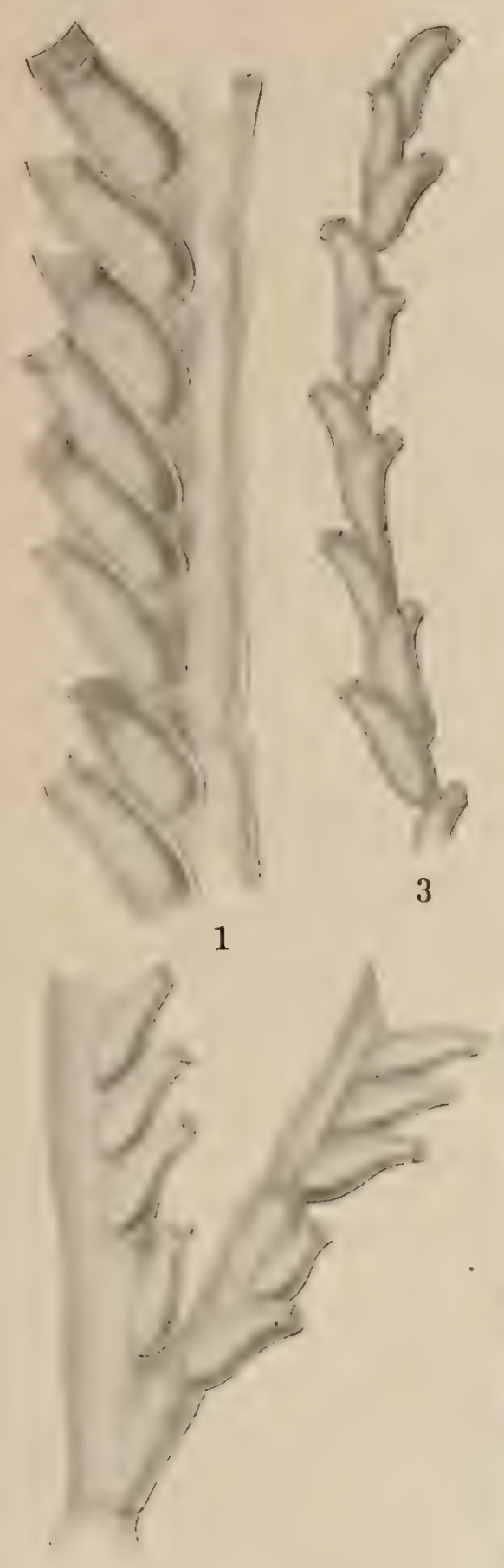

10

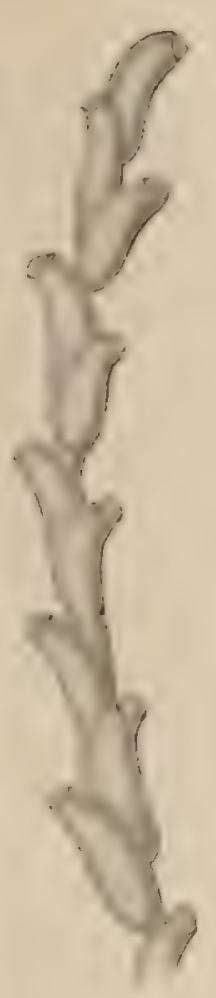

3
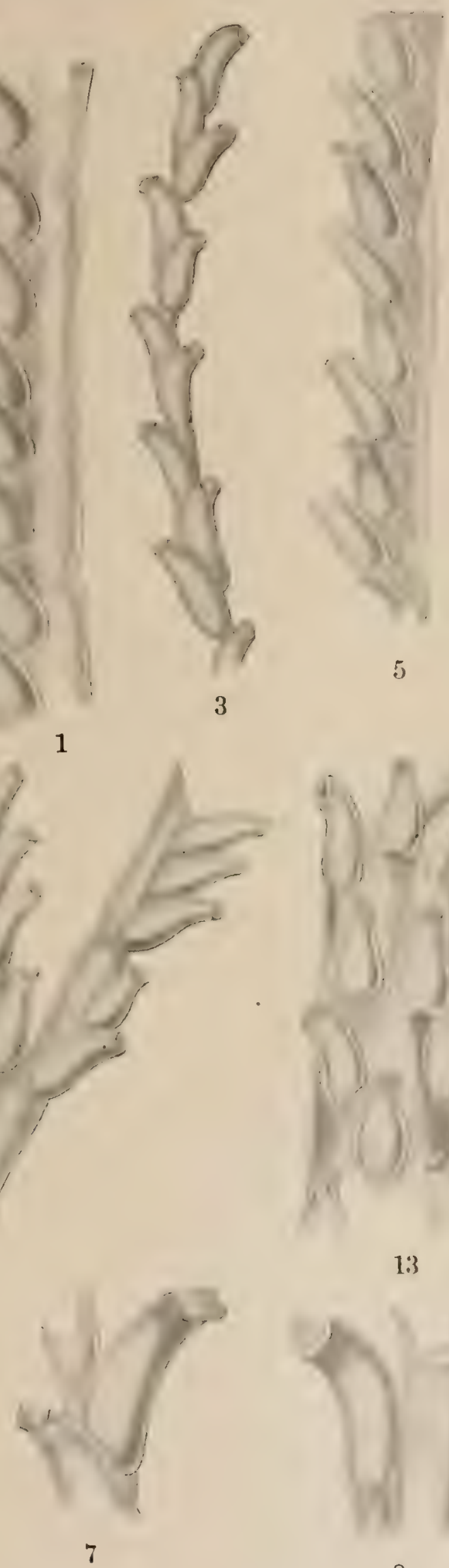

5

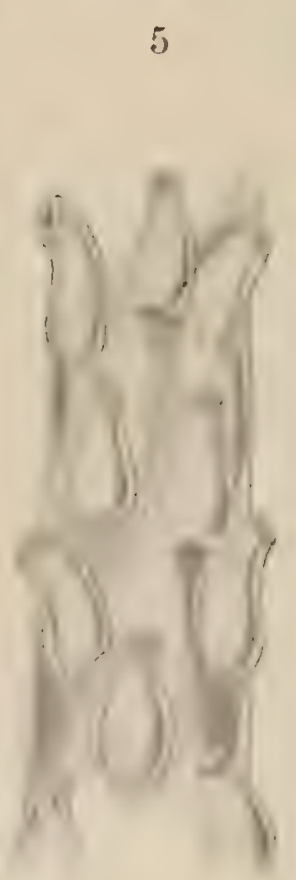

13

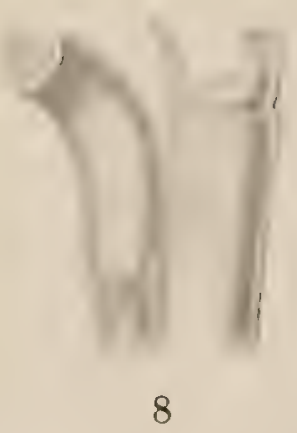

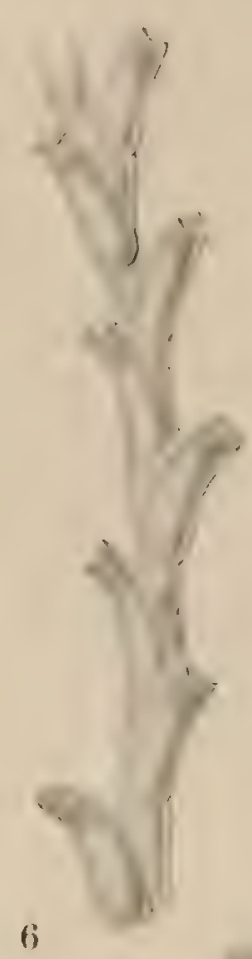
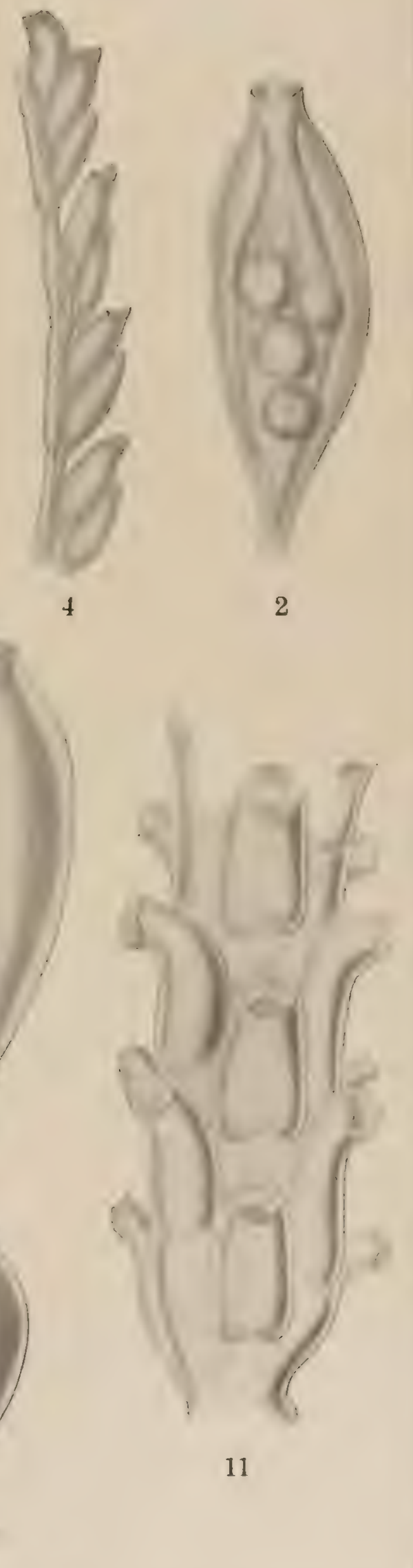


EXPLANATION TO PLATE XXXIX.

Fin. 1. Selaginnpis triscrialis Mereschkowsky. l'art of hranch (enlarged).

2. Selnginumsis triscruelis. Jabsal part of lnanch (enlarged).

$\therefore$ Selaginopsis plumiformis Nutting. Part of main stem, branch and branchlets, showing manner of hr:mchiun. (enlarged).

4. Seluginopsis olsoldte (Lepechin). Part of branch (enlarged).

i. Selurimopis obsulete. Cross section of branch (enlared).

1. Selnginopsis pimutu Mereschkowsky. Part of branch (enlarged).

7. Seluginopssis cylindricen (Clark). Part of branch (enlarged).

५. Schuimopsis cylindrica. Single hydrotheca (greatly enlarged).

:OH 




\section{EXPLANATION TO PLATE XL.}

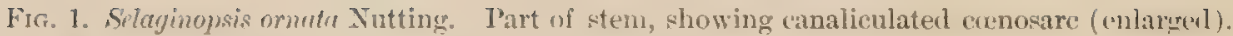

2. Selaginopsis omata. Part of a branch (enlarged).

i. Seluginopsis ornutr. Gonangium (enlarged).

t. Shlaginopsis obsoleta (Lepechin). Part of branch (enlarged). (After Kirchenpauer.)

i. Selagimopsis utternithert (Levinsen), Front view of part of branch (enlarged).

1i. Sthginopsis ullemilheer. Side view of part of branch (enlarged).

7. Seluginopsis ultemitheca. Gonangium (enlarged).

¿. Shluginopsis hartlaubi Nutting. Part of branch (enlarged).

$30 \mathrm{~s}$ 


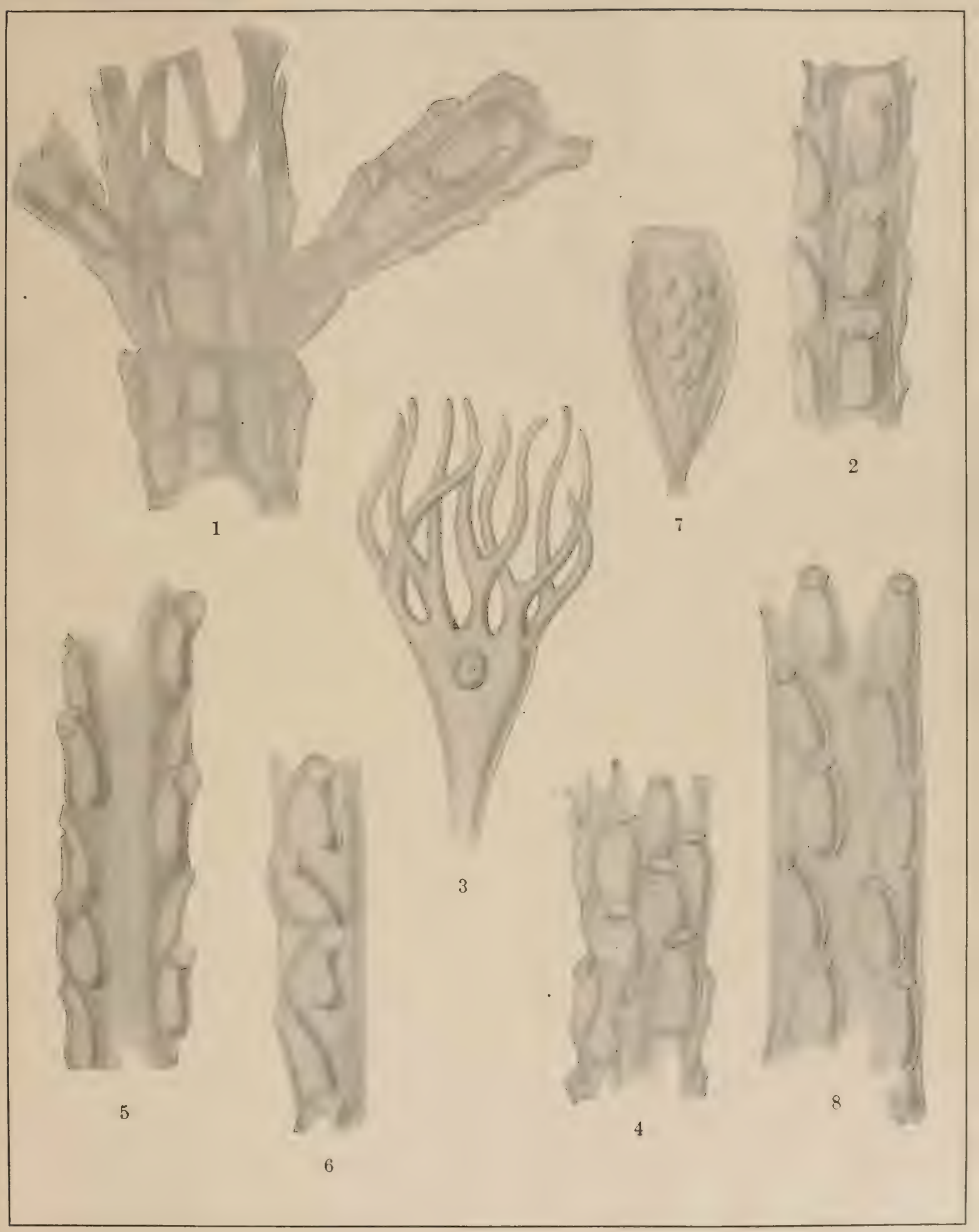






\section{EXPLANATION TO PLATE XLI}

Fir, 1. Synthecium tubithecum (Allman). Part of colony, showing opposite branches (enlarced).

2. Symthrcium rectum Nutting. Part of colony (enlarged).

3. SSynthecium marginatum (Allman). I'art of branch (enlarged). (After Allman.)

4. Symthecium robustum Nutting. Part of colony with gonangia (less enlarged).

5. Symthecium robustum. Part of branch, front view (enlarged).

6. Synthecinm robustum. Part of branch, side view (enlarged).

7. Simthecium cylindricum (Bale). Part of branch (enlarged). (After Bale.)

312 


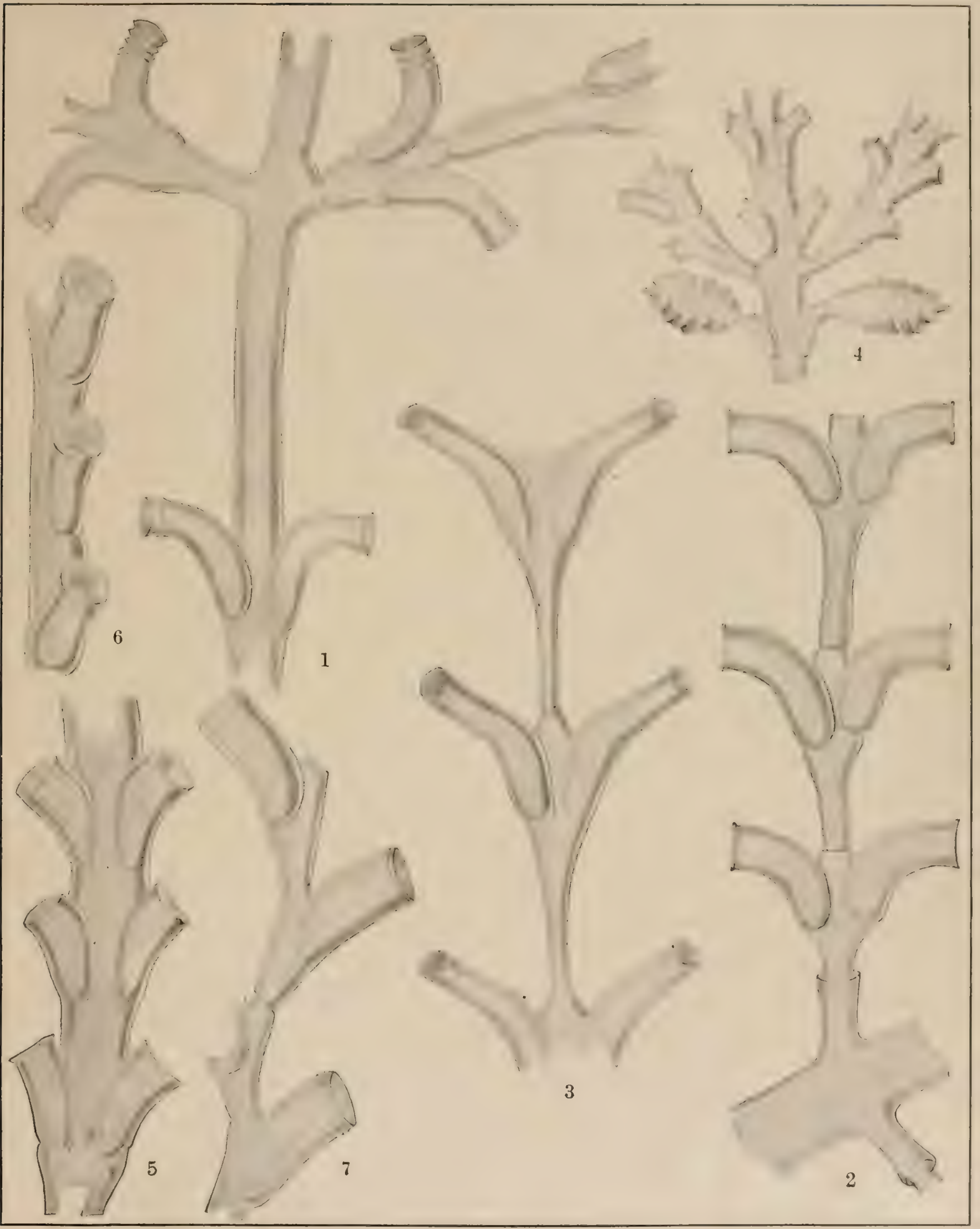





\section{N D E X .}

[The figures in black-faced type indicate references to the formal descriptions in the systematie part of the work.]

I’agc.

Abietinaria $\ldots \ldots \ldots \ldots \ldots \ldots \ldots \ldots \ldots \ldots \ldots \ldots \ldots, 17,20,23,39,41,43,44,50,62,76,106,107,113,121,12.2$

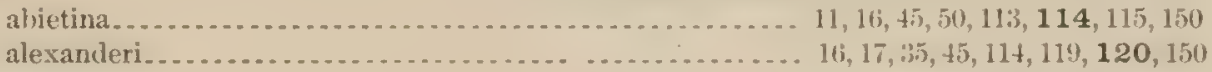

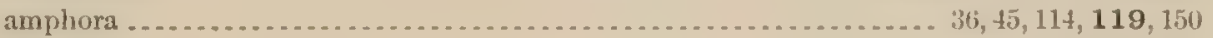

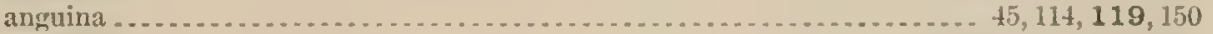

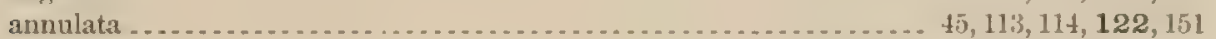

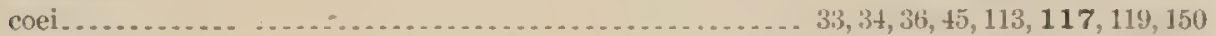

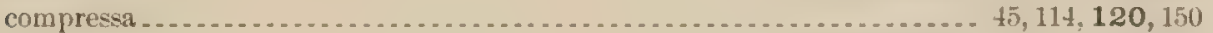

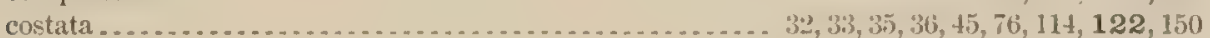

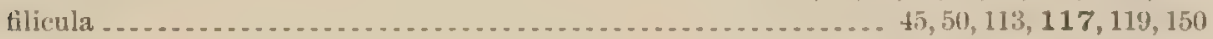

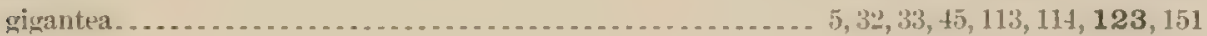

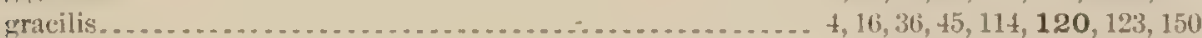

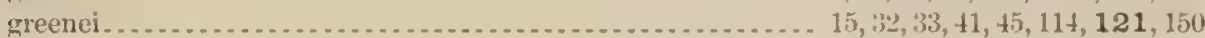

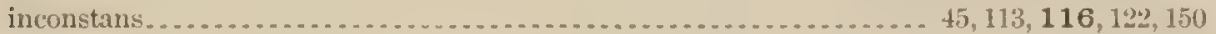
(labrata) - na

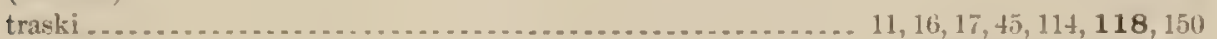

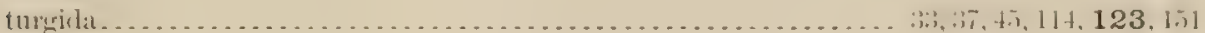

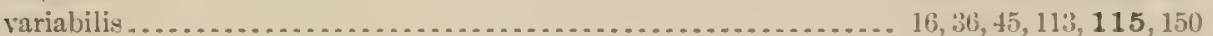

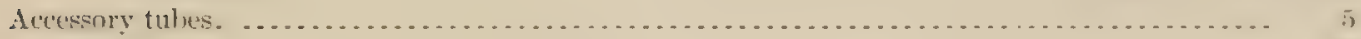

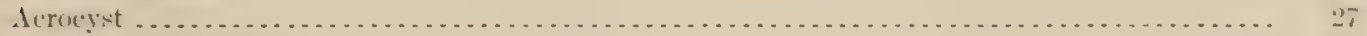

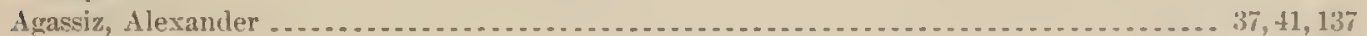

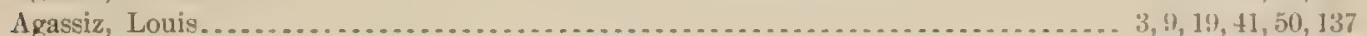

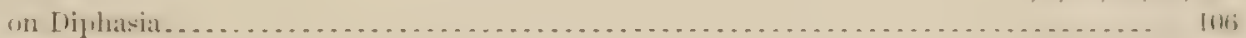

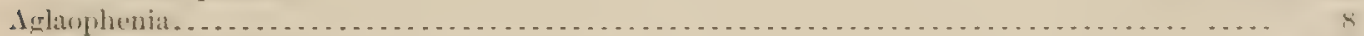

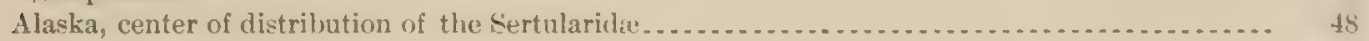

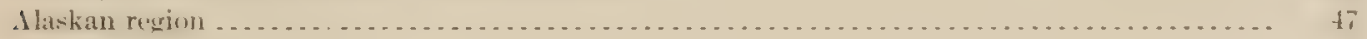

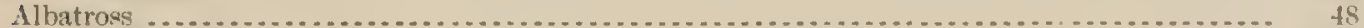

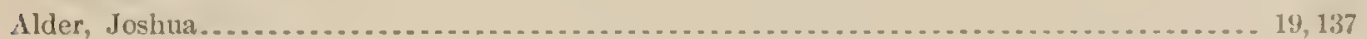

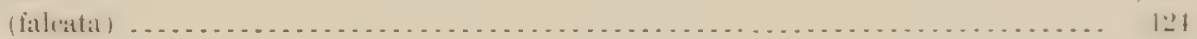

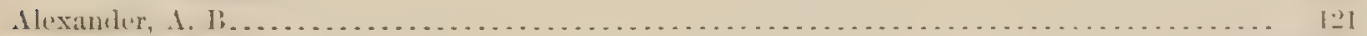

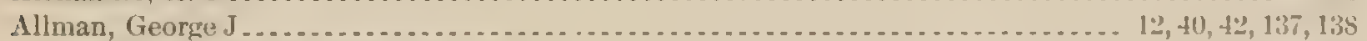

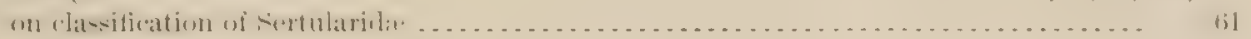

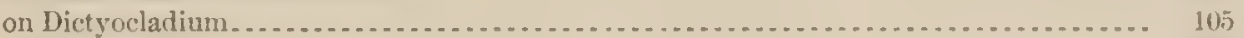

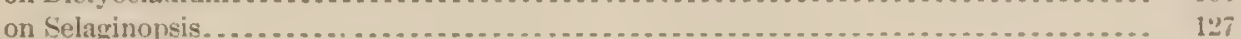

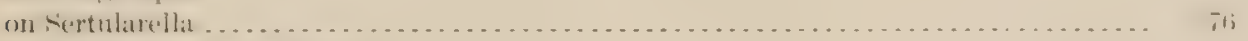

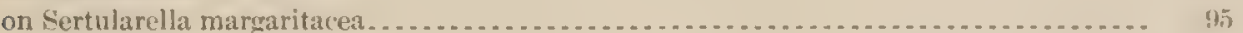

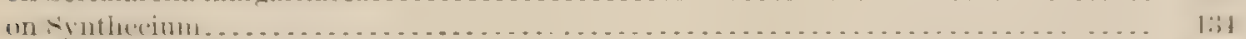

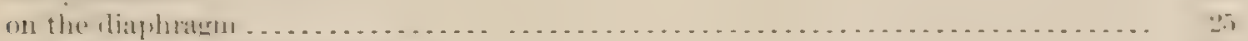

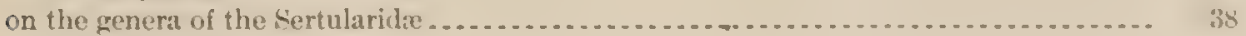

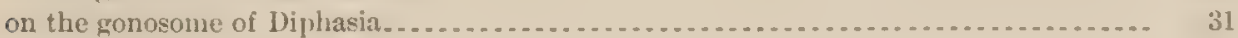

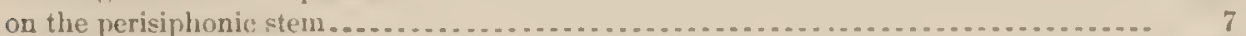

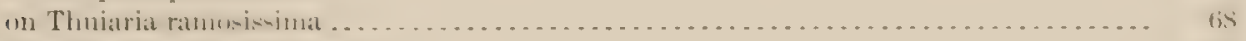

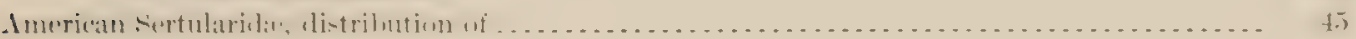

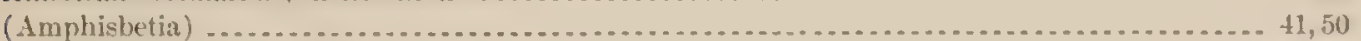

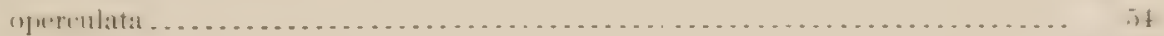

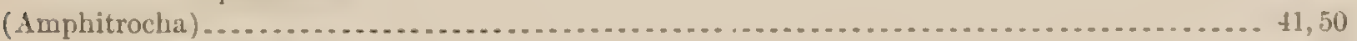

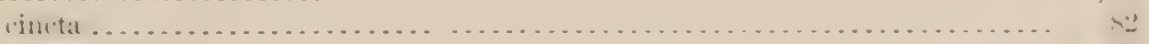

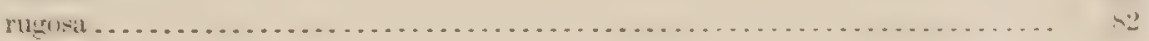

Hate.

IXIII

$\mathrm{XXI}$

IIXIY

xixiv

XIXVI

I.IIII

XXYV

xixis

XXIiv

XIXIII

IXIV

Xxivi

XXXII

xxxil

I.T.11

XIXI 
Antennularia

Iretic lieurisit

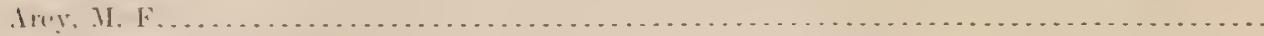

Australia, sertularian famna of

Axial tube

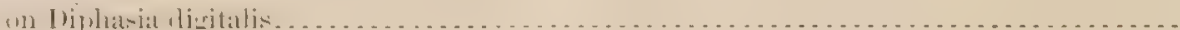

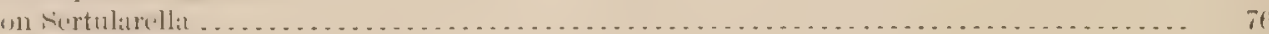

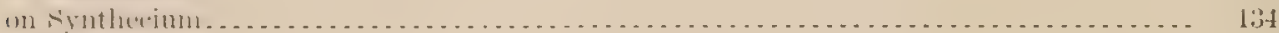

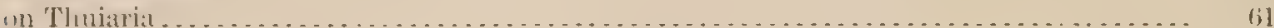

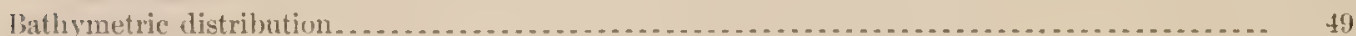

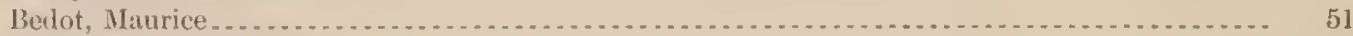

Betot, Maurice, and I'ictet, Camille . . . . . . . . . .

liennet en ran Olivier.

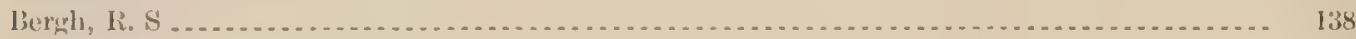

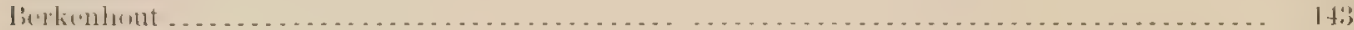

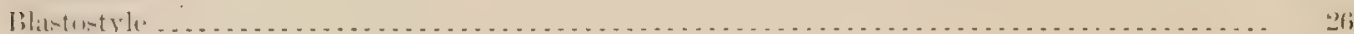

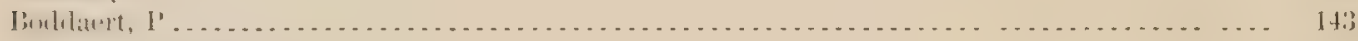

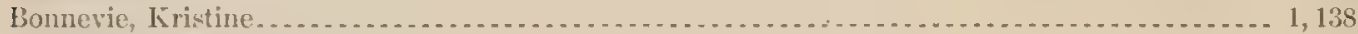

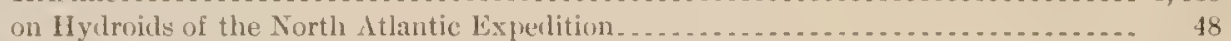

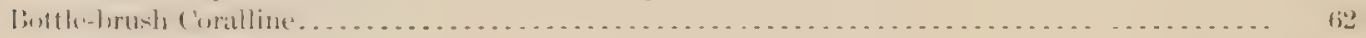

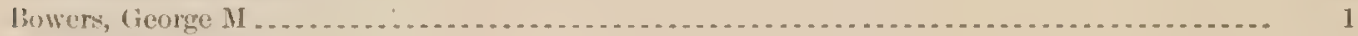

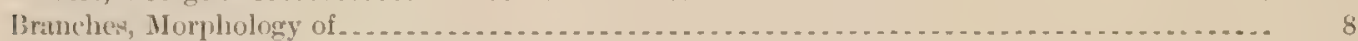

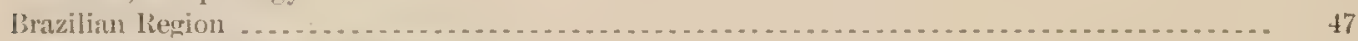

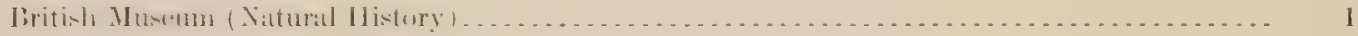

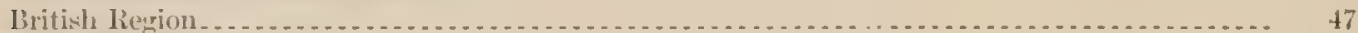

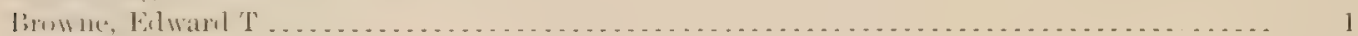

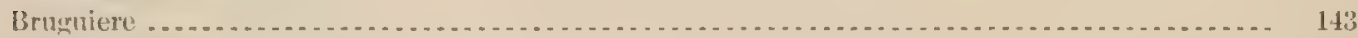

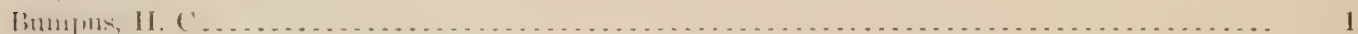

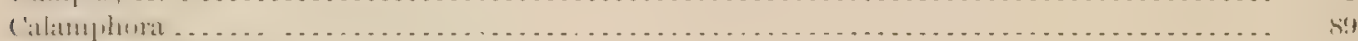

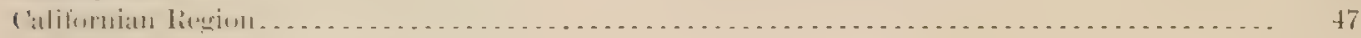

Calkins, (iary $N$. . . .

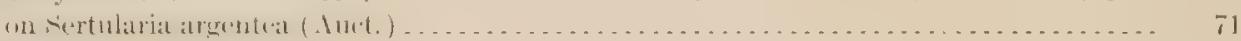

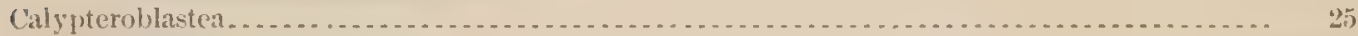

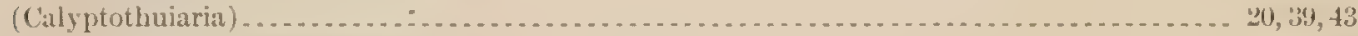

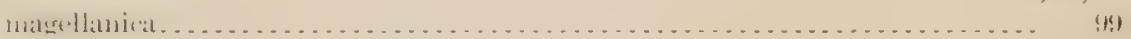

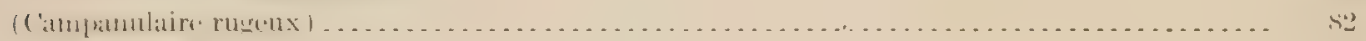

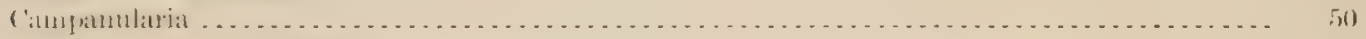

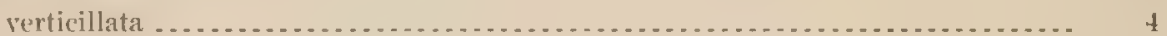

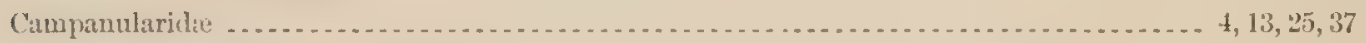

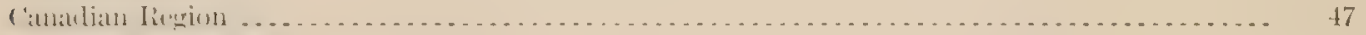

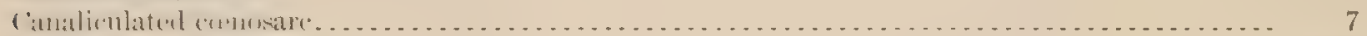

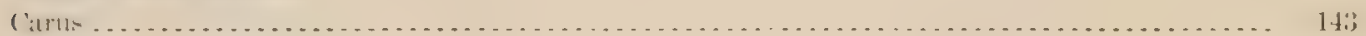

$($ (')

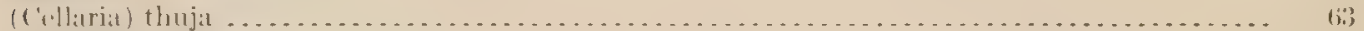

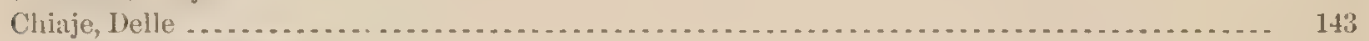

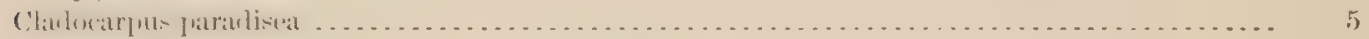

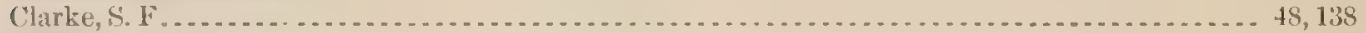

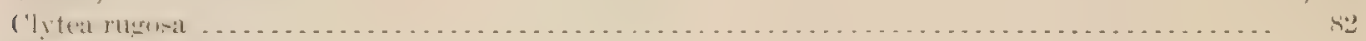

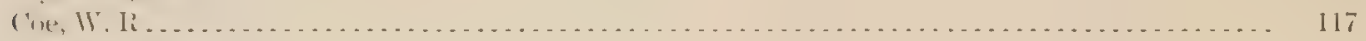

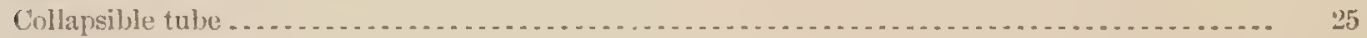

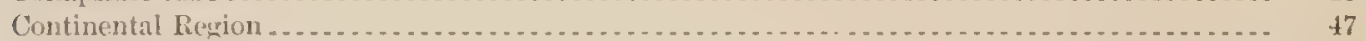

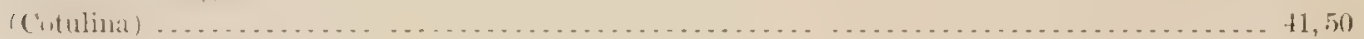

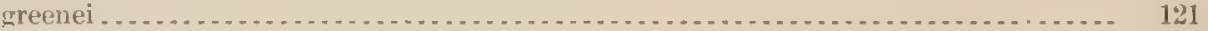

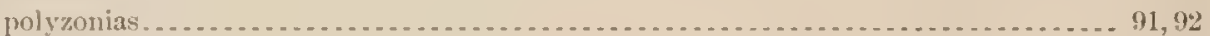

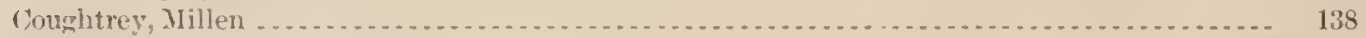

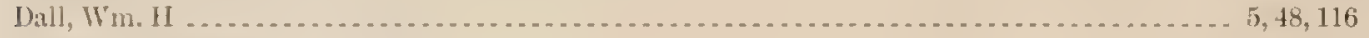

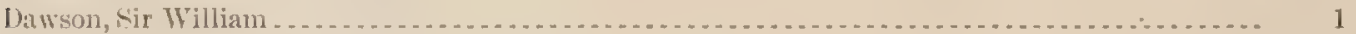

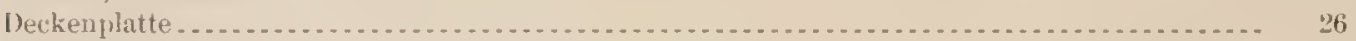

Deslongschan

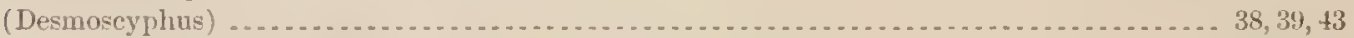

acanthocarpus ............................................ 19, 110, 111

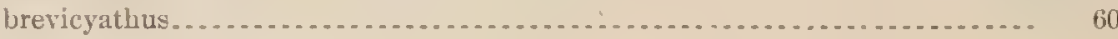




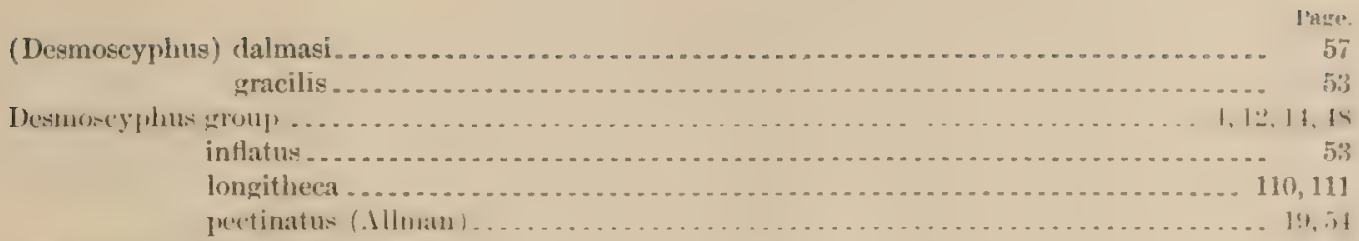

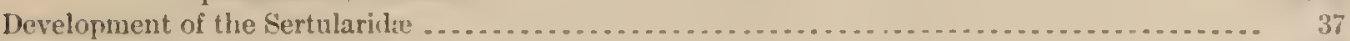

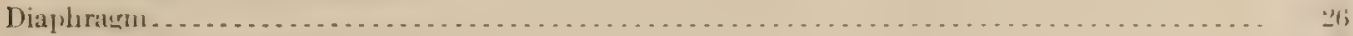

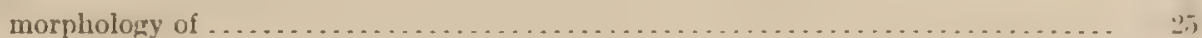

Dictyocladium

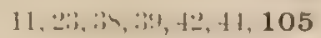

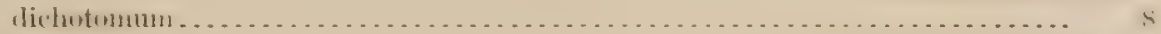

flabellum........................................ $4,8,24,29,323,33,45,105,149$

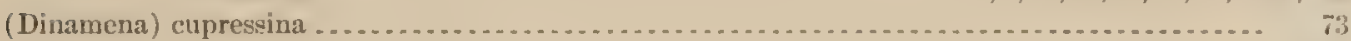

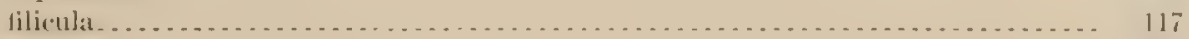

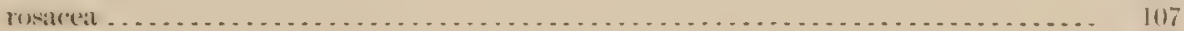

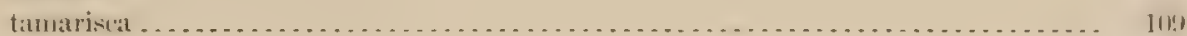

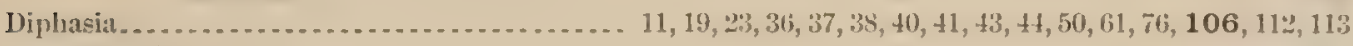

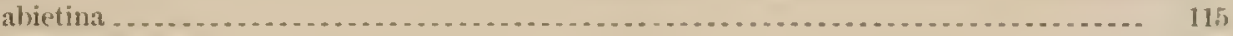

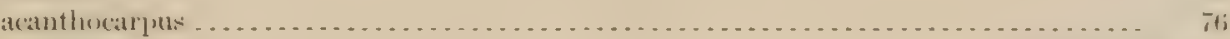

corniculata .................................................... $45,106,112,149$

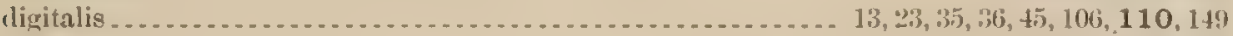

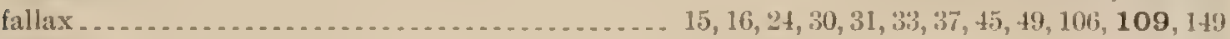

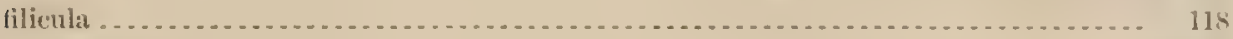

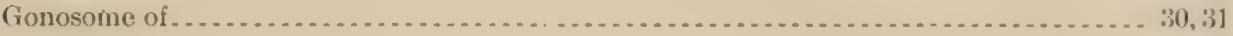

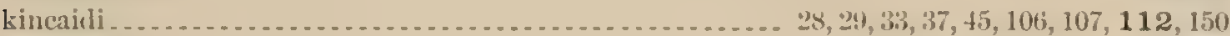

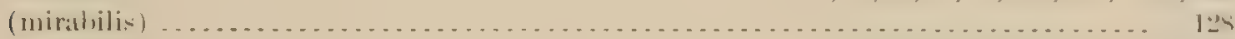

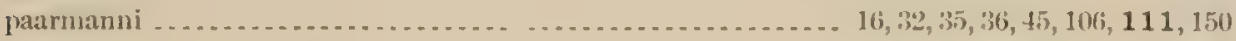

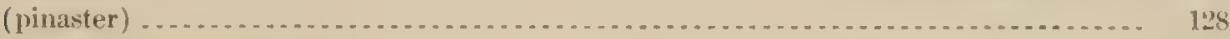

pinnata. . . . . . . . . . . .

pulchra . ................................................. 45, $106,107,111,150$

rosacea ............................ $4,16,17,24,25,30,31,32,35,45,106,107,108,149$

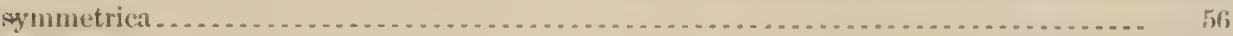

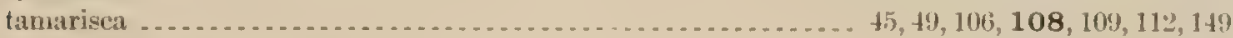

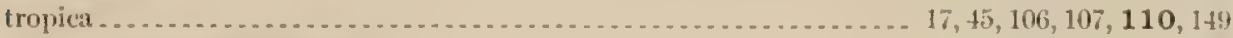

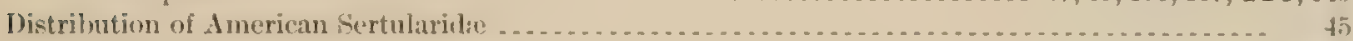

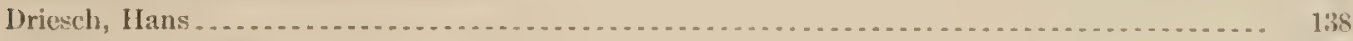

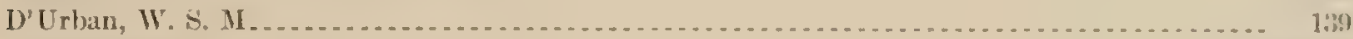

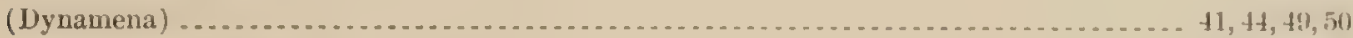

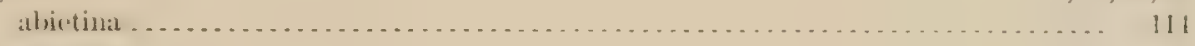

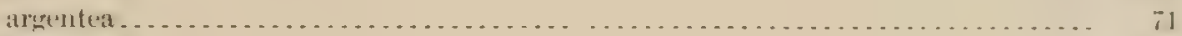

bivpinosa . . . . . .

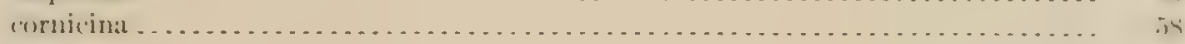

distank . . . . . . . .

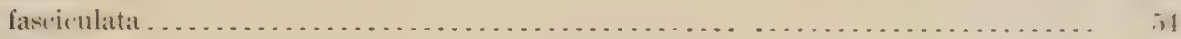

dilicula .........

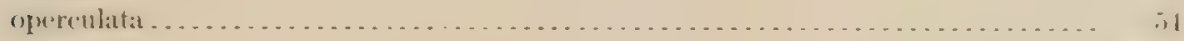

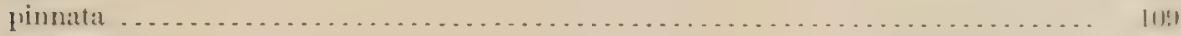

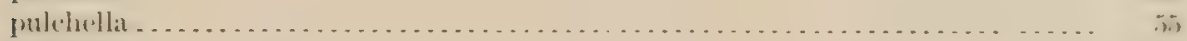

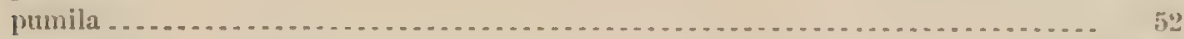

rosticea ......................................................... 107,1114

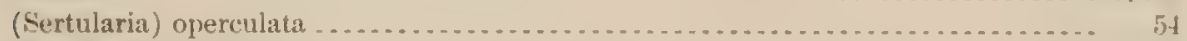

(Sertularia) pumila ............................................... 5

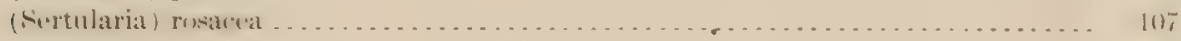

tamarisca. . . . . . . . . .

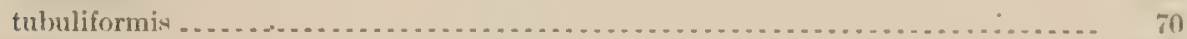

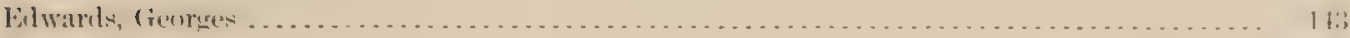

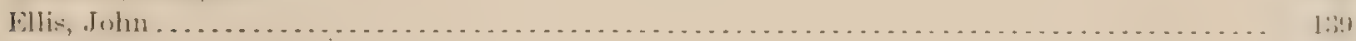

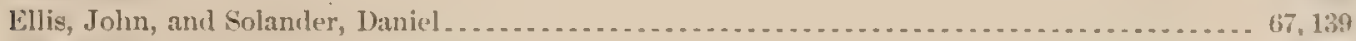

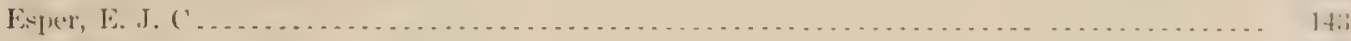

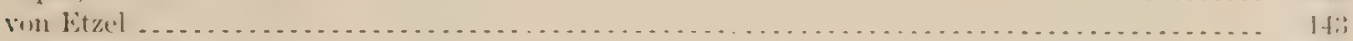

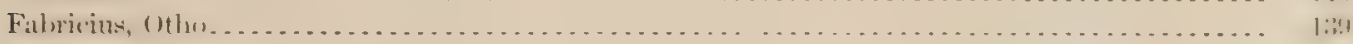

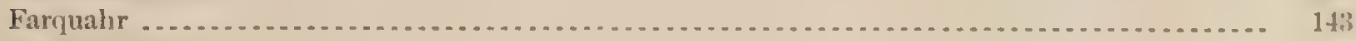

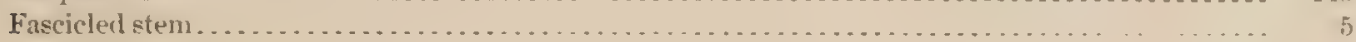

X.x

XXX

IXIX

XXXI

xxx

IXXI

IXV111

XXVII

IIX 
Fewkes, J. Walter

Fleming, John

139

Flowers, Charles B

$37,50,67$

Gilus Mrs G

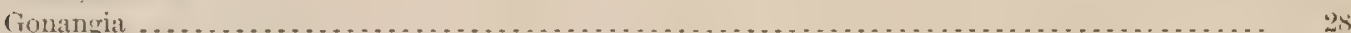

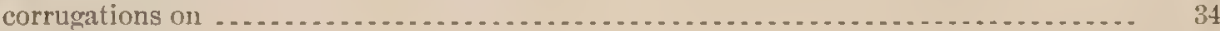

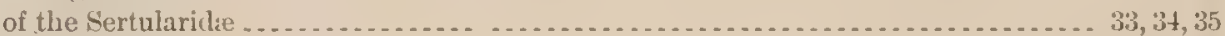

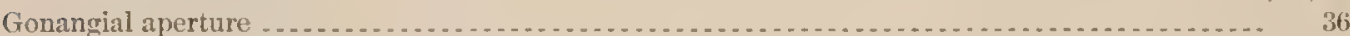

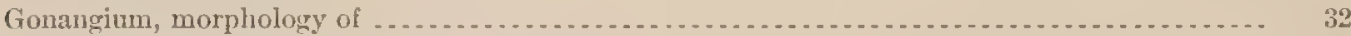

Gonophore...... . . .

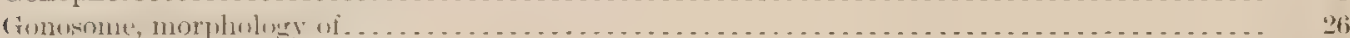

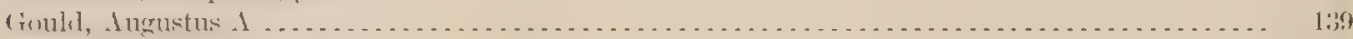

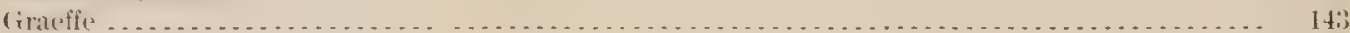

Grammaria ... . . . .

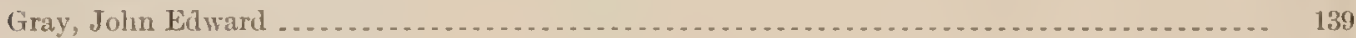

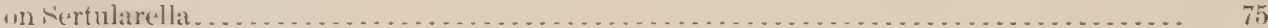

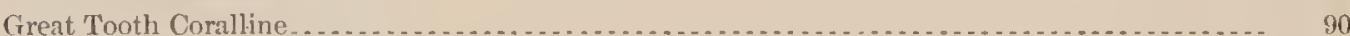

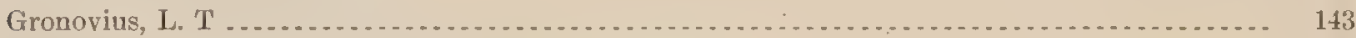

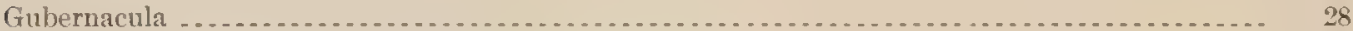

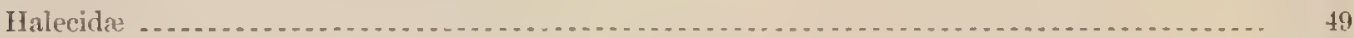

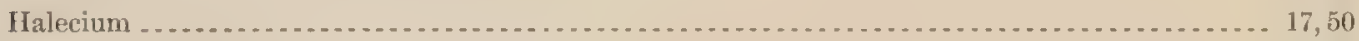

Hamamn, (Hto . . . . . . . . . . . . . . . . . . . . . . . . . . . . . . . . . . . . . . . . . 139

Hargitt, Charles W . . .

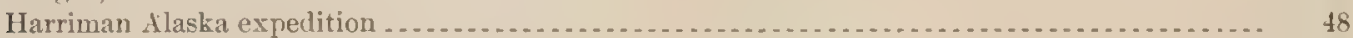

Hartlaub, Clemens. . ......................................... 1, $4,19,80,97,105,136,139$

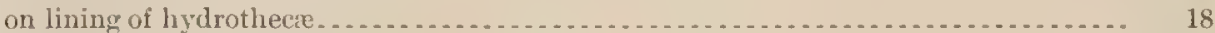

on sertularellat . . . . . . . . . . . . .

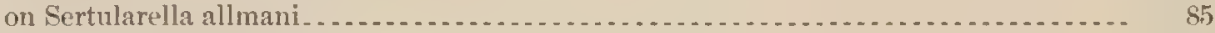

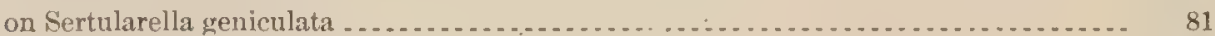

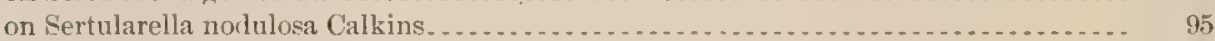

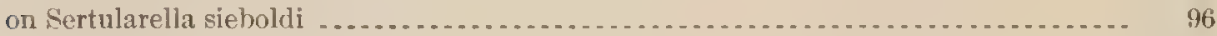

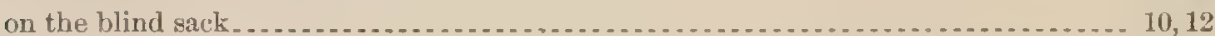

Heller, Cam . . . . . . . . . . . . . . . . . . . . . . . . . . . . . . . . . . . . . . . . . . . . . . 139

Herklotz_...

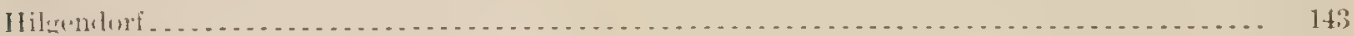

Hincks, Thomas H . . . . . . . . . . . . . . . . . . . . . . . . . . . . . . . . . . . . . . . . . . $19,37,140$

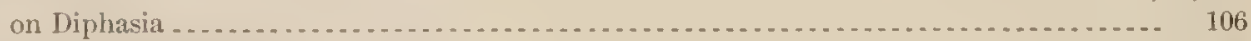

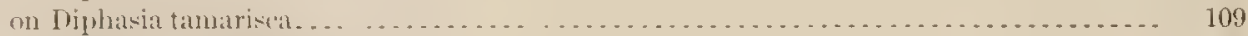

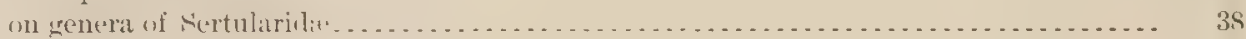

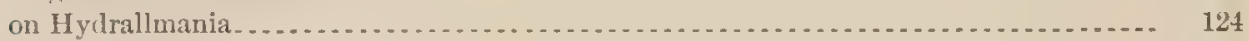

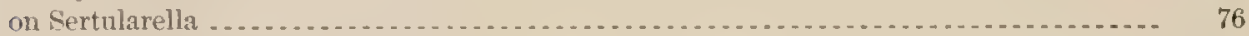

on Sertularella fusiformis . . . . . . . . . . . .

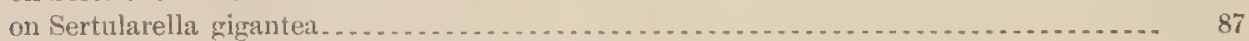

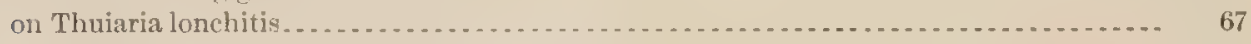

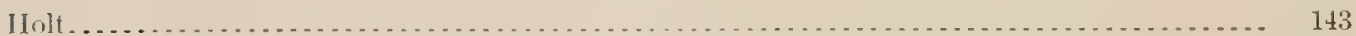

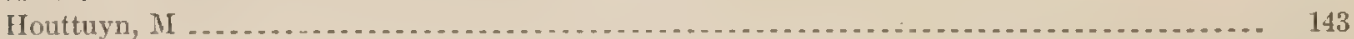

Hydrallmania . . . . . . . . . . . . . . . . . . . . . . . . . . . . . . . . . 11, 14,38, 39, $40,41,4 t, 50,124$

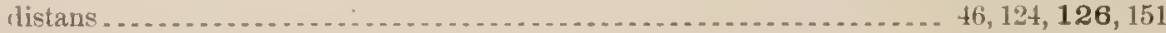

falcata .......................... $4,14,24,26,28,30,33,37,46,124,125,126,151$

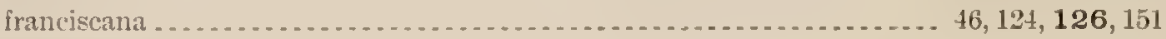

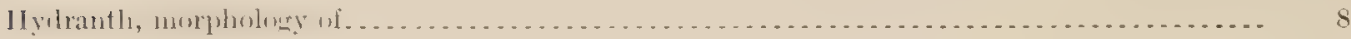

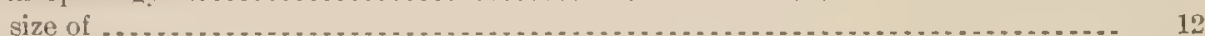

Hydrothece, morphology of ... . . . . . . . . .

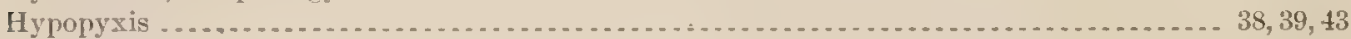

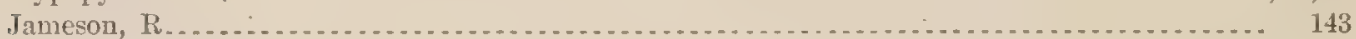

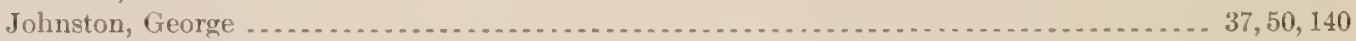

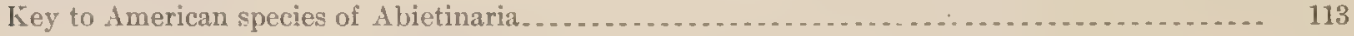

Diphasia ...

Hydrallmania . . . . . . . . . . . . . . . . . . . . . . . . . . 124

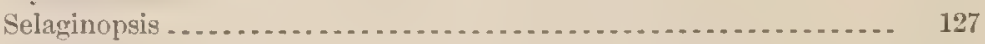

Sertnlarella............................................ 77

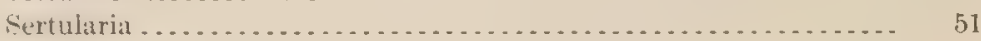


Thuiaria

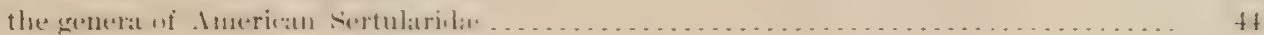

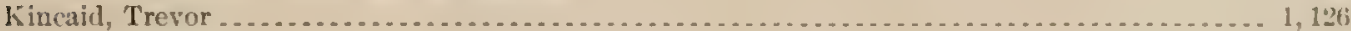

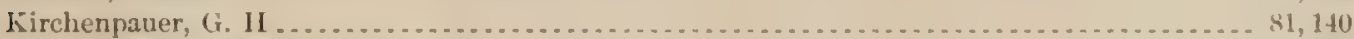

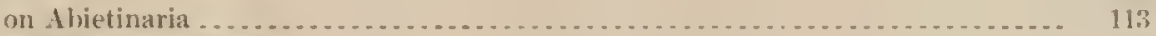

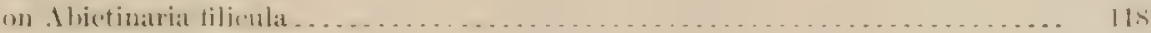

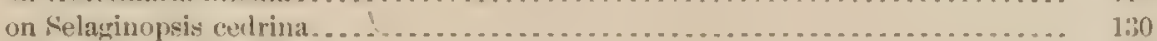

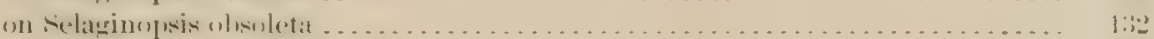

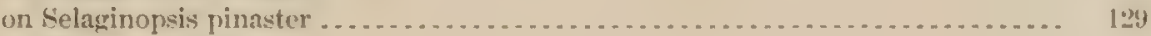

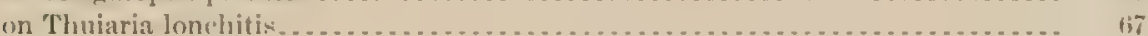

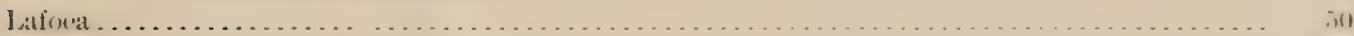

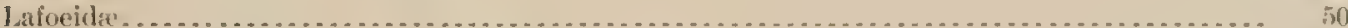

Lamarck, J. IB. P. A. de . . . . . . . . . . . . . . . . . . . . . . . . . . . . . . . . . . . . . . .

Lamouroux, J. V. F . . . . . . . . . . . . . . . . . . . . . . . . . . . . . . . . . . . . $49,50,74,140$

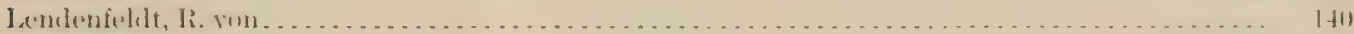

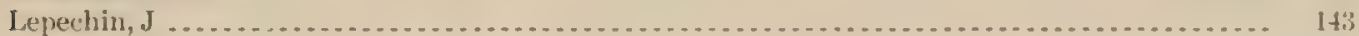

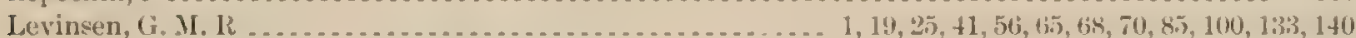

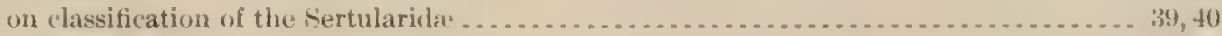

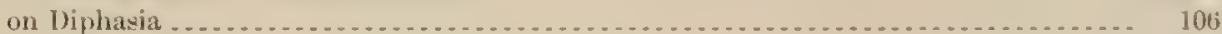

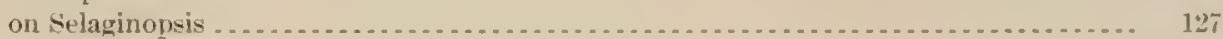

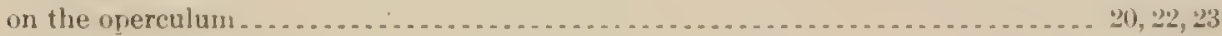

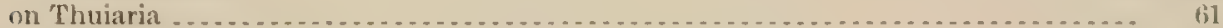

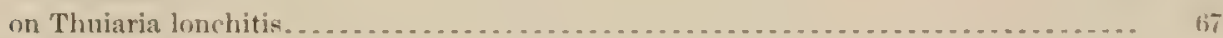

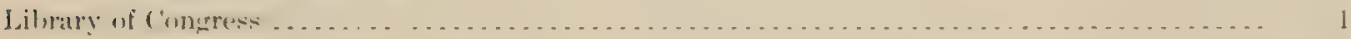

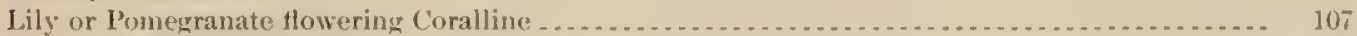

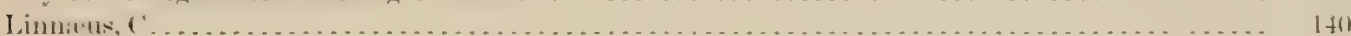

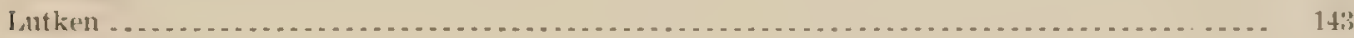

M(Cresuly, John . . . . . . . . . . . . . . . . . . . . . . . . . . . . . . . . . . . . . . . . . . . . 37,140

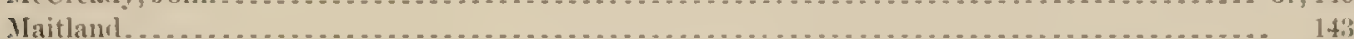

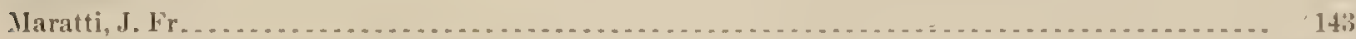

Marktanner-Tumeretacher, (rottlieh) . . . . . . . . . . . . . . . . . . . . . . . . . . . . . . . . . . . . . 40,140

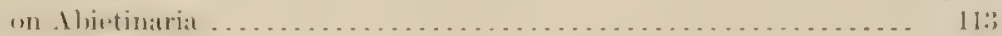

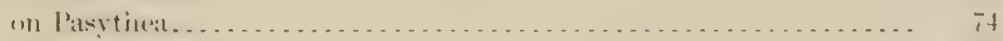

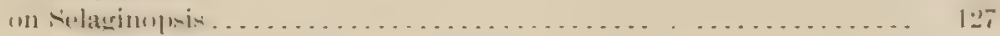

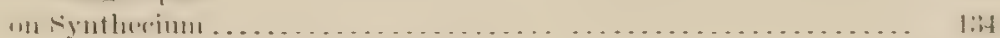

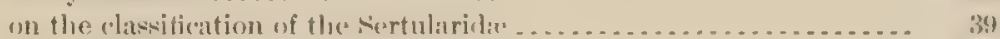

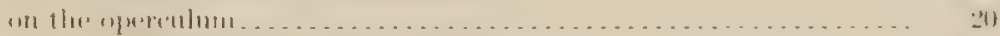

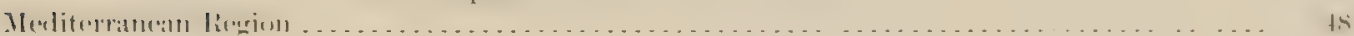

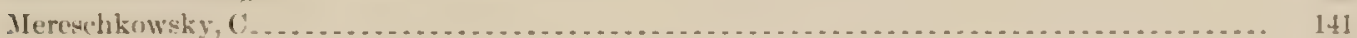

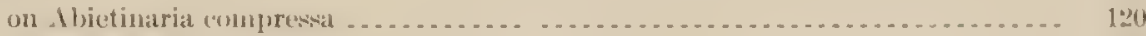

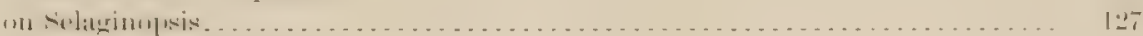

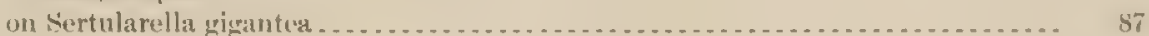

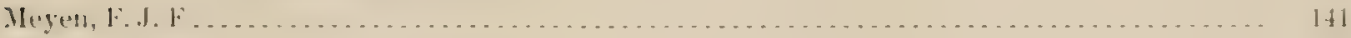

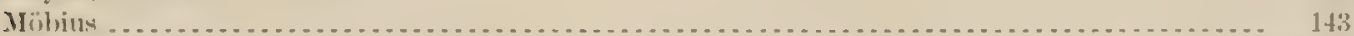

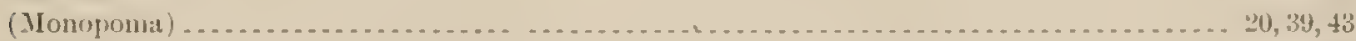

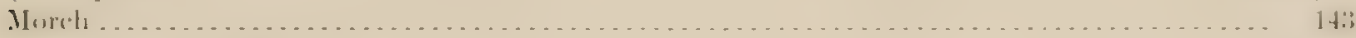

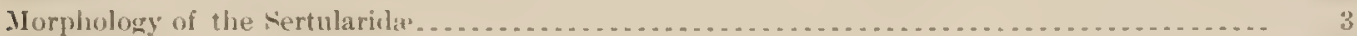

Inller, 0.1

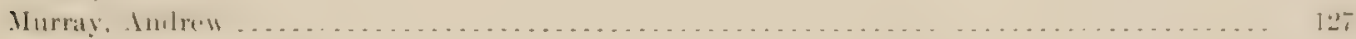

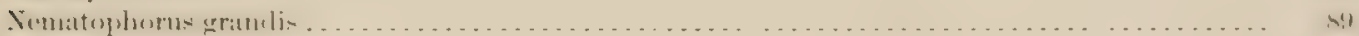

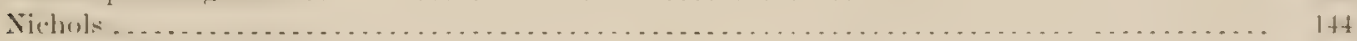

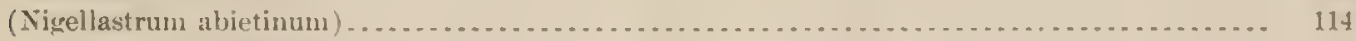

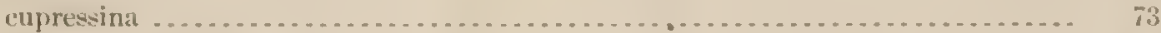

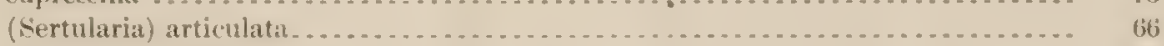

(Sertularia) cedrina............................................ 130

(Sertularia) nigellastrum. . . . . . . . . . . . . . . . . .

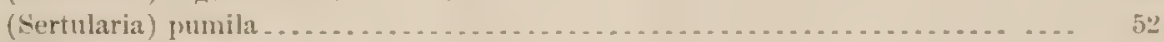

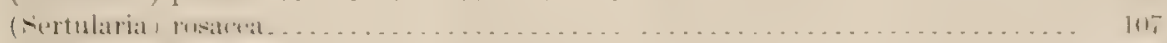

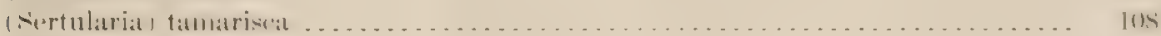

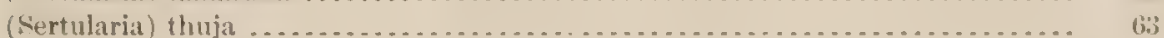

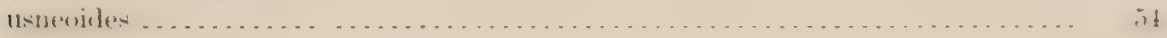

$5125-1 T^{2}-(14-21$ 
[']ite.

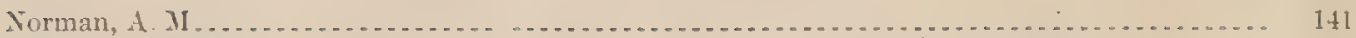

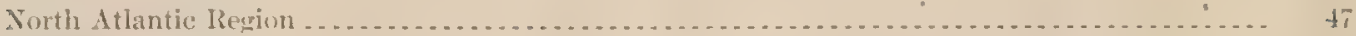

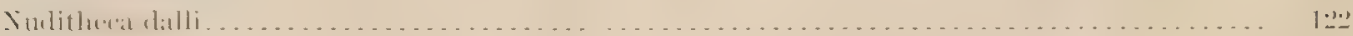

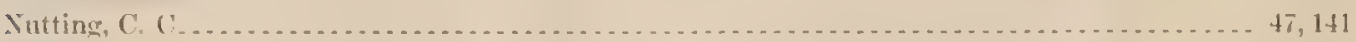

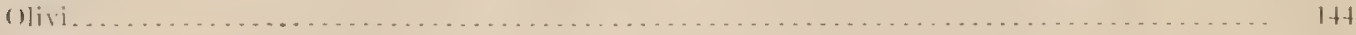

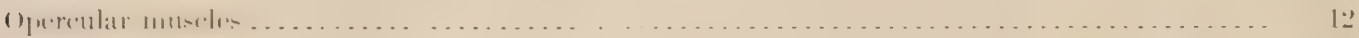

(1)

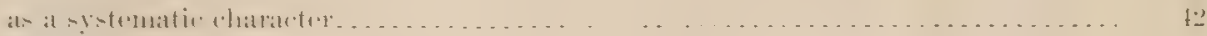

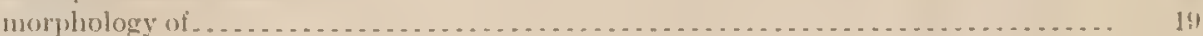

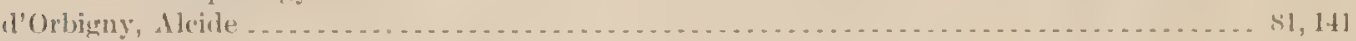

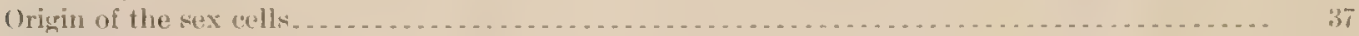

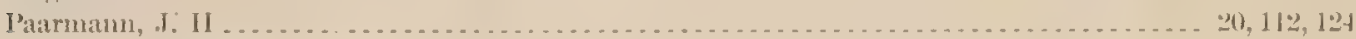

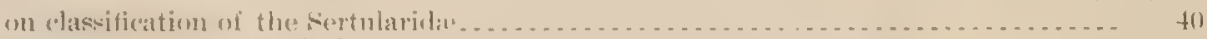

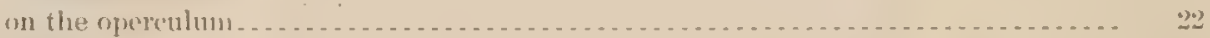

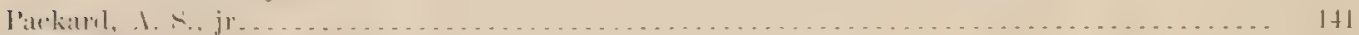

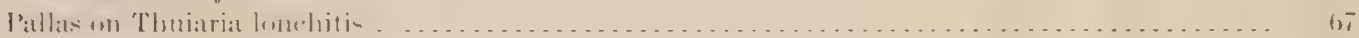

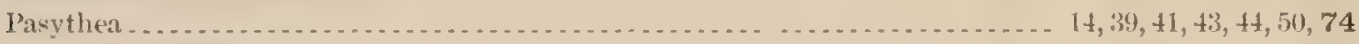

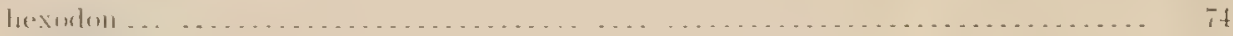

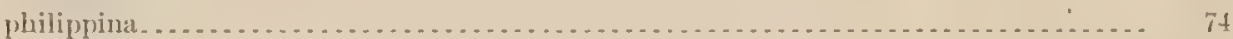

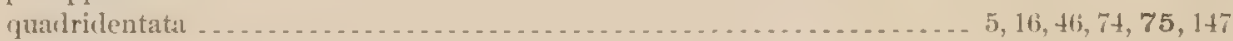

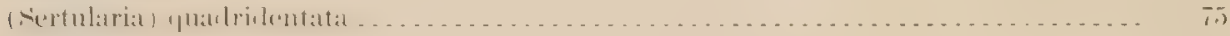

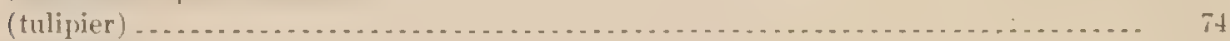

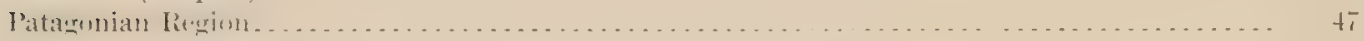

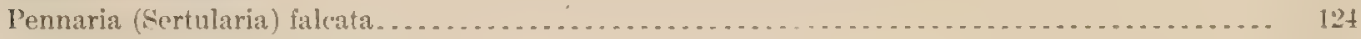

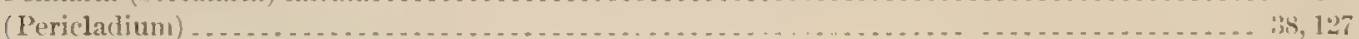

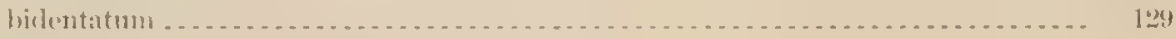

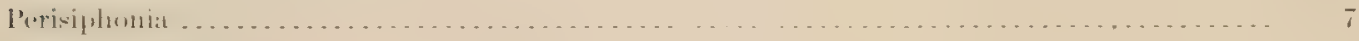

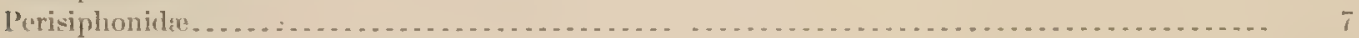

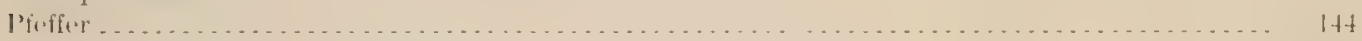

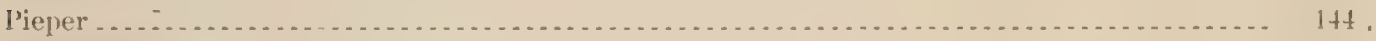

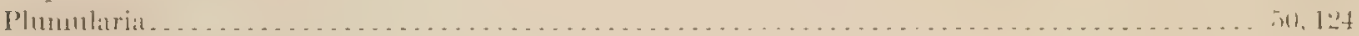

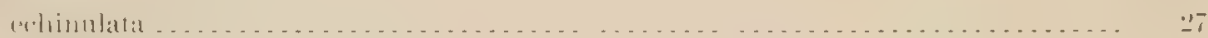

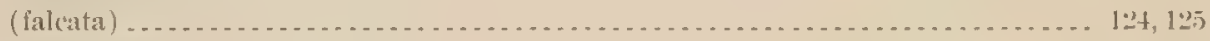

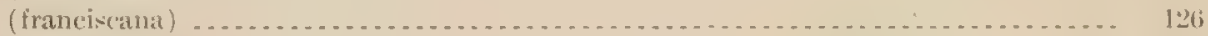

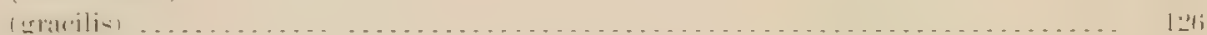

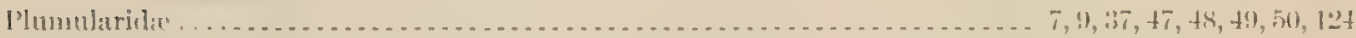

loints of intergralation letween dhietinaria and other genera. . . . . . . . . . . . . . . . . . . 113

between Diphasia and other genter . .......................... 107

letween fertularella and other generat........................ 76

between Sertularia and other genera ........................... 50

between Thuiaria and other genera ............................. 6.

letween Synthecium and other genera ........................ 134

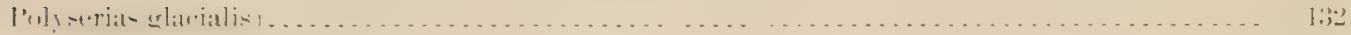

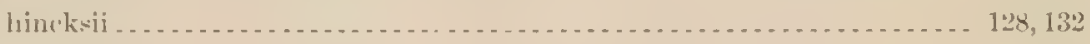

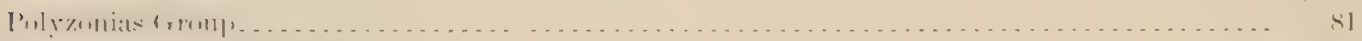

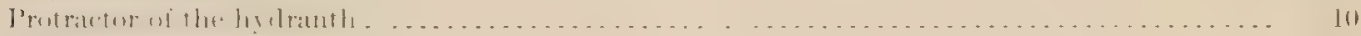

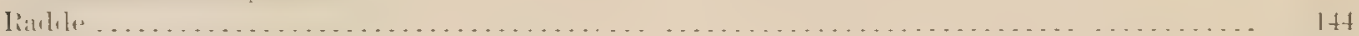

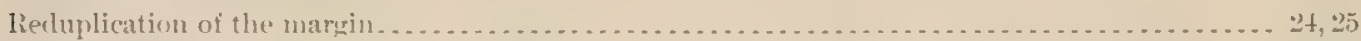

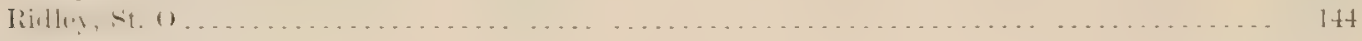

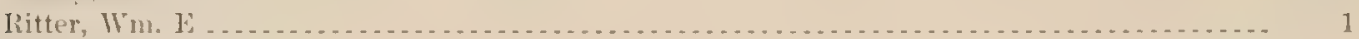

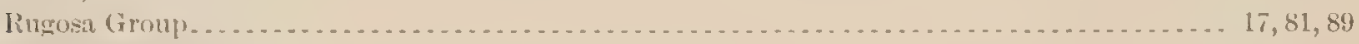

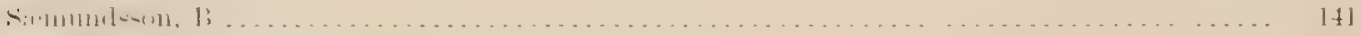

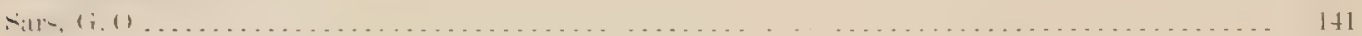

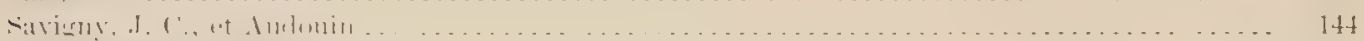

-

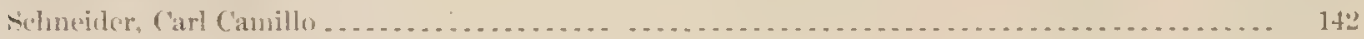

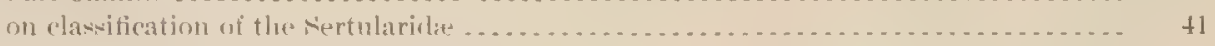

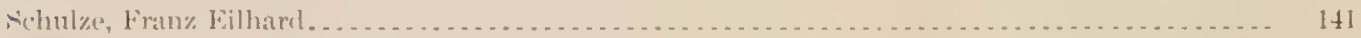

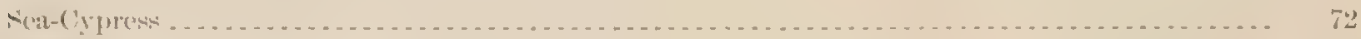

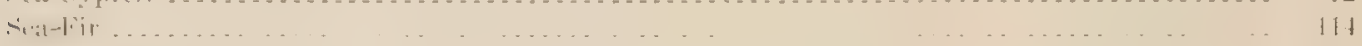

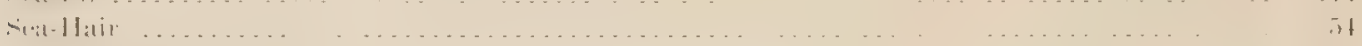

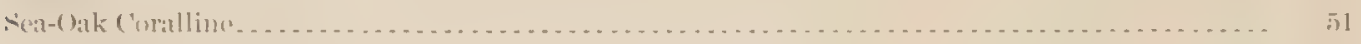

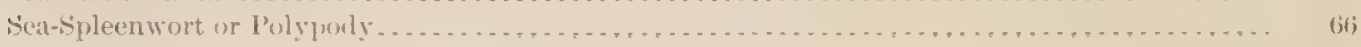


Sea-Tamarisk

Selaginopsis............................ $7,11,14,17,23,36,34,41,42,44,127,129,130$ alternitheca ..................................... $46,61,128,133,151$

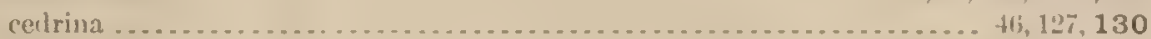

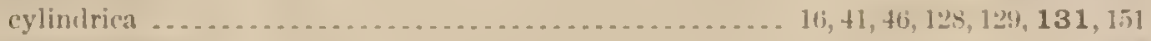

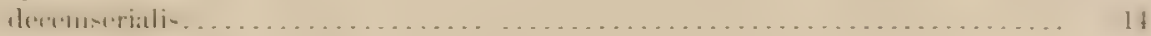

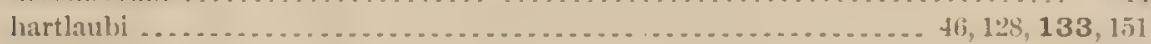

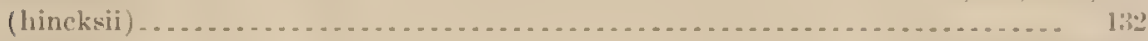
mirabilis...................................... $41,46,127,128,151$ obsoleta . . . . . . . . . . . . . . . . . . . . . . . . . . . . . . 4t, 128, 132, 151

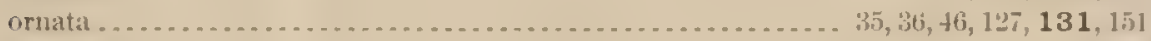

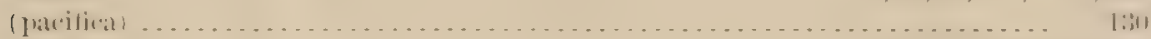
pinaster . . . . . . . . . . . . . . . . . . . . . . . . . . . $46,127,128,129,151$ pinnata ............................................ 18, $46,12 \pi, 130,151$ plumiformis. . . . . . . . . . . . . . . . . . . . . . . . . . . . . . . . . $46,127,129,151$

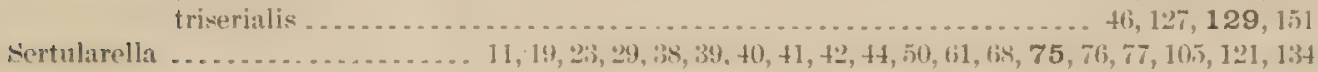

(allietima) (allinis) albirla (1)

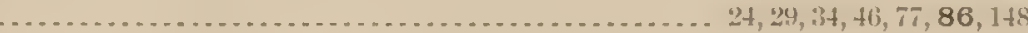
allmani ........................................... $14,32,34,46,77,84,148$

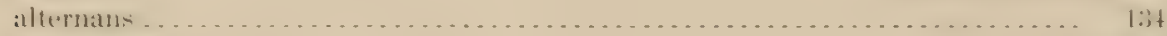

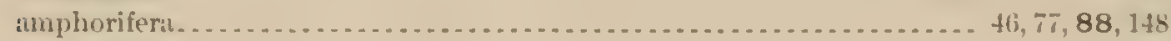

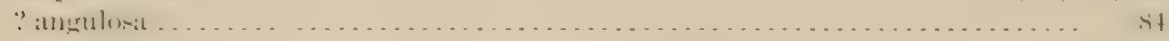

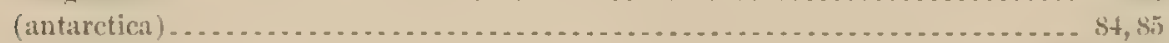

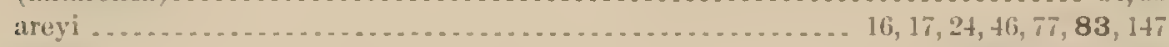
catena . . . . . . . . . . . . . . . . . . . . . . . . . . . . . . . .

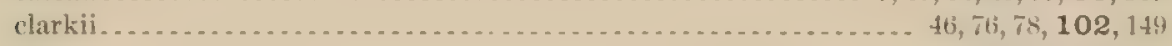

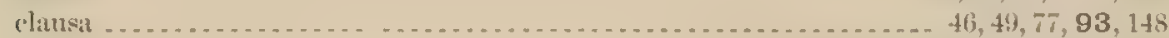
complexa .............................. $24,28,29,34,36,37,46,77,94,148$

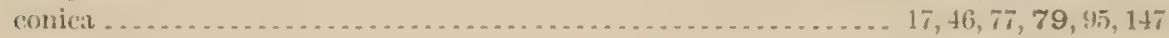
contortit ......................................... $34,36,46,77,85,145$

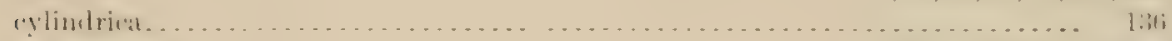

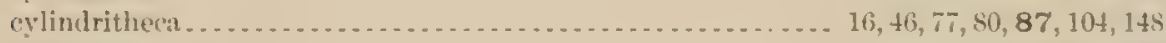

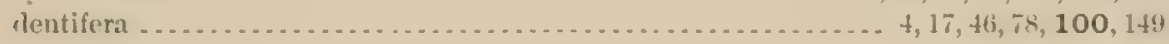
dichotoma .............

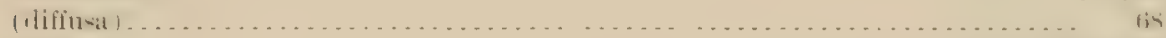

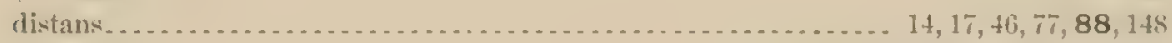
elegans . . . . . . . . . . . . . . . . . . . . . . . . . $8,32,333,34,35,46,74,98,149$

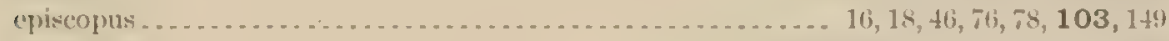

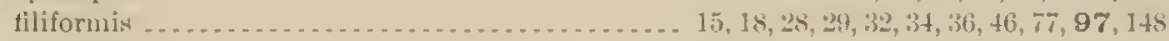

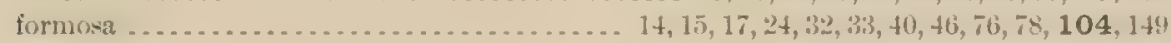
(fimticulisia . . $14,15,17,24,32,33,40,46,76,78,104,149$

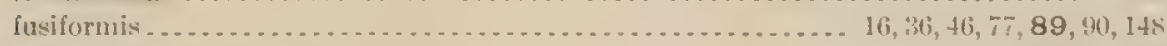
gayi . . . . . . . . . . . . . . . . . . . . . . . . . 5, 6, $7,12,17,24,46,77,78,93,147$ Layi. var. rulumalia

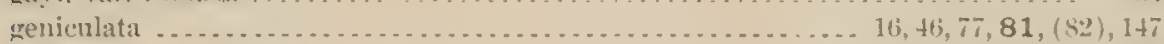

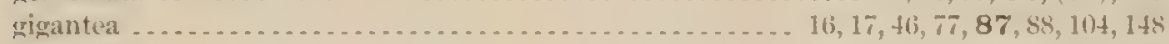
$($ (1)

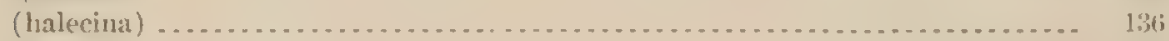
hartlaubi ......................................... $16,17,40,4 i, 78,104,149$

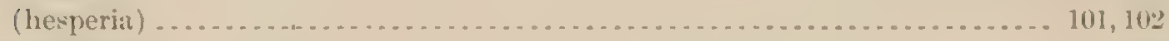

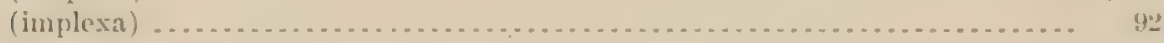
(integritheed) . . . . . . . . lata ................................................ $74,18,46,77,85,8 s, 148$

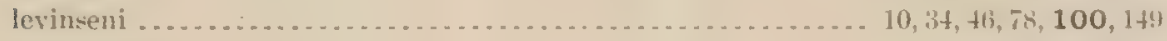
magellanic . ....................................... 10, 14, 46, 7 $8,99,144$

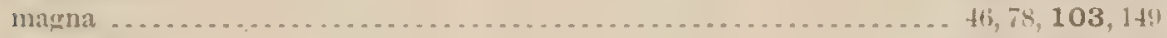

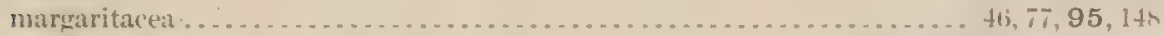

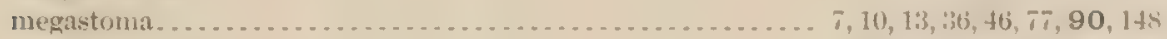

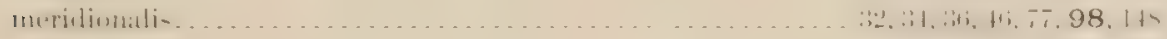
milneana . . . . . . . . . . . . . . . . . . . . . . . . . . . . . $46,78,98,149$ minuta....................................................... $46,78,99,149$

IXXIX

II.

IXXVIII

SXXIX, XI

XI.

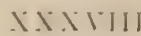

XIXIX

XIXIX

S.XIX

XIX
$x$ XIII

III

XV

l.ju

IXI

IXI

$\mathrm{AV}$

XVIII

IIX

$\mathrm{XXV}$

IIX

XXIV

IXv1

XXII

cxill

$x$

IIV

XII

IIX

SxvI]

IVIII

x.1

XXIV

XXII

ㅈI]

AX

I.XIII

र्रा

XXI 


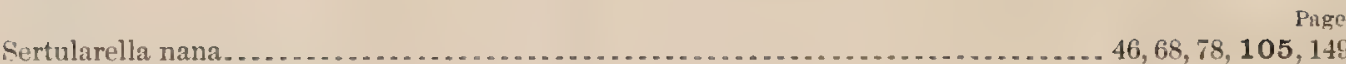

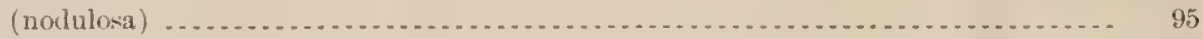

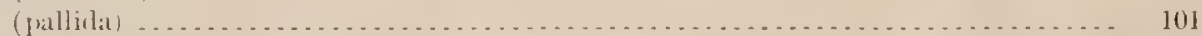

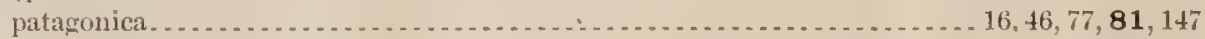

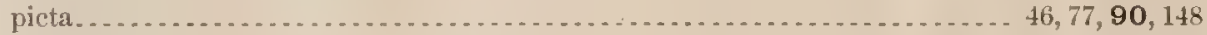

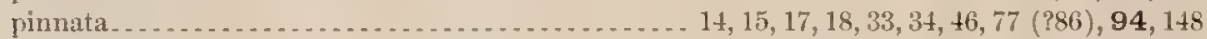

pinnigera. . . . . . . . . . . . . . . . . . . . . . . . . . . . . . . . . 7, 18, 46,77, 86, 148

polyzonias .................. 13, 19, 24, 29, 34, 36, 37, $46,75,77,88,90,91,92,93,148$

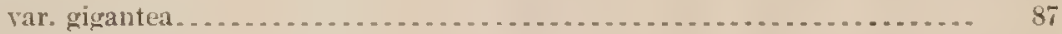

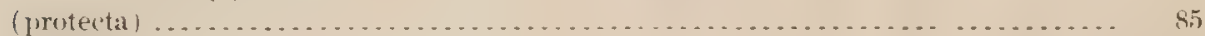

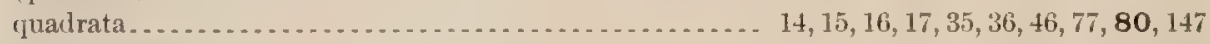

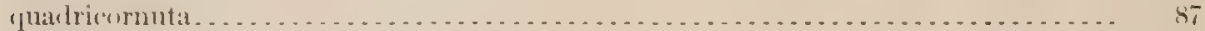

quadrifida. ....................................................... $46,77,97,148$

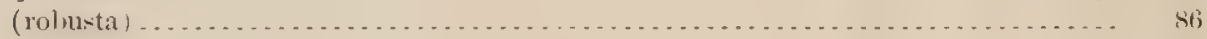

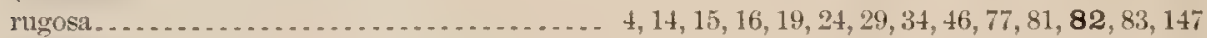

(Nacrata) . . . . . . . . . . . . . . . . . . . . . . . . . . . . . . . .

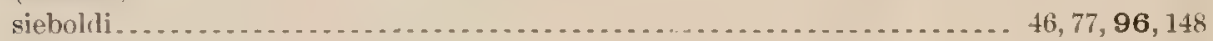

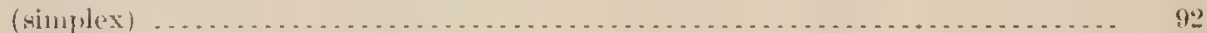

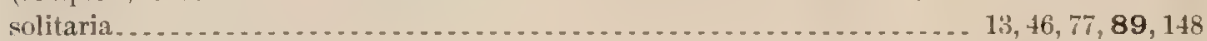

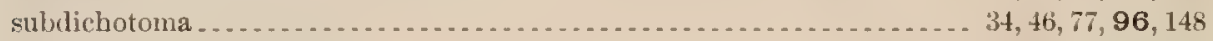

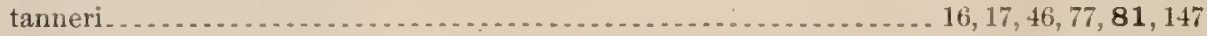

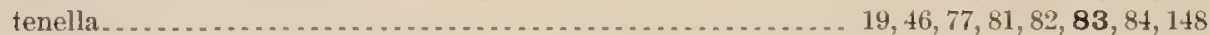

tricuspidata . . . . . . . . . . . . . . . . 15, 18, 19, 24, 32, $36,46,49,78,97,99,100,101,102,149$

tropica............................................ $7,46,49,78,99,100,102,149$

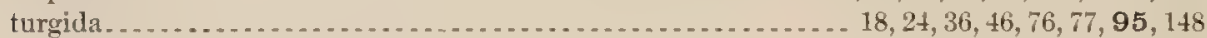

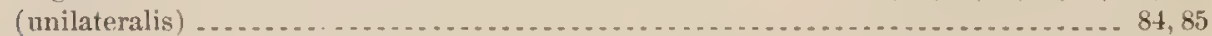

XXI

XV

XXIII

XVII

XXII

$\mathrm{XX}$

XXII

XVI

XVIII

XXV

XXVI

XXII

(abietina)

$11,12,17,18,25,38,39,40,42,43,44,49,50,61,62,107,134$

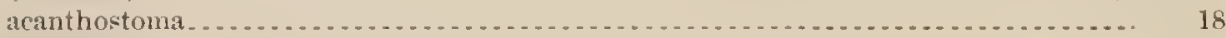

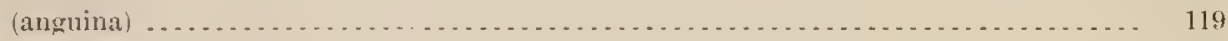

var. robusta ...

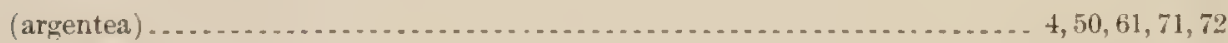

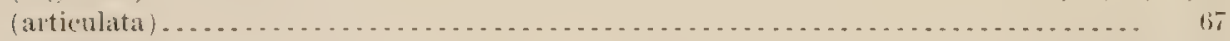

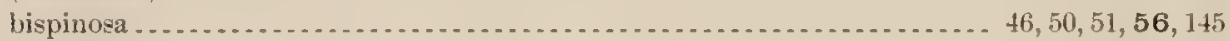

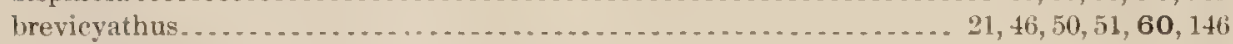

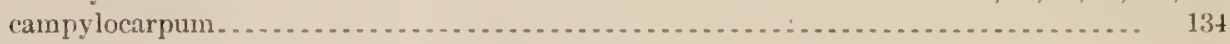

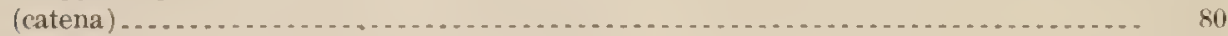

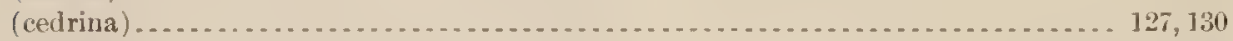

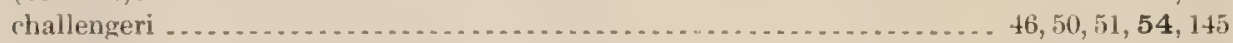

(ciliata) ... . . . . . . .

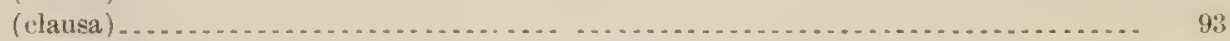

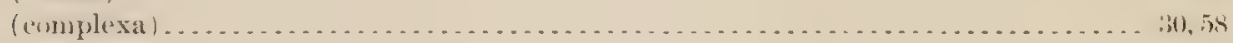

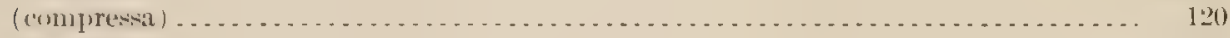

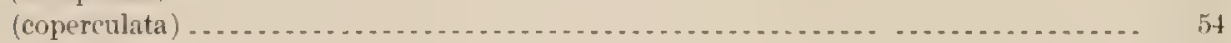

cornicina .......................................... 15, 21, 29, 33, 34, 46, 51, 58, 145

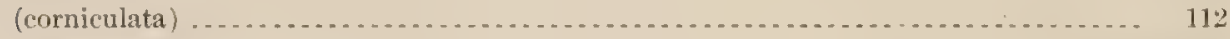

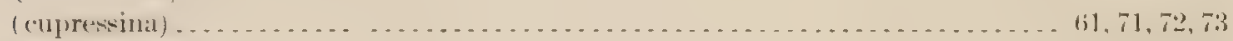

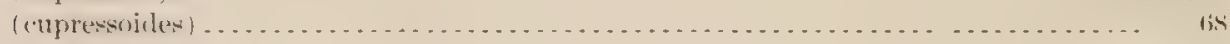

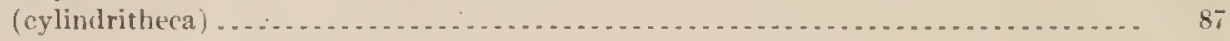

desmoides . . . . . . . . . . . . . . . . . . . . . . . . . . .

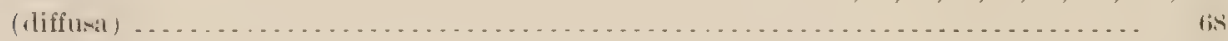

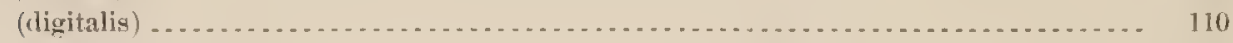

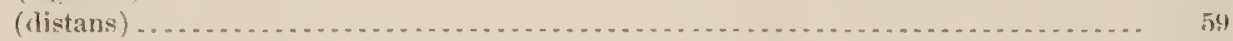

(I)ynamena) pmunila ....

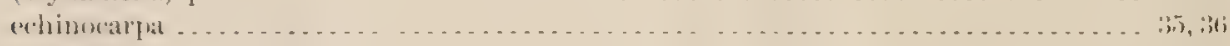

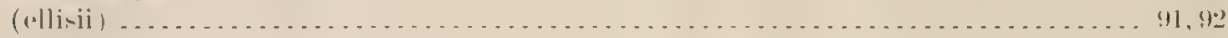

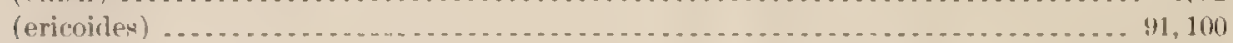

(1)

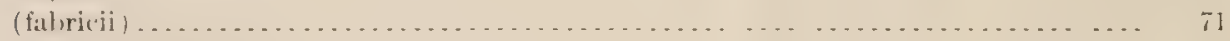

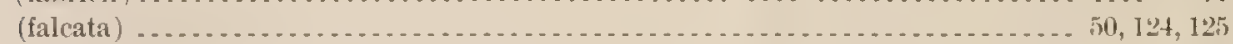

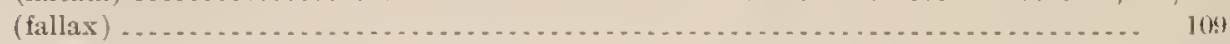

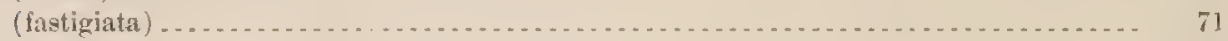

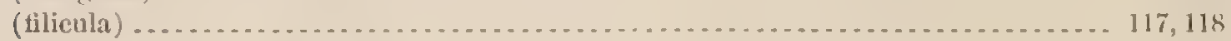


Sertularia (filiformis)

Hate.

(htexus:at

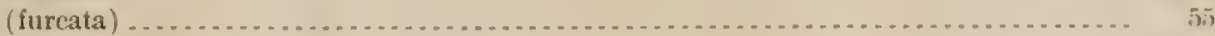

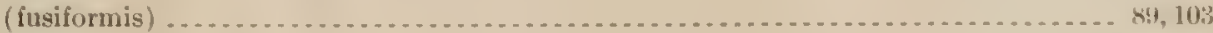

(de Gay) . . . . . . . . . . . . . . . . . . . . . .

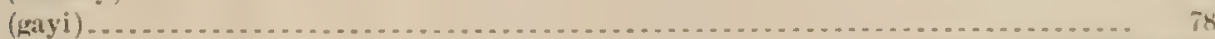

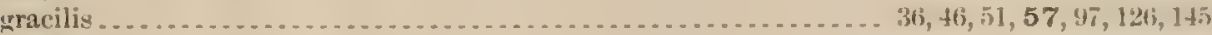

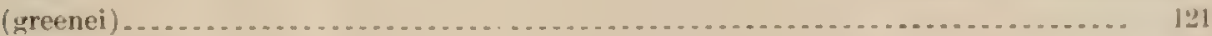

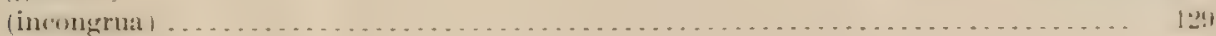

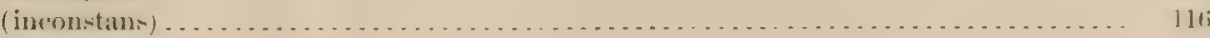

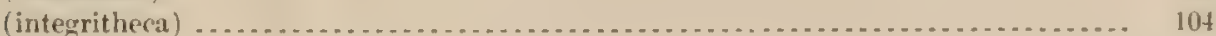

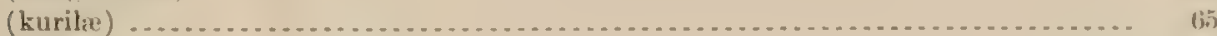

(labiata) . . . . . . . . . . . . . . . . . . . .

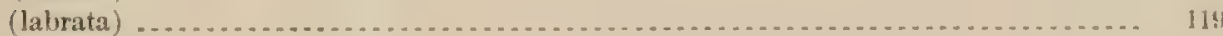

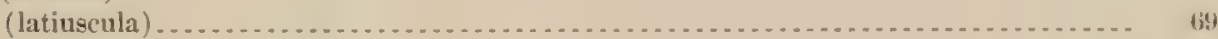

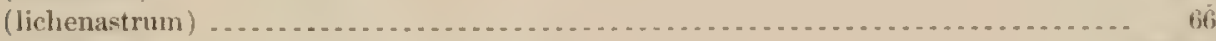

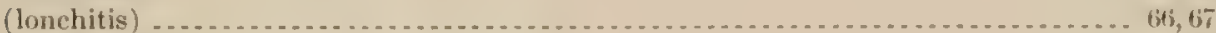

(longiensta) . . . . . . . . . . . . . . .

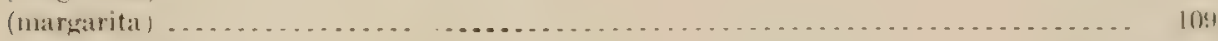

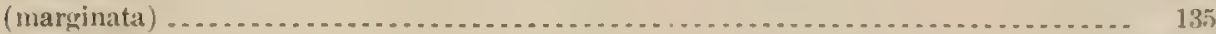

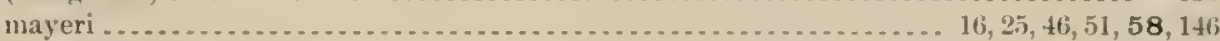

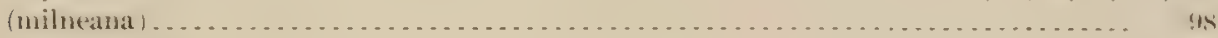

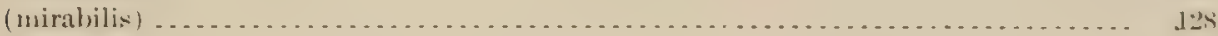

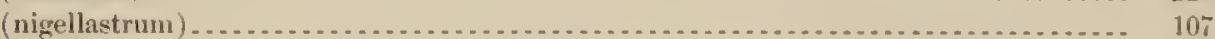

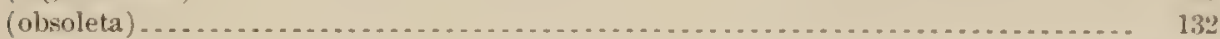

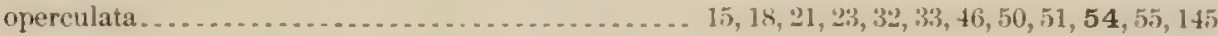

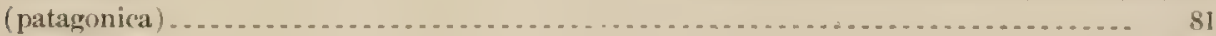

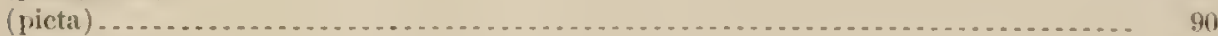

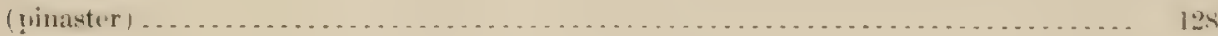

(pinnata) . . .

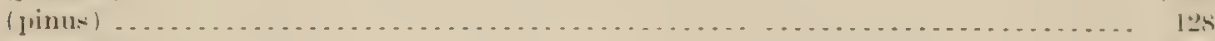

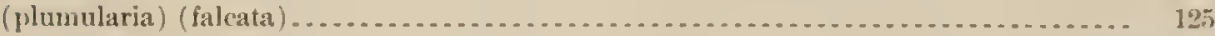

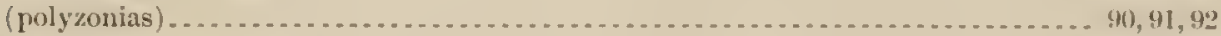

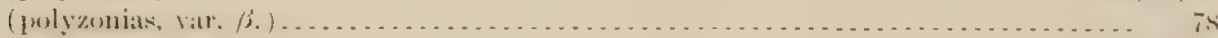

pourtalesi .................................................... $46,59,146$

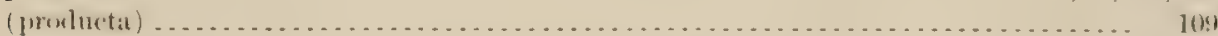

pulchella . . . . . . . . . . . . . . . . . . . . . . . . . . . . . . . . . . . . . . $46,51,55,145$

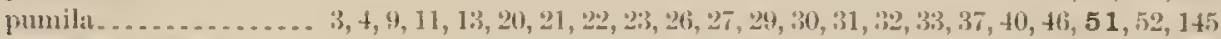

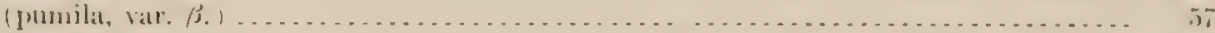

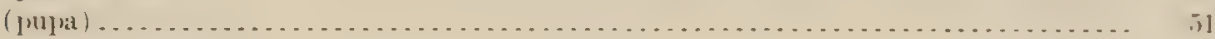

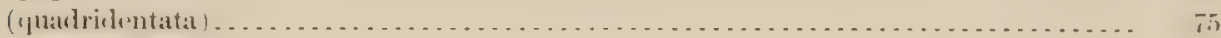
rathbuni ...................................................

(rosa) ... . . . . . . . . . . . . . . . . . . . . . . . .

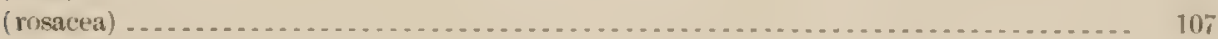

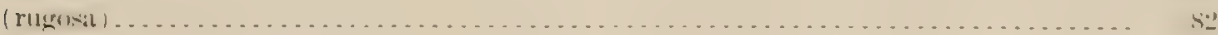

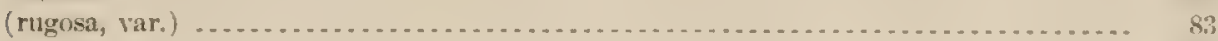

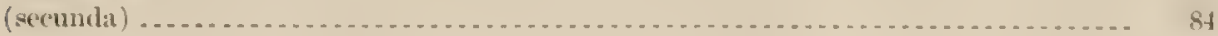

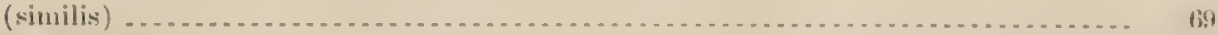

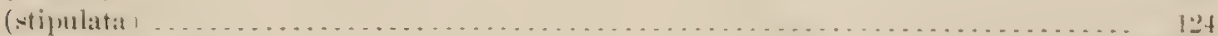

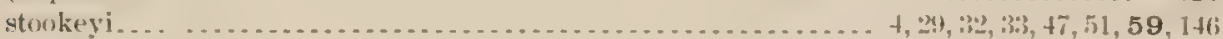

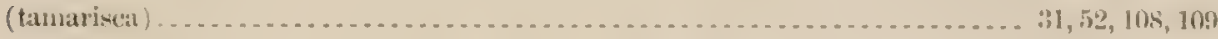

(tenella) . . . . . . . . . . .

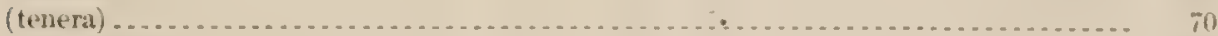

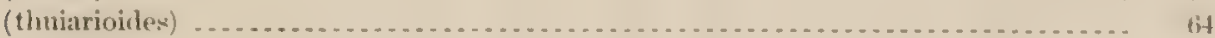

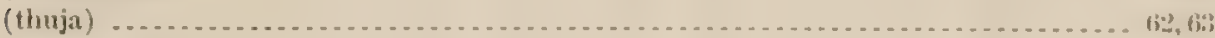

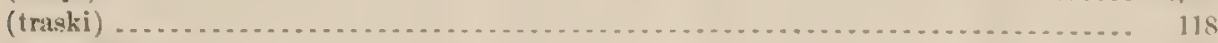

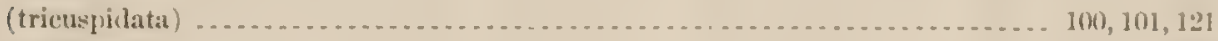

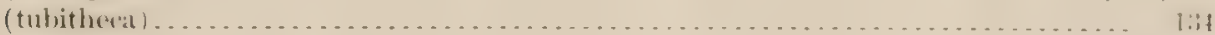

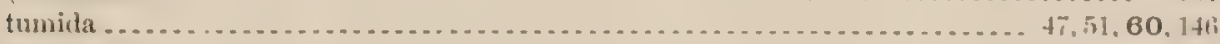

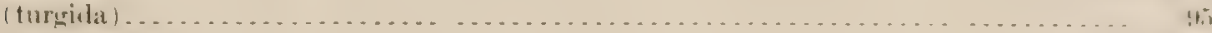

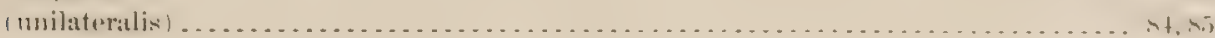


Cintularia (unneristes

P'ate

(variabilis) _.

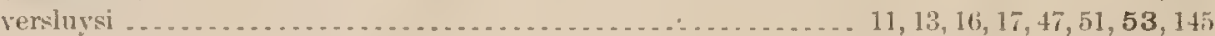

Sertularidie ...................................... 9, $25,32,37,40,47,48,49,75,124$ discussion of genera . . . . . . . . . . . . . . . . . . . . . . . . . . . . . . . 41,42

grign of

Sex cells, origin of

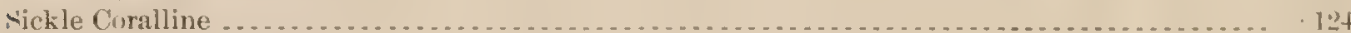

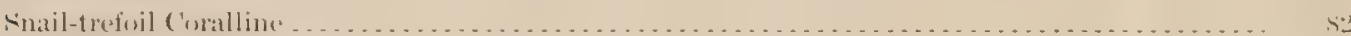

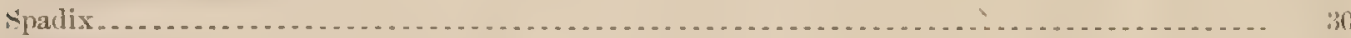

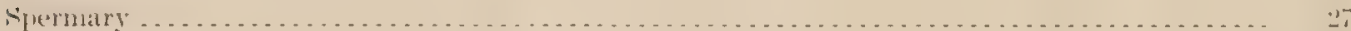

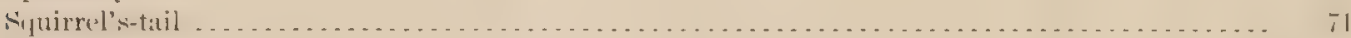

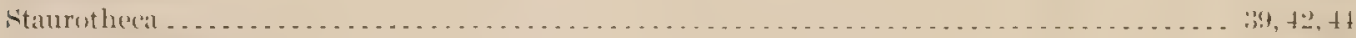

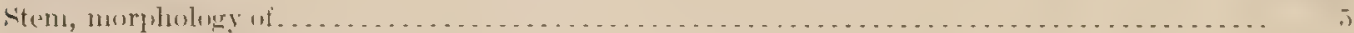

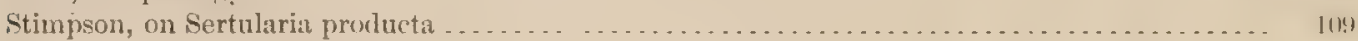

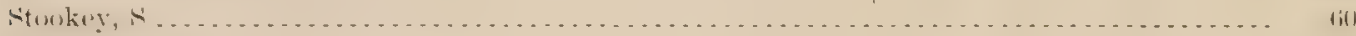

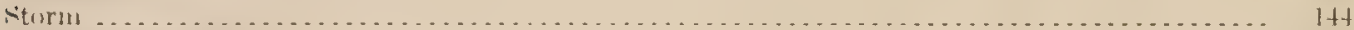

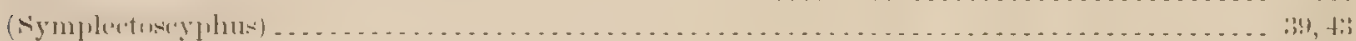

Synthecium. ..................................... 11, 14, 17, 25, 38, 39, 42, 44, 133, 134

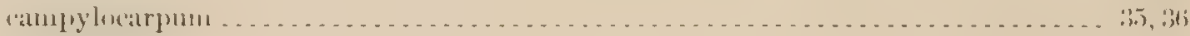
cylindricum . . . . . . . . . . . . . . . . . . . . . . . . . . . . . . . . . . 14, 47, 1:34, 136, 151

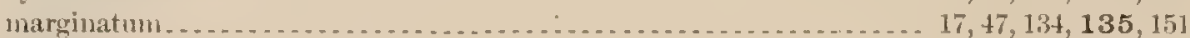

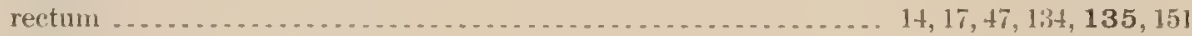

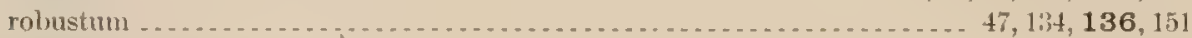

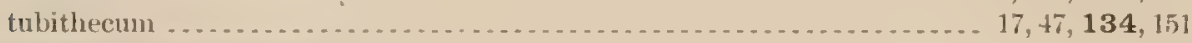

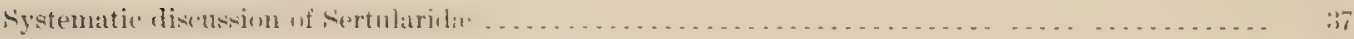

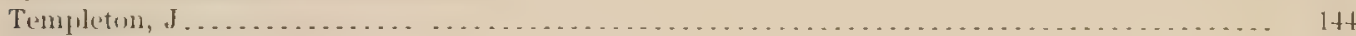

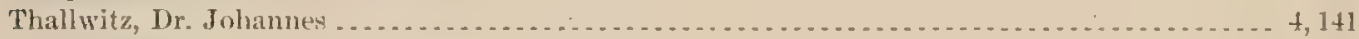

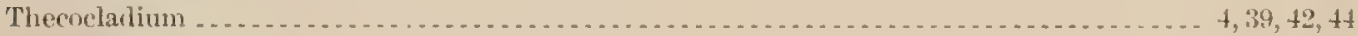

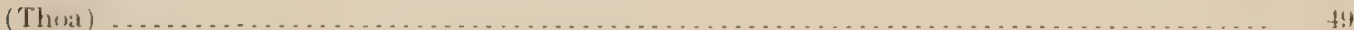

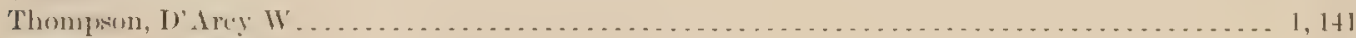

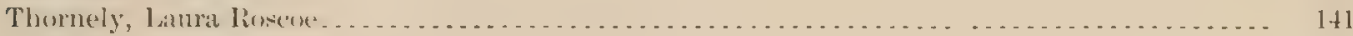

Thuiaria ........ 11, 14, 17, 19, 23, 25, 36, 38, 39, 40, 41,42, 44, 61, 68, $49,76,86,105,107,113,121,127,129$

(abietinit) . . . . . . . . . . . . . . . . . . . . . . . . . . . . . . . . . . 115

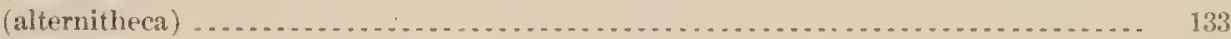

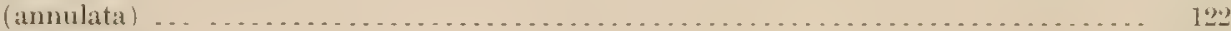

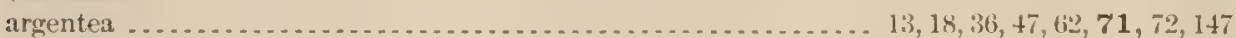

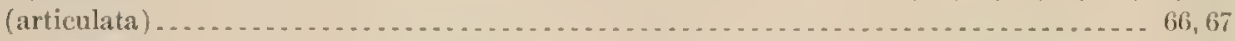

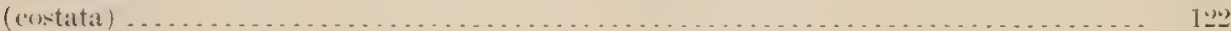

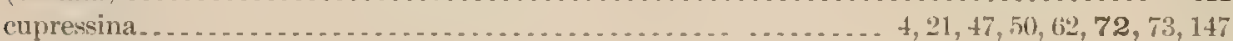

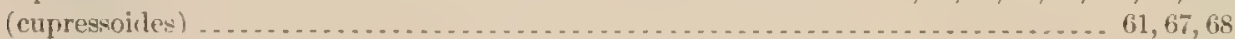

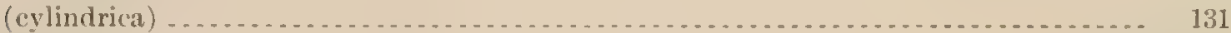

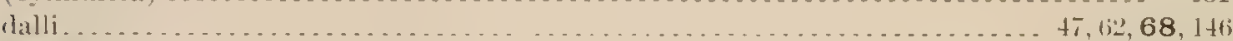

diffusa .................................................... 17, 18,47,62,68,146

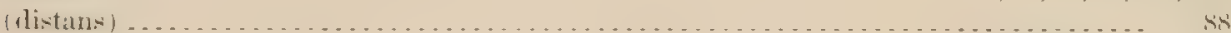

elegans......... . . . . . . . . . . . . . . . . . . . . . . . . . . . . . . 18, $47,60,64,112,146$

fahrivii . . . . . . . . . . . . . . . . . . . . . .

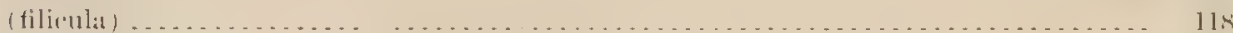

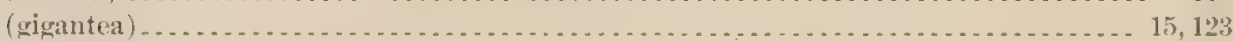

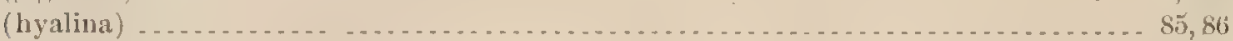

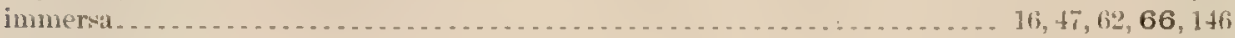

(kincaidi) . . . . . . . . . . . . . . . . . . . . . . . . . . . . . . . . . . .

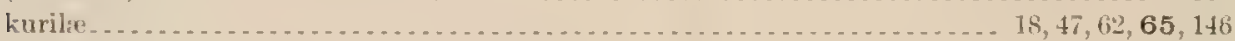

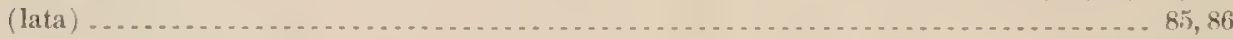

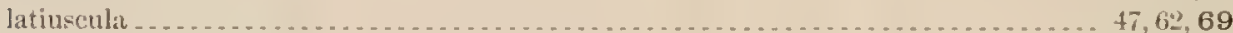

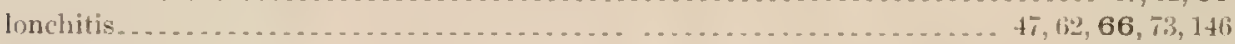

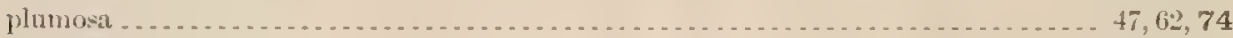

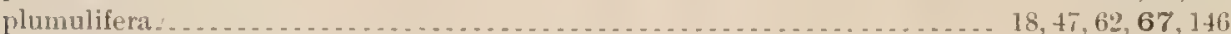

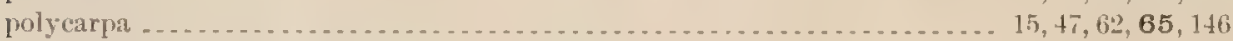

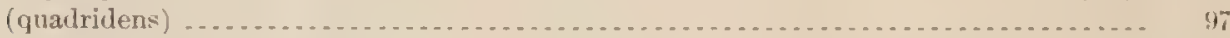

ramosissima . . . . . . . . . . . 47, 62, 68

robusta ............................... $11,15,21,26,29,35,47,61,62,64,146$

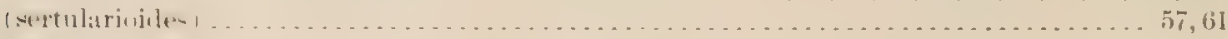


Thuiarit similis

l'uke?

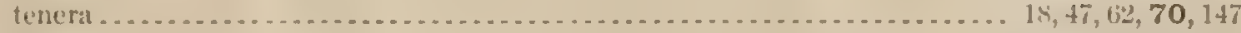

thuiarisiley ......................................... $36,47,62,64,146$

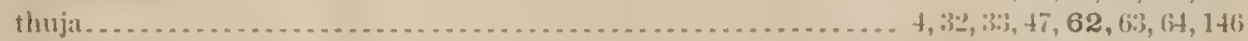

tubuliformis .................................... $16,18,21,25,32,233,47,62,70,147$

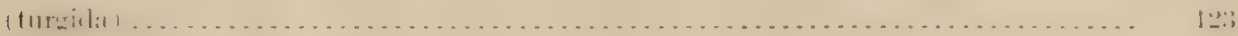

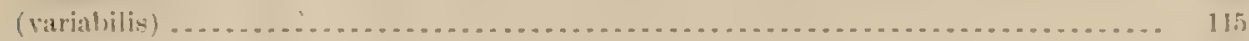

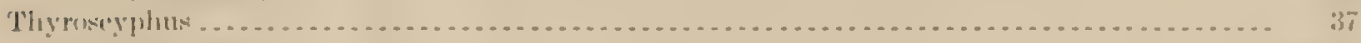

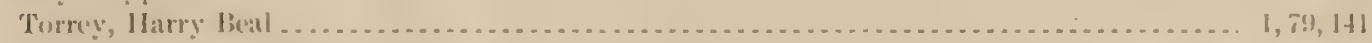

nा

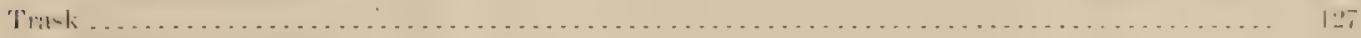

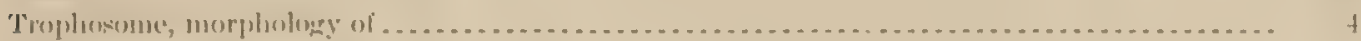

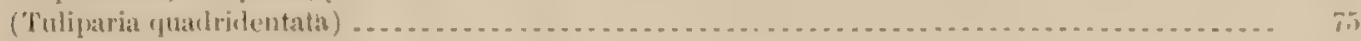

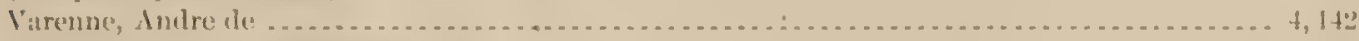

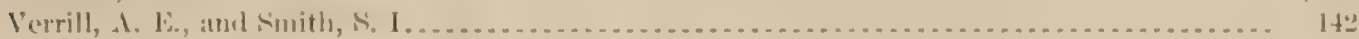

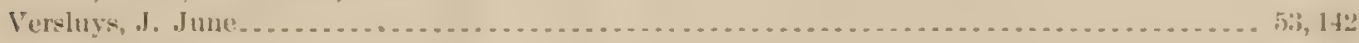

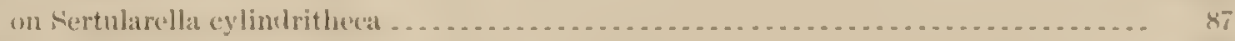

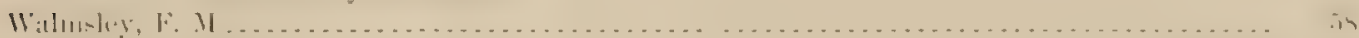

Weismann, lugust . . . . . . . . . . . . . . . . . . . . . . . . . . . . . . . . . 26; $27,28,219,142$

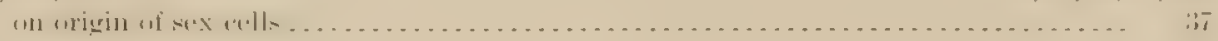

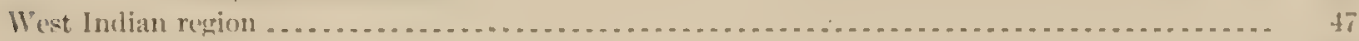

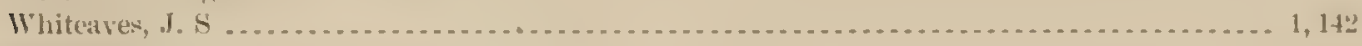

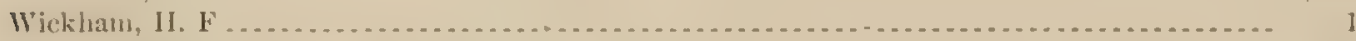

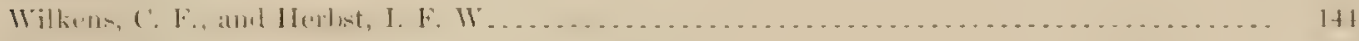

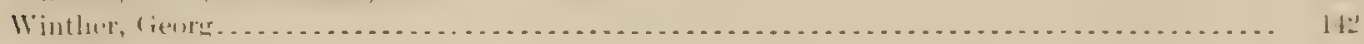

I'hate.

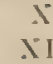

VIII

VII

II 




